IIIIIIIIIIIII)

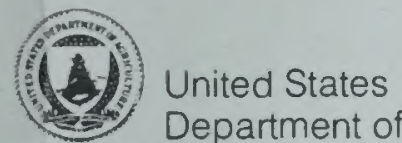
Department of
Agriculture

Forest Service UAS

(n)

United States Department of the Interior

Bureau of Land Management

5y

United States Department of Health and Human Services

Food and Drug Administration FD)

\title{
Pacific Yew \\ Draft Environmental Impact Statement
}

\section{$\square$ JANUARY, 1993}

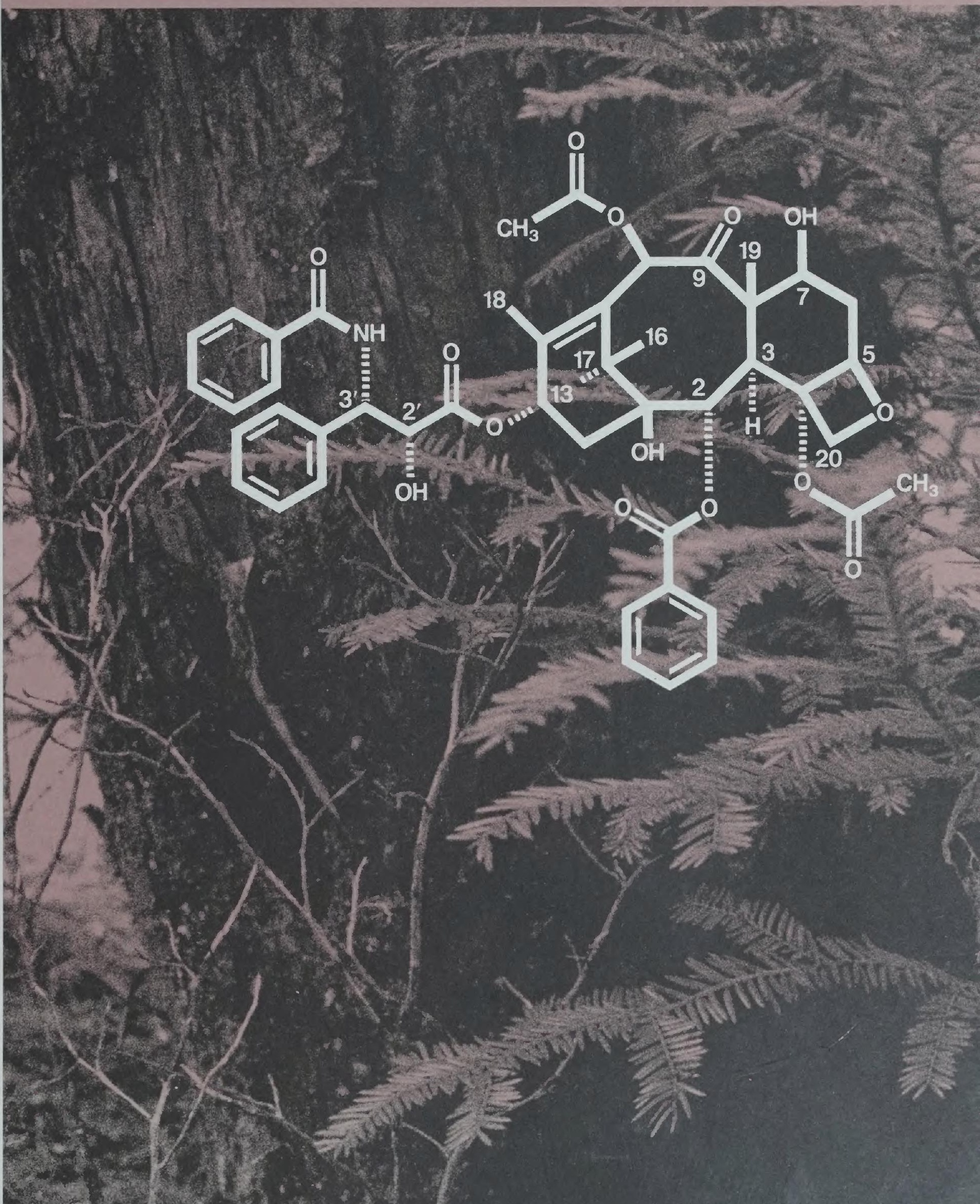




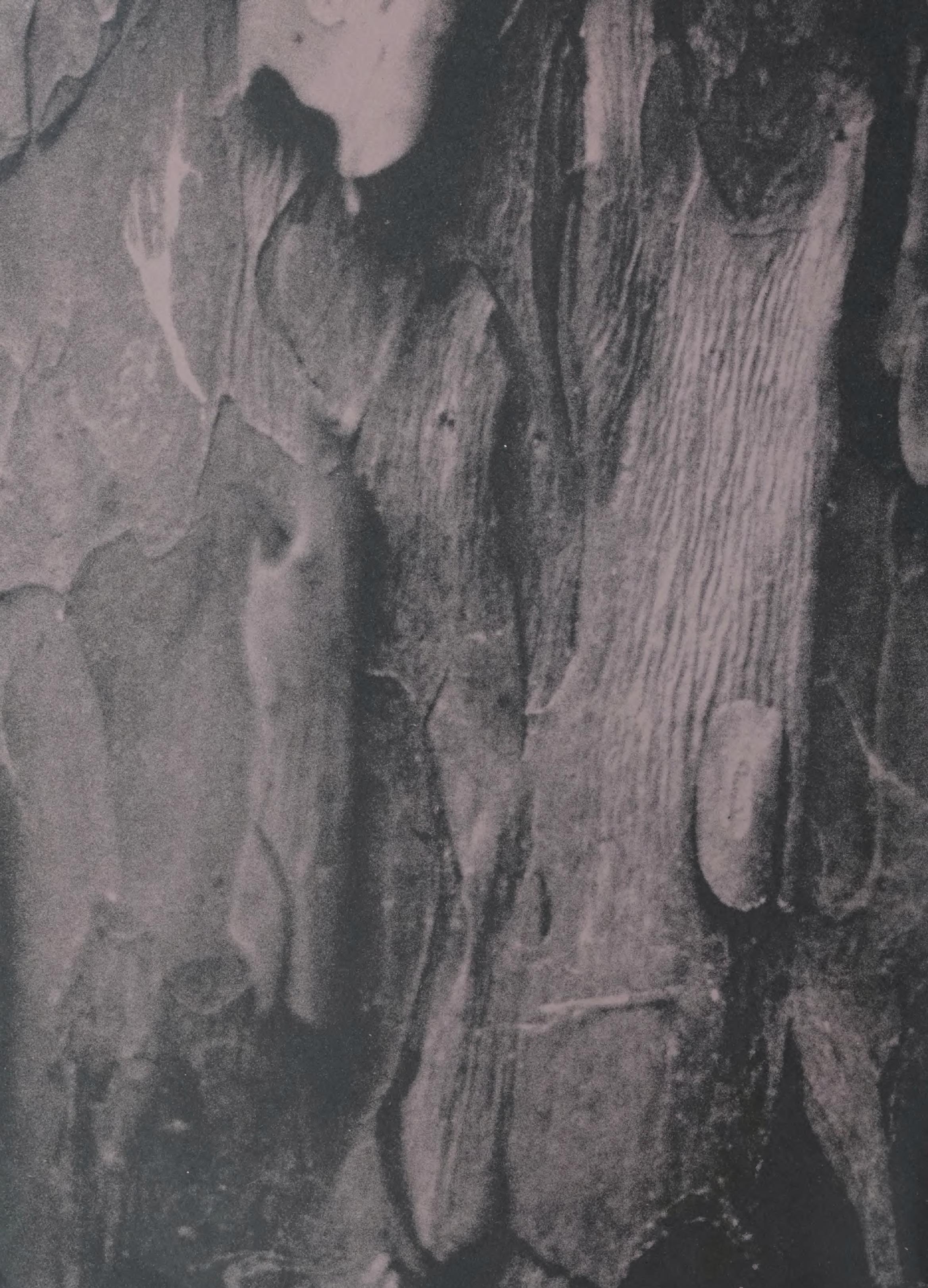




\section{Pacific Yew \\ Draft Environmental Impact Statement}

USDA Forest Service in Cooperation With USDI Bureau of Land Management and USDHHS Food and Drug Administration

Lead Agency:

Responsible Official:

For Further Information

Contact:

Comments Must Be Received By:
USDA Forest Service

Pacific Northwest Regional Office

333 SW First Avenue

PO Box 3623

Portland, OR 97208-3623

John Lowe

Regional Forester

USDA Forest Service

Pacific Northwest Region

Sally Campbell

Pacific Yew EIS Team Leader

USDA Forest Service

Pacific Northwest Region

333 SW First Avenue

PO Box 3623

Portland, OR 97208-3623

(503) 326-7755

March 15, 1993

Cover photos by Michael Ellis, Copyright - All rights reserved.

BLM LIBRARY

6C.653, BLDG. 50 
The Forest Service and the Bureau of Land Management (BLM), in compliance with the National Environmental Policy Act of 1969, is presenting seven alternative ways of managing the five-year (1993 to 1997) harvest of the Pacific yew tree (Taxus brevifolia) on federal lands. This harvest program is prompted by the need for taxol, a compound found in the yew tree which is an effective treatment for cancer.

Highlights of the alternatives are as follows:

A - Alternative A gives no emphasis to Pacific yew bark harvest; it emphasizes all resources according to forest plans and BLM resource management plans.

B - Alternative B emphasizes utilization of Pacific yew where it would otherwise be wasted; production of yew bark is dependent on timber harvest programs.

C - Alternative $\mathrm{C}$ emphasizes the highest degree of protection of Pacific yew and the ecosystem in yew harvest areas; it would produce a small amount of bark.

D - Alternative D emphasizes a high degree of protection of Pacific yew and the ecosystem in yew harvest areas while producing a moderate amount of bark.

E - Alternative E was dropped (see Chapter II).

F - Alternative F emphasizes high yew bark production with moderate protection of Pacific yew and the ecosystem in yew harvest areas.

G1 - Alternative G1 emphasizes moderate to high bark production and efficiency of bark collection with moderate protection of yew and the ecosystem in yew harvest areas.

G2 - Alternative G2 emphasizes entry into Owl Conservation Areas (as well as other areas) to provide the highest level of bark production with moderate protection of Pacific yew and the ecosystem in yew harvest areas.

Alternative $\mathrm{A}$ is the No Action Alternative.

Alternative G1 is the Forest Service and BLM preferred alternative.

A precedent established in court obliges reviewers participating in the $\mathrm{Na}$ tional Environmental Policy Act (NEPA) process to alert the agency to their positions in a meaningful way. Also important to those concerned with the issues presented in this EIS is another legal precedent which established that environmental objections that could have been raised at the draft stage may be waived if they are not raised until after completion of the final environmental impact statement (FEIS). We look forward to your comments. Please make specific suggestions to help us improve this assessment. 


\section{How This ElS is Organized}
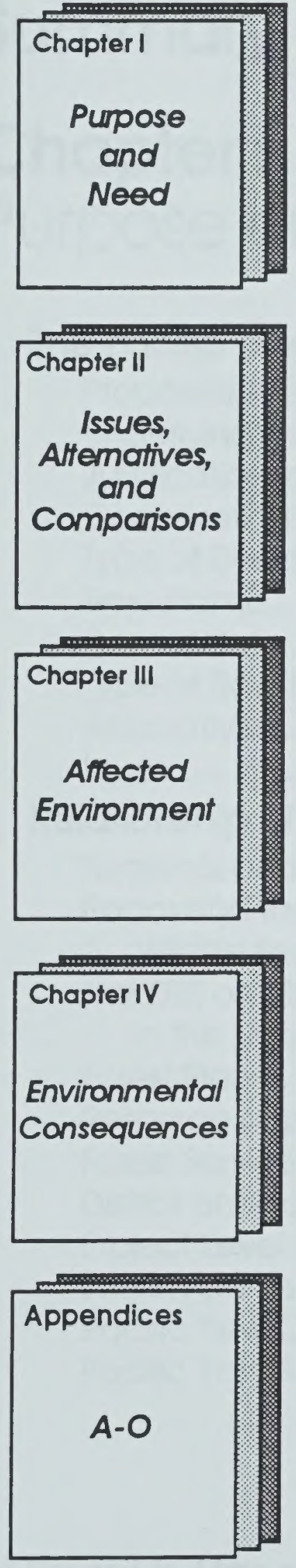

Introduces Pacific yew and the underlying need for taxol;

discusses the major public issues associated with the Pacific yew, taxol, and the EIS; and discusses the relationship

of the Pacific yew EIS to other documents.

Discusses the public issues used to help evaluate the alternatives; gives an overview of the alternatives; the Pacific yew harvest Standards and Guidelines; and how the alternatives respond to the issues.

Addresses the affected environment. This chapter is divided into three parts: Part One--The Pacific yew, Part Two--The Forest, and Part Three--The Yew and People.

Provides the analysis used for comparison of the alternatives; and discusses the environmental consequences of the alternatives. This Chapter is divided in the same manner as Chapter III.

Additional supporting and background information is presented in Appendices A-O. 

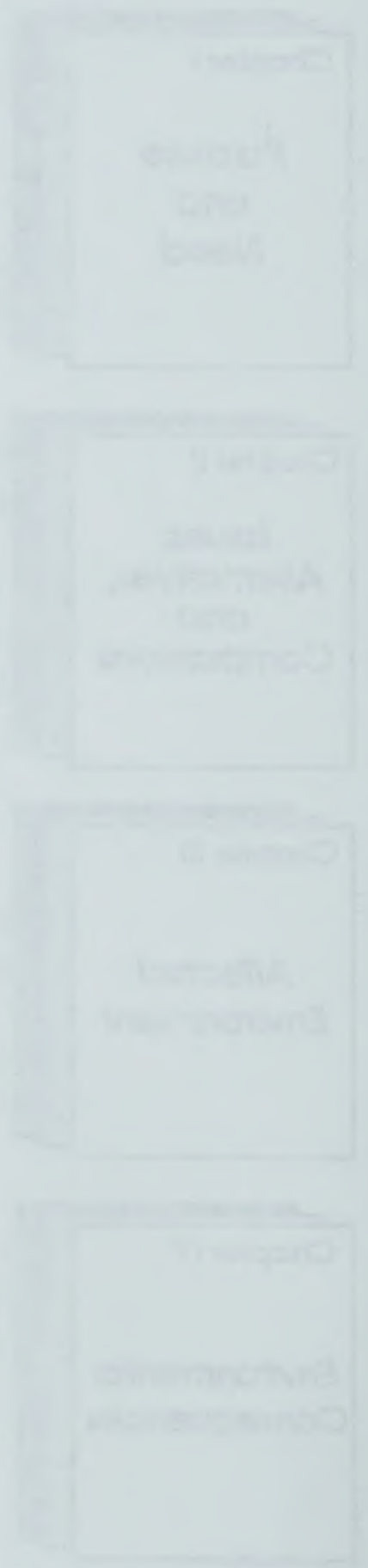


\section{Table of Contents}

Summary

\section{Chapter I \\ Purpose and Need}

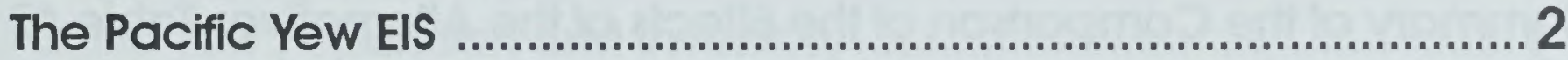

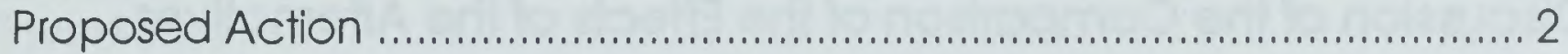

Underlying Need for Proposed Action .................................................... 2

Justification for Need ............................................................................. 2

Cooperating Agencies and Others ............................................... 4

Type of Decision ....................................................................... 4

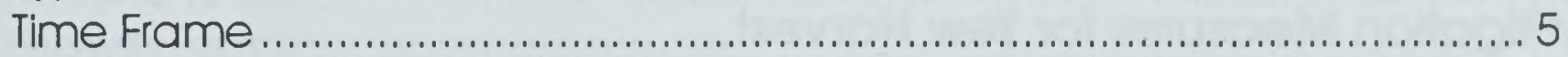

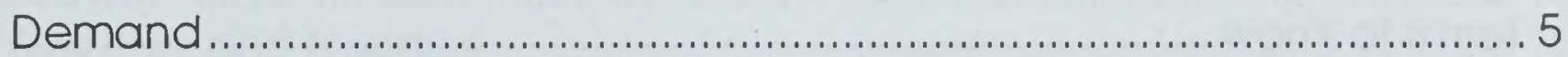

Type of Raw Material ...................................................................... 5

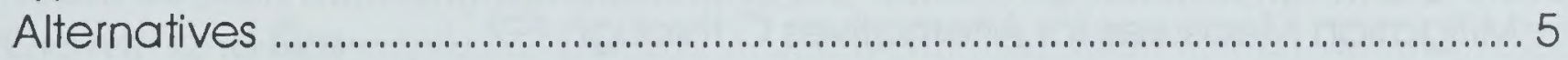

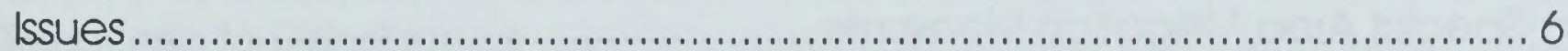

Relationship of the Pacific Yew ElS to Other Documents ................. 8

Regional and Multi-regional Vegetation Management EIS's ................... 8

Recovery Plan for the Northern Spotted OWL-USDI Fish and

Wildlife Service ..................................................................................... 9

The FEIS on Management for the Northern Spotted Owl

in the National Forests ................................................................ 9

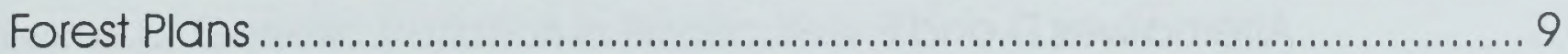

Resource Management Plans ....................................................... 9

Forest Service and BLM Yew Policies and Direction ................................ 10

District and Forest Decision Documents ................................................. 10

Project Level Analysis Documents ............................................................. 10

Interim Guide to the Conservation and Management of Pacific Yew ...... 10

Pacific Yew Comprehensive Management Strategy ............................... 11

Pacific Yew Act of 1992 ......................................................................... 11

\section{List of Figures}

Figure 1-1: Map of the Native Range of Pacific Yew .................................. 3 


\section{Chapter II \\ Issues, Alternatives, and Comparisons}

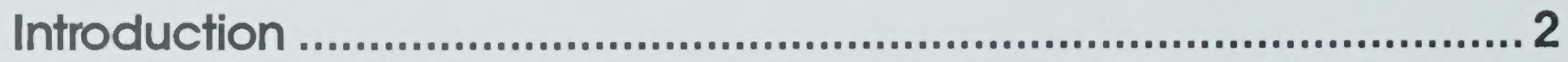

Issues Used to Help Evaluate the Altematives .................................2

Altematives Considered but Eliminated From Further Study ............. 10

Components Considered but Eliminated ……........................................ 10

Alternatives Considered But Eliminated ................................................ 11

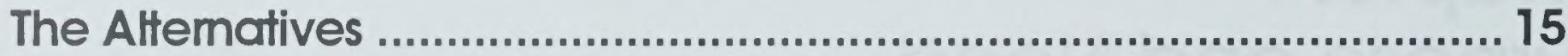

Description of Alternatives ............................................................ 19

Terms to Know .............................................................................. 20

Summary of the Comparison of the Effects of the Alternatives Table 40 Discussion of the Comparison of the Effects of the Altematives ........ 45

Issues: Provide Taxol, Protect the yew, Protect the Ecosystem .................... 45

Suggestion: Establish Sustainable Collection Level ....................................52 52

Suggestion: Consider Socio-economic Concerns ...................................... 52

Suggestion: Establish Areas of Collection .................................................... 55

Mitigation Measures for Yew Harvest.................................................56 56

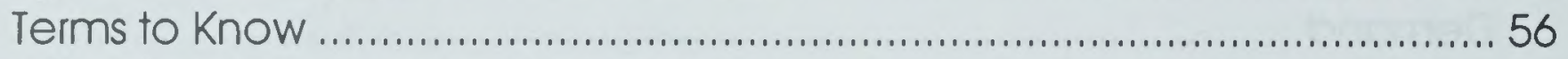

Mitigation Measures for Alternative B .....................................................57

Mitigation Measures for Alternatives C through G2 ……..........................6 60

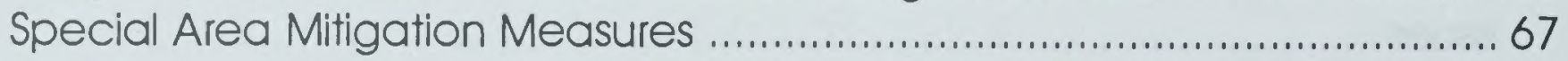

\section{List of Figures}

Figure II-1: Graphic Overview of the Alternatives:

Alternatives A, B, and C ..................................................... 16

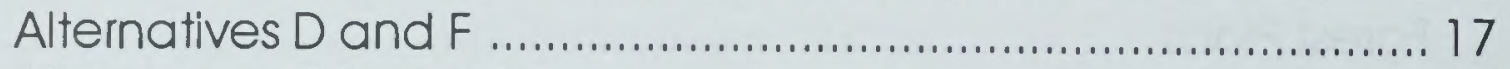

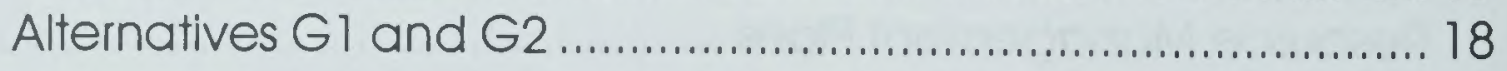

\section{List of Tables}

Table II-1: Comparison of the Effects Between Alternatives 


\section{Chapter III Affected Environment}

\section{Part One: The Pacific Yew}

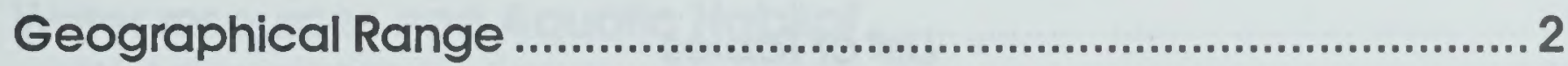

Land Ownership Patterns ......................................................... 2

Land Allocations ..................................................................... 5

Forest Service Management Plans .................................................. 5

Forest Service Management Areas .................................................... 5

BLM Management Plans ........................................................................ 7

Pacific Yew Population and Inventory ....................................... 8

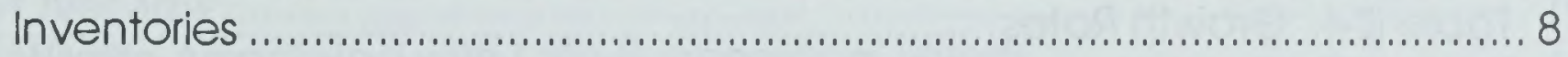

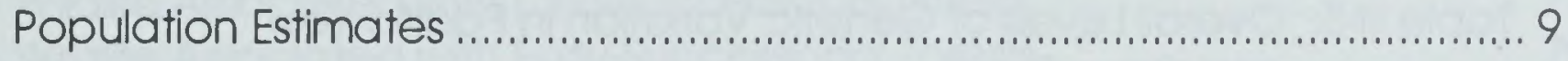

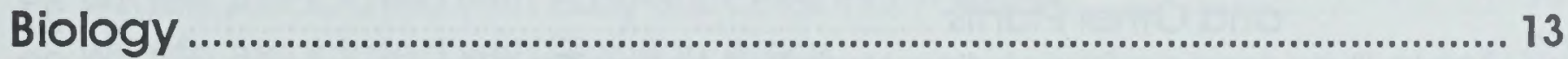

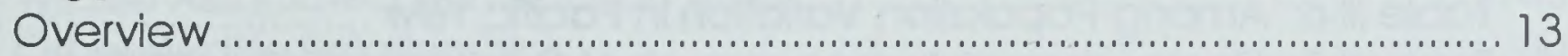

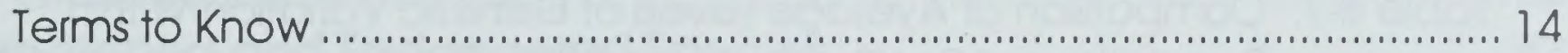

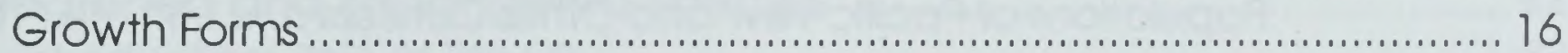

Yew Bark and Needles................................................................... 16

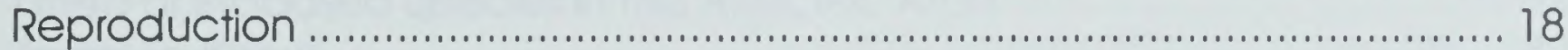

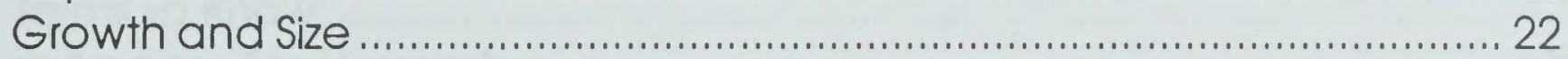

Response to Disturbance ....................................................................... 23

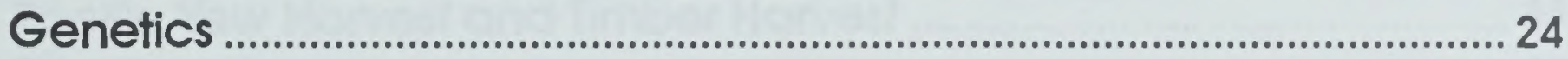

Relationships to Other Taxus Species ..................................................... 24

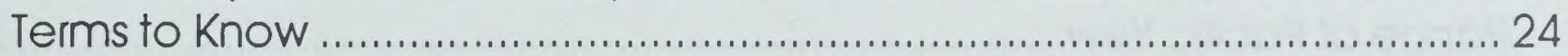

Genetic Variability ....................................................................... 25

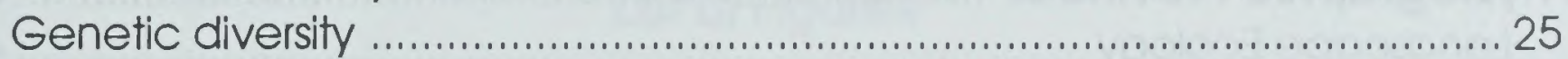

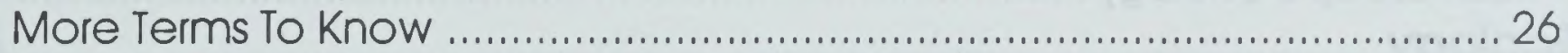

Levels of Genetic Variation in Pacific Yew ............................................... 26

Structure of Genetic Variation ............................................................... 27

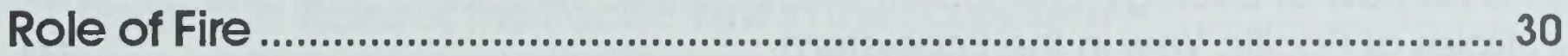

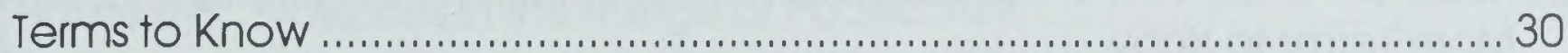

Role of Fire ..................................................................................... 30

Insects and Diseases of Pacific Yew ................................................... 33

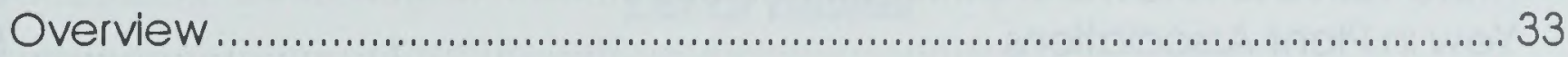

Insects and Diseases ........................................................................ 33

Port-Orford-Cedar Root Disease ........................................................... 34 


\section{List of Figures}

Figure III-1: Example of Diameter Distributions .................................... I 1

Figure III-2: Yew In The Understory ...................................................... 15

Figure III-3: Seeds and Foliage of Pacific Yew ...................................... 18

Figure III-4: Yew Regeneration ......................................................... 20

\section{List of Tables}

Table III-1: Affected Federal Lands, by Administrative Unit ..................... 4

Table III-2: Estimated Number of Yew Trees In Several National

Forests and BLM Districts

Table III-3: Average Amount of Bark (pounds) by Diameter at Breast Height (dbh) .................................................... 17

Table III-4: Growth Rates ...................................................................... 22

Table III-5: Overall Levels of Genetic Variation in Pacific Yew and Other Plants ........................................................ 27

Table III-6: Among-Population Variation in Pacific Yew ............................ 28

Table 1I-7: Comparison of Average Levels of Genetic Variation Within Populations of Pacific Yew and Other Conifers

\section{CHAPTER III - PART TWO: The Forest}

Landscape Pattems

Range of Pacific Yew ......................................................................... 36

Physiographic Provinces ..................................................................... 36

Landscape Ecology ........................................................................... 48

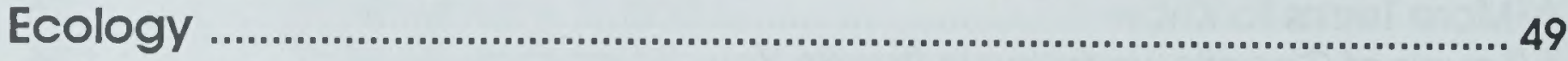

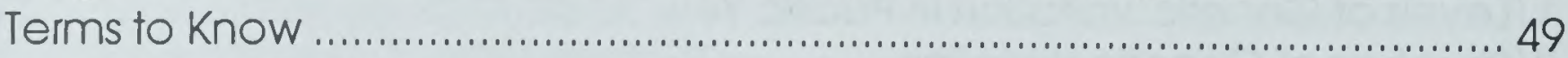

Overview of Ecology .......................................................................... 49

Roles of Pacific Yew in the Ecosystem ................................................. 50

More Terms to Know.................................................................... 50

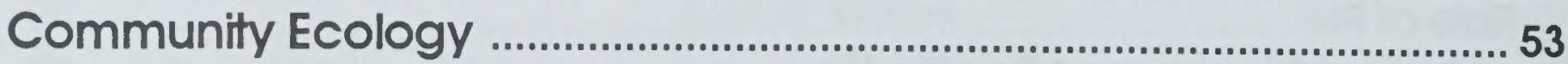

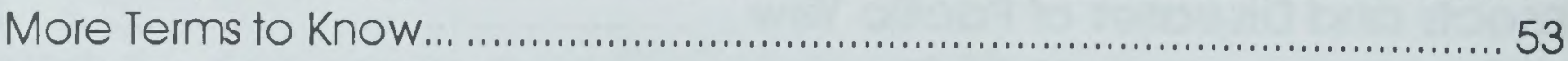

Yew in Plant Associations ..................................................................... 54

Other Components of the Ecosystem ............................................... 57

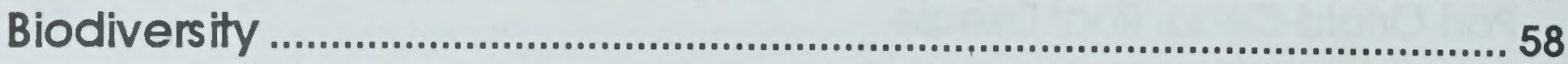

Overview of Biodiversity .................................................................. 58

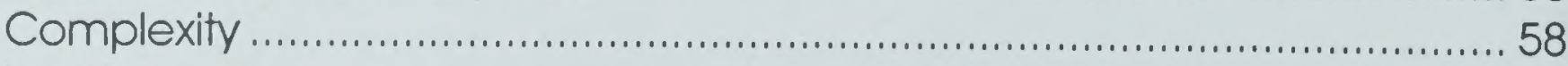

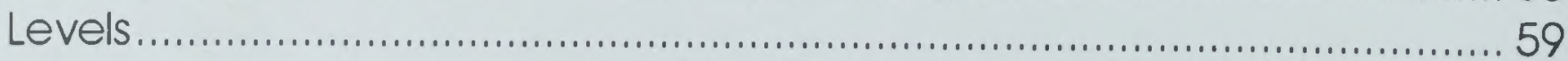




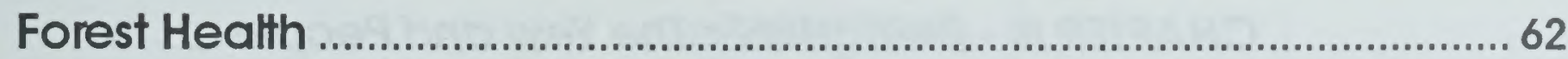

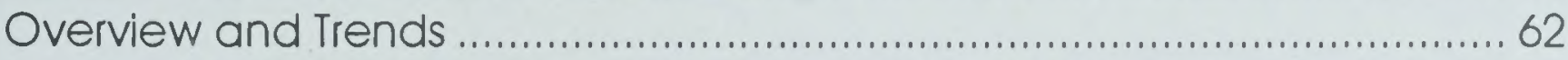

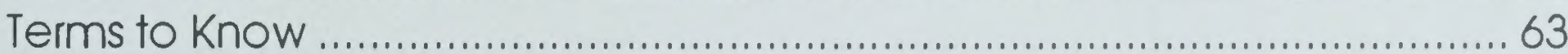

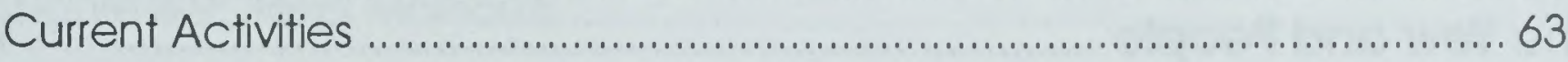

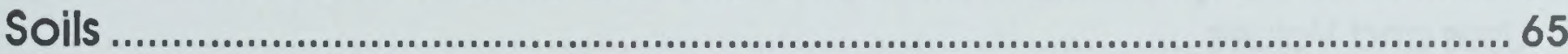

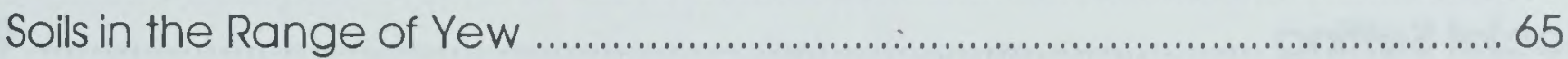

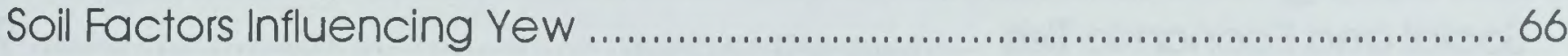

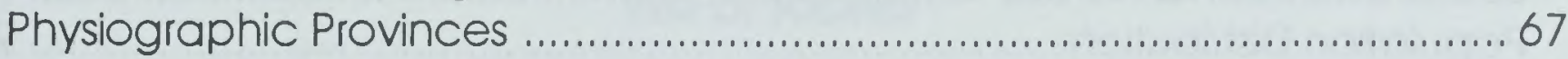

Water resources and Aquatic Habitat................................................. 69

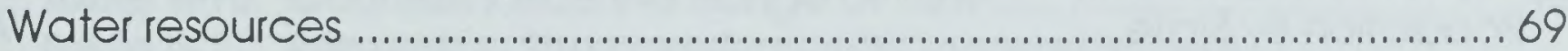

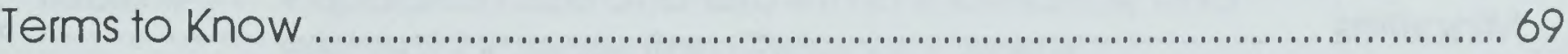

Aquatic and Fish Habitat ................................................................. 72

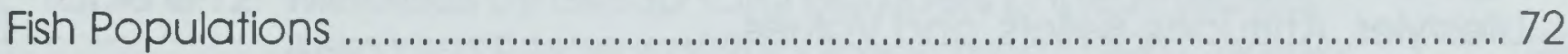

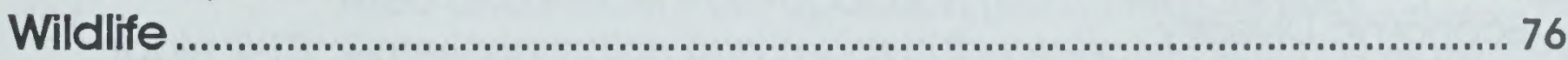

Terms to Know ...................................................................................... 76

Overview .......................................................................................... 76

Wildlife Associated with Late-Successional Forests ................................... 77

Wild life Associated with Early-Successional Forests .................................. 79

Wildlife Associated with Riparian Areas .................................................. 80

Other Wildlife Relationships ............................................................... 80

Threatened and Endangered Species .............................................. 82

Introduction; Role of This EIS ............................................................... 82

Listed or Proposed Species in the Affected Area ...................................... 82

Terms To Know ..................................................................................... 82

Yew Access for Harvest ......................................................................... 88

Pacific Yew Harvest and Timber Harvest .............................................. 88

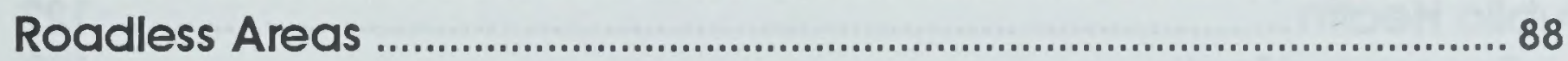

\section{List of Figures}

Figure III-5: Physiographic Provinces Within the Range of Pacific Yew ...... 37

Figure III-6: Potential Natural Vegetation Types ......................................... 39

Figure 1II-7: Roles of the Pacific Yew in the Ecosystem ............................. 51

Figure III-8: Provinces in the Range of Pacific Yew ................................6 68

\section{List of Tables}

Table III-8: Exampoles of Levels and Components of Biodiversity ............ 61

Table 1I-9: Summary of Threatened, Endangered and

Proposed Species 


\section{CHAPTER III - PART THREE: The Yew and People}

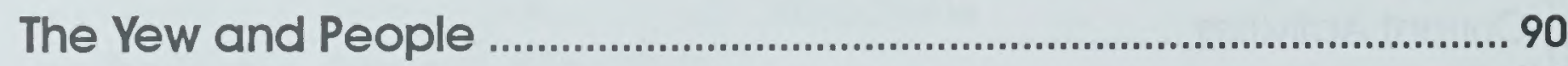

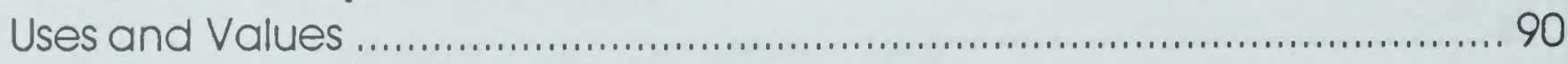

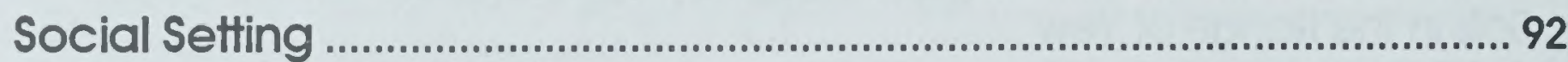

Social and Economic Ties ............................................................... 92

Population Distribution …………....................................................... 94

Population by Zone ……................................................................... 94

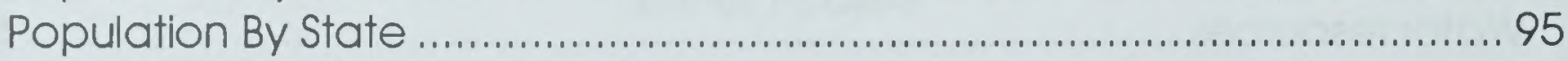

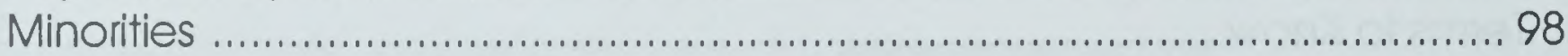

Age, Sex, and Labor Force Participation ……...................................... 100

Lifestyles, Attitudes, Beliefs, and Values ................................................... 100

Economic Diversity ..................................................................... 101

Market and Nonmarket Considerations ................................................... 103

Sources of Taxol ............................................................................... 103

Demand and Supply for Yew Bark....................................................... 106

Market for Yew Bark .......................................................................... 108

Theft of Pacific Yew Bark ..................................................................... 109

Market Value of Pacific Yew Tree ........................................................... 109

Nonmarket Value of Yew ................................................................... 110

Alternate Sources of Taxol .................................................................... 111

Collection Methods for Pacific Yew Bark, Needles, and
Wood for Taxol Production ................................................ 114

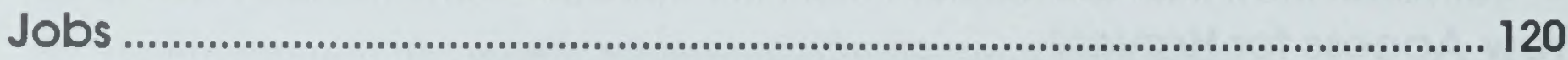

Bark Collection and Processing .......................................................... 120

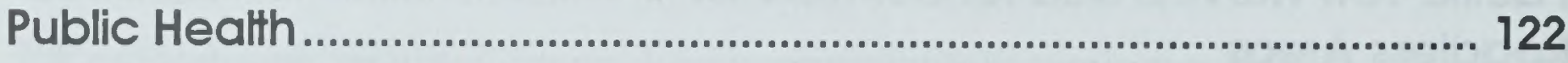

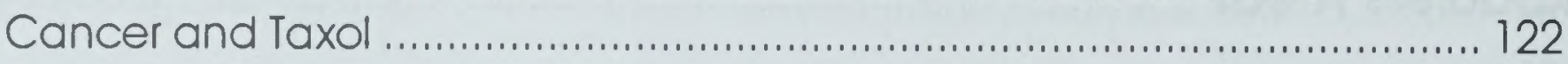

Taxol and Ovarian Cancer ............................................................. 122

Status of Taxol ................................................................................ 123

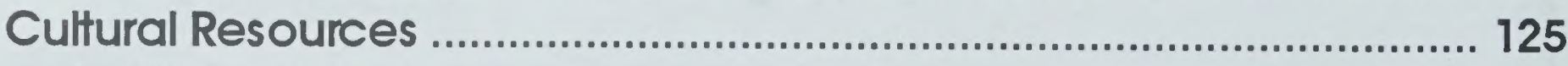

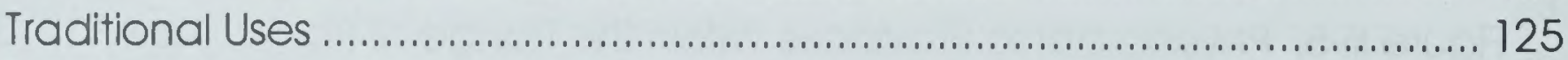

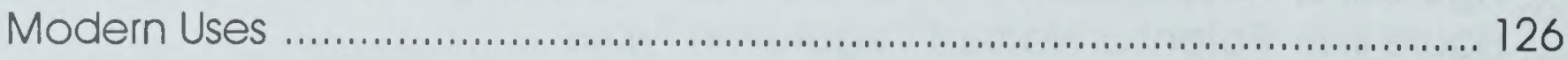

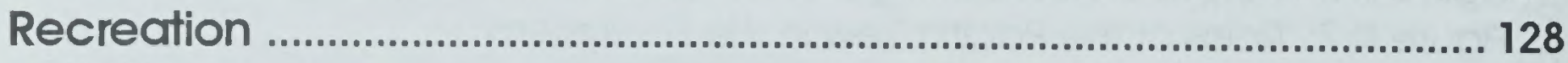

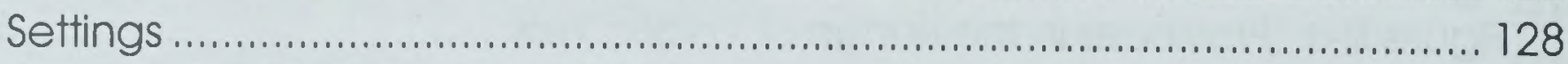

Congressionally Designated Areas .................................................... 129

Values and Activities ........................................................................ 131

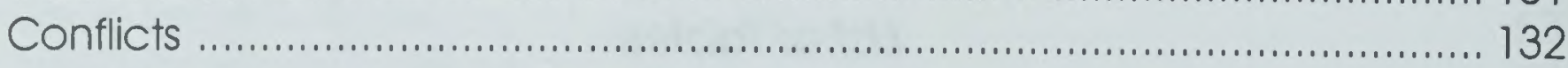




\section{List of Figures}

Figure III-9: Taxol Molecule

\section{List of Tables}

Table II-10: Counties Inside the Range of Yew

Table 1II-1 1: Population Size and Growth in Thousands, and

Percent Increase from Previous Census

Table III-12: Minorities by Group Total Numbers in the Affected

Area and Percent of Population (from 1990 Census) ............ 98

Table III-13: American Indian Trust Lands in the Affected Area by State .. 99

Table III-14: Bark Harvest

Table III-15: Pacific Yew Bark Harvesting Employment in Oregon, Washington, Idaho, and Montana, 1991 (Total Jobs) 


\section{Chapter IV \\ Environmental Consequences}

PART ONE: The Pacific Yew

How This Chapter is Organized

Assumptions Forming the Basis for Estimating

Environmental Effects

Assumptions and Guidelines .......................................................... 4

Pacific Yew Population and Inventory ................................................ 7

Population Estimation Methods .......................................................... 7

Impact of Yew Harvest on Yew Populations ............................................. 9

Projected Harvest of Yew Bark and Needles ......................................... 11

Acres Available for Yew Harvest ........................................................ 14

Effect of Inventory Error ..................................................................... 17

Sustainability of Pacific Yew ...................................................... 17

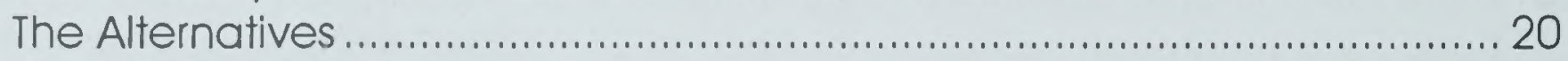

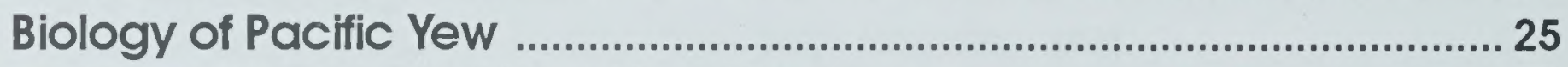

Effects Common to All the Alternatives ................................................. 25

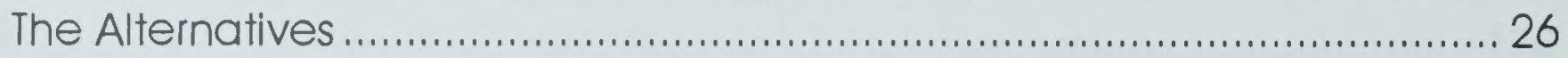

Genetics of the Pacific Yew .................................................................... 32

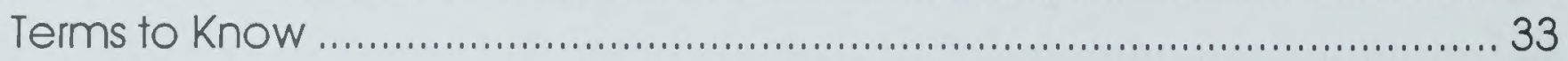

The Alternatives ............................................................................. 35

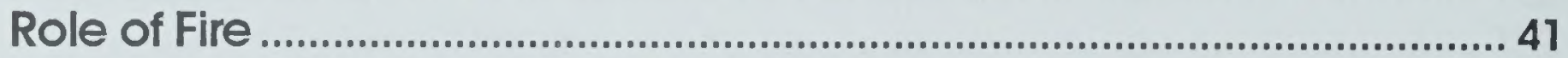

Risk of Fire from Yew Harvest ............................................................. 41

The Alternatives .............................................................................. 41

Survival of Yew Following Fire ............................................................ 43

The Alternatives ................................................................................. 43

Insect and Disease Pests of Pacific Yew ............................................... 47

The Alternatives ......................................................................... 48

Port-Orford-Cedar Root Disease ...................................................... 50 


\section{List of Figures}

Figure IV-1: Uneven and Even Flow of Pacific Yew Harvest

\section{List of Tables}

Table IV-1: The Impact of the Alternatives on the Estimated Yew

Population - Combined National Forests and BLM Districts .... 9

Table IV-2: The Impact of the Alternatives on Yew

Populations in the Nez Perce National Forest, Idaho ............. 10

Table IV-3: The Impact of the Alternatives on Yew Populations in

Seven National Forests in Washington and Oregon .............. 10

Table IV-4: The Impact of the Alternatives on Yew Populations in

BLM Districts, Western Oregon .............................................. 11

Table IV-5: Maximum Bark Available for Harvest in National Forests

and BLM Districts, Combined ............................................ 12

Table IV-6: Maximum Bark Available for Harvest in the Nez Perce

National Forest in Idaho ..................................................... 12

Table IV-7: Maximum Bark Available for Harvest in Seven National

Forests in Washington and Oregon

Table IV-8: Maximum Bark Available for Harvest in BLM Districts,

Western Oregon .............................................................. 13

Table IV-9: Maximum Needles Available for Yew Harvest in

National Forests and BLM Districts, Combined ...................... 14

Table IV-10: Maximum Acres Available for Yew Harvest in

National Forests and BLM Districts, Combined ..................... 15

Table IV-11: Maximum Acres Available for Yew Harvest in the Nez Perce National Forest in Idaho ..................................... 15

Table IV-12: Maximum Acres Available for Yew Harvest in

Seven National Forests in Washington and Oregon ............. 16

Table IV-13: Maximum Acres Available for Yew Harvest in

BLM Districts, Western Oregon ......................................... 16

Table IV-14: Potential Effects on the Genetic Resource Under

the Different Alternatives 


\section{CHAPTER IV - PART TWO: The Forest}

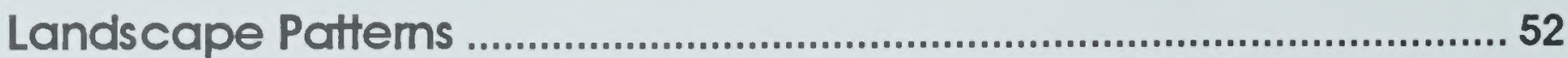

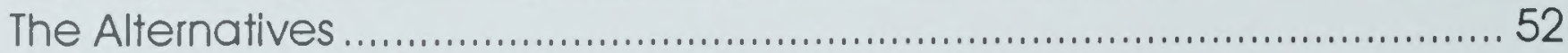

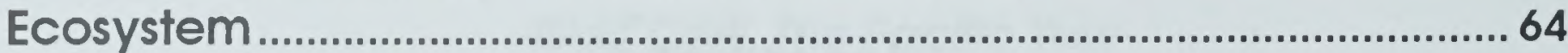

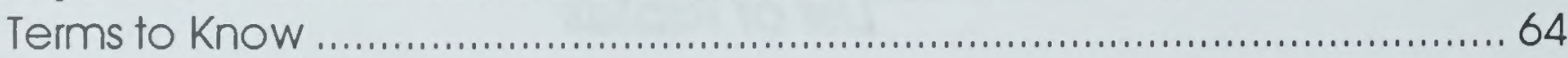

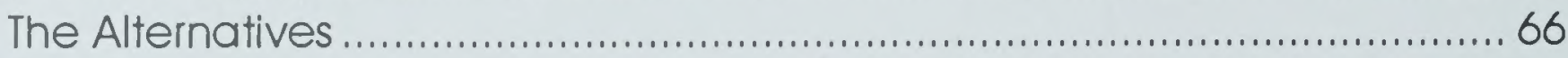

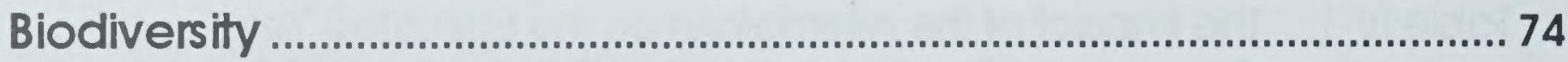

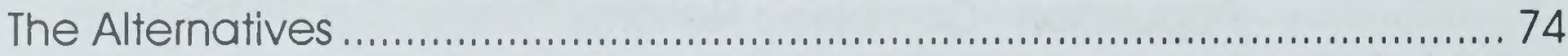

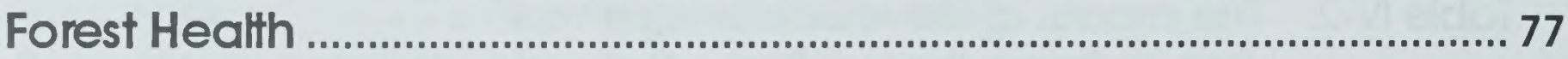

Ecosystem Management ............................................................... 77

The Alternatives ............................................................................... 78

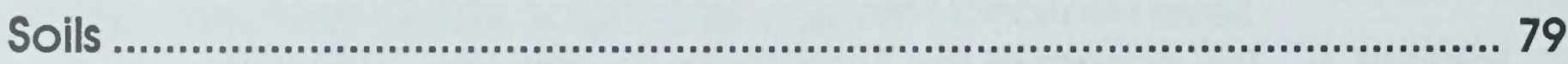

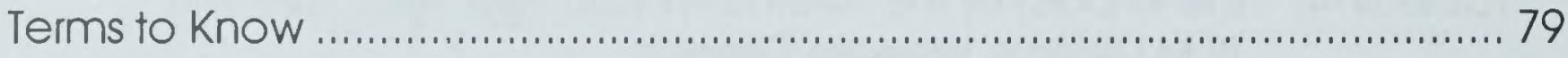

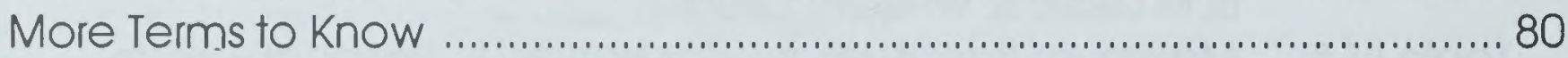

The Alternatives .......................................................................... 81

Water Resources and Aquatic Habitat ............................................... 84

The Alternatives ...................................................................................... 85

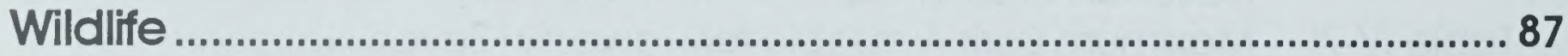

Terms To Know .................................................................................. 88

Species Associated with Late-Successional Forests .............................. 88

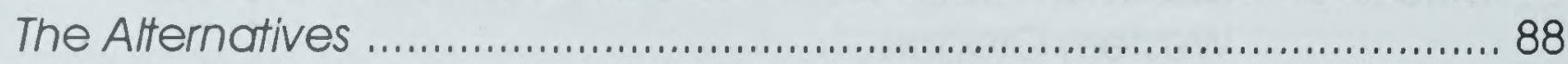

Species Associated with Early-Successional Forests ................................. 97

The Alternatives .............................................................................. 97

Species Associated with Riparian Areas .................................................. 100

The Alternatives ............................................................................ 100

Threatened and Endangered Species ................................................. 102

The Alternatives ...................................................................... 103

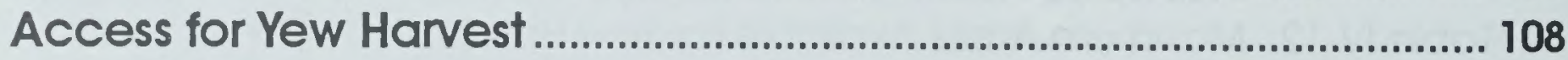

The Alternatives ................................................................................... 108

Pacific Yew Harvest and Timber Harvest ............................................... 110

The Alternatives ............................................................................... 110

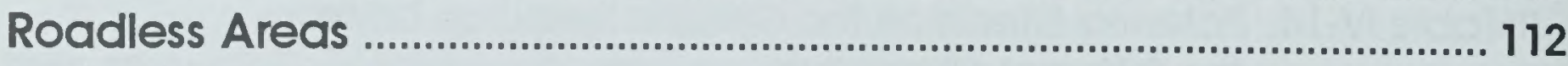

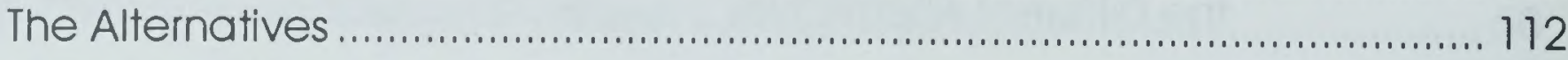

\section{List of Tables}

Table IV-15: Types of Potential Impacts on Physiographic Provinces, Vegetation Zones, and Land Slope Categories 
Social and Economic Effects ........................................................... 114

The Alternatives ......................................................................... 115

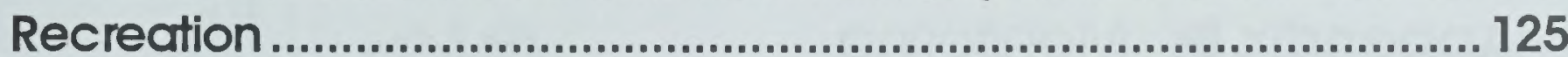

The Alternatives .......................................................................... 126

Summary of Irreversible or Irretrievable

Committment of Resources ................................................... 128

Irreversible Effects .................................................................... 128

Irretrievable Effects _................................................................... 129

List of Tables

Table IV-16: Social and Economic Effects Under Each Alternative

\section{List of Preparers}

\section{Distribution List}

\section{References}

\section{Glossary}

Index 


\section{Appendices}

Appendix A: Public Involvement

Appendix B: Monitoring

Appendix C: Mitigation Measures for the Pacific Yew

Appendix D: Land Ownerships

Appendix E: Bristol-Myers Squibb and

Federal Government Agreement

Appendix F: Pacific Yew Inventories

Appendix G: Insects and Diseases of Pacific Yew

Appendix H: Pacific Yew Plant Associations

Appendix I: Soils

Appendix J: Wildlife and Biological Assessment

Appendix K: Taxol

Appendix L: Cultural History of Pacific Yew

Appendix M: Pacific Yew Research

Appendix N: Pacific Yew harvest Policies

Appendix O: Annotated Bibliography 


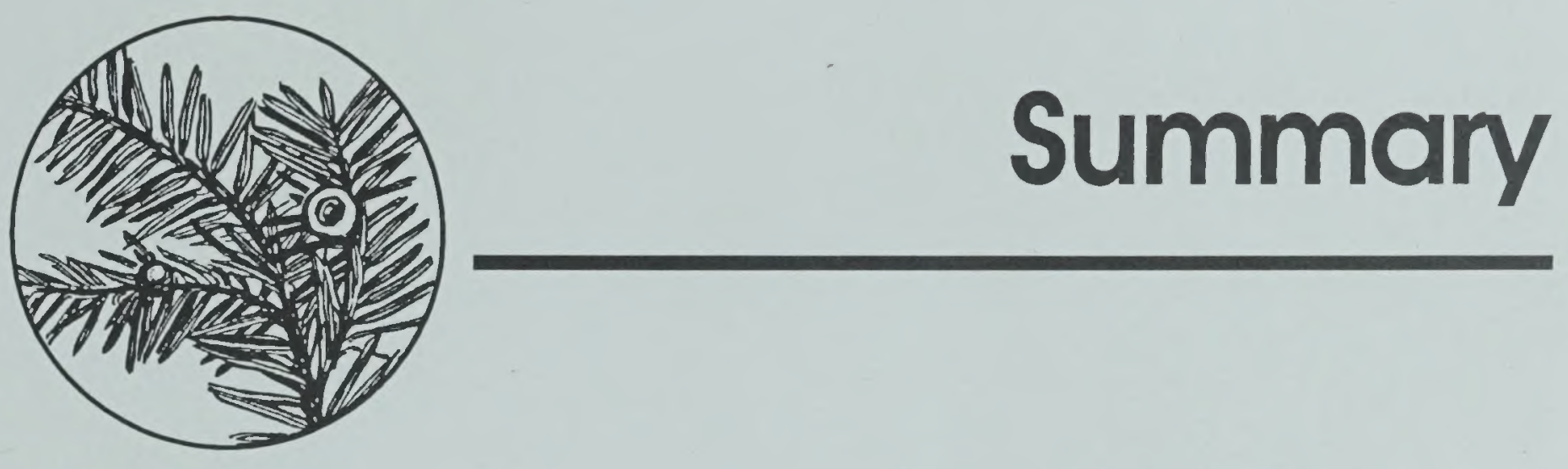




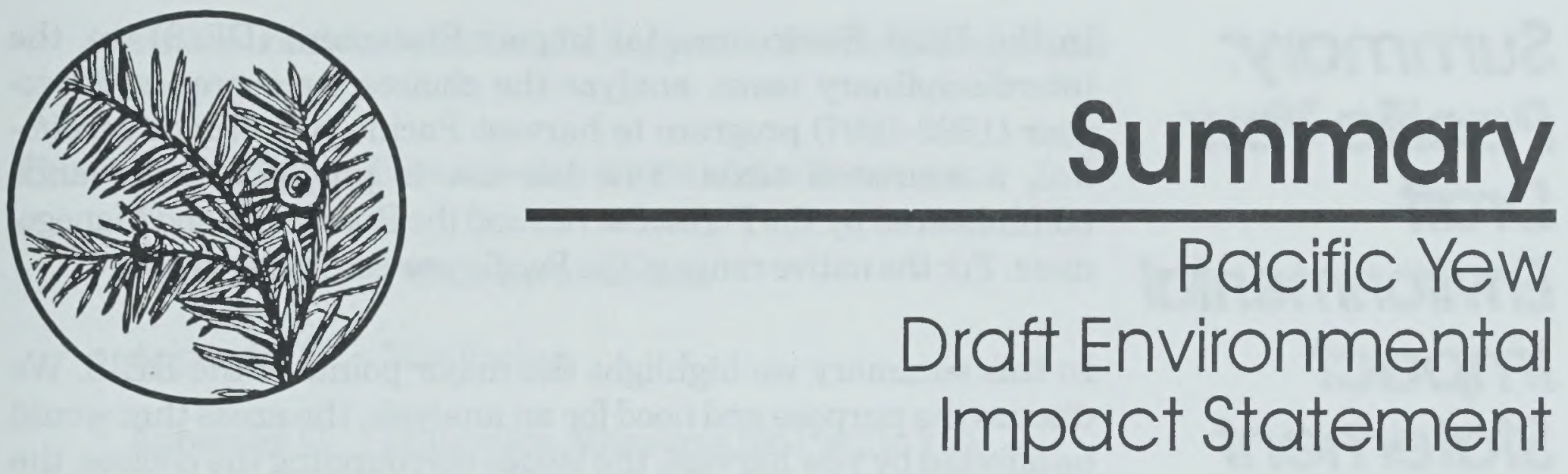

Summary: Pacific Yew Draft Environmental Impact Statement

Table of Contents

How this DEIS is organized

Why This DEIS? — Purpose and Need Terms to know

The Affected Area

The Issues

The Proposed Alternatives

Alternative $A$

Alternative $B$

Alternative $C$

Alternative D

Alternative $F$

Alternative $G 1$

Alternative $G 2$

Summary of the Comparison of the Effects of the Altematives

Consequences
Discussion of the Comparison of the Effects of the Alternatives Main Issues: Provide Taxol, Protect the yew, Protect the Ecosystem

Suggestion: Establish Sustainable Collection Level

Suggestion: Socio-economic

Concerns

Suggestion: Establish Areas of

Collection

Response Form 
Summary:

Pacific Yew

Draff

Environmental

Impact

Statement
In the Draft Environmental Impact Statement (DEIS) we, the interdisciplinary team, analyze the choices for a proposed fiveyear (1993-1997) program to harvest Pacific yew (Taxus brevifolia), a source of taxol. Yew harvest is proposed from lands administered by the Forest Service and the Bureau of Land Management. For the native range of the Pacific yew see Figure S-1.

In this summary we highlight the major points of the DEIS. We discuss the purpose and need for an analysis, the areas that would be affected by yew harvest, the issues surrounding the choices, the proposed alternatives, and the preferred alternative. We also summarize the analysis of the effects of implementing the alternatives. We look at the effects on Pacific yew biology and range; the forest ecosystems yew is a part of; and the socioeconomic implications of harvesting yew for taxol production.

\section{How this DEIS is organized}

Environmental Impact Statements are organized in several sections, and it is sometimes confusing and difficult to follow the issues or to find out about the particular topics that are of most interest to you. In order to help you find your way, this is how the document is organized:

- Chapter I discusses the purpose of the proposed action and need for the environmental impact statement.

- Chapter II describes the proposed alternatives or choices. We compare the choices and the consequences of implementing them (based on the analysis in Chapter IV). We identify a preferred alternative.

- Chapter III describes the ecological, social, and economic aspects of the affected area. This chapter is divided into three sections: The Pacific Yew; The Forest; and The Yew and People.

- Chapter IV describes the consequences of implementing the alternatives proposed in Chapter II. We analyze the possible ways the environment could be affected. This is a prediction based on available information and our analy- 
sis; we consider what might happen in the near future and long-term.

The following Appendices are also a part of the document:

- Appendix A - Public Involvement

- Appendix B - Monitoring

- Appendix C - Mitigation Measures,for Pacific Yew

- Appendix D - Land Ownerships

- Appendix E - Bristol-Myers Squibb and Federal Government Agreements

- Appendix F - Pacific Yew Inventories

- Appendix G - Insects and Diseases of Pacific Yew

- Appendix H - Pacific Yew Plant Associations

- Appendix I - Soils

- Appendix J - Wildlife and Biological Assessment

- Appendix K - Taxol

- Appendix L - Cultural History of Pacific Yew

- Appendix M - Ongoing and Needed Research for Pacific Yew

- Appendix N - Pacific Yew Harvest Policies

- Appendix O - Annotated Bibliography

\section{Why This DEIS? - Purpose and Need}

The Forest Service, the Bureau of Land Management, and the Food and Drug Administration (the three agencies cooperating to prepare this EIS) propose to harvest, over the next five years, anywhere from one million to 30 million pounds of dry yew bark. 


\section{Summary}

The bark would come from yew trees and shrubs on federal lands in the northwest to provide taxol for cancer research and treatment.

The underlying need is for an immediate supply of Pacific yew bark, from which taxol can be extracted. Taxol, a compound found in all parts of Pacific yew, is among the most effective drugs currently available for treating ovarian and other types of cancer. Extraction of taxol from the bark of the Pacific yew is currently the only FDA-approved process for taxol production.

In the DEIS we weigh the effects of various yew harvest alternatives on Pacific yew, the ecosystem, and the communities located within the native range of the Pacific yew. We recommend the harvest regime we believe would be best for maintaining a balance between environmental concerns and human needs.

The Forest Service Regional Forester for the Pacific Northwest Region and the Oregon State Director of the Bureau of Land Management (BLM) will select a yew harvest alternative after the public comments on the DEIS are analyzed. A Final EIS will then be published along with two Records of Decision (one from the Forest Service and one from BLM) documenting each deciding official's selection and the rationale for the decision.

The following are definitions of a few terms used throughout this summary: 


\section{Terms to Know}

Timber Sale Unit - an area within a timber sale that has a silvicultural prescription for a (1) clearcut, (2) shelterwood, or (3) seed tree harvest.

Partial-cut Sale Unit-an area within a timber sale that has a silvicultural prescription to cut only part of a stand. Techniques that involve "partial cutting" include thinning, salvage operations, and prescriptions designed to produce an uneven-aged stand of trees.

Non-sale Area-an area in a national forest or BLM district where no timber sales, as described above, are scheduled in the next five years, but where yew harvest is allowed according to land use plans.

Old Growth-A forest composed of many large trees, snags, and numerous down logs with a multilayered canopy composed of several tree species, usually the final or a transitional stage of forest stand development.

Owl Conservation Areas- those areas formally designated for protection of the northern spotted owl. They provide a contiguous block of habitat to be managed and conserved for spotted owls. The blocks are placed so as to be well distributed throughout the range of the owl and spaced closely enough to facilitate dispersal of owls among them. We are using "Owl Conservation Areas" (OCAs) to include Forest Service habitat conservation areas (HCAs), and BLM's old-growth emphasis areas (OGEA), connectivity areas (CON), and owl pair sites (OPS).

Set-aside Areas- for this EIS, these are defined as lands where timber harvest is precluded by other resource management objectives. 


\section{Summary}

\section{The Affected Area}

In the DEIS we cover a large portion of the native range of the Pacific yew. (See figure S-1.)

The Pacific yew tree and shrub is unique to northwestern forests. Important to Native Americans and a small contingency of woodworkers, it has been largely ignored by modern society. Recently, taxol, a substance extracted from yew, dramatically enhanced its value. Taxol is considered the most promising cancer fighting compound discovered in recent years.

Pacific yew grows in forests from the southern tip of southeast Alaska south through the Pacific Coast region of British Columbia to the Olympia Peninsula of Washington and to northeastern Oregon. Yew is rare in the coast range between the Olympic Peninsula and the Umpqua River in Oregon and northern California and fairly common in low to moderate elevations within the Cascade range. It is unusually common in the south fork of the Clearwater River basin in Idaho where, instead of being a minor forest component, it becomes a more dominant species.

When Pacific yew became important as a source of taxol, the Forest Service and the BLM developed procedures to inventory the species. Inventory crews worked in the field in 1991 and 1992 gathering information for a sample estimate (a complete census of yew trees would take years and be too costly). The inventory numbers are presented under each alternative as number of yew trees available, number of acres available for yew harvest, and pounds of dry bark.

Pacific yew as an ecosystem component is not well-understood. The importance of yew in cycling nutrients, modification of microclimate, maintenance of specialized mycorrhizae, and other organisms is unknown. Yew wood is one of the most decay resistant woods of the northwestern conifers; consequently its decomposing boles and branches have a relatively long presence in northwest forest ecosystems. Given the unique biochemistry of the species, it is likely that yew plays a unique role in the forest.

The socioeconomic implications of harvesting Pacific yew range from providing cancer patients with taxol, to creating jobs in local communities, to maintaining and ensuring the sustainability of natural resources for future generations. 
Figure S-1: The Native Range of Pacific Yew

- Prince Rupert
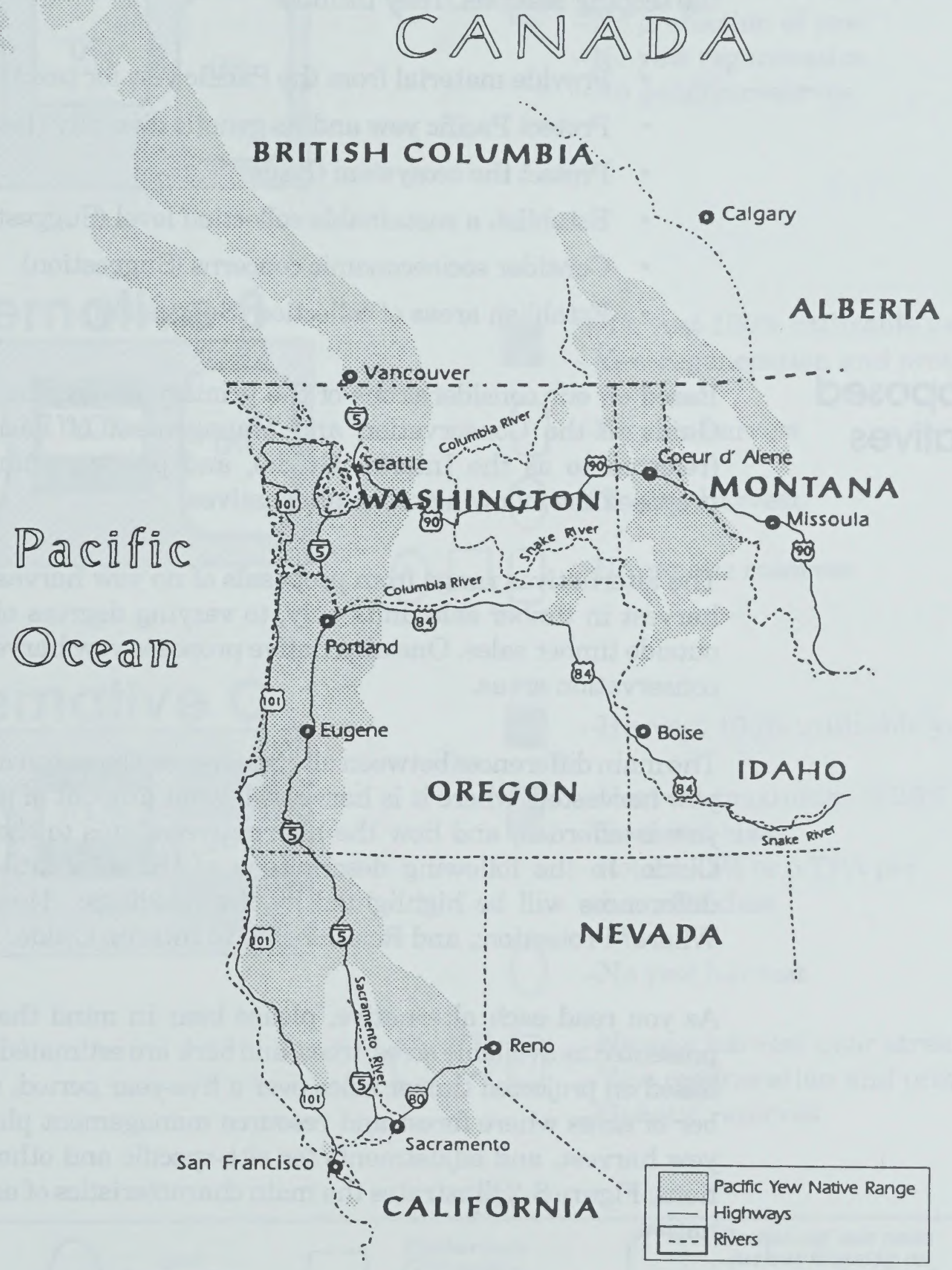


\section{summary}

\section{The Issues}

The interdisciplinary team identified several major issues and suggestions after reviewing public comments and material from the scoping sessions. They include:

- Provide material from the Pacific yew for taxol (Issue)

- Protect Pacific yew and its genetic diversity (Issue)

- Protect the ecosystem (Issue)

- Establish a sustainable collection level (Suggestion)

- Consider socioeconomic concerns (Suggestion)

- Establish areas of collection (Suggestion)

\section{The Proposed Altematives}

Based on our considerations of the primary issues, the "Interim Guide to the Conservation and Management of Pacific Yew" (referred to as the Interim Guide), and public comments, we proposed the following seven alternatives.

The alternatives range from proposals of no yew harvest, to yew harvest in timber sale units only, to varying degrees of harvest outside timber sales. One alternative proposes yew harvest in owl conservation areas.

The main differences between alternatives are based on amount of yew harvested, where it is harvested, what amount of protection yew is afforded, and how the alternative relates to the Interim Guide. In the following descriptions of the alternatives these differences will be highlighted by the headings: How Much?, Where? Protection:, and Relationship to Interim Guide.

As you read each alternative, please bear in mind that figures presented as available acres, trees, and bark are estimated amounts based on projected timber sales over a five-year period, the number of acres where forest and resource management plans allow yew harvest, and adjustments for site-specific and other restrictions. Figure S-2 illustrates the main characteristics of each alternative. 
Figure $S$-2

Graphic Overview of the Alternatives: Alternatives A, B, and C

\section{Alternative A}

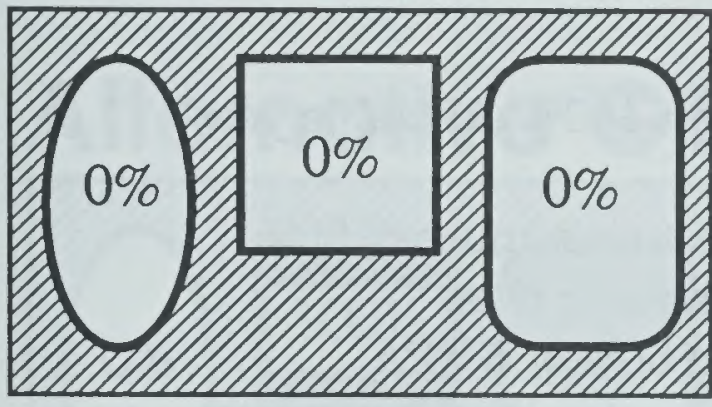

Alternative B

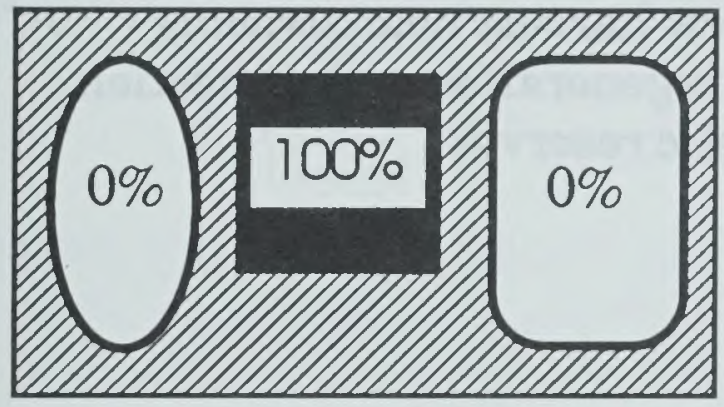

\section{Alternative C}

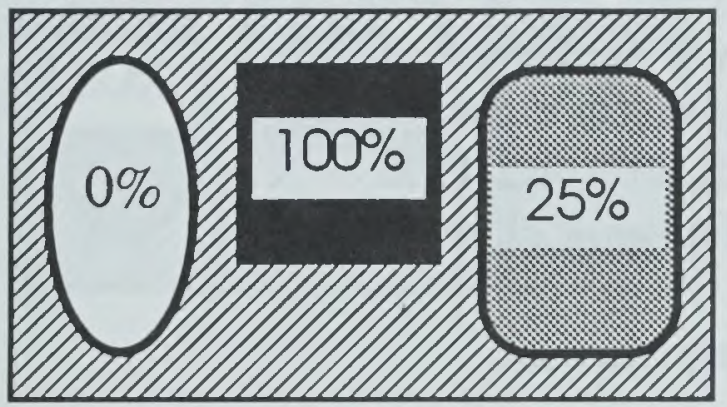

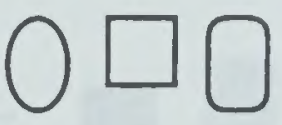

--No yew harvest for taxol production

--No protection of yew

--No yew regeneration

--No genetic reserves

--Harvest $100 \%$ utilizable yew

--Yew regeneration and protection

--No yew harvest

--No yew harvest

--No genetic reserves

--Harvest $100 \%$ utilizable yew

--Harvest maximum of $25 \%$ per diameter class

--Retain $75 \%$ or 5 TPA per diameter class

--No yew harvest

--No yew harvest near streams

--Yew regeneration and protection

--Genetic reserves

Key

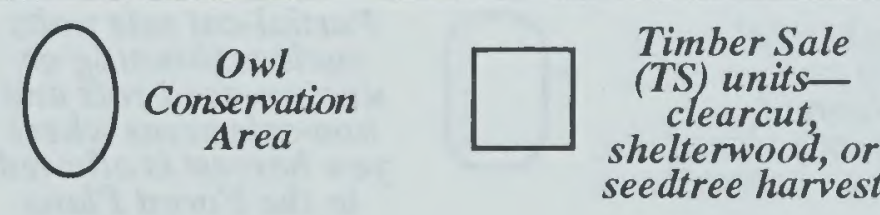

Partial-cut sale units such as thinning or uneven-aged cuts and non-sale areas where yew harvest is allowed in the Forest Plans 


\section{summary}

Figure S-2 (continued)

Graphic Overview of the Alternatives: Alternatives $D$ and $F$

Alternative D

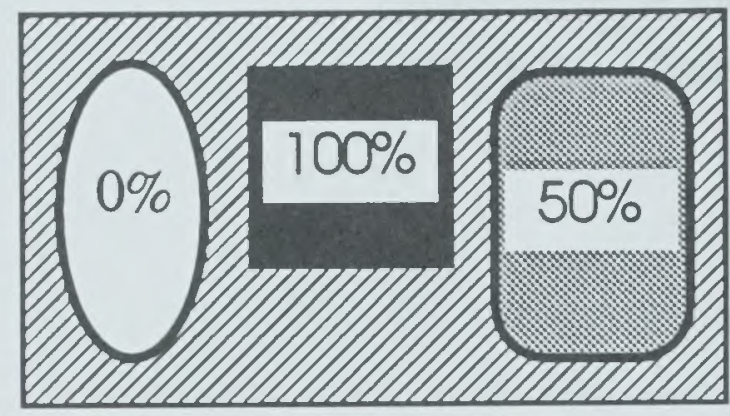

\section{Alternative $\mathrm{F}$}

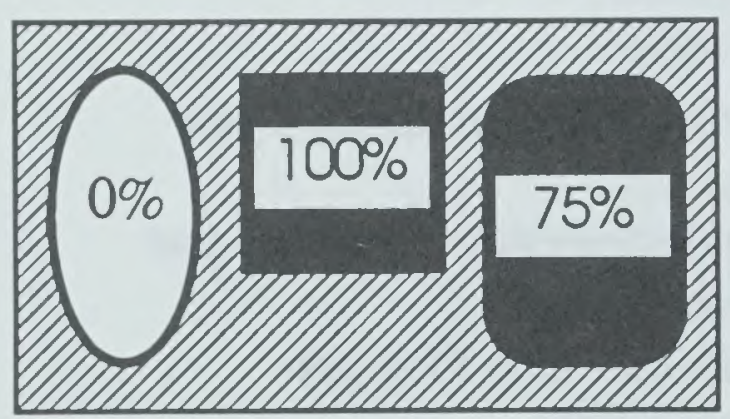

--Harvest 100\% utilizable yew

--Harvest maximum of $50 \%$

per diameter class

--Retain $50 \%$ or 5 TPA

per diameter class

--No yew harvest

$0 \square 0$

--No yew harvest near streams

--Yew regeneration and protection

--Genetic reserves

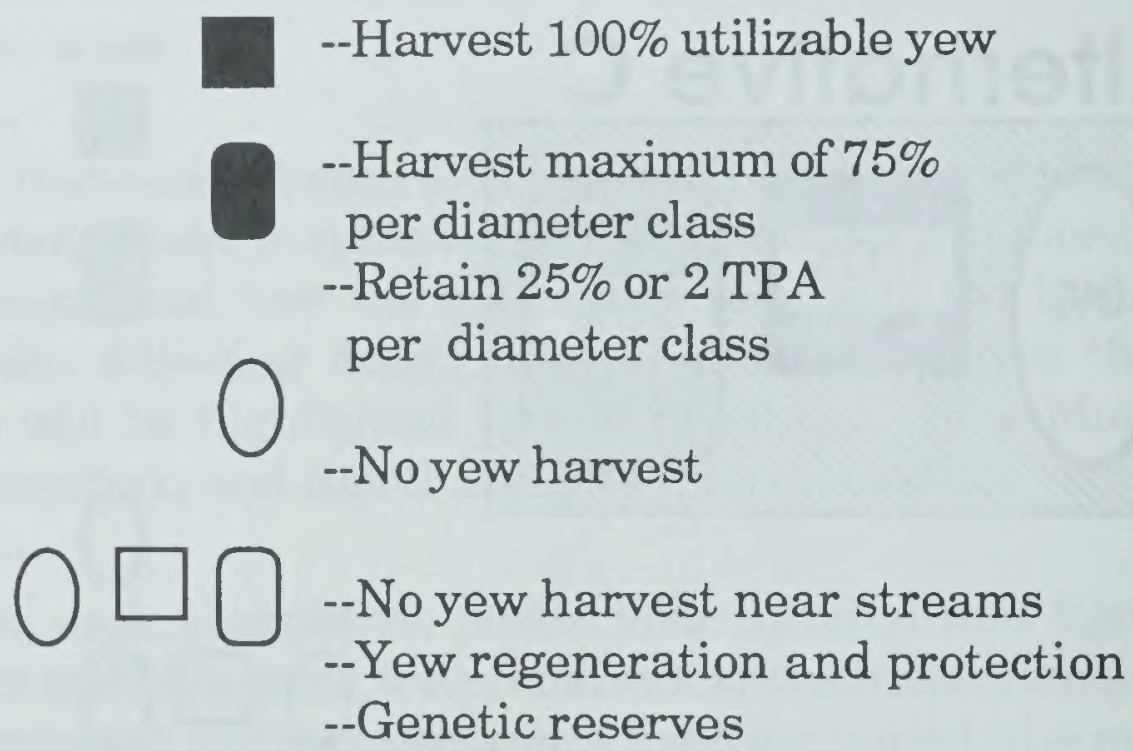

Key
Timber Sale (TS) unitsclearcut, shelterwood, or seedtree harvest
Partial-cut sale units such as thinning or uneven-aged cuts and non-sale areas where yew harvest is allowed in the Forest Plans 

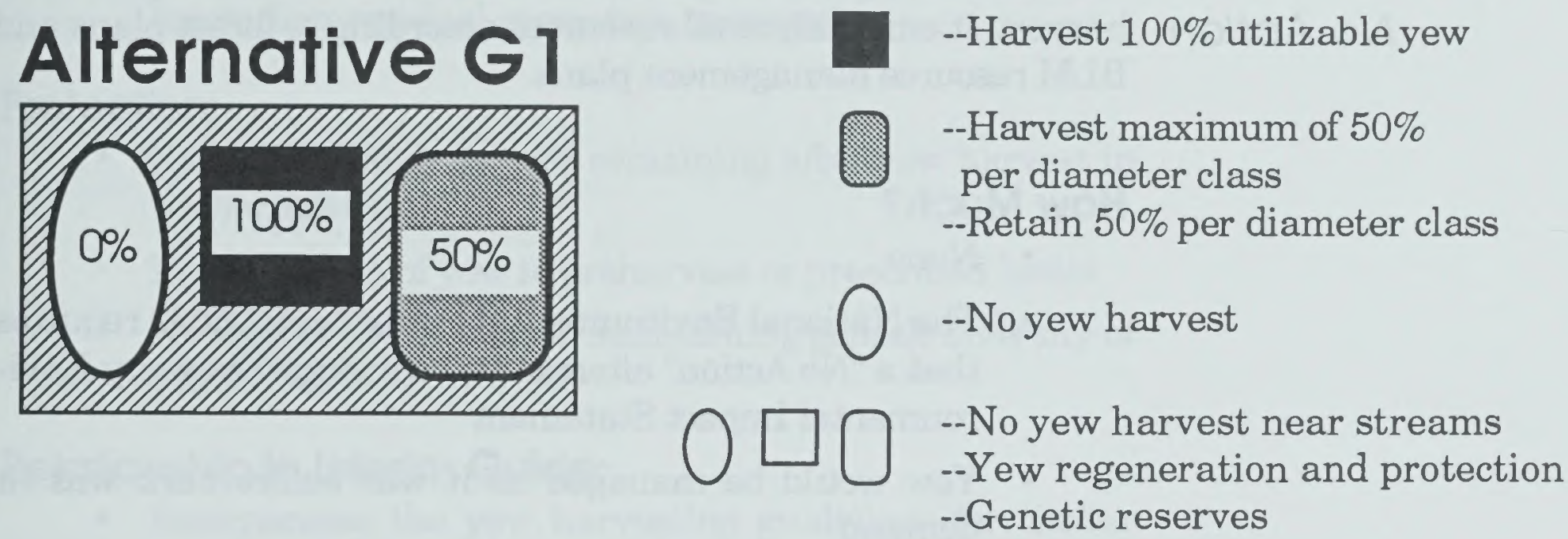

\section{Alternative $\mathbf{G 2}$}
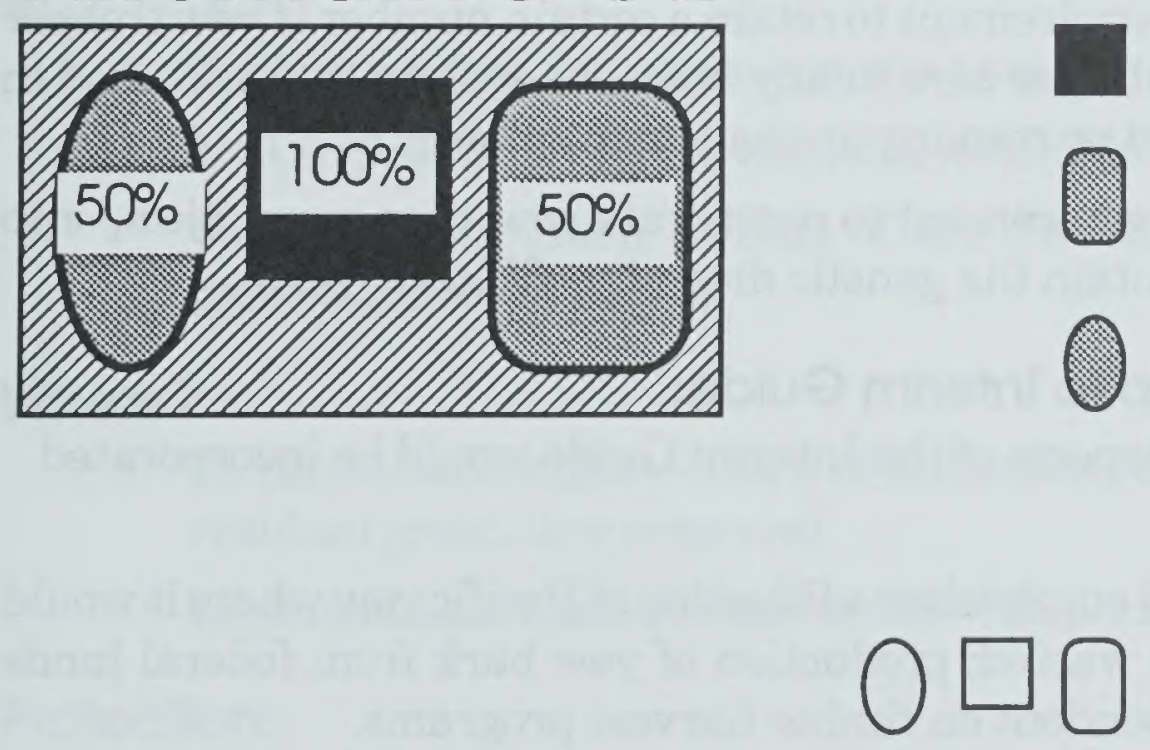

--Harvest 100\% utilizable yew

--Harvest 50\% per diameter class

--Retain $50 \%$ per diameter class

--Harvest maximum of 50\%

per diameter class

--Retain $50 \%$ or 5 TPA

per diameter class

--No yew harvest near streams

--Yew regeneration and protection

--Genetic reserves

Key

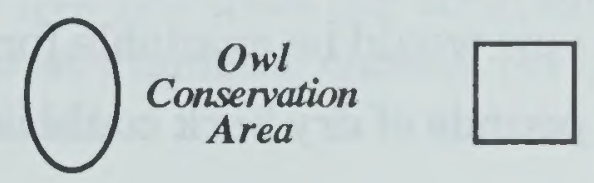

Timber Sale
(TS) units-
clearcut,
shelterwood, or
seedtree harvest

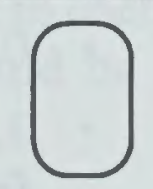

Partial-cut sale units such as thinning or uneven-aged cuts and non-sale areas where yew harvest is allowed in the Forest Plans 


\section{Summary}

\section{Alternatives}

Alternative A - Alternative A gives no particular emphasis to Pacific yew bark No Action harvest; it emphasizes all resources according to forest plans and BLM resource management plans.

\section{How Much?}

- None

- The National Environmental Policy Act (NEPA) requires that a "No Action" alternative be included in every Environmental Impact Statement

- Yew would be managed as it was before bark was in demand

\section{Where?}

- Not in federal lands, including owl conservation areas and designated wildernesses

\section{Protection:}

- No special protection

- No requirement to retain a certain number of yew trees or shrubs per acre in any area (other than that specified in forest or resource management plans)

- No requirement to regenerate yew after any project, or to maintain the genetic diversity of Pacific yew

\section{Relationship to Interim Guide:}

- No aspects of the Interim Guide would be incorporated

Alternative $B$ Alternative B emphasizes utilization of Pacific yew where it would otherwise be wasted; production of yew bark from federal lands would be dependent on timber harvest programs.

\section{How Much?}

- 0.078 to 0.118 million acres over the next five years

- 0.26 to 0.38 million yew would be available for harvest

- 1.30 to 1.95 million pounds of dry bark could be removed from these yew 


\section{Where?}

- Timber sale units only- 100 percent of utilizable yew (excluding residual green tree reserves)

\section{Protection:}

- Some protection for yew remaining after yew harvest in timber sale units

- Regeneration of yew to preharvest or prescribed levels

- No special provisions for maintaining genetic diversity of Pacific yew

\section{Relationship to Interim Guide:}

- Incorporates the yew harvesting guidelines for timber sale areas from the Interim Guide

Alternative $\mathrm{C}$ emphasizes the highest degree of protection of Alternative C Pacific yew and the ecosystem in yew harvest areas; it would produce a relatively small amount of bark.

\section{How Much?}

- 1.47 to 2.20 million acres over the next five years

- 1.81 to 2.72 million yew would be available for harvest

- 6.01 to 9.02 million pounds of dry yew bark could be removed from these yew

\section{Where?}

- In timber sale units - 100\% of utilizable yew (excluding residual green tree reserves)

- In partial-sale and non-sale areas - 25 percent

\section{Protection:}

- Genetic reserve areas would be established in yew harvest areas

- In partial-cut and non-sale areas, at least $75 \%$ of the yew or five yew trees per acre (whichever is greater) in each of three diameter classes $(<11,11-20,>20 ")$ would be retained 
- Yew would be regenerated to preharvest or prescribed levels in timber sale units

- Additional regeneration would not be required in partialcut sale and non-sale areas

- Harvest methods would follow the Mitigation Measures for Alternatives C through G2, found at the end of Chapter II and in Appendix C in the DEIS

\section{Relationship to Interim Guide:}

- Most parts of the Interim Guide would be incorporated into this alternative

- Harvest levels in partial-cut and non-sale areas are lower than prescribed in the Interim Guide (50\% in Guide, $25 \%$ for Alternative C)

Alternative $D$ Alternative $\mathrm{D}$ emphasizes a high degree of protection of Pacific yew and the ecosystem in yew harvest areas while producing a moderate amount of bark.

\section{How Much?}

- 1.47 to 2.20 million acres over the next five years

- 2.88 to 4.32 million yew would be available for harvest

- 9.82 to 14.72 million pounds of dry yew bark could be removed from these yew

\section{Where?}

- Timber sale units -100 percent of utilizable yew (excluding the residual green tree reserves)

- Partial-cut sale units and non-sale areas -50 percent (Interim Guide level)

\section{Protection:}

- Genetic reserve areas would be established in yew harvest areas

- In partial-cut and non-sale areas, at least $50 \%$ of the yew or five yew trees per acre (whichever is greater) would be retained 
- Yew would be regenerated to preharvest or prescribed levels in timber sale units

- Additional regeneration would not be required in partialcut sale and non-sale areas

- Harvest methods would follow the Mitigation Measures for Alternatives $\mathrm{C}$ through G2, found at the end of Chapter II and in Appendix C in the DEIS

\section{Relationship to Interim Guide:}

- Alternative D would incorporate most of the measures in the Interim Guide.

Alternative $\mathrm{E}$ was dropped from further consideration (See Alter- Alternative $E$ natives Considered but Not Carried Forward in the DEIS).

Alternative $\mathrm{F}$ emphasizes high yew bark production with moderAlternative $F$ ate protection of Pacific yew and the ecosystem in yew harvest areas.

\section{How Much?}

- 1.47 to 2.20 million acres over the next five years

- 4.44 to 6.66 million yew would be available

- 16.25 to 24.37 million pounds of dry bark could be removed from these yew

\section{Where?}

- Timber sale units 100 percent of utilizable yew

- Partial-cut sale units and non-sale areas- 75 percent of utilizable yew

Protection:

- Genetic reserve areas would be established in yew harvest areas

- In partial-cut and non-sale areas, at least $25 \%$ of the yew or two yew trees per acre (whichever is greater) in each of three diameter classes would be retained 


\section{Summary}

- Yew would be regenerated to preharvest or prescribed levels in timber sale units

- Additional regeneration would not be required in partialcut sale and non-sale areas

- Harvest methods would follow the Mitigation Measures for Alternatives $\mathrm{C}$ through G2, found at the end of Chapter II and in Appendix $\mathrm{C}$ in the DEIS

\section{Relationship to Interim Guide:}

- Most parts of the Interim Guide would be incorporated

- The main difference is the level of harvest (50\% in Guide, $75 \%$ in Alternative F) and

- The number of trees per acre (TPA) retained in each diameter class (5 TPA in Guide, 2 TPA in Alternative F) in partial-cut and non-sale areas

Alternative G1 The Preferred Alternative
Alternative G1 emphasizes efficiency of bark collection and moderate to high bark production, with moderate protection of yew and the ecosystem in yew harvest areas.

\section{How Much?}

- 1.47 to 2.20 million acres over the next five years

- 3.39 to 5.09 million yew would be available for harvest

- 15.75 to 23.63 million pounds of dry bark could be harvested from these yew.

\section{Where?}

- Timber sale units - 100 percent of utilizable yew (excluding the residual green tree reserves)

- Partial-cut sale units and non-sale areas - 50 percent of the yew, with no minimum number of leave trees

\section{Protection:}

- Genetic reserve areas would be established in yew harvest areas

- In partial-cut and non-sale areas, at least $50 \%$ of the yew in each of three diameter classes would be retained 
- Yew would be regenerated to preharvest or prescribed levels in timber sale units

- Additional regeneration would not be required in partialcut sale and non-sale areas

- Harvest methods would follow the Mitigation Measures for Alternatives $\mathrm{C}$ through G2, found at the end of Chapter II and in Appendix $\mathrm{C}$ in the DEIS

\section{Relationship to Interim Guide:}

- Much of the Interim Guide would be incorporated

- The main difference would be the number of trees per acre retained in each diameter class in partial-cut and non-sale areas (5 TPA in Guide, no minimum TPA in Alternative G1)

Alternative G2 emphasizes efficiency of collection as well as entry into owl conservation areas to provide the highest level of bark production with moderate protection of Pacific yew and the ecosystem in yew harvest areas.

\section{How Much?}

- 2.31 to 3.47 million acres over the next five years

- 4.47 to 6.71 million yew would be available for harvest

- 19.29 to 28.94 million pounds of dry bark could be harvested from these yew

\section{Where?}

- owl conservation areas -50 percent of the yew, with five leave trees per acre per diameter class

- Timber sale units - 100 percent of utilizable yew (excluding the residual green tree reserves)

- Partial-cut sale units, non-sale areas - 50 percent of the yew, with no minimum number of leave trees 


\section{Protection:}

- Genetic reserve areas would be established in yew harvest areas

- In partial-cut and non-sale areas, at least $50 \%$ of the yew in each of three diameter classes would be retained

- In owl conservation areas, at least $50 \%$ of the yew or five TPA in each diameter class, whichever is greater, would be retained

- Yew would be regenerated to preharvest or prescribed levels in timber sale units

- Additional regeneration would not be required in partialcut sale and non-sale areas

- Harvest methods would follow the Mitigation Measures for Alternatives C through G2 and the Mitigation Measures for owl conservation areas, found at the end of Chapter II and in Appendix C in the DEIS

\section{Relationship to Interim Guide:}

- Much of the Interim Guide would be incorporated into Alternative G2

- The main differences would be the number of trees left per acre in each diameter class in partial-cut and nonsale areas (5 TPA in Guide, no minimum TPA in Alternative G2) and entry into owl conservation areas for yew harvest 


\section{Consequences}

Table S-1 compares the seven alternatives based on the issues and suggestions presented to the interdisciplinary team, summarized earlier.

The table is organized with the issues and suggestions as major headings, and the resource areas listed below each relevant issue as a subheading.

A summary of the comparison of effects between the alternatives is provided following Table $\mathrm{S}-1$.

\section{Summary of the Comparison of the Effects of the Altematives}




\section{Summary}

Table S-1: Comparison of the Effects Between Alternatives

\begin{tabular}{|c|c|c|c|c|c|c|c|}
\hline \multirow{2}{*}{$\begin{array}{l}\text { MAIN ISSUES: } \\
\text { Provide Taxol, Protect the } \\
\text { Ecosystem and the Yew }\end{array}$} & \multicolumn{7}{|c|}{ ALTERNATIVES } \\
\hline & $\begin{array}{c}\text { A } \\
\text { (No Action) }\end{array}$ & $\begin{array}{c}\text { B } \\
\text { Timber } \\
\text { Sales } \\
\text { Only } \\
\end{array}$ & $\begin{array}{l}25 \% \\
5 \text { TPA }\end{array}$ & $\begin{array}{r}50 \%, \\
5 \text { TPA } \\
\end{array}$ & $\begin{array}{r}75 \% \\
2 \text { TPA } \\
\end{array}$ & $\begin{array}{c}\text { G1 } \\
\text { Preferred } \\
\\
\text { 50\% } \\
\text { 0 TPA } \\
\end{array}$ & $\begin{array}{l}\text { G2 } \\
\text { 50\%, } \\
\text { 0 TPA, } \\
\text { OCAs } \\
\end{array}$ \\
\hline $\begin{array}{l}\text { a. Amount of Bark Available } \\
\text {--Would the alternative supply } \\
\text { enough bark in combination with } \\
\text { bark from non-federal lands to } \\
\text { meet current demand? }\end{array}$ & ${ }^{*}$ no & ${ }^{*}$ yes & -federal ha & $\mathrm{est}=500$ & pound of $t$ & ${ }^{*}$ yes & *yes \\
\hline $\begin{array}{l}\text { b. Landscape Patterns } \\
\text {--probability of reducing yew } \\
\text { population connectivity }\end{array}$ & low risk & low risk & low risk & low risk & $\begin{array}{l}\text { moderate } \\
\text { risk }\end{array}$ & $\begin{array}{l}\text { moderate } \\
\text { risk }\end{array}$ & $\begin{array}{l}\text { moderate } \\
\text { risk }\end{array}$ \\
\hline $\begin{array}{l}\text {--probability of reducing the } \\
\text { range of yew }\end{array}$ & low risk & low risk & low risk & low risk & low risk & low risk & low risk \\
\hline $\begin{array}{l}\text { c. Biology of Yew } \\
\text {--seed production }\end{array}$ & $\begin{array}{l}\text { moderate } \\
\text { reduction }\end{array}$ & $\begin{array}{l}\text { minor } \\
\text { reduction }\end{array}$ & $\begin{array}{l}\text { minor } \\
\text { reduction }\end{array}$ & $\begin{array}{l}\text { minor } \\
\text { reduction }\end{array}$ & $\begin{array}{l}\text { minor to } \\
\text { moderate } \\
\text { reduction }\end{array}$ & $\begin{array}{l}\text { minor to } \\
\text { moderate } \\
\text { reduction }\end{array}$ & $\begin{array}{l}\text { minor to } \\
\text { moderate } \\
\text { reduction }\end{array}$ \\
\hline --vegetative reproduction & $\begin{array}{l}\text { moderate } \\
\text { reduction }\end{array}$ & $\begin{array}{c}\text { minor } \\
\text { reduction }\end{array}$ & $\begin{array}{c}\text { minor } \\
\text { reduction }\end{array}$ & $\begin{array}{l}\text { minor } \\
\text { reduction }\end{array}$ & $\begin{array}{l}\text { minor } \\
\text { reduction }\end{array}$ & $\begin{array}{l}\text { minor } \\
\text { reduction }\end{array}$ & $\begin{array}{l}\text { minor } \\
\text { reduction }\end{array}$ \\
\hline --needle regeneration & $\begin{array}{c}\text { not } \\
\text { applicable }\end{array}$ & $\begin{array}{c}\text { not } \\
\text { applicable }\end{array}$ & $\begin{array}{c}\text { no } \\
\text { effect }\end{array}$ & $\begin{array}{c}\text { no } \\
\text { effect }\end{array}$ & $\begin{array}{l}\text { minor } \\
\text { impact }\end{array}$ & $\begin{array}{l}\text { minor } \\
\text { impact }\end{array}$ & $\begin{array}{l}\text { minor } \\
\text { impact }\end{array}$ \\
\hline --planting & $\begin{array}{c}\text { no } \\
\text { planting }\end{array}$ & $\begin{array}{l}\text { planting if } \\
\text { needed }\end{array}$ & $\begin{array}{l}\text { planting if } \\
\text { needed }\end{array}$ & $\begin{array}{l}\text { planting if } \\
\text { needed }\end{array}$ & $\begin{array}{l}\text { planting if } \\
\text { needed }\end{array}$ & $\begin{array}{l}\text { planting if } \\
\text { needed }\end{array}$ & $\begin{array}{l}\text { planting if } \\
\text { needed }\end{array}$ \\
\hline $\begin{array}{l}\text { d. Genetics of Yew } \\
\text {--change in overall genetic } \\
\text { variation (based on before and } \\
\text { after harvest; probability of } \\
\text { losing rare alleles) }\end{array}$ & $\begin{array}{l}\text { minor } \\
\text { reduction }\end{array}$ & none & none & $\begin{array}{l}\text { minor } \\
\text { reduction }\end{array}$ & $\begin{array}{l}\text { moderate } \\
\text { reduction }\end{array}$ & $\begin{array}{l}\text { minor } \\
\text { reduction }\end{array}$ & $\begin{array}{l}\text { minor } \\
\text { reduction }\end{array}$ \\
\hline $\begin{array}{l}\text {--effects on heterozygosity } \\
\text { of next generation (future } \\
\text { breeding, education and } \\
\text { aesthetic values) }\end{array}$ & $\operatorname{minor}$ & none & minor & minor & high & moderate & moderate \\
\hline $\begin{array}{l}\text {--effects on genetic erosion at } \\
\text { edges }\end{array}$ & $\begin{array}{l}\text { continued } \\
\text { erosion }\end{array}$ & none & $\begin{array}{l}\text { reduced } \\
\text { (positive } \\
\text { change) } \\
\end{array}$ & $\begin{array}{l}\text { reduced } \\
\text { (positive } \\
\text { change) } \\
\end{array}$ & $\begin{array}{l}\text { reduced } \\
\text { (positive } \\
\text { change) } \\
\end{array}$ & $\begin{array}{l}\text { reduced } \\
\text { (positive } \\
\text { change) }\end{array}$ & $\begin{array}{l}\text { reduced } \\
\text { (positive } \\
\text { change) } \\
\end{array}$ \\
\hline $\begin{array}{l}\text { e. Insects and Diseases } \\
\text {--change in incidence of } \\
\text { pests on Pacific yew }\end{array}$ & $\begin{array}{c}\text { no } \\
\text { change }\end{array}$ & $\begin{array}{l}\text { minor } \\
\text { increase }\end{array}$ & $\begin{array}{l}\text { minor } \\
\text { increase }\end{array}$ & $\begin{array}{l}\text { minor } \\
\text { increase }\end{array}$ & $\begin{array}{l}\text { minor } \\
\text { increase }\end{array}$ & $\begin{array}{l}\text { minor } \\
\text { increase }\end{array}$ & $\begin{array}{l}\text { minor } \\
\text { increase }\end{array}$ \\
\hline $\begin{array}{l}\text {--Port-Orford-cedar root disease } \\
\text { impact on yew }\end{array}$ & $\begin{array}{c}\text { no } \\
\text { impact }\end{array}$ & $\begin{array}{l}\text { minor } \\
\text { impact }\end{array}$ & $\begin{array}{l}\text { minor } \\
\text { impact }\end{array}$ & $\begin{array}{l}\text { minor } \\
\text { impact }\end{array}$ & $\begin{array}{l}\text { minor } \\
\text { impact }\end{array}$ & $\begin{array}{l}\text { minor } \\
\text { impact }\end{array}$ & $\begin{array}{l}\text { minor } \\
\text { impact }\end{array}$ \\
\hline $\begin{array}{l}\text { f. Fire } \\
\text {--risk of increased fire occurrence }\end{array}$ & $\operatorname{minor}$ & minor & $\begin{array}{l}{ }^{*} \text { minor } \\
<----^{*}(\text { dep }\end{array}$ & nds on yew & $\begin{array}{l}{ }^{*} \text { minor to } \\
\text { moderate } \\
\text { ensity and } \mathrm{t}\end{array}$ & $\begin{array}{l}\text { * minor to } \\
\text { moderate } \\
\text { rvest perce }\end{array}$ & $\begin{array}{l}\text { *minor to } \\
\text { moderate } \\
\text { age)----->> }\end{array}$ \\
\hline $\begin{array}{l}\text {--impact of yew harvest on yew } \\
\text { survival and regeneration } \\
\text { following fire }\end{array}$ & $\begin{array}{l}\text { moderate to } \\
\text { high } \\
\text { decrease }\end{array}$ & $\begin{array}{l}\text { minor to } \\
\text { moderate } \\
\text { decrease }\end{array}$ & $\begin{array}{c}\text { *minor } \\
\text { decrease }\end{array}$ & $\begin{array}{c}\text { *minor } \\
\text { decrease }\end{array}$ & $\begin{array}{l}\text { *minor to } \\
\text { moderate } \\
\text { decrease }\end{array}$ & $\begin{array}{l}\text { * minor to } \\
\text { moderate } \\
\text { decrease }\end{array}$ & $\begin{array}{l}\text { *minor to } \\
\text { moderate } \\
\text { decrease }\end{array}$ \\
\hline
\end{tabular}


Table S-1: Comparison of the Effects Between Alternatives (continued)

\begin{tabular}{|c|c|c|c|c|c|c|c|}
\hline MAIN ISSUES: & \multicolumn{7}{|c|}{ ALTERNATIVES } \\
\hline $\begin{array}{c}\text { Provide Taxol, Protect the } \\
\text { Ecosystem and the Yew } \\
\text { (continued) }\end{array}$ & $\begin{array}{c}\text { A } \\
\text { (No } \\
\text { Action) }\end{array}$ & $\begin{array}{l}\text { B } \\
\text { Timber } \\
\text { Sales } \\
\text { Only }\end{array}$ & $\begin{array}{c}\mathrm{C} \\
25 \% \\
5 \text { TPA }\end{array}$ & $\begin{array}{c}\text { D } \\
50 \% \text {, } \\
5 \text { TPA }\end{array}$ & $\begin{array}{c}\text { F } \\
75 \% \\
2 \text { TPA }\end{array}$ & $\begin{array}{c}\text { G1 } \\
\text { Preferred } \\
\text { 50\%, } \\
0 \text { TPA }\end{array}$ & $\begin{array}{l}\text { G2 } \\
50 \% \text {, } \\
0 \text { TPA, } \\
\text { OCAs }\end{array}$ \\
\hline $\begin{array}{l}\text { g. Ecosystem } \\
\text {--potential for negative impact } \\
\text { on ecosystem structure and } \\
\text { function }\end{array}$ & low risk & low risk & low risk & $\begin{array}{l}\text { low to } \\
\text { moderate } \\
\text { risk }\end{array}$ & high risk & $\begin{array}{l}\text { moderate } \\
\text { risk }\end{array}$ & $\begin{array}{l}\text { moderate } \\
\text { risk }\end{array}$ \\
\hline $\begin{array}{l}\text { h. Biodiversity } \\
\text {--loss of diversity }\end{array}$ & $\begin{array}{l}\text { some loss } \\
\text { of } \\
\text { diversity }\end{array}$ & $\begin{array}{l}\text { little or no } \\
\text { loss }\end{array}$ & $\begin{array}{l}\text { little or no } \\
\text { loss }\end{array}$ & $\begin{array}{l}\text { little or no } \\
\text { loss }\end{array}$ & $\begin{array}{l}\text { little or no } \\
\text { loss }\end{array}$ & $\begin{array}{l}\text { little or no } \\
\text { loss }\end{array}$ & $\begin{array}{l}\text { little or no } \\
\text { loss }\end{array}$ \\
\hline $\begin{array}{l}\text { 1. Soils } \\
\text {--potential for impact on soils } \\
(1=\text { least; } 6=\text { most })\end{array}$ & $\begin{array}{c}\text { no } \\
\text { impact }\end{array}$ & 1 & 2 & 3 & 4 & 5 & 6 \\
\hline $\begin{array}{l}\text { j. Water and Aquatic Habitat } \\
\text {--impact on resource }\end{array}$ & $\begin{array}{c}\text { no } \\
\text { impact }\end{array}$ & $\begin{array}{c}\text { no } \\
\text { impact }\end{array}$ & $\begin{array}{l}\text { negligible } \\
\text { to minor }\end{array}$ & $\begin{array}{l}\text { negligible } \\
\text { to minor }\end{array}$ & $\begin{array}{l}\text { negligible } \\
\text { to minor }\end{array}$ & $\begin{array}{l}\text { negligible } \\
\text { to minor }\end{array}$ & $\begin{array}{l}\text { negligible } \\
\text { to minor }\end{array}$ \\
\hline $\begin{array}{l}\text { k. Wildlife } \\
\text {--composite risk to wildlife in la te } \\
\text { successional forests }\end{array}$ & minor & minor & minor & minor & high & moderate & moderate \\
\hline $\begin{array}{l}\text {--composite risk to wildlife in } \\
\text { early successional forests }\end{array}$ & minor & minor & minor & minor & minor & minor & minor \\
\hline $\begin{array}{l}\text {--composite risk to wildlife in } \\
\text { riparian areas }\end{array}$ & none & none & $\begin{array}{l}\text { none to } \\
\text { minor }\end{array}$ & $\begin{array}{l}\text { none to } \\
\text { minor }\end{array}$ & $\begin{array}{l}\text { none to } \\
\text { minor }\end{array}$ & $\begin{array}{l}\text { none to } \\
\text { minor }\end{array}$ & $\begin{array}{l}\text { none to } \\
\text { minor }\end{array}$ \\
\hline $\begin{array}{l}\text { 1. Threatened and Endangered } \\
\text { Species } \\
\text {--impacts to T\&Es }\end{array}$ & minor & minor & minor & moderate & $\begin{array}{l}\text { moderate } \\
\text { to high }\end{array}$ & moderate & moderate \\
\hline $\begin{array}{l}\text { m. Northern Spotted Owl } \\
\text {--impacts on prey species }\end{array}$ & minor & minor & minor & minor & moderate & $\begin{array}{l}\text { moderate } \\
\text { to high }\end{array}$ & $\begin{array}{l}\text { moderate } \\
\text { to high }\end{array}$ \\
\hline --impacts on roosting habitat & none & none & moderate & moderate & high & $\begin{array}{l}\text { moderate } \\
\text { to high }\end{array}$ & $\begin{array}{l}\text { moderate } \\
\text { to high }\end{array}$ \\
\hline $\begin{array}{l}\text { n. Forest Health } \\
\text {--impact to forest health }\end{array}$ & minor & ${ }^{*}$ minor & ${ }^{*}$ minor & *minor & ${ }^{*}$ minor & *minor & * minor \\
\hline & & ased & ct on $\mathrm{fc}$ & health w & amount o & w harvested & \\
\hline
\end{tabular}




\section{Summary}

Table S-1: Comparison of the Effects Between Alternatives (continued)

\begin{tabular}{|c|c|c|c|c|c|c|c|}
\hline \multirow{2}{*}{$\begin{array}{l}\text { SUGGESTION: } \\
\text { Establish Sustainable } \\
\text { Collection Level }\end{array}$} & \multicolumn{7}{|c|}{ ALTERNATIVES } \\
\hline & $\begin{array}{c}\text { A } \\
\text { (No } \\
\text { Action) }\end{array}$ & $\begin{array}{c}\text { B } \\
\text { Timber } \\
\text { Sales } \\
\text { Only }\end{array}$ & $\begin{array}{l}25 \% \\
5 \text { TPA }\end{array}$ & $\begin{array}{l}50 \% \\
5 \text { TPA }\end{array}$ & $\begin{array}{l}75 \% \\
2 \text { TPA }\end{array}$ & $\begin{array}{c}\text { G1 } \\
\text { Preferred } \\
\\
\text { 50\% } \\
\text { 0 TPA }\end{array}$ & $\begin{array}{c}\text { G2 } \\
50 \% \\
\text { 0 TPA, } \\
\text { OCAs }\end{array}$ \\
\hline a. Number of available trees & 0 & $0.26-0.38$ & $1.81-2.72$ & $2.88-4.32$ & 4.44-6.66 & $3.39-5.09$ & $4.47-6.71$ \\
\hline $\begin{array}{l}\text { b. Sustainable Yield } \\
\text { in lbs. of Bark }\end{array}$ & \multicolumn{7}{|c|}{ None of the alternatives harvest at an even-flow rate estimated at 1.48 million pounds of bark. } \\
\hline $\begin{array}{l}\text { c. Available bark from federal } \\
\text { lands over five years (in lbs.) }\end{array}$ & 0 & $\begin{array}{c}1.30-1.95 \\
\mathrm{MM}\end{array}$ & $\begin{array}{c}6.01--9.02 \\
\mathrm{MM}\end{array}$ & $\begin{array}{c}9.82-14.72 \\
\mathrm{MM}\end{array}$ & $\begin{array}{c}16.25-24.37 \\
\mathrm{MM}\end{array}$ & $\begin{array}{c}15.75-23.63 \\
M M\end{array}$ & $\begin{array}{c}19.29-28.94 \\
\text { MM }\end{array}$ \\
\hline \multicolumn{8}{|l|}{$\begin{array}{c}\text { SUGGESTION: } \\
\text { Consider Socioeconomic } \\
\text { Concerns }\end{array}$} \\
\hline $\begin{array}{l}\text { a. Public Health and Safety } \\
\text {--bark availability in pounds } \\
\text { from federal lands per year }\end{array}$ & 0 & $.3-.4 \mathrm{MM}$ & $1.2-1.8 \mathrm{MM}$ & $2.0-2.9 \mathrm{MM}$ & 3.2-4.9 MM & 3.2-4.7 MM & 3.9-5.8 MM \\
\hline $\begin{array}{l}\text {--taxol available for clinical } \\
\text { trials, in kilograms, based on } \\
\text { bark from federal lands } \\
(15,000 \mathrm{lbs} \text {. bark }=1 \text { kilogram })\end{array}$ & 0 & 17.3-26.0 & $80.2-120.3$ & $130.9-196.3$ & 216.6-324.9 & $210.0-315.0$ & $257.2-385.8$ \\
\hline $\begin{array}{l}\text {--potential patients treated, } \\
\text { based on bark from federal } \\
\text { lands (assuming } 1 \text { kilogram } \\
\text { treats } 480 \text { patients) }\end{array}$ & 0 & $\begin{array}{l}8,300- \\
12,400\end{array}$ & $\begin{array}{l}38,400- \\
57,700\end{array}$ & $\begin{array}{l}62,800- \\
94,200\end{array}$ & $\begin{array}{l}103,900- \\
155,900\end{array}$ & $\begin{array}{l}100,800- \\
151,200\end{array}$ & $\begin{array}{l}123,400- \\
185,100\end{array}$ \\
\hline --injuries to woodworkers & none & $0-5$ & $0-10$ & $0-15$ & $0-25$ & $0-25$ & $0-30$ \\
\hline $\begin{array}{l}\text { b. Social Setting-- } \\
\text { Groups Affected }\end{array}$ & \multicolumn{7}{|c|}{ Health-Related } \\
\hline $\begin{array}{l}\text {--access to raw material for } \\
\text { taxol: cancer patients, } \\
\text { women, and others }\end{array}$ & $\begin{array}{l}\text { denies } \\
\text { access }\end{array}$ & $\begin{array}{l}\text { access } \\
\text { limited }\end{array}$ & $\begin{array}{l}\text { adequate } \\
\text { access }\end{array}$ & $\begin{array}{l}\text { adequate } \\
\text { access }\end{array}$ & $\begin{array}{l}\text { adequate } \\
\text { access }\end{array}$ & $\begin{array}{l}\text { adequate } \\
\text { access }\end{array}$ & $\begin{array}{l}\text { adequate } \\
\text { access }\end{array}$ \\
\hline \multirow[b]{2}{*}{--bark harvester jobs (seasonal) } & \multicolumn{7}{|c|}{ Jobs-Related } \\
\hline & $\begin{array}{l}\text { no job } \\
\text { creation }\end{array}$ & $75-113$ & $347-521$ & $566-849$ & $937-1,406$ & $909-1,363$ & $1,113-1,669$ \\
\hline $\begin{array}{l}\text {--traditional woodworkers } \\
\text { and log purchasers }\end{array}$ & no effect & no effect & no effect & no effect & no effect & no effect & no effect \\
\hline \multirow[b]{2}{*}{--hikers, campers, hunters } & \multicolumn{7}{|c|}{ Recreationists } \\
\hline & $\begin{array}{c}\text { no } \\
\text { effect }\end{array}$ & $\begin{array}{l}\text { minor } \\
\text { effect }\end{array}$ & minor effect & minor effect & minor effect & minor effect & minor effect \\
\hline \multirow[b]{2}{*}{$\begin{array}{l}\text {--ceremonial, cultural, } \\
\text { traditional use of wood }\end{array}$} & \multicolumn{7}{|c|}{ Native Americans } \\
\hline & \multicolumn{7}{|c|}{$\begin{array}{l}\text { Effects on utilization uses would be minor. Spiritual and medicinal value effects must be } \\
\text { assessed after local consultation. }\end{array}$} \\
\hline $\begin{array}{l}\text { c. Women and Other } \\
\text { Minorities }\end{array}$ & $\begin{array}{c}\text { slight } \\
\text { negative }\end{array}$ & $\begin{array}{l}\text { moderate } \\
\text { positive }\end{array}$ & $\begin{array}{l}\text { moderate } \\
\text { positive }\end{array}$ & $\begin{array}{c}\text { high } \\
\text { positive }\end{array}$ & $\begin{array}{c}\text { high } \\
\text { positive }\end{array}$ & $\begin{array}{l}\text { high } \\
\text { positive }\end{array}$ & $\begin{array}{c}\text { high } \\
\text { positive }\end{array}$ \\
\hline $\begin{array}{l}\text { MM=millions } \\
M=\text { thousands }\end{array}$ & & & & & & & \\
\hline
\end{tabular}


Table S-1: Comparison of the Effects Between Alternatives (continued)

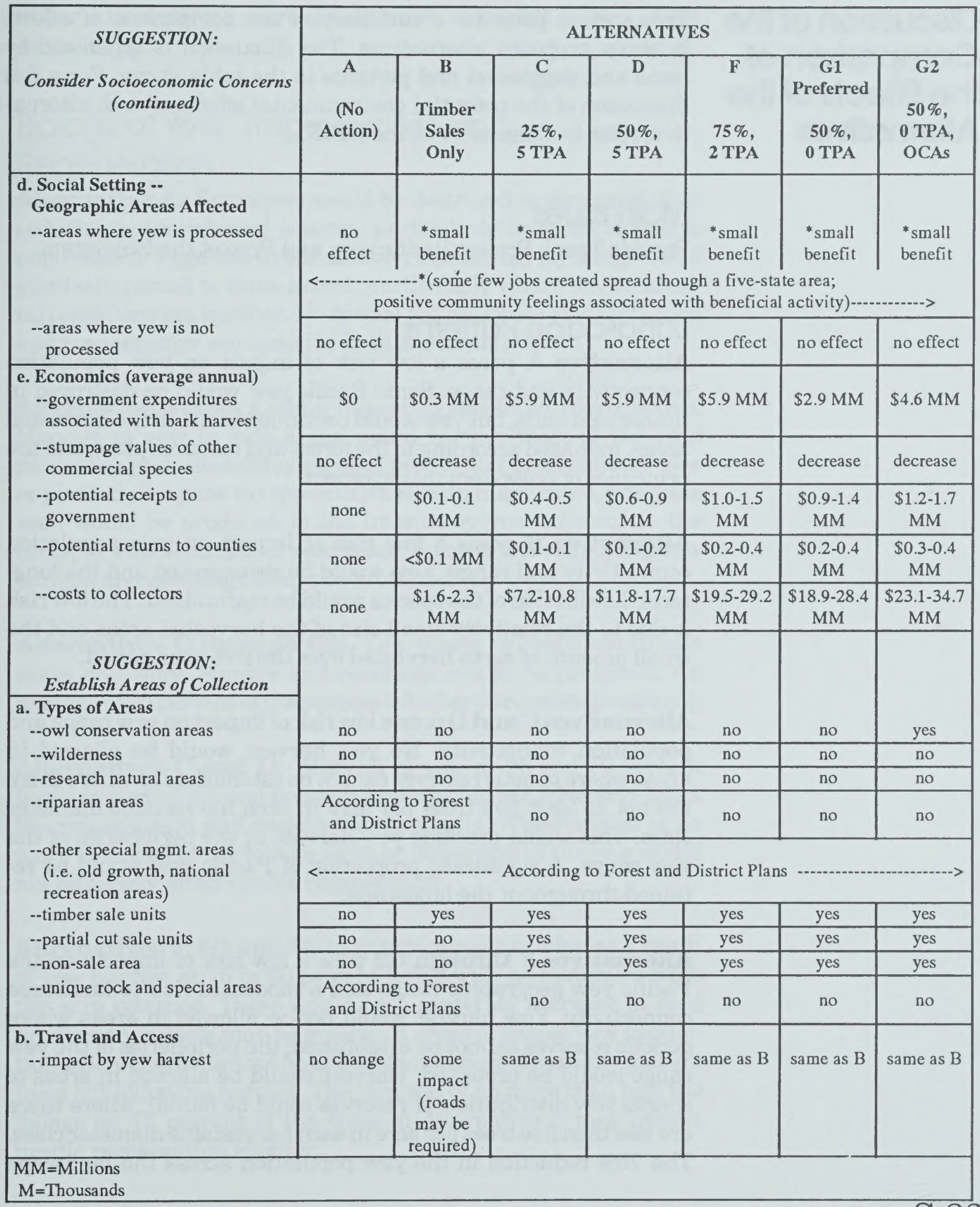


Discussion of the Comparison of the Effects of the Altematives
This section presents a summary of the comparison of effects between proposed alternatives. The discussion is organized by issue and suggestion and pertains to the table above. For a full discussion of the potential environmental effects of each alternative, refer to Chapter IV of the DEIS.

\section{Main Issues}

Provide Taxol, Protect Pacific yew, and Protect the Ecosystem

\section{Landscape Patterns}

Alternative A poses a low risk of impact on yew population connectivity and range. Some Pacific yew would be destroyed in timber sale units, but yew would continue to exist in the harvested areas, managed according to the forest and resource plans and the principles of ecosystem management.

Alternative $\mathbf{B}$ poses a low risk of impact on yew population connectivity and range. Yew would be regenerated and the longterm distribution of the species would be maintained. The low risk is due to the relatively small size of the harvested areas and the small amount of acres harvested over the five-year period.

Alternatives $\mathbf{C}$ and $\mathbf{D}$ pose a low risk of impact on yew range and population connectivity. No yew harvest would be allowed in areas where genetic reserves cannot be established or where there are not at least five trees per acre in each harvestable diameter class. This would preclude yew harvest at the peripheries of the yew range. A significant proportion of Pacific yew would be retained throughout the landscape.

Alternatives $\mathbf{F}$ through G2 pose a low risk of impacts on the Pacific yew geographic range and a moderate risk to landscape connectivity. Yew harvest would not be allowed in areas where genetic reserves cannot be established; the peripheries of the yew range would be protected. Harvest would be allowed in areas of sparse yew distribution (if reserves could be found), where there are less then five trees per acre in each harvestable diameter class. The $75 \%$ reduction in the yew population across the landscape 
under Alternative $\mathrm{F}$ increases the risk of impact to population connectivity.

\section{Biology of Yew: Reproduction and Regeneration}

Alternative A: Some yew would be destroyed or damaged, thus reducing potential seed sources, particularly in areas of sparse populations. Vegetative reproduction (sprouting, layering) would also be impacted to some extent, particularly where environmental conditions are harsher. No special provisions for yew protection and regeneration are included in this alternative.

Alternative $\mathbf{B}$ poses a minor impact on vegetative reproduction. Harvest of yew in sale areas would remove most of the seed producing yew, thus delaying seed production until residual yew or planted yew grow to reproductive size. In many cases, adequate seed would be produced in the interim by yew adjacent to the units, or yew retained as seed trees. Some of the remaining yew stumps and seedlings would be protected.

Alternatives C through G2: Yew would be replanted in sale units and some stumps and seedlings would be protected. An average of 70 percent of the stumps left after harvest may resprout.

Alternatives $\mathbf{C}$ and D: Harvest of yew at 25 and 50 percent levels in partial cut and non-sale areas would not adversely affect the reproduction and regeneration potential. The removal of no more than half of the foliage on 25 or 50 percent of the yew would not adversely affect needle regeneration.

Alternatives F, G1 and G2 may reduce regeneration as a result of yew harvest at 75 or 50 percent levels with no minimum trees per acre retained. There would be a moderate decrease in seed production. Effects may be greater in areas of sparse yew population where there may not be adequate numbers of sexually mature trees left following harvest. The removal of no more than half the foliage on 75 percent of the trees in Alternative $\mathrm{F}$ may impact needle regeneration slightly. 


\section{Genetics}

Alternative A may result in a small decrease in levels of genetic variation as small populations on the periphery as well as in the center of the range may not maintain themselves. No efforts would be made to maintain genetic diversity under this alternative. Some populations with unique genetic combinations could be lost; this would affect the ability of subsequent generations to adapt to changing environments, as well as reduce the yew's potential for use in breeding programs.

Alternative B would have less impact on genetic diversity and potential contribution to breeding programs than Alternative A, because provisions are made for the protection of individual yew in harvest units, and units are regenerated to preharvest or prescribed levels. This ensures the survival of more genotypes in populations. Current erosion of small, peripheral populations would be halted under this alternative.

Alternatives C through G2: Alternative C (25 percent harvest) poses no reduction in overall genetic variation. The reduction potential would increase slightly for Alternative D, and for each alternative as larger proportions of trees are harvested. Genetic reserves would be established in harvest areas in order to protect genetic diversity. Slight reductions in genetic variation could occur, however, as larger proportions of trees are harvested.

The current erosion of genetic variation in peripheral yew populations would be halted or reversed.

Gene conservation for use in future breeding programs would remain unchanged in Alternatives $\mathrm{C}$ and $\mathrm{D}$, but would be reduced by Alternatives F, G1, and G2 because of reduced overall genetic variation in future generations. 


\section{Insects and Diseases}

Alternative A poses no change in levels of impact by insects and diseases.

Alternatives B through G2 would have a minor impact on insect and disease populations. Harvest in areas that contain Port-Orford-cedar (POC) must follow the mitigation measures specified in the POC analysis, intended to reduce or prevent the spread of $P O C$ root disease.

\section{Fire}

Alternative A: Risk of wildfire would remain unchanged. However, survival and regeneration of yew could be quite poor on some sites where fire is used for site preparation, as there would be no attempt made to change burning prescriptions to protect yew in the site.

Alternative $\mathbf{B}$ poses no increased risk of wildfire. There would be a higher probability for survival and regeneration of yew following fire for site preparation or other purposes, because there would be an attempt to protect and replant wherever residual survival was poor. Some yew may be damaged or killed by site preparation fires, but the probability of affecting the current distribution of yew is minor.

Alternatives $\mathbf{C}$ through G2 pose minor to moderate risk of wildfire, varying with the level of harvest and density of yew (generally higher for those alternatives that harvest higher levels of yew). The probability of survival and regeneration of yew following fire for site preparation treatment, would be high to moderate, decreasing as the amount of slash and the number of people involved in the harvesting increases. 


\section{Ecosystem}

Alternatives A and B pose minimal effects on ecosystem structure and function. The impacts of 100 percent yew removal (Alternative B) or loss of some of the yew in harvest units (Alternative A) would be minimal; the effects result from timber harvest, not yew harvest. Pacific yew would be a part of the regenerating stand. There would be less risk of impact in timber sale units which retained yew in green tree reserves.

Alternatives C through G2: The impacts of yew harvest on ecosystem structure and function would vary from stand to stand depending on the presence of substitute species and structures. Risk of impact increases with the amount of yew that is harvested:

Alternative $\mathbf{C}$ (25 percent yew removal) — low risk of impact

Alternative D (50 percent yew removal) - low to moderate risk of impact

Alternative F ( 75 percent yew removal) — high risk of impact

Alternatives G1 and G2 (50 percent yew removal) - moderate risk of impact due to the harvest of more of the larger yew trees and to harvest in areas of sparse yew distribution

Alternative G2, with harvest in spotted owl conservation areas, would have the most impact on old-growth ecosystems.

\section{Biodiversity}

Alternative A poses some loss in genetic and species diversity in areas where yew is sparse, due to potential loss of unique populations in these areas.

Alternatives B through G2 pose little or no impact on biodiversity. As stands regenerate and abundance of yew increases, the contributions to genetic, species, and community diversity would increase. 


\section{Soils, Water and Aquatic Habitat}

Alternative A poses no additional impact to forest soils, water, and aquatic habitat managed according to the current standards and guidelines of forest plans and BLM resource management plans.

Alternatives B through G2 pose minimal impacts on the soil and negligible to small impacts on water and aquatic habitat. The risk of impact would increase proportionately with the level of yew harvest: Alternative $\mathrm{B}$ - least impact; Alternative $\mathrm{C}$ - next largest impact; followed by Alternatives D, F, G1 and G2.

\section{Wildlife}

Alternative A poses insignificant effects on plant and animal populations. Animal species diversity might be reduced over time because of the incremental loss of yew from the understory of many timber sale units and changes in the mid-story vegetative structure.

Alternatives B through G2 pose minor to moderate impacts, increasing as the level of harvest increases. Yew harvest in latesuccessional forests would change the character of the habitat, which could affect some species. In general, removal of 50 percent or less of the yew (Alternatives B through D) has a low probability of reducing or removing species from the area; removal of 75 percent of the yew (Alternative F) could have a moderate effect on some species abundance.

The role of yew in providing for wildlife habitat is poorly understood. This could result in a substantial risk to wildlife if large areas of yew were harvested in a short time frame. 


\section{Threatened and Endangered Species}

Alternative A poses no added impact to threatened and endangered species. The impacts result from timber harvest, not yew harvest.

Alternatives B through G2 have a potential for impacts to threatened and endangered populations, increasing proportionately with the level of yew harvest.

The potential exists for positive and negative impacts (minor to moderate in intensity) to deer, elk, and moose and associated predator populations. In certain cases the positive and negative impacts could cancel each other out (i.e. the decrease in thermal cover from yew and timber harvest could be partially or completely mitigated by the increase in forage from yew sprouting and from opening the canopy), depending on local conditions.

There is potential for minor negative impacts to fish species that increases proportionately with the level of yew harvest.

The potential exists for positive and negative impacts (minor to moderate in intensity) to avian populations and associated predator populations. Impacts increase with the level of yew harvest, but are site-specific in some cases.

\section{Northern Spotted Owl}

Alternatives A and B pose little or no impacts on spotted owls and their habitat, because there would be no habitat disturbance in addition to that normally occurring from implementing forest plans or BLM resource management plans.

Alternatives $\mathbf{C}$ through G2 pose negative impacts both on prey species and on roosting habitat for spotted owls, increasing with the level of harvest. The intensity of the impact would depend on the proportion of yew in the stand and how much is harvested. Alternatives C, D, F and G1 permit harvest within suitable habitat, including removal of a portion of the midstory before scheduled timber harvest. Alternative G2 poses the greatest negative 
impacts because the largest area is available for harvest and includes harvest within owl conservation areas.

\section{Forest Health}

Alternative A poses little or no change in forest health under the present guidelines for ecosystem management. Although the numbers of yew trees in harvested stands would decline, it is unlikely that populations would disappear.

Alternatives B through G2 Pose a minor impact on forest health. Mitigation measures for the protection of Pacific yew populations would maintain yew at acceptable threshold levels, no matter what percentage of yew is harvested.

\section{Suggestion: Establish Sustainable Collection Level Inventory and Sustainable Yield}

Alternative A poses minor impacts on the yew population on federal lands although impacts to the yew population on nonfederal lands could be significant. No yew for taxol from federal lands would be available under this alternative. This alternative does not preclude a long-term, even-flow sustainable harvest level.

Alternative $\mathbf{B}$ poses minor impacts on the yew population on Forest Service and BLM lands. Approximately 0.511 million yew could be harvested from federal lands. Implementing Alternative $\mathrm{B}$ does not preclude a long-term, even-flow sustainable harvest level of 1.5 million pounds dry bark per year.

Alternatives $\mathbf{C}$ through $\mathbf{G} \mathbf{2}$ impact the total yew population ranging from 4 to 13 percent of the total inventoried yew population on Forest Service and BLM lands. The amount of yew harvested on federal lands under these alternatives would range from 3.62 to 8.95 million. These alternatives preclude a long-term, even-flow level of harvest ( 1.5 million pounds dry bark per year) in the current rotation, but not in future rotations. 


\section{Suggestion: Socioeconomic Concerns}

\section{Public Health and Safety}

Alternative A: Because there would be no yew harvested from federal lands, there would be no yew bark or taxol available from federal sources and no potential for treating patients with taxol derived from federal yew. There would be no increase in injuries to woodsworkers associated with yew bark collection on federal lands.

Alternatives B through G2 pose varying impacts on public health by offering a range of amounts of bark available for taxol for potential treatment of cancer patients.

These alternatives pose a small potential for injuries to woodsworkers associated with each of the action alternatives.

\section{Social Setting: Groups Affected}

Alternative A would not respond to the need for bark for taxol production. Taxol production in the immediate future would be reduced to half of current levels. This would place severe restrictions on the number of cancer patients who could be treated and the availability of clinical trials. Women as a group would be adversely impacted if taxol therapy were limited. Cancer patients' access to taxol may also be threatened.

No additional job opportunities would be created for woodsworkers and log purchasers. There would be no effect to recreational or Native American uses of the Pacific yew or the forest.

Alternative B through G2: Alternative B could limit access to taxol for cancer patients and clinical testing, with increased availability in Alternatives C through G2. Alternatives C through G2 would have a high positive impact on cancer patients.

Alternatives B through G2 would generate some seasonal employment. The yew program is not expected to affect access to logs or supply of logs for timber workers and log purchasers. 
Recreationists may experience minor effects due to visual degradation.

Social Setting: Geographic Area

Alternative A has no effect on the social/geographical setting.

Alternatives B through G2 pose a small benefit to the social setting, due to some jobs created, but unevenly distributed in the five-state region, and positive feelings associated with yew harvest programs.

\section{Economics}

Alternative A: There would be no government expenditures or returns, and no jobs created as a result of yew bark harvest from federal lands. Bark harvesting jobs would increase on other ownerships in response to yew bark demand. This alternative is not responsive to yew bark demand from federal lands.

Alternatives B through G2 pose various economic impacts: government expenditures vary with the amount of harvest, the number of acres accessed, and the guidelines for establishing the number of trees retained on each acre. Alternatives $\mathrm{C}$ through $\mathrm{F}$ require specified numbers of yew trees to be maintained by diameter class which increases survey and layout costs above Alternatives G1 and G2. Potential revenues returned to the government vary between $\$ 100,000$ and $\$ 1,700,000$. Presently, there is no charge for yew bark from national forest lands. Returns from BLM lands in 1992 were approximately $\$ 21,000$.

The increase in jobs associated with yew bark harvest varies between 75 and 1,700 bark harvesters per year and is directly related to the amount of available bark.

Increased protection of yew in timber sale areas increases commercial harvesting costs resulting in slight decreases in stumpage values received by the federal government. There is also a potential for slight reductions in long-term commercial forest production if yew protection results in substandard site preparation. 
The alternatives address the existing demand for yew bark to different degrees. Alternative $\mathrm{B}$ underachieves existing bark processing capacity. Alternatives C through G2 meet existing capacity demands. Alternatives D through G2 satisfy projected future processing capacity.

\section{Suggestion: Establish Areas of Collection}

\section{Areas and Access}

Alternative A poses no new areas established and no change in access to the forest under this alternative.

Alternatives B through G2 pose some increase in access to timber sale units, partial-cut units, and non-sale areas; road or trail construction and upgrading may be required.

For mitigating measures and more details about the alternatives and the analysis see the DEIS.

Please let us know what you think. The response form is on the next page. Thank you. 


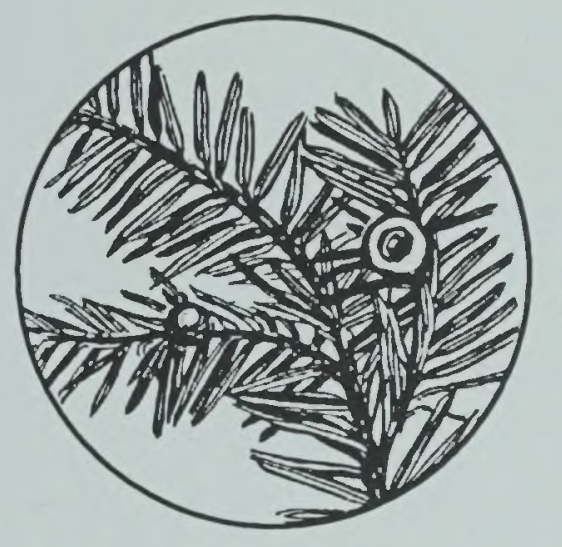

\section{Chapter I \\ Purpose and Need}





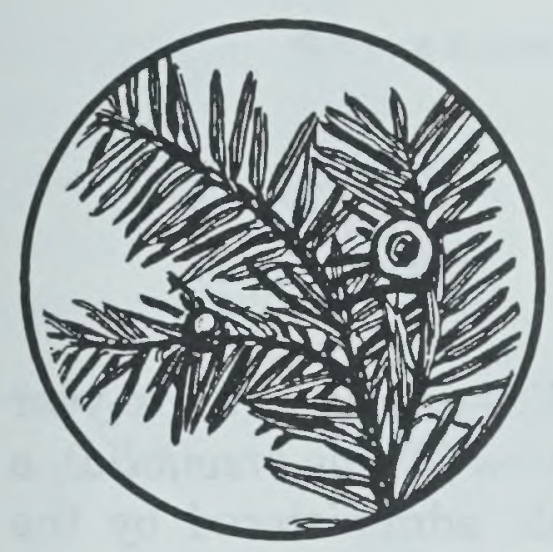

\section{Chapter I}

Purpose and Need

\section{Table of Contents}

\section{The Pacific Yew EIS}

Proposed Action

Underlying Need for Proposed Action

Justification for Need

Cooperating Agencies and Others

Type of Decision

Time Frame

Demand

Type of Raw Material

Alternatives

Issues

\section{Relationship of the Pacific Yew ElS to Other Documents}

Regional and Multi-regional Vegetation Management EIS's

Recovery Plan for the Northern Spotted OWL-USDI Fish and Wildife Service

The FEIS on Management for the Northern Spotted OWl

in the National Forests

Forest Plans

Resource Management Plans

Forest Service and BLM Yew Policies and Direction

District and Forest Decision Documents

Project Level Analysis Documents

Interim Guide to the Conservation and Management of Pacific Yew Pacific Yew Comprehensive Management Strategy

Pacific Yew Act of 1992 


\section{The Pacific Yew \\ EIS}

Chapter I Purpose and Need

\section{Proposed Action}

This environmental impact statement (EIS) addresses a five-year (1993-1997) program to harvest Pacific yew (Taxus brevifolia), a source of taxol, from yew-bearing lands administered by the Forest Service and the Bureau of Land Management (BLM). The proposed action is to harvest anywhere from one million to 30 million dry pounds of yew bark over five years.

\section{Underlying Need for Proposed Action}

The underlying need to which the lead agencies-the Forest Service, the BLM, and the Food and Drug Administration (FDA) are responding is the need for an immediate supply of Pacific yew bark from National Forest System Lands and public lands administered by the BLM for cancer research and treatment. The purpose of the proposed action is to maximize the amount of available taxol while sustaining yew, and to minimize the amount of adverse effects to the ecosystem.

\section{Justification for Need}

The bark, needles and heartwood of Pacific yew contain the compound taxol and related chemicals. Results from clinical trials indicate that taxol is an effective drug for treatment of ovarian and other types of cancer. According to the National Cancer Institute (NCI), taxol is one of the most important anti-cancer drugs discovered in the past 15 years (Medford Tribune, 1992). (See Chapter III, and Appendix $\mathrm{K}$ for further details on taxol history and alternate sources.)

Currently, the only FDA-approved process for taxol production is extraction of taxol from the bark of Pacific yew. Other methods of taxol production from other parts of Pacific yew (wood, needles, and twigs), from other yew species, in nonforest settings (nurseries and plantations), and by other methods (cell culture, semisynthesis, and full synthesis) are in the developmental stage. 
- Prince Rupert
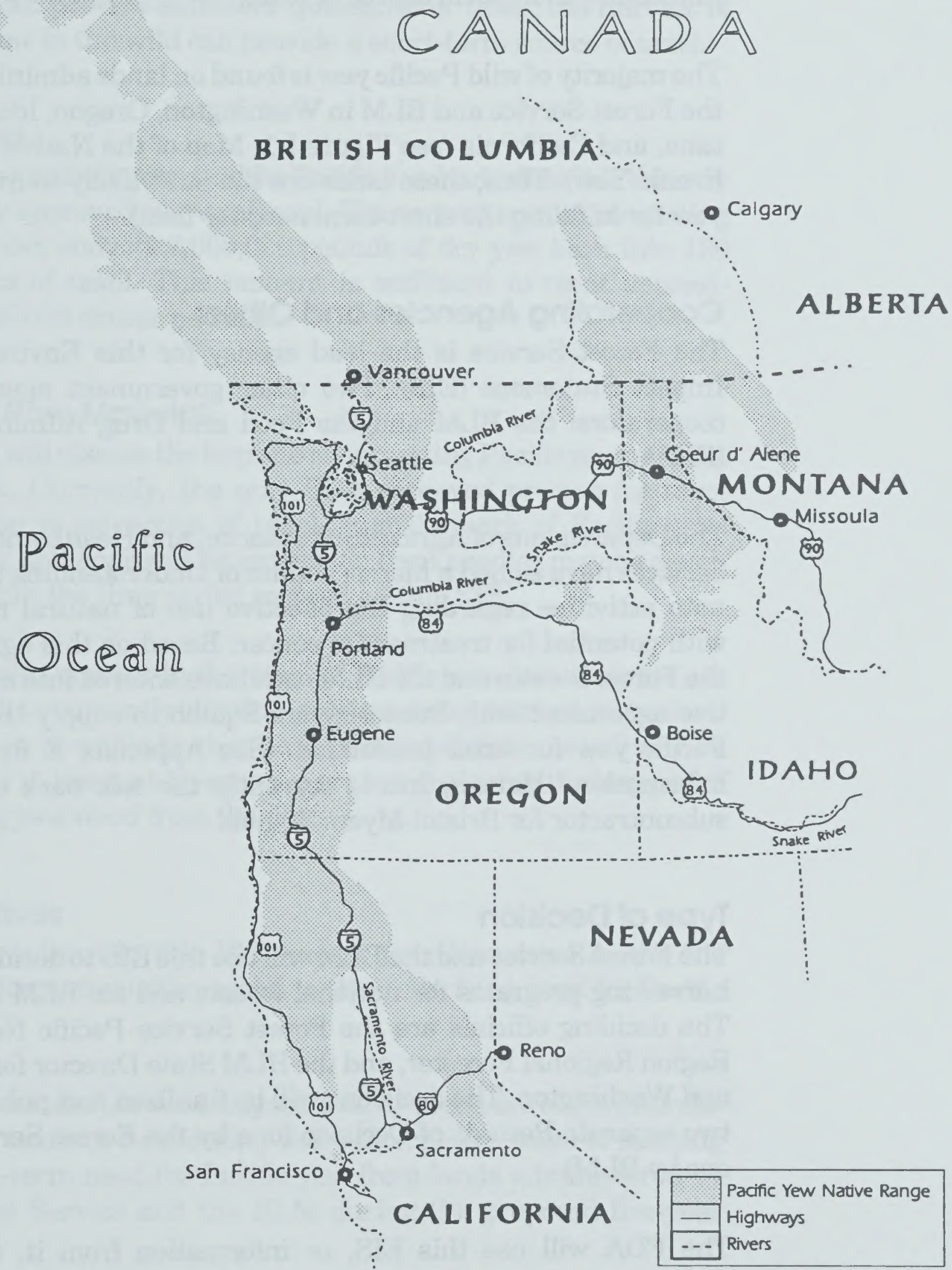
Until other sources of taxol are available and approved, the harvest of bark from Pacific yew in the wild can provide an immediate short-term source of taxol.

The majority of wild Pacific yew is found on lands administered by the Forest Service and BLM in Washington, Oregon, Idaho, Montana, and California (see Figure I-1: Map of the Native Range of Pacific Yew). Thus, these lands are the most likely source of wild yew for fulfilling the short-term need for taxol.

\section{Cooperating Agencies and Others}

The Forest Service is the lead agency for this Environmental Impact Statement (EIS). Two other government agencies are cooperators: the BLM and the Food and Drug Administration (FDA).

The Departments of Agriculture, Interior, and Health and Human Services have signed a Memorandum of Understanding to coordinate activities regarding the effective use of natural resources with potential for treatment of cancer. Based on this agreement, the Forest Service and the BLM each have entered into a cooperative agreement with Bristol-Myers Squibb to supply them with Pacific yew for taxol production. (See Appendix E for further information.) Hauser, Inc. is currently the sole bark collection subcontractor for Bristol-Myers Squibb.

\section{Type of Decision}

The Forest Service and the BLM will use this EIS to decide on yew harvesting programs for national forests and for BLM districts. The deciding officials are the Forest Service Pacific Northwest Region Regional Forester, and the BLM State Director for Oregon and Washington. The decisions will be finalized and published in two separate Records of Decision (one by the Forest Service and one by BLM).

The FDA will use this EIS, or information from it, to make decisions about new drug applications for taxol. 


\section{Time Frame}

This EIS addresses a five-year harvest program. Until other sources can provide sufficient quantities of taxol, the harvest of Pacific yew in the wild can provide a short-term source of taxol.

\section{Demand}

There is significant demand for Pacific yew bark since it is the only currently approved source of taxol. The current annual processing capacity can convert $2,000,000$ pounds of dry yew bark into 130 kilograms of taxol. This amount is sufficient to treat approximately 65,000 cancer patients.

\section{Type of Raw Material}

This EIS will discuss the impacts of harvesting Pacific yew needles, and bark. Currently, the only FDA-approved process for taxol production is extraction of taxol from the bark of Pacific yew. Processes and approval for extraction from needles may be developed within the time period covered by this EIS.

Taxol is also present in the wood of Pacific yew, but amounts are too small to currently develop a commercial extraction process. Because it is unlikely that taxol extracted from wood will be developed in the next 5 years, we are not analyzing the impacts of removing yew wood from the forests.

\section{Altematives}

The alternatives in this EIS (except for Alternative A, the "no action" alternative) all respond to the underlying need for Pacific yew.

This EIS documents the analyses used by members of the interdisciplinary team in considering these alternative ways of meeting the short-term need for Pacific yew from lands administered by the Forest Service and the BLM during the proposed five-year period. 
See Chapter II for the description of the alternatives, the comparison of their effects, and discussion of the degree to which the alternatives satisfy both the needs of the proposal and the concerns raised in the issues.

\section{Issues}

The regulations for implementing the National Environmental Policy Act of 1969 (NEPA) require that important environmental issues be identified early. Information about issues related to this proposal were distilled from the comments of the general public, members of interested groups, and employees of government agencies who participated in early public involvement (scoping) efforts.

After reviewing the material from the scoping sessions and reading the comments, the interdisciplinary team identified the major issues associated with the proposal. These major issues and suggestions, listed below, played a substantial role in forming the alternatives and in raising questions for analysis. They were also used to focus the thinking and discussions required to identify the preferred alternative(s). They include:

\section{Issues:}

Provide material from the Pacific yew tree for the production of taxol

Protect the yew species

Protect the ecosystem

\section{Suggestions:}

Establish a sustainable level of collection-analyze minimum to maximum amounts.

Consider social, cultural, and tribal impacts of collecting yew.

Regenerate yew-plant and manage for natural regeneration. 
Consider the economic impacts of yew collection on timber production, local employment, and sustained forest ecology to ensure future supplies of taxol and other possible drugs, and agreements for taxol production.

Establish areas of collection-decide whether or not to enter set-aside areas such as wilderness, spotted owl habitat, Research Natural Areas, and roadless areas; decide whether or not to build new roads for access; and concentrate collection in certain areas or spread collection over wide areas.

Establish collection methods-partially or wholly strip bark or fell trees; collect needles and twigs.

Utilize the yew completely-all bark, twigs, needles, and wood.

Develop other sources of taxol as soon as possible.

Stop theft and illegal harvest.

A description of all issues, including those outside the scope of this proposal, is presented at the beginning of Chapter II as an aid to understanding and evaluating the alternatives. In addition, more detail about the issues can be found in Appendix A, Public Involvement. 
Relationship of the Pacific Yew ElS to Other Documents
The Pacific yew EIS and Record of Decision (ROD) will give direction for harvesting Pacific yew on federal lands in five states. How it relates to other NEPA documents and other yew strategy documents is outlined below.

\section{Regional and Multi-regional Vegetation Management ElSs}

There are several programmatic EIS's in the west for vegetation management programs on National Forest System lands and public lands administered by the BLM. These are listed below. We do not expect inconsistencies between the vegetation management EIS's and the Pacific Yew EIS.

FEIS for Managing Competing and Unwanted Vegetation This EIS provides direction for vegetation management on national forests in the Pacific Northwest Region; it was completed in November 1988.

FEIS Pacific Southwest Region

Vegetation Management for Reforestation

This EIS, published in December 1988, provides direction for vegetation management on national forests in the Pacific Southwest Region.

\section{FEIS Western Oregon}

Program Management of Competing Vegetation

This EIS provides direction for vegetation management on public lands administered by the BLM in western Oregon; it was published in August, 1992.

\section{FEIS Vegetation Treatment on}

BLM Lands in Thirteen Western States

This EIS, completed in May 1991, gives direction for vegetation management on public lands administered by the BLM in Arizona, Colorado, Idaho, Montana, Nevada, New Mexico, North Dakota, eastern Oregon, South Dakota, Utah, Washington, and Wyoming. 


\section{Recovery Plan for the Northern Spotted Owl USDI Fish and Wildlife Service}

The Recovery Plan, prepared by USDI Fish and Wildlife Service, is in a draft stage. The decision by the Forest Service and BLM to adopt the plan in lieu of other plans has not yet been made. The Forest Service is analyzing the recovery plan as a possible additional alternative in the supplement to the FEIS on Management for the Northern Spotted Owl in National Forests; the draft is due to be published in early Spring 1992. Consistency between the Pacific Yew EIS and any new decision adopting the Recovery Plan, or parts of it, will need to be determined when the supplement to the Owl EIS is approved.

\section{The FEIS on Management for the Northern Spotted Owl in the National Forests}

This is a Forest Service programmatic EIS for northern spotted owl management in the Pacific Northwest and the Pacific Southwest Regions. A supplement to this Spotted Owl FEIS is being prepared in response to a court order issued in July, 1992. Alternative G2 in the Pacific Yew EIS, the only alternative proposing entry into spotted owl habitat conservation areas, may not be consistent with this supplement (to be finalized August of 1993). If Alternative G2 is selected, consistency will be evaluated by an internal Forest Service process and then referred to the Interagency Scientific Oversight Group (a group of agency directors from state and federal organizations in the Pacific Northwest) for final resolution.

\section{Forest Plans}

Activities on national forests are guided by forest plans. Project level decision developed for yew harvest will be consistent with forest plans and the decision that results from this EIS.

\section{Resource Management Plans}

Activities on BLM Districts will be guided by resource management plans (RMPs); RMPs will replace management framework plans. Direction in RMPs should be consistent with that in the 
Pacific yew EIS; draft RMPs for Western Oregon were published in August 1992, with the finals expected in 1993.

\section{Forest Service and BLM Yew Policies and Direction}

Direction given to National Forest and BLM districts regarding yew harvest and management will be revised to reflect the guidance in the Pacific yew EIS, if there are differences or conflicts. (See Appendix N.)

\section{District and Forest Decision Documents}

Direction given in environmental assessments (EAs) or other decision documents may need to be amended to reflect guidance in the Pacific Yew EIS if inconsistencies are present.

\section{Project Level Analysis Documents}

Specific yew harvesting activities and projects on districts and forests will be planned, analyzed, and implemented to carry out the direction in the yew EIS. Because this EIS is a programmatic document, future project level (site-specific) environmental analyses will be required. Project level environmental analyses will be tiered to the yew final EIS.

\section{Interim Guide to the Conservation and Management of Pacific Yew}

This guide, developed by a team of scientists, outlines a low-risk strategy for managing and conserving yew. This strategy, completed in March 1992, will be used by the Forest Service and BLM until an analysis of the impacts of harvesting yew is completed and an EIS is published. Many aspects of the strategy are incorporated in the EIS by the Pacific Yew EIS interdisciplinary team. The Interim Guide is not a NEPA document and is not legally binding. 


\section{Pacific Yew}

\section{Comprehensive Management Strategy}

This document was prepared by the BLM in response to direction from Congress in November of 1991 "to develop a comprehensive strategy document for ensuring a sustainable supply of Pacific yew for the medical community with the least impact to the environment and to the Pacific yew resource." Published in July, 1992, it describes the current and planned Pacific yew programs undertaken by the BLM. It is not a NEPA document.

\section{Pacific Yew Act of 1992}

The Pacific Yew Act provides for the management of federal lands containing the pacific yew to ensure a sufficient supply of taxol. The act also provides for the sale of Pacific yew from such lands for the commercial production and subsequent sale of taxol at a reasonable cost to cancer patients; for the long-term conservation of yew, and prevention of wastage while successful and affordable alternative methods of manufacturing taxol are being developed. The act will expire once sufficient supplies of taxol are available from sources other than the Pacific yew. Proposed regulations are currently being drafted for implementation of the Pacific Yew Act. All the action alternatives (Alternatives B through G2) are consistent with this act. 



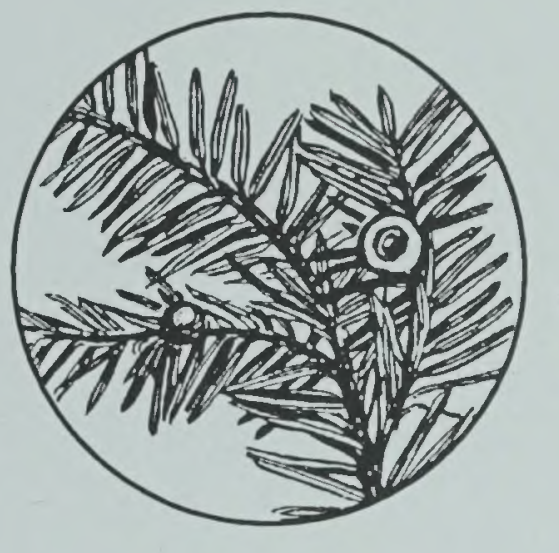

\section{Chapter II}

Issues, Alternatives, and Comparisons 



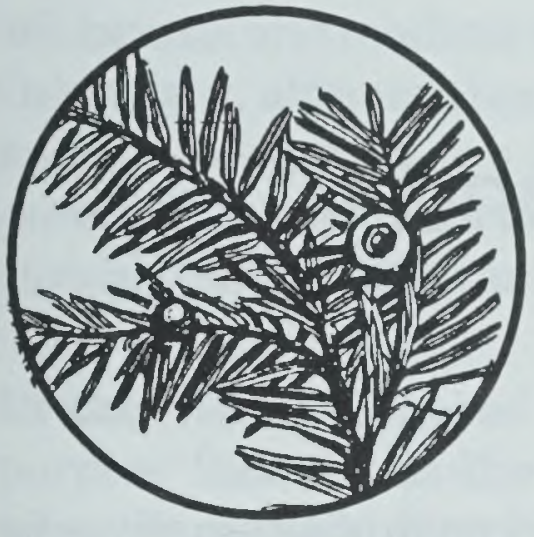

\section{Chapter II \\ Issues, Alternatives, and Comparisons}

Table of Contents

Introduction

Issues Used to Help Evaluate the Altematives

Altematives Considered but Eliminated From Further Study

Components Considered but Eliminated

Alternatives Considered But Eliminated

\section{The Altematives}

\section{Description of Alternatives}

Terms to Know

Summary of the Comparison of the Effects of the Altematives Table Discussion of the Comparison of the Effects of the Alfematives

Issues: Provide Taxol, Protect the yew, Protect the Ecosystem

Suggestion: Establish Sustainable Collection Level

Suggestion: Consider Socio-economic Concerns

Suggestion: Establish Areas of Collection

Mitigation Measures for Yew Harvest

Terms to Know

Mitigation Measures for Alternative B

Mitigation Measures Alternatives $C$ through $G 2$

Special Area Mitigation Measures 


\section{Chapter II Issues, Alternatives, and Comparisons}

\section{Introduction}

Issues Used to Help Evaluate the Altematives
This chapter describes and summarizes a range of alternatives for harvesting yew bark. Issues identified during scoping are presented. Alternatives considered but eliminated from further study are documented, and the reasons for their elimination are given. Following this is a detailed discussion of the seven alternatives, including the "No Action" alternative and a recommended preferred alternative, Alternative G1. The alternatives are developed to address the major issues identified in Chapter I. Next, the effects of each alternative are compared and contrasted in a table and accompanying summary discussion. Mitigation measures for each of the action alternatives are presented at the end of the chapter.

The following section describes the public issues and suggestions that were used to help evaluate the alternatives. In some cases, suggestions were made that are outside the scope of this proposal for various reasons. For example, in the case of developing other sources of taxol, the concern was outside the jurisdiction of the agencies involved. See Appendix A for a more detailed discussion of the issues and suggestions.

\section{Special Note}

If an issue is outside the scope of the proposal, the reasons are documented here.

\section{Issue Provide Material from the Pacific Yew for Taxol}

Most people who responded want material from the Pacific yew to be available for the production of taxol and its use in clinical trials and treatment of ovarian and possibly other cancers. Some say that saving human lives should be the top priority; yew harvests should be maximized regardless of environmental impacts; and 
wilderness and roadless areas should be opened for yew collection. Others say, although taxol should be made available, the yew tree and the ecosystem are important in themselves and for future generations and deserve protection; the harvest of yew for taxol should proceed with care, caution, and safeguards.

In this EIS... The need for the cancer-fighting drug taxol is the purpose that drives the proposed action to harvest Pacific yew trees or shrubs. Our big question is: How can we provide material from the Pacific yew for taxol and protect the species and the ecosystem? We will show how much yew is available under different alternatives, look at various areas where yew might be harvested, and analyze the effects of harvest on the species, and the ecosystem (including humans).

\section{Protect the Ecosystem}

People who commented want protection for the yew's ecosystem in order to ensure forest diversity. They want studies of the role yew plays in its community and the impact of yew harvest; some feel the forest has already been ruined by timber harvests. A major concern within ecosystem protection is the old growth or ancient forests; people want to protect and sustain ancient forests for future generations and for the unknown resources they may contain.

Other concerns regarding the health of the ecosystem are for protection and understanding of wildlife, including deer, elk, moose (Idaho and Montana), birds, insects, the northern spotted owl and other threatened or endangered species; riparian zones, watersheds, and fish habitat; plants, including fungi; soils and soil organisms; and aesthetics.

In this EIS... Protecting the Pacific yew ecosystem is covered by the mitigation measures as part of six of the seven alternatives. The guidelines provide for yew reserve areas; protection of riparian areas; and consultation with wildlife biologists about deer, elk, moose, northern spotted owl habitat, and many more species. 


\section{Issue Protect Pacific Yew and Maintain its Genetic Diversity}

Here, the concern is for careful management to protect Pacific yew and its gene pool, while balancing short versus long-term needs for taxol. People want studies of yew in order to understand how to maintain the population and provide a viable gene pool for the future. With recent reports of infection of small amounts of yew trees with the root disease Phytopthora lateralis, found in PortOrford-cedar, people want to know what steps can be taken to protect yew.

In this EIS... Protecting and maintaining the genetic diversity of Pacific yew is part of six of the seven alternatives presented. The Interim Guide calls for reserves to be established in every harvest area at 2,000-foot elevation intervals.

We also discuss the effects of Phytopthora lateralis. (See the section on insects and diseases in Chapters III and IV.)

\section{Suggestion Analyze and Establish a Suitable and Sustainable Level of Harvest and Taxol Production}

This issue refers to the need for an accurate inventory of Pacific yew and its range in order to avoid over-harvesting, and to carefully manage for present needs and future generations.

In this EIS... We incorporate the Pacific yew inventory, show a sustainable output, and analyze a short-term (five-year) output. Until other sources can provide sufficient quantities of taxol, the harvest of Pacific yew in the wild can provide a short-term source of taxol for the treatment of various cancers.

\section{Suggestion Consider Cultural, Social,}

\section{Spiritual, and Tribal Values of Yew}

Most people who responded were in favor of utilizing a balanced system of harvest while preserving the yew at historic levels, and giving consideration to multiple use and whole-ecosystem health. Many people felt that more attention should be given to the spiritual, cultural, and historical value of the yew. Some said that, because Native Americans have a long tradition of using the yew 
for its healing powers, they should be guaranteed continued access to the trees. Several people felt that the yew is sacred, and no harvesting of wild stands should take place.

In this EIS... We discuss cultural social, spiritual, and tribal values of yew in the "Yew and People" sections of Chapters III and IV.

\section{Plant and Manage for}

\section{Regeneration of Pacific Yew}

In this case, people who commented are concerned about protecting the Pacific yew as a future resource. Most who commented agreed with harvesting yew trees for taxol, as long as sound reforestation practices that allow for natural regeneration or call for replanting are in place and that nursery propagation efforts continue.

In this EIS... We include requirements for regeneration to preharvest or prescribed levels in six of the seven alternatives. Forest Service and private nurseries continue to propagate Pacific yew for reforestation.

\section{Consider the Economic Effects of Yew Collection on Resources, Economies, and Future Options}

Here, many people commented that maintaining a sustained forest ecology is essential for ensuring the future of taxol and other important drugs yet to be discovered.

A significant number of people said they think the agreement with Bristol-Myers Squibb company is "monopolistic," and that many companies, not just one, should benefit from taxol production.

The economic impacts of yew harvest and bark collection on the timber industry was another area of concern. Several people suggested that yew harvest take place only in active timber sale areas. Some expressed concern over whether yew harvest and bark collection projects would be used to provide jobs for local residents, especially in areas where there are significant numbers of displaced timber workers. 
In this EIS... We look at the economic impacts of yew harvest. Modification of agreements with Bristol-Myers Squibb is outside the scope of this EIS. (See Appendix E for more information about the agreements.)

\section{Suggestion Establish and Define}

\section{Areas of Collection or Reserve Areas}

In this issue the number one public concern is the Forest Service treatment of set-aside areas. Sentiment is divided between those favoring:

a. Absolutely no harvest in any set-aside areas. This includes Research Natural Areas (RNAs), designated wilderness, and owl conservation areas (OCAs).

b. Limited harvest in set-aside areas.

c. Comprehensive harvest of yew wherever it is found, in whatever quantity needed.

Many people think that old growth forests should be left alone, although minimum intrusion may be allowed for research and inventory purposes.

In this EIS... We consider one alternative that looks at yew collection in set-aside areas (owl conservation areas only). We look at some level of harvest in owl conservation areas because these areas cover a large number of acres, and could make a sizable difference in the amount of yew material available for harvest.

In this EIS we do not consider entering wilderness areas, or Research Natural Areas for yew harvest.

\section{Suggestion Establish Collection Methods}

In this case, many people want to know what kinds of yew harvest methods will be allowed, and how harvests will be incorporated into existing forest management prescriptions. Some said efficient collection methods should be established to ensure full utilization 
of the tree. Others said harvest methods that result in the death of the tree should be discontinued. Several people asked whether the yew trees can survive if they are partially stripped of their bark. A small number of respondents said only the needles and twigs should be collected. At least two people asked for a definition of "harvest" in regards to the yew.

In this EIS... Specific collection methods are beyond the scope of this EIS, and will be addressed in site-specific analyses. Current yew harvest direction calls for harvesting yew before timber is cut on sale units. Partial-stripping of yew bark is not currently practiced because of the unknown effect on the viability of the tree and the fact that more trees would be affected. Current utilization standards call for stripping bark from boles and branches down to one inch in diameter.

\section{Utilize All Parts of Harvested Yew}

Most people who commented want the whole yew tree to be used if the bark is going to be collected. They suggest it be used (perhaps commercially, for a fee) for fenceposts, firewood, bows, musical instruments, ornamental wood working, tool handles, and lumber.

Many people are concerned about waste of the tree during the harvesting process and want all bark from large and small limbs to be collected; they don't want to see the remaining tree burned or left to rot. Many want the small branches and needles to be used as well as the bark; some suggest collecting needles instead of bark in order to save the trees. Others would like to see the entire tree used for the extraction of taxol.

In this EIS... We analyze the effects of harvesting needles and bark.

Currently, the only FDA approved process for taxol production is extraction of taxol from the bark of Pacific yew. We are analyzing needle harvest because processes and approval for extraction from 
needles may be developed within the time period covered by this EIS. Although taxol is present in wood, current taxol extraction methods from wood are not practical. Yew wood for purposes other than taxol is available to those who can make use of it, including bowyers, musical instrument makers, and other woodworkers. Current utilization standards require that bark be stripped from branches and boles down to one inch in diameter; this may vary after site-specific analysis.

\section{Suggestion Develop Other Sources of Taxol as Soon as Possible} Many people called for the development of other sources of taxol as soon as possible, to avoid the burden on the yew species and the potential impacts of a long-term harvest program.

Many wanted to see a progress report on the development of other sources of taxol through synthesis, semisynthesis, cell culture, nursery propagation, heartwood extraction, and needle extraction.

Some people feel the Forest Service and BLM should fund research into alternate methods of producing taxol. Several say that taxol will soon be synthesized and the need for yew harvest will diminish. A few people asked what will become of the yew when it is no longer desired for its taxol.

In this EIS... While this issue is outside the scope of the proposal, a number of efforts to develop other sources are underway. These are discussed in Chapter III and Appendix K.

Our "no action" alternative assumes other sources of taxol will be developed. All alternatives could accommodate possible breakthroughs in taxol production from another source. 
Many people expressed concern about the theft and illegal harvest of wild yew trees. Most wanted to know how illegal harvest would be stopped, and what kinds of punishment poachers would face if caught. Many felt there should be serious consequences for stealing yew trees. Some people questioned how to protect wild yew trees on their private lands. At least one respondent suggested using public awareness to monitor poaching and discourage theft.

In this EIS... Theft may have an impact on how much yew is available for harvest. Law enforcement responsibilities are assigned to each national forest and BLM resource area or district. Because yew theft law enforcement is included with all other types of law enforcement, this issue is outside the scope of this EIS. 


\section{Altematives Considered but Eliminated From Further Study}

In addition to the seven alternatives discussed in this chapter, several other alternatives were considered but eliminated from further study. Many different components were suggested, but not all of them were included. The first part of this section will describe those components and explain why they were not incorporated. The second part will describe the broader, more fully developed alternatives and provide an explanation of what was learned from studying them before they were excluded.

\section{Components Considered but Eliminated}

\section{Harvest Yew in Wildemess Areas}

Yew harvest in wilderness areas would require revision of current legislation at the congressional level. Projected harvest goals are attainable without entering these areas.

\section{Harvest Yew in Research Natural Areas (RNAs)}

RNAs are areas set aside for the study of ecological systems in a setting that has been undisturbed by humans. Removal of yew from these areas would defeat their purpose. Because these areas tend to be fairly small in terms of overall acreage, yew on these acres would not contribute substantially to yew bark production.

\section{Harvest Yew in Special Management Areas}

Acreage and management in these areas varies so widely across different forests, that a programmatic EIS adequately address yew harvest in them. Special management areas would be better left to forest level decisions where site-specific circumstances can be considered in an Environmental Assessment.

\section{Harvest Complete Tree in Timber Sale Areas, Strip Bark in Other Areas}

In the Interim Guide, the Yew Technical Committee recommends either cutting the trees, or removing the foliage. It does not recommend partial bark stripping from standing live trees because of lethal risk. 


\section{Alternatives Considered But Eliminated}

\section{Protect Yew}

An alternative was considered that would modify existing management plans to protect yew. Yew would not be harvested on Forest Service and Bureau of Land Management lands; all yew material would be obtained from other sources such as privately owned lands, biomass production in nurseries, cell culture, and total synthesis.

The "no harvest" part of this alternative is covered in Alternative A (see Description of Alternatives in this chapter). The Interim Guide as well as the mitigation measures in this EIS, call for protection of the genetic diversity and viability of the yew species. Comprehensive management of yew is beyond the scope of this analysis; we focus solely on the potential impacts of yew harvest.

\section{Harvest Yew Only if Other Activities Would Harm Yew}

An alternative was considered that would allow harvest of yew only where it would be destroyed by other activities, such as clearcutting and road building. Yew that would not be impacted within the activity area would not be harvested.

Additional components of this alternative are:

- Do not harvest yew in non-sale/non-activity areas. Take only the yew that would be killed during the activity; all other yew within the activity area boundary would be untouched;

- Harvest bark, needles, and branches;

- Harvest whole tree (cutting instead of barkstripping);

- Base the supply of yew products for taxol on the level of timber sales or other activity;

- Do not make specific provisions for regeneratio;

- Do not modify harvest regimes to enhance yew production or to protect yew;

- Do not provide for specific gene pool reserve areas; and

- Do not harvest in restricted areas. 
This alternative is identical to Alternative B (see Description of Alternatives in this chapter) except that in B we harvest all yew meeting size standards within the unit (not just the ones that would be damaged) and we regenerate to preharvest or prescribed levels. It was not carried forward because Alternatives A and B more fully encompass the intent of this alternative.

\section{Prioritize Harvest Areas}

In another considered alternative, yew would be harvested according to the Interim Guide. The following priorities would be used to identify yew harvest areas:

- Near communities that would most benefit from the increased employment created by yew harvest activities;

- In general forest areas designated for timber management in forest or resource management plans;

- No harvest in designated wilderness areas or Research Natural Areas; and

- In other areas, only if designated amounts of bark and/or needles cannot be provided by the above areas, in this order:
a. roadless areas
b. owl critical habitat areas
c. significant old growth areas
d. owl conservation areas (OCAs)

This alternative addresses the concerns about the increasing numbers of displaced timber workers, and harvest in old growth forests and spotted owl designated areas. It was not carried forward because all the action alternatives provide for increased employment opportunities for displaced timber workers. Harvest areas are prioritized in the Mitigation Measures section of this chapter.

\section{Hanest $100 \%$ of Yew}

An alternative was considered that would allow yew harvest according to the Interim Guide, and also 100\% harvest in partialcut and non-sale areas and some harvest in OCAs. Because of its similarity to Alternative G2 it was eliminated from further analysis. 


\section{Maximize Yew Harvest for Taxol Production}

Another alternative was considered that would harvest yew at a $100 \%$ level from all areas. Additional components of this alternative would be:

- Harvest at a level that maximizes production of taxol over the short-term;

- Emphasize maximum drug production without provisions for long-term viability of the species;

- Enter set-aside areas (wilderness, OCAs, botanical areas);

- Plan timber sales specifically for yew harvest (areas of high concentration);

- Harvest regardless of unusual parent rock, geology, or vegetation; and

- Harvest in riparian areas.

This alternative would maximize production of taxol through an intense short-term harvest strategy. It was eliminated from further analysis due to its total lack of protection for the yew or sensitive areas, coupled with intense harvest in all areas.

\section{Altemative $\mathrm{E}$}

This alternative proposed harvesting yew in owl conservation areas as well as partial-cut sale units, non-sale areas, and timber sale units. Harvest levels would follow the Interim Guide (leave $50 \%$ of the yew or five trees per acre (TPA) per diameter class, whichever is greater; harvest the remainder). Mitigation measures developed for Alternatives C, D, F, G1, and G2 would be followed.

Alternative $\mathrm{E}$ was eliminated from further consideration in order to avoid redundancy with Alternative D and G2. 


\section{Long-Term Even-Flow Harvest}

This alternative considered harvesting yew in sale units, partialsale units, and non-sale areas at a level that could be harvested each year for 100 years. No more than a specified amount of yew could be harvested over the five-year period of the yew harvest program. A minimum of five TPA would be retained in each of three diameter classes. Mitigation measures would be the same as those for Alternatives C, D, F, G1, and G2.

This alternative was dropped from further consideration because it is unlikely that we will need a long-term, low-yield yew harvest program. The best information currently available indicates that there will be alternative sources of taxol available on a commercial scale within three to five years, in which case harvest of yew for taxol on federal lands will cease after five years. 
This section describes the seven alternatives for managing harvest of Pacific yew on federal lands. These seven alternatives include a "no action" alternative which defines the continuation of yew harvest as it was prior to any large scale harvest for taxol. This section also indicates the preferred alternative (Alternative G1), which was identified by the Regional Foresters and the BLM State Director.

The first part of this section is a graphic oyerview of the alternatives (see Figure II-1), followed by a discussion of the features common to all alternatives and a brief view of how they vary from one another. This is followed by full descriptions of each alternative.

After the description of the alternatives, we compare, in a summary table, the effects of each alternative on each resource. The chapter closes with the mitigation measures. 


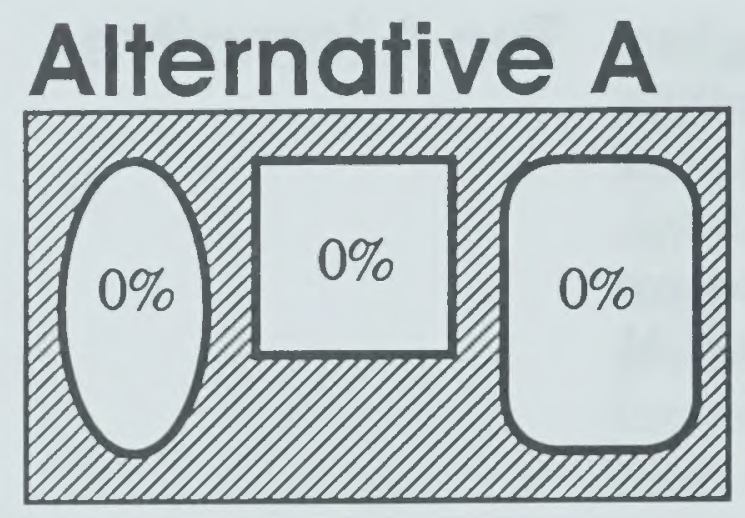

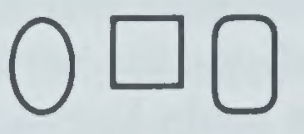

--No yew harvest for taxol production --No protection of yew --No yew regeneration --No genetic reserves
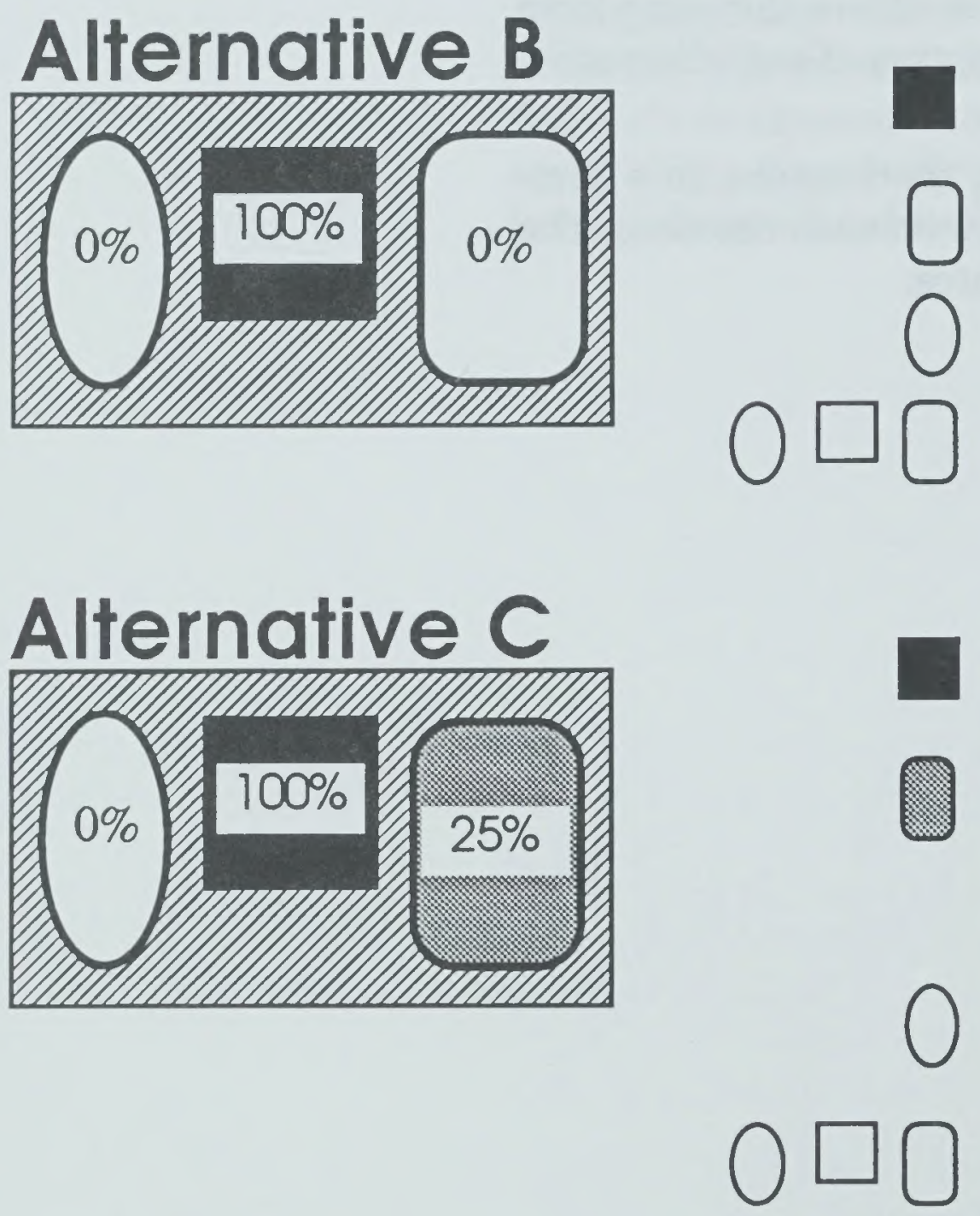

--Harvest 100\% utilizable yew

--Yew regeneration and protection

--No yew harvest

--No yew harvest

--No genetic reserves

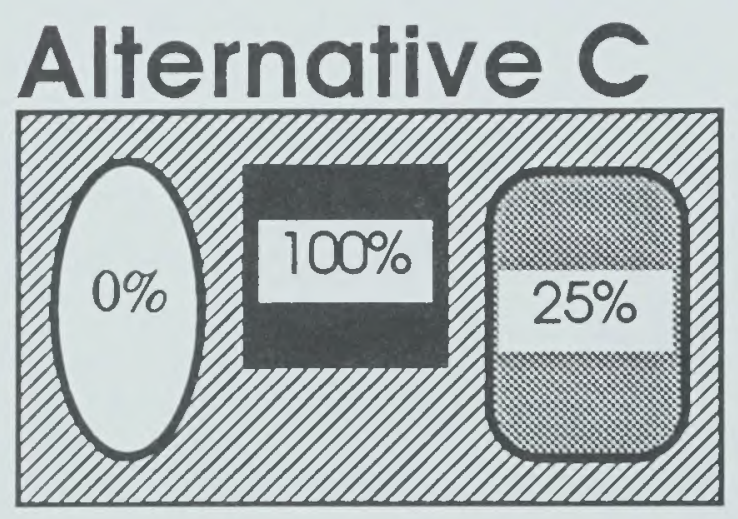

--Harvest $100 \%$ utilizable yew

--Harvest maximum of $25 \%$ per diameter class

--Retain $75 \%$ or 5 TPA per diameter class

--No yew harvest

--No yew harvest near streams

--Yew regeneration and protection

--Genetic reserves

Key
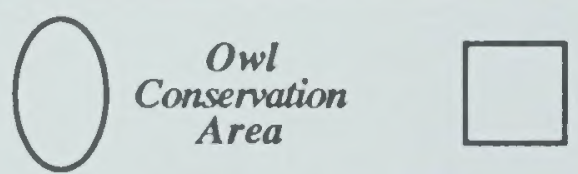

Timber Sale

(TS) units-

clearcut shelterwood, or seedtree harvest
Partial-cut sale units such as thinning or uneven-aged cuts and non-sale areas where yew harvest is allowed in the Forest plans 


\section{Alternative D}

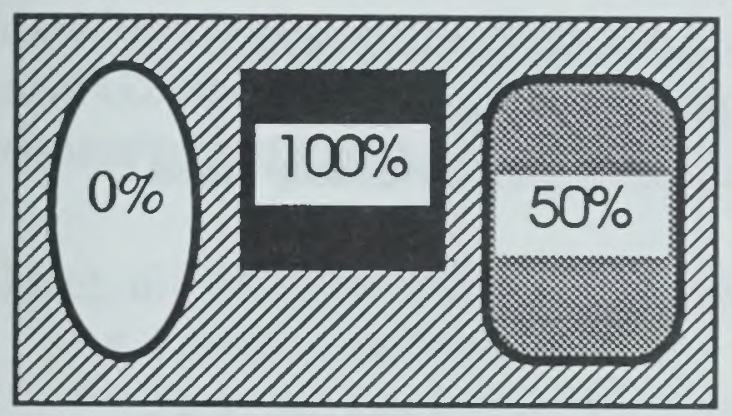

\section{Alternative $\mathrm{F}$}

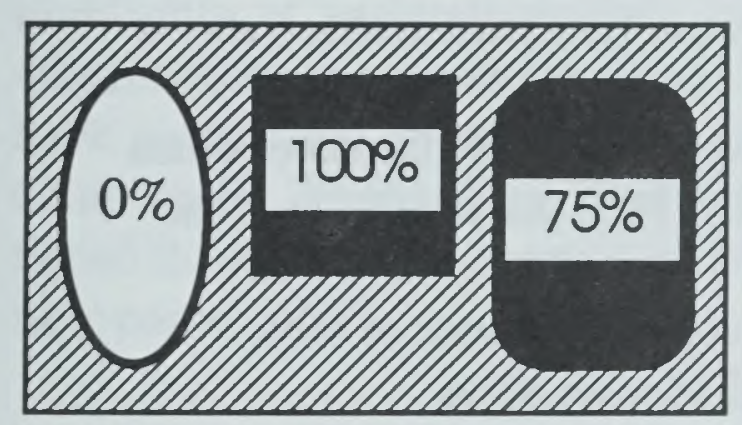

--Harvest 100\% utilizable yew

--Harvest maximum of $50 \%$ per diameter class

--Retain $50 \%$ or 5 TPA per diameter class

$\bigcirc$--No yew harvest

$0 \square 0$

--No yew harvest near streams

--Yew regeneration and protection --Genetic reserves

--Harvest $100 \%$ utilizable yew

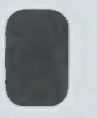

--Harvest maximum of $75 \%$ per diameter class --Retain $25 \%$ or 2 TPA per diameter class

--No yew harvest

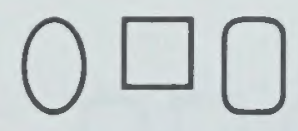

--No yew harvest near streams

--Yew regeneration and protection --Genetic reserves

Key
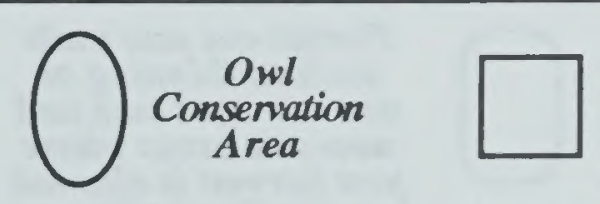

Timber Sale (TS) unitsclearcut shelterwood, or seedtree harvest
Partial-cut sale units such as thinning or uneven-aged cuts and non-sale areas where yew harvest is allowed in the Forest Plans 
Alternative $\mathbf{G 1}$

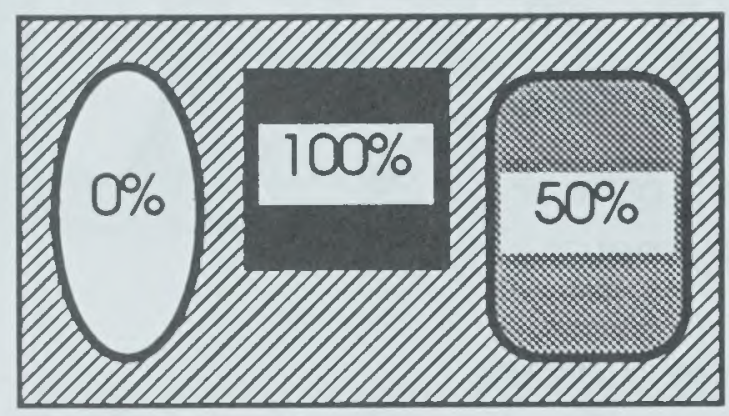

Alternative $\mathbf{G} 2$

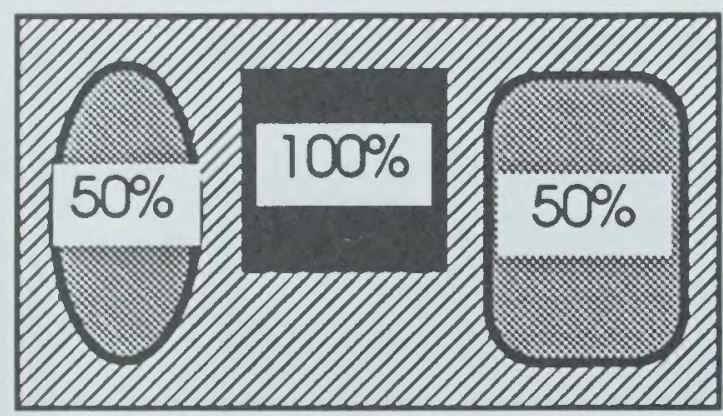

--Harvest $100 \%$ utilizable yew

\# --Harvest maximum of $50 \%$ per diameter class

--Retain $50 \%$ per diameter class

--No yew harvest

--No yew harvest near streams

--Yew regeneration and protection

--Genetic reserves

--Harvest $100 \%$ utilizable yew

--Harvest 50\% per diameter class

--Retain $50 \%$ per diameter class

--Harvest maximum of $50 \%$ per diameter class

--Retain $50 \%$ or 5 TPA per diameter class

--No yew harvest near streams --Yew regeneration and protection --Genetic reserves

Key
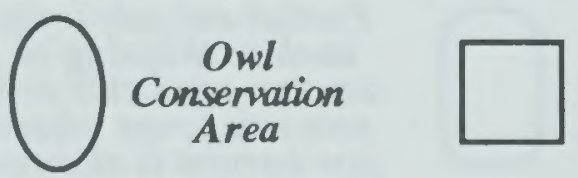

Timber Sale

(TS) unitsclearcut shelterwood, or seedtree harvest
Partial-cut sale units such as thinning or uneven-aged cuts and non-sale areas where yew harvest is allowed in the Forest Plans 
This section describes the seven alternatives for managing the harvest of yew trees and shrubs on federal lands. The alternatives are identified with the letters A through G2. Alternative E was dropped from further consideration during a late stage in the development process. The two $\mathrm{G}$ alternatives were designated G1 and G2 due to their similarity in all aspects except entry into owl conservation areas. Alternative G1 is the preferred alternative.

Each alternative description includes the following components:

- Landscape Perspective;

- Harvest Location; Harvest Levels;

- Set-Aside Areas;

- Protection of Yew;

- Protection of Other Resources;

- Regeneration;

- Genetic Diversity;

- Relationship to Interim Guide;

- Available Trees and Bark; and

- Sustainability of Harvest.

In the interest of readability, a succinct statement distilling the highlights of each alternative precedes its description. Further details about the numbers of available acres for harvest, trees, and bark mentioned in each alternative description can be found in Chapter IV, Pacific Yew Population and Inventory. Terms mentioned throughout the description of the alternatives are defined on the next page:
Description of Altematives 


\section{Terms to Know}

"Residual green tree reserve"-green trees left on a site to provide a local seed source or for other purposes. Where silvicultural prescriptions call for retaining green trees, the inclusion of yew trees and shrubs in the green tree reserve provides a local seed source for natural regeneration.

"Timber sale unit"- an area within a timber sale which has a silvicultural prescription for a (1) clearcut, (2) shelterwood, or (3) seed tree harvest method. It also refers to an area that is to be cleared for road or building construction, or an area to be preharvested for prescribed fire treatment.

"Partial-cut sale unit" - an area within a timber sale which has a silvicultural prescription to cut only part of a stand. Techniques which involve "partial cutting" include thinning, salvage operations, and prescriptions designed to produce an uneven-aged stand of trees.

"Non-sale area"- an area in a national forest or district where no timber sales, as described in above definitions, are scheduled in the next five years, but where yew harvest is allowed according to land use plans.

"Owl conservation areas"- those areas formally designated for protection of the northern spotted owl. They provide a contiguous block of habitat to be managed and conserved for spotted owls. The blocks are placed so as to be well distributed throughout the range of the owl and spaced closely enough to facilitate dispersal of owls among them. We are using "owl conservation areas" (OCAs) to include Forest Service habitat conservation areas (HCAs), and BLM's old-growth emphasis areas (OGEA), connectivity areas (CON), and owl pair sites (OPS). 
Alternative A gives no particular emphasis to Pacific yew bark harvest; it emphasizes all resources according to forest plans and BLM resource management plans.

Alternative $\mathrm{A}$ is the "no action" alternative. A "no action" alternative is required by the National Environmental Policy Act (NEPA). Under Alternative A, no harvest of Pacific yew for taxol production would take place; thus, no yew material for taxol production would be available from federal lands. This alternative also describes the manner in which Pacific yew was managed on federal lands prior to 1989, before the demand for yew bark for taxol emerged. Alternative A conflicts with the Pacific Yew Act (see Chapter I).

\section{Landscape Perspective}

There would be no planned harvest of yew for taxol under this alternative. Pacific yew trees could potentially be killed or injured without utilizing the bark; however, yew would be harvested on 0.078 to 0.118 million acres over the next five years in timber sale units that contain Pacific yew.

\section{Harvest Locations; Harvest Levels}

Pacific yew for bark or needle production would not be collected in or removed from any area.

\begin{tabular}{|l|c|c|c|}
\hline \multicolumn{1}{|c|}{ Locations } & $\begin{array}{c}\text { Yew } \\
\text { Harvest? }\end{array}$ & $\begin{array}{c}\text { Maximum } \\
\text { Amount } \\
\text { Harvested }\end{array}$ & $\begin{array}{c}\text { Minimum } \\
\text { Yew Left of } \\
\text { Utilizable Size }\end{array}$ \\
\hline Timber Sale Unit & No & None & NA \\
\hline Partial-Cut Sale Units & No & None & NA \\
\hline Non-sale Areas & No & None & NA \\
\hline Owl Conservation Areas & No & None & NA \\
\hline
\end{tabular}

\section{Set-Aside Areas}

Yew would not be harvested in owl conservation areas, designated wilderness, or other areas in national forests or BLM districts set aside for specific purposes. 


\section{Protection of Yew}

Dead or damaged yew, or yew in danger of being killed or damaged by other activities (including timber harvest) would not be given special protection. There would be no requirement to retain a certain number of yew trees or shrubs per acre in any area (other than that specified in forest or resource management plans).

\section{Protection of Other Resources}

As yew would not be harvested under this alternative, no special provisions to protect yew would be made in this alternative. However, protection of streams, wildlife, and other vegetation as defined in site-specific analyses and existing forest and resource management plans would apply to all projects.

\section{Regeneration}

There would be no special requirement to regenerate Pacific yew after any project, other than that specified in silviculture prescriptions.

\section{Genetic Diversity}

There would be no special provisions for maintaining the genetic diversity of Pacific yew.

\section{Relationship to Interim Guide}

No aspects of the Interim Guide would be incorporated into Alternative $\mathrm{A}$.

\section{Available Trees and Bark}

There would be no yew trees or bark available for taxol production under this alternative.

\section{Sustainability of Harvest}

There would be no yew harvest for taxol production in this alternative, and therefore, no output of yew for that purpose over the fiveyear period covered by this EIS. This alternative would not preclude a sustained yield harvest of yew in the future. 


\section{Alternative B emphasizes utilization of Pacific yew where it would otherwise be wasted; production of yew bark from federal lands is dependent on timber harvest programs.}

Alternative B would allow harvest in timber sale units only. Approximately 1.3 to 1.95 million pounds of dry yew bark would be available over five years with this alternative.

\section{Landscape Perspective}

Yew would be harvested from an estimated 0.078 to 0.118 million acres over the next five years in timber sale units that contain Pacific yew (see tables in Chapter IV Pacific Yew Population and Inventory section).

\section{Harvest Locations; Harvest Levels}

Alternative B would allow harvest of 100 percent of the yew of utilizable size in timber sale units (excluding residual green tree reserves).

\begin{tabular}{|l|c|c|c|}
\hline \multicolumn{1}{|c|}{ Locations } & $\begin{array}{c}\text { Yew } \\
\text { Harvest? }\end{array}$ & $\begin{array}{c}\text { Maximum } \\
\text { Amount } \\
\text { Harvested }\end{array}$ & $\begin{array}{c}\text { Minimum } \\
\text { Yew Left of } \\
\text { Utilizable Size }\end{array}$ \\
\hline Timber Sale Unit & Yes & $100 \%$ & no mininum \\
\hline Partial-Cut Sale Units & No & None & All \\
\hline Non-sale Areas & No & None & All \\
\hline Owl Conservation Areas & No & None & All \\
\hline
\end{tabular}

\section{Set-Aside Areas}

Yew would not be harvested in spotted owl conservation areas, designated wilderness, or other areas in national forests or BLM districts set aside for specific purposes.

\section{Protection of Yew}

Some of the yew remaining after yew harvest (stumps, seedlings, etc.) would be protected in timber sale units. Yew harvesting activities would follow mitigation measures for Alternative B, found at the end of this chapter.

\section{Protection of Other Resources}

Protection of streams, wildlife, and other vegetation would follow the guidelines provided in site-specific NEPA analyses, forest plans, and 
BLM resource management plans. Harvest of yew in moose winter range and in the vicinity of Port-Orford-cedar would follow the mitigation measures for moose (found at the end of this chapter) and the mitigation measures for Port-Orford-cedar (found in Appendix C).

\section{Regeneration}

Yew would be regenerated to preharvest or prescribed levels by planting seedlings or rooted cuttings and/or by ensuring survival of residual yew on the site.

\section{Genetic Diversity}

There would be no special provisions for maintaining genetic diversity of Pacific yew.

\section{Relationship to Interim Guide}

Alternative $\mathrm{B}$ would incorporate the yew harvesting guidelines for timber sale areas from the Interim Guide.

\section{Available Trees and Bark}

From 0.26 to 0.38 million yew trees would be available for harvesting, based on current projections of timber sale acres over a fiveyear period and adjustments for other harvest restrictions. Approximately 1.30 to 1.95 million pounds of dry bark could be removed from these trees over five years.

\section{Sustainability of Harvest}

The harvest rate for this alternative would be determined by the yearly timber harvest; the amount of yew harvested each year would vary depending on the amount of yew present in scheduled timber sales. The output from this alternative is lower than the output from a longterm, even-flow ("sustainable") level on the acres available for yew harvest. Since the timber sale program would not enter all the available acres in the next five years (the period covered by this EIS), not all yew would be harvested in these five years. This rate of yew harvest would not preclude an even-flow, sustained yield harvest of yew in the future. 
Alternative $\mathrm{C}$ emphasizes the highest degree of protection of Pacific yew and the ecosystem in yew harvest areas; it would produce a relatively small amount of bark.

Alternative $\mathrm{C}$ would allow yew harvest in both sale and non-sale units. Harvest levels would be lower than those specified in the Interim Guide. Approximately 6.01 to 9.02 million pounds of dry yew bark would be available over five years under this alternative. (These numbers have been adjusted to reflect additional harvest restrictions, e.g. from site-specific analysis.)

\section{Landscape Perspective}

Yew could potentially be harvested from an estimated 1.47 to 2.20 million acres over the next five years. No yew harvest would be allowed in areas where genetic reserves could not be established, either within or outside of timber sale units (see exceptions in Mitigation Measures section). There would be no yew harvest in riparian areas, in the set-aside areas described below, or in the genetic reserves. Yew could be harvested from all other areas where there are more than five yew trees per acre (TPA) in each harvested diameter class $(<11,11-20$, and $>20$ inches stump diameter).

\section{Harvest Locations; Harvest Levels}

Alternative $\mathrm{C}$ would allow the harvest of 100 percent of utilizable size yew in timber sale units (excluding the residual green tree reserves) and 25 percent of utilizable size yew in each of three diameter classes in partial-cut sale units and non-sale areas.

\begin{tabular}{|l|c|c|c|}
\hline \multicolumn{1}{|c|}{ Locations } & $\begin{array}{c}\text { Yew } \\
\text { Harvest? }\end{array}$ & $\begin{array}{c}\text { Maximum } \\
\text { Amount } \\
\text { Harvested }\end{array}$ & $\begin{array}{c}\text { Minimum } \\
\text { Yew Left of } \\
\text { Utilizable Size }\end{array}$ \\
\hline Timber Sale Unit & Yes & $100 \%$ & no minimum \\
\hline Partial-Cut Sale Units & Yes & $25 \%$ & 5 Trees/Acre \\
\hline Non-sale Areas & Yes & $25 \%$ & 5 Trees/Acre \\
\hline Owl Conservation Areas & No & None & All \\
\hline
\end{tabular}




\section{Set-Aside Areas}

Yew would not be harvested in owl conservation areas, designated wilderness, or other areas in national forests or BLM districts set aside for specific purposes, nor in areas with unusual features such as uncommon parent rock or vegetation.

\section{Protection of Yew}

At least five yew TPA in each of the three diameter classes or $75 \%$ of yew shrubs must be left in the partial-cut and non-sale areas. Yew harvesting activities would follow the Mitigation Measures for Alternatives $\mathrm{C}$ through G2, included at the end of this chapter.

\section{Protection of Other Resources}

No yew would be harvested within 50 to 75 feet (slope distance) of the average high-water level on either side of perennial streams.

Protection of streams, wildlife, and other vegetation would follow the guidelines provided in site-specific NEPA analyses, forest plans, and BLM resource management plans. Harvest of yew in moose winter range and in the vicinity of Port-Orford-cedar would follow mitigation measures for moose (found at the end of this chapter) and mitigation measures for Port-Orford-cedar (found in Appendix C).

\section{Regeneration}

In clearcut, shelterwood, and seed-tree sale units, yew would be regenerated to preharvest or prescribed levels by planting seedlings or rooted cuttings and/or ensuring survival of residual yew on the site. No additional regeneration of yew would be required in partial-cut units and non-sale areas.

\section{Genetic Diversity}

Under this alternative, genetic reserve areas would be established. Yew harvest, or any other activity that alters the structure or composition of the stands, would not be permitted in these reserves. 


\section{Relationship to Interim Guide}

Alternative $\mathrm{C}$ would incorporate most parts of the Interim Guide. The main difference would be that the level of harvest prescribed in this alternative for partial-cut and non-sale areas ( 25 percent) would be lower than the level permitted by the Interim Guide (50 percent).

\section{Available Trees and Bark}

Approximately 1.81 to 2.72 million yew trees would be available for harvest, based on projected timber sale acres over a five-year period, the number of acres where management plans allow for yew harvest, and adjustments for other harvest restrictions. Approximately 6.01 to 9.02 million pounds of dry bark could be removed from these trees over five years.

\section{Sustainability of Harvest}

This alternative describes an uneven-flow rate of yew harvest. All yew that is available for harvest under this alternative could be harvested in the five-year period covered by this EIS. In the event that all available yew would actually be harvested, no further harvest could occur until yew regeneration and growth had replaced the original harvested volume. This alternative would preclude an even-flow sustained yield harvest of yew in the present rotation but not in future rotations. 

producing a moderate amount of bark.

Alternative D would allow harvest in partial-cut sale units and non-sale areas as well as timber sale units. Harvest levels would follow those in the Interim Guide. Approximately 9.82 to 14.72 million pounds of dry yew bark would be available under this alternative over five years. (These numbers have been adjusted to reflect additional harvest restrictions, e.g., from site-specific analysis.)

\section{Landscape Perspective}

This alternative would impact the same amount of acreage as Alternative C. Yew could potentially be harvested from an estimated 1.47 to 2.20 million acres over the next five years. No yew harvest would be allowed in areas where genetic reserves could not be established (see exceptions in the Mitigation Measures section), either within or outside of timber sale units. There would be no yew harvest in riparian areas, in the set-aside areas described below, or in the genetic reserves. Yew could be harvested from all other areas where there are more than five yew TPA in each harvested diameter class $(<11,11-20$, and $>20$ inches stump diameter).

\section{Harvest Locations; Level of Harvest}

Alternative $\mathrm{D}$ would allow the harvest of 100 percent of utilizable yew in timber sale units (excluding the residual green tree reserves) and 50 percent utilizable size yew in partial-cut sale units and non-sale areas.

\begin{tabular}{|l|c|c|c|}
\hline Locations & $\begin{array}{c}\text { Yew } \\
\text { Harvest? }\end{array}$ & $\begin{array}{c}\text { Maximum } \\
\text { Amount } \\
\text { Harvested }\end{array}$ & $\begin{array}{c}\text { Minimum } \\
\text { Yew Left of } \\
\text { Utilizable Size }\end{array}$ \\
\hline Timber Sale Unit & Yes & $100 \%$ & no minimum \\
\hline Partial-Cut Sale Units & Yes & $50 \%$ & 5 Trees/Acre \\
\hline Non-sale Areas & Yes & $50 \%$ & 5 Trees/Acre \\
\hline Owl Conservation Areas & No & None & All \\
\hline
\end{tabular}




\section{Set-Aside Areas}

Yew would not be harvested in owl conservation areas, designated wilderness, or other areas in national forests or BLM districts set aside for specific purposes, nor in areas with unusual features such as uncommon parent rock or vegetation.

\section{Protection of Yew}

At least five yew TPA, in each of the three diameter classes, or $50 \%$ of yew shrubs must be left in the partial-cut and non-sale areas. Yew harvesting activities would follow the mitigation measures for Alternatives $\mathrm{C}$ through G2, included at the end of this chapter.

\section{Protection of Other Resources}

There would be no yew harvest within 50 to 75 feet (slope distance) of the average high-water level on either side of perennial streams.

Protection of streams, wildlife, and other vegetation would follow the guidelines provided in site-specific NEPA analyses, forest plans, and BLM resource management plans. Harvest of yew in moose winter range and in the vicinity of Port-Orford-cedar would follow mitigation measures for moose (found at the end of this chapter) and mitigation measures for Port-Orford-cedar (found in Appendix C).

\section{Regeneration}

In clearcut, shelterwood, and seed tree sale units, yew would be regenerated to preharvest or prescribed levels by planting seedlings or rooted cuttings and/or ensuring survival of residual yew on the site. No additional regeneration of yew would be required in either partial-cut or non-sale areas following yew harvest.

\section{Genetic Diversity}

Under this alternative, genetic reserve areas would be established. Yew harvest, or any activity that alters the structure or composition of the reserve stands, would not be permitted. 


\section{Relationship to Interim Guide}

Alternative D would incorporate the majority of parts of the Interim Guide.

\section{Available Trees and Bark}

From 2.88 to 4.32 million yew trees would be available for harvest, based on projected timber sale acres over a five-year period, the number of acres where management plans allow for yew harvest, and adjustments for other harvest restrictions. Approximately 9.82 to 14.72 million pounds of dry bark could be removed from these trees over five years.

\section{Sustainability of Harvest}

This alternative describes an uneven-flow rate of harvest of yew. All yew that is available for harvest under this alternative could be harvested in the five-year period covered by this EIS. In the event that all available yew would actually be harvested, no further harvest could occur until yew regeneration and growth had replaced the original harvested volume. This alternative would preclude an even-flow sustained yield harvest of yew in the present rotation but not in future rotations.

Dropped. (Refer to "Alternatives Considered but Not Carried Forward.") 
Alternative $\mathrm{F}$ emphasizes high yew bark production with Alternative $F$ moderate protection of Pacific yew and the ecosystem in yew harvest areas.

Alternative $\mathrm{F}$ would allow harvest in partial-cut sale units and non-sale areas as well as timber sale units. Harvest levels would exceed those in the Interim Guide. Approximately 16.25 to 24.37 million pounds of dry yew bark would be available with this alternative over five years. (These numbers have been adjusted to reflect additional harvest restrictions, e.g., from site-specific analysis.)

\section{Landscape Perspective}

Yew could potentially be harvested from an estimated 1.47 to 2.20 million acres over the next five years. No yew harvest would be allowed in areas where genetic reserves could not be established, either within or outside of timber sale units (see exceptions in Mitigation Measures section). There would be no yew harvest in riparian areas, in the set-aside areas described below, or in the genetic reserves. Yew could be harvested from all other areas where there are more than two yew TPA in each harvested diameter class ( $<11,11$ to 20 , and $>20$ inches). This alternative would impact more acreage than Alternatives $\mathrm{C}$ and $\mathrm{D}$, because of the two TPA minimum; harvest would be allowed in areas of more sparse yew distribution, which would not be harvested under the previous alternatives.

\section{Level of Harvest; Location of Harvest}

Alternative $\mathrm{F}$ would allow the harvest of 100 percent of utilizable yew in timber sale units (excluding the residual green tree reserves) and 75 percent utilizable size yew in partial-cut sale units and non-sale areas.

\begin{tabular}{|l|c|c|c|}
\hline \multicolumn{1}{|c|}{ Locations } & $\begin{array}{c}\text { Yew } \\
\text { Harvest? }\end{array}$ & $\begin{array}{c}\text { Maximum } \\
\text { Amount } \\
\text { Harvested }\end{array}$ & $\begin{array}{c}\text { Minimum } \\
\text { Yew Left of } \\
\text { Utilizable Size }\end{array}$ \\
\hline Timber Sale Unit & Yes & $100 \%$ & no minimum \\
\hline Partial-Cut Sale Units & Yes & $75 \%$ & 2 Trees/Acre \\
\hline Non-sale Areas & Yes & $75 \%$ & 2 Trees/Acre \\
\hline Owl Conservation Areas & No & None & All \\
\hline
\end{tabular}




\section{Set-Aside Areas}

Yew would not be harvested in owl conservation areas, designated wilderness, or other areas in national forests or BLM districts set aside for specific purposes, nor in areas with unusual features such as uncommon parent rock or vegetation.

\section{Protection of Yew}

At least two yew TPA, in each of the three diameter classes, or 25 percent of yew shrubs, must be left in the partial-cut and non-sale areas. Yew harvesting activities would follow the mitigation measures for Alternatives C through G2, included at the end of this chapter.

\section{Protection of Other Resources}

There would be no yew harvest within 50 to 75 feet (slope distance) of the average high-water level on either side of perennial streams.

Protection of streams, wildlife, and other vegetation would follow the guidelines provided in site-specific NEPA analyses, forest plans, and BLM resource management plans. Harvest of yew in moose winter range and in the vicinity of Port-Orford-cedar would follow mitigation measures for moose (found at the end of this chapter) and mitigation measures for Port-Orford-cedar (found in Appendix C).

\section{Regeneration}

In clearcut, shelterwood, and seed tree sale units, yew would be regenerated to preharvest or prescribed levels by planting seedlings or rooted cuttings and/or ensuring survival of residual yew on the site. There would be no additional regeneration required in partial-cut units and non-sale areas following yew harvest.

\section{Genetic Diversity}

Under this alternative, genetic reserve areas would be established. Yew harvest, or any activity that alters the structure or composition of the reserve stands, would not be permitted within reserves. 


\section{Relationship to Interim Guide}

Alternative $\mathrm{F}$ would incorporate most parts of the Interim Guide. The main difference would be the level of harvest in partial-cut and non-sale areas prescribed (50 percent) versus the level prescribed in this alternative ( 75 percent) and the number of trees per acre or TPA retained in each diameter class (five TPA in the Interim Guide and two TPA in this alternative).

\section{Available Trees and Bark}

From 4.44 to 6.66 million yew trees would be available for harvest, based on projected timber sale acres over a five-year period, the number of acres where management plans allow yew harvest, and adjustments for other harvest restrictions. Approximately 16.25 to 24.37 million pounds of dry bark could be removed from these trees over five years.

\section{Sustainability of Harvest}

This alternative describes an uneven-flow rate of harvest of yew. All yew that is available for harvest under this alternative could be harvested in the five-year period covered by this EIS. In the event that all available yew would actually be harvested, no further harvest could occur until yew regeneration and growth had replaced the original harvested volume. This alternative would preclude an even-flow sustained yield harvest of yew in the present rotation but not in future rotations. 


\section{Alternative G1- The Preferred Alternative}

Alternative G1 emphasizes efficiency of bark collection
and moderate to high bark production, with moderate
protection of yew and the ecosystem in yew harvest areas.

Alternative G1 would allow harvest in partial-cut sale units, nonsale units, and timber sale units. Harvest levels exceed those in the Interim Guide. Approximately 15.75 to 23.63 million pounds of dry yew bark would be available under this alternative over five years. (These numbers have been adjusted to reflect additional harvest restrictions, e.g., from site-specific analysis.)

\section{Landscape Perspective}

Yew could potentially be harvested from an estimated 1.47 to 2.20 million acres over the next five years. No yew harvest would be allowed in areas where genetic reserves could not be established, either within or outside of timber sale units (see exceptions in the Mitigation Measures section). There would be no yew harvest in riparian areas, in the set-aside areas described below, or in genetic reserves. There would be no minimum number of yew trees or shrubs left after harvest, allowing harvest in areas of sparse yew distribution.

\section{Harvest Locations; Harvest Levels}

Alternative $\mathrm{G} 1$ would allow the harvest of 100 percent of utilizable yew in timber sale units (excluding the residual green tree reserves) and 50 percent, with no minimum number of leave trees of utilizable size yew, in partial-cut sale units and non-sale areas.

\begin{tabular}{|l|c|c|c|}
\hline \multicolumn{1}{|c|}{ Locations } & $\begin{array}{c}\text { Yew } \\
\text { Harvest? }\end{array}$ & $\begin{array}{c}\text { Maximum } \\
\text { Amount } \\
\text { Harvested }\end{array}$ & $\begin{array}{c}\text { Minimum } \\
\text { Yew Left of } \\
\text { Utilizable Size }\end{array}$ \\
\hline Timber Sale Unit & Yes & $100 \%$ & No minimum \\
\hline Partial-Cut Sale Units & Yes & $50 \%$ & No minimum \\
\hline Non-sale Areas & Yes & $50 \%$ & No minimum \\
\hline Owl Conservation Areas & No & None & All \\
\hline
\end{tabular}

\section{Set-Aside Areas}

Yew would not be harvested in designated wilderness, or other areas in national forests or BLM districts set aside for specific 
purposes, nor in areas with unusual features such as uncommon parent rock or vegetation.

\section{Protection of Yew}

There would be no specified number of yew that must be left per acre in the partial-cut and non-sale areas; half of each existing diameter class ( $<11,11-20,>20$ inches stump diameter) of yew, however, would be left on each acre in harvested areas. Yew harvesting activities would follow the mitigation measures for Alternatives $\mathrm{C}$ through G2, included at the end of this chapter.

\section{Protection of Other Resources}

No yew would be harvested within 50 to 75 feet (slope distance) of the average high-water level on either side of perennial streams.

Protection of streams, wildlife, and other vegetation would follow the guidelines provided in site-specific NEPA analyses, forest plans, and BLM resource management plans. Harvest of yew in moose winter range and in the vicinity of Port-Orford-cedar would follow mitigation measures for moose (found at the end of this chapter) and mitigation measures for Port-Orford-cedar (found in Appendix C).

\section{Regeneration}

In timber sale units, yew would be regenerated to preharvest or prescribed levels by planting seedlings or rooted cuttings and/or ensuring survival of residual yew on the site. No additional regeneration would be required after bark harvesting in partialcut units and non-sale areas.

\section{Genetic Diversity}

Under this alternative, genetic reserve areas would be established. Yew harvesting, or any activity that alters the structure or composition of the reserve stands, would not be permitted within reserves. 


\section{Relationship to Interim Guide}

Alternative $\mathrm{G} 1$ would incorporate most parts of the Interim Guide. The main differences would be the number of TPA retained in each diameter class (five TPA in the Interim Guide, and no minimum required under this alternative).

\section{Available Trees and Bark}

From 3.39 to 5.09 million yew trees would be available for harvest, based on projected timber sale acres over a five-year period, the number of acres where management plans allow yew harvest, and adjustments for other harvest restrictions. Approximately 15.75 to 23.63 million pounds of dry bark could be harvested from these trees over five years.

\section{Sustainability of Hanest}

This alternative describes an uneven-flow rate of harvest of yew. All yew that is available for harvest under this alternative could be harvested in the five-year period covered by this EIS. In the event that all available yew would actually be harvested, no further harvest could occur until yew regeneration and growth has replaced the original harvested volume. This alternative would preclude an even-flow sustained yield harvest of yew in the present rotation but not in future rotations. 
Alternative G2 emphasizes efficiency of collection as well as entry into owl conservation areas (and other areas) to provide the highest level of bark production with moderate protection of Pacific yew and the ecosystem in yew harvest areas.

Alternative G2 would allow harvest in owl conservation areas as well as partial-cut sale units, non-sale units, and timber sale units. If selected, consistency with the current spotted owl decision would have to be evaluated and referred to the Interagency Scientific Oversight Group for final resolution. Harvest levels exceed those in the Interim Guide. Approximately 19.29 to 28.94 million pounds of dry yew bark would be available under this alternative over five years. (These numbers have been adjusted to reflect additional harvest restrictions, e.g., from site-specific analysis.)

\section{Landscape Perspective}

This alternative would impact the largest area. Yew could potentially be harvested from an estimated 2.31 to 3.47 million acres over the next five years, including owl conservation areas. No yew harvest would be allowed in areas where genetic reserves could not be established, either within or outside of timber sale units (see exceptions in the Mitigation Measures section). There would be no yew harvest in riparian areas, in the set-aside areas described below, or in genetic reserves. Except in owl conservation areas, there would be no minimum number of yew trees or shrubs in each diameter class left on each acre after harvest, allowing harvest in areas of more sparse yew distribution.

\section{Harvest Locations; Harvest Levels}

Alternative G2 would allow the harvest of 100 percent of utilizable yew in timber sale units (excluding the residual green tree reserves); up to 50 percent, with no minimum TPA, in partial-cut sale units and non-sale areas; and up to 50 percent, with five trees left per acre per diameter class of utilizable size yew, in some areas within owl conservation areas. 


\begin{tabular}{|l|c|c|c|}
\hline \multicolumn{1}{|c|}{ Locations } & $\begin{array}{c}\text { Yew } \\
\text { Harvest? }\end{array}$ & $\begin{array}{c}\text { Maximum } \\
\text { Amount } \\
\text { Harvested }\end{array}$ & $\begin{array}{c}\text { Minimum } \\
\text { Yew Left of } \\
\text { Utilizable Size }\end{array}$ \\
\hline Timber Sale Unit & Yes & $100 \%$ & No minimum \\
\hline Partial-Cut Sale Units & Yes & $50 \%$ & No minimum \\
\hline Non-sale Areas & Yes & $50 \%$ & No minimum \\
\hline Owl Conservation Areas & Yes & $50 \%$ & 5 Trees/Acre \\
\hline
\end{tabular}

\section{Set-Aside Areas}

Yew would not be harvested in designated wilderness, or other areas in national forests or BLM districts set aside for specific purposes, nor in areas with unusual features such as uncommon parent rock or vegetation.

\section{Protection of Yew}

There would be no minimum TPA in the partial-cut and non-sale areas; half of each existing diameter class of yew, however, would be left on each acre in harvested areas per the 50 percent harvest level. At least five yew TPA in each of the three diameter classes must be left in owl conservation areas. Yew harvesting activities would follow the mitigation measures for Alternatives $\mathrm{C}$ through G2, included at the end of this chapter.

\section{Protection of Other Resources}

No yew would be harvested within 50 to 75 feet (slope distance) of the average high-water level on either side of perennial streams.

Protection of streams, wildlife, and other vegetation would follow the guidelines provided in site-specific NEPA analyses, forest plans, and BLM resource management plans. Harvest of yew in owl conservation areas and in moose winter range would follow mitigation measures found at the end of this chapter. Yew harvest in the vicinity of Port-Orford-cedar would follow mitigation measures for Port-Orford-cedar (found in Appendix C).

\section{Regeneration}

In timber sale units, yew would be regenerated to preharvest or prescribed levels by planting seedlings or rooted cuttings and/or 
ensuring survival of residual yew on the site. No additional regeneration would be required after bark harvesting in partialcut units, non-sale areas, or owl conservation areas.

\section{Genetic Diversity}

Under this alternative, genetic reserve areas would be established. Yew harvesting, or any activity that alters the structure or composition of the reserve stands, would not be permitted within reserves.

\section{Relationship to Interim Guide}

Alternative G2 would incorporate most parts of the Interim Guide. The main differences would be entry into owl conservation areas, and the minimum TPA retained in partial-cut and non-sale areas (no minimum number of unharvested TPA in this alternative, compared to a minimum of five TPA per diameter class, prescribed in the Interim Guide).

\section{Available Trees and Bark}

From 4.47 to 6.71 million yew trees would be available for harvest, based on projected timber sale acres over a five-year period, the number of acres where management plans allow yew harvest, the number of available acres within owl conservation areas, and adjustments for other harvest restrictions. Approximately 19.29 to 28.94 million pounds of dry bark could be harvested from these trees over five years.

\section{Sustainability of Harvest}

This alternative describes an uneven-flow rate of harvest of yew. All yew that is available for harvest under this alternative could be harvested in the five-year period covered by this EIS. In the event that all available yew would actually be harvested, no further harvest could occur until yew regeneration and growth has replaced the original harvested volume. This alternative would preclude an even-flow sustained yield harvest of yew in the present rotation but not in future rotations. 
Summary of the Comparison of the Effects of the Altematives
Table II-1 compares the seven alternatives based on the issues and suggestions presented to the interdisciplinary team. These are:

- Provide taxol (Issue);

- Protect Pacific yew (Issue);

- Protect the ecosystem (Issue);

- Establish a sustainable collection level (Suggestion);

- Socioeconomic concerns (Suggestion); and

- Establish areas of collection (Suggestion).

The table is organized with the above issues and suggestions as major headings, and the resource areas listed below each relevant issue as a subheading.

A summary of the comparison of effects between the alternatives is provided following Table II-1. 
Table II-1: Comparison of the Effects Between Alternatives

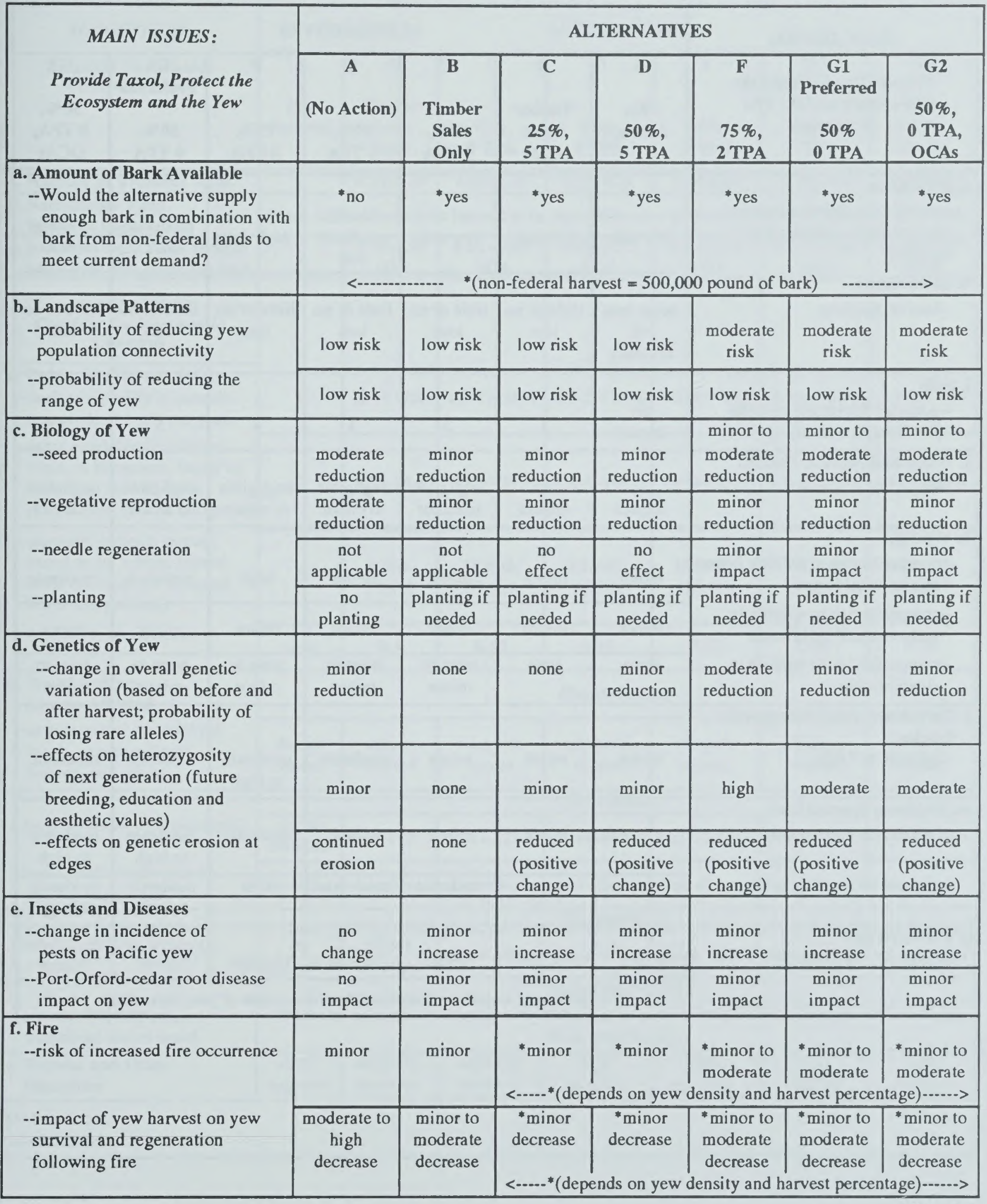


Table II-1: Comparison of the Effects Between Alternatives

\begin{tabular}{|c|c|c|c|c|c|c|c|}
\hline $\boldsymbol{N}$ & \multicolumn{7}{|c|}{ ALTERNATIVES } \\
\hline $\begin{array}{l}\text { Provide Taxol, Protect the } \\
\text { Ecosystem and the Yew } \\
\text { (continued) }\end{array}$ & $\begin{array}{c}\text { A } \\
\text { (No } \\
\text { Action) }\end{array}$ & $\begin{array}{l}\text { B } \\
\text { Timber } \\
\text { Sales } \\
\text { Only }\end{array}$ & $\begin{array}{l}\text { C } \\
25 \% \text {, } \\
5 \text { TPA }\end{array}$ & $\begin{array}{l}\text { D } \\
50 \% \text {, } \\
5 \text { TPA }\end{array}$ & $\begin{array}{l}\mathrm{F} \\
2 \mathrm{TPA} \\
2 \mathrm{TP}\end{array}$ & $\begin{array}{c}\text { G1 } \\
\text { Preferred } \\
\text { 50\%, } \\
0 \text { TPA }\end{array}$ & $\begin{array}{l}\text { G2 } \\
50 \% \text {, } \\
0 \text { TPA, } \\
\text { OCAs }\end{array}$ \\
\hline $\begin{array}{l}\text { g. Ecosystem } \\
\text {--potential for negative impact } \\
\text { on ecosystem structure and } \\
\text { function }\end{array}$ & low risk & low risk & low risk & $\begin{array}{l}\text { low to } \\
\text { moderate } \\
\text { risk }\end{array}$ & high risk & $\begin{array}{l}\text { moderate } \\
\text { risk }\end{array}$ & $\begin{array}{l}\text { moderate } \\
\text { risk }\end{array}$ \\
\hline $\begin{array}{l}\text { h. Biodiversity } \\
\text {--loss of diversity }\end{array}$ & $\begin{array}{l}\text { some loss } \\
\text { of } \\
\text { diversity }\end{array}$ & $\begin{array}{l}\text { little or no } \\
\text { loss }\end{array}$ & $\begin{array}{l}\text { little or no } \\
\text { loss }\end{array}$ & $\begin{array}{l}\text { little or no } \\
\text { loss }\end{array}$ & $\begin{array}{l}\text { little or no } \\
\text { loss }\end{array}$ & $\begin{array}{l}\text { little or no } \\
\text { loss }\end{array}$ & $\begin{array}{l}\text { little or no } \\
\text { loss }\end{array}$ \\
\hline $\begin{array}{l}\text { i. Soils } \\
\text {--potential for impact on soils } \\
(1=\text { least; } 6=\text { most })\end{array}$ & $\begin{array}{c}\text { no } \\
\text { impact }\end{array}$ & 1 & 2 & 3 & 4 & 5 & 6 \\
\hline $\begin{array}{l}\text { j. Water and Aquatic Habitat } \\
\text {--impact on resource }\end{array}$ & $\begin{array}{c}\text { no } \\
\text { impact }\end{array}$ & no & $\begin{array}{l}\text { negligible } \\
\text { to minor }\end{array}$ & $\begin{array}{l}\text { negligible } \\
\text { to minor }\end{array}$ & $\begin{array}{l}\text { negligible } \\
\text { to minor }\end{array}$ & $\begin{array}{l}\text { negligible } \\
\text { to minor }\end{array}$ & $\begin{array}{l}\text { negligible } \\
\text { to minor }\end{array}$ \\
\hline $\begin{array}{l}\text { k. Wildlife } \\
\text {--composite risk to wildlife in late } \\
\text { successional forests }\end{array}$ & minor & minor & minor & minor & high & moderate & moderate \\
\hline $\begin{array}{c}\text {--composite risk to wildlife in } \\
\text { early successional forests }\end{array}$ & minor & minor & minor & minor & minor & minor & minor \\
\hline $\begin{array}{l}\text {--composite risk to wildlife in } \\
\text { riparian areas }\end{array}$ & none & none & $\begin{array}{l}\text { none to } \\
\text { minor }\end{array}$ & $\begin{array}{l}\text { none to } \\
\text { minor }\end{array}$ & $\begin{array}{l}\text { none to } \\
\text { minor }\end{array}$ & $\begin{array}{l}\text { none to } \\
\text { minor }\end{array}$ & $\begin{array}{l}\text { none to } \\
\text { minor }\end{array}$ \\
\hline $\begin{array}{l}\text { 1. Threatened and Endangered } \\
\text { Species } \\
\text {--impacts to T\&Es }\end{array}$ & minor & minor & minor & moderate & $\begin{array}{l}\text { moderate } \\
\text { to high }\end{array}$ & moderate & moderate \\
\hline $\begin{array}{l}\text { m. Northern Spotted Owl } \\
\text {--impacts on prey species }\end{array}$ & minor & minor & minor & minor & moderate & $\begin{array}{l}\text { moderate } \\
\text { to high }\end{array}$ & $\begin{array}{l}\text { moderate } \\
\text { to high }\end{array}$ \\
\hline --impacts on roosting habitat & none & none & moderate & moderate & high & $\begin{array}{l}\text { moderate } \\
\text { to high }\end{array}$ & $\begin{array}{l}\text { moderate } \\
\text { to high }\end{array}$ \\
\hline $\begin{array}{l}\text { n. Forest Health } \\
\text {--impact to forest health }\end{array}$ & minor & *minor & *minor & *minor & *minor & *minor & *minor \\
\hline
\end{tabular}


Table II-1: Comparison of the Effects Between Alternatives

\begin{tabular}{|c|c|c|c|c|c|c|c|}
\hline \multirow{2}{*}{$\begin{array}{c}\text { SUGGESTION: } \\
\text { Establish Sustainable } \\
\text { Collection Level }\end{array}$} & \multicolumn{7}{|c|}{ ALTERNATIVES } \\
\hline & $\begin{array}{c}\text { A } \\
\text { (No } \\
\text { Action) }\end{array}$ & $\begin{array}{l}\text { B } \\
\text { Timber } \\
\text { Sales } \\
\text { Only }\end{array}$ & $\begin{array}{l}25 \% \\
5 \mathrm{TPA}\end{array}$ & $\begin{array}{l}50 \%, \\
5 \text { TPA }\end{array}$ & $\begin{array}{l}75 \% \\
2 \text { TPA }\end{array}$ & $\begin{array}{c}\text { G1 } \\
\text { Preferred } \\
\\
\text { 50\% } \\
\text { 0 TPA }\end{array}$ & $\begin{array}{l}\text { G2 } \\
\text { 50\% } \\
\text { 0 TPA, } \\
\text { OCAs }\end{array}$ \\
\hline a. Number of available trees & 0 & $0.26-0.38$ & $1.81-2.72$ & $2.88-4.32$ & $4.44-6.66$ & $3.39-5.09$ & $4.47-6.71$ \\
\hline $\begin{array}{l}\text { b. Sustainable Yield } \\
\text { in lbs. of Bark }\end{array}$ & \multicolumn{7}{|c|}{ None of the alternatives harvest at an even-flow rate estimated at 1.48 million pounds of bark. } \\
\hline $\begin{array}{l}\text { c. Available bark from federal } \\
\text { lands over five years (in lbs.) } \\
\end{array}$ & 0 & $\begin{array}{c}1.30-1.95 \\
\mathrm{MM}\end{array}$ & $\begin{array}{l}6.01--9.02 \\
+\quad \mathrm{MM} \\
\end{array}$ & $\begin{array}{c}9.82-14.72 \\
\mathrm{MM}\end{array}$ & $\begin{array}{c}16.25-24.37 \\
\mathrm{MM}\end{array}$ & $\begin{array}{c}15.75-23.63 \\
\mathrm{MM}\end{array}$ & $\begin{array}{c}19.29-28.94 \\
\mathrm{MM}\end{array}$ \\
\hline \multicolumn{8}{|l|}{$\begin{array}{l}\text { SUGGESTION: } \\
\text { Consider Socioeconomic } \\
\text { Concerns }\end{array}$} \\
\hline $\begin{array}{l}\text { a. Public Health and Safety } \\
\text {--bark availability in pounds } \\
\text { from federal lands per year }\end{array}$ & 0 & $.3-.4 \mathrm{MM}$ & 1.2-1.8 MM & 2.0-2.9 MM & 3.2-4.9 MM & 3.2-4.7 MM & 3.9-5.8 MM \\
\hline $\begin{array}{l}\text {--taxol available for clinical } \\
\text { trials, in kilograms, based on } \\
\text { bark from federal lands } \\
(15,000 \text { lbs. bark }=1 \text { kilogram })\end{array}$ & 0 & $17.3-26.0$ & $80.2-120.3$ & 130.9-196.3 & 216.6-324.9 & $210.0-315.0$ & 257.2-385.8 \\
\hline $\begin{array}{l}\text {--potential patients treated, } \\
\text { based on ba } \mathrm{k} \text { from federal } \\
\text { lands (assuming } 1 \text { kilogram } \\
\text { treats } 480 \text { patients) }\end{array}$ & 0 & $\begin{array}{l}8,300 \\
12,400\end{array}$ & $\begin{array}{l}38,400- \\
57,700\end{array}$ & $\begin{array}{l}62,800- \\
94,200\end{array}$ & $\begin{array}{l}103,900- \\
155,900\end{array}$ & $\begin{array}{l}100,800 \\
151,200\end{array}$ & $\begin{array}{l}123,400 \\
185,100\end{array}$ \\
\hline --injuries to woodworkers & none & $0-5$ & $0-10$ & $0-15$ & $0-25$ & $0-25$ & $0-30$ \\
\hline $\begin{array}{l}\text { b. Social Setting-- } \\
\text { Groups Affected }\end{array}$ & \multicolumn{7}{|c|}{ Health-Related } \\
\hline $\begin{array}{l}\text {--access to raw material for } \\
\text { taxol: cancer patients, } \\
\text { women, and others }\end{array}$ & $\begin{array}{l}\text { denies } \\
\text { access }\end{array}$ & $\begin{array}{l}\text { access } \\
\text { limited }\end{array}$ & $\begin{array}{l}\text { adequate } \\
\text { access }\end{array}$ & $\begin{array}{l}\text { adequate } \\
\text { access }\end{array}$ & $\begin{array}{l}\text { adequate } \\
\text { access }\end{array}$ & $\begin{array}{l}\text { adequate } \\
\text { access }\end{array}$ & $\begin{array}{l}\text { adequate } \\
\text { access }\end{array}$ \\
\hline \multirow{3}{*}{--bark harvester jobs (seasonal) } & \multicolumn{7}{|c|}{ Jobs-Related } \\
\hline & $\begin{array}{l}\text { no job } \\
\text { creation }\end{array}$ & $75-113$ & $347-521$ & $566-849$ & $937-1,406$ & $909-1,363$ & $1,113-1,669$ \\
\hline & no effect & no effect & no effect & no effect & no effect & no effect & no effect \\
\hline \multirow[b]{2}{*}{--hikers, campers, hunters } & \multicolumn{7}{|c|}{ Recreationists } \\
\hline & $\begin{array}{c}\text { no } \\
\text { effect }\end{array}$ & $\begin{array}{l}\text { minor } \\
\text { effect }\end{array}$ & minor effect & minor effect & minor effect & minor effect & minor effect \\
\hline \multirow[b]{2}{*}{$\begin{array}{l}\text {--ceremonial, cultural, } \\
\text { traditional use of wood }\end{array}$} & \multicolumn{7}{|c|}{ Native Americans } \\
\hline & \multicolumn{7}{|c|}{$\begin{array}{l}\text { Effects on uses would be minor. Spiritual and medicinal value effects must be assessed after } \\
\text { local consultation. }\end{array}$} \\
\hline $\begin{array}{l}\text { c. Women and Other } \\
\text { Minorities }\end{array}$ & $\begin{array}{c}\text { slight } \\
\text { negative }\end{array}$ & $\begin{array}{l}\text { moderate } \\
\text { positive }\end{array}$ & \begin{tabular}{c|} 
moderate \\
positive
\end{tabular} & \begin{tabular}{c|c} 
high \\
positive
\end{tabular} & \begin{tabular}{c|c} 
high \\
positive
\end{tabular} & \begin{tabular}{c|} 
high \\
positive
\end{tabular} & $\begin{array}{l}\text { high } \\
\text { positive }\end{array}$ \\
\hline $\begin{array}{l}M M=\text { millions } \\
M=\text { thousands }\end{array}$ & & & & & & & \\
\hline
\end{tabular}


Table II-1: Comparison of the Effects Between Alternatives

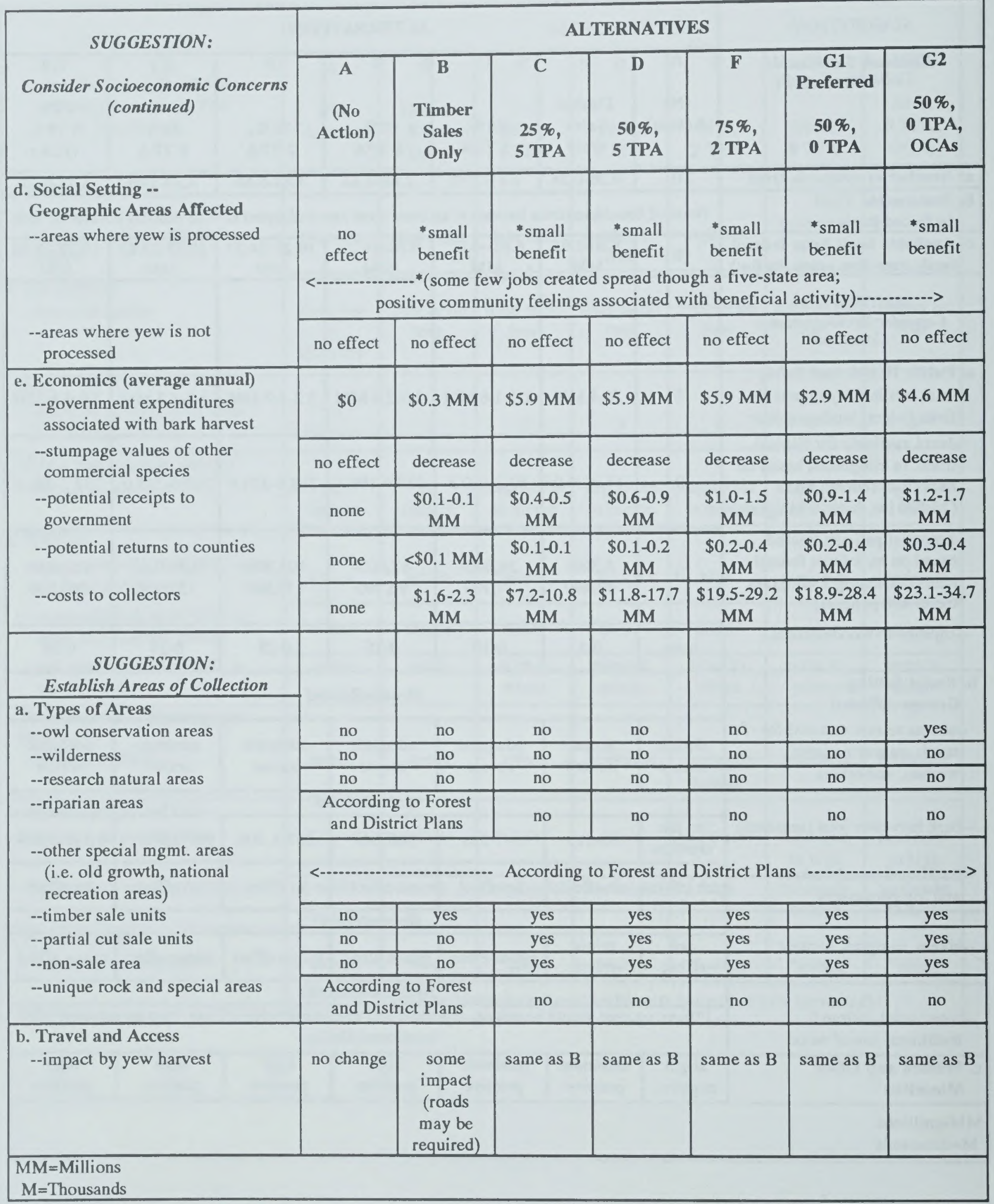


This section presents a summary of the comparison of effects between proposed alternatives. The discussion is organized by issue and suggestion and pertains to the table above. For a full discussion of the potential environmental effects of each alternative, refer to Chapter IV.

\section{Issues: Provide Taxol, Protect the Pacific yew, and Protect the Ecosystem}

\section{Landscape Pattems}

This alternative would have a low risk of impact on yew population connectivity and the range of Pacific yew. Some Pacific yew would be destroyed in timber sale units, but yew would continue to exist in the harvested areas under the forest and resource plans and the principles of ecosystem management.

There would be a low risk of impact on yew population connectivity and the range of yew under this alternative. Yew would be regenerated and the long-term distribution of the species would be maintained. Due to the relatively small size of the harvested areas and the small amount of acreage impacted over the five-year harvest period, there should be only a low risk of reducing yew population connectivity.

No yew harvest would be allowed in areas where genetic reserves cannot be established or where there are not at least five trees per acre (TPA) in each harvestable diameter class. This would preclude yew harvest at the peripheries of the species' range, and there would be a low risk of impact on the range of yew. A significant proportion of Pacific yew would be retained throughout the landscape and there would be a low risk of impact to population connectivity.

Yew harvest would not be allowed in areas where genetic reserves cannot be established. The peripheries of the species' range would be protected and there would be a low risk of impacts on the Pacific yew geographic range. Harvest would be allowed in areas of sparse yew distribution (if reserves could be found), where there are less then five TPA in each harvestable diameter class, posing a moderate risk to landscape connectivity. The 75 percent reduction in the yew population across the landscape under Alternative $F$ increases the risk of impact to population connectivity.

\section{Discussion of the Comparison of the Effects of the Altematives}

Alternative A

Alternative $B$

Alternatives

$C$ and $D$

\section{Alternatives \\ F through G2}




\section{Biology of Yew: Reproduction and Regeneration}

Alternative A Some yew would be destroyed or damaged, thus reducing potential seed sources, particularly in areas of sparse populations. Vegetative reproduction (sprouting, layering) would also be impacted to some extent, particularly where environmental conditions are harsher. No special provisions for yew protection and regeneration are included in this alternative.

Alternative $B$ Harvest of yew in sale areas would remove most of the seed producing yew, thus delaying seed production until residual yew or planted yew grow to reproductive size. In many cases, adequate seed would be produced in the interim by yew adjacent to the units, or yew retained as seed trees. Some of the remaining yew stumps and seedlings would be protected; therefore the impact on vegetative reproduction would be minor.

Alternatives Yew would be replanted in sale units and some stumps and $C$ through G2 seedlings would be protected. An average of $70 \%$ of the stumps left after harvest may resprout.

Alternatives Harvest of yew at the 25 percent and 50 percent levels in partial$C$ and $D$ cut and non-sale areas would not adversely affect the reproduction/regeneration potential. The removal of no more than half of the foliage on 25 percent or 50 percent of the yew would not adversely affect needle regeneration.

Alternatives Harvest of yew at the 75 percent level or 50 percent level with no $F, G 1$ and G2 minimum TPA retained may affect regeneration. There would be a moderate decrease in seed production under these alternatives. This would have a greater effect in more sparse areas where there may not be adequate numbers of sexually mature trees left following harvest as potential seed producers. The removal of no more than half the foliage on 75 percent of the trees in Alternative $F$ may impact needle regeneration slightly.

\section{Genetics}

Alternative $A$ No efforts would be made to maintain genetic diversity under this alternative. This may result in a small decrease in levels of genetic variation as small populations on the periphery as well as in the 
center of the range may not maintain themselves. Some populations containing unique genetic combinations could be lost, which would affect the ability of subsequent generations to adapt to changing environments, as well as reduce the yew's potential for use in breeding programs.

Alternative B would have less impact on genetic diversity and potential contribution to breeding programs than Alternative A, because provisions are made for the protection of individual yew in harvest units, and units are regenerated to preharvest or prescribed levels. This ensures the survival of more genotypes in populations. Current erosion of small, peripheral populations would be halted under this alternative.

Under these alternatives, genetic reserves would be established in harvest areas in order to protect genetic diversity. Slight reductions in genetic variation could occur, however, as larger proportions of trees are harvested. Thus, in Alternative C ( $25 \%$ harvest) there would be no reduction in overall genetic variation. The reduction potential would increase slightly for Alternative $\mathrm{D}$, and for each alternative as larger proportions of trees are harvested.

The current erosion of genetic variation peripheral yew populations would be halted or reversed under these action alternatives.

Gene conservation for use in future breeding programs would remain unchanged in Alternatives $\mathrm{C}$ and $\mathrm{D}$, but would be reduced for Alternative F, G1, and G2 because of reduced overall genetic variation in future generations.

\section{Insect and Diseases}

There would be no change in what are considered insignificant levels of impact by insects and diseases.

All alternatives proposing harvest would have an estimated minor impact on insect and disease populations. Harvest in areas that contain Port-Orford-cedar (POC) must follow the mitigation measures specified under the POC analysis process, intended to reduce or prevent the spread of $\mathrm{POC}$ root disease.

\section{Alternative $B$}

\section{Alternatives \\ C through G2}

\section{Alternatives \\ B through $G 2$}

number of trees left standing per acre

\section{Alternative $A$}




\section{Fire}

Alternative A Risk of wildfire would remain unchanged, due primarily to fuels treatment on sale units. However, survival and regeneration of yew could be quite poor on some sites where fire is used for site preparation, as there would be no attempt made to pull slash away from yew trees, stumps or seedlings or change burning prescriptions to protect yew in the site.

Alternative $B$ For the same reasons described under Alternative A, there would be no increased risk of wildfire under this alternative. There would, however, be a higher probability for survival and regeneration of yew following fire for site preparation or other purposes, because there would be an attempt to protect and replant wherever residual survival was poor. Some yew may be damaged or killed by site preparation fires due to site-specific conditions or lack of knowledge or experience in protecting yew from fire; but the probability of affecting the current distribution of yew is minor.

Alternatives The increased risk of wildfire occurrence, due to yew harvest, C through G2 would be minor to moderate under these alternatives, varying with the level of harvest and density of yew (generally higher for those alternatives that harvest higher levels of yew). The probability of survival and regeneration of yew, following fire for fuels or site preparation treatment, would be high to moderate, decreasing as the amount of slash and the number of people involved in the harvesting increases.

\section{Ecosystem}

Alternatives The impacts of $100 \%$ yew removal (under Alternative B) or loss of $A$ and $B$ some of the yew in harvest units (under Alternative A) on ecasystem structure and function would be minimal compared to the effects of the timber harvest itself. Pacific yew would be a part of the regenerating stand. There would be less risk of impact in timber sale units which retained yew in green tree reserves.

Alternatives

C through G2
The impacts of yew harvest on ecosystem structure and function would vary from stand to stand depending on the presence of substitute species and structures. Risk of impact increases with 
the amount of yew that is harvested. Alternative $\mathrm{C}$ (with $25 \%$ yew removal) would have a low risk of impact, Alternative $\mathrm{D}$ (with $50 \%$ yew removal) would have a low to moderate risk of impact, and Alternative $\mathrm{F}$ (with $75 \%$ yew removal) would have a high risk of impact to ecosystem structure and function. Alternatives G1 and G2, while only harvesting $50 \%$ of the yew, would have a moderate risk of impacting the ecosystem due to the harvest of more of the larger yew trees and to harvest in areas of sparse yew distribution. Alternative G2, with harvest in spotted owl conservation areas, would have the most impact on old-growth ecosystems.

\section{Biodiversity}

There could be some loss in genetic and species diversity in areas where yew is sparse, due to potential loss of unique populations in these areas (refer to Genetics section).

There would be little or no impact on biodiversity under each of the action alternatives. As stands regenerate and abundance of yew increases again, the contributions to genetic, species and community diversity would increase.

\section{Soils, Water and Aquatic Habitat}

There would be no additional impact to forest soils under the current standards and guidelines of forest plans and BLM resource management plans. Similarly, there would be no added impact to water and aquatic habitat.

Impacts on the soil resources are expected to be minimal under current standards and guidelines of forest plans and BLM resource management plans. The risk of impact would increase proportionately with the level of yew harvest. Alternative B, therefore, would have the least amount of impact; Alternative $C$ would have the next largest impact, followed by Alternative D, then $\mathrm{F}$, then $\mathrm{G} 1$ and $\mathrm{G} 2$.

The effect of yew harvest on water and aquatic habitat is expected to be negligible to small, especially with mitigation measures in place.

Alternative A

Alternatives

B through $\mathrm{G} 2$

Alternative A

Alternatives

B through $\mathrm{G} 2$ 


\section{Wildlife}

Alternative $A$ The effects on plant and animal populations would probably not be significant in most cases. Animal species diversity might be reduced over time because of the incremental loss of yew from the understory of many timber sale units. This would also lead to changes in the mid-story vegetative structure and possible changes in animal species distribution and abundance compared with forests areas of comparable age.

Alternatives Yew harvesting in late-successional forests would change the B through $\mathrm{G} 2$ character of the habitat, which could affect some species. The risk of impacts would probably be minor to moderate, increasing as the level of harvest increases. In general, removal of $50 \%$ or less of the yew in the area (Alternatives B through D) has a low probability of reducing or removing species from the area, whereas removal of $75 \%$ of the yew population could have a moderate effect on some species abundance.

In most cases there would probably be no significant effect on early successional forest species or riparian species under any of the action alternatives except that caused by other activities.

The role yew has in providing for wildlife habitat is poorly understood. This could result in a substantial risk to wildlife if large areas of yew were harvested in a short time frame.

\section{Threatened and Endangered species}

Alternative $A$ There would be no added impact to threatened and endangered species associated with Alternative A beyond that of timber sales.

Alternatives

B through $G 2$

A potential exists for impacts to threatened and endangered populations under all action alternatives, increasing proportionately with the level of yew harvest.

The potential exists for positive and negative impacts (minor to moderate in intensity) to ungulates and associated predator populations under all action alternatives. The level of impact increases proportionately with the level of yew harvest. In certain cases the positive and negative impacts could cancel each other out (i.e., the 
decrease in thermal cover from yew and timber harvest could be partially or completely mitigated by the increase in forage from yew sprouting and the increase in forage from opening the canopy), depending on local conditions.

There is potential for minor negative impacts to fish species under all action alternatives that increases proportionately with the level of yew harvest.

The potential exists for positive and negative impacts (minor to moderate in intensity) to avian populations and associated predator populations under all action alternatives. The level of impact increases with the level of yew harvest, but is site-specific in some cases.

\section{Northem Spotted Owl}

There would be little or no impacts on spotted owls and their habitat under these alternatives, because there would be no habitat disturbance in addition to that normally occurring from implementing forest plans or BLM resource management plans.

Negative impacts both on prey species and on roosting habitat for spotted owls would increase with the level of harvest. The intensity of the impact would depend on the proportion of yew in the stand and how much is harvested. Alternatives C, D, F and G1 permit harvest within suitable habitat, including removal of a portion of the midstory before scheduled timber harvest. The greatest negative impacts would be possible under Alternative G2, because the largest area is available for harvest and includes harvest within owl conservation areas.

\section{Forest health}

There would be little or no change in forest health equilibrium under the present guidelines for ecosystem management. Although the numbers of yew trees in harvested stands would decline, it is unlikely that those populations would disappear.

$\mathbf{A}=$ No Action
$\mathbf{B}=$ Timber Sales Only
$\mathbf{C}=25 \%, 5$ TPA
$\mathbf{D}=50 \%, 5$ TPA
$\mathbf{F}=75 \%, 2$ TPA
G1 $=50 \%, 0$ TPA,
G2 $=50 \%, 0$ TPA, OCAs
TPA is the minimum
number of trees left
standing per acre

Alternatives

$A$ and $B$

Alternatives

C through G2

Alternative $A$ 
Alternatives B through $\mathrm{G} 2$

Alternative $A$

Alternative $B$

Alternatives

C through $\mathrm{G} 2$

\section{Alternative $A$}

\section{Suggestion: Consider Socioeconomic Concerns \\ Public Health and Safety}

Because there would be no yew harvested from federal lands under this alternative, there would be no yew bark or taxol available from federal sources and no potential for treating patients with taxol derived from federal yew. There would be no increase in injuries to woodsworkers associated with yew bark collection on federal lands. 
Refer to the summary table for preliminary data on bark availability and potential patients treated by alternative.

Alternatives

B through $\mathrm{G} 2$

There would be a small potential for injuries to woodsworkers associated with each of the action alternatives.

\section{Social Setting: Groups Affected}

The "no action" alternative would not respond to the need for bark for taxol production. Taxol production in the immediate future would be reduced to half of current levels (reflecting conditions prior to 1991 harvest). This would place severe restrictions on the number of cancer patients who could be treated and the availability of clinical trials. Since taxol therapy is targeted at cancers that mostly affect women, women as a group would be adversely impacted if taxol therapy were limited. Cancer patients' access to taxol may also be threatened by the "no action" alternative.

No additional job opportunities would be created for woodworkers and log purchasers. There would be no effect to recreational or Native American uses of the Pacific yew or the forest.

Access to taxol for cancer patients and clinical testing could be limited under Alternative $\mathrm{B}$, with increased availability in Alternatives $\mathrm{C}$ through G2. Likewise, Alternatives C, D, F, G1, and G2 would have a high positive impact on cancer patients; Alternative $B$ would have a moderate impact.

Some seasonal employment would be generated under all action alternatives. The yew program is not expected to affect access to logs or supply of logs for timber workers and log purchasers.

Recreationists may experience minor effects in the form of visual degradation, varying depending on the ROS class associated with particular harvest area.

\section{Alternatives \\ $B$ through $\mathrm{G} 2$}

\section{Alternative $A$}
$A=$ No Action
B = Timber Sales Only
$\mathrm{C}=25 \%, 5$ TPA
$\mathrm{D}=50 \%, 5 \mathrm{TPA}$
$\mathbf{F}=75 \%, 2 \mathrm{TPA}$
G1 $=50 \%, 0$ TPA,
G2 $=$ 50\%, 0 TPA, OCAs
TPA is the minimum number of trees left standing per acre 


\section{Social Setting: Geographic Area}

Alternative $A$ There would be no effect on the social/geographical setting associated with this alternative. (See Table II-1.)

Alternatives Some small benefit to the social setting could result under the $B$ through G2 action alternatives, due to some jobs created, but unevenly distributed in the five-state region, and positive feelings associated with yew harvest programs.

\section{Economics}

Alternative A There would be no government expenditures or returns, and no jobs created as a result of yew bark harvest from federal lands. Bark harvesting jobs would increase on other ownerships in response to yew bark demand. This alternative is not responsive to yew bark demand from federal lands.

Alternatives

Under each of the action alternatives, government expenditures B through $\mathrm{G} 2$ vary with the amount of harvest, the number of acres accessed, and the guidelines for establishing the number of trees retained on each acre. Alternatives $\mathrm{C}$ through $\mathrm{F}$ require specified numbers of yew trees to be maintained by diameter class which increases survey and layout costs above Alternatives G1 and G2. Potential revenues returned to the government vary between $\$ 100,000$ and $\$ 1,700,000$. Presently, there is no charge for yew bark from national forest lands and returns from BLM lands in 1992 were approximately $\$ 30,000$.

The increase in jobs associated with yew bark harvest varies between 75 and 1700 bark harvesters per year and is directly related to the amount of available bark.

Increased protection of yew in timber sale areas increases commercial harvesting costs resulting in slight decreases in stumpage values received by the federal government. There is also a potential for slight reductions in long-term commercial forest production if yew protection results in substandard site preparation. 
All of the action alternatives address the existing demand for yew bark to different degrees. Alternative $\mathrm{B}$ underachieves existing bark processing capacity. Alternatives $\mathrm{C}$ through $\mathrm{G} 2$ meet existing capacity demands. Alternatives D through G2 satisfy projected future processing capacity.

\section{Suggestion: Establish Areas of Collection}

\section{Areas and Access}

There would be no new areas established and no change in access to the forest under this alternative.

Some increase in access to timber sale units, partial-cut units, and non-sale areas could occur with each of the action alternatives, as road or trail construction and upgrading may be required.

Alternatives

B through G2

$$
\begin{aligned}
& \mathbf{A}=\text { No Action } \\
& \mathbf{B}=\text { Timber Sales Only } \\
& \mathbf{C}=25 \%, 5 \text { TPA } \\
& \mathbf{D}=50 \%, 5 \text { TPA } \\
& \mathbf{F}=75 \%, 2 \text { TPA } \\
& \text { G1 }=50 \%, 0 \text { TPA, } \\
& \text { G2 }=50 \%, 0 \text { TPA, OCAs } \\
& \text { TPA is the minimum } \\
& \text { number of trees left } \\
& \text { standing per acre }
\end{aligned}
$$




\section{Mitigation Measures for Yew Harvest}

This section describes a number of mitigation measures which accompany the alternatives. The mitigation measures help define each alternative by describing more specifically how the yew is to be harvested, protected, and regenerated under each alternative.

\section{Terms to Know}

"Tree form yew"- Upright yew plants exhibiting apical dominance, usually with only one main stem. Tree form yew typically grows taller than shrub form yew, with larger diameter stem(s).

"Shrub form yew"- Those yew plants with a more brush-like form, howing multiple, smaller diameter stems, none of which exhibit apical dominance. Shrub form yew are typically shorter than tree form yew.

"Clearcut"- a type of harvest where an entire stand of trees is removed in one cutting operation, leading to the establishment of an even-aged stand.

"Shelterwood Cut"- a type of harvest method where a portion of the mature stand is retained as a source of seed and/or shelter during the period of regeneration. The mature stand is removed in two or more cuttings. The resulting stand is even-aged.

"Seed Thee Cut"- a type of harvest similar to a clearcut, except that a few of the better trees of the desired species are left scattered over the area to provide seed for regeneration. The resulting stand is even-aged.

"Local management area"- is used for Forest Service lands and refers to an area not larger than about 20,000 acres, or to "one National Forest System Watershed (fourth or fifth-order stream basin)". (Refer to Forest Service Handbook 2509.24).

"Tree seed zones"- are used for BLM lands and refer to the areas established by the Western Forest Tree Seed Council; they delineate areas of similar climatic and geographic conditions. 


\section{Mitigation Measures for Alternative B}

\section{Timber Sale Units}

\section{Both Tree and Shrub Form Yew}

- Where yew harvest is planned, harvest yew in the sale unit prior to the harvest of other species, to the extent that timber harvesters' health and safety will not be jeopardized. Preharvesting may be accomplished by decking yew logs in specific locations within the sale unit during logging operations;

- Consider including vigorous, undamaged yew trees or shrubs in the green tree reserves whenever possible;

- Harvest yew that is not in the residual green tree reserve;

- To facilitate sprouting, leave yew tree stumps at least 12" high. Yew shrubs should be cut to leave 12 " length above the root collar; generally this can be met by cutting shrubs where the stem emerges from the duff;

- Leave bark intact on yew stumps;

- Site-specific prescriptions will identify logging systems, site preparation and fuels reduction treatments, and conifer regeneration plans with regard to yew survival and regeneration;

- Wherever possible and practical, shade yew stumps with slash or adjacent vegetation and position reserve green trees to provide shade for yew stumps and advanced yew regeneration. Shading is not necessary in all areas and is not normally required on shrub form yew; site-specific analysis may help determine how much shading is needed;

- Monitor yew regeneration until yew regeneration prescriptions have been met. Where possible, monitor yew regeneration in conjunction with conifer regeneration and other area surveys;

- If prescribed regeneration of yew has not been achieved and there is assurance that regeneration by other means is not occurring, yew will be planted as prescribed in sitespecific prescriptions; and

$\mathbf{A}=$ No Action
$\mathbf{B}=$ Timber Sales Only
$\mathbf{C}=25 \%, 5$ TPA
$\mathbf{D}=50 \%, 5$ TPA
$\mathbf{F}=75 \%, 2$ TPA
G1 $=50 \%, 0$ TPA,
G2 $=50 \%, 0$ TPA, OCAs
TPA is the minimum
number of trees left
standing per acre


- Do not harvest yew within 75 feet (R-5, R-6, BLM) or 50 feet (R-1) slope distance from the average high-water level of a perennial stream. This requirement may be increased to meet other resource needs.

\section{Tree Form Yew}

- Do not harvest yew trees adjacent to cut units due to their importance as a seed source; and

- Use one or more of the following methods to maintain or replace yew on the site at preharvest or prescribed levels or, where very abundant, at a minimum of 50 yew plants per acre:

1. Retain and protect as much of the residual yew (stumps, trees, shrubs, advanced regeneration remaining after harvest) as possible and practical from post-harvest activities such as slash piling and burning. Plan logging systems and slash disposal methods which favor the survival of residual yew plants and stumps, e.g., grapple piling or combined machine and burning methods or special burn prescriptions. Include retention of yew and yew stumps as one of the prescribed fire objectives in burning plans. Leave litter and down wood in those patches for seedling establishments;

2. Encourage natural regeneration (from seed already present on site) by using any site preparation methods known to favor yew seed germination and establishment. Monitor occurrence and distribution of natural seedlings; and

3. Plant rooted cuttings or seedlings from on-site sources of cuttings or seed. Cuttings could be collected before harvest. Use vexar tubing or other animal protection where browsing of young yew is predicted.

\section{Shrub Form Yew}

- Harvest shrub form yew only where practical (i.e. sufficient number of stems of utilizable size);

- Consider seed source needs on and adjacent to the unit in site-specific NEPA analysis; 
- Regenerate yew shrubs to maintain adequate numbers and distribution while meeting other land management objectives. Where preharvest yew density would preclude meeting other land management objectives (for example, conifer regeneration within five years), yew density may be reduced from preharvest conditions. Site-specific silvicultural prescriptions will describe desired yew densities compatible with meeting other objectives;

- Site-specific prescriptions will provide desired site conditions for natural regeneration of yew and protect concentrations of existing yew where feasible, while still meeting other management objectives. Where on-the-ground conditions preclude this, planting of yew will be prescribed; and

- Site preparation treatments will be considered in the following general order of preference:

1. No additional site preparation;

2. Low intensity mechanical site preparation which maintains patches of undisturbed ground including yew stumps and residual yew shrubs (Grapple piling can be effective on slopes less than $35 \%$ );

3. Slashing in lieu of burning;

4. Cool burning prescriptions to maintain duff on site and limit mineral soil exposure (a cool burn would retain more duff and expose 10-20\% mineral soil);

5. Yarding of whole trees or unmerchantable timber (YUM) prior to burning to reduce fuel loadings, facilitate slash disposal and reduce burn intensities. Slash from yew harvest could be spot piled away from residual plants and stumps; and

6. High intensity burning will be a last resort, when other methods will not meet management objectives.

\begin{tabular}{|l|}
$\mathbf{A}=$ No Action \\
$\mathbf{B}=$ Timber Sales Only \\
$\mathbf{C}=25 \%, 5$ TPA \\
$\mathbf{D}=50 \%, 5$ TPA \\
$\mathbf{F}=\mathbf{7 5} \%, 2$ TPA \\
G1 $=50 \%, 0$ TPA, \\
G2 $=$ 50\%, 0 TPA, OCAs \\
TPA is the minimum \\
number of trees left \\
standing per acre
\end{tabular}


Mitigation Measures

Alternatives $C$ through $\mathrm{G} 2$

\section{All Sites}

Conditions for Harvesting: In order to harvest yew in a local management area or tree seed zone, sites of 20 to 100 acres within that management area with at least an effective population size of 500 sexually mature trees (may require census numbers larger than 500) that show evidence of reproductive buds and are at least 25 feet apart. Genetic reserve areas must be established first. If there are not sufficient yew in a local management area or tree seed zone to meet the above criteria, no yew would be harvested and existing populations would be protected as much as practical from other activities, except as provided below.

\section{Sites Where There is Insufficient Yew for Yew Harvest}

In some instances, yew may be harvested in local management areas or tree seed zones where there are not enough yew to establish a reserve area and, therefore, a yew harvest program. For example:

- Prior to the activity, preharvest yew that is in danger of being killed by activities such as timber sales, site preparation, prescribed fire, road construction, reconstruction, administrative site-development/maintenance, recreation site development/maintenance, or Native American uses; and

- Salvage yew that is inadvertently killed by management activities or by natural causes.

Do not harvest yew that is not in danger of being killed. Protect this yew by avoiding damage to it and maintaining or providing shade whenever practical or necessary.

If yew is killed during other activities, regenerate it to achieve the yew densities consistent with management objectives. 


\section{Sites Where There is Sufficient Yew for Yew Harvest}

\section{Both Sale and Non-sale Areas}

Genetic reserve areas: Establish genetic reserve areas of 20 to 100 acres for every 1,000-foot (BLM) or 2,000-foot (Forest Service) elevation band in each management area where yew is present in sufficient numbers. Each reserve contains an effective population of 500 sexually mature trees (may require census numbers larger than 500) that show evidence of reproductive buds and are at least 25 feet apart. Reserve areas may be located within larger reserve systems such as northern spotted owl conservation areas, designated wilderness, selected old growth areas or Research Natural Areas. BLM elevation bands were established at 1,000 feet intervals to compensate for the intermingled private lands which often are barren of reproductive yew.

Riparian Areas: No yew will be harvested within 75 feet ( $R$ $5, \mathrm{R}-6, \mathrm{BLM})$ or 50 feet (R-1) slope distance from the average high-water level of a perennial stream. This requirement may be increased to meet other resource needs.

Utilization of Yew Material: Follow current Forest Service and BLM policies for utilization of yew wood, bark, and needles. These policies may differ between Forest Service regions or national forests or between BLM districts.

Transfer of Yew, Administration of Permits, and Theft Prevention: Follow current Forest Service and BLM policies.

\section{Timber Sale Units}

\section{Both Tree and Shrub Form Yew}

- Where yew harvest is planned, harvest yew of utilizable size in the sale unit prior to the harvest of other species, to the extent that timber harvesters' health and safety will not be jeopardized;

- Consider including vigorous, undamaged yew trees or shrubs in the green tree reserves whenever possible;

- Harvest yew that are not in the residual green tree reserve; 
- To facilitate sprouting, leave yew tree stumps at least 12" high. Yew shrubs should be cut to leave $12^{\prime \prime}$ length above the root collar; generally this can be met by cutting shrubs where the stem emerges from the duff;

- Leave bark intact on yew stumps;

- Site-specific prescriptions will identify logging systems, site preparation and fuels reduction treatments, and conifer regeneration plans with regard to yew survival and regeneration;

- Wherever possible and practical, shade yew stumps with slash or adjacent vegetation and position reserve green trees to provide shade for yew stumps and advanced yew regeneration. Shading is not necessary in all areas and is not normally required on shrub form yew; site-specific analysis may help determine how much shading is needed;

- Monitor yew regeneration until yew regeneration prescriptions have been met. Where possible, monitor yew regeneration in conjunction with conifer regeneration and other area surveys; and

- If adequate numbers (number of yew plants that are represented in natural stands at the same successional stage on similar sites) of yew are not present, after assurance that regeneration by other means is not occurring, yew will be planted as prescribed in site-specific prescriptions.

\section{Tree Form Yew}

- Do not harvest yew trees adjacent to cut units due to their importance as a seed source; and

- Use one or more of the following methods to maintain or replace yew on the site at preharvest or prescribed levels or, where very abundant, at a minimum of 50 yew plants per acre:

1. Retain and protect as much of the residual yew (stumps, trees, shrubs, advanced regeneration remaining after harvest) as possible and practical from post-harvest activities such as slash piling and burning. Plan logging systems and slash disposal methods which favor the survival of residual yew plants and stumps, e.g., grapple piling or combined machine and burning methods or 
special burn prescriptions. Include retention of yew and yew stumps as one of the prescribed fire objectives in burning plans. Leave litter and down wood in those patches for seedling establishments;

2. Encourage natural regeneration (from seed already present on site) by using any site preparation methods known to favor yew seed germination and establishment. Monitor occurrence and distribution of natural seedlings; and

3. Plant rooted cuttings or seedlings from on-site sources of cuttings or seed. Cuttings could be collected before harvest. Use vexar tubing or other animal protection where browsing of young yew is predicted.

\section{Shrub Form Yew}

- Harvest shrub form yew only where practical (i.e. sufficient number of utilizable size);

- Consider seed source needs on or adjacent to the unit in site-specific NEPA analysis;

- Regenerate yew shrubs to maintain adequate numbers and distribution while meeting other land management objectives. Where preharvest yew density would preclude meeting other land management objectives (for example, conifer regeneration within five years), yew density may be reduced from preharvest conditions. Site-specific silvicultural prescriptions will describe desired yew densities compatible with meeting other objectives;

- Site-specific prescriptions will provide desired site conditions for natural regeneration of yew and protect concentrations of existing yew where feasible, while still meeting other management objectives. Where on-the-ground conditions preclude this, planting of yew will be prescribed; and

- Site preparation treatments will be considered in the following general order of preference:

1. No additional site preparation;

2. Low intensity mechanical site preparation which maintains patches of undisturbed ground including yew stumps and residual yew shrubs (Grapple piling can be effective on slopes less than $35 \%$ );
$A=$ No Action
B = Timber Sales Only
$\mathrm{C}=25 \%, 5$ TPA
$\mathrm{D}=50 \%, 5$ TPA
$\mathbf{F}=75 \%, 2$ TPA
G1 = 50\%, 0 TPA,
G2 $=50 \%, 0$ TPA, OCAs
TPA is the minimum number of trees left standing per acre 
3. Slashing in lieu of burning;

4. Cool burning prescriptions to maintain duff on site and limit mineral soil exposure (a cool burn would retain more duff and expose $10-20 \%$ mineral soil);

5. Yarding of whole trees or unmerchantable timber (YUM) prior to burning to reduce fuel loadings, facilitate slash disposal and reduce burn intensities. Slash from yew harvest could be spot piled away from residual plants and stumps; and

6. High intensity burning will be a last resort, when other methods will not meet management objectives.

\section{Partial-Cut Units/Non-sale Areas}

\section{Both Tree and Shrub Form Yew}

Prioritization of Harvest Areas: In areas where no clearcut, shelterwood, or seed tree timber sales are planned, stands containing yew will be prioritized for yew harvest. Stand priority order will vary from area to area. Low priority stands will be harvested for yew last; these stands will be stands that are valued for certain extraordinary characteristics (such as old-growth, wildlife habitat, unique yew scarcity/abundance). High priority stands are stands that are less extraordinary for the above values and will be harvested for yew first.

Percent of Harvest and Leave Thees or Shrubs: The alternatives call for different maximum percentages of yew harvest in each stand, as well as different minimum numbers of unharvested yew trees per acre (TPA) for each of three diameter classes: (For shrub form, there are no diameter classes)

\begin{tabular}{|c|c|c|}
\hline Alternatives & $\begin{array}{c}\text { Maximum } \\
\text { Percent Harvest }\end{array}$ & $\begin{array}{c}\text { Minimum TPA } \\
\text { Not Harvested }\end{array}$ \\
\hline A & 0 & NA \\
\hline B & 100 & No minimum \\
\hline C & 25 & 5 \\
\hline D & 50 & 5 \\
\hline F & 75 & 2 \\
\hline G1 & 50 & No minimum \\
\hline G2 & 50 & 5 in OCAs only \\
\hline
\end{tabular}


Fire Hazard Reduction: Where fire risk due to yew harvest is high, decrease risk by one or more of the following measures: treat yew slash; identify potential fire-hazardous conditions and activities and develop guidelines to reduce or eliminate them in site-specific prescriptions; control human access to woods by regulating the number of people and time of entry; and when fire danger is high, prohibit use of machinery and use instead handtools, horses, etc.

\section{Tree Form Yew}

- Leave unharvested yew trees distributed through the stand to reflect the natural distribution in each of three diameter classes (<11", 11-20", >20" stump diameter);

- In any one harvest area, either cut the whole yew tree for bark, wood, or needle production or remove up to half of the foliage for foliage-only production;

- For whole yew tree harvest, leave at least a $12^{\prime \prime}$ high stump, with the bark intact; shade the yew stump with slash or adjacent vegetation wherever possible or necessary; do not re-enter the stand to harvest whole yew trees for at least ten years; and

- For foliage harvest, remove half of the foliage evenly throughout the crown from yew greater than 1" DBH (diameter at breast height); do not remove foliage from yew with less than 1" DBH; re-enter the stand only after foliage re-growth has occurred; re-harvest foliage from the same trees each time.

\section{Shrub Form Yew}

- In any one harvest area, cut either the whole shrub for bark or needle production or remove half the foliage for foliage-only production;

- Retain at least 75,50 , or 25 percent (depending on alternative) of the shrub cover by one of the following methods:

1. Harvest shrubs from no more than 75,50 , or 25 percent of the unit. Site-specific prescriptions will decide whether distribution of unharvested area is by strip, block or individual shrub harvesting method;

2. Harvest single shrubs or groups of shrubs; and 
3. Harvest all merchantable stems where there is at least 75,50 , or 25 percent cover provided by remaining unmerchantable stems.

- For whole shrub harvest, leave a stump length of 12 " from the root collar, with bark intact; do not cut yew shrubs less than 1" diameter (the diameter is measured where the stem emerges from the duff); do not re-enter the stand to harvest whole shrubs for at least 10 years; and

- For foliage harvest from shrubs, remove no more than half of the foliage, evenly distributed throughout the crown, from yew with diameters over 1" (the diameter is measured where the stem emerges from the duff); do not remove foliage from yew that is less than 1 " diameter; do not reenter the stand to harvest foliage for at least five years. 


\section{Special Area Mitigation Measures}

\section{Mitigation Measures for Yew Harvest \\ in Owl Conservation Areas for Altemative G2}

Conservation Areas: Conservation areas are defined here as Habitat Conservation Areas (HCA) for national forest land, as defined by the Final EIS on Management for the Northern Spotted Owl (1992). For BLM forest lands, conservation areas are defined as Old-Growth Emphasis Areas (OGEA), Connectivity Areas (CON), and Owl Pair Sites (OPS), as described in the preferred alternative of the BLM's draft resource management plans and Klamath Resource Area Management Plan.

- On Forest Service lands, harvest yew only in Category 1 HCAs that have more than 15 pairs or resident singles and Category $2 \mathrm{HCAs}$ that have occupancy greater than $75 \%$ of the future adjusted occupancy target. On BLM lands, harvest yew only in Non-Deferred OGEAs and $\mathrm{CON}$ areas. There are four categories of HCAs:

Category 1- blocks of habitat to support at least 20 pairs.

Category 2- blocks of habitat to support 2 to 19 pairs.

Category 3- blocks of habitat to support individual pairs.

Category 4- blocks of habitat that may be smaller than the median annual home-range size but provide connectivity or potential habitat for future nest sites.

- On Forest Service lands, harvest yew only after the HCA has been inventoried following current protocol. On BLM lands, harvest yew only after project areas have been surveyed according to standard BLM Northern spotted owl survey procedures;

- Do not harvest yew within 0.5 mile radius (500 acres) of known spotted owl nest sites or activity centers on Forest Service lands. For BLMlands, do not harvest yew in the 100 acres surrounding known nest sites or activity centers; and

\begin{tabular}{|l|}
\hline$A=$ No Action \\
$\mathbf{B}=$ Timber Sales Only \\
$\mathbf{C}=25 \%, 5 \mathrm{TPA}$ \\
$\mathbf{D}=50 \%, 5 \mathrm{TPA}$ \\
$\mathbf{F}=75 \%, 2 \mathrm{TPA}$ \\
$\mathbf{G} 1=50 \%, 0 \mathrm{TPA}$, \\
$\mathbf{G}=\mathbf{5 0} \%, 0 \mathrm{TPA}$, OCAs \\
TPA is the minimum \\
number of trees left \\
standing per acre
\end{tabular}


- Harvest yew according to the Partial-cut Units/Non-sale Areas guidelines, found within the Mitigation Measures for Alternatives $\mathrm{C}$ through G2. In each of the three diameter classes ( $<11,11-20$, and $>20$ inches stump diameter), harvest no more than $50 \%$ of the yew in each area while retaining at least $50 \%$ of the yew or five yew TPA (whichever is greater).

\section{Mitigation Measures for Yew Harvest in Moose Winter Range for Altematives B through G2}

Designated Lands for Moose Winter Range on the Nez Perce National Forest: Moose winter range is managed for its Pacific yew component on the Nez Perce National Forest in north-central Idaho. The Nez Perce Forest Plan identifies 63,000 acres as Management Area \#21 (MA21). The stated goal for MA21 is to "Manage the grand fir-Pacific yew plant communities to provide for a continuing presence of Pacific yew "suitable" for moose winter habitat."

Optimum Conditions: Limited research suggests that stands which have optimum conditions for the yew component of moose winter range have $50 \%$ cover of large overstory trees (at least 40 feet tall and usually over 90 years old) and at least 30 percent cover of tree-form yew. Suggested minimum size for land units to be managed for winter range is 1,000 acres. Riparian areas, ridgetops, and benches are the most frequently used topographic areas. Key winter range characteristics related to Pacific yew include thermal cover and browse availability. Some other characteristics include topographic site, elevation and slope.

On areas of the Forest where site-specific NEPA analysis has been completed, stands have been validated as MA21. The $\mathrm{Nez}$ Perce National Forest is in the process of refining the standards for MA21 based upon Forest-wide inventory data collected during the 1992 field season. With the new inventory data, many more MA21 stands will be confirmed.

Follow the mitigation measures for Alternatives $\mathrm{C}$ through G2. Exceptions are noted below. 


\section{All Sites}

Meet the mitigation measures for Management Area 21 of the $\mathrm{Nez}$ Perce National Forest Plan. Harvest Pacific yew only where the suitability as moose winter habitat is maintained.

\section{Timber Sale Units}

Follow the Timber Sale Unit portion of the Mitigation Measures for Alternatives C through G2, except leave $50 \%$ of the original preharvest yew in patches or other patterns that can be protected from logging damage or site preparation activities.

\section{Partial-Cut Timber Sale Units}

Follow the Partial-cut Units/Non-sale Area portion of the Mitigation Measures for Alternatives C through G2, at the $50 \%$ harvest level.

Leave either $50 \%$ of the yew trees or five yew TPA (whichever is greater) distributed across the stand to reflect ecological needs for each of three yew size classes $(<11,11-20$, and $>20$ inches stump diameter).

\section{Non-sale Areas}

Follow the Partial-cut Units/Non-sale Area portion of the Mitigation Measures for Alternatives C through G2, except for determining the harvest level.

The interdisciplinary team conducting the site-specific analysis will include a wildlife biologist. Yew harvest will consider snow interception and browse availability, as well as providing yew products. Actual harvest levels will be recommended during site-specific analysis.

Leave a minimum of either $50 \%$ of the yew trees or five yew TPA (whichever is greater) evenly distributed through the stand for each of three yew size classes $(<11,11-20,>20$ inches stump diameter).

Harvest a maximum of $50 \%$ of the yew in the stand; either cut the whole tree or remove one-half of the foliage. 


\section{Mitigation Measures for Yew Harvest in Port-Orford-cedar Areas for Altematives B through G2}

Management of Pacific Yew in areas within the natural range of Port-Orford-cedar (POC) will follow the same analysis process developed for the management of Port-Orford-cedar root disease. The standards, guidelines, or mitigation measures to use are determined by using a process developed by pest management staff to analyze the risk inherent in various management activities. The complete process is described in Appendix $\mathrm{C}$ under Mitigation Measures for Yew Harvest in Port-Orford-cedar Areas. 


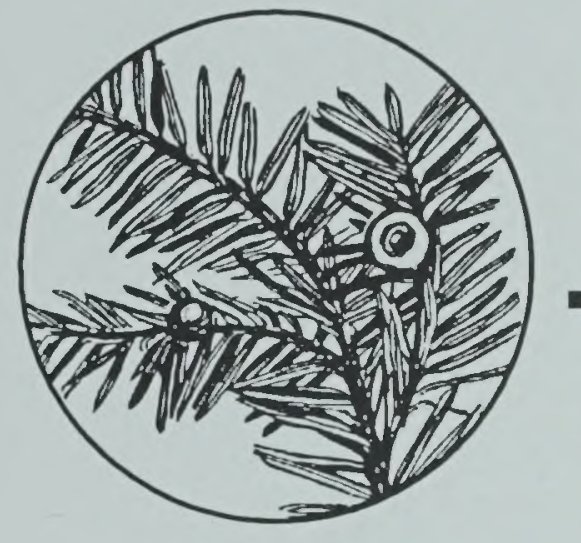

\section{Chapter III}

Affected Environment 



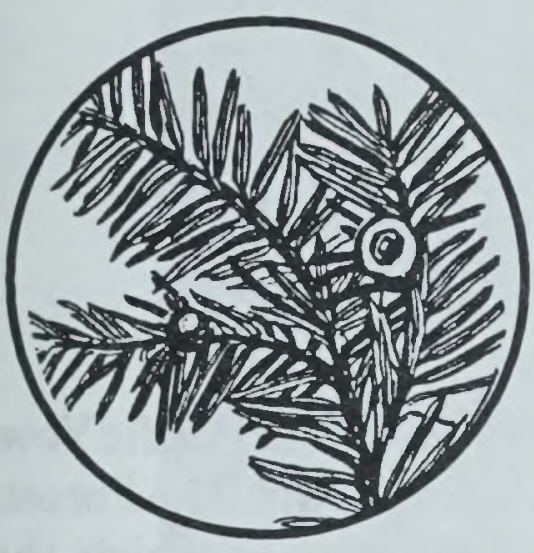

\section{Chapter III}

Affected Environment

\section{Part One: The Pacific Yew}

\section{Table of Contents}

Geographical Range

Land Ownership Patterns

\section{Land Allocations}

Forest Service Management Plans

Forest Service Management Areas

BLM Management Plans

Pacific Yew Population

and Inventory

Inventories

Population Estimates

\section{Biology}

Overview

Terms to Know

Growth Forms

Yew Bark and Needles

Reproduction

Growth and Size

Response to Disturbance
Genetics

Relationships to Other Taxus Species

Terms to Know

Genetic Variability

Genetic Diversity

More Terms To Know

Levels of Genetic Variation in Pacific Yew

Structure of Genetic Variation Role of Fire

Terms to Know

Role of Fire

Insects and Diseases

of Pacific Yew

Overview

Insects and Diseases

Port-Orford-Cedar Root Disease 


\section{Chapter III Affected Environment}

\section{Part One: The Pacific Yew}

\section{Geographical Range}

Chapter III is arranged in three parts: Part One: The Pacific Yew, contains information specific to the species. Part Two: The Forest, provides information about the forest ecosystems of which the Pacific yew is a part. Part Three: The Yew and People, addresses its cultural, medicinal and economic values.

This part of Chapter III discusses the Pacific yew, from its geographic occurrence to afflicting diseases. It focuses on the distribution and biology of Pacific yew (Taxus brevifolia), and is arranged from broadest terms to more specific. Topics include population of Pacific yew, genetics, regeneration, and role of fire.

\section{Land Ownership Patterns}

\section{Mixed Ownerships}

A variety of land ownerships and designations lie within the five state range of Pacific yew. These include state, county, city, industrial and nonindustrial private lands, as well as those administered by federal agencies.

These include lands administered by the U.S. Department of Agriculture Forest Service, and three U.S. Department of the Interior agencies - the Bureau of Land Management; the National Park Service; and the Bureau of Indian Affairs.

\section{Affected Federal Lands}

Of these lands, those administered by the Forest Service and the Bureau of Land Management are subject to the Cooperative Research Development Agreement (CRADA)(see Appendix E). See Table III-1. 


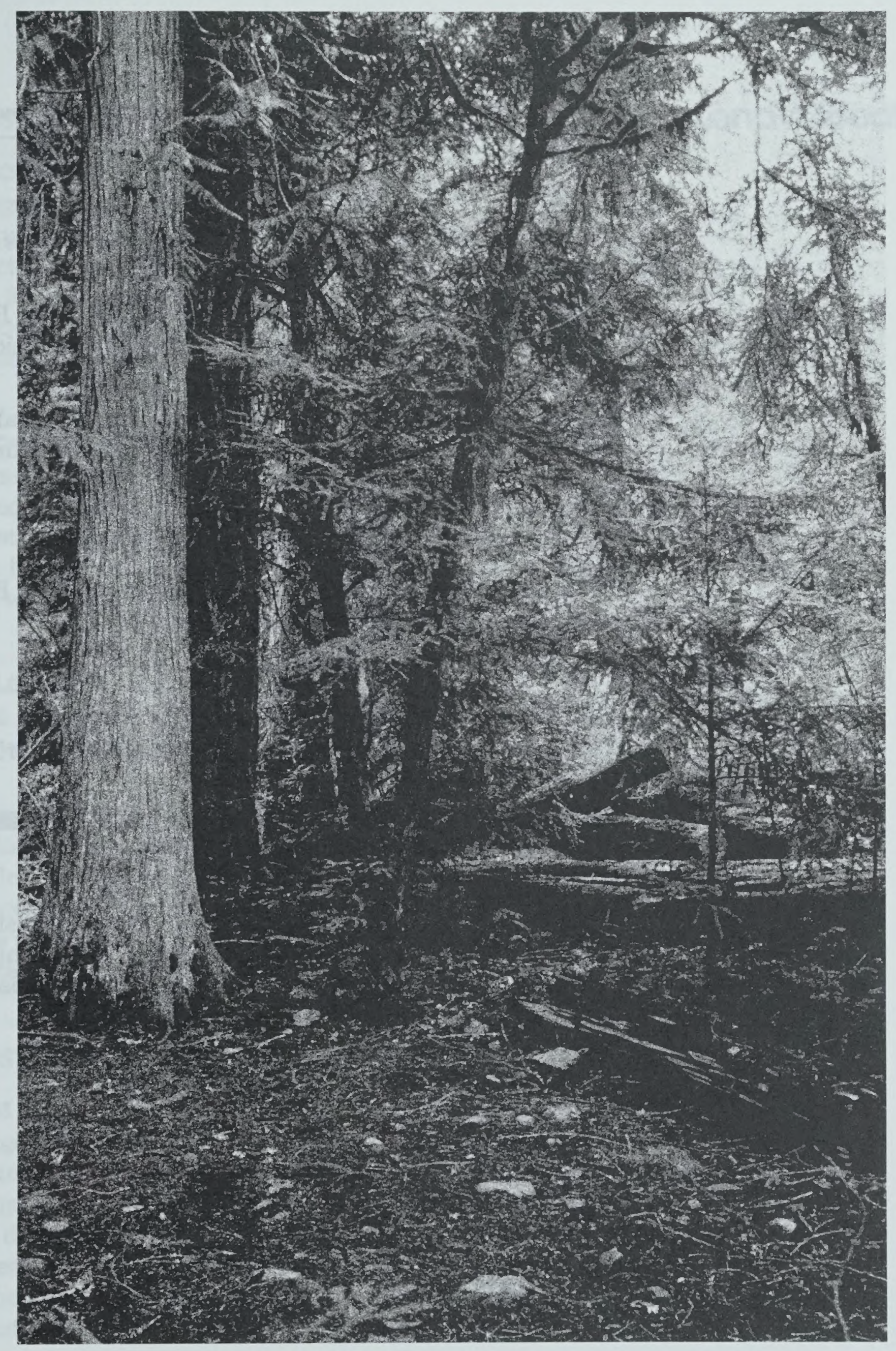


Table III-1: Affected Federal Lands, by Administrative Unit

\section{Forest Service}

Pacific Northwest Region: All 19 National Forests and the Columbia Gorge National Scenic Area.

Northern Region: Clearwater, Kootenai, Idaho Panhandle, Flathead, Lolo, Bitterroot, and Nez Perce National Forests.

Pacific Southwest Region: Six Rivers, Klamath, Tahoe, Shasta-Trinity, Lassen, Eldorado, Mendocino, and Plumas National Forests.

\section{Bureau of Land Management}

Oregon: Medford, Salem, Eugene, Roseburg, Coos Bay, Vale, Prineville, and Lakeview Districts.

Washington: Spokane District.

Idaho: Coeur d'Alene District.

California: Ukiah, Susanville, and Bakersfield Districts.

\section{For More Details}

Tables in Appendix D provide detailed listings of administrative units within the five-state area affected by the proposal. These are displayed by state and, where useful, by geographical subarea. 
Forest Service Management Plans

\section{Management Direction}

Management direction varies by agency and is specific to the particular national forest or Bureau of Land Management (BLM) district involved. The management direction for an area is the basis for determining whether harvesting of Pacific yew is allowed. Also, it will be used to calculate activities, outputs, and environmental effects for the analysis in this EIS.

\section{Source of Direction}

For most national forests, management direction is provided by the recently completed land and resource management plans ("forest plans"). If the forest plans have not been implemented, forest lands are now being managed to be compatible with the plans when they are implemented.

\section{Two Levels}

Forest plans typically have two levels of management direction: (1) forest-wide direction, and (2) site-specific direction.

Forest-wide direction comes from formal goals and objectives and established standards and guidelines for each forest plan. Areaspecific direction is spelled out in the management direction for management areas identified in each Forest. (See the discussion on the relationship of this EIS to other management direction in Chapter II.)

\section{Forest Service Management Areas}

\section{Focus}

Management areas tend to be larger areas of land that are managed towards a common focus. For example, most forests have management areas for such emphasis areas as developed recreation, designated wilderness, research natural areas, timber management, and visuals. Except for special administrative boundaries and those established by Congress, management area boundaries are not firm lines, and may be adjusted after more detailed 
reconnaissance to better meet the focus of each of the bordering management areas. The exact type and number of management areas vary, forest by forest.

\section{Direction; Roles}

Typically, the direction for management areas include area-specific Standards and Guidelines, and identifies acceptable practices for managing the area. This would include whether yew harvesting is permissible.

\section{Congressionally-Designated Management Areas}

Many forests have management areas established by Congress as national monuments, national recreation areas, designated wilderness, or wild and scenic rivers. All are managed under direction that arises from the originally established legislation. No timber harvesting - including that of Pacific yew - is allowed in designated wilderness or in areas designated as "wild" in corridors of the National Scenic Rivers System.

\section{Other Management Areas}

Many forests have established management areas for old growth. Typically, harvesting is not permitted in these areas. The recent Environmental Impact Statement for the management of the northern spotted owl established formal owl Habitat Conservation Areas (HCAs) that will supersede the management direction originally established for those areas by the forest plans. In addition, the Secretary of Agriculture has designated "research natural areas." Typically, harvesting of yew is not allowed in research natural areas.

\section{Locations}

For a description of the management areas within a particular national forest, please refer to the forest plan for that forest. The map that accompanies each plan also provides the location of the management areas. 


\section{BLM Management Plans}

Role and Status of Plans: The Bureau of Land Management (BLM) currently receives management direction from the Management Framework Plans and associated Timber Management Plans developed between 1979 and 1983. These plans include management areas similar to those in the forest plans described above. The BLM is presently preparing new Resource Management Plans, which are scheduled for release as final documents in 1993. 


\section{Pacific Yew Population and Inventory}

Pacific yew was not inventoried in the past because it was not a valued commercial species. Because of limited time and money, inventory efforts had been concentrated on the more commercially valued timber species. This has changed in the last ten years as increased interest in the biological value of other flora and fauna prompted people to gather information on noncommercial species.

\section{Inventories}

\section{Yew Inventories on State and Private Lands}

The Forest Service Research Stations include yew as one of the species tallied in their ongoing inventories of state and private lands in five northwestern states. The Pacific Northwest Research Station in Portland estimates that there are approximately 10 million yew trees (greater than 1 inch) on state and private lands in California, Oregon and Washington. Most of those trees are in smaller size classes with only 35 percent larger than five inches and only seven percent larger than 11 inches (see Appendix F).

\section{Yew Inventories on Federal Lands}

Prior to 1991 the Forest Service and Bureau of Land Management had no inventory method specifically designed to measure Pacific yew trees.

The Forest Service in Idaho collected some information in conjunction with the normal timber inventory, as did the Bureau of Land Management. For national forests in Oregon, Washington, and California, however, no previous yew inventory existed.

When Pacific yew became important as a source of taxol, the Forest Service in Oregon and Washington developed procedures that were specifically designed to inventory Pacific yew (see Appendix F).

\section{1}

Inventory crews began field work in six national forests within Oregon and Washington during the fall season of 1991. 


\section{2}

Field work continued in the national forests in Oregon and Washington; another national forest was added, for a total of seven. The BLM incorporated many of the procedures of the Forest Service inventory and began field work. Inventory crews began field work in the Nez Perce National Forest in Idaho, using slightly different procedures due to differing site conditions. Each inventory was completed by the end of the field season.

\section{Sampling}

To get the best information in the shortest time available, efforts focused on those areas that are known to have concentrations of yew. These areas include: the Rogue River, Umpqua, Siskiyou, Willamette, and Mt. Hood National Forests in Oregon; the Gifford Pinchot and Mt. Baker-Snoqualmie National Forests in Washington; the Nez Perce National Forest in Idaho; and BLM district lands in western Oregon.

\section{Population Estimates}

We recognize that by restricting the sampling we are missing portions of the yew population. As a result, our estimates of total population are conservative. We know populations of Pacific yew exist on state and private lands and in other national forests and BLM districts that were not sampled in the inventory.

The inventory does not provide mapped locations of yew populations; it simply gives us an estimate of the number of trees. Locating yew trees and shrubs on the ground will require further field work during site-specific planning. For more information about inventory methods and results see Appendix F.

Table III-2 shows the estimated numbers of Pacific yew trees and shrubs (>1") in one national forest in Idaho, seven national forests in Oregon and Washington, and BLM lands in western Oregon. 
Table III-2: Estimated Number of Yew Trees

In Several National Forests and BLM Districts

\begin{tabular}{|c|c|c|}
\hline State & $\begin{array}{l}\text { National Forest } \\
\text { and BLM }\end{array}$ & Stems* \\
\hline Idaho & Nez Perce National Forest & $6,944,000$ \\
\hline Oregon & $\begin{array}{l}\text { Mt. Hood National Forest } \\
\text { Roque River National Forest } \\
\text { Siskiyou National Forest } \\
\text { Umpqua National Forest } \\
\text { Willamette National Forest } \\
\text { Coos Bay District } \\
\text { Eugene District } \\
\text { Lakeview District } \\
\text { Medford District } \\
\text { Roseburg District } \\
\text { Salem District }\end{array}$ & $\begin{array}{r}1,961,300 \\
8,732,600 \\
352,800 \\
6,083,200 \\
8,513,400 \\
41,196 \\
104,656 \\
6,527 \\
743,367 \\
845,160 \\
339,878\end{array}$ \\
\hline Washington & $\begin{array}{l}\text { Gifford Pinchot National Forest } \\
\text { Mt. Baker/Snoqualmie Nat'l Forest }\end{array}$ & $\begin{array}{l}8,955,300 \\
6,797,400\end{array}$ \\
\hline Total & & $50,420,784$ \\
\hline
\end{tabular}

\section{Size Distribution}

The inventories show a wider variation in the average size and occurrence of Pacific yew than is typically found with more common tree species such as Douglas-fir. Yew often grows in clumps with widespread areas between without any yew at all. Yew occurs over a broader area than we had originally suspected. One generalization that we can make is that there are many more small yew trees than large yew trees; preliminary theories attribute this pattern to wildfire history and browsing by wildlife. 
Figure III-1: Example of Diameter Distributions

\section{Trees Der Acre}

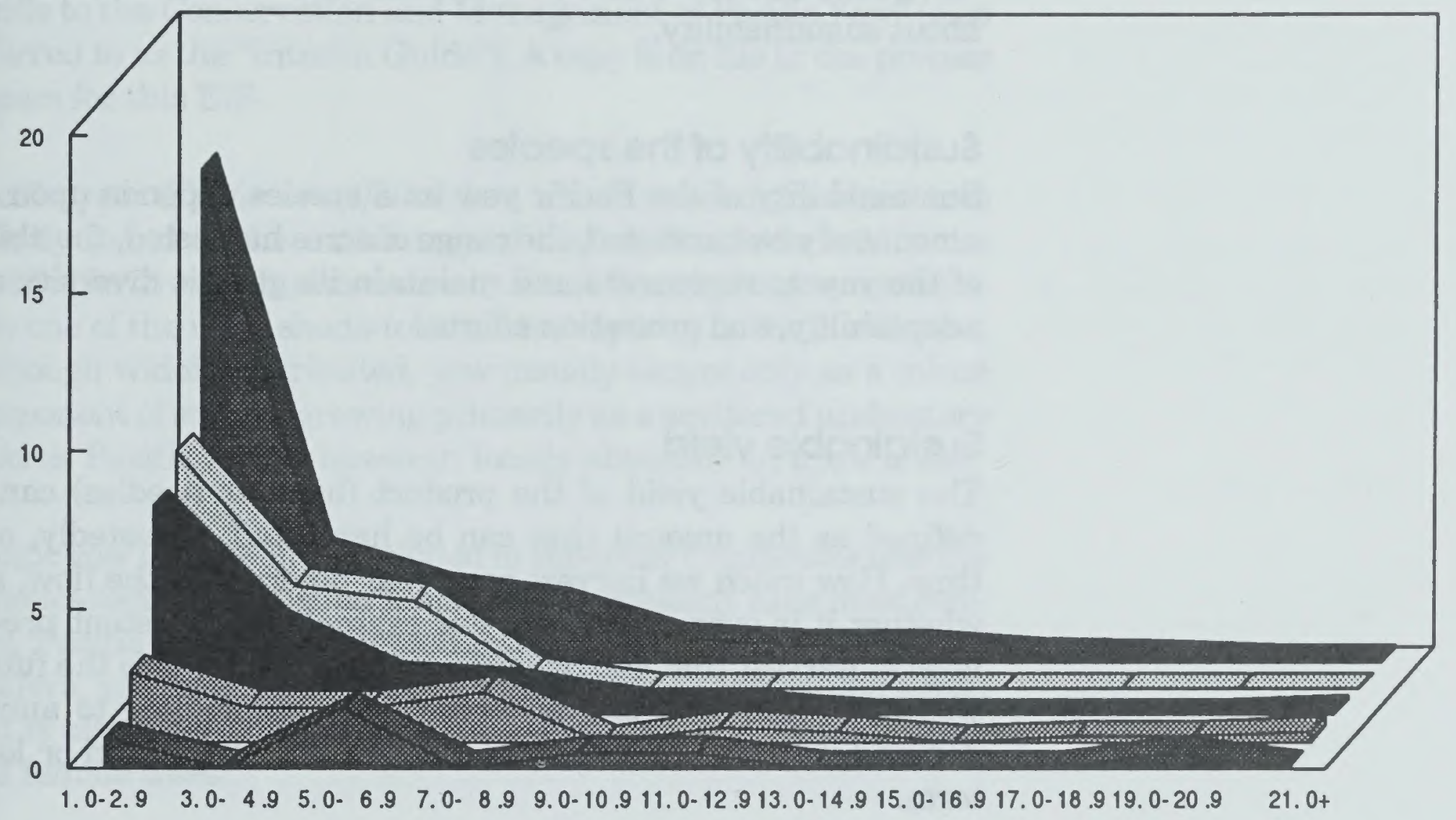

Diameter Class

Figure III-1 illustrates five examples of the patterns of size distributions of yew trees, taken from the Pacific Northwest pacific yew inventory information. Each line represents the size classes of yew trees distributed over one acre. In a single drainage, it would be possible to find each of these distributions scattered between acres without yew. When we look at the inventories as a whole they most resemble the shape of the farther curve (many small trees, with fewer big trees).

\section{Sustainability of Pacific Yew}

Sustainability of Pacific yew can be defined in two ways: 1. sustainability of the species and, 2. sustainable yield of the product (yew bark or needles used to make taxol). 
The calculation of sustainability of the species and sustainability of the product (bark or needles) is tied to the Pacific yew inventory; we need to know how much we have in order to talk meaningfully about sustainability.

\section{Sustainability of the species}

Sustainability of the Pacific yew as a species depends upon the amount of yew harvested, the range of acres harvested, the ability of the yew to regenerate and maintain its genetic diversity and adaptability, and protection efforts.

\section{Sustainable yield}

The sustainable yield of the product (bark or needles) can be defined as the amount that can be harvested, repeatedly, over time. How much we harvest each year determines the flow, and whether it is even or uneven. For example, a consistent pre-set level of harvest that can be achieved consistently into the future would be even-flow, and a harvest level responding to annual demand would be uneven-flow. Flow can be short-term or longterm.

In this EIS, we analyze the effects of several short-term, unevenflow harvest levels under Alternatives $\mathrm{C}$ through G2. These alternatives would allow harvest of a given amount of yew within five years to meet the immediate needs for taxol for clinical trials and treatment. In contrast, a long-term, even-flow harvest over a 100year rotation period would ensure a continuous supply of small amounts of material for taxol from wild yew, but may not meet the immediate demand. 


\section{Overview}

Unless otherwise indicated, this section owes much to "An Interim Guide to the Conservation and Management of Pacific Yew" (also referred to as the "Interim Guide"). A copy is on file in the process papers for this EIS.

Pacific yew (Taxus brevifolia) is a small to medium-sized tree usually found in the understory of the coniferous forests in the Pacific Northwest. It also occurs in shrub form in large quantities. It is one of the most shade-tolerant tree species in the Northwest. Although widely distributed, yew usually occurs only as a minor component of stands, growing primarily as a scattered understory species. Pacific yew is, however, locally abundant in a few areas.

Pacific yew is frequently included in the order Coniferales (see the genetics section for further taxonomic discussion). Like most conifers, Pacific yew has evergreen, needle-like leaves. Unlike most conifers, yew bears no cones, has the ability to sprout and layer, and is also dioecious, which means that there are separate male and female trees.

Pacific yew may be allelopathic. Allelopathy is when secondary chemicals produced by a plant inhibit the germination, growth, or occurrence of other plant species. McCune (1982) noted that seedlings of other tree species were rarely found beneath Pacific yew in western Montana. Yew has also been found to inhibit other plant species, both in laboratory experiments and in the field (Del Moral and Cates, 1971; Rice, 1974).

\section{Biology}




\section{Terms to Know}

Aril- the fleshy, berry-like structure that encases the seeds on female yew trees.

Allelopathy - when secondary chemicals produced by a plant inhibit the germination, growth, or occurrence of other plant species.

Axil-the angle between the stem and a branch, a petiole, or any appendage attached to it.

Dioecious - having male or female reproductive parts on different individuals or plants.

Epicormic branches - grow from adventitious buds on the trunk of a tree.

Internode - the length of stem between branches or leaf attachments.

Layering - occurs when branches that have been pressed to the ground (by fallen debris or snow) take root and form new individuals.

Stratification - a method for overcoming seed dormancy which usually involves varying temperature and moisture storage times.

Strobili-cones; structures with spore-bearing or ovule-bearing appendages concentrated on a common axis. 


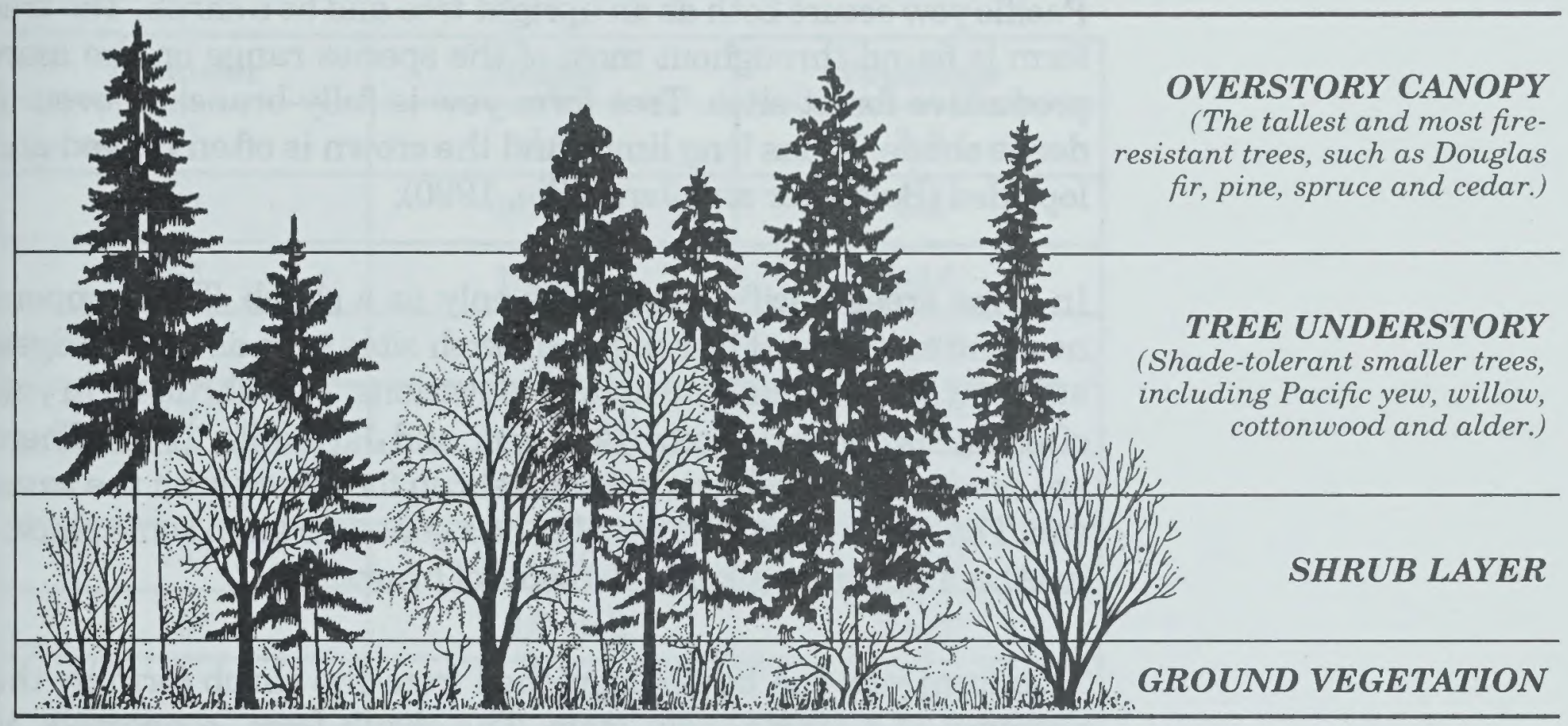

The Forest's Double Canopy, formed by the overstory and understory, intercepts snow and rain, sheltering the animal habitat beneath, and protecting less hardy vegetation such as shrubs, herbs, grasses, mosses, lichens, and the fungi that live in the top layer of the soil.

\section{Climate}

Pacific yew is found over a wide range of moisture and temperature conditions. Yew can tolerate summer temperatures as high as 110-115 degrees Fahrenheit for short periods, and winter low temperatures of -15 degrees. It survives where growing seasons are as short as 60 days and as long as 300 or more (Bolsinger and Jaramillo, 1990). With some exceptions, yew seems to thrive best in warmer areas within the humid maritime climate, areas that have relatively mild winters and fairly long growing seasons (250 days or more).

\section{Range of Elevations}

The range of elevations where Pacific yew occurs is also very wide. In Oregon and Washington yew is found from just above sea level to near upper timberline. It is found primarily at higher elevations in Idaho and Montana, and in the Sierra Nevada Mountains of California. Yew is also found in the low elevation coastal fog zone of northern California (Bolsinger and Jaramillo, 1990). 


\section{Growth Forms}

Pacific yew occurs both as an upright tree and as a shrub. The tree form is found throughout most of the species range on the more productive forest sites. Tree form yew is fully branched even in dense shade. It has long limbs and the crown is often ragged and lopsided (Bolsinger and Jaramillo, 1990).

In some areas Pacific yew occurs only as a shrub. This happens near the extremes of its range, on harsh sites such as rocky ridges, adjacent to wetlands, and at high elevations. This shrub-form yew often forms dense thickets (Bolsinger and Jaramillo, 1990). There are areas where both the tree and shrub forms occur on the same site. The shrub form is believed to be a genetic trait in some places; in others it is more likely the result of browsing.

Tree form yew can be distinguished from the shrub form by the presence of a single main stem. The shrub form, conversely, is multi-forked and multi-stemmed. Shrubby yews in the Cascades can grow as tall as 12 to 15 feet, while the yew shrubs that form dense thickets in northern Montana rarely exceed five feet in height.

\section{Yew Bark and Needles}

\section{Bark}

The bark of Pacific yew is thin (approximately one-eighth of an inch thick), scaly, and dark reddish purple (Harlow et al., 1979). The base of Pacific yew trees is frequently fluted and asymmetrical (Collingwood and Brush, 1978; Preston, 1976). The total amount of bark on individual yew trees varies due to these irregularities in the shape of the bole.

Table III-3 presents estimates of the average weight of freshly peeled bark for a range of tree diameters. 
Table III-3: Average Amount of Bark (Pounds) by Diameter at Breast Height (dbh)

\begin{tabular}{|c|c|c|}
\hline Diameter & Height* & Poundage \\
\hline $3^{\prime \prime}$ & $1 / 2$ & $2-5$ \\
\hline $4^{\prime \prime}$ & $1 / 2$ to 1 & $4-8$ \\
\hline $6^{\prime \prime}$ & $1 / 2$ to 1 & $8-14$ \\
\hline $8^{\prime \prime}$ & 1 to $1-1 / 2$ & $14-25$ \\
\hline $10^{\prime \prime}$ & 1 to $1-1 / 2$ & $30-40$ \\
\hline $12^{\prime \prime}$ & 1 to $1-1 / 2$ & $30-50$ \\
\hline $14^{\prime \prime}$ & $1-1 / 2$ to 2 & $40-60$ \\
\hline $16^{\prime \prime}$ & $1-1 / 2$ to 2 & $50-80$ \\
\hline $18^{\prime \prime}$ & 2 to $2-1 / 2$ & $70-100$ \\
\hline $20^{\prime \prime}$ & $2-1 / 2$ to 3 & $80-120$ \\
\hline $24^{\prime \prime}$ & $2-1 / 2$ to 3 & $100-140$ \\
\hline $28^{\prime \prime}$ & 3 to $3-1 / 2$ & $100-160$ \\
\hline
\end{tabular}

\section{Needles}

Pacific yew has evergreen, sharply-pointed needles. Studies regarding length of Pacific yew needle retention have not been made, but needles appear to remain on a tree for four to seven years. 


\section{Reproduction}

Figure III-3: Seeds and Foliage of Pacific Yew

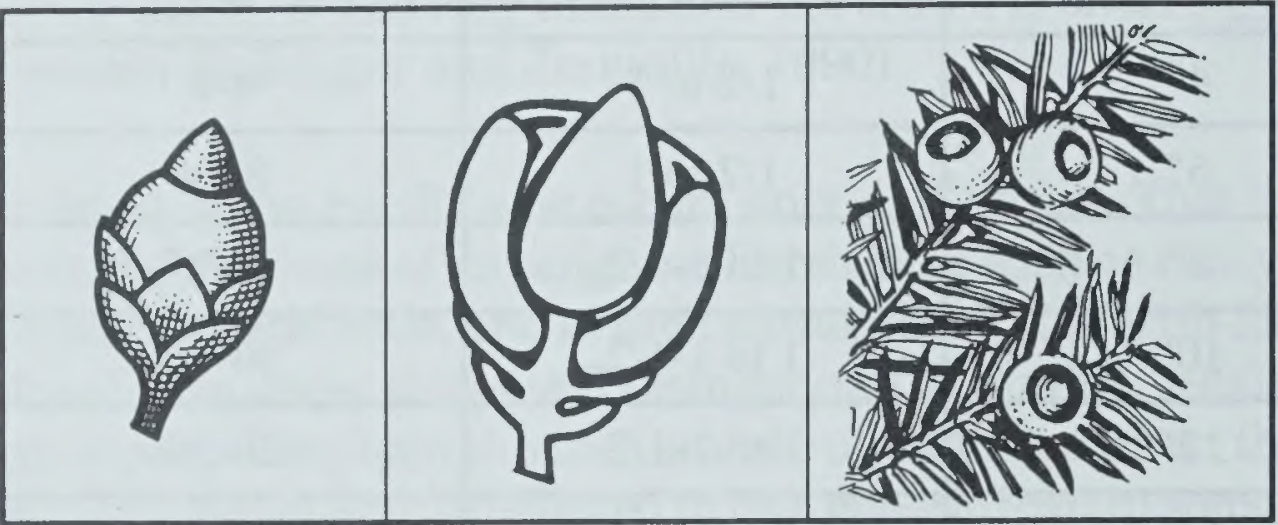

Development of the Seed, left to right:

- Female Pacific yew ovule ready for pollination

- Seed with mature aril (cross section)

- Mature aril as it appears on foliage. The seed is poisonous to people and some animals, but the red berry is edible.

\section{Sexual Regeneration}

Pacific yew is dioecious - there are separate male and female trees. Male strobili are stalked, globose, green when immature and pale yellow at pollination. These are borne on the underside of branches, at leaf axils, usually on the terminal and second internodes, and typically in clusters of four to several per internode.

Female strobili are ovoid and pointed, and composed of several scales. They are also borne on the underside of branch sprays, usually on the terminal, second and third internodes, and are much less abundant than male strobili.

No quantifiable information is available on age of sexual maturity of male or female trees. Yew trees larger than one inch diameter at breast height appear to be capable of sexual reproduction. The ratio of male to female yew plants is typically $1: 1$.

\section{Pollination}

Yew trees are wind-pollinated. After pollination, female strobili develop into fleshy, berry-like fruiting bodies called arils. Each aril contains one seed. Most of the arils ripen between August and 
October. It is not unusual to find arils in various stages of maturity - from undeveloped and dark green to fully developed and yellow, pink, or scarlet - on the same tree. This suggests the possibility of a rather wide pollination "window," or multiple pollination events in one season.

\section{Seeds}

Seed is dispersed by birds, which are attracted to the fleshy arils, and also by small mammals. Like most tree species, Pacific yew does not produce a good seed crop every year. The frequency, size, and distribution of yew seed crops are unknown. (See also the discussion of genetics in this part of Chapter III.) Observations in Oregon and Washington (Vance, 1992; Wheeler et al., 1992) indicate that more seeds are produced by Pacific yew trees in partial or full sun than those under complete canopy cover.

\section{Germination}

Germination of Pacific yew seeds usually occurs in heavy organic matter. A study in Idaho found that wild yew seedlings usually germinate in forest litter (61\%), but can also be found on decaying wood (20\%), in bird and rodent caches (16\%), and occasionally in mineral soil (3\%). (Crawford, 1983.)

There is some indication that yew seeds can remain in the soil for many years before germinating (Hartzell, 1990; Hofmann, 1917). This could be a survival mechanism that allows yew to delay germination until after new forest growth has closed in, thus concealing yew seedlings from browsing animals.

\section{Asexual Regeneration}

Pacific yew can also regenerate vegetatively. It sprouts readily from stumps, rootstocks, and broken or cut limbs and branches. It is also capable of layering. Layering occurs when branches that have been pressed to the ground by fallen debris or snow, take root and form new individuals (Bolsinger and Jaramillo, 1990; Crawford, 1983). 


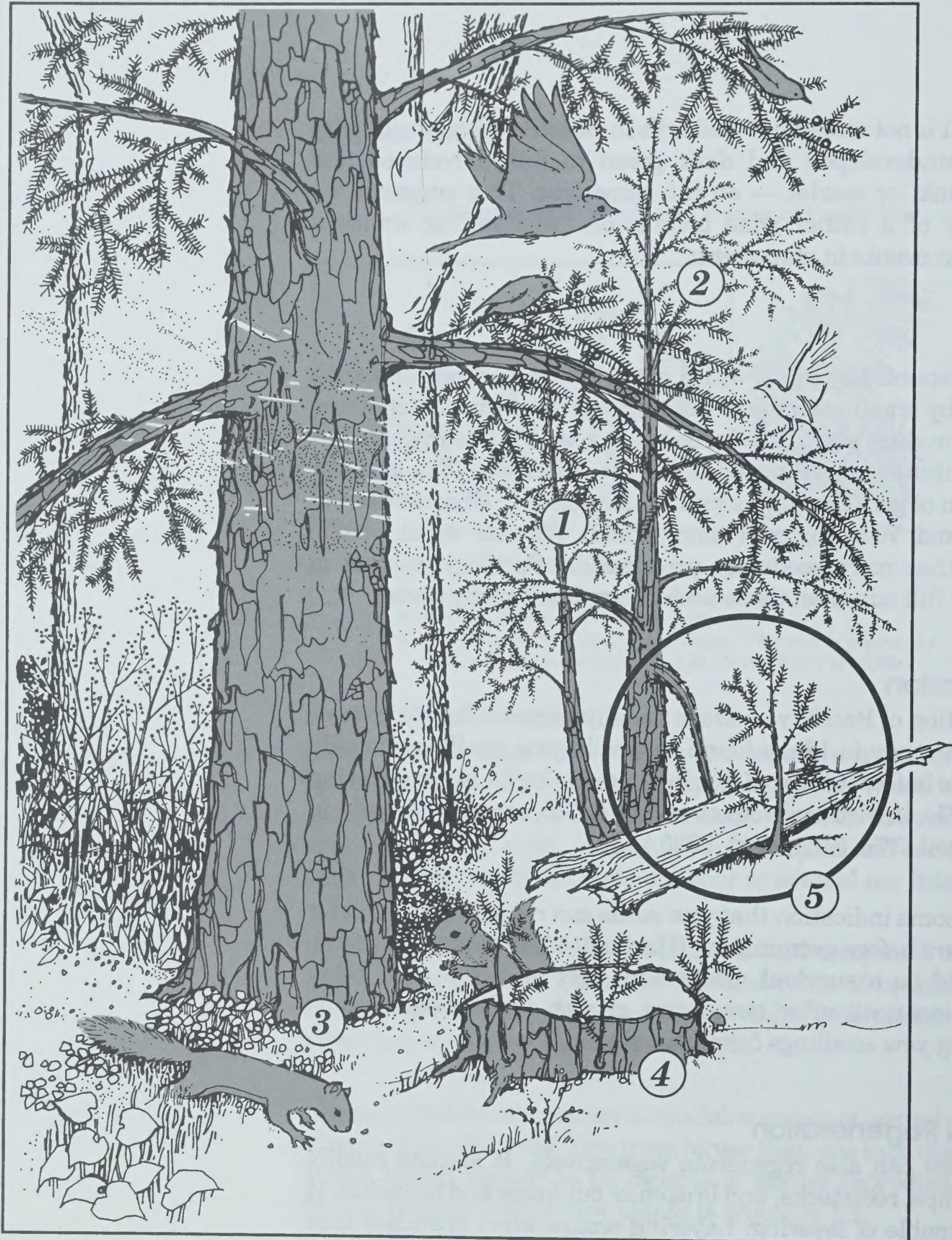

\section{Yew Regeneration}

1 Pollen from the male yew is carried by wind to the ovules of the female tree.
2 and 3 Seed is dispersed by berry and seed eating birds and mammals.

4 Stump sprouting is common both from cut trees and after forest fires.

5 Layering occurs most frequently when a branch is held to the ground by a fallen tree or other considerable weight. 
Stump sprouting is most successful on stumps with intact bark and partial shading (Minore, 1991). Preliminary results of a sprouting study in western Oregon found that 69 percent of the stumps sprouted in unburned timber sale areas (Minore, 1991). There is no information available about what percentage of sprouts can be expected to survive to maturity.

\section{Artificial Regeneration}

Inducing germination of Pacific yew is more difficult than for the seeds of conifer trees with which it is commonly associated. Apparently, Pacific yew possesses a compound dormancy, and stratification is necessary to break this dormancy.

The J. Herbert Stone Nursery, a Forest Service nursery in Oregon, reported 95 percent germination rates the second year after stratification (Steinfeld, 1992). Pacific yew can also be regenerated by cuttings. The J. Herbert Stone Nursery estimates rooting success between 40 and 50 percent (Steinfeld, 1992). Preliminary observations indicated that seedlings propagated from the seed of treeform yew adopt a natural tree-form, while rooted cuttings retain a branching morphology.

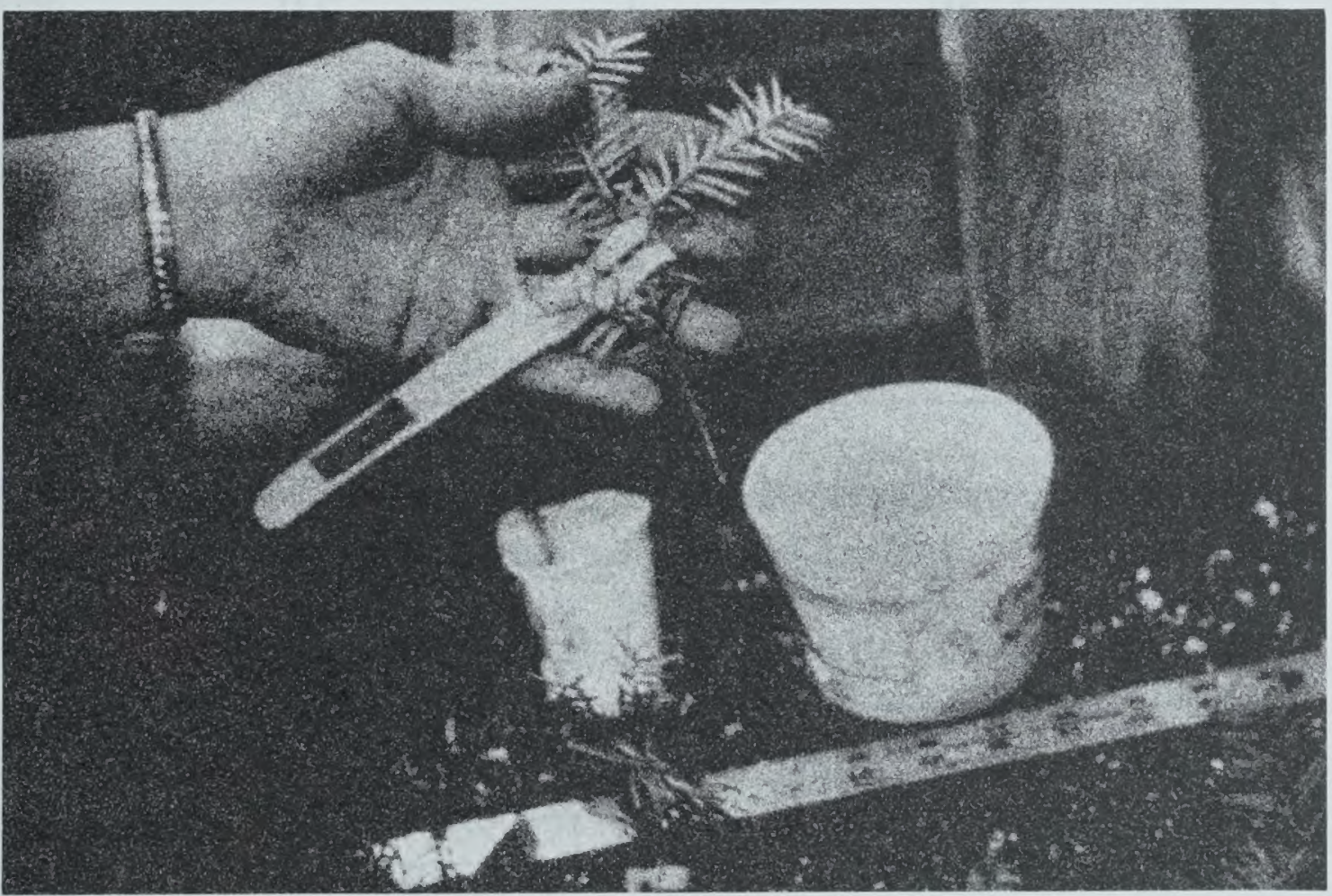

Yew cutting 


\section{Growth and Size}

\section{Growth Rate}

Pacific yew is an extremely slow growing species, both in terms of diameter and height. As with any tree species, growth rates of Pacific yew vary considerably by age, stand characteristics, and site productivity. A typical 100-year old yew tree has an average diameter of 4 to 8 inches. There have been reports of some faster growing trees. A 29-inch diameter log at Hauser's processing facility in Cottage Grove, Oregon was found to be only 125 years old.

In Idaho, an analysis of increment cores and stem sections of yew trees and shrubs from mature stands showed the following growth rates (Crawford, 1983):

Table III-4: Growth Rates

\begin{tabular}{|c|c|}
\hline $\begin{array}{c}\text { Age } \\
\text { (Years) }\end{array}$ & $\begin{array}{c}\text { Diameter } \\
\text { 6 Inches Above Ground } \\
\text { (Inches) }\end{array}$ \\
\hline 25 & 1.0 \\
\hline 50 & 2.0 \\
\hline 75 & 4.5 \\
\hline 100 & 6.0 \\
\hline 125 & 9.0 \\
\hline
\end{tabular}

Note: The diameter growth rate of the Idaho trees ranged from .02 to .1 inches each year. Average diameter growth rates of yew trees in western Oregon range from .02 to .08 inches per year (Betlejewski, 1991; Bolsinger, 1990). Yew trees remaining in partially harvested stands have been found to have increased diameter growth rates (Bolsinger, 1990). 


\section{Size}

The maximum size of Pacific yew trees in most areas is 15 to 30 inches in diameter and 30 to 50 feet tall. Trees larger than 20 inches in diameter at breast height ( 4.5 feet from the base of the tree on the uphill side) and taller than 40 feet are rare throughout most of its range (Bolsinger and Jaramillo, 1990). The largest known Pacific yew tree (56 inches in diameter and 60 feet tall) was found in western Washington (Hunt, 1986).

\section{Response to Disturbance}

\section{Overstory Removal}

Pacific yew has the ability to grow in both full sunlight and in the deep understory shade of tall forests. Yew trees that have grown in the shade for long periods of time may be damaged if suddenly exposed to full sunlight. In many cases, however, Pacific yew is able to adapt to removal of the overstory canopy. The foliage frequently turns brown and the top dies back due to increased exposure to heat, frost, and wind, but the trees are often able to survive (Bolsinger et al., 1988).

Inventories of nonfederal lands in California, Oregon, and Washington have found an estimated 700,000 Pacific yew trees 11 inches in diameter and larger (see Appendix F). Many of these trees are survivors of past removal of the old growth overstory (Bolsinger and Jaramillo, 1990).

Adaptation to overstory removal is made possible through changes in leaf morphology and twig distribution, and through the growth of epicormic branches from the bole and branches within the tree crown.

\section{Fire}

Pacific yew is sensitive to fire. (See the discussion of the role of fire at the end of this part of Chapter III.)

\section{For More Information}

Information about Pacific yew and its characteristics and requirements are found throughout this part of Chapter III. General information about forests and other lands within the native range of the species can be found in Part Two: The Forest. 


\section{Genetics}


addition, chromosome counts of $2 \mathrm{~N}=24$ have been observed for four species in Taxus (Price, 1990), which tends to indicate that Taxus species are fairly similar.

\section{Genetic Variability}

\section{Growth Forms; Rooting}

There has been limited investigation into genetic variability for specific traits in Pacific yew. Presumably there is genetic control over growth forms, as there are many specific cultivars of yew used in the landscaping industry, but the inheritance of form (tree or shrub) is unknown. Rooting studies in Corvallis, Oregon demonstrate that some individuals have greater rooting potential than others (Vance, 1992).

\section{Taxol Content}

Genetic variation in taxol content is being studied, and several early surveys indicate there is substantial phenotypic variation for this trait (Millar, 1991; Wheeler, 1992). However, none of these surveys have been able to separate environmental variation from genetic variation.

\section{Genetic diversity}

\section{Role of Genetic Variation}

The amount and distribution of genetic variation in Pacific yew is critical to its ability to persist in the ecosystem and adapt to changing environments. No single individual or small population contains all of the genetic information in the species. The sum of the genetic differences among scattered populations and individuals within these populations constitutes the gene pool.

\section{Measuring Genetic diversity-Methods; Objectives}

Genetic diversity in forest trees is usually measured with common garden studies or electrophoresis studies. Each method has different objectives, and the results are used differently in practical application (see More Terms to Know). 


\section{More Terms To Know}

Common-garden study-an investigation in which different seed sources are grown in a uniform environment to examine genetic variation in traits or characteristics.

Electrophoresis - a laboratory technique used to characterize biological entities by inspecting the differential movement of charged molecules through a porous medium in an electric field.

Common-garden studies reveal genetic differences in growth and growth rhythm traits. Variation in these traits shows adaptive responses to the environment and reflects previous natural selection pressures. Patterns in these adaptive traits are often correlated with the geographic distribution of the sample and show clinal trends.

Electrophoretic studies reveal genetic variation in selectively neutral traits. These studies are used to characterize genetic variability in a species over a broad geographic range. Patterns observed in electrophoretic studies show genetic relationships which may be due to ancestral migration routes. Mating patterns such as inbreeding and out-crossing can also be described.

\section{Levels of Genetic Variation in Pacific Yew}

\section{Overall Levels}

Overall levels of genetic variation for Pacific yew were determined from electrophoresis analysis of samples collected in 1990 from throughout the range of Pacific yew in the continental U.S. and Alaska.

\section{Initial Estimates}

Initial estimates of genetic variation (Table III-5) are somewhat higher than average for all plant species, though not as high as for conifers as a whole. 
The following table displays the average observed heterozygosity for several plant groups and Pacific yew. Heterozygosity is the condition of having one or more pairs of dissimilar alleles (alternative forms of a given gene) at a locus (location) on a strand of DNA. The mean number of alleles per locus for Pacific yew is 2.21 (standard error, .19).

Table III-5: Overall Levels of Genetic Variation in Pacific Yew and Other Plants

\begin{tabular}{|l|c|c|l|}
\hline Group Species & $\begin{array}{c}\text { Number } \\
\text { of Taxa }\end{array}$ & $\begin{array}{c}\text { Average } \\
\text { Observed } \\
\text { Heterozygosity }\end{array}$ & \multicolumn{1}{|c|}{ Source } \\
\hline Pacific yew & 1 & .17 & $\begin{array}{l}\text { USDA Forest Service } \\
\text { unpublished data, 1992 }\end{array}$ \\
\hline Tropical trees & 6 & .211 & Hamrick (1990) \\
\hline Coniferous trees & 20 & .207 & Hamrick (1990) \\
\hline Dicots & 74 & .113 & Hamrick (1990) \\
\hline All plant species & 113 & .141 & Hamrick (1990) \\
\hline
\end{tabular}

\section{Structure of Genetic Variation}

\section{Types}

Overall genetic variation can be partitioned into "among-population" variation and "within-population" variation. Approximate expectations of genetic variation structure can be gained from surveys which correlate patterns found in electrophoretic studies with life history traits.

\section{Among-Population Variation}

Among-population genetic variation is important because different combinations of alleles and their frequencies occur in different populations. Populations located on the periphery of the species range are under different selection regimes than populations in the center of the range; this leads to genetic differentiation. 
One common-garden study currently underway indicates there are genetic differences among populations from different geographic areas; there are also genetic differences among families within these populations for height, number of growing points, and bud-set (Wheeler, 1991).

Table III-6: Among-Population Variation in Pacific Yew

\begin{tabular}{|l|c|l|}
\hline \multicolumn{1}{|c|}{ Species } & Gst* & \multicolumn{1}{c|}{ Source } \\
\hline Pacific yew & .107 & $\begin{array}{l}\text { USDA Forest Service } \\
\text { unpublished data, 1992 }\end{array}$ \\
\hline $\begin{array}{l}\text { Douglas fir: } \\
\text { Coastal } \\
\text { North Interior } \\
\text { South Interior }\end{array}$ & .071 & $\begin{array}{l}\mathrm{Li} \text { and Adams (1989) } \\
\mathrm{Li} \text { and Adams (1989) } \\
\mathrm{Li} \text { and Adams (1989) }\end{array}$ \\
\hline Lodgepole Pine & .043 & Wheeler and Guries (1982) \\
\hline Ponderosa Pine & .015 & Hamrick (1983) \\
\hline $\begin{array}{l}\text { *Proportion of genetic diversity due to among-population } \\
\text { differences }\end{array}$
\end{tabular}

The amount of genetic diversity due to among-population differences was estimated from the electrophoretic analysis mentioned above (Table III-6). This amount is somewhat higher than for other wind-pollinated conifers in the Northwest, supporting the idea that Pacific yew populations are somewhat unique and no two are identical. Pacific yew propagates itself by asexual and sexual methods, and seed dispersed by animals. It has life history characteristics in common with plants that have high levels of among-population differences (Hamrick, 1990).

\section{Within-Population Variation}

All populations of a species do not have the same levels of genetic variation within them. Each population has a unique array of genotypes as a result of the mating patterns among individuals within the population over previous generations. (Note: Genotype refers to the genetic constitution of an organism, as distinguished 
from its physical appearance, or phenotype). Adaptive responses of these genotypes to the local environment further shape withinpopulation variation.

Table III-7 displays the average observed heterozygosity within populations for several conifers, including Pacific yew.

Table III-7: Comparison of Average Levels of Genetic Variation Within Populations of Pacific yew and Other Conifers.

\begin{tabular}{|l|c|l|}
\hline \multicolumn{1}{|c|}{ Species } & $\begin{array}{c}\text { Average } \\
\text { Observed } \\
\text { Heterozygosity }\end{array}$ & \multicolumn{1}{|c|}{ Source } \\
\hline Pacific yew & .17 & $\begin{array}{l}\text { USDA Forest Service } \\
\text { unpublished data, 1992 }\end{array}$ \\
\hline Douglas-fir & .21 & Conkle (1990) \\
\hline Ponderosa pine & .29 & Hamrick (1983) \\
\hline Monterey pine & .16 & Conkle (1990) \\
\hline Bishop pine & .15 & Conkle (1990) \\
\hline
\end{tabular}

These estimates indicate that Pacific yew has an average level of within-population genetic variation that is less than conifers with wide environmental distributions, such as Douglas-fir and Ponderosa pine. This value corresponds more closely to conifers with a more restricted environmental distribution, such as Monterey pine or Bishop pine (Conkle, 1990).

Local populations of Pacific yew may have a strong family structure due to limited pollen dispersal and seed dispersal by birds and small mammals. This would result in levels of within-population variation lower than those of conifers with a wide environmental distribution. 


\section{Role of Fire}

\section{Terms to Know}

Broadcast burn- a prescribed fire that may be of uniform or varied intensity.

Intense fire- fires which burn hot enough to consume much of the forest floor organic matter, along with most of the vegetation and surface fuels in a stand.

Light ground fires - fires that consume less of the forest floor. They are often patchy, creating a mosaic of burned and unburned areas.

Slash - branches and other woody material left on a site after logging.

\section{Role of Fire}

\section{Yew and Fire}

Pacific yew has thin bark and is sensitive to fire. Tree form yew is frequently killed when exposed to flames or intense heat. Shrub form yew may be better adapted to survive light ground fires, but is still frequently killed by hotter burns. Stumps that are burned do not sprout (Minore, 1992). Severe fires can create post-fire environments that are unfavorable to yew seedling regeneration.

Pacific yew's sensitivity to fire does not mean that entire populations will be lost following a burn. Both surviving yew and yew regeneration can be found in areas that were burned by light ground fires. These fires are patchy, creating a mosaic of burned and unburned areas where yew can survive. It is passible to retain yew in prescribed fire areas, provided measures are taken to protect it from heat and flames.

\section{Pacific Yew Response to Fire}

There have been few studies documenting the response of Pacific yew to fire and research continues throughout the range of the species. 
Survival of yew after a fire, either natural or prescribed, depends on the burn pattern and intensity. Even light ground fires can kill the thin-barked tree (Crawford, 1983; McCune, 1982), but it often persists in areas following a light burn. Surviving yews are usually on north aspects and near roads where heat from the fire is lowest, or in unburned patches. In areas where yew has survived fire, unburned slash and duff indicate that the fire was not intense, or was totally absent, immediately surrounding the yew tree. Yew can be totally lost from areas burned by intense fires (Spies, 1991).

There are many factors affecting the survival of yew on a site following a fire, these include: amount of fuel, fuel moisture content, ambient temperature, relative humidity, wind, ignition pattern, and slope position (Betlejewski, 1992).

\section{Shrub Form Yew}

There is speculation that shrub form yew may be better able to survive light fires than the tree form. Only the periphery of shrub clumps were found to have burned following a prescribed fire on the BLM's Medford District in southern Oregon (Betlejewski, 1992). It is possible that the interior of large shrub clumps have cooler, wetter microclimates, making them more fire resistant. There are also examples, however, where fire has completely eliminated shrub form yew from a site (Stickney, 1980). As with the tree form, survival of shrub form yew is probably dependent on a number of factors which determine the intensity and pattern of a fire.

\section{Yew Regeneration}

Yew regeneration (sprouts or seedlings) can be found in old clearcuts where the slash has been burned (Bolsinger, 1991) and in young forests that originated following fire (Spies, 1991). But it occurs in much smaller numbers in these situations than in mid-to-late seral stands that have little to no fire history (Spies, 1991).

Stumps burned by fire (showing evidence of charring) do not sprout (Minore, 1992; Green and Ward, 1991). Yew seedlings have been found growing in burned areas. Some have been found in the shaded microsites surrounding dead yew stumps on sites in west- 
ern Oregon (Minore, 1992). The seedlings were growing around only a few of the stumps, however, and this was in a moist environment. Yew seedlings have also been found in broadcast burn units on the BLM Medford District in southern Oregon, primarily in wetter areas where the fire would not have been intense (Betlejewski, 1992). On a broadcast burned clearcut in northwestern Montana, yew seedlings were found only on unburned microsites with disturbed mineral soil (Stickney, 1992).

\section{Pacific Yew Effect on Fire Behovior}

Pacific yew can also influence fire behavior in a stand. Tree form yew is a mid-story species which can provide fuel ladders for fire to the upper canopy. Yew's role as a fuel ladder is tempered, however, by its slow-to-burn foliage and the cool, damp microsite which it creates.

\section{Management Implications}

Past broadcast burning practices have reduced, and undoubtedly eliminated, yew from many sites. A 23-year study of post-logging forest succession in the Oregon Cascades found that cover of yew returned to prelogging levels most rapidly in plots where there was no evidence of burning for site preparation. Another study on the Nez Perce National Forest in northern Idaho found that only four out of 50 yew trees and shrubs survived a patchy broadcast burn.

Yew can be retained on a burned site, provided that it is part of the prescribed fire objective. There was a 90 percent yew survival rate following broadcast burning of six clearcut units in southern Oregon (Betlejewski, 1991). There was some effort made, by the ignition pattern, to keep hot fires away from the yew trees. Fire is a natural part of the ecosystem and is not inconsistent with yew management, as long as measures are taken to protect yew from flames and heat. Cooler burns, ignition patterns designed to protect yew, inclusion of yew in green tree reserves, piling and burning of slash, and pulling slash back from residual yew plants and stumps are just some of the options available to ensure yew survival after burning. 


\section{Overview}

Insects and diseases that affect yew are as much a natural part of the ecosystem as the tree itself. In balance, the activities of insects and diseases are neither positive nor negative from the tree's point of view; they are only considered pests when their activities cause effects such as mortality and growth reduction that are above some background or established threshold.

Little is known about the occurrence, distribution, or effects of insects and diseases on Pacific yew. Most reports of insect or disease damage are incidental and anecdotal because, until recently, yew has not been a major species in resource management in the Pacific Northwest. What we do know from the available literature and from personal contacts is that yew appears to be relatively free of any major insect or disease pest or combination of pests.

\section{Insects and Diseases}

In one of the few documented studies, Pacific yew was found to be resistant to damage by sulfur dioxide pollution when compared to other western conifers. The most visible indicator of potential damage to yew is a browning or bronzing of the foliage, especially when an overstory canopy is removed. However, this appears to be a physiological reaction by the tree to increased exposure to light, not of pest damage.

Twig bark beetles have been found in dead branches on Pacific yew, but the occurrence of primary stem bark beetles, defined as those that are the primary cause of mortality, is rare. Pacific yew has no important defoliators that we know of; in fact, damage that was thought to be related to a spruce budworm infestation turned out to be the effects of increased exposure to sunlight.

Of the major categories of forest diseases (dwarf mistletoes, root diseases, stem decays, rusts, and foliage diseases) only root diseases, stem decays, and foliage diseases have been reported on the tree. The effects of foliage diseases are rarely serious, usually only affecting needles on individual branches or small portions of the crown. Fungi that cause root diseases in other western conifers
Insects and

Diseases of Pacific Yew 
have been seen on Pacific yew (except for Port-Orford-cedar root disease, see below) but have not been confirmed as pathogens; in many cases, only a few roots or portions of the root collar were affected.

\section{Port-Orford-Cedar Root Disease}

\section{New Information}

The newest, and potentially the most serious reported disease of Pacific yew is Port-Orford-cedar root disease. The root disease fungus, Phytophthora lateralis, normally associated with PortOrford-cedar, has recently been found on some Pacific yew trees in southern Oregon and northern California. Laboratory tests have confirmed that the fungus can kill inoculated seedlings, although yew appears to be much less susceptible than Port-Orford-cedar. The potential effect of this disease on yew in the field is unknown.

The fungus most likely infects yew in the same manner that it infects Port-Orford-cedar: Penetration of root tips by motile spores of the fungus, followed by colonization and death of the cambium and phloem tissue of the roots and lower stem. Once the cambium and phloem are killed, the tree is unable to transport water upwards from the roots, and the tree becomes desiccated and dies.

\section{Current Status}

At present, 19 infected Pacific yew trees have been found in 13 locations. In all locations where infection of yew occurred, yew trees are mixed with infected Port-Orford-cedar. The total area with infected trees is less than 30 acres.

\section{Management Significance}

Practices that allow movement of infected water, soil, and plant material may contribute to the spread of the fungus and disease. 


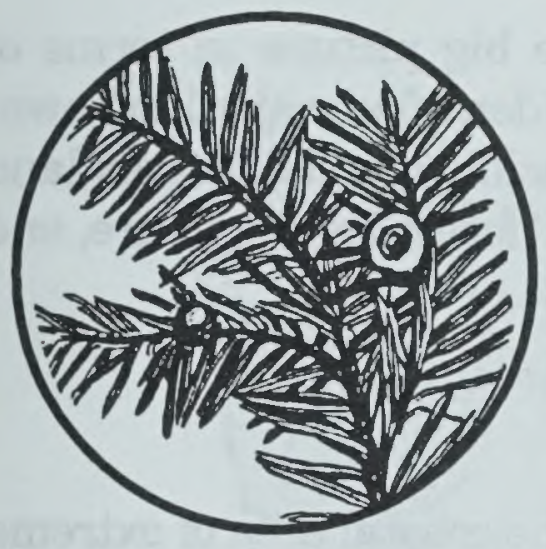

\section{Chapter III Affected Environment}

\section{Part Two: The Forest \\ Table of Contents}

Landscape Pattems

Range of Pacific Yew

Physiographic Provinces

Landscape Ecology

\section{Ecology}

Terms to Know

Overview of Ecology

Roles of Pacific Yew in the Ecosystem More Terms to Know...

\section{Community Ecology}

More Terms to Know...

Yew in Plant Associations

Other Components of the Ecosystem

Biodiversity

Overview of Biodiversity

Complexity

Levels

Forest Health

Overview and Trends

Terms to Know

Current Activities

Soils

Soils in the Range of Yew

Soil Factors Influencing Yew

Physiographic Provinces
Water Resources and Aquatic Habitat

Water Resources

Terms to Know

Aquatic and Fish Habitat

Fish Populations

Wildlife

Terms to Know

Overview

Wildlife Associated with

Late-Successional Forests

Wildlife Associated with

Early-Successional Forests

Wildlife Associated with

Riparian Areas

Other Wildlife Relationships

Threatened and Endangered

Species

Introduction; Role of This EIS

Listed or Proposed Species in the Affected Area

Terms To Know

Yew Access for Harvest

Pacific Yew Harvest and Timber

Hanvest

Roadless Areas 


\section{Part Two: The Forest}

This part of Chapter III describes the big picture in terms of landscape, diversity, and geography. It identifies major land ownership patterns within the range of Pacific yew, addresses land allocations and resources within the big "forest-level" picture, and identifies forest health-related concerns.

\section{Range of Pacifc Yew}

The range of Pacific yew extends from the coastal area of extreme southeastern Alaska to central California, and as far inland as western Montana and the Kamloops and Kootenai Districts of British Columbia.

This EIS covers five states, or portions of states, within the range of Pacific yew: Oregon, Washington, Idaho, northern California, and western Montana.

Physiographic Provinces
This area can be divided into 19 generalized physiographic provinces (see Figure III-5: Physiographic Provinces). The following is a brief description of the provinces in which yew can be found and its general occurrence within each area. For further information regarding the geology, climate, vegetation and soils of each province see Appendix I.

\begin{tabular}{|c|l|}
\hline $\begin{array}{c}\text { Map } \\
\text { Legend } \\
\text { Number }\end{array}$ & Area \\
\hline 1. & Olympic \\
\hline 2. & Coast Range \\
\hline 3. & Siskiyous \\
\hline 7. & Cascades \\
\hline 11. & Sierra Nevadas \\
\hline 14. & Okanogan Highlands \\
\hline 16. & Blue Mountain \\
\hline 18. & Wallowas \\
\hline 19. & Rocky Mountains North Part \\
\hline & Other Areas Where Yew Grows \\
\hline
\end{tabular}




\section{$\mathbb{C} \mathbb{N} \mathbb{A} \mathbb{A}$}

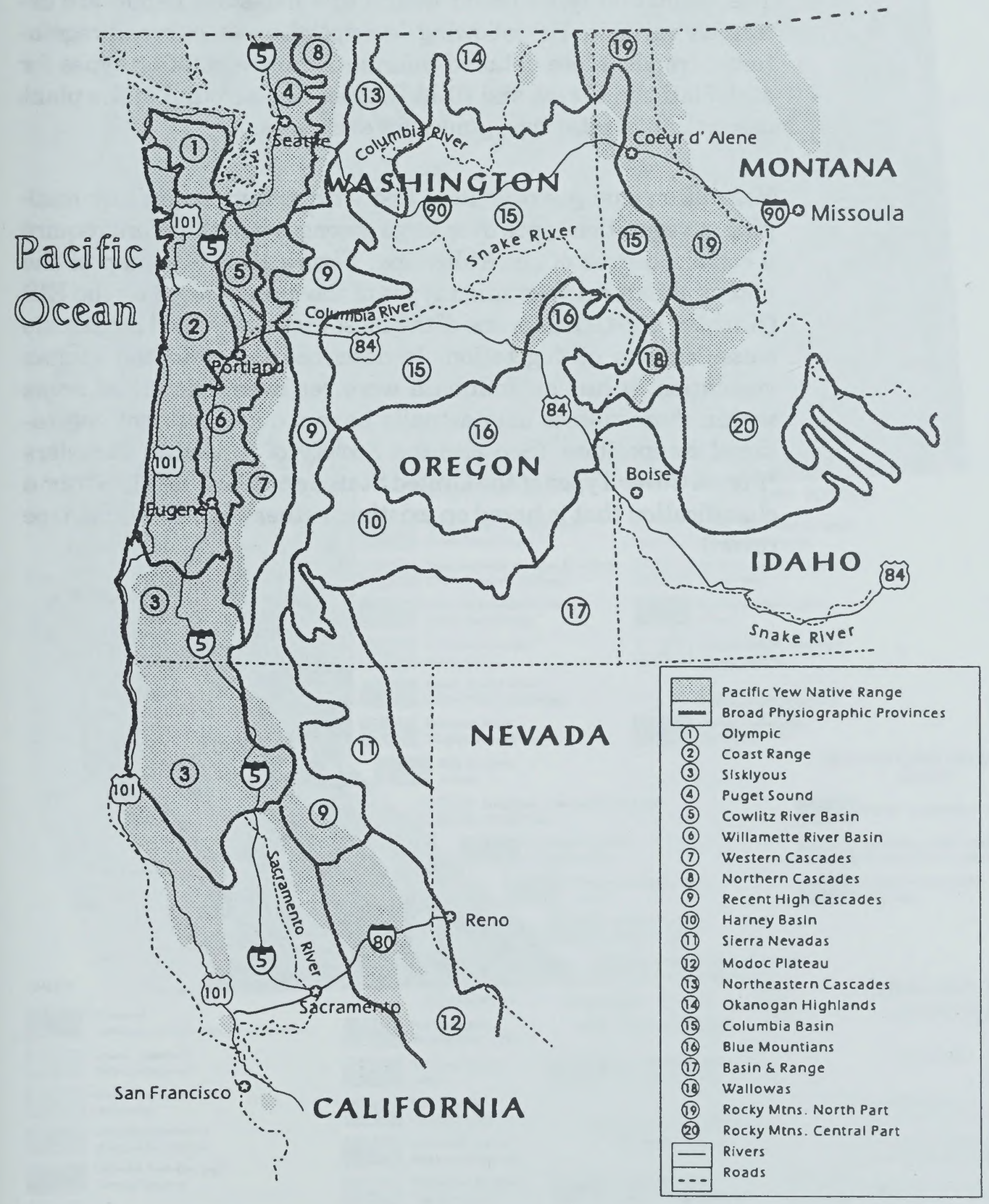




\section{Vegetation}

The vegetation types found within this five-state region are extremely variable. The following description assesses broad vegetational trends. More detailed information on vegetation types for each National Forest and BLM District can be found in the plant association/habitat type guides for each area.

Vegetation changes over time and with disturbances; any mapping of vegetation types over large acreages will therefore require a certain degree of generalization. Figure III- 6 is a map of the potential natural vegetation types of the area covered by the EIS (Kuchler, 1964). This is one of the most commonly used large scale classifications of vegetation. It describes the potential climax vegetation, if human influence were removed. Disturbed areas within these classes may actually have a quite different vegetational composition. (See also the Society of American Foresters "Forest Cover Types of the United States and Canada" (1980) for a classification that is based on existing, rather than potential, tree cover.) 


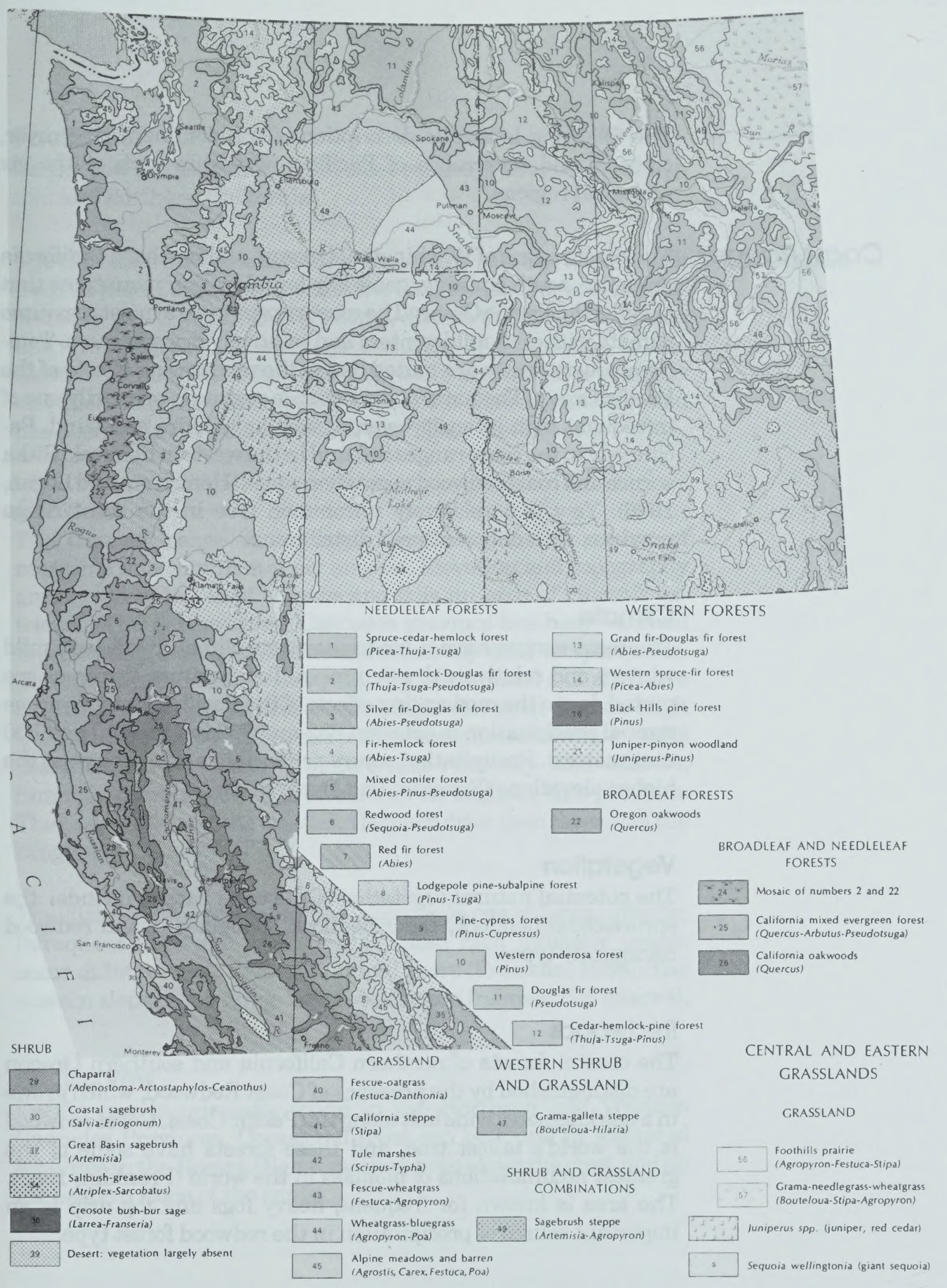


The following is a brief description of the dominant tree cover, climate, and occurrence of Pacific yew within each of the six ecological regions.

Coast Ranges

The coast ranges of Washington, Oregon, and northern California are north-south running, generally low elevation mountains that parallel the Pacific Ocean. The coast ranges have a moist maritime climate with wet, mild winters and relatively dry summers. Temperature extremes are muted due to the moderating effects of the Pacific Ocean. The natural disturbance regime is primarily one of infrequent high intensity events, such as wildfire and wind. $\mathrm{Pa}-$ cific yew in the coast ranges is found in the western hemlock, Sitka spruce and coast redwood vegetation zones (Hemstrom and Logan, 1986). Yew is a relatively uncommon tree in the coast range province, with only scattered distribution.

\section{Climate}

The coast ranges have a moist maritime climate with wet, mild winters and relatively dry summers. Temperature extremes are muted due to the moderating effects of the Pacific Ocean. Average annual precipitation is between 432 and 762 inches (170 and 300 centimeters). Precipitation occurs primarily as rain, except at the higher elevations (Franklin and Dyrness, 1973).

\section{Vegetation}

The potential natural vegetation of the coast ranges include: the spruce/cedar/hemlock, cedar/hemlock, Douglas-fir, and redwood community types.

\section{Redwoods}

The coastal forests of northern California and southern Oregon are distinguished by the presence of Coast Redwood, which grows in a one kilometer wide belt along the Pacific Coast. Coast redwood is the world's tallest tree, and these forests have some of the greatest accumulations of biomass in the world (Franklin, 1988). The area is known for frequent, heavy fogs and fog drip is an important source of precipitation in the redwood forest type. 


\section{Pacific yew}

Pacific yew is uncommon in the coast ranges of Oregon, Washington, and northern California.

The Cascades are a chain of high mountains running north-south from British Columbia to northern California. The range is bisected by the Columbia River, which divides the states of Oregon and Washington. The average elevation of mountains in the Cascades is 8000-9000 feet, although there are a number of higher elevation volcanic peaks found throughout the range. Glaciation has been an important process at the higher elevations.

\section{Climate}

The Cascade range is the major barrier to the movement of maritime and continental air masses. Elevation and topography greatly effect the local climate and it is an area of climatic extremes. The northwestern Cascades province has heavy annual precipitation, high humidities and relatively mild temperatures. The western Cascades receive slightly less rainfall and also have relatively mild temperatures. The high elevation Recent High Cascades province receives more of its precipitation as snow and is characterized by warm summers and relatively cold winters. Summer thunderstorms are common throughout this province. The eastern slope of the Cascades is much drier than the rest of the range.

The disturbance regime in the Cascades is one of large, intense, infrequent fires and windstorms. These high intensity events occur at intervals of several hundred years (Franklin, 1988). The eastern slope of the range has a much more frequent fire interval.

\section{Pacific yew}

Pacific yew is primarily found in the Northern and Western Cascades Provinces. Occasional trees can be found in scattered localities in the Recent High Cascades, both along the crest and on the eastern slope of the range.
Cascades

.


Olympics The major portion of the Olympic province exhibits extensive glaciation. The steep, rugged Olympic Mountains provide a central core surrounded by almost level lowlands. The climate of the region varies from very wet, humid and maritime along the far west coast, to relatively dry and almost continental in the rainshadow of the northeastern corner of the province. The disturbance regime is primarily one of infrequent high intensity events, such as wildfire and wind. Average fire frequencies in the area range from 138 to 900 years, depending on the vegetation type (Henderson et al., 1989).

Tree-form yew is the dominant growth form in the province. It can be found in the western hemlock, Douglas-fir, mountain hemlock, and Pacific silver fir vegetation zones (Henderson et al., 1989).

\section{Climate}

The Cascade range is the major barrier to the movement of maritime and continental air masses. Elevation and topography greatly affect the local climate. While still quite wet, the Cascades are drier than the coast range. Much of the precipitation in the area falls as snow.

\section{Vegetation}

The potential natural vegetation of the western Cascades and Olympic Mountains includes: the silver fir/Douglas-fir, fir/hemlock, western spruce/fir, Douglas-fir, cedar/hemlock/Douglas-fir, and spruce/cedar/hemlock types. The drier eastern Cascades support the western ponderosa pine type.

Vegetation types vary greatly between the Douglas-fir and western hemlock-dominated low elevation western Cascades, the true fir and mountain hemlock-dominated high Cascades, and the ponderosa pine-dominated eastern Cascades.

Pacific yew occurs as a scattered understory tree throughout the northern and western Cascades. It is found in occasional clumps and as stringers along riparian areas. Yew can be found in a wide variety of plant associations within the western hemlock, pacific silver fir, western redcedar, Douglas-fir, white fir, and grand fir 
vegetation zones (Brockway et al., 1983; Franklin et al., 1988; Hemstrom et al., 1982; Halverson et al., 1986).

On the west side of the Cascades, yew can be found at a wide range of elevations, on all aspects and slope positions, on benches, ridgetops and bottomlands. Tree form yew is the dominant growth form, but the shrub form is also present. Shrub form yew is primarily found on harsh sites, adjacent to wetlands, and at higher elevations.

\section{Pacific yew}

Pacific yew is also found on the east side of the Cascade range, although it is relatively uncommon. Here the shrub form predominates, and is usually found in riparian areas.

The Siskiyou province of northern California and southern Oregon is an area of unique geologic and ecological characteristics. The area contains regions of complex and strongly contrasting geology, including ultrabasic rock types such as serpentine (Franklin and Dyrness, 1973). There are also a large number of endemic species and unique plant communities.

Pacific yew in the Siskiyou province is found in the western hemlock, white fir, Douglas-fir, Pacific silver fir, and western redcedar vegetation zones (Atzet and Wheeler, 1984). Pacific yew is relatively widespread in the northern portion of the province, although it is still not abundant. Yew can be found in a wide variety of environments in the area from high elevation snow chutes to low elevation drainages. It is usually associated with areas of high humidity and in older, undisturbed stands. Yew is only occasionally found on midslopes or in open stand conditions (Atzet, 1991). In the southern portion of the province, yew is primarily found only in drainages and on the lower third of northfacing slopes (Scher and Jimerson, 1989).

\section{Climate}

The climate in the Siskiyou province is maritime, with relatively high summer humidities on the coastal side, and drier conditions in the east (Atzet and Wheeler, 1984). The area contains sharp 
temperature and moisture gradients (Whittaker, 1960). The coastal side of the region is relatively humid with more arid conditions in the east. The disturbance regime is one of frequent light ground fires.

\section{Vegetation}

The potential natural vegetation in the Siskiyou province includes: the cedar/hemlock/Douglas-fir, silver fir/Douglas-fir, mixed conifer, red fir, Oregon oakwoods, California mixed evergreen, and chaparral types.

\section{Pacific yew}

Yew seems to thrive in warmer, non-coastal areas within the humid maritime climate. The Siskiyou province has such a climate and yew is widespread in the area, although it is still not abundant.

Sierra Nevada The Sierra Nevada is the dominant mountain range in California, extending 360 miles along the eastern portion of the state, from Mt. Lassen to Bakersfield. The province is located within the Mediterranean climatic zone, and has wet winters and hot, dry summers. Climate varies throughout the Sierra Nevada Range due to its diverse topography and the wide span in latitude and altitude. The east side of the range, within a rain shadow, is much drier than the west side. The natural disturbance regime is one of frequent, low-intensity ground fires (Barbour, 1988). Fire frequency varies with vegetation type, but an average interval is every 8 to 16 years.

\section{Pacific yew}

Pacific yew is found in the northern portion of the Sierra Nevada range primarily within the mixed conifer vegetation zone, which occupies an elevational band between 3000 and 5000 feet. Yew is almost always associated with cool, moist riparian environments. It is usually found along drainages, or on the lower portion of north-facing slopes. Seedlings are occasionally found on midslopes, but full-grown trees are not (Fites, 1992). 
The Okanogan Highland reflects repeated glaciation, resulting in a generally rolling terrain of moderate slopes and broad, rounded summits. Scattered peaks rise 3,000 to 4,000 feet above the general terrain, dividing the area into several upland areas separated by a series of broad north-south valleys. The province is in the continental climatic zone, with cold winters, warm summers and high summer rainfall intensities.

\section{Pacific yew}

Pacific yew in the province occurs as a scattered, very low-growing shrub. It rarely reaches stem sizes that would be harvestable for bark. Pacific yew shrubs can be found in the western hemlock, western redcedar, and grand fir vegetation zones (Williams et al, 1990).

The Blue Mountains Province is composed of several mountain ranges. The most prominent of these are the Blue and Ochoco Mountains. The topography of the region is highly variable, and moderately steep slopes are common. The province is within the warm continental climatic zone.

\section{Climate}

The Cascade range to the west provides a barrier to warm, moist fronts coming in from the Pacific Ocean. The Columbia River Gorge, however, allows cloudy, marine conditions to reach the northern portion of the Blue Mountain range. This provides an environment for some vegetation types similar to those found in the Cascade range (Johnson and Clausnitzer, 1992). The Blue Mountain region is characterized by light precipitation, low relative humidity, rapid evaporation, abundant sunshine, and wide fluctuations in temperature and precipitation.

The natural disturbance regime in the area is one of frequent, lightning-caused fires (Johnson and Clausnitzer, 1992).

\section{Pacific yew}

Pacific yew is found only in the northeastern corner of the province, in the northern Blue Mountains. The yew is sporadically distributed both individually and in small, isolated clumps at
Okanogan

Highland

\section{Blue Mountains}


moderate elevations within the grand fir vegetation zone (Johnson and Clausnitzer, 1992). The yew is found in cool, moist environments that have been sheltered from disturbances. It is often confined to canyon bottoms, lower slope positions, or favorable cove and basin settings at the head of drainages (Johnson, 1992). The growth-form of yew in the area is most commonly a mid to tall shrub-like tree (Johnson, 1992).

Wallowas The Wallowas province consists of a mountainous "island" (the Wallowa Mountains) surrounded by lava plateaus. The Wallowas, unlike the Blue Mountains to the west, have been heavily glaciated, creating steep, rugged slopes. Climate is similar to that in the Blue Mountains province except that the Wallowas have higher precipitation and colder temperatures. The natural disturbance regime is one of frequent, lightning-caused fires.

\section{Pacific yew}

The occurrence of yew in the Wallowas is similar to that described for the northern Blue Mountains. It is found primarily in undisturbed cool, moist environments in the grand fir vegetation zone (Johnson and Simon, 1987). The shrub-like tree is usually found in canyon bottoms, on lower slope positions, and at the head of drainages (Johnson, 1992). Although usually found on cool sites in the area, yew has been found growing in the bottom of Hell's Canyon along the Snake River, where summer temperatures can occasionally reach up to 115 degrees Fahrenheit.

Rocky Mountains

North Part

This province encompasses the portion of the Rocky Mountain range that runs through northern Idaho, northwestern Montana, and northeastern Washington. It is an area of high rugged mountains and flat valleys. The Northern Rocky Mountains are in the continental climatic zone. The area has strong climatic seasons with cold, snowy winters and warm summers.

The disturbance regime in the Northern Rockies is variable. The low elevation ponderosa pine woodlands have a history of frequent, low intensity fires with an average fire interval of five to twelve years (Arno, 1980; Gruell, 1985). The higher elevation forests have a longer fire interval and more severe, stand-replacing crown fires. 
Average annual precipitation is 127 to 254 inches (50-100 centimeters). Precipitation occurs mainly in the fall, winter, and spring months, and the summers are usually dry. Although winter snowfall is heavy, permanent snowfields and glaciers cover only rather small areas.

\section{Pacific yew}

Pacific yew occurs in very small amounts, in scattered localities over millions of acres in northern Idaho and western Montana. Yew can be found in the western hemlock, western redcedar, grand fir, and subalpine fir vegetation zones. It is also occasionally found in the mountain hemlock and spruce zones (Cooper et al., 1991; Pfister et al., 1977).

Pacific yew is locally abundant in a few areas within the province. One such area is in the Nez Perce National Forest in northern Idaho in the drainage of the South Fork of the Clearwater River. Throughout most of the drainage, yew occurs as a clumped or scattered tree, but there are some localized areas of dense, treeform yew. Yew is the predominant tree species in these stands, beneath a scattered overstory of grand fir, larch, douglas-fir, lodgepole pine, and Engelmann spruce. It has even been suggested that Pacific yew may be the climax species on these sites (Crawford, 1983).

Abundant yew can also be found in localized areas on the Flathead National Forest in northwestern Montana. The shrub-form yew in this area forms dense, continuous thickets.

Pacific yew is also found in southeastern Alaska, western Canada, and on the Payette National Forest in Central Idaho. These areas are not covered by this EIS.
Other Areas Where Yew Occurs 


\section{Landscape Ecology}

Landscape ecology is an emerging discipline in the field of ecology that examines patterns in time and space across large land areas, and how these patterns develop. The landscape perspective shifts from a more traditional focus on individual stands to a view of the entire landscape. A landscape can be defined as a cluster of interacting ecosystems, and is usually measured on the scale of thousands of acres or multiple watersheds (Forman and Godron, 1986). Connectivity, or spatial continuity, across the landscape is an important aspect of viewing the forest through a landscape perspective.

A landscape approach is particularly appropriate to the management of Pacific yew because we are dealing with almost the complete range of the species. It is important to understand the distribution of Pacific yew both within and between the physiographic provinces described above. The reproductive dynamics, plant-animal relationships, growth forms, and habitats in which yew occurs are different between the provinces.

Viability of a species is dependent on interaction between localized populations, which facilitates gene flow and dispersal. Connections between populations also allow for the movement of organisms that may depend on that species, or on the kind of habitat which it creates. When examining connections between yew populations, it is important to remember that Pacific yew is a naturally "clumpy" species, with scattered distribution. The continued presence of Pacific yew throughout its natural range should be provided for by maintaining interaction and gene flow among yew populations.

Yew population connectivity across the landscape is an important consideration. Many areas such as wilderness, research natural areas, and unique and special interest areas, for example, are already reserved from any harvesting activity. These reserves provide for maintenance of the yew populations within these designated areas. Connections between these set-aside areas should be considered on a landscape scale - across ownership and management unit boundaries. A degree of replication in maintaining populations is desired in order to allow for reductions in concentration or abundance due to natural disturbances. 


\section{Terms to Know}

Ecology the study of the relationship between organisms and their environment.

Population - a group of individuals of any one kind of organism.

Community - all of the populations in a given area. The biotic community and the non-living environment function together as an ecosystem.

\section{Overview of Ecology}

Ecology is the study of the relationship between organisms and their environment. It examines the structure, function, and patterns of nature.

The biological world can be divided into six major levels of organization: genes, cells, organs, organisms, populations, and communities. A population is a group of individuals of a particular kind of organism. A community encompasses all of the populations within a given area. The community and the nonliving environment function together as an ecosystem (Odum, 1971).

It is important that we consider not only the most obvious components of the ecosystem, the large plants and animals, but also smaller and often overlooked organisms. Fungi, mosses, lichens, soil and canopy invertebrates, mycorrhizae, bacteria, and other microorganisms are all important parts of natural systems, although their roles in the forest ecosystem are not yet completely understood.

Note: Ecology, by definition, examines the interconnections in nature. There is therefore a great deal of overlap between this section and other sections of the EIS, particularly in Parts One and Two of this chapter and Chapter IV. 


\section{Roles of Pacific Yew in the Ecosystem}

Note: This description of the ecology of Pacific yew owes much to the Interim Guide. A copy is on file with the process records for this EIS (see also Chapter II).

Pacific yew is an ecologically unique species. There are few other plant species in the world with broad habitat occurrence and wide distribution, that have such small local population sizes.

\section{Function}

Little is known about the functional role of yew. It is an important component of some ecosystems and may have a wide variety of roles which should be understood and sustained. Yew may play important roles in controlling the microclimate, nutrient cycling, and biological diversity (see biodiversity section) of forest stands. Given the unique biochemistry of the species, it is entirely possible that yew may play a special role in cycling nutrients, altering soil chemistry, and possibly maintaining a unique community of invertebrates and microorganisms.

\section{More Terms to Know...}

Vertical structure - the layering of vegetation, the vertical arrangement of herbs, shrubs, midcanopy and canopy trees, and snags.

Horizontal structure- the distribution and spatial arrangement of life forms and species.

\section{Structure}

\section{Vertical Structure}

An important determinant of diversity in a forest stand is the structure of the vegetation (see the wildlife and biodiversity sections). Vegetation can be grouped into five main vertical layers: Herbs, low shrubs, tall shrubs, understory trees, and overstory 
trees. Stands with multiple canopy layers, or more vertical structure, often support a wider variety of organisms than less structurally diverse stands.

\section{Horizontal Structure}

Horizontal structure, or the spatial arrangement of vegetation in a stand, also contributes to structural diversity. A patchy stand, with a variety of vegetation, is more diverse than a stand with uniform distribution. A horizontally diverse stand contains a variety of microsites, and can therefore support a more diverse biotic community.

\section{Pacific Yew's Role in Stand Structure}

Pacific yew contributes to both the vertical and horizontal structure of forest stands. It occupies the midcanopy layer in a wide variety of stand types, providing vertical structure. Pacific yew is a valuable long-term midstory species due to its small stature and shade tolerance. Its clumpy, scattered distribution also adds to horizontal diversity.

\section{Snags and Woody Debris}

Snags (standing dead trees) and down logs also contribute to structural and habitat diversity. Pacific yew's decay resistant wood could make it a valuable species for down woody debris, both on land and in streams. This may be offset, however, by yew's small size. The importance of snags and down logs to wildlife is discussed in the wildlife section. Yew's role in riparian areas and fish habitat is discussed in the hydrology section. 


\section{More Terms to Know...}

Plant association- a grouping of plant species that recur across the landscape within particular environments (Daubenmire, 1968).

Climax plant community - a mature, highly stable, selfreplacing plant community (Clements, 1916). It is the end result of the successional development of a plant community, in the absence of disturbance.

Indicator species- plant (or animal) species whose presence has been correlated with certain environmental conditions.

Mycorrhizae - an association, usually symbiotic, between a root tip of a plant and one of several species of fungus. The mycorrhizal relationship aids a plant in absorbing water and minerals.

Succession - the sequence of change in communities during development of vegetation in an area.

\section{Community Ecology}

\section{Succession}

Succession is the sequence of change in communities during development of vegetation in an area. Plant communities on a site replace each other over time, due to changes in physical and biological conditions. The end result of the successional process is the climax community, a mature, highly stable, self-replacing plant community (Clements, 1916). The climax condition is rarely reached, however, due to both natural and human-caused disturbances.

\section{Plant Associations}

Plant associations are units that are used to classify plant communities. They are groupings of plant species recurring across the landscape within particular environments (Daubenmire, 1968). Plant associations describe the potential, or climax, plant community, the vegetation that would eventually occupy a site in the absence of disturbance. 
The group of species that eventually becomes dominant on a site is an indicator of environmental conditions. The classification of sites into plant association types allows us to make inferences about a wide range of ecosystem functions and responses, simply by examining the vegetation.

A stand does not have to be in a climax condition to classify the plant association type. The plant association concept relates to environmental conditions that determine where a species could be climax and where it could not. Plant associations are named after the climax tree species and the shrub or herbaceous species that typify the association.

\section{Yew in Plant Associations}

Pacific yew is found in an extremely large number of diverse plant associations, implying a wide environmental tolerance. It can be found in associations as varied as the sea level sitka spruce/devil's club/ladyfern (Pisi/Opho/Atfi) association; the high elevation mountain hemlock-Alaska yellow-cedar/five-leaved bramble association (Tsme-Chno/Rupe); and the foothill type California black oak-bigleaf maple/Oregon ash (Quga-Acma/Frla2) association. Yew was found to occur in 108 different plant associations in Oregon and Washington, 29 in Idaho and Montana*, and 16 in California.

For a listing of plant associations where yew is present in Oregon, Washington, Idaho, Montana, and California, see Appendix H.

*Note: Terminology differs between Forest Service Regions: "Associations" in the Pacific Northwest Region are equivalent to "series/habitat type/phase" in the Northern Region.

\section{Indicator species}

Indicator species are plant species whose presence has been correlated with certain environmental conditions. Pacific yew is associated with a wide variety of indicator species, and therefore with a wide variety of environmental conditions. 


\section{Yew in Old growth Stands}

Old growth forests are the later stages in forest development. They are often compositionally, and always structurally, distinct from earlier successional stages (Franklin and Spies, 1991). Definitions of old growth vary by geographic area and forest type, but old growth stands are typically characterized by a wide range of tree ages and sizes (including some very old trees), by a deep, multi-layered canopy, and by the presence of large snags and down woody debris.

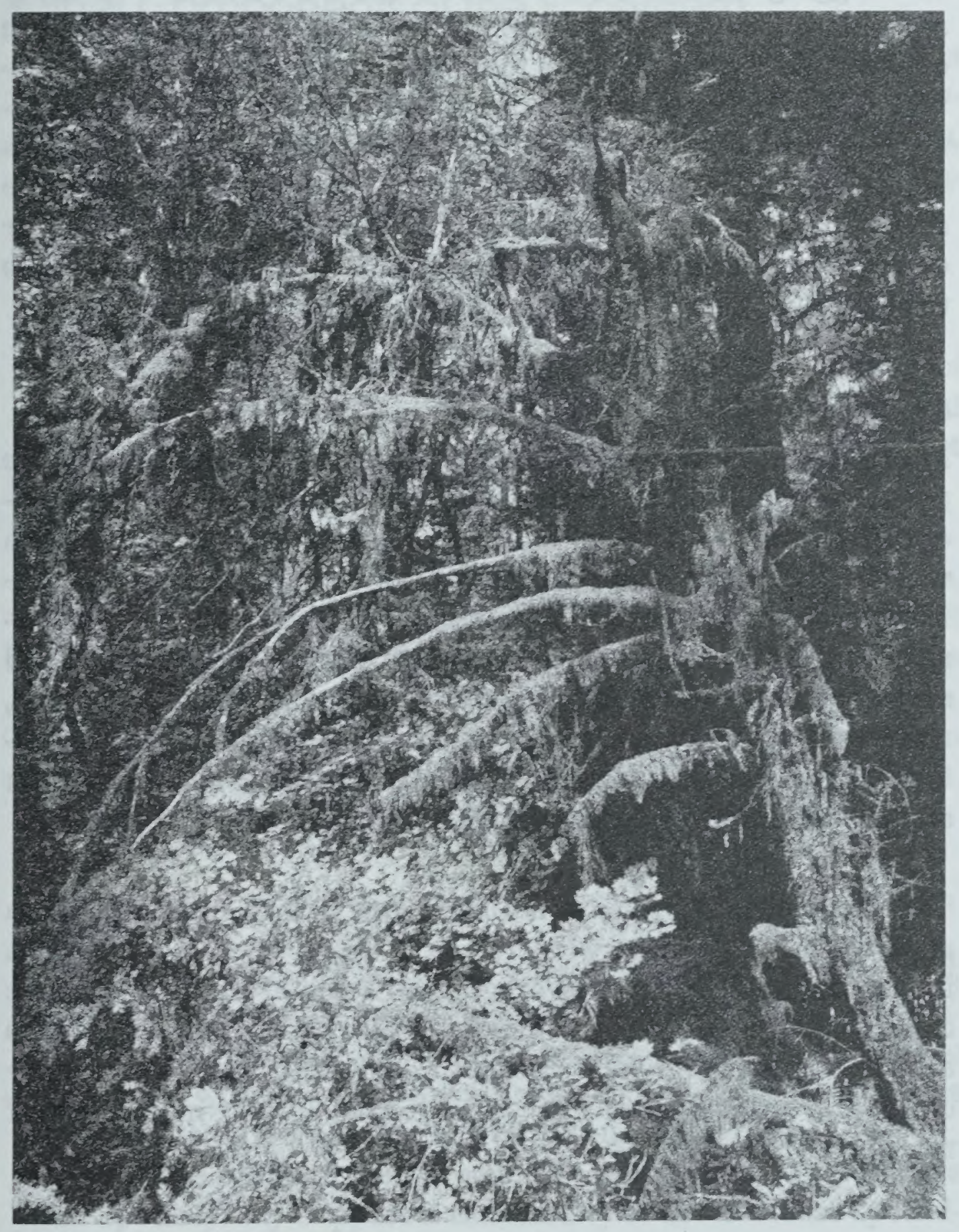

Old, moss-laden yew 
Pacific yew has been found to be more abundant in old growth Douglas-fir forests than in younger stands (Spies, 1991). It does, however, also grow in young stands (USDA Forest Service, 1991; USDI Bureau of Land Management, 1991). There is indication that yew trees and shrubs often originate after the main vegetation in a stand has already been established (Spies, 1992; McCune, 1982), making it more commonly a late seral species.

Past logging of old growth has undoubtedly reduced the quantity and distribution of larger yew trees. Yew has most likely been eliminated from many sites following burning after timber harvest. The reduction of Pacific yew as the result of past management practices may, however, be somewhat tempered by decades of fire suppression throughout the range of the fire-sensitive species. Historically, wildfire has also undoubtedly reduced or eliminated yew on many sites, although it has probably been able to eventually recolonize many areas over time.

\section{Occurrence of Yew}

Pacific yew occurrence is determined by more than simply the presence of late-successional forests. For example, the plant association in western Oregon (and parts of western Washington) in which Pacific yew was most commonly found was western hemlock/rhododendron/beargrass (Tshe/Rhma/Xete). Pacific yew is considered a late seral to climax species; it increases in number and relative dominance with time after disturbance. Because of this, one would expect late seral stages of the Tshe/Rhma/Xete association to have the highest probability of containing yew. Many such stands, however, are totally devoid of Pacific yew.

One of the puzzling aspects of Pacific yew is that, although it can grow in an extremely wide range of conditions, it is still an infrequent tree. Yew can even grow in some areas that could be classified as nonforest; in avalanche chutes (Deevy, 1991), on talus and scree slopes in which yew is the only tree present, on rocky cliffs, and in chaparral-like yew thickets in the mountains of northern Montana. 
It is apparent that factors other than site are at play. Among these are fire history, browsing animals, and the possibility of other episodic events. Windstorms, drought, floods, past insect or disease epidemics, and long periods of poor seed crops could be involved. Another possibility is that Pacific yew could be less efficient than the other species with which it grows in utilizing site resources, and is therefore unable to successfully compete in many stands.

\section{Other Components of the Ecosystem}

There are other components of the ecosystem besides vegetation that must also be considered. These include above and belowground invertebrates, canopy flora, fungi, and microorganisms. Much more remains to be discovered about Pacific yew's relationship with these organisms.

\section{Mycorrhizae}

The term mycorrhizae refers to an association between a root tip of a plant and one of several species of fungus. The mycorrhizal relationship aids a plant in absorbing water and minerals. Most woody plant species require mycorrhizae for their survival.

Pacific yew has been found to be strongly mycorrhizal (Trappe, 1992). The mycorrhizal fungi associated with yew is a variety that can also be found on other trees and shrubs. Pacific yew is associated with vesicular-arbuscular (VA) mycorrhizae (Trappe, 1992), a type found mainly on angiosperms, but also present on some genera of gymnosperms such as Cupressus, Thuja, Taxodium, Juniperus, and Sequoia, (Gerdemann, 1975; Safir, 1980).

\section{Invertebrates}

Not much is known of Pacific yew's invertebrate community. Yew, like other tree families containing high levels of chemical compounds (such as the Cupressaceae), probably has an invertebrate community with lower species diversity than other coniferous families (Lattin, 1992). Yew's invertebrate community, however, may be quite distinct. Pacific yew, like other ecologically unique plant species, may support a community of invertebrate specialists of species that are not found on other plants (Lattin, 1992). 


\section{Biodiversity}

\section{Overview of Biodiversity}

\section{Definition}

Biological diversity, or biodiversity, refers to the variety of life, and its processes, in all its forms and at all levels of organization. It includes the variety of living organisms, the genetic differences among them, and the communities and ecosystems in which they occur. At large geographic scales (from watersheds to the entire biosphere), it includes variety in the kinds of ecosystems, their patterns, and linkages across regional landscapes (Keystone Policy dialogue, Keystone Center, 1991).

\section{Importance}

Maintaining biological diversity is important because it:

is critical to maintaining the natural resiliency of forest ecosystems (Franklin et al., 1989);

serves as a source of new foods and needed medicines (e.g. taxol);

serves as a gene pool for the improvement of domesticated crops and animals; and

has intrinsic aesthetic, educational, and recreational value.

\section{Relevant Legislation}

There are also legislative reasons for concern. The National Forest Management Act (1976), the National Environmental Policy Act (1969), and the Endangered Species Act (1973) mandate federal agencies to conserve biological diversity and consider it in the planning process.

\section{Complexity}

\section{Levels and Components}

Because of its complexity, ecologists often divide biological diversity into levels and components. Biodiversity can be divided into four levels: genetic, species, community, and landscape diversity. 
The three main components of biological diversity are composition, structure, and function. Composition refers to the identity and variety of elements in a collection, and includes measures of species and genetic diversity. Structure is the pattern of organization and distribution of the different compositional elements. Function involves the ecological and evolutionary processes which occur at the various levels (Noss, 1990).

For a matrix view of how the levels and components fit together, see Table III-8 at the end of this section.

\section{Levels}

\section{Genetic Diversity}

The most basic level of life is genetic diversity. Genetic variation determines physical characteristics of species, and affects productivity, resilience to stress, and adaptability to change. (See the genetics discussion in Part One of this chapter.)

\section{Species Diversity}

Most people's concept of biological diversity focuses on species diversity. Species diversity includes both the number of species present (referred to as species richness), and the distribution of abundance among different species (known as evenness).

Pacific yew contributes to species diversity in several ways. Its presence adds a species to a community and region, and through its structural and functional role in the community, it provides habitat for other species. Due to Pacific Yew's unique array of secondary chemicals, it may support some rather specialized and unique species which are not supported by the other components in the ecosystem. Pacific yew's allelopathic properties also affect plant diversity by inhibiting the germination and growth of other plant species beneath its canopy.

\section{Biological Communities}

Associations of species, often called biological communities, are another level of biological diversity. These associations of species 
share the same local environment, such as an old growth Douglasfir forest stand, a riparian area, or an alpine meadow. Communities combined with the physical components of their environment (soil, moisture, light, etc.) are called ecosystems.

Vegetation structure, the kinds of structural units, and the vertical and horizontal dimensions of that structure are important community attributes. The structure of the vegetation is a key habitat feature for wildlife.

Pacific yew contributes both structurally and functionally to the communities in which it occurs. Its role as a midstory species adds to the vertical structure in stands. Yew's clumpy, scattered distribution may also add to horizontal diversity. This scattered distribution may break up continuous stands and could possibly reduce the risk of insect pest and disease epidemics (McCune, 1982).

Pacific yew has extremely decay-resistant wood, and any processes that depend on long-lasting woody structures are likely optimized with Pacific yew.

\section{Landscape and Regional Scale}

At the landscape and regional scale, biological diversity includes variety in types of ecosystems, and their patterns and linkages across large, regional landscapes. Landscape diversity involves spatial relationships. (See Bioregion section in this chapter for further information on the landscape level perspective.)

At the landscape level, structure is important in terms of the patchiness of a given type of vegetation, sizes of the patches, and their pattern of distribution across a large area. Connectivity, or how continuous a certain community type is across a landscape, influences gene flow and distribution of species. Landscape structure can therefore affect the other levels of biodiversity.

A distribution of community types, with a variety of seral stages and age classes, is desirable for maximizing compositional diversity across a landscape. Some examples of landscape level functional processes include nutrient cycling, energy flow, and 
hydrologic processes. These are all influenced by the disturbance regime, another landscape level process which greatly affects biodiversity.

Table III-8: Examples of Levels and Components of Biodiversity

\begin{tabular}{|c|c|c|c|}
\hline \multirow[b]{2}{*}{$\begin{array}{l}\text { Levels of } \\
\text { Biodiversity }\end{array}$} & \multicolumn{3}{|c|}{ Components of Biodiversity } \\
\hline & Compositional & Structural & Functional \\
\hline Genetic & $\begin{array}{c}\text { number of } \\
\text { genes, alleles }\end{array}$ & $\begin{array}{l}\text { genetic structure, } \\
\text { levels of variation }\end{array}$ & $\begin{array}{l}\text { recombination, } \\
\text { evolution, } \\
\text { mating systems }\end{array}$ \\
\hline Species & $\begin{array}{l}\text { number of } \\
\text { species }\end{array}$ & $\begin{array}{c}\text { species distribution } \\
\text { and abundance }\end{array}$ & $\begin{array}{l}\text { trophic levels, } \\
\text { life histories }\end{array}$ \\
\hline $\begin{array}{l}\text { Community } \\
\text { or } \\
\text { Ecosystem }\end{array}$ & $\begin{array}{l}\text { number of } \\
\text { communities, } \\
\text { ecosystems }\end{array}$ & $\begin{array}{l}\text { habitat structure, } \\
\text { community } \\
\text { distribution and } \\
\text { abundance }\end{array}$ & $\begin{array}{l}\text { ecosystem } \\
\text { processes }\end{array}$ \\
\hline $\begin{array}{l}\text { Landscape } \\
\text { or Region }\end{array}$ & $\begin{array}{l}\text { number of } \\
\text { distinctive } \\
\text { ecosystem } \\
\text { patterns }\end{array}$ & $\begin{array}{c}\text { pattern of } \\
\text { successional stages } \\
\text { and vegetation } \\
\text { types over a large } \\
\text { area }\end{array}$ & $\begin{array}{l}\text { regional } \\
\text { processes }\end{array}$ \\
\hline
\end{tabular}




\section{Forest health}

\section{Overview and Trends}

A large segment of the public, as well as the resource management community, is concerned by the recent decline in the health of the nation's forests. This decline is particularly evident in the forests of eastern Oregon and Washington where increased levels of tree mortality, epidemic levels of forest insects and diseases, and a recent history of large catastrophic fires are seen as important indicators of this decline.

\section{Measures of Forest health}

The term forest health can have many meanings. It can describe the forest's ability to meet the goals of the land manager and the landowner. In a broader sense, it also describes the relationship between biotic and abiotic influences, including the influence of human activities, on forests and their short and long term impact on management objectives for a forest unit.

At the heart of this relationship is the concept of ecosystem sustainability on a broad scale or landscape level. The concept represents a balance of all the interrelated aspects of an ecosystem that allows the system to maintain and perpetuate itself throughout time.

Ecosystem function can be a hard concept to define. It is a combination of many influences, the most significant of which, for forest health, are the presence and activities of insects, diseases and fire.

A healthy forest, like a healthy body, is a self-regulating system composed of a myriad of interconnecting parts that must all be functioning correctly. It is the goal of good resource management to ensure that all the parts of the system are present and balanced. One potential baseline for normality for forest health could be the condition of the forests before settlement; another could be the ability of forest ecosystems to meet desired future conditions in forest plans and BLM resource management plan. 


\section{Terms to Know}

Forest health-A condition where biotic and abiotic influences (i.e. insects, diseases, atmospheric deposition, fire, silvicultural treatments, and harvesting practices) do not threaten ecosystem sustainability and attainment of management objectives for a given forest unit now or in the future.

\section{Roles of Insects and Diseases}

Insects and diseases have many roles in ecosystem functioning. They influence succession, they compete for resources, and they interact with fire to serve as important agents of necessary change. In the Pacific Northwest Region, insects, diseases, and fire are a natural part of any functioning ecosystem and have evolved as a part of that system.

\section{Role of Change}

Change is an important part of ecosystem development. Changes in vegetation quality, quantity, composition, density, and distribution are mediated to a large degree by the actions of the agents of forest health.

Forests become unhealthy when the balance between these agents is disturbed by human activities, such as the exclusion of fire, the introduction of exotic pests or vegetation, or by natural causes such as a change in local weather patterns, major geologic events, or global climatic changes.

\section{Current Activities}

Regional efforts to address forest health began with Forest health assessments for the Blue Mountain National Forests (WallowaWhitman, Umatilla, and Malheur) and the Ochoco National Forest in 1991. The conclusion of these assessments was that forest health was declining due to a combination of past management practices, including the exclusion of fire from the ecosystem. 
Forest health assessments will be drafted for the eastern Washington (Okanogan, Colville, and Wenatchee) National Forests and other forests on the west side. A region-wide network of coordinators to work with forest health-related activities now exists. In addition, the Blue Mountain Natural Resources Institute serves as a clearinghouse for research and demonstration projects on forest health.

The national forests most immediately affected by the decline in forest health include the limits of the natural range of Pacific yew. However, any long-term change in the overall health of the forest ecosystem could have a detrimental effect on the yew population.

At the same time, any significant decrease in the ability of the ecosystem to sustain a viable population of Pacific yew would be an important and serious indication of a decline in forest health. Efforts to maintain forest health should include the goal of maintaining viable, resilient populations of all species. 


\section{Great Variety}

The range of the Pacific yew is so extensive that it is found in a great variety of soils and climatic conditions. The soils within the five-state area range from deep and productive forest soils at the lower and gentler slopes of the Cascade and coastal forests of California, Oregon and Washington, to shallower and stony soils of the steeper, mid-and-high elevations of the Cascades and recent (high) Cascades.

The tree seems to be able to grow on a wide range of soils including those in the orders Ultisols, Alfisols, and Inceptisols. Within these orders, it grows best on deep, moist and rich soils, (such as alluvial deposits) and yet it can also be found on "avalanche chutes" in Montana.

\section{East-side Soils}

In the east-side forests of California, Oregon, Washington, Idaho, and Montana, Pacific yew can be found on soils derived from coarse pumice, finer volcanic ash, and even on soils that develop directly from the parent rocks. Within these east-side forests, glacial materials mixed with pumice and ash also influence soil development. Generally, areas with these soil types are moderately to highly productive tree-growing sites.

\section{Soils from Uttramafic Materials}

Pacific yew can also be found on soils developing from ultramafic* rocks such as serpentine, which are unique to the Six Rivers, Klamath, Siskiyou, Wenatchee, and Wallowa-Whitman National Forests. These soils are unusual in that they contain a nutritional imbalance limiting the kind of vegetation present to that which can adapt to this condition.

*Ultramafic - Some igneous rocks and most varieties of meteorites containing less than 45 percent silica and virtually no quartz or feldspar, and composed essentially of ferro magnesium silicates, metallic oxides and sulfides, and native metals. 


\section{Soil Factors Influencing Yew}

\section{Best Soil Conditions for Yew}

For the most part, moist, cool, and productive soils seem to promote the establishment of yew. In British Columbia, yew tends to be most productive in alluvial habitats where soils are nutrientrich. A study conducted in the Bitterroot Mountains of Montana and Idaho, indicated that sites dominated by Pacific yew have high levels of nitrogen (McCune, 1982).

\section{Yew and Slope Position}

Over much of its range within the humid parts of the northwest, Pacific yew can be found on all slopes, benches, ridgetops, and bottomlands.

In dry, subhumid areas with an average annual precipitation as low as 19 inches, yew is confined to canyon bottoms and the lower third of north-facing slopes. It is also found on dry, rocky sites and in avalanche chutes east of the Cascades (Deevy, 1991).

Near the southern limit of its range in California, yew is generally confined to canyon bottoms. In the coastal areas of British Columbia and southeastern Alaska (outside the area of consideration for the purposes of this proposal) it is seldom found far from tidewater (Yanchuk, 1992).

\section{Fire and Soils}

Although this tree is sensitive to fire, past wildfires and their effect on soils do not appear to provide any conclusive evidence regarding the presence or absence of Pacific yew.

\section{Influence of Bedrock}

Soils developing directly from bedrock do not appear to influence the growth of Pacific yew since it can be found on soils developing from sandstone, granite, diorite, gabbro, pre-Cambrian metasediments, schists, gneiss, basalts, and other materials mentioned earlier (Crawford and Johnson, 1985; Whittaker, 1960). 


\section{Site-Specific Analysis; Activities}

There is great variation in soil and water resources and environmental conditions within the five-state region. Whether and how activities (including bark harvest) take place in specific areas is determined on a case-by-case basis using a prescription process compatible with each national forest or BLM district plan. These take into account such variables as the amount and condition of resources such as soil and water, as well as resource objectives.

\section{Physiographic Provinces}

\section{Overview}

For the purpose of describing the soil and water conditions associated with the variety of conditions, and for predicting the effects of yew harvest on soils, the affected area has been broken down into physiographic provinces, based on landforms. Generalized soil and water conditions usually associated with each particular province are included for the major vegetation zones, which are based on characteristic plant occurrences. Provinces are delineated in the following figure.

Note: Each province has been described, but the volume of material is too extensive to include here. Province descriptions are found in Appendix I. 


\section{$\mathbb{C} \mathbb{N} \mathbb{A} \mathbb{A}$}

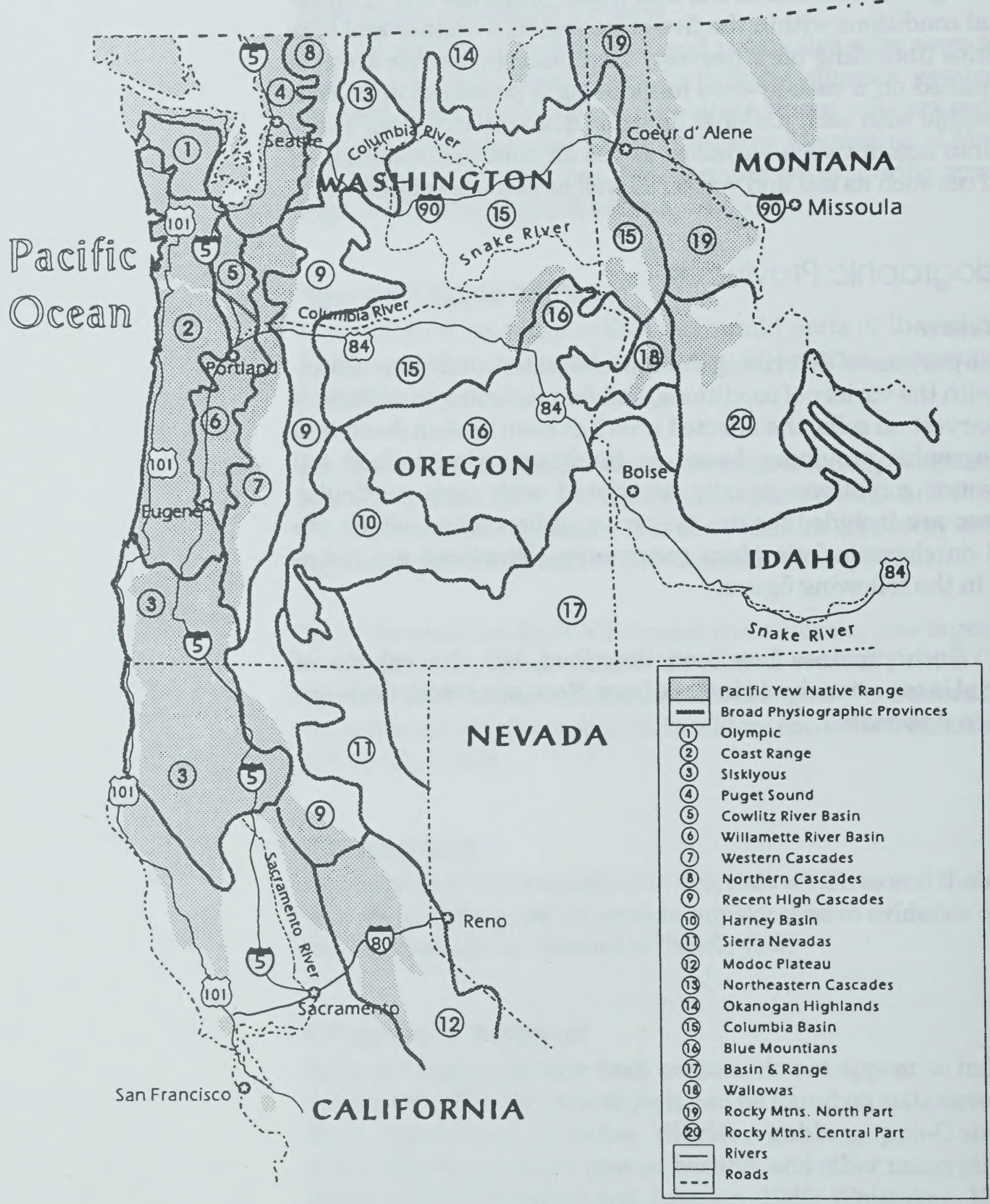




\section{Water resources}

Forested areas are important sources of water for aquatic habitats of streams, wetlands, lakes and ponds; groundwater recharge for aquifers; and for domestic, municipal, and industrial uses.

The interactions between climate, geology, human activity, and landforms directly affect watershed processes and water quality. The quality of the aquatic habitat reflects processes and activities occurring throughout the watershed.

\section{Terms to Know}

A snowmelt-dominated streamflow regime typically has one peak flow period which commences with snowmelt and terminates with the onset of base flow, or the period when groundwater releases regulate flow levels.

High-intensity summer storms can create devastating flash flood conditions such as those of summer, 1964, in the Northern Rocky Mountains of Montana along both sides of the Continental Divide.

Storms of lesser extent and intensity and greater frequency occur throughout the regions east of the Cascades. Typically, these storms occur during periods in or approaching base flow and display a substantial, sharp increase of flow followed by an almost equally sharp decline in flow back to base flow.

\section{Stream Flow}

Undisturbed forests typically regulate releases of water to the drainage network that has been shaped by land-forming processes and major climatic events. Less intense climatic events "fine tune" the network to accommodate the routine or yearly cyclic events that define the normal streamflow regime. Within the elevation ranges where Pacific yew is found, stream flows typically vary greatly during the course of the year. 
In snowmelt-dominated streamflow regimes, the greatest annual streamflow occurs in the spring. The northern Rockies typify this regime. The period of annual high flows along the coast and Cascade ranges from California to Canada is mid-winter because of the prevalence of rain-on-snow events. This occurs especially in the 1500 to 4500 foot elevational range, called the transient snow zone, followed by smaller snowmelt-only flows during the spring. To a lesser extent, rain-on-snow affects the Okanogan highlands and the windward mountain front of northern Idaho.

In both regimes, the seasonal low flow period extends from early summer to mid-fall, or whenever the fall rains begin.

Extreme events resulting in major floods differ between the two regimes. In the transient snow zone, major floods occur during early winter. An example of this type of flood is that of December, 1964. The upper limit of this elevational range may extend to well above timberline during these periods. Where snowmelt dominates the flow regime, major floods occur during the summer. An example in this regime was that in the northern Rockies in July, 1965.

\section{Peak Flows}

The frequency and magnitude of peak flows may increase following land use activities. Intensive timber harvest may aggravate the effects of rain-on-snow events, situations where rainfall on snowpack can cause runoff amounts greater than the rainfall or snowmelt would alone. Rain-on-snow events may result in higher peak flows which may cause damage to stream channels and associated fish habitat. These effects are typically reduced in lessintensely disturbed watersheds.

Similar effects may occur in snowmelt-dominated streamflow regimes as well, principally the result of a redistribution of snow.

However, even in watersheds unaltered by land management activities, peak flows resulting from a major runoff-producing event will cause changes in channel alignment and encroach onto the floodplain and degrade some existing aquatic habitat while creating new habitat elsewhere. Human intervention is not neces- 
sary to cause a change in this dynamic system, though it may accelerate change and create less desirable and complex habitats.

\section{Water Quality}

Water quality varies by season:

During snowmelt or a rain-on-snow event, quality declines substantially, particularly that associated with sediment, as sediments are mobilized and transported downstream. During extreme events, even large boulders are mobilized.

In most stream systems, sediment supply is limiting, such that water quality begins to improve before flows reach their peak, and continues to improve at a faster rate than the flow peak declines. It is common for sediment concentrations to appear unusually high during the fall rains before the snowpack begins to build, as the summer's accumulation of fine sediment along stream bottoms and banks is mobilized and washed downstream with slowly increasing streamflows.

Dissolved minerals typically reach their peak concentration during annual low flows, and their lowest during snowmelt or rain-on-snow periods (a matter of dilution). The source of most minerals is the groundwater contribution to surface water flows, and it varies little throughout the year.

Dissolved gasses, typically oxygen, are rarely a problem in forested streams due to the stream's turbulence.

\section{Yew and Riparian Areas}

Pacific yew in riparian areas contributes to stream bank stabilization, stream shading, and coarse wood input, adding structural complexity to the aquatic, terrestrial, and riparian habitats, important prey base habitat for riparian-dependent species. Its relatively small stature makes yew a more valuable source of woody debris in smaller, headwater channels than in large streams. Its durability has long been recognized. Ranchers, for instance, favor the species for fence posts. The larger branches of Pacific yew remain in riparian or aquatic habitats substantially longer than the wood of other species such as alder, which decomposes rapidly. This makes it a valuable species for woody debris despite its small 
size. The tendency for large Pacific yew trees to have hollow boles (Bolsinger and Jaramillo, 1990; Crawford, 1983) could offset its relative longevity as in-stream large woody debris, since these portions would decompose faster than corewood. The boles, however, could play an important role by providing additional hiding cover for fish as well as small terrestrial mammals.

\section{Aquatic and Fish Habitat}

\section{Mosaic of Conditions}

National forests and BLM districts in the range of Pacific yew contain a mosaic of terrestrial, riparian, and aquatic habitat conditions. These range from pristine areas (i.e., wilderness, unroaded areas, reserves, etc.) with the normal seasonal variation in water quality and streamflow distribution and with complex, productive aquatic and fish habitats, to areas where man's land use practices have caused a decline in water quality and a substantial decrease in aquatic habitat complexity.

\section{Large Trees, Debris, and Habitat}

Large trees moderate water temperatures by shading streams. When these trees fall into the stream, the new large woody debris creates new habitat for fish and aquatic insects, provides nutrients, stabilizes and sorts bedload, and stabilizes the channel.

Many streams no longer have complex habitats due to activities such as removal of woody debris, channelization for flood control or river travel, and land use practices which now appear unsound. The functions of large wood in streams, the history of wood removal from streams, and the influence of forest and range land management throughout the Pacific Northwest are described by Maser et al., (1988) and Mehan (1991).

\section{Fish Populations}

Fish populations are affected by many factors in addition to habitat, such as interactions with other species, commercial fishing, sport fishing, dams, high seas interception, and weather. Isolating any one factor's effect on populations is difficult. How- 
ever, for many of the stocks at risk, the highest quality spawning and rearing habitat remaining is in national forests.

\section{Salmonid Fishes}

The salmonid fishes, notably the anadromous, or sea-going forms, are the most valuable to the region, both culturally and economically. Eight species of anadromous salmonids are found within the range of Pacific yew. These include:

- chum salmon (Oncorhynchus keta)

- pink salmon (O.gorbuscha);

- chinook salmon (O. tshawytscha)

- coho salmon (O. kisutch);

- sockeye salmon (O. nerka)

- cutthroat trout (O. clarki);

- steelhead trout (O. mykiss)

- Dolly Varden (Salvelinus malma).

Within the Pacific yew's range, most precipitation occurs from November through April. The increased volume of freshwater flowing into the ocean triggers spawning migrations for many stocks of anadromous fishes into rivers and streams.

Individual stocks of these species constitute unique gene pools for different river systems. A stock is defined as a group of interbreeding individuals which is largely reproductively isolated from other groups (Ricker, 1972). There may be several different stocks within a species in an individual river system.

Observing variations in life history characteristics, such as the timing of adult migrations, is one method to identify stocks. Examples include early and late run coho, spring, summer, fall, and winter chinook, and summer and winter steelhead.

Anadromous salmonids throughout the region support sport and commercial fisheries, Native American fisheries, and Native American cultural practices. The decline in populations of these fishes in many watersheds has led to serious concern among management 
agencies, user groups, the scientific community, and the general public. A committee of the American Fisheries Society, a professional society of fishery biologists and natural resource managers, recently identified 214 native, naturally-spawning stocks of anadromous fish at risk in California, Oregon, Idaho, and Washington (Nehlsen et al., 1991). In addition, they listed 106 extinct populations of west coast salmon and steelhead.

\section{Salmonid Spawning Habitat}

National forests and BLM districts in the range of Pacific yew provide spawning habitat for returning adults and rearing habitat for juveniles before they migrate to the ocean. This is less true for chum and pink salmon, as they spawn in the lowermost reaches of streams near tidewater, and the juveniles spend little time rearing in freshwater.

\section{Resident Salmonid and Nongame Species}

Resident salmonid species and nongame fishes are also found within the range of the Pacific yew. Whether located within national forest or BLM district streams or downstream from them, they are also dependent on high-quality water and habitat resulting from activities and conditions upstream and upslope.

\section{Endangered species}

Two species of fish federally listed as endangered are found on national forests within lands considered in this document. They are the Klamath short-nosed sucker (Chasmistes brevirostris) and the Lost River sucker (Deltistes luxatis).

Indication of public and scientific concern about anadromous fishes in the region was the publishing in 1991 of proposed rules in the Federal Register by the National Marine Fisheries Service to list Snake River sockeye and chinook salmon under the Endangered Species Act. The National Marine Fisheries Service has since listed the Snake River sockeye as an endangered species. These salmon use the Columbia River as they migrate to and from spawning grounds in the Snake River system. 


\section{Other Discussion in the EIS}

For additional information, see the sections on bioregions, ecology, and wildlife in this part of Chapter III, and the discussion of fire in this chapter. 


\section{Wildlife}

\section{Overview}

While states retain specific responsibility for managing wildlife populations, the key responsibility of the Forest Service and the Bureau of Land Management is caring for wildlife habitat as well as meeting the intent of laws associated with wildlife management. Thus, this discussion of the wildlife resource is organized to reflect that apparent dichotomy in terms of habitat and species.

\section{How This Section Is Arranged}

After an introduction to Pacific yew as habitat, the subsections discuss wildlife by general habitat type (late-successional forests, early-successional forests, and riparian areas) with an additional discussion of threatened and endangered species.

Within each subsection is more information about habitat elements, especially as they relate to Pacific yew, and a discussion of species associated with that general habitat type. To improve readability, only common names of species are used. A list of scientific names of species mentioned in this section are included in Appendix $\mathrm{J}$.

\section{Pacific Yew As Habitat}

Pacific yew provides habitat components for a variety of wildlife species. The most noted wildlife associations are found with latesuccessional forests and riparian areas. 
Yew provides forage and thermal cover for some species. Yew foliage in the midstory layer of the forest contributes to structural complexity and plant species diversity that may enhance animal diversity. Yew associated with headwater streams contributes to stream shading and water cooling.

\section{Wildlife Associated with Late-Successional Forests}

Pacific yew is closely associated with late-successional forests throughout its range (Bolsinger, 1990; Crawford and Johnson, 1985; Scher and Jimerson, 1989; Spies, 1991).

\section{Species}

Over 100 species of amphibians, reptiles, birds, and mammals occur in late-successional forests (Brown, 1985; Thomas, et al., 1979b). A summary of recent empirical studies for forests in the Douglas-fir/western hemlock zone of western Oregon and Washington and northwestern California (Ruggiero et al., 1991) listed 17 species that were closely associated with late-successional forests. Other studies indicate strong associations between additional species and late-successional forests (USDA Forest Service, 1992b). Little is known about the relationship of yew to most of these species. Species for which information is available are discussed below.

\section{Diversity; Functional Processes}

The structural diversity and biological richness within late-successional forests provide unique habitat features that are required, preferred, or used by many wildlife species. The functional processes that occur within late-successional forests are not well understood. Some processes have been studied, such as those involving mycorrhizal fungi and arboreal rodents, but most ecological relationships among species in mature and old growth forests are virtually unknown. (See biodiversity and ecology sections for more information.) 


\section{Habitat Features}

Habitat features commonly recognized as being important components of late-successional forests include snags, large logs, large trees, and multilayered canopies. The decay resistant nature of Pacific yew wood may make it a valuable species for woody debris, despite its relatively small size. There is a tendency for large Pacific yew trees to have hollow boles (Bolsinger and Jaramillo, 1990; Crawford, 1983). This may shorten the longevity of snags and logs, but may also encourage use by some species of wildlife and invertebrates. The size and growth form of Pacific yew makes the species a noted contributor to the structure of multilayered canopies.

\section{Moose and Other Ungulates}

Many wild ungulates feed on Pacific yew including deer, elk, and moose (Bolsinger and Jaramillo, 1990; Crawford and Johnson, 1985; McCune, 1982; Pierce and Peek, 1984).

\section{Moose}

In parts of northern Idaho, yew is a preferred winter browse for moose (Crawford and Johnson, 1985). Old growth grand fir/Pacific yew forests are often considered critical winter habitat for moose (Pierce and Peek, 1984).

Old growth double-canopy forests with grand fir in the overstory and Pacific yew in the understory, provide winter habitat offering snow interception, thermal protection, and forage (Pierce and Peek, 1984; Peek et al., 1987). Moose eat both bark and foliage (Crawford and Johnson, 1985).

Crawford and Johnson (1985) estimated that these yew habitats occupy approximately 40,000 acres (16,000 hectares) in the Nez Perce National Forest, while Peek et al. (1987) estimate that they occupy as many as 74,000 acres (29,905 hectares).

Patches of Pacific yew are thought to be the most important as winter range when they appear above about 4,000 feet $(1,220$ meters) elevation in zones of snow accumulation, and below 6,000 feet (1,800 meters) elevation (USDA Forest Service, 1987). 
The best winter sites have 50 percent canopy cover from large trees that are at least 40 feet tall and usually over 90 years old. Tree-form yew providing at least 30 percent cover intercepts snow as well as providing browse.

The Nez Perce National Forest Plan allocates about 62,900 acres (25,000 hectares) of complexes of Pacific yew and adjacent grand fir to management for moose winter range. The actual extent of these stands with yew habitat patches across the Nez Perce National Forest is not well known.

\section{Other Ungulates}

Deer and elk also feed on Pacific yew throughout its range (Crawford and Johnson, 1985; Everett, 1957; McCune, 1982) and the dense subcanopy that develops in some areas provides hiding and thermal cover for large ungulates (Johnson and Simon, 1987).

\section{Northem Spotted Owls}

Northern spotted owls have been observed using Pacific yew as roost sites (USDA Forest Service, 1992b). Based on limited observations, owls were seen roosting in yew trees ranging in diameter from 4 to 16 inches, with 72 percent of the yew roost trees being greater than 8 inches in diameter (USDA Forest Service, 1992b).

\section{Wildlife Associated with Early-Successional Forests}

A variety of wildlife species within the range of the Pacific yew use early-successional forests as primary habitat for breeding and feeding (Brown, 1985; Thomas, 1979a).

Some of these species include the western bluebird, orange-crowned warbler, song sparrow, white-crowned sparrow, American goldfinch, western meadowlark, mountain beaver, and Townsend's vole (Brown, 1985). Young forests, especially those in the open grass/forb/shrub stage, also provide foraging habitat for big game animals, such as the black-tailed and mule deer and elk. Browsing by ungulates may be a significant factor influencing the abun- 
dance, growth form, and distribution of yew in stands, especially during the early stages of plant succession (Bolsinger and Jaramillo, 1990; Bolsinger, 1990).

\section{Wildlife Associated with Riparian Areas}

Pacific yew is closely associated with riparian areas in parts of its range (Bolsinger and Jaramillo, 1990). This is possibly related to a history of infrequent fire (Bolsinger and Jaramillo, 1990; Scher and Jimerson, 1989). In some places, yew totally dominates the understory (Johnson and Simon, 1987).

\section{Yew; Influence}

On riparian sites, yew provides shade which maintains cool water temperatures. This benefits salmonids and other anadromous fish (Scher and Jimerson, 1989), and vertebrates associated with cool water, such as Olympic salamanders and tailed frogs (USDA Forest Service, 1992b). See the Water Resources and Aquatic Habitat section for additional information on fish habitat.

Riparian areas often support a greater abundance and variety of wildlife than adjacent uplands (Thomas et al., 1979a; McGarigal and McComb, 1992), especially in drier environments. Yew may influence animal occurrence and abundance by contributing to plant species diversity and the structural complexity of vegetation. See the Biodiversity section for more discussion of species diversity.

\section{Other Wildlife Relationships}

The fruit of Pacific yew is sweet, but reportedly poisonous to some species (Standley, 1921). It is readily eaten by many species of songbirds, including the Townsend's solitaire, varied thrush, and hermit thrush (Johnson and Simon, 1987). Raccoons also feed on the fruit of Pacific yew (Van Dersal, 1938). Woodpeckers and jays have also been observed feeding on the fruit (Mannan, 1977).

Chipmunks have been observed eating yew seeds (Crawford, 1992) and rabbits and other small herbivores may also browse 
Pacific yew (Everett, 1957). Yew trees provide nest opportunities for various neotropical birds (rufous hummingbird, hermit thrush, and American robin) and nest cavities for an occasional nuthatch and wren (Neitro, 1992). Little is known about the role that yew plays for other species of wildlife. For instance, the importance of yew for invertebrates of the tree canopy and of the soil is unknown. 


\section{Threatened and Endangered Species}

Introduction; Role of This EIS

This EIS evaluates possible effects of harvesting Pacific yew from a "program" point of view, rather than looking at the specific effects of actions on a given site. Site-specific effects are evaluated during project planning through an environmental analysis, as required by NEPA. See Chapter IV for a discussion of these effects.

\section{Listed or Proposed Species in the Affected Area}

The occurrence and status of federally listed threatened, endangered and proposed species on national forests and Bureau of Land Management districts within the geographic range of the Pacific yew are summarized in Table III-9. Threatened, endangered, and proposed species that occur within this EIS's area of consideration, but do not occur within Pacific yew habitat, are marked with an asterisk. See Appendix $J$ for a discussion of threatened, endangered, and proposed species that may be affected by yew harvest.

This listing does not completely cover BLM and USFS property in California.

\section{Terms To Know}

Endangered - The classification of endangered refers to those species in danger of becoming extinct throughout all or a significant portion of their range.

Threatened - Threatened species are those likely to become endangered in the foreseeable future (50 CFR 240).

Proposed-Those species named in formal documents published in the Federal Register under the direction of the Endangered Species Act and 50 CFS 402.2, but have not been listed as endangered or threatened at this time.

Sensitive- The classification "sensitive" refers to species designated by regional foresters or BLM state directors for which population viability is a concern. Sensitive species are not federally designated under the Endangered Species Act and are not discussed in detail in this document. 
Table II-9: Summary of Threatened, Endangered and Proposed Species

\begin{tabular}{|c|c|c|}
\hline \multicolumn{3}{|c|}{$\begin{array}{l}\text { Federal Threatened Species } \\
\text { that Occur in Range of Pacific Yew }\end{array}$} \\
\hline Species & Occurrence & Habitat \\
\hline $\begin{array}{l}\text { Foskett } \\
\text { Speckled Dace }\end{array}$ & --Documented on BLM Lakeview District & $\begin{array}{l}\text { Aquatic: endemic to Foskett and Dace } \\
\text { Springs, Lake Co., OR }\end{array}$ \\
\hline $\begin{array}{l}\text { Lahontan } \\
\text { Cutthroat Trout }\end{array}$ & $\begin{array}{l}\text {--Documented on BLM Vale and Burns } \\
\text { District }\end{array}$ & $\begin{array}{l}\text { Aquatic: restricted to southern Malheur } \\
\text { and Harney Co., OR }\end{array}$ \\
\hline $\begin{array}{l}\text { Warner } \\
\text { Sucker }\end{array}$ & --Documented on BLM Lakeview District & $\begin{array}{l}\text { Aquatic: endemic to Warner Basin, Lake } \\
\text { Co., OR }\end{array}$ \\
\hline $\begin{array}{l}\text { Hutton } \\
\text { Tui Chub }\end{array}$ & --Suspected on BLM Lakeview District & $\begin{array}{l}\text { Aquatic: endemic to private land at } \\
\text { Hutton Springs, Lake Co., OR }\end{array}$ \\
\hline $\begin{array}{l}\text { Aleutian } \\
\text { Canada Goose }\end{array}$ & $\begin{array}{l}\text {--Documented on BLM Coos Bay District. } \\
\text {--Suspected on BLM Spokane District. } \\
\text {--Documented on USFS Siuslaw National } \\
\text { Forest. }\end{array}$ & $\begin{array}{l}\text { Stops in Pacific Northwest while } \\
\text { migrating from Alaska to California. } \\
\text { Winters at wetlands, grasslands, or } \\
\text { cultivated fields, usually near large, } \\
\text { undisturbed bodies or water. }\end{array}$ \\
\hline Bald Eagle & $\begin{array}{l}\text {--Documented on BLM Burns, Coos Bay, } \\
\text { Eugene, Lakeview, Medford, Prineville, } \\
\text { Roseburg, Salem, Spokane, and Vale } \\
\text { Districts. } \\
\text {--Documented on all USFS National } \\
\text { Forests in Region } 6 . \\
\end{array}$ & $\begin{array}{l}\text { Winter roosts in large trees in conifer and } \\
\text { mixed conifer forests with structural or } \\
\text { topographic protection. Nests in habitat } \\
\text { similar to winter roost, within two miles } \\
\text { of water. }\end{array}$ \\
\hline $\begin{array}{l}\text { Northern } \\
\text { Spotted Owl }\end{array}$ & $\begin{array}{l}\text {--Documented on BLM Coos Bay, } \\
\text { Eugene, Lakeview, Medford, Roseburg, } \\
\text { Salem, Spokane, and Vale Districts. } \\
\text {--Documented on USFS Deschutes, } \\
\text { Gifford Pinchot, Mt. Baker-Snoqualmie, } \\
\text { Mt. Hood, Okanogan, Olympic, Rouge } \\
\text { River, Siskyou, Siuslaw, Umpqua, } \\
\text { Wenatchee, Willamette, and Winema } \\
\text { National Forests. }\end{array}$ & Resident of old growth conifer forests. \\
\hline Grizzly Bear & $\begin{array}{l}\text {--Documented on BLM Spokane, and } \\
\text { Coeur d'Alene Districts. } \\
\text {--Documented on USFS Colville, Mt. } \\
\text { Baker-Snoqualmie, and Okanogan } \\
\text { National Forests. } \\
\text {--Suspected on USFS Wenatchee } \\
\text { National Forest. }\end{array}$ & $\begin{array}{l}\text { An opportunistic feeder using a variety of } \\
\text { habitats. }\end{array}$ \\
\hline
\end{tabular}




\begin{tabular}{|c|c|c|}
\hline \multicolumn{3}{|c|}{$\begin{array}{l}\text { Federal Endangered Species } \\
\text { that Occur in Range of Pacific Yew }\end{array}$} \\
\hline Species & \begin{tabular}{|c|} 
Occurrence \\
\end{tabular} & \begin{tabular}{|l} 
Habitat \\
\end{tabular} \\
\hline $\begin{array}{l}\text { Borax Lake } \\
\text { Chub }\end{array}$ & --Documented on BLM Burns District. & $\begin{array}{l}\text { Aquatic: endemic to Borax Lake, Harney Co., } \\
\text { OR. }\end{array}$ \\
\hline $\begin{array}{l}\text { Lost River } \\
\text { Sucker }\end{array}$ & $\begin{array}{l}\text {--Documented on BLM Lakeview District. } \\
\text {--Documented on USFS Winema National } \\
\text { Forest. }\end{array}$ & Aquatic: Klamath Basin, Klamath Co., OR. \\
\hline \begin{tabular}{|l|} 
Snake River \\
Sockeye Salmon \\
\end{tabular} & $\begin{array}{l}\text {--Documented on BLM Vale, and Coeur } \\
\text { d'Alene Districts. }\end{array}$ & Aquatic: in the Snake River drainage. \\
\hline \begin{tabular}{|l|} 
Shortnose \\
Sucker
\end{tabular} & $\begin{array}{l}\text {--Documented on BLM Lakeview District. } \\
\text {--Documented on USFS Winema National } \\
\text { Forest. } \\
\text {--Suspected on USFS Fremont National Forest. }\end{array}$ & $\begin{array}{l}\text { Aquatic: Klamath and Lost River systems, } \\
\text { Klamath Co., OR. Also in California. }\end{array}$ \\
\hline $\begin{array}{l}\text { American } \\
\text { Peregrine } \\
\text { Falcon }\end{array}$ & $\begin{array}{l}\text {--Documented on BLM Burns, Coos Bay, } \\
\text { Lakeview, Medford, Prineville, Roseburg, } \\
\text { Salem, Spokane, Vale, and Coeur d'Alene } \\
\text { Districts. } \\
\text {--Documented on USFS Clearwater, Flathead, } \\
\text { Idaho Panhandle, Kootenai, Lolo, and Nez } \\
\text { Perce National Forests in Region 1. } \\
\text {--Documented in USFS Deschutes, Fremont, } \\
\text { Mt. Baker-Snoqualmie, Mt. Hood, Rouge } \\
\text { River, Siskiyou, Siuslaw, Umpqua, } \\
\text { Wallow-Whitman, and Willamette National } \\
\text { Forests. } \\
\text {--Suspected on USFS Colville, Gifford Pinchot, } \\
\text { Malheur, Olympic, Umatilla, Wenatchee, and } \\
\text { Winema National Forests. }\end{array}$ & $\begin{array}{l}\text { Typically nests on cliff or bluffs a long river } \\
\text { courses or other large bodies of water. }\end{array}$ \\
\hline Bald Eagle & $\begin{array}{l}\text {--Documented on USFS Clearwater, Flathead, } \\
\text { Idaho Panhandle, Kootenai, Lolo, and Nez } \\
\text { Perce National Forests. } \\
\text {--Documented on BLM Coeur d'Alene District. }\end{array}$ & See habitat description for Bald Eagle above. \\
\hline $\begin{array}{l}\text { California } \\
\text { Brown Pelican }\end{array}$ & $\begin{array}{l}-- \text { Documented on BLM Coos Bay, and Salem } \\
\text { Districts. } \\
\text {--Suspected on BLM Spokane District. } \\
\text {--Documented on USFS Siuslaw National } \\
\text { Forest. } \\
\end{array}$ & $\begin{array}{l}\text { Frequents beaches and offshore islands along } \\
\text { the Pacific coast occasionally large protected } \\
\text { estuaries. }\end{array}$ \\
\hline $\begin{array}{l}\text { Columbia } \\
\text { Whitetailed } \\
\text { Deer }\end{array}$ & $\begin{array}{l}\text {--Documented on BLM Roseburg District. } \\
\text {--Suspected on BLM Salem District. }\end{array}$ & $\begin{array}{l}\text { Oak woodlands and savannahs; riparian areas } \\
\text { of the lower Columbia River and Douglas Co., } \\
\text { OR. }\end{array}$ \\
\hline Gray Wolf & $\begin{array}{l}\text {--Documented on BLM Spokane, and Coeur } \\
\text { d'Alene Districts. } \\
\text {--Suspected on BLM Vale District. } \\
\text {--Documented on USFS Clearwater, Flathead, } \\
\text { Idaho Panhandle, Kootenai, Lolo, and Nez } \\
\text { Perce National Forests. } \\
\text {--Documented on USFS Colville, Fremont, Mt. } \\
\text { Baker-Snoqualmie, and Wallowa-Whitman } \\
\text { National Forests. } \\
\text {--Suspected on USFS Okanogan National } \\
\text { Forest. }\end{array}$ & $\begin{array}{l}\text { Utilizes many habitat; prey availability } \\
\text { determines suitability of habitat. }\end{array}$ \\
\hline
\end{tabular}




\begin{tabular}{|c|c|c|}
\hline \multicolumn{3}{|c|}{$\begin{array}{l}\text { Federal Endangered Species } \\
\text { that Occur in Range of Pacific Yew } \\
\text { (continued) }\end{array}$} \\
\hline Species & Occurrence & Habitat \\
\hline $\begin{array}{l}\text { Woodland } \\
\text { Caribou }\end{array}$ & $\begin{array}{l}\text {--Documented on BLM Coeur d'Alene District. } \\
\text {--Documented on USFS Colville National } \\
\text { Forest. }\end{array}$ & $\begin{array}{l}\text { Requires lichens associated with mature or old } \\
\text { growth trees. }\end{array}$ \\
\hline $\begin{array}{l}\text { Bradshaw's } \\
\text { Desert-parsley }\end{array}$ & $\begin{array}{l}\text {--Documented on BLM Eugene District. } \\
\text {--Suspected on BLM Salem District. }\end{array}$ & Wet prairies in Willamette Valley, OR. \\
\hline $\begin{array}{l}\text { Malheur } \\
\text { Wirelettuce }\end{array}$ & --Documented on BLM Burns District. & $\begin{array}{l}\text { Endemic to a single zeolite hill with sagebrush } \\
\text { in Harney Co., OR. }\end{array}$ \\
\hline $\begin{array}{l}\text { MeDonald's } \\
\text { Rock-cress }\end{array}$ & --Suspected on BLM Medford District. & Serpentine soils. \\
\hline $\begin{array}{l}\text { Snake River Fall } \\
\text { Chinook Salmon }\end{array}$ & $\begin{array}{l}\text {--Documented on BLM Coeur d'Alene District. } \\
\text {--Suspected on BLM Vale District. }\end{array}$ & Aquatic: Grande Ronde River Drainage in OR \\
\hline $\begin{array}{l}\text { Snake River } \\
\text { Spring/Summer } \\
\text { Chinook Salmon }\end{array}$ & $\begin{array}{l}\text {--Documented on BLM Vale and Coeur } \\
\text { d'Alene Districts. }\end{array}$ & Aquatic: Grande Ronde River Drainage in OR \\
\hline
\end{tabular}




\begin{tabular}{|l|l|l|}
\hline \multicolumn{3}{|c|}{$\begin{array}{c}\text { Federal Proposed Species } \\
\text { that Occur in Range of Pacific Yew }\end{array}$} \\
\hline \multicolumn{1}{|c|}{ Species } & \multicolumn{1}{|c|}{ Occurrence } & \multicolumn{1}{c|}{ Habitat } \\
\hline $\begin{array}{l}\text { Nelson's } \\
\text { Checkermallow }\end{array}$ & $\begin{array}{l}\text {--Documented on BLM Salem District. } \\
\text {--Suspected on BLM Eugene District. }\end{array}$ & $\begin{array}{l}\text { Wet meadows in Willamette Valley and Coast } \\
\text { Range, OR }\end{array}$ \\
\hline $\begin{array}{l}\text { Applegate's } \\
\text { Milk-vetch }\end{array}$ & - Suspected on BLM Lakeview District. & $\begin{array}{l}\text { Endemic to moist meadows in the Applegate } \\
\text { area in Klamath Co., OR }\end{array}$ \\
\hline Marsh Sandwort & $\begin{array}{l}- \text {-Suspected on BLM Salem and Spokane } \\
\text { Districts. }\end{array}$ & Coastal salt marsh \\
Marbled Murrelet & $\begin{array}{l}\text {--Documented on BLM Coos Bay and Salem } \\
\text { Districts. }\end{array}$ & \\
\hline $\begin{array}{l}\text { Western Snowy } \\
\text { Plover }\end{array}$ & $\begin{array}{l}\text {--Documented on BLM Burns, Coos Bay, } \\
\text { Lakeview, and Vale Districts. }\end{array}$ & Coastal sand dunes and beaches \\
\hline
\end{tabular}




\section{Species, Responsibilities, and Existing Direction}

On March 9, 1992 the Forest Service sent a letter to the U.S. Department of Commerce, National Marine Fisheries Service (NMFS) asking for a contact person and confirmation of a list of threatened and endangered anadromous fish species. Figure III-9 reflects NMFS confirmation of those species.

On March 9, 1992 the Forest Service sent a letter to the U.S. Department of the Interior, Fish and Wildlife Service (FWS) asking for a contact person and a list of the proposed and listed threatened and endangered species in the geographical range of Pacific yew. Table III-9 reflects the FWS list.

A list of endangered, threatened, proposed, and sensitive species; a discussion of Forest Service and BLM responsibilities under the Endangered species Act; and biological evaluations can be found in most Forest Service offices (USDA Forest Service Manual 2670, USDA Forest Service, 1990a) and Bureau of Land Management State Offices (BLM Manual 6840, 1988).

Upon completion of analysis of the alternatives a biological assessment will be completed. The final biological assessment will be sent to NFMS and FWS for formal and informal consultation.

\section{Yew as Forage}

Pacific yew provides habitat components for a variety of wildlife species, and may also occur on range lands where cattle forage. Green slash of yew may be harmful or fatal to domestic livestock when eaten in large quantities (Sampson and Malmstein, 1975). 


\section{Yew Access for Harvest}

\section{Access to yew harvest areas}

Access to areas where yew could be harvested would most typically occur over the existing road system on each national forest or BLM district. Access to some areas may be allowed on roads and trails that are normally closed to vehicle travel, following sitespecific analysis. It is also possible that yew harvest would occur in areas not currently accessible by roads. In these cases, access might be gained on foot trails, horse trails, or new road construction. Yew bark might also be removed by helicopter in areas not accessible by roads. The specific access method that would be used for each yew sale would be decided after a site-specific analysis for that sale.

\section{Pacific Yew \\ Harvest and \\ Timber Harvest}

\section{Transition in timber havest programs}

Timber harvest programs in national forests and BLM districts are ongoing, and are undergoing change as the agencies develop and implement ecosystem management. They are currently guided by forest plans (Forest Service) and BLM resource management plans. Timber harvest programs for commercial species may be affected by the harvest of Pacific yew.

\section{Roadless Areas}

\section{Roadless Area designation}

In the past, forests included formal Roadless Areas, classified under the RARE II (Roadless Area Review and Evaluation) designation, but this designation is no longer used. All former inventoried (RARE II) roadless areas were re-analyzed in the forest planning process for each national forest. As a result of this process, roadless areas became reallocated to various management allocations. Some portions of these areas are now within allocations that maintain roadless characteristics, such as wilderness or dispersed unroaded recreation; other portions are in allocations that permit a full range of multiple use activities. These areas and their current allocations are outlined within each forest plan. 


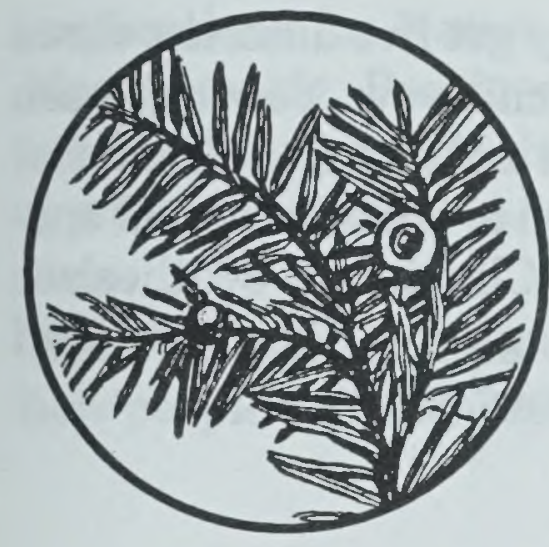

\section{Chapter III}

Affected Environment

\section{Part Three: The Yew and People \\ Table of Contents}

The Yew and People

Uses and Values

Social Setting

Social and Economic Ties

Population Distribution

Population by Zone

Population By State

Minorities

Age, Sex, and Labor Force

Participation

Lifestyles, Attitudes, Beliefs, and Values

Economic Diversity

Market and Nonmarket

Considerations

Sources of Taxol

Demand and Supply for Yew Bark

Market for Yew Bark

Theft of Pacific Yew Bark

Market Value of Pacific Yew Tree

Nonmarket Value of Yew

Alternate Sources of Taxol

Collection Methods for Pacific Yew

Bark, Needles, and Wood for Taxol

Production
Jobs

Bark Collection and Processing

Public Health

Cancer and Taxol

Taxol and Ovarian Cancer

Status of Taxol

Cultural Resources

Traditional Uses

Modern Uses

Recreation

Settings

Congressionally Designated Areas

Values and Activities

Conflicts 


\section{Part Three: The Yew and People}

Talk to five different people, and you may get five different views of the value - or lack of value - of Pacific yew. Yew has been viewed as everything from good post wood and a source of material for expensive archery bows, to "just another noncommercial species," or even "a weed tree." This part of Chapter III synthesizes elements of the first two parts of the chapter - "The Yew" and "The Forest" in the context of people, values and uses.

\section{Uses and Values}

The wood of both the Pacific and the European yew played an important role in centuries past as an ideal material for making powerful bows vitally needed for hunting and warfare.

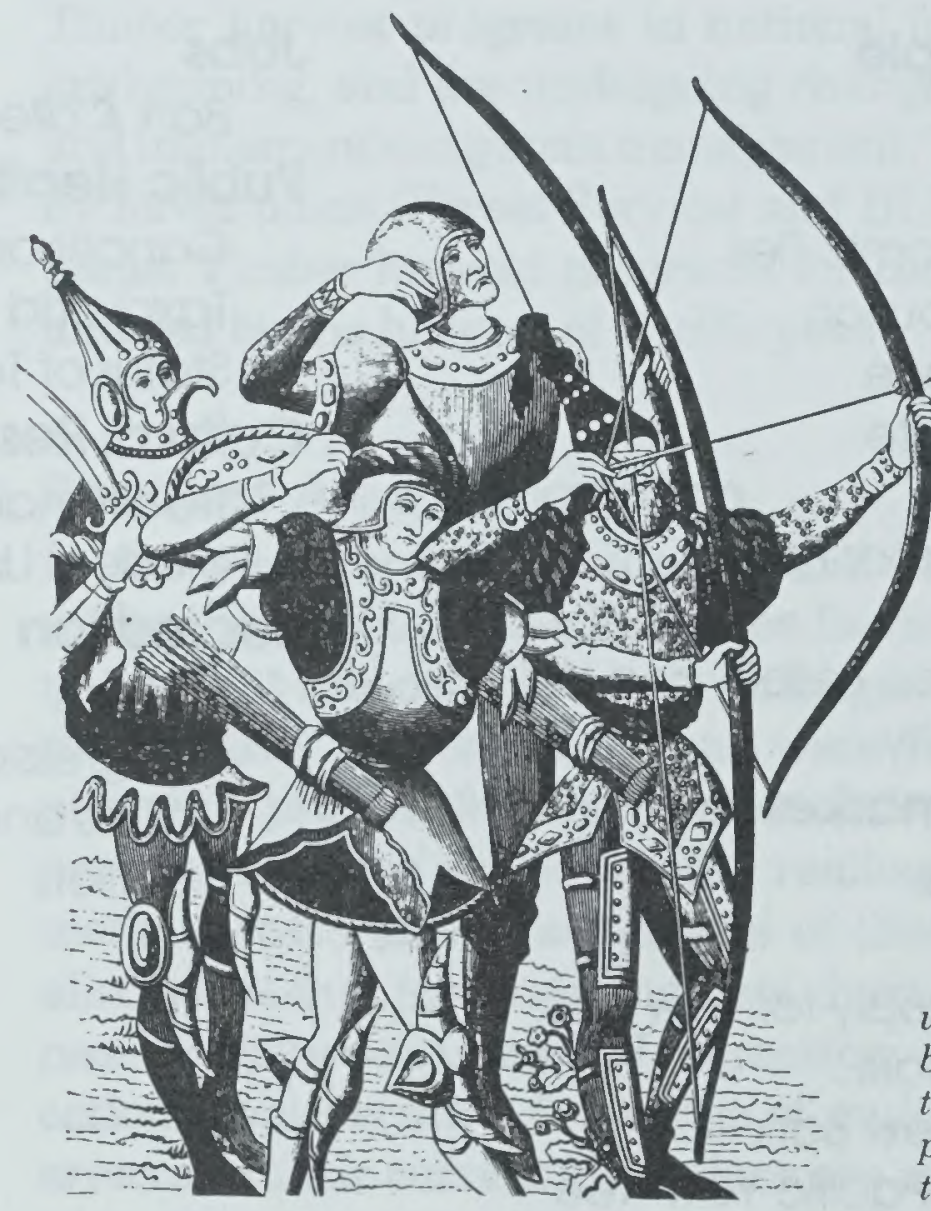

In Europe, longbows made of yew wood were first used by English archers at the battle of Crécy in 1346, where they proved to be such a superior weapon that they prevented the French from ever closing on the main English forces.

Before Europeans immigrated into the range of Pacific yew, indigenous people valued the wood and foliage for tools, bows, utensils, and even personal hygiene. Today Pacific yew is valued for its role as cover and browse for many wildlife species, and for spiritual 
implications for Native Americans as well (Tirmenstein, 1990). Most recently, Pacific yew has been in the news as a source of taxol, a drug currently being used in clinical trials and for compassionate care of certain cancer patients.

What all these uses have in common is that they are a result of how people value the species. 


\section{Social Setting}

\section{Social and Economic Ties}

\section{Geography and Yew}

Within the range of Pacific yew, the people and communities of Oregon, Washington, northern California, western Montana, and northern Idaho are most directly affected by yew harvesting activities in national forests and BLM districts.

\section{Zones}

The rugged Cascade range of mountains divides the Oregon and Washington portions of the Region into two distinct zones - west and east. Climate and vegetation - as well as population patterns and economic structures - differ between these areas. (For more information about the physical context within the range of Pacific yew, see Part Two: The Forest, in this chapter.)

Note: Information about northern California is sometimes presented separately, and sometimes combined with information about the western portion (sometimes called the "west-side") of the area affected by the proposal. Similarly, some discussions of the affected portions of Idaho and Montana are separate, but more often they are combined with discussions of the "east-side" of the five-state area.

\section{Counties Inside the Affected Area}

The range of Pacific yew does not conform neatly to boundaries set by human beings. While most counties in the states of Oregon, Washington, and the northern part of California are included in this analysis, a few are not. Table III-10 lists the counties within the range of Pacific yew. Because the "east-side" range of yew does extend into parts of Idaho and Montana, some counties (ten in Idaho; seven in Montana) in each of these states are included (see Table III-10). 
Table III-10: Counties Inside the Range of Yew

\begin{tabular}{|c|c|c|c|}
\hline Yew Range & \multicolumn{3}{|c|}{ Counties } \\
\hline Oregon & $\begin{array}{l}\text { Benton } \\
\text { Clackamas } \\
\text { Clatsop } \\
\text { Columbia } \\
\text { Coos } \\
\text { Crook } \\
\text { Curry } \\
\text { Deschutes } \\
\text { Douglas }\end{array}$ & $\begin{array}{l}\text { Hood River } \\
\text { Jackson } \\
\text { Jefferson } \\
\text { Josephine } \\
\text { Klamath } \\
\text { Lane } \\
\text { Lincoln } \\
\text { Lin } \\
\text { Marion }\end{array}$ & $\begin{array}{l}\text { Multnomah } \\
\text { Polk } \\
\text { Tillamook } \\
\text { Umatilla } \\
\text { Union } \\
\text { Wallowa } \\
\text { Wasco } \\
\text { Washington } \\
\text { Yamhill }\end{array}$ \\
\hline Washington & $\begin{array}{l}\text { Asotin } \\
\text { Clallam } \\
\text { Clark } \\
\text { Columbia } \\
\text { Cowlitz } \\
\text { Ferry } \\
\text { Garfield } \\
\text { Grays Harbor } \\
\text { Island } \\
\text { Jefferson }\end{array}$ & $\begin{array}{l}\text { King } \\
\text { Kitsap } \\
\text { Klickitat } \\
\text { Lewis } \\
\text { Lincoln } \\
\text { Nasib } \\
\text { Pacific } \\
\text { Pend Oreille } \\
\text { Pierce } \\
\text { San Juan }\end{array}$ & $\begin{array}{l}\text { Skagit } \\
\text { Skamania } \\
\text { Snohomish } \\
\text { Spokane } \\
\text { Stevens } \\
\text { Thurston } \\
\text { Wahkiakum } \\
\text { Walla Walla } \\
\text { Whatcom }\end{array}$ \\
\hline Northern California & $\begin{array}{l}\text { Del Norte } \\
\text { Siskiyou } \\
\text { Humboldt } \\
\text { Trinity } \\
\text { Shasta } \\
\text { Lassen } \\
\text { Tehama }\end{array}$ & $\begin{array}{l}\text { Plumas } \\
\text { Mendocino } \\
\text { Gleen } \\
\text { Butte } \\
\text { Sierra } \\
\text { Yuba } \\
\text { Nevada }\end{array}$ & $\begin{array}{l}\text { Placer } \\
\text { Colusa } \\
\text { Lake } \\
\text { El Dorado } \\
\text { Marin } \\
\text { Amador } \\
\text { San Mateo }\end{array}$ \\
\hline $\begin{array}{l}\text { Northern Idaho } \\
\text { ("Panhandle") }\end{array}$ & $\begin{array}{l}\text { Benewah } \\
\text { Bonner } \\
\text { Boundary }\end{array}$ & $\begin{array}{l}\text { Clearwater } \\
\text { Idaho } \\
\text { Kootenai }\end{array}$ & $\begin{array}{l}\text { Latah } \\
\text { Lewis } \\
\text { Nez Perce } \\
\text { Shoshone }\end{array}$ \\
\hline Western Montana & $\begin{array}{l}\text { Flathead } \\
\text { Lake }\end{array}$ & $\begin{array}{l}\text { Lincoln } \\
\text { Mineral }\end{array}$ & $\begin{array}{l}\text { Missoula } \\
\text { Powell } \\
\text { Sanders }\end{array}$ \\
\hline
\end{tabular}




\section{Population Distribution}

\section{Population and Growth}

In 1990, according to the national census, 9.6 million people were living in the five-state area affected by this proposal. This is an increase from the previous two decades of almost 1.3 million people. In the 1980-1990 period, the population gains slowed in all counties, especially in Oregon, northern Idaho, and western Montana areas; these are once again growing steadily (see Table III-11).

Table III-11: Population Size and Growth in Thousands, and Percent Increase from Previous Census

\begin{tabular}{|c|c|c|c|c|}
\hline Affected States & 1960 & 1970 & 1980 & 1990 \\
\hline $\begin{array}{c}\text { Oregon } \\
(27 \text { counties })\end{array}$ & 1,694 & $\begin{array}{c}2,022 \\
(19 \%)\end{array}$ & $\begin{array}{c}2,553 \\
(25 \%)\end{array}$ & $\begin{array}{c}2,766 \\
(8 \%)\end{array}$ \\
\hline $\begin{array}{c}\text { Washington } \\
(29 \text { counties })\end{array}$ & 2,433 & $\begin{array}{c}2,974 \\
(22 \%)\end{array}$ & $\begin{array}{c}3,591 \\
(21 \%)\end{array}$ & $\begin{array}{c}4,282 \\
(19 \%)\end{array}$ \\
\hline $\begin{array}{c}\text { Northern California } \\
\text { (21 Counties) }\end{array}$ & 1,200 & $\begin{array}{c}1,458 \\
(22 \%)\end{array}$ & $\begin{array}{c}1,790 \\
(23 \%)\end{array}$ & $\begin{array}{c}2,150 \\
(20 \%)\end{array}$ \\
\hline $\begin{array}{c}\text { Northern Idaho } \\
(10 \text { Counties) }\end{array}$ & 153 & $\begin{array}{c}165 \\
(8 \%)\end{array}$ & $210(27 \%)$ & $\begin{array}{c}217 \\
(3 \%)\end{array}$ \\
\hline $\begin{array}{c}\text { Western Montana } \\
\text { (7 Counties) }\end{array}$ & 120 & $147(23 \%)$ & $184(25 \%)$ & $\begin{array}{c}195 \\
(6 \%)\end{array}$ \\
\hline Totals & 5,600 & $\begin{array}{c}6,766 \\
(21 \%)\end{array}$ & $\begin{array}{c}8,328 \\
(23 \%)\end{array}$ & $\begin{array}{c}9,610 \\
(15 \%)\end{array}$ \\
\hline
\end{tabular}

Source: 1990 Census, U.S. Census Bureau.

\section{Population by Zone}

\section{The West-Side}

In 1990 , the western side of the area affected by the proposal (often called the "west-side") includes approximately 2.5 million people who reside in the west side counties of Oregon, and approximately 3.8 million people who live in the western part of Washington. In western Oregon, the population is concentrated in the Willamette 
and Rogue River valleys. In western Washington, the population centers are concentrated along Puget Sound. (See also the discussions of urban and rural distributions in this section.)

\section{Northern California}

The northern California portion of the affected area covers approximately one-fifth of the land area in the five states. This portion contains about 22 percent of the population in the fivestate affected area. The main population centers are located in the Eureka/Arcata, Redding/Red Bluff, and Chico areas, and in the Peninsula area south of San Francisco. (See also the discussions of urban and rural distributions in this section.)

Not all of northern California is included in this analysis, as there are no known native yew trees present in some counties.

\section{The East-Side}

The eastern part of the affected area (often called the "east-side") covers two-thirds of the land area of the five states. It contains a smaller proportion of the population. About 12 percent (1.2 million people) of the population of this area lives within the range of Pacific yew east of the Cascade range.

Not all of the eastern portions of Oregon and Washington are within the range of Pacific yew, and these are excluded from this analysis (see Table III-11).

\section{Population By State}

\section{Totals, Trends, and Urban/Rural Distribution}

As mentioned earlier, 9.6 million people were living in the fivestate area affected by this proposal as of 1990 . There are significant differences in the distribution of population in the affected area.

Generally, over the last 40 years, states and counties have become increasingly urbanized, in part because of migration into the towns and cities from rural populations and from other states. This urbanization has closely followed the route of Interstate 
Highway 5, the "I-5 Corridor." The following paragraphs present general population totals, followed by the information about the proportion of rural and urban residents in each state. Because much of the Pacific yew is located in rural forest areas, where employment in the wood products sector is greatest, there is a potential to add jobs to rural areas due to yew harvesting and processing facilities.

Note: Differences for each county are not available from the 1990 census as of this writing.

\section{Oregon and Washington Totals}

Of the 9.6 million total, 7 million people were living in the 27 counties of Oregon and the 29 counties of Washington that are within the range of Pacific yew. This is a majority of the population in the two states.

Oregon's population, $28.8 \%$ of the region's total, is also primarily urban. The state has four metropolitan areas, all on the west side of the Cascades: Portland (which also includes Vancouver, Washington), Salem, Eugene-Springfield, and Medford.

Urban/Rural Split: Statewide in 1990, the rural/urban split was $70.5 \%$ urban and $29.5 \%$ rural. Among affected counties, the population is concentrated more in the urban areas, as several large rural counties are not included in the analysis (see Figure III-10).

Washington contains $44.6 \%$ of the region's population. The vast majority of these residents live in urban areas. There are five metropolitan areas in western Washington: Bellingham, Seattle-Everett, Bremerton, Tacoma, and Olympia. Three more areas are situated east of the Cascades: Yakima, Spokane, and Richland-Kennewick-Pasco.

Urban/Rural Split: Statewide in 1990, the rural/urban split was $76.4 \%$ urban and $23.6 \%$ rural. The affected counties are more heavily urban than the statewide average, as several lightly populated counties have been eliminated from the study. 


\section{Northern Califomia Totals}

The 21 counties of northern California that are within the range of Pacific yew account for 2.2 million people.

California's population, in the northern portion of the state, has approximately $22.4 \%$ of the people affected in the Pacific yew region. There are three metropolitan areas within the affected area: Redding, Chico, and San Mateo.

Urban/Rural Split: Statewide in 1990, the rural/urban split was $92.6 \%$ and $7.4 \%$ rural. However, in the northern California affected area, a much larger percentage lives in the rural settings.

\section{Idaho and Westem Montana Totals}

In the ten counties in Idaho affected by the DEIS proposed action, there were 216,792 people. In the seven counties of western Montana that are in the range of Pacific yew, there were 195,031 people.

Idaho's population, in the northern panhandle, contains about 2.3 percent of the region's total number of people. There are no metropolitan areas in the affected panhandle area, but the population is concentrated in the Coeur d'Alene and Lewiston areas.

Urban/Rural Split: Statewide in 1990, the rural/urban split was $57.4 \%$ urban and $42.6 \%$ rural.

Montana's population, along the western edge of the state, contains about $2.0 \%$ of the population in the five-state affected region. There are no metropolitan areas in this portion of the state, but people are concentrated around the Kalispell and Missoula areas.

Urban/Rural Split: Statewide in 1990, the rural/urban split was $52.2 \%$ urban and $47.5 \%$ rural. 


\section{Minorities}

\section{Percent of Population}

Racial and cultural minorities are a small segment of the 9.6 million people living in the five states of the affected area (see Table III-12).

Table III-12: Minorities by Group

Total Numbers in the Affected Area and Percent of Population

(From 1990 Census)

\begin{tabular}{|l|c|c|}
\hline \multicolumn{1}{|c|}{ Group } & Total Number & $\begin{array}{c}\text { Percent of } \\
\text { Total Population }\end{array}$ \\
\hline African (Black) Americans & 249,983 & 2.6 \\
\hline Native Americans & 152,535 & 1.6 \\
\hline Asians and Pacific Islanders & 418,047 & 4.4 \\
\hline Other Racial Affiliations & 173,874 & 1.8 \\
\hline Hispanic Origin* & 464,052 & 4.8 \\
\hline
\end{tabular}

*People of Hispanic origin (the largest minority group in the area under discussion) may be members of any racial group.

\section{Urban/Rural Distribution}

African Americans and Asians in the region are predominately urban dwellers, while Native Americans and Hispanics are more rural than the overall population. As a growing proportion of minorities are being employed in tree planting and related outdoor forest work, it is probable that Native American and Hispanic people could find more opportunities in the yew harvest on federal lands.

\section{American Indian Trust Lands}

Within the five-state area in the range of Pacific yew, there are 65 American Indian Trust Lands (reservations, rancherias, communities, etc.) that total some 3,908,341 acres. (See Table III-13.) Many of these trust lands vary in size from a few acres to over 1.4 
million acres. Many are adjacent to national forests, and Native Americans have significant concerns about general forest and wildlife/fish resources and management (USDI Bureau of Indian Affairs, 1990). The management of the Pacific yew, however, does not seem to be of significant concern, based on available information.

Table III-13: American Indian Trust Lands in the Affected Area by State

\begin{tabular}{|c|c|c|c|}
\hline State & Acres & \multicolumn{2}{|c|}{$\begin{array}{l}\text { Trust Lands } \\
\text { in the Affected Area }\end{array}$} \\
\hline Oregon & 624,851 & $\begin{array}{l}\text {--Coos, Lower } \\
\text { Umpqua, \& } \\
\text { Siuslaw } \\
\text {--Cow Creek Band } \\
\text { of Umpqua }\end{array}$ & $\begin{array}{l}\text {--Grand Ronde } \\
\text {--Klamath } \\
\text {--Siletz } \\
\text {--Umatilla } \\
\text {--Warm Springs }\end{array}$ \\
\hline Washington & 221,098 & $\begin{array}{l}\text {--Chehalis } \\
\text {--Colville } \\
\text {--Hoh } \\
\text {--Kalispel } \\
\text {--Lower Elwha } \\
\text {--Lummi; Makah } \\
\text {--Muckleshoot } \\
\text {--Nisqually } \\
\text {--Nooksack } \\
\text {--Ozette } \\
\quad \text { (Jamestown Klallam) } \\
\text {--Port Gamble } \\
\text {--Port Madison }\end{array}$ & $\begin{array}{l}\text {--Puyallup } \\
\text {--Quileute } \\
\text {--Quinault } \\
\text {--Sauk-Suiattle } \\
\text {--Shoalwater Bay } \\
\text {--Skokomish } \\
\text {--Spokane } \\
\text {--Squaxin Island } \\
\text {--Stillaguamish } \\
\text {--Swinomish } \\
\text {--Tulalip } \\
\text {--Upper Skagit } \\
\text {--Yakima }\end{array}$ \\
\hline $\begin{array}{l}\text { Northern } \\
\text { California }\end{array}$ & 121,745 & $\begin{array}{l}\text {--Berry Creek } \\
\text {--Big Bend } \\
\text {--Big Lagoon } \\
\text {--Big Valley } \\
\text {--Blue Lake } \\
\text {--Coyote Valley } \\
\text {--Enterprise } \\
\text {--Greenville } \\
\text {--Hoopa Valley } \\
\text {--Hopland } \\
\text {--Karok } \\
\text {--Laytonville } \\
\text {--Lookout } \\
\text {--Montgomery Creek }\end{array}$ & $\begin{array}{l}\text {--Pinoleville } \\
\text {--Redwood Valley } \\
\text {--Resighini } \\
\text {--Roaring Creek } \\
\text {--Robinson } \\
\text {--Round Valley } \\
\text {--Sherwood Valley } \\
\text {--Smith River } \\
\text {--Sulphur Bank } \\
\text {--Susanville } \\
\text {--Trinidad } \\
\text {--Upper Lake } \\
\text {--Yurok }\end{array}$ \\
\hline $\begin{array}{l}\text { Northern } \\
\text { Idaho }\end{array}$ & 58,640 & $\begin{array}{l}\text {--Kootenai } \\
\text {--Nez Perce }\end{array}$ & --Coeur d'Alene \\
\hline $\begin{array}{l}\text { Western } \\
\text { Montana }\end{array}$ & 581,907 & --Flathead & \\
\hline
\end{tabular}




\section{Age, Sex, and Labor Force Participation}

\section{Shifts}

After 1970, the age composition of the region's population shifted, and by 1980 a larger proportion of the population was of working age than ever before. A significant increase - from $43 \%$ to $52 \%$ in the number of women in the labor force occurred. As the age structure of the region continues to shift, the size and other characteristics of the labor force will be affected (U.S. Department of Energy, 1982).

\section{Lifestyles, Attitudes, Beliefs, and Values}

\section{No One Lifestyle}

Certainly, there is no one regional lifestyle or set of attitudes, beliefs, and values in the five-state area. Generalizations which typify an area's residents are as inaccurate today as they were in the past. However, if there is a thread of commonality in the region, it is the desirability of an active, outdoor lifestyle.

Continuing advancements in technologies are helping shift metropolitan economies from their historical resource bases to more diversified ones. Strong environmental concerns are being voiced in sectors of our society where previously little was ever said.

\section{Perceptions}

Because the economies of the rural communities are often associated with commodity production, residents of those areas are frequently perceived as being more likely to favor higher production levels and heightened development. Residents of metropolitan areas whose livelihoods are not directly or noticeably linked to the extraction of natural resources are more commonly viewed as favoring environmental concerns.

Environmentalists live in rural areas as well as in metropolitan areas, just as do those who favor development of the resource base. There is no simple line of demarcation between these camps. Environmentalists are concerned about their neighbors' jobs, and 
mill workers are frequently among the first to note their concern for the environment.

\section{Relationship to Growth}

Many people of all types find this region a very desirable place to live. To some extent, this quality has fostered the location of many new enterprises in the area. The 1980s, though, are likely to be remembered as a time when people in the region recognized that continued growth could not be ensured without effort; that it would have to attract suitable employers from a common, national pool, and that other areas of the country are indeed viable competition in our mutual marketplace.

\section{Economic Diversity}

\section{Trend Toward Economic Diversity}

The economy of the five-state region is moving toward greater diversity. The region's historic dependence on the removal of natural resources and the manufacture of "raw" products has lessened with the increase in other kinds of growth. With the social changes affected by these new directions has come a fresh recognition of the importance of the national forests. The opportunity to enjoy an unpolluted environment, to pursue one's favorite outdoor recreation, or to view a truly natural diversity, is still possible in the national forests.

\section{West-Side, Northern Califomia Are More Diverse}

The economy in the western portion of the region is relatively diversified; more so in Washington than in Oregon. Northern California is moderately diversified, but becomes more highly diversified the closer one gets to the San Francisco-Sacramento corridor (Interstate 80).

Aircraft manufacturing, shipbuilding, forest products industries, major financial centers, government, commercial fishing, agriculture, the livestock industries, recreation facilities, and mining all contribute to the economic picture along the "I-5 Corridor." 


\section{East-Side Is Less Diverse}

The economy of the eastern portion of the region depends more on agriculture, forest products industries, and the livestock industry than does the western portion. The relative dependence on these sectors has not been balanced by growth in other major employment sectors, except for some localized growth in the recreation and service industries.

The eastern part of the five-state area has fewer opportunities for employment, and the cities and towns generally reflect a ruralbased economy with little diversification. It is a region in transition, moving toward a more diversified economic base. The traditional employment sectors simply do not have the same labor requirements as they did in the past. Historically, many seem to feel that the natural wonders of the area would be sufficient to guarantee its growth. 


\section{Sources of Taxol}

\section{Development and Pharmacology}

Thirty years ago scientists discovered that bark from the Pacific yew contained a chemical compound (one of the taxanes, now known as taxol) when Forest Service collectors sent a sample of randomly collected bark, needles, and twigs from Pacific yew in Washington State to the National Cancer Institute (NCI) laboratory in 1962. This was one of the revelations of a plant screening program sponsored by the Natural Products Branch of NCI.

The following is a chronology of the development of taxol as a cancer-fighting drug.

1963 NCI found that yew samples showed activity against 9KB cancer-cell tissue culture. NCI sent a subsample to Monroe Wall, Ph.D., a medicinal chemist working under contract to NCI at Research Triangle Institute in North Carolina.

1964 Wall's group found that a crude extract of the yew bark was effective in both the cancer-cell tissue system and against a mouse leukemia. They worked to isolate the primary active principle of taxol.

1966 Wall asked NCI to give the yew material special priority for research. He isolated the active principle and named it taxol.

1969 NCI checked the activity of all parts of Pacific yew. They now knew three things: the structure of taxol, its success in cancer screens, and something about how it worked against cancer.

1971 Wall, with Mansukh Wani (at Research Triangle Institute) and Andrew McPhail (of Duke University), published the structure of the taxol molecule, a complex diterpene with an unusual oxetane ring and an ester side chain. This is illustrated in the following figure.

\section{Market and \\ Nonmarket Considerations}


Figure III-9: Taxol Molecule

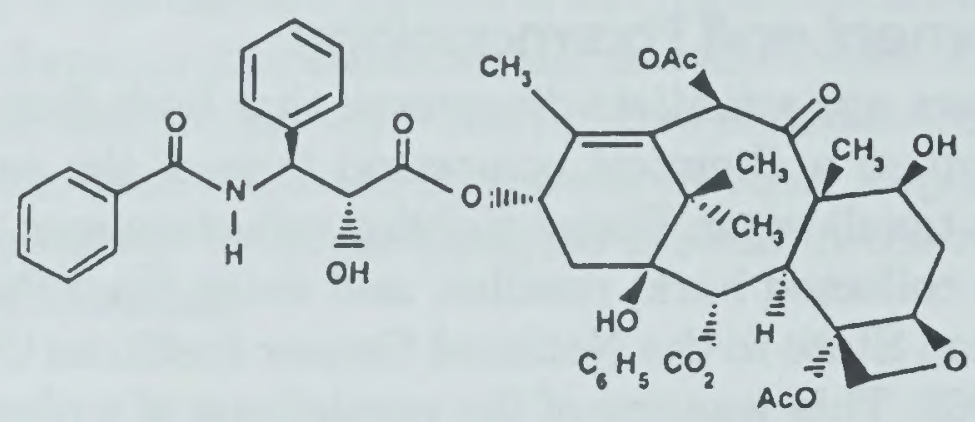

1974 Taxol began to show results against a recently developed B16 mouse melanoma system. During the 1970s, cytotoxicity tests continued with tumor lines in new animal screens, including human tumor xenografts (tissues grafted from one species to another).

1977 Preclinical work on taxol began. NCI contacted Susan Horowitz (professor of molecular pharmacology at Albert Einstein College of Medicine in the Bronx), who was working under an NCI Cancer Research Emphasis Grant, to ask her to investigate how taxol worked on cancer cells. With graduate student Peter Schiff, she found that taxol inhibited the replication of human tumor cells. (Specifically, the cancer cells stopped dividing. Taxol froze the division of microtubules, the structures needed at the critical point in cell division. The cell eventually died.)

1978 Taxol showed positive results in human cancer xenografts. Taxol showed activity in three systems, including a human breast cancer xenograft developed in the late 1970s.

1979 Horowitz and Schiff published their findings about taxol's action of freezing microtubules and causing the cell to die.

1980 Toxicology studies began. Scientists looked for a suitable surfactant formulation for administering the insoluble drug.

1982 NCI filed an Investigational New Drug Application (INDA) for taxol with the Food and Drug Administration. 
1983 Phase I clinical trials began, testing patients who were not responding to other treatments, determining doses and toxicity, and generating data on dose limits of taxol.

1987 NCI contracted for collection of 60,000 (Daly, 1992) pounds of dry Pacific yew bark.

1988 Phase II clinical trials showed 30 percent improvement in patients with unresponsive cases of advanced ovarian cancer.

1989 Trials of taxol progressed for other forms of cancers: Breast, cervical, colon, gastric, non-small-cell lung, prostate, head and neck, small-cell lung, and renal. NCI contracted for an additional 60,000 pounds of dry bark.

1990 Phase II trials showed 48 percent tumor shrinkage with metastatic breast cancer patients who had at least one prior chemotherapy regime. (Metastatic refers to cancers which tend to spread from one bdy part to another.)

1992 Clinical trials were conducted at 20 centers on a number of different cancers, with some experimenting with combinations of chemotherapies. Currently, Horowitz continues to work on taxol's interactions with microtubules and tubulin. 


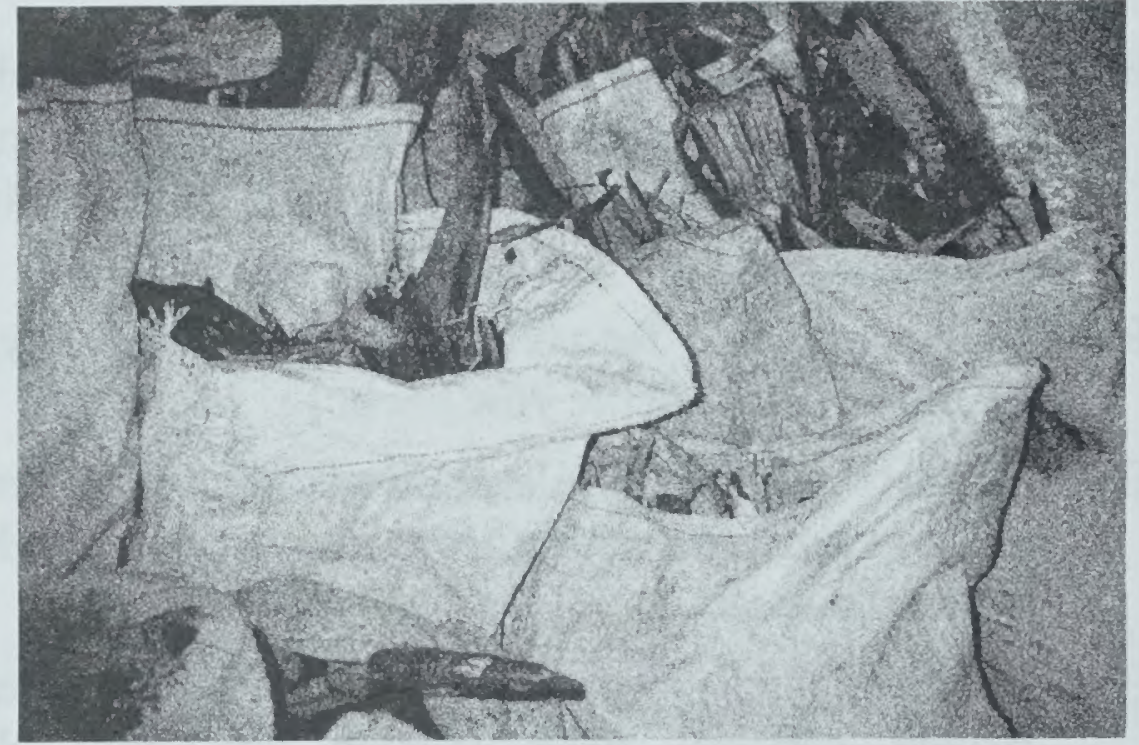

Sacks of harvested bark

\section{Demand and Supply for Yew Bark}

\section{Demand}

Current demand for Pacific yew bark is due to the fact that it is the only FDA-approved source of taxol. Existing bark processing capacity can convert 2 million pounds of dry yew bark into 130 kilograms of taxol each year and that capacity is expected to increase to 200 kilograms next year. In 1991, over 800,000 pounds of dry yew bark was provided by the Forest Service and BLM. These two agencies provided 750,000 pounds of dry yew bark in 1992.

The agreement (the CRADA) between the National Cancer Institute (NCI) and Bristol-Myers Squibb (BMS) calls for BMS to develop a source for taxol that does not depend on the harvest of Pacific yew bark. We expect that demand for bark will go down and eventually disappear as other sources of taxol become available.

Taxol therapy continues to show good progress in treating ovarian cancer, as well as several other cancers. Because of this, the number of patients enrolled in clinical trials of taxol has increased and is expected to increase further.

The five-year harvest program covered by this analysis was predicated on the assumption that at the end of five years Pacific yew bark would no longer be needed as a source of taxol. The amount of bark requested by Bristol-Myers Squibb from the federal agencies 
is determined annually. Each year Bristol-Myers Squibb negotiates with NCI to supply a certain quantity of taxol. Bristol-Myers Squibb then translates this into a need for bark. This need is met through bark harvest from federal, state, and private lands.

\section{Supply}

The supply of bark could come from several sources: federal lands, state and county lands, as well as private lands. The supply source being studied here is Forest Service and Burreau of Land Management (BLM) lands in Oregon, Washington, California, Idaho, and Montana. Table III-14 shows bark harvest and taxol production information for the past several years.

Table III-14: Bark Harvest

\begin{tabular}{|c|c|c|c|c|}
\hline $\begin{array}{c}\text { Bark Requested } \\
\text { by BMS }\end{array}$ & $\begin{array}{c}\text { Forest } \\
\text { Service }\end{array}$ & BLM & State & Private \\
\hline 1990 & 69,000 & 4,000 & 0 & 0 \\
\hline 1991 & 825,769 & 25,756 & 225,800 & NA \\
\hline 1992 & 639,300 & 120,100 & 55,900 & NA \\
\hline 1993 & $* 720,000$ & $* 110,000$ & NA & NA \\
\hline $\begin{array}{l}\text { NA = Information not available } \\
\text { = Projected harvest }\end{array}$ & & & \\
\hline
\end{tabular}

To date, the federal agencies have been able to supply all the bark that has been requested by Bristol-Myers Squibb. The results of an inventory to assess the supply of bark is discussed in the inventory section of Part One of this chapter, and in Appendix F which details the inventory procedures and results (see also Chapter IV). 
Although actual bark supply from private lands is not available, it has been estimated that total production from these lands exceeded 500,000 pounds during 1991 and 1992 . The analysis in this document assumes that the supply from private lands will continue at similar levels.

\section{Market for Yew Bark}

\section{Agreements}

To ensure a stable supply of Pacific yew bark, Bristol-Myers Squibb entered into an agreement with the USDA Forest Service and the Bureau of Land Management (BLM) to supply bark from lands they administer. The actual amount of bark is negotiated annually and has been approximately 750,000 pounds in 1991 and 1992 (see Table III-14). (See Appendix E for more information on the agreements between the Forest Service, Bureau of Land Management, and Bristol-Myers Squibb.)

Hauser Northwest serves as the collection agent for this bark for Bristol-Myers Squibb. Forest Service regulations prohibit the direct sale of bark to Hauser, so the Forest Service is transferring the bark under a research authority. Currently, BMS covers Forest Service administrative costs connected with bark harvest. On August 7, 1992 President Bush signed the Pacific Yew Act which allows the Forest Service to sell bark, but as of this writing the current system is still in place. The act gives the Forest Service and BLM the authority to negotiate the sale of Pacific yew to parties with approval to manufacture taxol for human use. Hauser Northwest pays collectors $\$ 1.95$ per pound (green) for bark. This is not intended to be a direct payment for the bark, but a compensation for the collectors' labor (Phil Hassrick, 1992).

\section{Current Market}

BLM regulations do allow the sale of Pacific yew bark. The BLM used an appraisal process to determine a "stumpage" value for green yew bark of 30 cents a pound. An open market sale of Pacific yew bark held recently in Idaho on state land sold for 25 cents a pound, green (Merrill Davis, 1992). Most sales on private land have been bought by Hauser Northwest at a price of 25 cents a pound. 


\section{Theft of Pacific Yew Bark}

Information on the total amount of bark stolen during 1991 was only available from the Forest Service. The Forest Service estimates that during 1991 about 300,000 pounds of bark were stolen. (About 825,000 pounds were harvested legally.) The Bureau of Land Management was unable to provide any information about the amount of bark stolen from their lands during 1991.

\section{Market Value of Pacific Yew Tree}

\section{Commercial Value}

The Pacific yew, although it has not been considered valuable on a large-scale commercial basis, does have some commercial value. This value is not for the bark, but for the wood. Pacific yew wood is resistant to decay, and can be bent and worked with good results. In the 1980s, Asian buyers were reported to have paid approximately $\$ 3,000$ to $\$ 6,000$ per thousand board feet for yew logs (Bolsinger et al., 1992).

The most common commercial use of the logs is for fenceposts. Woodworkers also value the wood, although they do not use it in great quantities. 


\section{Nonmarket Value of Yew}

\section{Cultural}

The yew tree has been seen as a valuable species for human use for centuries. European cultures have made various uses of the yew. It has been tied to Druidic rituals, and was often planted in churchyards. The Victorians believed the roots of yew trees in churchyards grew into the throats of the dead.

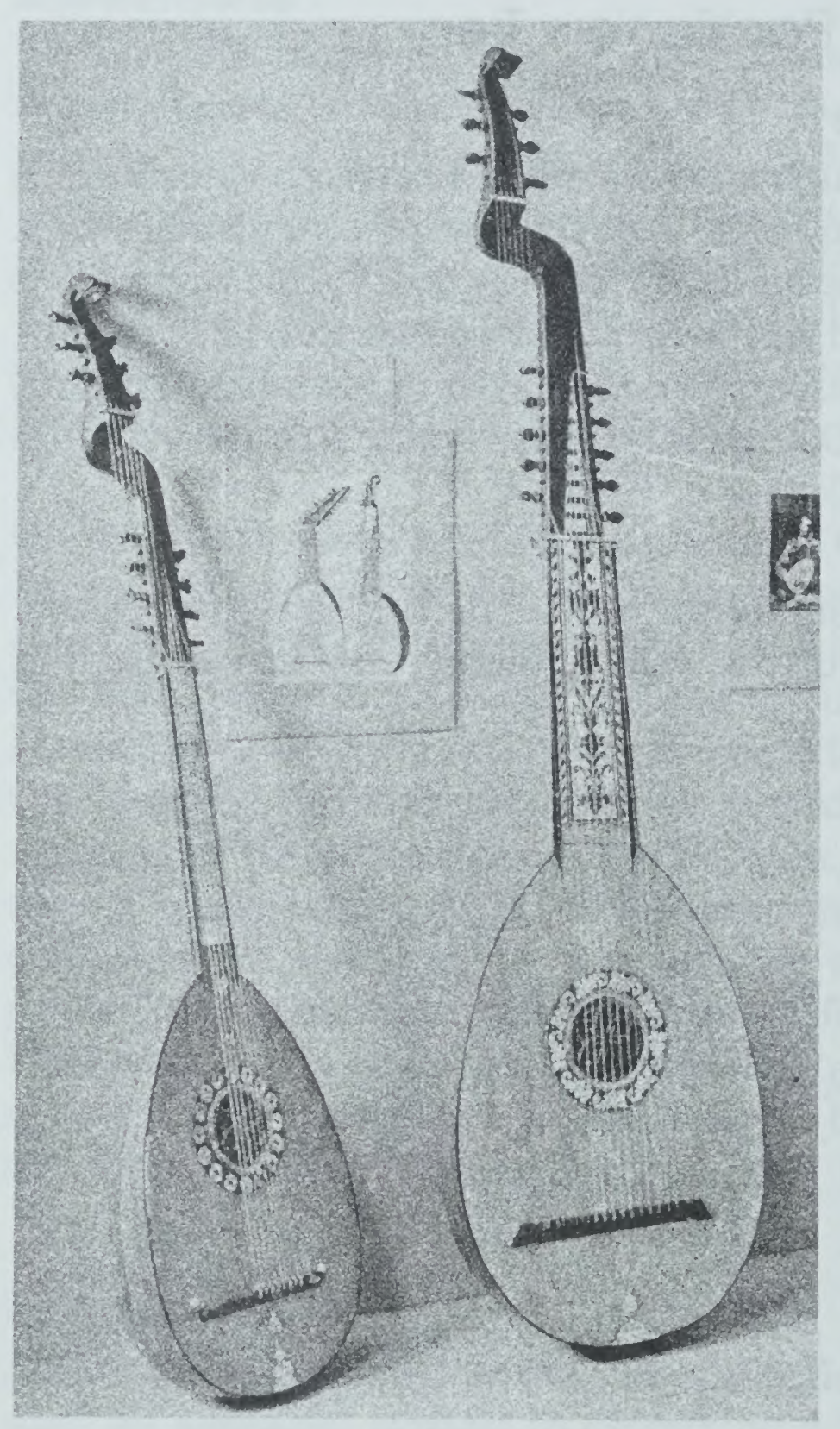

Lute makers have for many centuries prized the wood of both the European and the Pacific yew.
Yew wood was, and still is, prized for use in the manufacture of useful and decorative products, as well as having a symbolic function. Native American cultures throughout the fivestate area, historically, have also made extensive use of the yew, especially for tools, cups, and bowls (Hartzell, 1991). The Japanese use yew wood for ceremonial carvings. The resistance of yew to decay has also made it popular for fenceposts. Yew wood has also been used for furniture, musical instruments, and is particularly prized for bows (Richardson, 1991). 


\section{Alternate Sources of Taxol}

"Nobody owns the compound. We didn't patent it when we isolated it."-Monroe $\mathrm{E}$. Wall, chemist with Research Triangle Institute

\section{Taxanes}

Taxol belongs to a group of compounds called taxanes found in Taxus brevifolia (Pacific yew) and other Taxus species; it is one of the most complex taxanes known. Due to the complexity of the taxol molecule (according to researcher Susan Horowitz, it's "the kind of molecule that no chemist would ever sit down and think of making. It definitely comes from a tree"), synthesis of taxol is difficult and has yet to be achieved in useable quantities. Presently, the bark of Pacific yew is the only FDA-approved source of taxol for research and clinical use.

The development of alternative sources of taxol is being pursued actively by both the National Cancer Institute and Bristol-Myers Squibb. The Cooperative Research and Development Agreement (CRADA) requires them to develop alternative sources as soon as possible.

Researchers at companies, universities, and agencies world-wide are working to develop taxol or a closely-related drug. They are working on clinical and laboratory creation of taxol (total chemical synthesis, semisynthesis, and cell culture) and on alternate methods of large-scale production (extraction from needles, and biomass).

Here is a partial list of some of the current research and development of taxol:

\section{Total and Semisynthesis}

Taxol can be partially synthesized from a precursor - 10-deacetyl baccatin-III - found in needles of Taxus baccata, European yew, and from baccatin-III, found in virtually all yew species.

After a decade of trying, chemists are finding total synthesis of the taxol molecule difficult. Some researchers are removing pieces of 
the molecule to find what parts are essential to the bioactivity of taxol. These studies have potential for finding similar molecules that might be simpler and easier to synthesize, and may lead to semisynthesis.

Meanwhile, Dr. Robert Holton and coworkers at Florida State University are working on partial and total synthesis of taxol. Thirty or more other research groups across the United States are also investigating synthesis of taxol.

In addition, Rhone-Poulenc Rorer, a French pharmaceutical firm, has developed Taxotere, a taxol analog made by partial synthesis from a taxol precursor extracted from the needles of European yew, Taxus baccata.

\section{Cell Culture}

Phyton Catalytic Inc. of Ithaca, New York, and ESCAgenetics of San Carlos, California, are producing taxol and taxol-like compounds from yew cells grown in culture.

\section{Biomass From Nursery Cultivation}

The Weyerhaueser Company is propagating yew at a nursery in Washington State. Under an agreement with the Bristol-Myers Squibb Company, it is engaged in research and cultivation of domestic yew to provide a reliable, long-term, and affordable supply of taxol from yew biomass (needles, twigs, and possibly roots). Weyerhauser is also working with cultivars and exotic yew species.

In a similar vein, the National Cancer Institute and the USDA Cooperative State Research Service are cooperating with Zelenka Nursery in Michigan; Zelenka Nursery is coordinating the project with the University of Mississippi, Ohio State University and several other nurseries.

Together, these groups are researching the best methods for harvesting and drying needles and twigs from ornamental yew (Taxus media $v$. hicksii). They will supply dried biomass to the 
National Cancer Institute (NCI), which will contract the extraction of taxol from the biomass, and then give the resulting material to Bristol-Myers Squibb for final purification of taxol.

\section{Taxol From Yew Heartwood}

Researchers at the USDA Forest Products Laboratory in Madison, Wisconsin have successfully extracted taxol from Pacific yew heartwood, but the amounts of taxol were so small that the process was not considered feasible.

\section{Taxol From Needles}

NaPro Biotherapeutics Inc., in Boulder, Colorado is extracting taxol from yew needles and bark. 


\section{Collection Methods for Pacific Yew Bark, Needles, and Wood for Taxol Production}

\section{Bark, Needles, and Heartwood}

Three parts of the wild yew tree could be used to produce taxol: the bark, the needles, and the heartwood (in nursery grown seedlings even the roots may be used). In this EIS we will look at the effects of harvesting yew. Currently, production of taxol depends on the bark; in the future, researchers may perfect processes to extract taxol from needles and heartwood. Up-to-date information indicates that extraction of taxol from heartwood is not feasible.

\section{Bark Collection}

Bark collectors fell yew trees in order to strip the bark. The bark is peeled from the bole of the tree in the spring and summer months when the sap is moving and the bark peels easily. Peelers use a variety of small hand tools to cut and peel. Peelers strip the bark from the limbs of the tree according to current Forest Service and BLM requirements of peeling limbs down to the size of one inch in diameter.

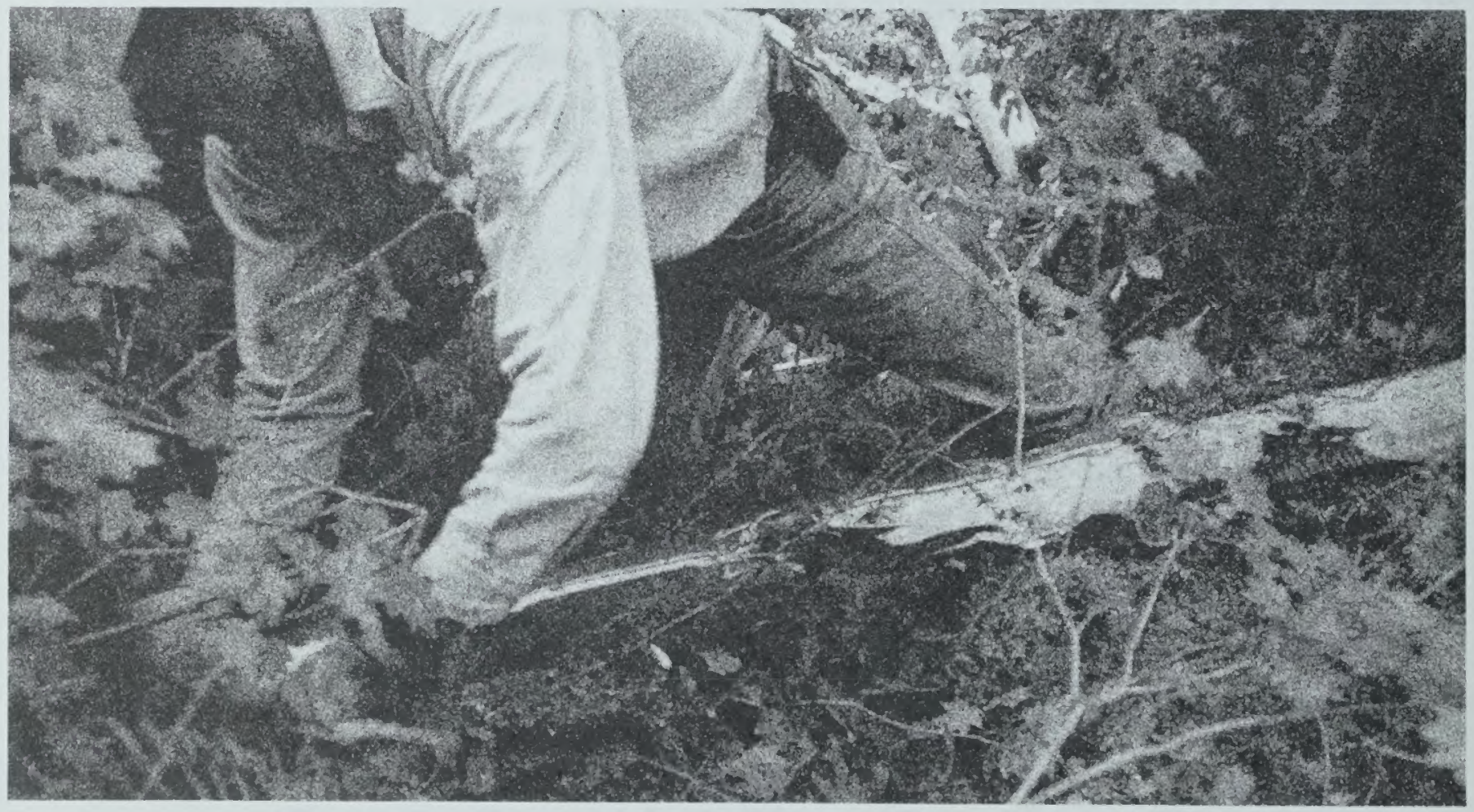




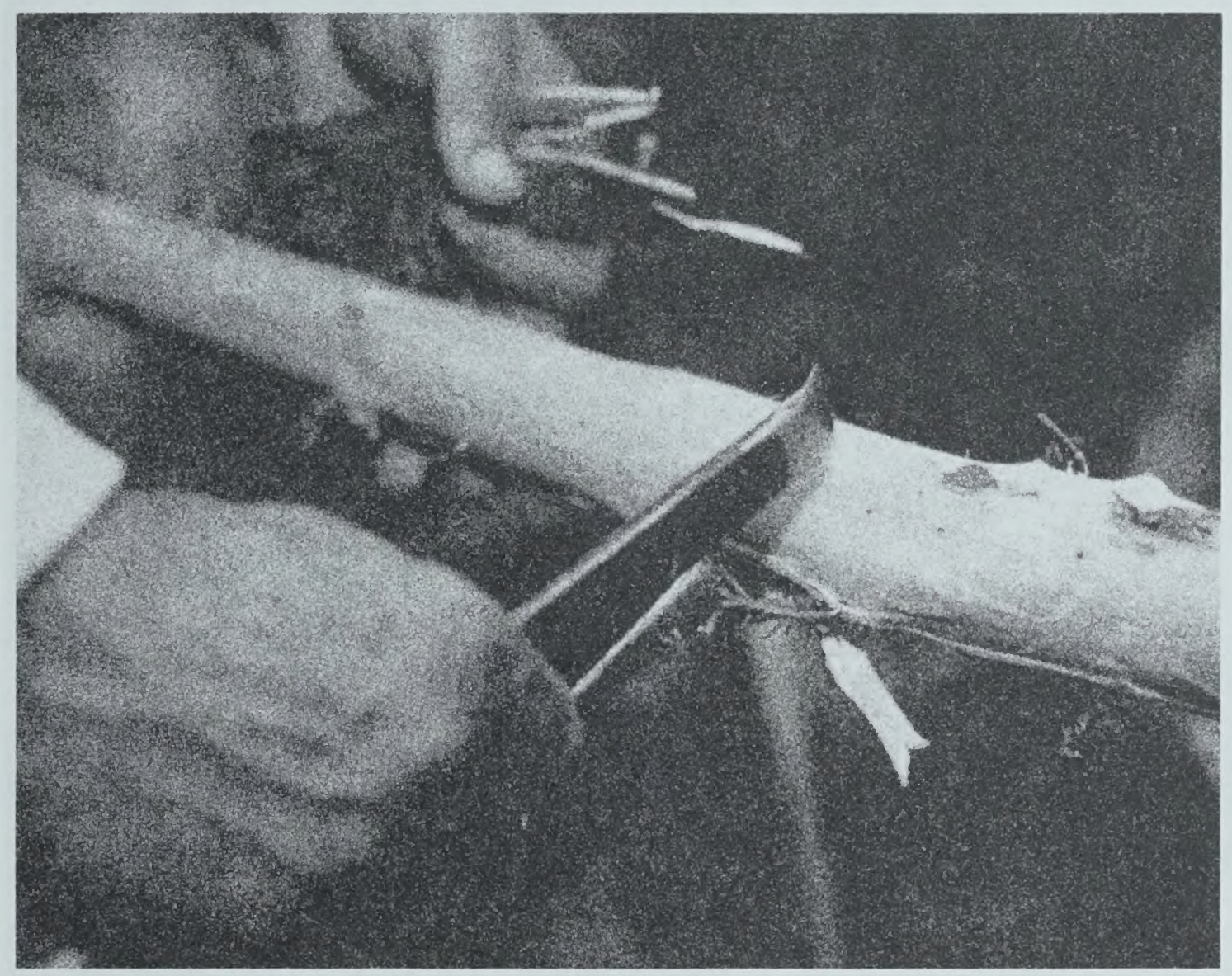

The bark is collected in bags, tagged, weighed, and trucked to the bark processing facility where it is ground, dried, boxed, and shipped to the extraction facility.

Another way to collect yew bark is to partially strip the bark from a living tree. Bark collectors are not pursuing this method because: (1) scientists say the effect on yew trees of partial bark stripping is unknown (the tree may die or become unhealthy), and (2) more trees over a wider land base would be affected by partial bark stripping than by felling to gather the same amount of bark. 


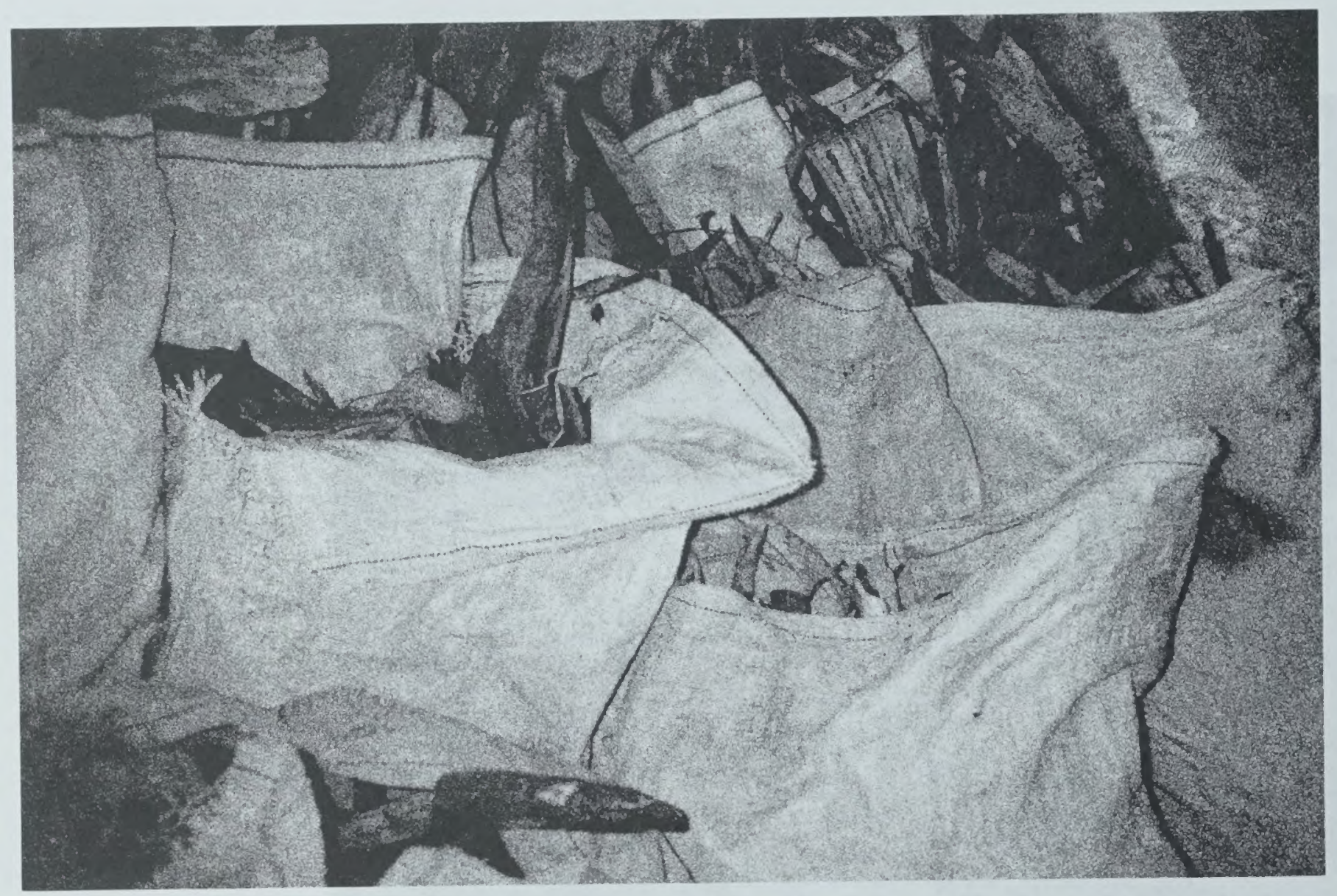

Sacks of harvested bark

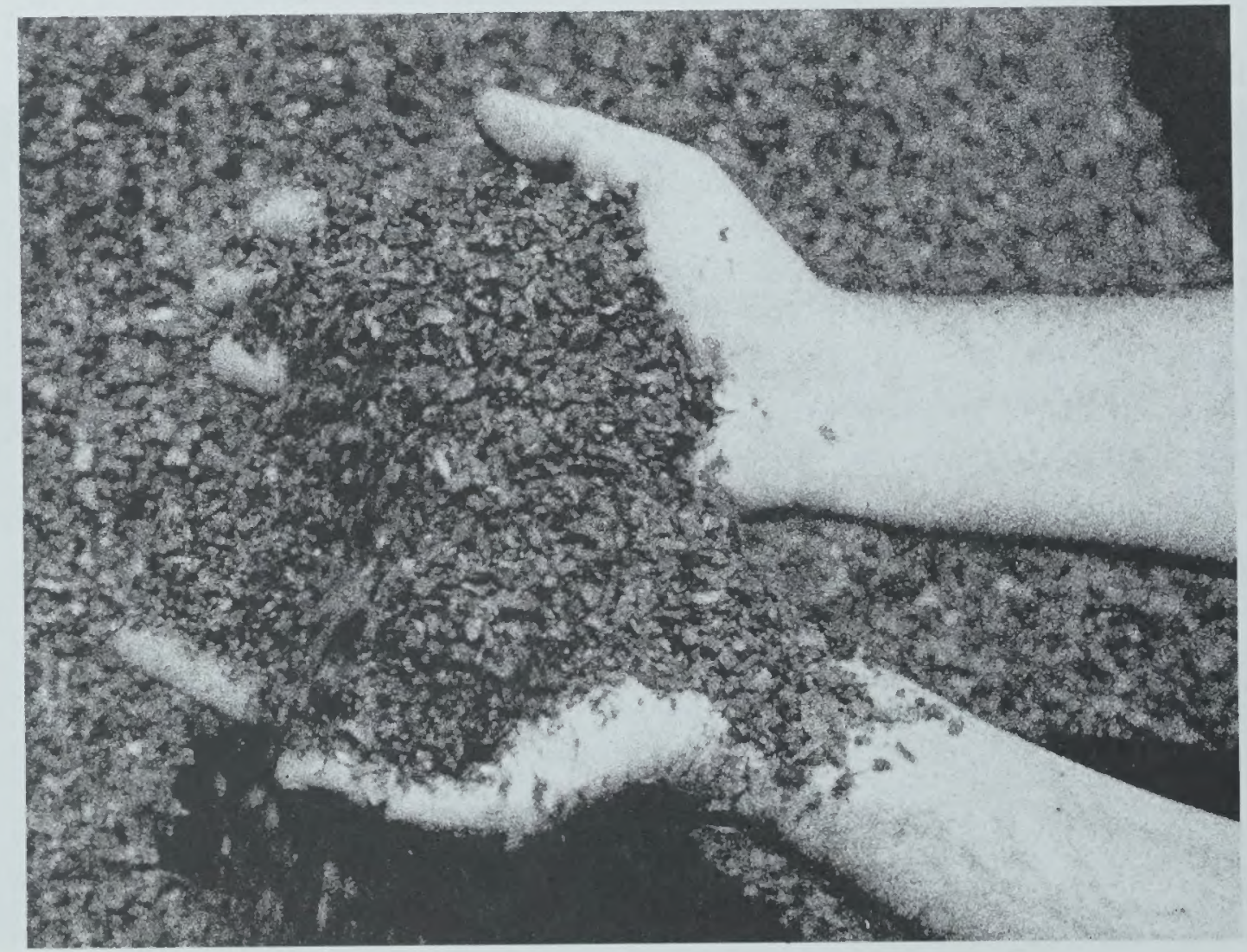

Bark ground to a uniform size, ready for drying 


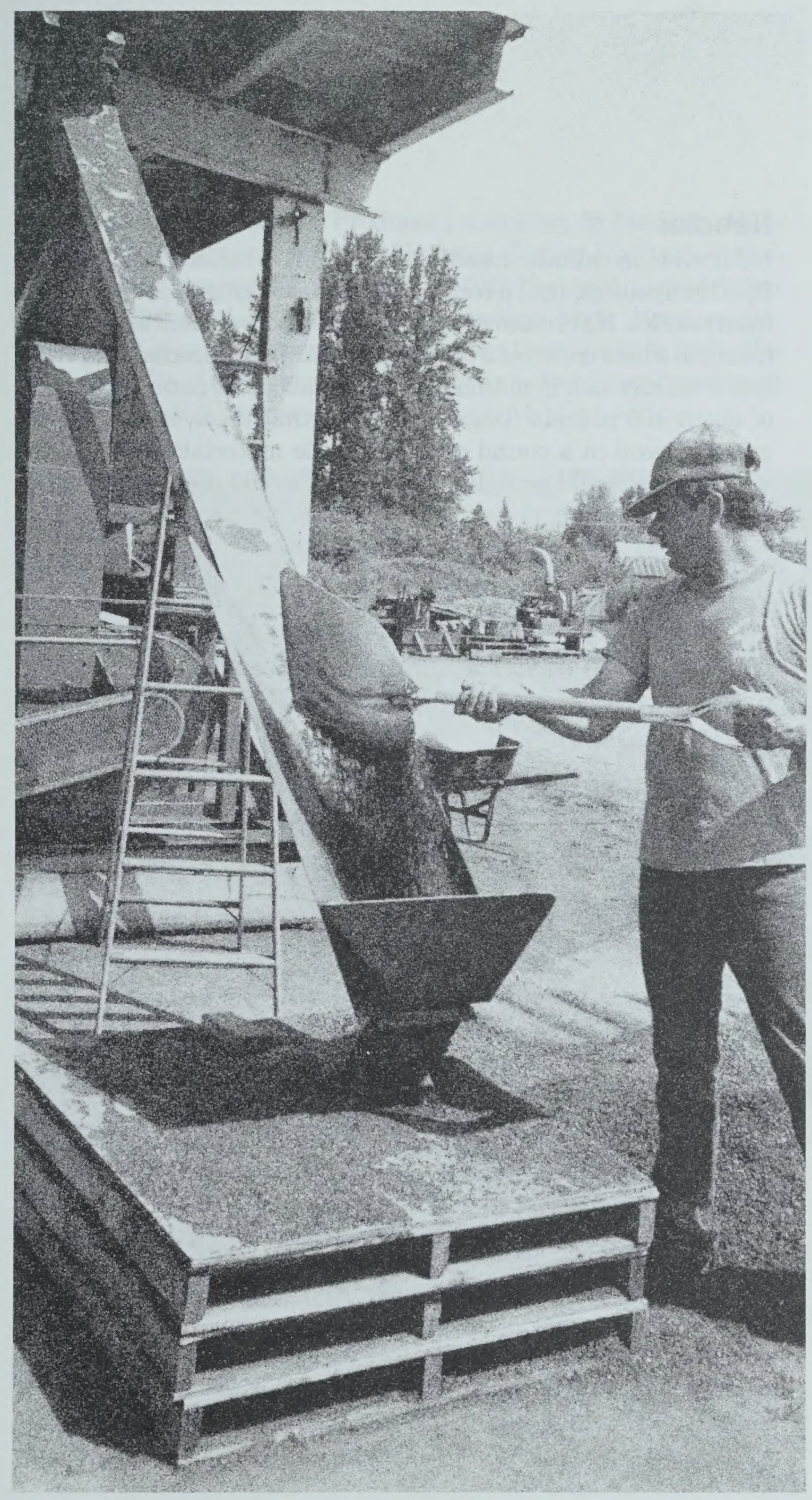

Part Three The Yew and People 


\section{Needles}

Information about needle collection comes from NaPro BioTherapeutics, Inc., a company that is working to produce taxol from needles. NaPro sampled branches selectively and also needles from the whole crown of a tree. NaPro estimates needles and twigs less than one inch in diameter to weigh about 80 pounds on a tree of about 400 pounds. Testing suggests that there is about 0.017 gram of taxol in a pound of dried needle material; however, the amount that could actually be produced would depend on factors such as harvesting, preservation, and extraction procedures.

\section{Wood}

Forest Service and BLM directions in February of 1992 called for all yew wood to be stored in a secure place after the bark was removed, in the eventuality that taxol could be extracted from the heartwood.

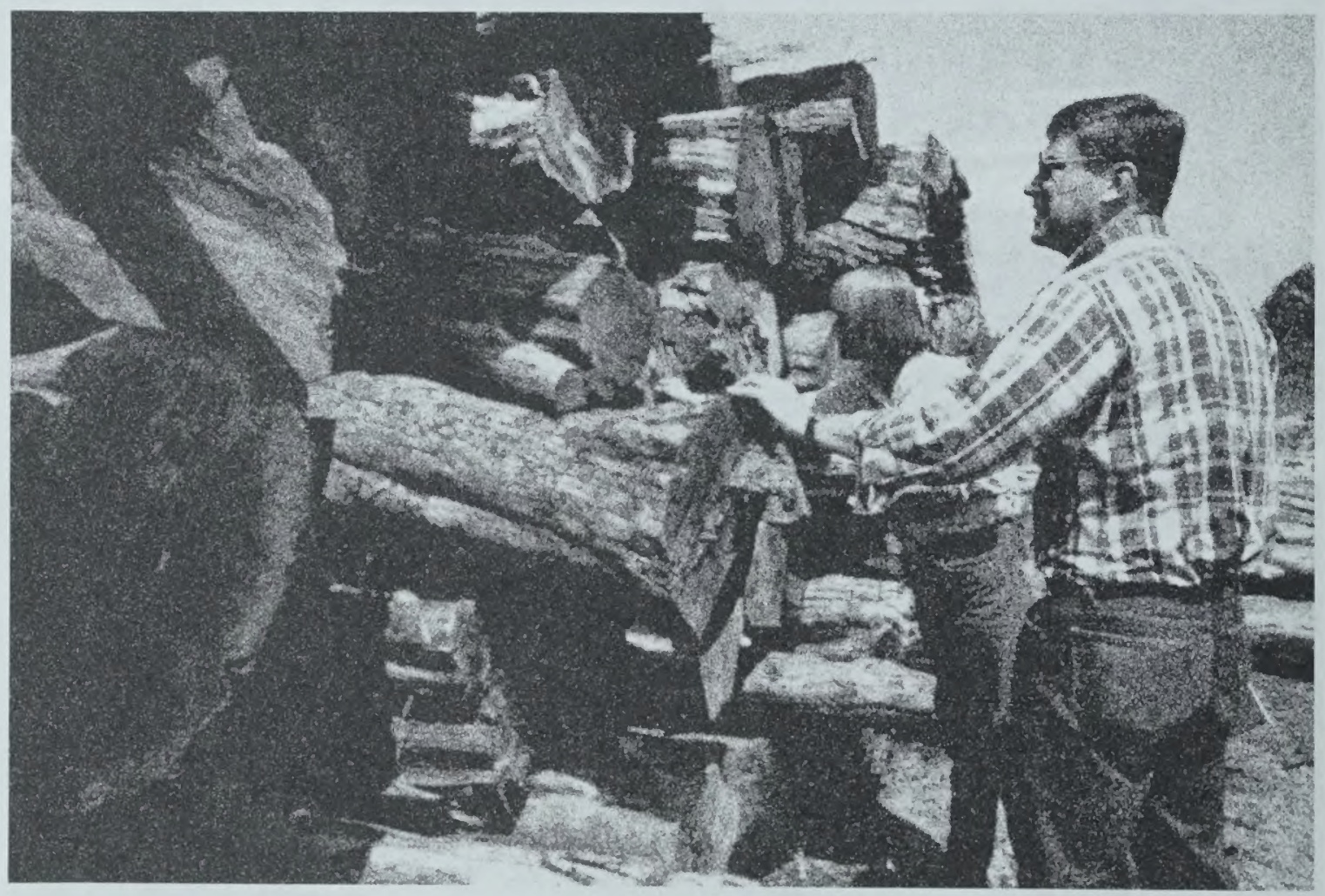

Stripped yew logs 
Researchers at the Forest Products Laboratory in Madison, Wisconsin, in cooperation with the National Cancer Institute, determined that there is approximately one-fifth the taxol concentration in the heartwood as in the corresponding bark. Because the heartwood is many times greater in mass than the thin bark, the initial results of studies suggested that up to ten times more taxol is present in the heartwood than in the bark of a yew tree.

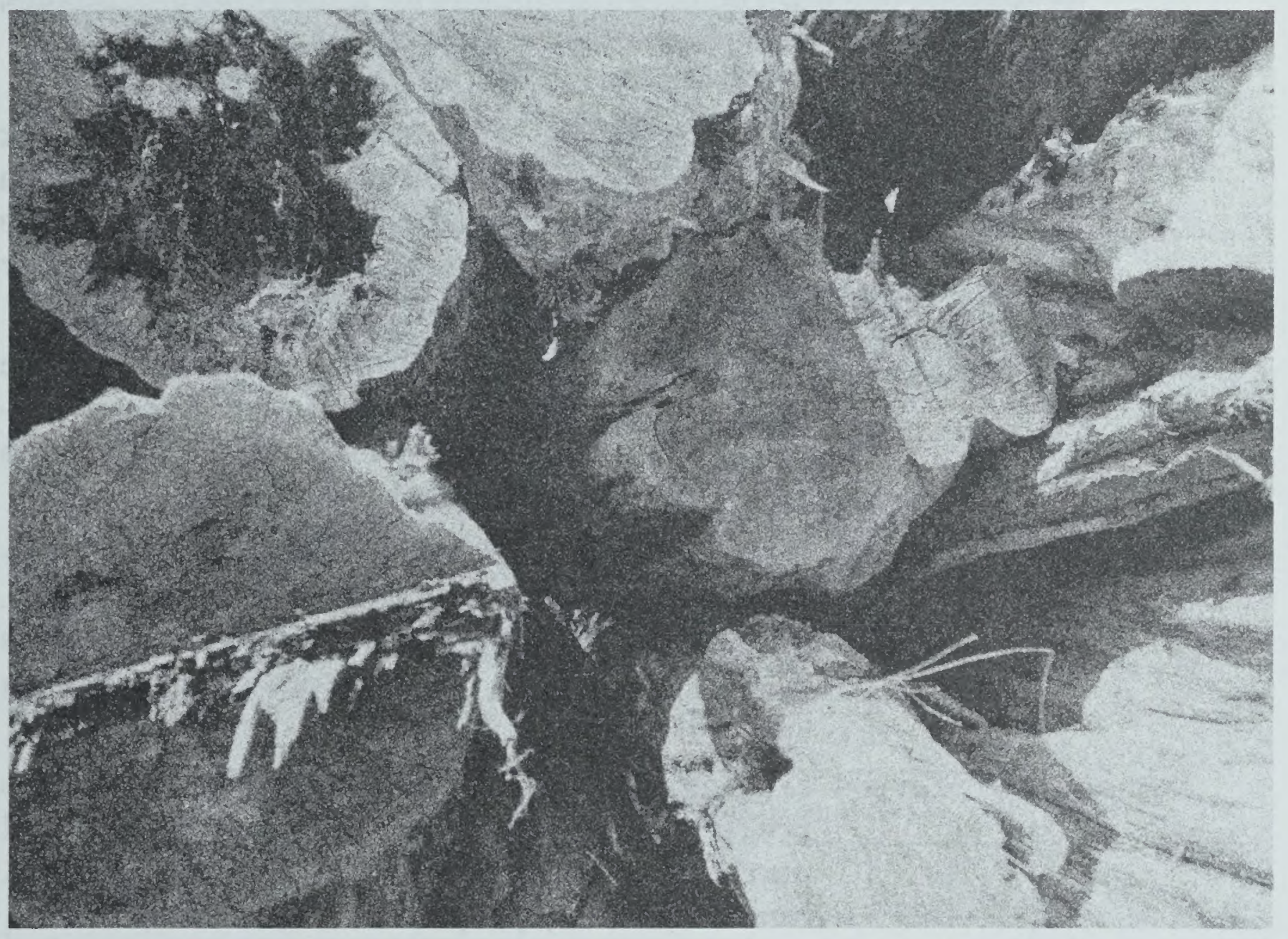

Ends of stripped logs show typical irregularities

Further research has shown, however, that there are many problems associated with the extraction of taxol from heartwood, and that these problems are not likely to be resolved in time to impact the supply of taxol prior to its availability from alternate sources. Therefore, the direction to save yew heartwood was subsequently rescinded in September of 1992. 


\section{Jobs}

\section{Bark Collection and Processing}

The interest in processing taxol from the bark of the Pacific yew tree has created jobs. Most of these jobs have been in the collection, harvest, or processing of yew bark. Hauser Chemical Research, Inc. of Boulder, Colorado, has an agreement with Bristol-Myers Squibb to collect bark and process it into taxol. Hauser has developed a four-level network for the collection and initial processing of bark. The network employs bark harvesters, collectors, processors, and logger-processors, who function as follows:

Level 1 Bark Harvesters: Bark harvesters form a network in a designated harvest area and remove bark from trees under supervision. Most of the work is done between May and August. Bark harvesters gather 50 to 300 pounds of wet bark daily.

Level 2 Bark Collectors: Collectors are assigned to specific geographic areas. Collectors supervise bark harvesters. They collect the peeled bark on a schedule and deliver it to a processor.

Level 3 Bark Processors: Processors receive bark from collectors and prepare it for extraction and shipment. To prepare bark, the processor chips, sizes, and dries it, then ships it to Hauser's processing plant in Colorado.

Level 4 Logging Operation/Bark Processors: Operators prelog Pacific yew in timber sales, salvage logs, and purchase logs from independent timber contractors, remove the bark, and process it as in Level 3 above.

\section{Labor Force and Earnings}

All of these jobs are filled by residents of the local communities where the work is located. These are mostly small rural towns where employment in natural resource industries is very important to the economic base. The average bark harvester earns $\$ 100$ to $\$ 150$ a day. Table III-14 shows employment by level during the 1991 harvesting season. 


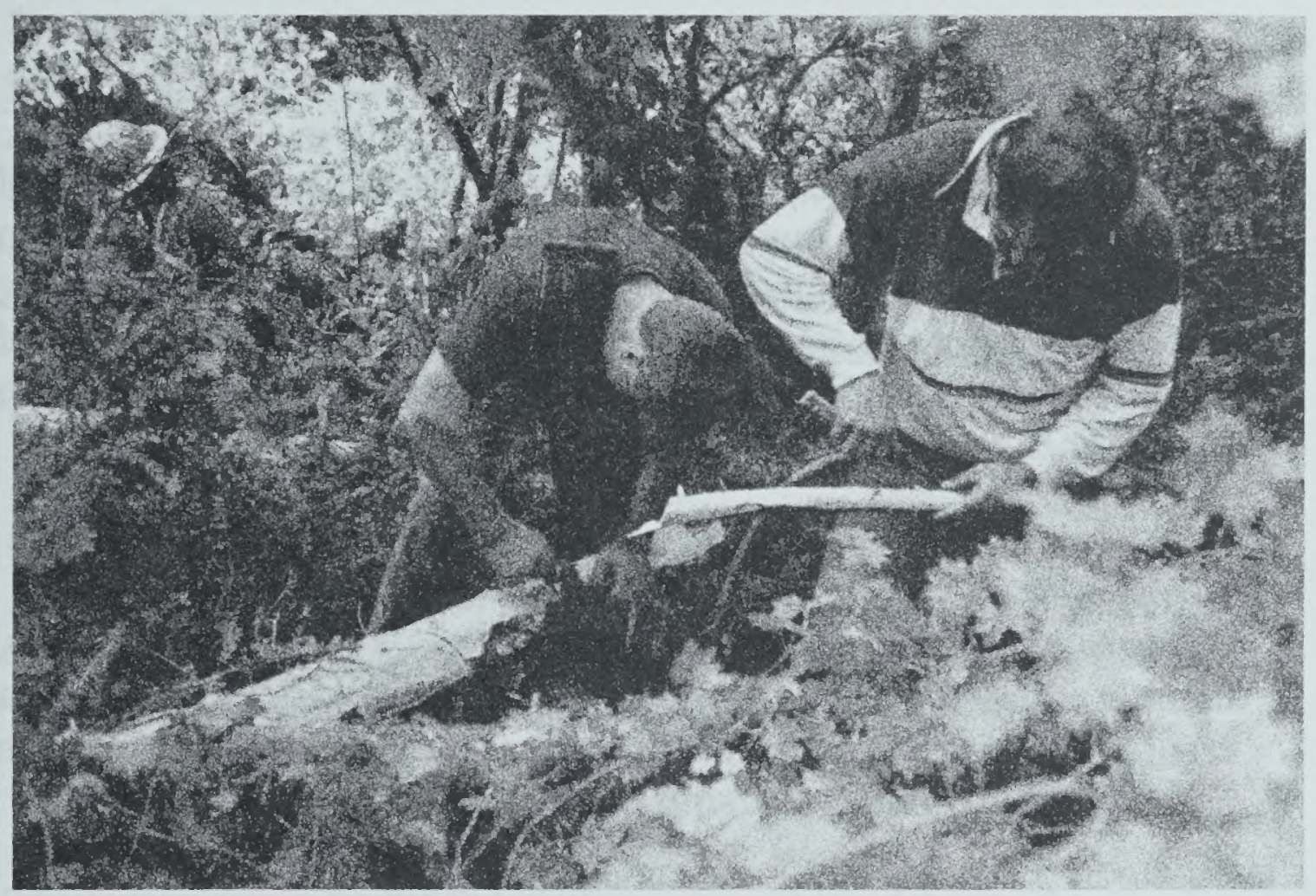

Three workers harvesting yew bark

Table III-15: Pacific Yew Bark Harvesting Employment in Oregon, Washington, Idaho, and Montana, 1991 (Total Jobs)

\begin{tabular}{|c|c|}
\hline Level & Total Jobs \\
\hline 1 & 550 \\
\hline 2 & 14 (approximately) \\
\hline 3 & 7 \\
\hline 4 & unknown \\
\hline
\end{tabular}

\section{Inventory Employment}

The interest in harvesting Pacific yew bark also created the need to do a detailed inventory of the species. The Forest Service and BLM is doing this inventory with funding from Bristol-Myers Squibb. Short-term employment was created for inventory crews during the summers of 1991 and 1992 . Over 150 people were employed on these crews. Some crew members come from local communities, while many are college students or others in search of temporary employment. 


\section{Public Health}

\section{Cancer and Taxol}

\section{Background}

This discussion owes much to the assistance of Linda Anderson of the National Cancer Institute (NCI). The drug taxol was thrown into the spotlight because of its apparent effectiveness in stopping certain types of cancers. Cancer is the second leading cause of death among Americans; 1,130,000 people are diagnosed with cancer each year, and 520,000 die of cancer.

\section{Definition}

Cancer is a general term that covers over 100 different diseases, usually characterized by unregulated cell growth. This cell growth creates tumors that move into organs of the body, destroying those organs and ultimately causing death.

\section{Detecting and Treating}

Some cancers are relatively easy to detect and treat, while others are more difficult. For example, many leukemias (cancer of the blood system) have high remission rates. Other cancers, including those for which taxol has shown much promise, are difficult to detect until the disease is in a late stage. This makes treatment difficult. Some cancers are easily detected through screening tests (such as colorectal, breast, and testicular cancer). Early detection is often crucial to successful cancer treatment.

\section{Taxol and Ovarian Cancer}

\section{Taxol}

The focus on taxol as an anticancer drug has been as a treatment for ovarian cancer, which affects women only. Other cancers may respond to taxol, and the drug has been tested on them to varying degrees. These include advanced breast cancer, head and neck cancer, gastro-intestinal cancer, lung cancer, and certain childhood cancers. 


\section{Detecting and Treating}

Each year 21,000 American women are diagnosed with ovarian cancer; each year 13,000 die from this disease. Women over 60 are at greatest risk of being diagnosed with ovarian cancer. There is no effective screening technique for ovarian cancer, therefore, a woman often does not know she is ill until symptoms appear. When diagnosed after the disease has spread, the five-year survival rate is 19 percent.

\section{Ovarian cancer is linked to heredity}

A woman who has a close female relative who had the disease has a greater chance of getting it herself. Women who are over 35 and who have never had children are also at greater risk.

\section{Approved Treatments}

There are a number of federally approved treatments for ovarian cancer; these vary in their effectiveness. Taxol is considered a promising treatment for ovarian cancer because in clinical tests, women who had not responded to other treatments responded to taxol treatment in about one-third of the cases.

\section{Status of Taxol}

\section{FDA Drug Approvals}

All drugs for human and veterinary use are approved for particular uses by the United States Food and Drug Administration, an agency of the Department of Health and Human Services. Taxol produced from the bark of the Pacific yew tree is in the process of being approved for commercial use in the treatment of ovarian cancer. (See the section on taxol and taxol pharmacology in this part of Chapter III and Appendix $\mathrm{K}$ for more information about taxol, sources of taxol, and FDA processes.)

\section{Current Uses and Clinical Trials}

Right now the drug is being used in clinical trials and for compassionate care treatment of patients with cancers that have not responded to other treatments. Clinical trials are used to establish a drug's effectiveness, and also to study possible side effects. In 
that way, health providers know how to safely use a drug after it is approved. Trials are limited to women who have failed to respond to three other approved treatments.

\section{Efficacy and Availability}

For information about demand, see the section addressing market and nonmarket-demand in this part of Chapter III and in Chapter IV. 
This section owes much to D.A. Tirmenstein's extensively-referenced 1990 compilation of information about Pacific yew for the Fire Effects Information System. For additional information, key citations from the original paper are listed in the reference section, although the Tirmenstein paper remains the original source document and is filed with the process records for this EIS. (Also see Appendix L.)

\section{Cultural Resources}

\section{Traditional Uses}

\section{American Indian}

Native Americans have, historically, used the yew wood and needles in various aspects of their lives. Probably the highest use
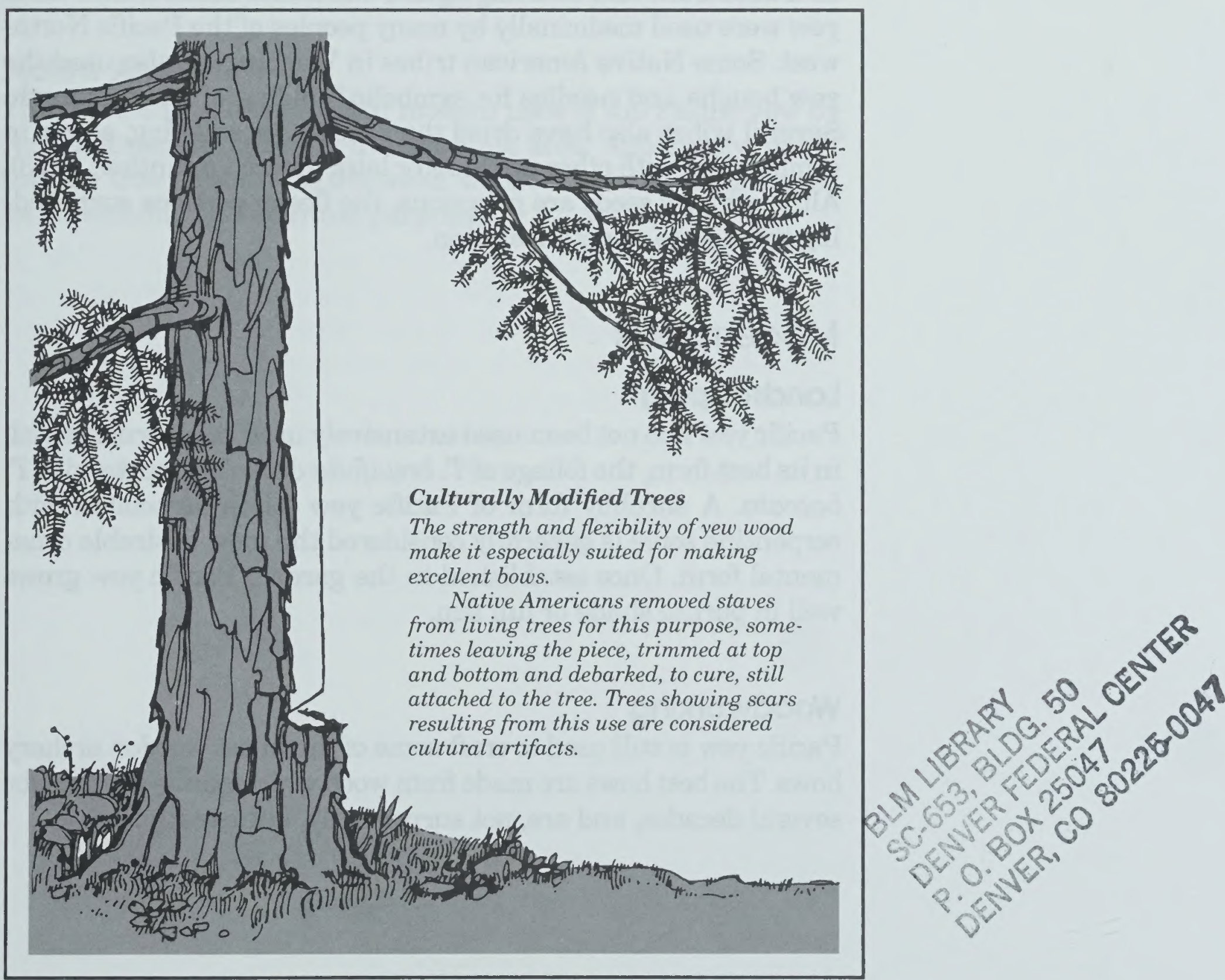
occurred along the coastal zones of Washington and British Columbia. It was here that uses were recorded for the manufacture of bows, arrows, harpoons, spear handles, paddles, war clubs, digging sticks, wedges, boxes, drums, spoons, dishes, cups, and bowls (Gunther, 1973; Hartzell, 1991; Heizer, 1978). Pacific yew is renowned for its value in making bows in native cultures from northern California to Canada and was formerly referred to as "bow plant" by the Salish People. Bows made from Pacific yew tended to be broad, short, and flat.

Some American Indian peoples traditionally associated Pacific yew with death and bereavement. The fragrant foliage was used as a deodorant and cleaning agent, and tonics made from Pacific yew were used medicinally by many peoples of the Pacific Northwest. Some Native American tribes in Washington also used the yew boughs and needles for symbolic building of body strength. Several tribes also have dried the needles for smoking, either in combination with other products or later tobacco. (Gunther, 1973). Although yew seeds are poisonous, the fleshy portions surrounding them were sometimes eaten.

\section{Modern Uses}

\section{Landscaping}

Pacific yew has not been used extensively used as an ornamental; in its best form, the foliage of $T$. brevifolia doesn't compete with $T$. baccata. A shrubby form of Pacific yew (often associated with serpentine soils) is generally considered the most desirable ornamental form. Once established in the garden, Pacific yew grows well in partial shade or full sun.

\section{Woodworking}

Pacific yew is still used to craft some of the finest wooden archery bows. The best bows are made from wood which has been cured for several decades, and are, not surprisingly, quite costly. 
This attractive wood is also used to make canoe paddles, tool handles, poles, lutes, and fence posts. It is valued as a wood for boat construction. It is sometimes used in carving, cabinet-making, and for turned articles, but up until its cancer-fighting properties were discovered, the tree had little commercial importance. For related information, see Market and Nonmarket Considerations in this chapter and in Chapter IV.

\section{Medicinal}

Pacific yew is used medicinally as a source for teas and tinctures in modern folk remedies and by naturopathic practitioners (see Appendix L).

\section{Native American}

There are only a few reported modern uses of the Pacific yew by Native American tribes in the five-state area. Apparently, use of the yew tree is related to the wood, which is in some cases carved for ceremonial and spiritual purposes. 


\section{Recreation}

\section{Settings}

\section{Who Went Where}

In 1991, around 150 to 170 million people visited national forests and Bureau of Land Management districts and resource areas within the natural range of the Pacific yew. The yew plays a small but important role in contributing to habitat, floral, and visual diversity. T. brevifolia has an in situ value, particularly in treeform.

Within the yew's range, the geographic settings people chose for their recreation varied dramatically, from the dunes of the Pacific coast to the rugged North Cascades; from the rain forest to the high desert fringe. Within this range of sites, they may have chosen quiet, private activities in remote places such as designated wilderness, or more social, accessible recreation at visitor centers and developed campgrounds.

\section{Definition of Setting}

A recreation "setting" results from a combination of the biological and physical surroundings, the social environment, and the management applied to an area. By altering the combinations of these three elements, it is possible to provide a continuum or spectrum of settings for recreationists that range from primitive, in Congressionally designated wilderness, to nearly urban, near metropolitan centers.

Pacific yew is an important midlevel component of the forests providing these recreational settings and contributes an important visual element in the diversity of settings.

\section{Relevance of Setting}

Research has shown that people choose a recreation setting from this continuum in order to realize a desired set of experiences. For example, camping in a large undeveloped setting with difficult access and few facilities offers a sense of solitude, challenge, and self-reliance. In contrast, camping in a setting having easy access and highly-developed facilities offers more comfort, security, and social opportunity. 


\section{Naturalness}

Whatever the category, naturalness of setting, including the Pacific yew, is important across the spectrum. While some level of alteration is acceptable in settings approaching the urban end of the spectrum (or which may be viewed from a distance or while traveling at some speed), in general, recreationists have shown a clear preference for natural conditions, and the value of the setting is usually ranked in direct proportion to its naturalness.

In addition, recent research in national forests is showing that naturalness and high visual quality are important. They are key factors in improving and maintaining the physical and mental well-being of visitors to public lands.

\section{Congressionally Designated Areas}

\section{Direction and Legislation}

Within the range of Pacific yew, a number of national recreation areas, national volcanic monuments, and an impressive selection of wild and scenic rivers and wildernesses have been designated by Congress. All are managed in accord with the establishing legislation. (See the section on Geographical Range in Chapter III, Part One: The Yew, for general information about land allocations and management direction.)

National Recreation Areas and Monuments are managed in accord with the establishing legislation, which typically sets aside an area with unique features - such as the sand dunes of the Oregon Dunes National Recreation Area or the volcanic landscape at Mount St. Helens National Volcanic Monument - for recreational and other values.

Depending on the intrinsic values of the area, and the scenic quality and type of recreation settings desired, harvest of yew trees and shrubs might be acceptable, depending on recreation settings desired, and the sensitivity of the scenic quality of the area. 
Wildernesses and Wild or Scenic Rivers are managed according to direction established in the original Congressional legislation, and comprehensive management plans.

Wildernesses are managed in accord with direction provided by the 1964 Wilderness Act: "in order to assure that an increasing population, accompanied by expanding settlement and growing mechanization, does not occupy and modify all areas within the United States... leaving no lands designated for preservation and protection in their natural condition..."

Harvesting yew bark, wood, or needles is not allowed in designated wilderness.

Wild and Scenic Rivers are managed in accord with The Wild and Scenic Rivers Act, which declares that it is the policy of the United States that certain selected rivers should be designated to preserve the river and the immediate environs in a "free-flowing condition," in contrast to the national policy of dams and other construction on rivers of the nation. Further, the "outstandingly remarkable values" and water quality of these rivers will be protected and enhanced.

Wild and scenic rivers are classified in one of three categories according to the level of development and modification of the river and its immediate environment. These categories are Wild, Scenic, and Recreational.

In a "Wild" river corridor, management emphasis is on maintaining natural conditions and visual quality.

Under most conditions, the harvest of yew bark, wood, or needles is not acceptable within this river classification.

In a "Scenic" or "Recreational" river corridor, a higher level of modification is permitted.

In these corridors, the harvest of yew trees or shrubs might be acceptable, depending on river management plan objectives and the need to protect the river and its immediate environment. 


\section{Research Natural Areas}

Research natural areas "...are part of a national network of ecological areas designated in perpetuity for research and education and/or to maintain biological diversity on National Forest System lands. Research natural areas are for nonmanipulative research, observation, and study. They also may assist in implementing the provisions of special acts, such as the Endangered Species Act and the monitoring provisions of the National Forest Management Act”. (Forest Service Manual 4063.)

In research natural areas, no harvest of yew wood, bark, or needles is allowed.

\section{Values and Activities}

\section{Traditional Values - Free Access}

Access on roads and trails to national forests, Bureau of Land Management (BLM) districts, and other public lands for recreation is a highly valued tradition, especially in the West. As the nation becomes more urban, these outdoor recreation opportunities, by virtue of their contrast with everyday life, become increasingly important to urban residents.

Forest visual quality, including the presence or absence of yew, can influence the quality of experience of traveling on these roads and trails.

\section{Traditional Values - Gathering}

Among the activities that might be considered recreational are a group of activities that might be described as gathering activities. They include looking for and collecting yew for native plant material for landscaping, for florist greens, medicinal uses, wooden musical instruments, turned work, kitchen utensils, furniture, boat building, bows, and carving/sculpture.

Gathering activities may also have spiritual implications for both Native and non-native Americans (see the Market and Nonmarket and Cultural Resources sections in this Chapter). 
Individuals involved in these gathering activities are often passionately interested in their activities which may be more of an avocation than a commercial activity. They tend to be very selective about the material they collect. For example, woodworkers who gather Pacific yew depend on finding the "right" tree with specific characteristics, such as a fine grain with few knots. These characteristics are found only in largersized, older trees (see Appendix L).

\section{Conflicts}

\section{All Kinds of Sites and Users}

Sometimes recreation or other resource activities - such as the harvest of Pacific yew - may conflict with what is needed to maintain a resource. For example, during breeding seasons for some species of wildlife, areas may be temporarily closed to vehicles or other forms of access.

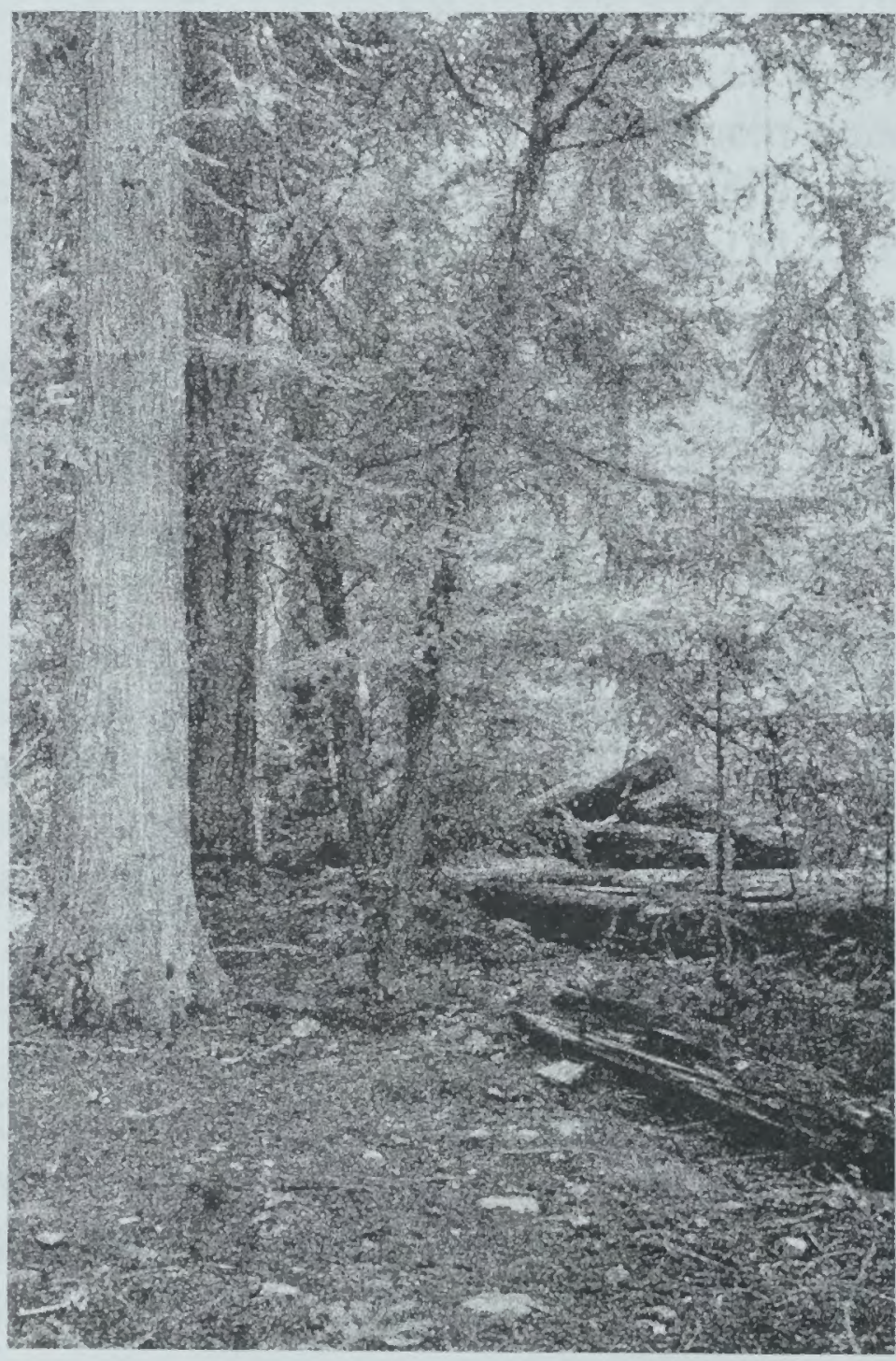




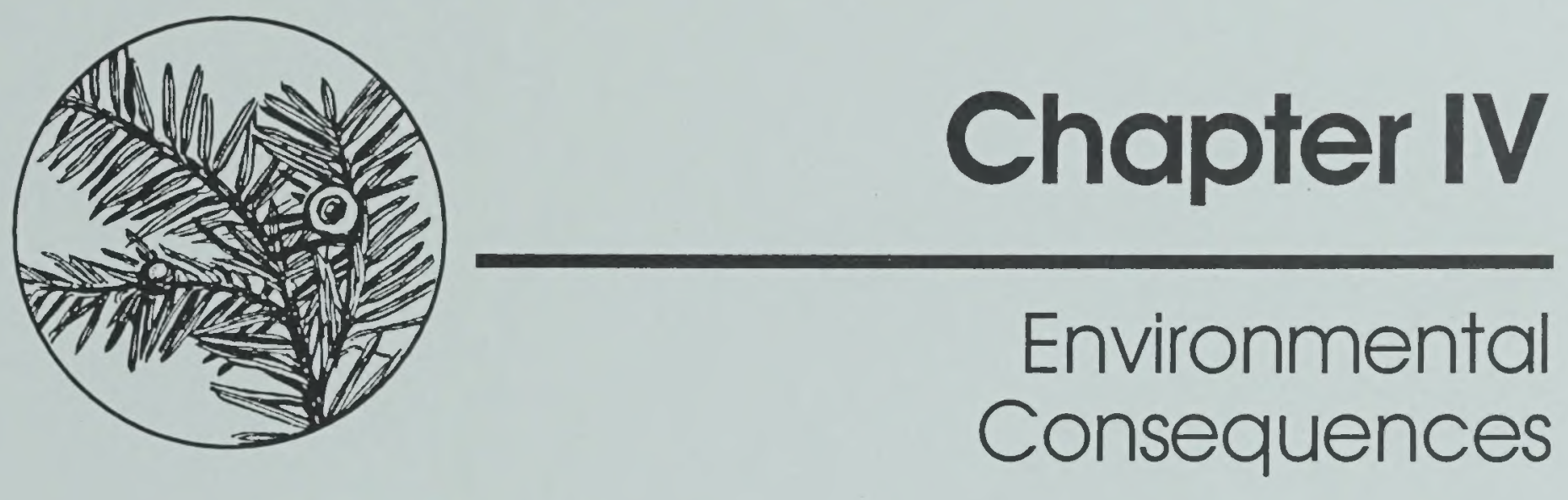





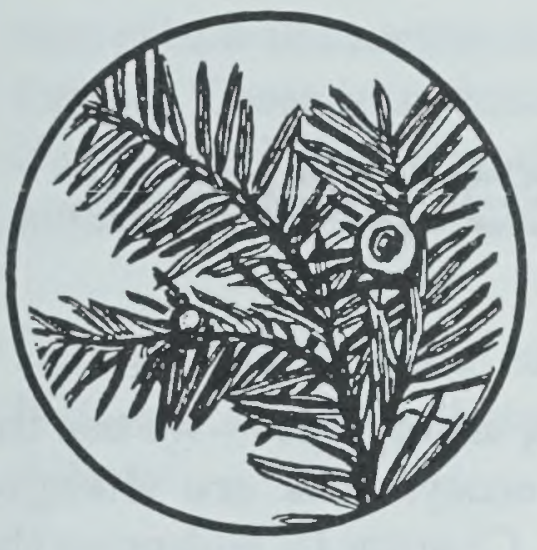

\section{Chapter IV Environmental Consequences}

\section{Part One: The Pacific Yew Table of Contents}

How This Chapter is Organized

Assumptions Forming the Basis for Estimating Environmental Effects

\section{Part One: The Pacific Yew}

Pacific Yew Population and Inventory

Population Estimation Methods

Impact of Yew Harvest on Yew

Populations

Projected Harvest of Yew Bark and Needles

Acres Available for Yew Harvest Effect of Inventory Error

Sustainability of Pacific Yew

The Alternatives
Biology of Pacific Yew

Effects Common to All the Alternatives The Alternatives

Genetics of the Pacific Yew

Terms to Know

The Alternatives

Role of Fire

Risk of Fire from Yew Harvest

The Alternatives

Survival of Yew Following Fre

The Alternatives

Insect and Disease Pests of Pacific Yew The Alternatives

Port-Orford-Cedar Root Disease 


\section{How This Chapter is Organized}

\section{Chapter IV Environmental Consequences}

Environmental consequences (or effects, or impacts - we use the terms interchangeably) occur when ecosystems are changed through management action or inaction. Chapter IV addresses the environmental consequences that could occur if the alternatives presented in this Environmental Impact Statement (EIS) are implemented. (The alternatives are presented in detail in Chapter II.) Under each alternative, the harvest of Pacific yew trees and shrubs on federal land would be managed in a different way. This chapter provides the basis for comparing effects in a summary presented in Chapter II.

This chapter opens with a discussion on the assumptions used to make these estimates.

After the opening, this chapter is arranged in three parts like Chapter III:

Part One: The Pacific Yew,

Part Two: The Forest, and

Part Three: The Yew and People

Note: Several Chapter III, Part Three sections have been merged under the main heading of "Social and Economic Effects" for Chapter IV.

These three major parts are followed by the Summary of Irretrievable and Irreversible Effects.

Within the three major parts, the description of consequences is organized by resource. The resource sections each open with an introduction providing background information, a brief discussion of related issues (see Chapter II and Appendix A), and an explana- 
tion of how the section is arranged if it deviates from the standard format. These introductions are followed by a discussion of what the direct, indirect, and cumulative effects would be under each alternative for that particular resource.

Direct, indirect, and cumulative effects are defined under the National Environmental Policy Act (40 CFR 1508.8 Effects) as follows:

Direct effects are caused by the action and occur at the same time and place.

Indirect effects are caused by the action and are later in time or farther removed in distance, but are still reasonably foreseeable.

Cumulative effects are the impacts on the environment which result from the incremental impact of the action when added to other past, present, and reasonably foreseeable future actions. Cumulative impacts can result from individually minor but collectively significant actions taking place over a period of time (40 CFR 1508.7). 

Assumptions
Forming the
Basis for
Estimating
Environmental
Effects

Environmental effects were estimated in many ways. Each interdisciplinary team member was responsible for estimating effects in their area of expertise. This analysis was based on scientific principles, research literature (which is limited at this point for the Pacific yew tree), and each team member's field experience. Team members also consulted with many experts in the Forest Service, BLM, National Cancer Institute, other agencies, and at universities and private consulting firms (see List of Preparers). Conclusions or statements that are not specifically referenced are professional opinions of the interdisciplinary team members responsible for that section.

Not much information is available about Pacific yew due to its previous low commercial value. Because of this dearth of information, our analysis also is based on several assumptions and guidelines.

\section{Assumptions and Guidelines}

The following assumptions and guidelines were used to develop the analyses in this EIS.

\section{Predictions of Effects}

Predictions of potential effects of the alternatives are based on current conditions, laws, policies, and trends, and represent a best professional estimate of reasonable foreseeable future actions. Unforeseen changes in these factors could result in different outcomes than those projected for this analysis.

\section{Yew Bark Emphasis in this Analysis}

In our analysis we concentrate more on the potential effects of yew bark harvest as opposed to needle harvest because this is the only raw material currently approved by the Food and Drug Administration as a source for taxol.

\section{Past, Present, and Future Timber Harvest}

Our analysis assumes that timber harvest levels have dropped significantly in the past 20 years and will continue to fall over the next five years, particularly for federal agencies; that clearcut size will continue to be relatively small in the foreseeable future; that 
timber harvest, especially within the central portions of the range of Pacific yew, will not completely remove yew from the site; and that yew will be regenerated and protected as a recognized tree species under forest and resource management plans.

\section{Timber Sales}

The amount of yew material available from timber sales is dependent on the federal timber sale program. The impact analysis for each alternative, as well as the calculations of amount of yew available, assumes a timber sale program equal to that described in forest plans and adjusted according to the FEIS for Management for the Northern Spotted Owl in the National Forests.

\section{Influence of Fire on Yew}

Historic fire patterns have affected the distribution of yew locally within its range; control of wildfire in the past fifty years, however, has probably allowed yew to extend its range. The reduced use of hot broadcast burns currently and in the foreseeable future will allow yew to better survive. Also, survival will improve on sites where cool burning is used for fuels reduction, vegetation management, and habitat conversion.

\section{Harvest of Yew on State and Private Lands}

The Pacific yew population on state and private lands in Oregon, Washington, and California is estimated to be about 10 million trees over one inch diameter breast height. These lands have provided an unspecified amount of yew bark, but probably in excess of 0.5 million pounds dry bark a year since 1991 . There are no overall protection and regeneration measures for yew on nonfederal lands, other than that afforded by NFMA, although some companies or states may have individual guidelines for yew conservation. We would expect more yew would be harvested from state and private lands if federal agencies do not have a bark harvest program. Otherwise, harvest of yew on nonfederal lands is projected to be similar to present harvest levels. 


\section{Other Forest Service and Bureau of Land Management Activities Affecting Yew}

Outside of yew harvest itself, timber harvest and the use of fire for site preparation or habitat modification are the activities that have had or will have the largest impact on Pacific yew. Other activities, such as road construction or the use of herbicides for vegetation control, will have minor or negligible impacts on yew overall. (The majority of road construction has been and will be associated with timber harvest).

\section{Past Yew Harvest}

Pacific yew has been harvested for taxol production in significant quantities only since 1991; prior to 1991, relatively insignificant amounts were taken from the woods for such things as fenceposts, firewood, woodworking, and Native American uses. The total amount removed from federal lands in 1991 and 1992 was approximately 1.6 million pounds of dry bark; the amount removed from state and private lands is estimated to be 1.3 million pounds dry bark. The yew inventories, completed in August 1992, accounted for yew harvested on federal lands prior to 1992.

\section{Short-ferm Demand}

Demand for Pacific yew from federal lands will taper off over the next five years as alternative sources are developed and become capable of meeting the demand for taxol.

\section{Processing Capacities}

Pacific yew processing plants currently have the capacity to process approximately $1,950,000$ pounds of bark per year.

\section{Funding}

The Forest Service will have the funding and workforce to implement the proposed action. 
This part of Chapter IV discusses environmental consequences of yew harvest on Pacific yew, from population and inventory to afflicting diseases. Topics include inventory efforts, genetics, regeneration, and the role of fire.

This section relates most directly to the issue of analyzing and establishing a suitable and sustainable level of harvest for taxol production. Here we present the best estimates of how much yew is present, what impact different harvest levels will have on the yew population, and how much material will be available for taxol production. We also discuss sustainability of harvest levels from both short-term and long-term viewpoints.

This section is organized somewhat differently than the other sections. It has a large amount of material that is displayed in tables - the numbers of yew trees available for harvest, the pounds of bark and needles that can be obtained from those trees, and the number of harvestable acres - for each of three inventoried areas. These tables and accompanying discussions are presented first and then the direct, indirect, and cumulative impacts for each alternative are summarized towards the end of the section.

\section{Population Estimation Methods}

Population estimates were developed from inventories conducted in seven national forests in Oregon and Washington, one national forest in Idaho, and the six BLM districts in western Oregon. These estimates were used as the basis for modeling the maximum number of trees that would be available for harvest and, therefore, the amount of available bark and needles for each alternative. For more information about the inventory and the modeling process see the "Pacific Yew Population and Inventory" section in Chapter III and Appendix F. 
The inventory modeling reduces the availability of the total estimated number of yew trees by two factors:

1. harvest area restrictions under each alternative and the percentage of harvest allowed, and

2. forest and area plan restrictions.

Reductions resulting from the alternatives include items such as: the percentage $(0 \%, 50 \%, 75 \%)$ of yew that can be harvested on a given acre in non-sale areas; leave tree requirements; genetic reserve requirements; and areas where harvest is not allowed according to the alternative (for example, owl conservation areas in Alternative B through G1 and non-sale areas in Alternative B).

Reductions resulting from forest and area plans include: areas where harvest activities are restricted such as wilderness, research natural areas, special interest areas, and the wild portion of wild and scenic rivers. Typically these types of restrictions have been mapped and/or quantified during the forest and area planning process. As a result, we were able to include them directly as constraints in the modeling process.

The site-specific analysis which will occur during project implementation is expected to make further reductions on the number of acres and trees that are available for yew harvest. Such things as raptor nests, threatened and endangered plants, and cultural sites will be located and must be protected. Also, less areas could be available due to timber sale injunctions, accessibility, areas with lower trees per acre than expected, and further restrictions from the spotted owl recovery plan. Previous forest and area plans did not quantify these reductions and consequently we cannot include them as constraints in the modeling process. However, they would likely be in the range of 50 percent to 25 percent. To display the fact that until site-specific analysis occurs we cannot guarantee how much bark will be available, we have chosen to show our estimates of final outputs in the form of a range. 


\section{Impact of Yew Harvest on Yew Populations}

The following tables show: (1) an estimate of the maximum yew trees available for harvest according to each alternative; and (2) the corresponding percent of yew trees that would be harvested from the total number of inventoried trees.

Table IV-1: The Impact of the Alternatives on the Estimated Yew Population-Combined National Forests and BLM Districts

\begin{tabular}{|c|c|c|c|c|}
\hline $\begin{array}{c}\text { Alterna- } \\
\text { tives }\end{array}$ & $\begin{array}{c}\text { Total Trees } \\
\text { in } \\
\text { Inventoried } \\
\text { Area* }\end{array}$ & $\begin{array}{c}\text { Trees } \\
\text { Available for } \\
\text { Harvest with } \\
\text { each } \\
\text { Alternative }\end{array}$ & $\begin{array}{c}\text { Trees Available } \\
\text { for Harvest with } \\
\text { each Alternative } \\
\mathbf{5 0 \% - 2 5 \%} \\
\text { Reduction }\end{array}$ & $\begin{array}{c}\text { Percent of } \\
\text { Total Trees } \\
\text { Harvested } \\
\mathbf{5 0 \% - 2 5 \% ~} \\
\text { Reduction }\end{array}$ \\
\hline A & $50.43 \mathrm{MM}$ & 0 & 0 & 0 \\
\hline B & $50.43 \mathrm{MM}$ & $.51 \mathrm{MM}$ & $.26-.38 \mathrm{MM}$ & $.51-76$ \\
\hline C & $50.43 \mathrm{MM}$ & $3.62 \mathrm{MM}$ & $1.81-2.72 \mathrm{MM}$ & $3.59-5.39$ \\
\hline D & $50.43 \mathrm{MM}$ & $5.76 \mathrm{MM}$ & $2.88-4.32 \mathrm{MM}$ & $5.71-8.57$ \\
\hline F & $50.43 \mathrm{MM}$ & $8.87 \mathrm{MM}$ & $4.44-6.66 \mathrm{MM}$ & $8.8-13.2$ \\
\hline G1 & $50.43 \mathrm{MM}$ & $6.79 \mathrm{MM}$ & $3.39-5.09 \mathrm{MM}$ & $6.73-10.1$ \\
\hline G2 & $50.43 \mathrm{MM}$ & $8.95 \mathrm{MM}$ & $4.47-6.71 \mathrm{MM}$ & $8.87-13.31$ \\
\hline
\end{tabular}

* > I" Diameter Breast Height (DBH) 
Table IV-2: The Impact of the Alternatives on Yew Populations in the Nez Perce National Forest, Idaho

\begin{tabular}{|c|c|c|c|c|}
\hline $\begin{array}{c}\text { Alterna- } \\
\text { tives }\end{array}$ & $\begin{array}{c}\text { Total Trees } \\
\text { in } \\
\text { Inventoried } \\
\text { Area* }\end{array}$ & $\begin{array}{c}\text { Trees } \\
\text { Available for } \\
\text { Harvest with } \\
\text { each } \\
\text { Alternative }\end{array}$ & $\begin{array}{c}\text { Trees Available } \\
\text { for Harvest with } \\
\text { each Alternative } \\
\text { 50\%-25\% } \\
\text { Reduction }\end{array}$ & $\begin{array}{c}\text { Percent of } \\
\text { Total Trees } \\
\text { Harvested } \\
\text { 50\%-25\% } \\
\text { Reduction }\end{array}$ \\
\hline A & $6.94 \mathrm{MM}$ & 0 & 0 & 0 \\
\hline B & $6.94 \mathrm{MM}$ & $.078 \mathrm{MM}$ & $.04-.06 \mathrm{MM}$ & $.56-.84$ \\
\hline C & $6.94 \mathrm{MM}$ & $1.20 \mathrm{MM}$ & $.6-.9 \mathrm{MM}$ & $8.65-12.97$ \\
\hline D & $6.94 \mathrm{MM}$ & $1.62 \mathrm{MM}$ & $.81-1.22 \mathrm{MM}$ & $11.67-17.51$ \\
\hline F & $6.94 \mathrm{MM}$ & $2.03 \mathrm{MM}$ & $1.02-1.52 \mathrm{MM}$ & $14.63-21.94$ \\
\hline G1 & $6.94 \mathrm{MM}$ & $1.62 \mathrm{MM}$ & $.81-1.22 \mathrm{MM}$ & $11.67-17.51$ \\
\hline G2 & $6.94 \mathrm{MM}$ & $1.62 \mathrm{MM}$ & $.81-1.22 \mathrm{MM}$ & $11.67-17.51$ \\
\hline
\end{tabular}

* >1" Diameter Breast Height (DBH)

Table IV-3: The Impact of the Alternatives on Yew Populations in Seven National Forests in Washington and Oregon

\begin{tabular}{|c|c|c|c|c|}
\hline $\begin{array}{c}\text { Alterna- } \\
\text { tives }\end{array}$ & $\begin{array}{c}\text { Total Trees } \\
\text { in } \\
\text { Inventoried } \\
\text { Area }\end{array}$ & $\begin{array}{c}\text { Trees } \\
\text { Available for } \\
\text { Harvest with } \\
\text { each } \\
\text { Alternative }\end{array}$ & $\begin{array}{c}\text { Trees Available } \\
\text { for Harvest with } \\
\text { each Alternative } \\
\mathbf{5 0 \% - 2 5 \%} \\
\text { Reduction }\end{array}$ & $\begin{array}{c}\text { Percent of } \\
\text { Total Trees } \\
\text { Harvested } \\
\text { 50\%-25\% } \\
\text { Reduction }\end{array}$ \\
\hline A & $41.40 \mathrm{MM}$ & 0 & 0 & 0 \\
\hline B & $41.40 \mathrm{MM}$ & $.39 \mathrm{MM}$ & $.2-.29 \mathrm{MM}$ & $.47-.71$ \\
\hline C & $41.40 \mathrm{MM}$ & $2.32 \mathrm{MM}$ & $1.16-1.74 \mathrm{MM}$ & $2.8-4.2$ \\
\hline D & $41.40 \mathrm{MM}$ & $3.98 \mathrm{MM}$ & $1.99-2.99 \mathrm{MM}$ & $4.81-7.21$ \\
\hline F & $41.40 \mathrm{MM}$ & $6.59 \mathrm{MM}$ & $3.3-4.94 \mathrm{MM}$ & $7.96-11.94$ \\
\hline G1 & $41.40 \mathrm{MM}$ & $4.95 \mathrm{MM}$ & $2.48-3.71 \mathrm{MM}$ & $5.98-8.97$ \\
\hline G2 & $41.40 \mathrm{MM}$ & $6.88 \mathrm{MM}$ & $3.44-5.16 \mathrm{MM}$ & $8.31-12.46$ \\
\hline
\end{tabular}

* $>1$ " Diameter Breast Height (DBH) 
Table IV-4: The Impact of the Alternatives on Yew Populations in BLM Districts, Western Oregon

\begin{tabular}{|c|c|c|c|c|}
\hline $\begin{array}{c}\text { Alterna- } \\
\text { tives }\end{array}$ & $\begin{array}{c}\text { Total Trees } \\
\text { in } \\
\text { Inventoried } \\
\text { Area* }\end{array}$ & $\begin{array}{c}\text { Trees } \\
\text { Available for } \\
\text { Harvest with } \\
\text { each } \\
\text { Alternative }\end{array}$ & $\begin{array}{c}\text { Trees Available } \\
\text { for Harvest with } \\
\text { each Alternative } \\
\mathbf{5 0 \% - 2 5 \%} \\
\text { Reduction }\end{array}$ & $\begin{array}{c}\text { Percent of } \\
\text { Total Trees } \\
\text { Harvested } \\
\mathbf{5 0 \% - 2 5 \%} \\
\text { Reduction }\end{array}$ \\
\hline A & $2.09 \mathrm{MM}$ & 0 & 0 & 0 \\
\hline B & $2.09 \mathrm{MM}$ & $.044 \mathrm{MM}$ & $.02-.03 \mathrm{MM}$ & $1.05-1.58$ \\
\hline C & $2.09 \mathrm{MM}$ & $.105 \mathrm{MM}$ & $.05-.08 \mathrm{MM}$ & $2.51-3.77$ \\
\hline D & $2.09 \mathrm{MM}$ & $.163 \mathrm{MM}$ & $.08-.12 \mathrm{MM}$ & $3.90-5.85$ \\
\hline F & $2.09 \mathrm{MM}$ & $.255 \mathrm{MM}$ & $.13-.19 \mathrm{MM}$ & $6.10-9.15$ \\
\hline G1 & $2.09 \mathrm{MM}$ & $.218 \mathrm{MM}$ & $.11-.16 \mathrm{MM}$ & $5.22-7.82$ \\
\hline G2 & $2.09 \mathrm{MM}$ & $.449 \mathrm{MM}$ & $.22-.34 \mathrm{MM}$ & $10.74-16.11$ \\
\hline
\end{tabular}

* > 1" Diameter Breast Height (DBH)

\section{Projected Harvest of Yew Bark and Needles}

The following tables show the maximum estimated amount of dry bark and needles that could be collected if each of the alternatives were implemented. The total tree numbers come from the inventory estimates. Available dry bark is based on estimates of pounds of bark produced by trees of given diameters. Needle amounts come from a conversion formula that relates pounds of needles to pounds of bark; this is based on a small sample and may be refined in the future. (Needle quantities are presented because an extraction process may be approved within the life of this EIS.)

The numbers presented in the tables below do not represent a target for the Forest Service or BLM; they only represent a maximum potential under the conditions of the alternatives, forest plans, and BLM resource management plans. 
Table IV-5: Maximum Bark Available for Harvest in National Forests and BLM Districts, Combined

\begin{tabular}{|c|c|c|c|c|}
\hline $\begin{array}{c}\text { Alter- } \\
\text { natives }\end{array}$ & $\begin{array}{c}\text { Total Trees } \\
\text { in } \\
\text { Inventoried } \\
\text { Areas* }\end{array}$ & $\begin{array}{c}\text { Maximum } \\
\text { Trees } \\
\text { Available for } \\
\text { Harvest }\end{array}$ & $\begin{array}{c}\text { Maximum } \\
\text { Pounds Dry } \\
\text { Bark }\end{array}$ & $\begin{array}{c}\text { Maximum } \\
\text { Pounds Dry Bark } \\
\text { with 50\%-25\% } \\
\text { Reduction }\end{array}$ \\
\hline A & $50.43 \mathrm{MM}$ & 0 & 0 & 0 \\
\hline B & $50.43 \mathrm{MM}$ & $.511 \mathrm{MM}$ & $2.60 \mathrm{MM}$ & $1.3-1.95$ \\
\hline C & $50.43 \mathrm{MM}$ & $3.62 \mathrm{MM}$ & $12.03 \mathrm{MM}$ & $6.01-9.02$ \\
\hline D & $50.43 \mathrm{MM}$ & $5.76 \mathrm{MM}$ & $19.63 \mathrm{MM}$ & $9.82-14.72$ \\
\hline F & $50.43 \mathrm{MM}$ & $8.87 \mathrm{MM}$ & $32.49 \mathrm{MM}$ & $16.25-24.37$ \\
\hline G1 & $50.43 \mathrm{MM}$ & $6.79 \mathrm{MM}$ & $31.50 \mathrm{MM}$ & $15.75-23.63$ \\
\hline G2 & $50.43 \mathrm{MM}$ & $8.95 \mathrm{MM}$ & $38.58 \mathrm{MM}$ & $19.29-28.94$ \\
\hline
\end{tabular}

* >1" Diameter Breast Height (DBH)

Table IV-6: Maximum Bark Available for Harvest in the Nez Perce National Forest in Idaho

\begin{tabular}{|c|c|c|c|c|}
\hline $\begin{array}{c}\text { Alter- } \\
\text { natives }\end{array}$ & $\begin{array}{c}\text { Total Trees } \\
\text { in } \\
\text { Inventoried } \\
\text { Areas* }\end{array}$ & $\begin{array}{c}\text { Maximum } \\
\text { Trees } \\
\text { Available for } \\
\text { Harvest }\end{array}$ & $\begin{array}{c}\text { Maximum } \\
\text { Pounds Dry } \\
\text { Bark }\end{array}$ & $\begin{array}{c}\text { Maximum } \\
\text { Pounds Dry Bark } \\
\text { with 50\%-25\% } \\
\text { Reduction }\end{array}$ \\
\hline A & $6.94 \mathrm{MM}$ & 0 & 0 & 0 \\
\hline B & $6.94 \mathrm{MM}$ & $.078 \mathrm{MM}$ & $.454 \mathrm{MM}$ & $.23-.34$ \\
\hline C & $6.94 \mathrm{MM}$ & $1.20 \mathrm{MM}$ & $3.82 \mathrm{MM}$ & $1.91-2.87$ \\
\hline D & $6.94 \mathrm{MM}$ & $1.62 \mathrm{MM}$ & $6.28 \mathrm{MM}$ & $3.14-4.71$ \\
\hline F & $6.94 \mathrm{MM}$ & $2.03 \mathrm{MM}$ & $8.74 \mathrm{MM}$ & $4.37-6.56$ \\
\hline G1 & $6.94 \mathrm{MM}$ & $1.62 \mathrm{MM}$ & $6.28 \mathrm{MM}$ & $3.14-4.71$ \\
\hline G2 & $6.94 \mathrm{MM}$ & $1.62 \mathrm{MM}$ & $6.28 \mathrm{MM}$ & $3.14-4.71$ \\
\hline
\end{tabular}

" >1" Diameter Breast Height (DBH) 
Table IV-7: Maximum Bark Available for Harvest in Seven National Forests in Washington and Oregon

\begin{tabular}{|c|c|c|c|c|}
\hline $\begin{array}{c}\text { Alter- } \\
\text { natives }\end{array}$ & $\begin{array}{c}\text { Total Trees } \\
\text { in } \\
\text { Inventoried } \\
\text { Area* }\end{array}$ & $\begin{array}{c}\text { Maximum } \\
\text { Trees } \\
\text { Available for } \\
\text { Harvest }\end{array}$ & $\begin{array}{c}\text { Maximum } \\
\text { Pounds Dry } \\
\text { Bark }\end{array}$ & $\begin{array}{c}\text { Maximum } \\
\text { Pounds Dry Bark } \\
\text { with 50\%-25\% } \\
\text { Reduction }\end{array}$ \\
\hline A & $41.40 \mathrm{MM}$ & 0 & 0 & 0 \\
\hline B & $41.40 \mathrm{MM}$ & $.389 \mathrm{MM}$ & $1.90 \mathrm{MM}$ & $.95-1.43$ \\
\hline C & $41.40 \mathrm{MM}$ & $2.32 \mathrm{MM}$ & $7.49 \mathrm{MM}$ & $3.75-5.62$ \\
\hline D & $41.40 \mathrm{MM}$ & $3.98 \mathrm{MM}$ & $12.43 \mathrm{MM}$ & $6.22-9.32$ \\
\hline F & $41.40 \mathrm{MM}$ & $6.59 \mathrm{MM}$ & $22.38 \mathrm{MM}$ & $11.19-16.79$ \\
\hline G1 & $41.40 \mathrm{MM}$ & $4.95 \mathrm{MM}$ & $23.72 \mathrm{MM}$ & $11.86-17.79$ \\
\hline G2 & $41.40 \mathrm{MM}$ & $6.88 \mathrm{MM}$ & $29.06 \mathrm{MM}$ & $14.53-21.8$ \\
\hline
\end{tabular}

* >1" Diameter Breast Height (DBH)

Table IV-8: Maximum Bark Available for Harvest in BLM Districts in Western Oregon

\begin{tabular}{|c|c|c|c|c|}
\hline $\begin{array}{c}\text { Alter- } \\
\text { natives }\end{array}$ & $\begin{array}{c}\text { Total Trees } \\
\text { in } \\
\text { Inventoried } \\
\text { Area* }\end{array}$ & $\begin{array}{c}\text { Maximum } \\
\text { Trees } \\
\text { Available for } \\
\text { Harvest }\end{array}$ & $\begin{array}{c}\text { Maximum } \\
\text { Pounds Dry } \\
\text { Bark }\end{array}$ & $\begin{array}{c}\text { Maximum } \\
\text { Pounds Dry Bark } \\
\text { with 50\%-25\% } \\
\text { Reduction }\end{array}$ \\
\hline A & $2.08 \mathrm{MM}$ & 0 & 0 & 0 \\
\hline B & $2.08 \mathrm{MM}$ & $.044 \mathrm{MM}$ & $.247 \mathrm{MM}$ & $.12-.19$ \\
\hline C & $2.08 \mathrm{MM}$ & $.105 \mathrm{MM}$ & $.715 \mathrm{MM}$ & $.36-.54$ \\
\hline D & $2.08 \mathrm{MM}$ & $.162 \mathrm{MM}$ & $.922 \mathrm{MM}$ & $.46-.69$ \\
\hline F & $2.08 \mathrm{MM}$ & $.255 \mathrm{MM}$ & $1.37 \mathrm{MM}$ & $.69-1.03$ \\
\hline G1 & $2.08 \mathrm{MM}$ & $.218 \mathrm{MM}$ & $1.50 \mathrm{MM}$ & $.75-1.13$ \\
\hline G2 & $2.08 \mathrm{MM}$ & $.449 \mathrm{MM}$ & $3.24 \mathrm{MM}$ & $1.62-2.43$ \\
\hline
\end{tabular}

* > 1" Diameter Breast Height (DBH) 
Table IV-9: Maximum Needles Available for Yew Harvest in National Forests and BLM Districts, Combined

\begin{tabular}{|c|c|c|c|}
\hline \multirow[b]{2}{*}{ Alternatives } & \multirow[b]{2}{*}{$\begin{array}{c}\text { Maximum } \\
\text { Pounds Dry Bark }\end{array}$} & \multicolumn{2}{|c|}{ Maximum Pounds Dry Needles* } \\
\hline & & $\begin{array}{c}\text { From whole tree } \\
\text { harvest in sale } \& \\
\text { non-sale areas } \\
\end{array}$ & $\begin{array}{l}\text { From whole tree harvest } \\
\text { in sale areas } \& \text { as only } \\
\text { product in non-sale areas }\end{array}$ \\
\hline $\mathbf{A}$ & 0 & 0 & 0 \\
\hline B & $2.60 \mathrm{MM}$ & $6.94 \mathrm{MM}$ & $6.94 \mathrm{MM}$ \\
\hline $\mathrm{C}$ & $12.03 \mathrm{MM}$ & $32.11 \mathrm{MM}$ & $19.53 \mathrm{MM}$ \\
\hline D & $19.63 \mathrm{MM}$ & $54.19 \mathrm{MM}$ & $29.68 \mathrm{MM}$ \\
\hline$F$ & $32.49 \mathrm{MM}$ & 86.74 MM & $46.84 \mathrm{MM}$ \\
\hline G1 & $31.50 \mathrm{MM}$ & $84.11 \mathrm{MM}$ & $45.53 \mathrm{MM}$ \\
\hline G2 & $38.58 \mathrm{MM}$ & 103.01 MM & $54.98 \mathrm{MM}$ \\
\hline
\end{tabular}

\section{Acres Available for Yew Harvest}

The following tables show the maximum number of acres that would be entered for yew harvest according to each alternative. The differences between alternatives reflect whether the alternative allows yew harvest in timber sale areas only, includes nonsale areas, includes owl conservation areas, and account for reductions of acres available for harvest according to forest and area plans. 
Table IV-10: Maximum Acres Available for Yew Harvest in National Forests and BLM Districts, Combined

\begin{tabular}{|c|c|c|c|}
\hline $\begin{array}{c}\text { Alter- } \\
\text { natives }\end{array}$ & $\begin{array}{c}\text { Total Acres in } \\
\text { Inventoried Area }\end{array}$ & $\begin{array}{c}\text { Maximum Acres } \\
\text { Available for } \\
\text { Harvest }\end{array}$ & $\begin{array}{c}\text { Maximum Acres } \\
\text { Available for } \\
\text { Harvest } \\
\mathbf{5 0 \% - 2 5 \%} \\
\text { Reduction }\end{array}$ \\
\hline A & $7.60 \mathrm{MM}$ & 0 & 0 \\
\hline B & $7.60 \mathrm{MM}$ & $.157 \mathrm{MM}$ & $.078-.118$ \\
\hline C & $7.60 \mathrm{MM}$ & $2.93 \mathrm{MM}$ & $1.47-2.2$ \\
\hline D & $7.60 \mathrm{MM}$ & $2.93 \mathrm{MM}$ & $1.47-2.2$ \\
\hline F & $7.60 \mathrm{MM}$ & $2.93 \mathrm{MM}$ & $1.47-2.2$ \\
\hline G1 & $7.60 \mathrm{MM}$ & $2.93 \mathrm{MM}$ & $1.47-2.2$ \\
\hline G2 & $7.60 \mathrm{MM}$ & $4.62 \mathrm{MM}$ & $2.31-3.47$ \\
\hline
\end{tabular}

Table IV-11: Maximum Acres Available for Yew Harvest in the Nez Perce National Forest in Idaho

\begin{tabular}{|c|c|c|c|}
\hline $\begin{array}{c}\text { Alter- } \\
\text { natives }\end{array}$ & $\begin{array}{c}\text { Total Acres in } \\
\text { Inventoried Area }\end{array}$ & $\begin{array}{c}\text { Maximum Acres } \\
\text { Available for } \\
\text { Harvest }\end{array}$ & $\begin{array}{c}\text { Maximum Acres } \\
\text { Available for } \\
\text { Harvest } \\
\mathbf{5 0 \% - 2 5 \%} \\
\text { Reduction }\end{array}$ \\
\hline A & $136,310 \mathrm{MM}$ & 0 & 0 \\
\hline B & $136,310 \mathrm{MM}$ & $3,070 \mathrm{MM}$ & $1,535-2,303$ \\
\hline C & $136,310 \mathrm{MM}$ & $67,870 \mathrm{MM}$ & $33,935-50,903$ \\
\hline D & $136,310 \mathrm{MM}$ & $67,870 \mathrm{MM}$ & $33,935-50,903$ \\
\hline F & $136,310 \mathrm{MM}$ & $67,870 \mathrm{MM}$ & $33,935-50,903$ \\
\hline G1 & $136,310 \mathrm{MM}$ & $67,870 \mathrm{MM}$ & $33,935-50,903$ \\
\hline G2 & $136,310 \mathrm{MM}$ & $67,870 \mathrm{MM}$ & $33,935-50,903$ \\
\hline
\end{tabular}


Table IV-12: Maximum Acres Available for Yew Harvest in Seven National Forests in Washington and Oregon

\begin{tabular}{|c|c|c|c|}
\hline $\begin{array}{c}\text { Alter- } \\
\text { natives }\end{array}$ & $\begin{array}{c}\text { Total Acres in } \\
\text { Inventoried Area }\end{array}$ & $\begin{array}{c}\text { Maximum Acres } \\
\text { Available for } \\
\text { Harvest }\end{array}$ & $\begin{array}{c}\text { Maximum Acres } \\
\text { Available for } \\
\text { Harvest } \\
\text { 50\%-25\% } \\
\text { Reduction }\end{array}$ \\
\hline A & $5.43 \mathrm{MM}$ & 0 & 0 \\
\hline B & $5.43 \mathrm{MM}$ & $.092 \mathrm{MM}$ & $.045-.069$ \\
\hline C & $5.43 \mathrm{MM}$ & $2.18 \mathrm{MM}$ & $1.09-1.64$ \\
\hline D & $5.43 \mathrm{MM}$ & $2.18 \mathrm{MM}$ & $1.09-1.64$ \\
\hline F & $5.43 \mathrm{MM}$ & $2.18 \mathrm{MM}$ & $1.09-1.64$ \\
\hline G1 & $5.43 \mathrm{MM}$ & $2.18 \mathrm{MM}$ & $1.09-1.64$ \\
\hline G2 & $5.43 \mathrm{MM}$ & $3.14 \mathrm{MM}$ & $1.57-2.36$ \\
\hline
\end{tabular}

Table IV-13: Maximum Acres Available for Yew Harvest in BLM Districts in Western Oregon

\begin{tabular}{|c|c|c|c|}
\hline $\begin{array}{c}\text { Alter- } \\
\text { natives }\end{array}$ & $\begin{array}{c}\text { Total Acres in } \\
\text { Inventoried Area }\end{array}$ & $\begin{array}{c}\text { Maximum Acres } \\
\text { Available for } \\
\text { Harvest }\end{array}$ & $\begin{array}{c}\text { Maximum Acres } \\
\text { Available for } \\
\text { Harvest } \\
\text { 50\%-25\% } \\
\text { Reduction }\end{array}$ \\
\hline A & $5.43 \mathrm{MM}$ & 0 & 0 \\
\hline B & $5.43 \mathrm{MM}$ & $.092 \mathrm{MM}$ & $.045-.069$ \\
\hline C & $5.43 \mathrm{MM}$ & $2.18 \mathrm{MM}$ & $1.09-1.64$ \\
\hline D & $5.43 \mathrm{MM}$ & $2.18 \mathrm{MM}$ & $1.09-1.64$ \\
\hline F & $5.43 \mathrm{MM}$ & $2.18 \mathrm{MM}$ & $1.09-1.64$ \\
\hline G1 & $5.43 \mathrm{MM}$ & $2.18 \mathrm{MM}$ & $1.09-1.64$ \\
\hline G2 & $5.43 \mathrm{MM}$ & $3.14 \mathrm{MM}$ & $1.57-2.36$ \\
\hline
\end{tabular}




\section{Effect of Inventory Error}

The sampling errors associated with the inventories are fairly large for individual plot data, due primarily to the unevenness of yew stocking and distribution over the inventoried landscape. There is also error associated with modeling the available acres, trees, bark, and needles but it cannot be statistically quantified. Therefore the amount of available needles and bark that are presented in the tables above may, in reality, be greater or less because of both sampling and modeling error.

\section{Sustainability of Pacific Yew}

Sustainability of Pacific yew can be defined two ways - sustainability of the species and sustainable yield of the product, in this case, yew bark or needles used to make taxol.

\section{Sustainability of the species/population}

The ability of Pacific yew to maintain a viable dynamic population depends on its ability to successfully reproduce and to adapt to changes in its environment (see the Biology and Genetics sections in this Chapter). Forest management directly influences yew survival, depending on efforts taken to protect and regenerate it. The Interim guide was designed to provide protection measures that guarantee a self-sustaining population. 


\section{Sustainable Yield}

Sustainable yield in the forest can be looked at in several ways. The flow of bark or wood can be uneven, where large quantities are produced over a short time, and then nothing for a long time, until the species has regained its lost volume or regenerated its lost portion of the population. The flow can also be even, producing a small quantity each year for a long period of time, often in perpetuity; this is the more conventional view of sustainable yield.

This EIS addresses a five-year harvest program. Until other sources can provide sufficient quantities of taxol, the harvest of Pacific yew in the wild can provide an uneven-flow short-term source of taxol for the treatment of various cancers.

Each proposed alternative shows a maximum amount of yew available for harvest to be gathered in a five-year period. This is an uneven-flow program. Additional yew harvest could not occur until new trees reached the desired size for harvesting. We are making the assumption that 100 years would produce a tree size that could be harvested. However, this could change if the maximum amount of trees was not harvested in the five-year period, or if the tree size desired was different than size reached in 100 years.

A long-term, even-flow harvest of the total available bark over 100 years would be approximately 1.48 million pounds a year. (See sustainable yield calculation in Appendix F.) Figure IV-1 graphically displays the maximum pounds of bark that would be available if each alternative was implemented. It also contrasts the five-year harvest of the alternatives with a 100-year even-flow harvest level. 
Figure IV-1: Uneven and Even Flow of Pacific Yew Harvest

Maximum Pounds of Yew Bark Available for Harvest (Per Year)

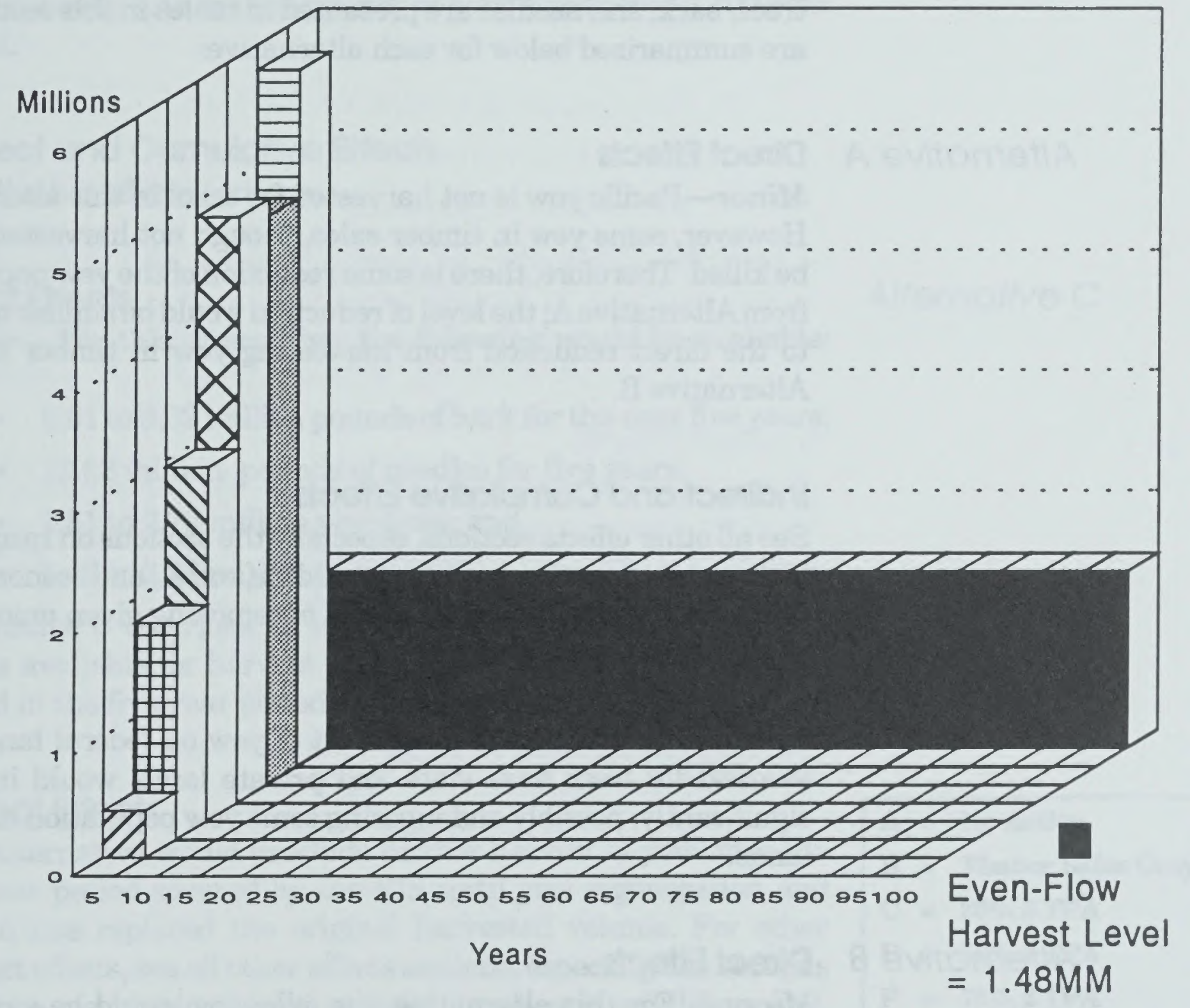

Alternatives

$\square \mathrm{A}=\mathrm{OMM}$

$\bigotimes B=.26$ to $.39 M M$ $\unrhd \mathrm{C}=1.2$ to $1.8 \mathrm{MM}$

Note: The bar graph shows the maximum of the ranges. The numbers are yearly figures derived from the values in the far right column of table IV-5. 


\section{The Alternatives}

We are basing the analysis of effects on the maximum allowable number of yew trees that, according to each alternative, would be harvested and removed from the ecosystem. The numbers of acres, trees, bark, and needles are presented in tables in this section and are summarized below for each alternative:

\section{Alternative A DirectEffects}

Minor-Pacific yew is not harvested for taxol in this alternative. However, some yew in timber sales, though not harvested, could be killed. Therefore, there is some reduction of the yew population from Alternative A; the level of reduction would be similar or lower to the direct reduction from harvesting yew in timber sales in Alternative B.

\section{Indirect and Cumulative Effects}

See all other effects sections, especially the sections on range, yew biology, yew genetics, landscape, wildlife, social, and economics for the indirect and cumulative effects of removing given amounts of yew from the ecosystem.

Because there would be no harvest of yew on federal lands, the demand for bark from state and private lands would increase significantly, possibly endangering some yew population on those lands.

\section{Alternative $B$ Direct Effects}

Minor-For this alternative, the following would be available:

- 1.30 to 1.95 million pounds of bark for the next five years;

- 6.94 million pounds of needles for five years;

- 0.26 to 0.38 million yew trees; and

- 0.078 to 0.118 million acres.

The actual amount of yew harvested each year will vary depending on the amount of yew present in the scheduled timber sales. [We recognize that timber species and yew do not necessarily have 
the same rotation age and therefore may have different sustainable harvest rates].

This alternative is closest to the even-flow rate of harvest of approximately 1.48 million pounds of bark a year over a 100 -year period.

\section{Indirect and Cumulative Effects}

See all other effects sections.

\section{Direct Effects}

Minor-For this alternative, the following would be available:

- 6.01 to 9.02 million pounds of bark for the next five years;

- 19.53 million pounds of needles for five years;

- 1.81 to 2.72 million yew trees; and

- 1.47 to 2.20 million acres.

Alternative $\mathrm{C}$ describes an uneven-flow rate of harvest. All yew that is available for harvest under this alternative could be harvested in the five-year period covered by this EIS.

\section{Indirect Effects}

This alternative would preclude further harvest of yew after the five-year period covered by the EIS until yew regeneration and growth has replaced the original harvested volume. For other indirect effects, see all other effects sections, especially the sections on range, yew biology, yew genetics, landscape, wildlife, social, and economics.

\section{Cumulative Effects}

See all other effects sections.
Alternative C
$A=$ No Action
B = Timber Sales Only
$\mathrm{C}=25 \%, 5$ TPA
$\mathrm{D}=50 \%, 5$ TPA
$\mathbf{F}=75 \%, 2$ TPA
G1 = 50\%, 0 TPA,
G2 = 50\%, 0 TPA, OCAs
TPA is the minimum number of trees left standing per acre 


\section{Alternative D Direct Effects}

Moderate - For this alternative, the following would be available:

- 9.82 to 14.72 million pounds of bark for the next five years;

- 29.68 pounds of needles for five years;

- 2.88 to 4.32 million yew trees; and

- 1.47 to 2.20 million acres.

Alternative $\mathrm{D}$ describes an uneven-flow rate of harvest. All yew that is available for harvest under this alternative could be harvested in the five-year period covered by this EIS.

\section{Indirect Effects}

This alternative would preclude further harvest of yew after the five-year period covered by the EIS until yew regeneration and growth has replaced the original harvested volume. For other indirect effects, see all other effects sections.

\section{Cumulative Effects}

See all other effects sections.

Alternative $F$

\section{Direct Effects}

Moderate- For this alternative, the following would be available:

- 16.25 to 24.37 million pounds of bark for the next five years;

- 46.84 million pounds of needles for five years;

- 4.44 to 6.66 million yew trees; and

- 1.47 to 2.20 million acres.

Alternative $\mathrm{F}$ describes an uneven-flow rate of harvest. All yew that is available for harvest under this alternative could be harvested in the five-year period covered by this EIS. 


\section{Indirect Effects}

This alternative would preclude further harvest of yew after the five-year period covered by the EIS until yew regeneration and growth has replaced the original harvested volume. For other indirect effects, see all other effects sections, especially the sections on range, yew biology, yew genetics, landscape, wildlife, social, and economics.

\section{Cumulative Effects}

See all other effects sections.

\section{Direct Effects}

Moderate - For this alternative, the following would be available:

- 15.75 to 23.63 million dry pounds of bark for the next five years;

- 45.53 million pounds of needles for five years;

- 3.39 to 5.09 million yew trees; and

- 1.47 to 2.20 million acres.

Alternative G1 describes an uneven-flow rate of harvest. All yew that is available for harvest under this alternative could be harvested in the five-year period covered by this EIS.

\section{Indirect Effects}

This alternative would preclude further harvest of yew after the five-year period covered by the EIS until yew regeneration and growth has replaced the original harvested volume. For other indirect effects, see all other effects sections.

\section{Cumulative Effects}

See all other effects sections. 


\section{Alternative G2 Direct Effects}

Moderate - For this alternative, the following would be available:

- 19.29 to 28.94 million dry pounds of bark for the next five years;

- 54.98 million pounds of needles for five years;

- 4.47 to 6.71 million yew trees; and

- 2.31 to 3.47 million acres.

Alternative G2 describes an uneven-flow rate of harvest of yew. All yew that is available for harvest under this alternative could be harvested in the five-year period covered by this EIS.

\section{Indirect Effects}

This alternative would preclude further harvest of yew after the five-year period covered by the EIS until yew regeneration and growth has replaced the original harvested volume. For other indirect effects see all other effects sections.

\section{Cumulative Effects}

See all other effects sections. 
This section relates to the issue of protecting yew by planting and providing for natural regeneration. People who commented agreed with harvesting yew trees for taxol as long as sound reforestation practices that allow for natural regeneration are in place (see Chapter II).

This section analyzes the effects of implementing the alternatives on the biology of Pacific yew. The aspects of biology that we examine in this analysis are:

Seed production and seedling establishment;

Seedbed conditions where the seeds and seedlings will grow;

Vegetative reproduction (primarily stump sprouting); and

Needle and strobili regeneration following needle harvest.

Harvest factors affecting yew biology include the method and level of harvest, post-harvest regeneration efforts (planting, natural regeneration, and stump protection), and the presence and abundance of yew within and adjacent to the harvest unit.

\section{Effects Common to All the Alternatives}

Seedbed conditions would not be negatively impacted under any of the alternatives. In sale units where all overstory species are removed, harvest of remaining yew would not alter seedbed conditions or seed germination. In most non-sale areas, seedbeds would be virtually unchanged following yew harvest; soil, temperature, moisture, and light conditions would change very little. In pure stands of yew, or in stands where yew is very abundant, harvest of 25 to 75 percent of the yew would open the stand to varying degrees, resulting in less shade and moisture and somewhat higher temperatures. Germination can occur without shading, at least in some locations.

All alternatives, except Alternative A, include planting yew as a means of regenerating and maintaining yew populations. Planting is required, along with protection of residual stumps, seedlings, and saplings, in timber sale units where all yew of utilization

\section{Biology of
Pacific Yew \\ Biology of
Pacific Yew}

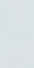


size is removed. Seed for nursery production of seedlings can be obtained from on-site yew that is scheduled for harvest, from yew in adjacent stands, and from yew in genetic reserves in the local management area or seed zone.

\section{The Alternatives}

Alternative A Direct Effects

Moderate-In timber sale units, some yew in the area would be destroyed or damaged, thus reducing the number of individuals capable of producing seed. However, not all yew would be killed and residual yews within the activity area, as well as yew on the edges of units, would be able to produce seed. Additionally, seed from past years is present in the duff for many years and germinates when conditions are favorable. Less seed would be produced in areas where yew is sparse and little or no yew exists adjacent to the unit.

Alternative A would also have some impact on vegetative reproduction of yew in timber sale areas because there would be no special provisions for protecting and shading yew stumps to encourage sprouting. On harsher sites and on burned sites, sprouting from unprotected and unshaded stumps might be reduced. However, on most sites a proportion of the stumps would sprout, as would some injured or pushed over trees or shrubs (which may layer, as well).

\section{Indirect Effects}

Minor - Yew populations on some units may be reduced slightly from preharvest levels, due to reduced seed production and sprouting. Seed to seedling ratios depend on a number of factors: the number of microsites available for seedling establishment in each stand, temperature and moisture conditions at critical times during germination and seedling development, good versus bad seed crop years, and populations of seed-eating birds and rodents. 


\section{Cumulative Effects}

Minor to Moderate - Lack of protection of yew on both federal and nonfederal lands in the past and in the next five years under this alternative, combined with the potential increase in harvest on state and private lands to compensate for no yew harvest on federal lands, may result in reduced yew regeneration in portions of the yew range.

\section{Direct Effects}

Minor-Harvest of yew in timber sale units would remove some of the seed-producing yew. Seed production would be delayed until residual yew or planted yew grows to reproductive size. In many cases, adequate seed would be produced in the interim by yew adjacent to the unit, yew that is retained in the green tree reserve, or yew retained as seed trees in either shelterwood or seed tree harvests. Yew seed already present in the duff would be another source of seed not affected by timber harvest.

Vegetative reproduction of yew would be greater with this alternative than with Alternative A (no yew harvest/no protection of yew); some of the yew stumps would be protected and shaded following the timber harvest so that the survival and sprouting would be enhanced. Recent data suggests that an estimated 70 percent of the stumps left after harvest should resprout (Minore, 1992). Planting of seedlings or rooted cuttings would supplement on-site regeneration to achieve desired population numbers.

\section{Indirect Effects}

Minor with some unknown aspects-Maximum seed production capability would be delayed until residual or planted yew reach sexual maturity, but the seed production potential would not be lost in timber sale units. The long-term success of vegetative reproduction, both in sale and non-sale areas, is unknown; at this time we do not know if sprouts on surviving stumps would survive for more than a few years and, if they do, how long until they would be able to produce seed or are of a sufficient size to contribute structurally to the stand.

\section{Alternative $B$}




\section{Cumulative Effects}

Minor to Moderate — Cumulative impacts on yew regeneration would be less than for Alternative $A$ since yew regeneration would be ensured on federal lands. However, yew harvested from state and private lands still may be relatively high to compensate for a relatively low level from federal lands.

\section{Alternatives}

\section{Direct Effects}

C and D Minor- As for Alternative B, harvest of yew in sale areas would remove some of the seed-producingyew. Seed production would be delayed until residual yew or planted yew grows to reproductive size. In many cases, adequate seed would be produced in the interim by yew adjacent to the unit, yew that is retained in the green tree reserve, or yew retained as seed trees in either shelterwood or seed tree harvests.

Harvest of yew trees or yew foliage at the 25 percent and 50 percent levels in partial-cut and non-sale areas would not adversely affect the Pacific yew's ability to produce seed and seedlings. Sufficient numbers of trees or amount of foliage would exist following harvest to ensure adequate numbers of male and female strobili for pollen and seed production (Interim guide, 1992). Removal of individuals from the same clone during harvest may, in fact, be beneficial by reducing gene exchange between closely related individuals and increasing gene exchange between less related individuals. The result would be improved exchange and mixing of genetic material, provided that remaining yew are well distributed in the stand and distances between individuals does not exceed pollen dispersal distances.

In sale areas, vegetative reproduction of yew would be greater under these alternatives than under Alternative A (no yew harvest/no protection of yew); some of the yew stumps would be protected and shaded following the timber harvest so that survival and sprouting would be enhanced. Recent data suggests that an estimated 70 percent of the stumps left after harvest should resprout (Minore, 1992). Planting of seedlings or rooted cuttings would supplement on-site regeneration to achieve desired population numbers. 
In partial-cut and non-sale areas, yew stumps remaining after harvest would be shaded by other species or other yew, optimizing good sprout survival.

Foliage can be harvested from trees already cut for bark removal in sale units or from standing live trees in non-sale areas. For foliage-only harvest, Alternatives $\mathrm{C}$ and $\mathrm{D}$ would allow for the removal of half the foliage from 25 percent or 50 percent of the yew trees in partial-cut and non-sale stands. The removal of no more than half the foliage would preserve some sexual buds on each tree. Shearing of foliage is common with cultivated yew and does not adversely affect the tree or shrub's ability to regenerate foliage or reproductive structures. Similarly, we do not expect 50 percent foliage removal to adversely affect wild yew trees, although the regrowth experienced by each individual yew would depend on a number of factors, including initial amounts of foliage, age and size of the tree, vigor and health of the tree, light conditions, etc.

\section{Indirect Effects}

Minor with some unknown aspects - On timber sale units, maximum seed production capability would be delayed until residual or planted yew reach sexual maturity, but the potential would not be lost for these areas. The long-term success of vegetative reproduction, both in sale and non-sale areas, is unknown; at this time we do not know if sprouts on surviving stumps would survive for more than a few years and, if they do, how long until they would be able to produce seed or are of a sufficient size to contribute structurally to the stand. On non-sale areas and partial-sale units, adequate numbers of trees are retained to ensure continued regeneration of Pacific yew in harvested areas.

\section{Cumulative Effects}

Minor-The cumulative effects of these two alternatives on yew regeneration would be minor. Yew regeneration on federal timber sales would be ensured; other federal activities such as burning for site preparation or road construction would not significantly impact yew regeneration. Yew harvest on state and private lands, and the impacts on yew regeneration on those lands would probably be less than that predicted for Alternative A.

$\mathbf{A}=$ No Action
$\mathbf{B}=$ Timber Sales Only
$\mathbf{C}=25 \%, 5$ TPA
$\mathbf{D}=50 \%, 5$ TPA
$\mathbf{F}=75 \%, 2$ TPA
G1 $=50 \%, 0$ TPA,
G2 $=50 \%, 0$ TPA, OCAs
TPA is the minimum
number of trees left
standing per acre




\section{Direct Effects}

Alternatives F, G1

and $G 2$

Minor to moderate- Harvest of yew in sale areas for these alternatives would remove some of the seed-producing yew. Seed production would be delayed until residual yew or planted yew grows to reproductive size. In many cases, adequate seed would be produced in the interim by yew adjacent to the unit, yew that is retained in the green tree reserve, or yew retained as seed trees in either shelterwood or seed tree harvests. Yew seed, already present in the duff, would be another source of seed not affected by timber harvest. The potential for successful vegetative reproduction following timber sales would be identical to that of Alternatives B, C, and D. Similarly, planting seedlings and rooted cuttings to supplement natural regeneration would achieve desired yew densities.

In non-sale areas, removal of 75 percent of the yew in each of the three diameter classes under Alternative F could adversely affect seed production. Two yew trees per acre in each of the three diameter classes would be left unharvested. Similarly, for Alternatives G1 and G2, removal of 50 percent of the yew in each diameter class in the stand could affect seed production in stands where yew is relatively sparse. For Alternatives G1 and G2, the minimum number of unharvested yew would vary between stands, depending on the initial yew density in the stand; at least one yew tree would be left on each harvested acre. Yew stumps remaining after harvest would be shaded by other species or other yew, allowing for optimal sprout survival.

Foliage can be harvested from trees already cut for bark removal in sale units or from standing live trees in non-sale areas. For foliage harvest only, Alternatives F, G1, and G2 would allow for the removal of half the foliage from 75 percent or 50 percent of the yew trees in partial-cut and non-sale stands. As with Alternatives $\mathrm{C}$ and $\mathrm{D}$, the regrowth experienced by each individual yew would depend on a number of factors, including initial amounts of foliage, age and size of the tree, vigor and health of the tree, light conditions, etc. Seed production in the stand would be impacted to some extent. 


\section{Indirect Effects}

Minor with some unknown aspects- On timber sale units, maximum seed production capability would be delayed until residual or planted yew reach sexual maturity, but the potential would not be lost for these areas. The long-term success of vegetative reproduction, both in sale and non-sale areas, is unknown; at this time we do not know if sprouts on surviving stumps would survive for more than a few years and, if they do, how long until they would be able to produce seed or are of a sufficient size to contribute structurally to the stand. On non-sale areas and partial-sale units, adequate numbers of trees are retained to ensure continued regeneration of Pacific yew in harvested areas.

\section{Cumulative Effects}

Minor- The establishment of fewer seedlings each year would probably not result in an overall lower population of yew. Over a five-year period, vegetative regeneration (sprouting and layering) could help maintain existing populations, although the long-term success of vegetative reproduction, both in sale and non-sale areas, is unknown. Maximum seed production potential would not be reached until stump sprouts, existing seedlings and saplings, and planted seedlings reached sexual maturity.

In Alternative G2, the impacts on both sexual (seed) and vegetative (sprouts) reproduction within owl conservation areas would be identical to that described in Alternative D. Both call for harvest of 50 percent of the yew with a minimum of five yew trees retained on each acre. Effects on reproduction of Pacific yew would be minor.

The cumulative effects of these three alternatives on yew regeneration would probably be less than that predicted for Alternatives $C$ and $D$. 


\section{Genetics of the Pacific Yew}

This section relates directly to the issue of protecting and maintaining the genetic diversity of Pacific yew. People are concerned about careful management to protect the gene pool and balancing short versus long-term needs for taxol. People also want studies of yew in order to understand how to provide a viable gene pool for the future.

Direct effects are changes which would happen to the structure and amount of genetic variation (levels of heterozygosity, Gst values, number of alleles) of existing populations. These changes would be noticed if sampling to determine genetic variation was carried out immediately prior to bark harvest and then a short period of time after bark harvest.

Indirect effects are changes which would happen to levels of genetic variation in future generations of $P$ acific yew derived from the populations where harvest has occurred. This genetic variation is crucial to the ability of Pacific yew to adapt and survive to changing environments. It is also a potential resource for use in breeding and hybridization programs, as well as having intrinsic, aesthetic, educational and scientific value.

Cumulative effects are gradual changes to the structure and amounts of genetic variation which are the result of many management activities over a long period of time.

The direct effects of needle harvest on genetic variation would be minor because individual trees would not be killed. Indirect effects (minor) would temporarily reduce the foliage area available for reproductive buds, reducing aril production; however, the foliage area would probably recover in less than five years. 


\section{Terms to Know}

Allele- one of a series of alternative forms of a given gene, differing in DNA sequence, and affecting the functioning of a single product (RNA and / or protein).

Gene migration - the movement of alleles between populations. In plants this is accomplished by pollen and/or seed movement.

Genetic drift-chance fluctuations in allele frequency due to small numbers of parents contributing to the next generation.

Genetic variation-genetic differences resulting from different combinations of alleles and their frequencies occurring among individuals in different populations.

Gst values indicate the proportion of genetic diversity due to differences among different populations.

Heterozygosity - the condition of having one or more pairs of dissimilar alleles at a locus.

Locus (plural, loci) - the location of a gene on a strand of DNA. 
Table IV-14: Potential effects on the genetic resource under the different alternatives

\begin{tabular}{|c|c|c|c|}
\hline $\begin{array}{l}\text { Alter- } \\
\text { natives }\end{array}$ & $\begin{array}{l}\text { Direct effects on existing } \\
\text { levels of genetic variation }\end{array}$ & $\begin{array}{l}\text { Indirect effects on levels of } \\
\text { genetic variation in future } \\
\text { generations }\end{array}$ & Cumulative effects \\
\hline A & $\begin{array}{l}\text { Risk of losing small } \\
\text { populations at edge of } \\
\text { range, thereby reducing } \\
\text { existing levels. }\end{array}$ & $\begin{array}{l}\text { Risk of losing small } \\
\text { populations at edge of } \\
\text { range, thereby reducing } \\
\text { future levels. }\end{array}$ & $\begin{array}{l}\text { Risk of genetic erosion at } \\
\text { edge of range. }\end{array}$ \\
\hline B & None & None & $\begin{array}{l}\text { Would negate risk to small } \\
\text { populations and halt genetic } \\
\text { erosion. }\end{array}$ \\
\hline C & $\begin{array}{l}\text { Risk of slightly reducing } \\
\text { levels within population of } \\
\text { genetic variation for some } \\
\text { populations. No effect on } \\
\text { overall variation. }\end{array}$ & $\begin{array}{l}\text { Risk of slightly reducing } \\
\text { some populations. No effect } \\
\text { on overall variation or } \\
\text { values. }\end{array}$ & $\begin{array}{l}\text { Would enhance gene } \\
\text { conservation. }\end{array}$ \\
\hline D & $\begin{array}{l}\text { Within population levels } \\
\text { could be reduced more than } \\
\text { in Alt. C. No effect on } \\
\text { overall genetic variation. }\end{array}$ & $\begin{array}{l}\text { Could be reduced more than } \\
\text { in Alternative C for some } \\
\text { populations. No overall } \\
\text { effect. }\end{array}$ & Same as Alt. C. \\
\hline $\mathbf{F}$ & $\begin{array}{l}\text { Within population levels } \\
\text { could be reduced more than } \\
\text { in Alt. D. Overall levels of } \\
\text { variation would be reduced } \\
\text { slightly. }\end{array}$ & $\begin{array}{l}\text { Could be reduced more than } \\
\text { in Alt. D. Potential } \\
\text { significant reduction in } \\
\text { adaptability of some } \\
\text { populations and some } \\
\text { reduction in values. }\end{array}$ & Same as Alt. C. \\
\hline G1 & Same as Alt. D. & Same as Alt. D. & Same as Alt. C. \\
\hline G2 & Same as Alt. D. & Same as Alt. D. & $\begin{array}{l}\text { Gene conservation would } \\
\text { not be well served because } \\
\text { of fewer reserves. }\end{array}$ \\
\hline
\end{tabular}




\section{The Alternatives}

\section{Direct Effects}

Minor- Under this alternative no effort would be made to maintain individual yew trees, breeding populations, or genetic diversity. Some of the small populations on the periphery of the species range (e.g. the Sierra Nevada Mountains in southern California) may be lost due to inadequate natural regeneration and/or reduction of stump sprouting in severe climates. Lass of populations containing unique genetic combinations could decrease levels of genetic variation in this species, particularly since there is more among-population variation in this species compared to other widely distributed conifers.

\section{Indirect Effects}

Minor - The ability of Pacific yew to adapt to changing environments could be impaired if populations containing unique genetic combinations are lost. Similarly, loss of rare alleles and/or unique genetic combinations could degrade its potential for use in breeding programs.

\section{Cumulative Effects}

Minor-The cumulative effects of this alternative would reflect conditions prior to the 1991 harvest season. There could be continued erosion of some genetic variation at the peripheries of the species range because some populations may be lost.

\section{Direct Effects}

None- Protection for yew stumps will encourage stump sprouting, giving individual genotypes a greater ability to survive and contribute to future reproduction. This alternative would have less impact on the genetic diversity of Pacific yew than Alternative A because fewer populations would be reduced below critical levels.

\section{Indirect Effects}

None-The indirect effects on potential contributions to breeding and hybridization programs, as well as the aesthetic, educational and scientific value of genetic diversity of Pacific yew would be less

\section{Alternative A}

$$
\begin{aligned}
& \mathbf{A}=\text { No Action } \\
& \mathbf{B}=\text { Timber Sales Only } \\
& \mathbf{C}=25 \%, 5 \text { TPA } \\
& \mathbf{D}=50 \%, 5 \text { TPA } \\
& \mathbf{F}=75 \%, 2 \mathrm{TPA} \\
& \text { G1 }=50 \%, 0 \mathrm{TPA} \\
& \text { G2 }=50 \%, 0 \mathrm{TPA}, \text { OCAs } \\
& \text { TPA is the minimum } \\
& \text { number of trees left } \\
& \text { standing per acre }
\end{aligned}
$$

\section{Alternative $B$}


Effects Common to Alternatives $C$ through $G 2$ than Alternative A. Also, the ability of Pacific yew to adapt to changing environments would be higher under this alternative due to higher survival of successful genotypes in populations.

\section{Cumulative Effects}

None- The cumulative effects for this alternative would be to halt the erosion of genetic variation at the peripheries of the species range.

\section{Direct Effects}

Minor to Moderate- Under these alternatives the following activities would maintain individual trees and populations. Artificial regeneration is used to maintain populations in timber sale areas and harvested yew stumps are protected and encouraged to sprout in non-sale areas. However, artificial regeneration is not done in non-sale areas. In spite of efforts to protect stumps, there will be mortality of individual trees from harvesting, perhaps as high as 50 percent of the trees harvested for bark. If individual trees die because of bark harvest, it is important they are not all the largest or fastest growing individuals. Harvesting should be spread out over all size classes to ensure these 'best' genotypes are not severely depleted.

As harvest levels and potential mortality increase, levels of withinpopulation genetic variation could decrease and probabilities of losing low frequency alleles in harvested populations would increase. We know that alleles occur in some yew populations at frequencies of as low as 0.033 . At this frequency, 274 individual genotypes would be needed to prevent an average loss of one allele at any of 100 loci (Namkoong, 1988). Individuals may have only a few hundred such loci with alleles at such a low frequency. As population census numbers drop below this level, the probabilities of losing low frequency alleles increase proportionately.

Under these alternatives genetic reserves are established in areas where yew harvest occurs. These reserves are in addition to other administratively withdrawn areas and riparian areas where yew harvest is prohibited. The genetic reserves sample and protect representative levels of within-population genetic variation within 
a 10,000 to 20,000 -acre management unit. A mosaic of genetic reserves over a landscape provides redundancy and offers the greatest species-wide protection for allelic diversity.

\section{Indirect Effects}

Minor to High - The indirect effects of these harvest activities could reduce the amount of genetic variation as measured by heterozygosity in the next generation of the populations harvested. This happens because the breeding population size is reduced, increasing 'chance' variations in allele frequency, or genetic drift. Gene migration, in the form of pollen flow which normally reduces genetic drift effects, would also be reduced. The amount of reduction in genetic variation would be proportional to the level of harvest. As genetic variation decreases, the ability of these populations to adapt and persist in the ecosystem decreases also. This has a negative effect on the value to hybridization programs and aesthetic, educational and scientific features.

\section{Cumulative Effects}

Positive - Cumulative effects of these alternatives would be to slightly reduce risks to survival of small populations in marginal environments as under Alternative B. The establishment of genetic reserves would actually enhance gene conservation and protection for this species.

\section{Direct Effects}

Minor- This alternative would harvest 25 percent of the yew in partial-cut and non-sale areas. Owl conservation areas are not entered under this alternative and would function as additional in situ reserves. Stump protection and sprouting will enable from one-half to two-thirds of harvested individuals to survive, reducing mortality to about 13 percent. Levels of within-population genetic variation could be reduced slightly, however, overall genetic variation would not be reduced due to the continued survival of genetically variable populations.
Alternative C

Pacific Yew DEIs $T$-37 


\section{Indirect Effects}

Minor- The effects on subsequent generations would be slight, the least of any alternatives harvesting in non-timber sale areas. Leaving a minimum of five trees per acre in each diameter class serves to keep a minimum population size for pollen dispersal and gene migration. There would not be a reduction in overall adaptability or values to either future breeding programs or aesthetic, educational and/or scientific values.

\section{Cumulative Effects}

Positive - The cumulative effects of this alternative would be to slightly reduce risks to survival of small populations in marginal environments as under Alternative B. The establishment of genetic reserves would actually enhance gene conservation and protection for this species compared with current practices.

\section{Alternative D Direct Effects}

Minor- Under this alternative 50 percent of the yew would be harvested in partial-cut and non-timber sale areas, in addition to that harvested from timber sale areas. Owl conservation areas are not entered in this alternative and would function as in situ reserves. Maximum mortality would be about 25 percent of the population. Levels of within-population genetic variation would be reduced more than in Alternative C; however, overall genetic variation would not be reduced significantly because of the continued survival of many populations.

\section{Indirect Effects}

Minor-Effects on within-population genetic variability in future generations could be more than in Alternative C. The breeding population would be reduced by 50 percent until surviving sprouts were able to contribute to sexual reproduction. Leaving five trees per acre in each size class assures a minimum population is left for pollen dispersal and gene migration. Overall genetic variation would not be significantly affected in this alternative, nor would values to other uses of the gene pool. 


\section{Cumulative Effects}

Positive- Same as for Alternative C.

\section{Direct Effects}

Moderate- Under this alternative 75 percent of the yew would be harvested in partial-cut and non-sale areas, in addition to that harvested from timber sale areas. Maximum mortality would be about 38 percent of the population. Owl conservation areas are not entered in this alternative and would function as in situ reserves. Levels of within-population genetic variation would be reduced for those populations where harvest occurs. More low frequency alleles would be lost under this alternative than under others. Overall genetic variation would not be significantly reduced because of the continued survival of many populations.

\section{Indirect Effects}

High-This alternative would significantly reduce levels of withinpopulation genetic variation in future generations by removing 75 percent of the breeding individuals. This would occur only in harvested populations; however, decreasing the minimum number of trees per acre to two increases the number of acres where harvest will occur. Pacific yew is an understory tree and probably has limited pollen dispersal distance. Two trees per acre may not be enough to ensure much gene flow or successful pollination between trees within populations. This could lead to increased levels of inbreeding which could result in an increase of amongpopulation variation. As surviving stump sprouts started contributing to sexual reproduction, within-population genetic variation would increase and among-population genetic variation would be reduced. Indirect effects of this alternative would be to reduce the overall genetic variation in future generations and the ability of Pacific yew to adapt to changing environments. Values to breeding programs, education, aesthetics and science would also be reduced.

\section{Cumulative Effects}

Positive - Same as for Alternative C.
Alternative $F$
$A=$ No Action
B = Timber Sales Only
$\mathrm{C}=25 \%, 5$ TPA
D $=50 \%, 5$ TPA
$F=75 \%, 2$ TPA
G1 $=50 \%, 0$ TPA,
G2 $=50 \%, 0$ TPA, OCAs
TPA is the minimum number of trees left standing per acre 


\section{Alternatives Direct Effects \\ G1 and G2 Minor-Same as Alternative D except owl conservation areas are entered in this alternative and would not function as in situ reserves in Alternative G2.}

\section{Indirect Effects}

Minor-Same as Alternative D except that no minimum number of trees per acre are left. This would result in indirect effects similar to those in Alternative $F$ for populations where only one or two trees per acre are left. However, overall genetic variation would not be significantly affected in this alternative, nor would values to other uses of the gene pool.

\section{Cumulative Effects}

Positive - reserves would be established wherever harvest occurs. Alternative G2 would not have the owl areas for large additional in situ reserves. 
This area relates to the issue of protecting the ecosystem and regenerating yew.

This section looks at two aspects of fire and yew:

1. How risk of wildfire is influenced by the alternatives; and

2. The effect of the alternatives on the ability of yew to survive or regenerate following a slash fire, wildfire, or prescribed burn.

\section{Risk of Fre from Yew Harvest}

The risk of wildfire can be influenced by:

1. The amount of fuels generated by wood or bark harvest under each alternative, and

2. The risks from people working in the woods (fires started from machinery, chainsaws, cigarettes, arson, etc.) for any type of harvest (wood, bark, or needle).

\section{The Alternatives}

\section{Direct, Indirect, and Cumulative}

Minor- There would be no increased risk of fire over current levels with these two alternatives, due primarily to treatment of yew slash (unused portions of the yew tree) along with other fuels on sale units.

The amount of slash created and the number of people working in the woods would vary with the level of harvest and the density of yew. Where yew is very abundant or exists in pure stands, larger amounts of slash would be generated for bark harvest and large numbers of workers may be employed for both needle and bark harvest. 


\section{Alternatives C Direct Effects \\ through G2 Minor to moderate- Risk of fire occurrence would vary for all alternatives, but would generally be higher for those alternatives that harvest higher levels of yew (Alternatives F and G2).}

\section{Indirect Effects}

Minor to moderate- Fire incidence may increase in areas where yew is abundant and harvest is occurring.

\section{Cumulative Effects}

None-Fire risk would be lower as fuels decay over time. 


\section{Survival of Yew Following Fire}

The impacts of yew harvest on the survival and regeneration of yew following fire would depend upon the level of harvest as well as the density of yew present initially in the stand. Together these factors would determine the amount of slash created and the distribution of fuels in relation to the yew on the site. In areas where large quantities of slash are produced, yew stumps and unharvested yew trees could be damaged or destroyed by fire, due to the proximity of fuels to stumps and trees. This would reduce both the vegetative (stump sprouting), layering, and reproductive (seed-producing) capability of the yew in that stand. Diminished reproduction could result in fewer seedlings, and subsequent decrease in certain yew populations over time.

This portion of the analysis would only be affected by harvest of trees for their bark or wood, rather than by harvest of needles. Needle harvest in all alternatives would have negligible impact on the yew's ability to survive following fire. There is very little slash associated with needle harvest and, to the best of our knowledge, removal of half the needles does not affect the yew tree's ability to survive fire.

\section{The Alternatives}

This alternative would not allow for harvest of yew and would have no special provisions for protecting yew. On sale units where there is yew, there would be no attempt to pull slash away from yew trees, stumps, or seedlings. Survival of the yew on these sites following any type of fire could be quite poor. Yew has thin bark and is not considered fire-resistant. Intense heat would kill the cambium and dormant buds, greatly reducing the ability of a severely burned stump to sprout. Survival of yew following fire would be dependent on the intensity of the fire and distribution of fuels in relation to the yew on the site.

\section{Direct Effects}

Moderate to High - Lack of special protection of yew would result in poor survival of yew in sale units or other areas where fire occurs.

\section{Alternative $A$}

$\mathbf{A}=$ No Action
$\mathbf{B}=$ Timber Sales Only
$\mathbf{C}=25 \%, 5$ TPA
$\mathbf{D}=50 \%, 5$ TPA
$\mathbf{F}=75 \%, 2 \mathrm{TPA}$
G1 $=50 \%, 0$ TPA,
G2 $=50 \%, 0$ TPA, OCAs
TPA is the minimum
number of trees left
standing per acre




\section{Indirect Effects}

High - Poor survival of yew stumps and sexually mature trees would reduce the amount of regeneration on the site.

\section{Cumulative Effects}

Minor to high - The cumulative effect of implementing this alternative would depend, to a large degree, on the federal timber sales in the northwest: more timber sales would result in larger cumulative effects than fewer sales. Lack of protection during and after fire could result in a decrease in the yew population and could impact the extent of its range. However, fire is being used less often as a site-preparation method due to air quality restrictions; therefore, damage to yew by fire may be decreased.

Protection of yew in sale units is an integral part of this alternative. A portion of the residual yew (yew stumps, trees, and seedlings remaining on the site following harvest of both yew and other tree species) would be protected from site preparation fires. However, due to lack of knowledge and experience with yew protection and survival following fire, some damage would be possible.

\section{Alternative $B$ Direct Effects}

Minor to moderate - Yew may be damaged or killed by site preparation fire due to lack of knowledge and experience in protecting yew from fire.

\section{Indirect Effects}

None to minor-There would be little or no impact on regeneration since yew must be planted where residuals survival is poor.

\section{Cumulative Effects}

None- There should be no cumulative effects. 
The impact of these alternatives on survival of yew in sale areas would be the same as for Alternative B. The impact on survival in non-sale areas would be dependent on the level of harvest (25 percent, 50 percent, or 75 percent) as well as the amount of yew present initially. Harvest in stands that have very high densities of yew would create large amounts of yew slash. Fire-caused mortality of yew stumps and unharvested yew trees would increase as the amount of slash increased due to the proximity of fuels to stumps and trees. The amount of mortality, of course, would vary with the intensity of the fire: light burns may kill only a portion of the stumps and none of the standing trees; very hot burns may kill all stumps as well as all standing trees. For the purposes of this analysis, we have assumed that stumps are less likely to survive fire than standing green trees.

An indirect effect on survival is the ability to regenerate. Regeneration following fire can occur from the sprouting of surviving stumps, or seed production from surviving standing yew trees. Alternatives that leave a higher proportion of standing trees versus stumps would probably have more regeneration following fire.

\section{Direct Effects}

Minor to moderate- The effects of Alternatives $\mathrm{C}$ and $\mathrm{D}$ on the survival of yew following fire in non-sale areas would vary depending on the amount of yew present initially in the stand, but would generally be small. For Alternatives F, G1, and G2, the effect in non-sale areas would also vary depending on the amount of yew present initially. Overall, however, less yew would survive with Alternatives F, G1 and G2 than with Alternatives C and D, due to greater harvest intensities and the potential for large quantities of slash in close proximity to yew stumps and trees.

Survival in owl conservation areas under Alternative G2 would be similar to survival in Alternative D (because harvest levels are identical in Alternative D and owl areas).
Alternatives $C$ through $\mathrm{G} 2$ 


\section{Indirect Effects}

Minor to moderate - Regeneration following a moderately severe fire would depend primarily on standing trees and the seed that they provide rather than stump sprouting. Alternatives $C$ and D would have very small impacts on regeneration, since Alternative $\mathrm{C}$ would retain at least 75 percent of the yew as standing trees and Alternative $\mathrm{D}$ would retain at least 50 percent. The impacts on regeneration would be somewhat higher for Alternatives F, G1, and G2, since less yew is retained as standing trees - at least 25 percent for Alternative $F$ and at least 50 percent with Alternatives G1 and G2 - resulting in less seed and possibly fewer seedlings. See also effects on Alternatives C through G2 in the Biology section.

\section{Cumulative Effects}

Minor to moderate - In individual stands, many stumps and some trees could be destroyed by fire, reducing both the vegetative and sexual reproductive capability of the yew in that stand. Collectively, diminished yew reproduction in adjacent stands could result in reduced size of certain yew populations. The potential for cumulative effects would increase from Alternative $\mathrm{C}$ to Alternative G2. 
This section relates to the issue of protecting the ecosystem.

This section deals with the potential impacts of a special group of organisms called forest pests. This group is composed of arthropods, fungi, bacteria, viruses, and higher plants. Forest pests are singled out as a special group because the effects of their natural activities, such as growth loss and mortality in trees, often result in impacts that conflict with human goals and objectives for a particular area. This analysis evaluates, the effects of various harvest levels on populations of potential yew pests. Because specific pest population levels do not always translate directly into equal levels of damage, estimates of pest impact on yew populations are described in general terms. The impacts of various alternatives on populations of insects, plants, and microorganisms are discussed in the Ecology section of Chapter IV.

Two types of yew harvest were evaluated for this analysis; needle harvest and whole tree or bark harvest. Whole tree harvest has the greater potential for increasing forest pest activities because stumps created during the harvest may provide root disease and decay fungi with means of entry into yew stems, trees, and stands. Needle harvest may reduce the vigor of individual trees and make them more susceptible to attacks by insects. The only disease of Pacific yew we know that might be increased by harvest activities is a root disease caused by the fungus Phytophthora lateralis. As described in Chapter III, this fungus has been found infecting yew only within the range of infected Port-Orford-cedar in southern Oregon and northern California. Yew outside the natural range of Port-Orford-cedar is not considered at risk to this disease.

This section is arranged according to alternatives, beginning with Alternative A. Each of the alternatives is followed by a discussion of the direct, indirect, and cumulative effects. Because Port-Orfordcedar root disease is an effect common to all of the alternatives, an in-depth discussion of the disease is included at the end of the section.

\section{Insect and Disease Pests of Pacific Yew}




\section{The Alternatives}

\section{Alternative A Direct Effects}

Minor-There would be no change in what are considered insignificant levels of impact by insects and diseases. Since yew would not be harvested for taxol production under this alternative, no yew stumps would be created and tree vigor would not be decreased by needle harvest.

\section{Indirect Effects}

Minor - No change would be expected. Past harvest activities within the range of Pacific yew have not altered the ecological balance between pests and the tree. An increase in pest populations and activity would be due to changes in stand conditions caused by harvest of other species. Because most pests are host specific and the potential crossover to yew is small, there would be no significant impacts.

\section{Cumulative Effects}

Minor-The major impact to yew under this alternative would depend on the number, size, and location of harvest units for other tree species. The planned reduction in timber harvests on yewbearing lands, as well as the move away from clearcutting as the most common harvest method, should mitigate any potential impacts by insects and/or disease.

Alternatives $B$ All alternatives proposing harvest of yew would have an unthrough G2 known, but probably minor impact on insect and disease populations. Insects and diseases reported on yew are not host specific; that is, they attack a wide range of conifers found in Pacific northwest forests. The interactions between various kinds and levels of tree harvest on populations of these pests, and the subsequent risk to trees, has been studied for years. We are quite knowledgeable about these effects on other species. The most significant potential impact is that of changing the structure of existing vegetation in such a way as to make the trees more susceptible to attack and damage by pests. 


\section{Direct Effects}

Minor- By creating stumps and sprouts as potential areas of infection by diseases, yew harvest could increase the amount of root disease and stem decay in stands. This increased risk of disease infection would be restricted to stumps of harvested trees and sprouts from those stumps. Seedlings would not be affected. Harvest of needles could reduce the vigor of trees and, especially under adverse environmental conditions, make them more susceptible to attack by pests.

\section{Indirect Effects}

Minor-The removal of yew as a component, however small, from forested stands may result in the species becoming more susceptible to pest activity. None of the alternatives, however, propose to completely eliminate yew from the ecosystem. All of the alternatives include provisions for protecting and regenerating yew.

\section{Cumulative Effects}

Minor-There could be potential for an increase in root disease, stem decay, bark beetle, and defoliator activity in harvested areas. Alternatives having the highest levels of harvest would have the highest risk of increased activity.

$\mathbf{A}=$ No Action
$\mathbf{B}=$ Timber Sales Only
$\mathbf{C}=\mathbf{2 5} \%, 5$ TPA
$\mathbf{D}=50 \%, 5$ TPA
$\mathbf{F}=\mathbf{7 5} \%, 2 \mathrm{TPA}$
G1 $=50 \%, 0 \mathrm{TPA}$
G2 $=50 \%, 0 \mathrm{TPA}$, OCAs
TPA is the minimum
number of trees left
standing per acre


Port-OrfordCedar Root Disease
The effects to yew caused by Port-Orford-cedar root disease, Phytophthora lateralis, would be minor for all alternatives.

Our ability to analyze the risk posed to yew by this disease depends on how accurately we can predict two unknowns: How susceptible yew is to this disease; and how much harvest would take place in the forests where the natural range of the two species overlap. The results of inoculation tests and field observations support the conclusion that Pacific yew is much less susceptible to infection by $P$. lateralis than is Port-Orford-cedar. Only seventeen Pacific yew trees have tested positive for infection. All were located in areas where the fungus has been established on Port-Orfordcedar for many years and where the inoculum load (number of spores responsible for infection) is considered to be very high. At this time, Pacific yew is considered to be "at risk" to this disease only in areas where Port-Orford-cedar has been infected for many years. Yew outside these areas, including all yew outside the natural range of Port-Orford-cedar, is considered to be safe from infection.

At present, harvest activities in areas that include Port-Orfordcedar must follow the standards and guidelines specified under the Port-Orford-cedar action plan (Appendix C). The purpose of these standards and guidelines is to reduce or prevent the spread of the disease into uninfected areas, and to prevent disease intensification in areas already infected. Future harvest activities, including harvest of yew bark and/or yew needles, would also follow these same procedures. Because of the mitigating measures already in place, the low level of disease susceptibility of yew, and the relatively small number of yew at risk, we conclude that the impacts of this disease under all of the proposed alternatives would be negligible. 


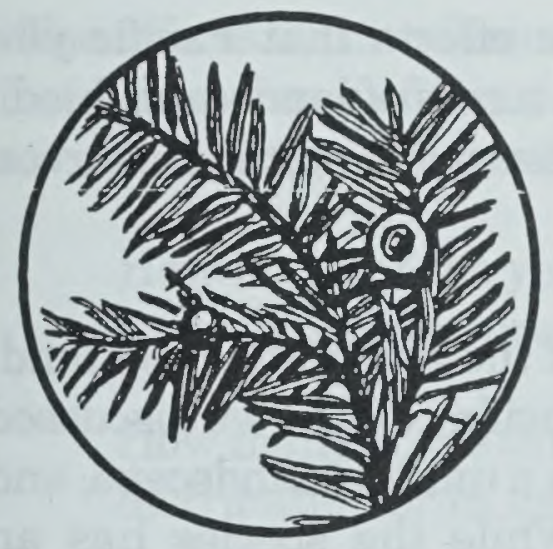

\section{Chapter IV}

\section{Environmental Consequences}

\section{Part Two: The Forest \\ Table of Contents}

Landscape Pattems

The Alternatives

Ecosystem

Terms to Know

The Alternatives

Biodiversity

The Alternatives

Forest health

Ecosystem management

The Alternatives

Soils

Terms to Know

The Alternatives

Water Resources

and Aquatic Habitat

The Alternatives
Wildlife

Terms To Know

Species Associated with

Late-Successional Forests

The Alternatives

Species Associated with

Early-Successional Forests

The Alternatives

Species Associated with Riparian

Areas

The Alternatives

Threatened and Endangered Species

The Alternatives

Access for Yew Harvest

The Alternatives

Pacific Yew Harvest

and Timber Harvest

The Alternatives

Roadless Areas

The Alternatives 


\section{Part Two: \\ The Forest}

\section{Landscape Pattems}

This part of Chapter IV describes the effects that Pacific yew harvest may have on the big picture in terms of landscape, biodiversity, and forest health. It also addresses soils, water resources, wildlife, and access for harvest.

In this section we analyze the effects of the alternatives on landscape connectivity and distribution of Pacific yew. As we discussed in Chapter III, yew does not exist within a uniform landscape, and is not distributed evenly across it. While the species has an unusually broad habitat occurrence and distribution, it is generally found in small, localized populations.

The two primary issues concerning the landscape pattern of $\mathrm{Pa}$ cific yew are the effect of the alternatives on the geographic range of the species and on population connectivity. Connectivity is important in facilitating gene flow and maintaining the genetic variability of the species. Connections between yew populations also allow for the movement of any organisms that may depend on Pacific yew, or on the kind of habitat it creates. For the purposes of this analysis, we assumed that the continued presence of Pacific yew throughout its range is essential to maintaining the viability of the species and its ability to adapt and survive in changing environments.

\section{The Alternatives}

Alternative A Direct Effects

Low-risk - There would be no harvest of yew bark or needles under this alternative. Some Pacific yew trees and shrubs could potentially be destroyed on 0.157 million acres over the next five years in timber sale units that contain Pacific yew. Under this alternative, yew would not be protected from site preparation activities or from damage during logging. 
The effects of this alternative depend on three major factors:

How many of the timber sale areas over the next five years contain Pacific yew?

How much of the yew survives and regenerates after timber harvest and site preparation activities?

How many of the timber sales occur in areas with sparse yew distribution or in unique habitats?

There would be a low risk of impact on landscape connectivity and the geographic range of Pacific yew. Undisturbed yew populations would be distributed throughout the landscape in management areas set-aside from timber harvest. Riparian areas are largely removed from regeneration harvest methods leaving a network of connecting corridors for Pacific yew gene flow and possible movement of some yew-dependent species.

Due to the small size of the harvested areas, some loss of yew in timber sale areas over the next five years should have a low risk of impact on the overall landscape connectivity within areas of relatively abundant yew distribution. Some yew would remain following harvest activities and yew would be retained in sale units that contain green tree reserves. There is more potential risk to the landscape distribution of yew when timber sales occur in areas of sparse yew distribution, especially at the peripheries of the species range. The risk of impact should still be relatively low due to the fact that some yew will remain following timber harvest.

\section{Indirect Effects}

Low-risk-Although not specifically required by this alternative, Pacific yew would be planted in most sale units as part of the natural species mix. The long-term landscape distribution of yew would be maintained. Artificial regeneration would be especially important in areas of sparse yew distribution where natural regeneration may be impacted by a reduction in the population following timber harvest activities. There is a risk that loss of some of the yew population at the peripheries of the species' range or in areas with unusual ecosystems could reduce yew's genetic variability (see Genetics section in this chapter). This could reduce the

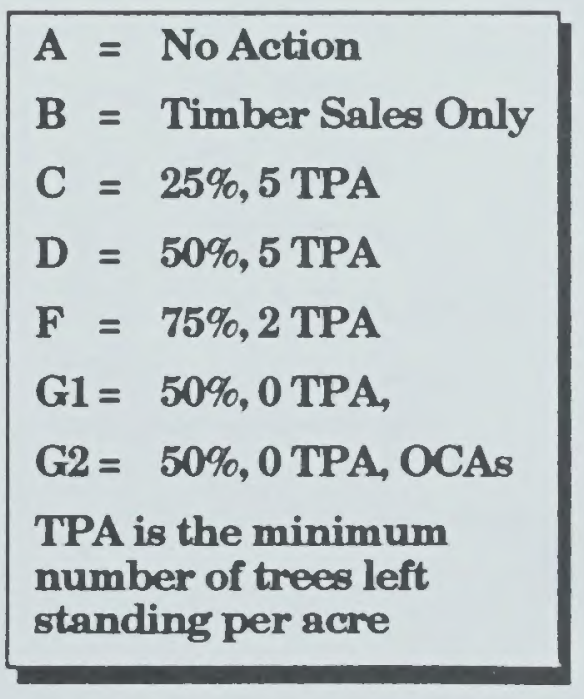


ability of Pacific yew to adapt to changing environments, and could impact future yew distribution across the landscape.

\section{Cumulative Effects}

Low-risk - The effects of this alternative over the five-year planning period must be considered together with the effects of past and future management of the yew resource. Past timber harvest activities have undoubtedly reduced the distribution of Pacific yew, and have had the greatest impact in areas of already sparse yew distribution. These effects may be offset, however, by decades of fire suppression (see Role of Fire section in Chapter III). Fire suppression has probably allowed yew to maintain itself on sites where it may not have survived under the natural fire regime. Under ecosystem management practices yew will be retained throughout its range. Harvest practices which retain green trees in sale units, cooler and spatially modified prescribed burns, and regeneration of the natural mix of species would retain yew in present and future timber sale units.

\section{Alternative $B$ Direct Effects}

Low-risk - Yew would be harvested from an estimated 0.157 million acres $(0.078$ to 0.118 million acres after reductions for potential site-specific and other restrictions) over the next five years in timber sale units that contain Pacific yew. There would be no effect on yew populations in management areas removed from regeneration timber harvest (wilderness, RNAs, most riparian areas), leaving populations and connecting networks of Pacific yew distributed throughout the landscape. Some yew would also be retained in sale areas with green tree reserves.

Yew would be planted in sale areas, and a portion of the residual trees and stumps would be protected. There would be a temporary reduction in the distribution of large, reproductively mature yew trees and shrubs scattered throughout the landscape. Due to the small size and scattered occurrence of timber sale units, there should be only a low risk of adversely affecting the landscape distribution of yew. Yew harvest in areas of sparse distribution could have impacts on landscape connectivity, gene flow, and the dispersal of yew-dependent organisms. 


\section{Indirect Effects}

Low-risk-- Yew would be regenerated, through both planting and encouragement of stump sprouting. There would be a low risk of impact on the long-term landscape distribution and geographic range of the species. Until regrowth of the trees occurs, movement of any organisms dependent on large Pacific yew trees or the habitat they create may be disrupted. This would primarily impact only areas of sparse yew distribution. Yew harvest in unique ecosystems could influence the future ability of the species to adapt to changing environments.

\section{Cumulative Effects}

Low-risk- Long-term yew population connectivity should not be impacted, due to the relatively small area involved over the fiveyear harvest period. There could be a potential for impacts on population connectivity in extremely cut over or burned landscapes, where Pacific yew distribution may have already been greatly reduced. A continuation of past harvest practices could affect the connectivity of yew populations. After the five-year bark harvest period, however, regeneration and retention of Pacific yew in green tree reserves would continue, maintaining yew throughout the landscape. There is risk to landscape RNAs if large quantities of yew are harvested from private ownerships adjacent to federal land. This is a special concern on BLM land due to the "checkerboard" ownership pattern. There are also potential effects of other management activities, especially the reintroduction of fire into fire dependent ecosystems. Ecosystem management decisions must be made on a site-specific basis to integrate the requirements of all species. Some individual trees or shrubs may be lost but their presence in the landscape will be retained. Some yew populations on the edges of its range may have been established under more favorable climates and future environmental conditions may not be suitable for their survival. The future range of the species could possibly be reduced. 
Elements Common to Alternatives $C$ through $\mathrm{G} 2$
The following are major elements in the landscape distribution of Pacific yew common to Alternatives C, D, F, G1, and G2.

\section{Set-asides}

Yew would not be harvested in designated wilderness or other management areas that have been set aside from harvest for a variety of specific purposes (see Recreation section in Chapter III). These areas are spread throughout the five-state area covered by this EIS, and ensure protection of a significant portion of the yew resource throughout the landscape.

\section{Riparian Areas}

No yew harvest would be allowed within 50 to 75 feet (slope distance) of any perennial stream. This would ensure a network of mature Pacific yew populations throughout the landscape, and would facilitate gene flow and possible dispersal of yew-dependent organisms across the landscape and between the set-aside areas.

\section{Genetic reserves}

Genetic reserves would be established throughout all areas where yew is harvested. No harvest would be allowed in these reserves, leaving additional populations of yew undisturbed throughout the range of the species. These reserves, coupled with areas already removed from harvest and riparian corridors, would maintain connectivity between yew populations throughout the landscape.

\section{Areas of Sparse Distribution}

No yew harvest would be allowed within local management areas where yew genetic reserves could not be established. This would retain yew population structure and distribution in areas with very sparse yew populations. Harvest in these areas would have the highest likelihood of severing connections for gene flow and species dispersal.

\section{Unique ecosystems}

No yew would be harvested from areas with unique ecosystems. 


\section{Physiographic Provinces}

Restricting harvest from riparian areas and areas of sparse yew distribution (where genetic reserves cannot be established), would greatly limit harvest in some of the physiographic provinces described in Chapter III. The Sierra Nevadas, the southern portion of the Siskiyou region, much of the Blue Mountains, and much of the Blue and Wallowa Mountains, would be largely reserved from harvest. Most of the yew in these areas is found in riparian areas, with a small amount sparsely distributed upslope. Areas in the coast ranges of California, Oregon, Washington, and the High Cascades, would also have limited yew harvest, due to the sparse distribution of the species.

\section{Harvest Pattem}

Yew harvest would be evenly distributed throughout each harvest area, as much as is possible with a species such as yew, which tends to grow in clumps.

\section{Sale Areas}

There would be small, temporary breaks in the continuity of yew distribution due to 100 percent harvest in sale areas. Some yew would be retained, however, in sale areas with green tree reserves. Yew would not be harvested in timber sale units in areas where genetic reserves could not be established unless they are in danger of being destroyed. Yew would only be harvested in areas where it is relatively abundant and connections across the landscape would be maintained after harvest in sale areas. Because yew tends to grow in clumps, it is unlikely that small breaks in population continuity would greatly affect any yew-dependent organisms. The following discussion, therefore, focuses on the impacts of yew harvest outside of timber sale units.

\section{Direct Effects}

Low risk - There are an estimated 2.93 million acres on which yew occurs in harvestable management allocations (1.47 to 2.20 million acres after reductions for potential site-specific and other restrictions). No yew harvest would be allowed in areas where genetic reserves could not be established, either within or outside
$A=$ No Action
$B=$ Timber Sales Only
$\mathrm{C}=25 \%, 5$ TPA
$\mathrm{D}=50 \%, 5 \mathrm{TPA}$
$\mathbf{F}=75 \%, 2 \mathrm{TPA}$
G1 $=50 \%, 0$ TPA,
G2 $=50 \%, 0$ TPA, OCAs
TPA is the minimum number of trees left standing per acre

Alternative C 
of timber sale units (unless in danger of being destroyed). There would be no yew harvest in riparian areas, in the set-aside areas described below, or in the genetic reserves. Yew could be harvested from all other areas where there are more than five yew trees or shrubs per acre in each harvested diameter class (3"-10", 11"-20", and greater than 20 " stump diameter).

Under this alternative, 75 percent of the yew trees (or shrubs) or five trees per acre (whichever is greater) in each of the diameter classes would be retained. This Alternative allows harvest only in areas where yew is abundant, and leaves a significant portion of the trees. Yew population connectivity would be maintained.

Needle harvest would have no direct effects on the landscape distribution of Pacific yew. No more than half of the foliage would be removed from 25 percent of the trees. No trees would be killed, and reproduction would not be affected (see Biology section in Chapter III).

\section{Indirect Effects}

Low risk - An estimated 70 percent of the stumps left after harvest should resprout (Minore, 1992). Sprouting success will vary and it is unknown how many sprouts will survive to maturity. There would be a slight reduction in the yew population, but long-term connectivity across the landscape should be maintained.

\section{Cumulative Effects}

Low risk - There is a low risk of negative impact on landscape connectivity and the geographic range of yew under this alternative. There would be potential impacts on population connectivity in extremely cut over or burned landscapes, where the distribution of Pacific yew may already have been significantly reduced. This impact would primarily be associated with yew harvest in timber sale units. Connectivity outside of timber sale units would be maintained. There are potential risks of further population reductions in areas where past yew harvest has occurred for fenceposts. Cumulative impacts could also occur if adjacent private ownerships are harvested extensively. Reintroduction of fire into the ecosystem could impact some yew populations, but its presence in the landscape will be retained. 


\section{Direct Effects}

Low risk - This alternative impacts the same acreage as Alternative $\mathrm{C}$. The only difference between this Alternative and Alternative $\mathrm{C}$ is that only 50 percent of the trees (or five trees per acre, whichever is greater) instead of 75 percent, would be left after harvest. This alternative retains a significant portion of the yew population throughout the forest matrix. Distribution across the landscape would be maintained. There is a very low risk of impacting the species range. No harvest, will occur in areas of sparse distribution at the species periphery.

Needle harvest would have no direct effects on the landscape distribution of Pacific yew. No more than half of the foliage would be removed from 50 percent of the trees. No trees would be killed, and reproduction would not be affected (see Biology section in Chapter III).

\section{Indirect Effects}

Low risk - An estimated 70 percent of the stumps left after harvest could resprout. Sprouting success will vary, and it is unknown how many sprouts will survive to maturity. There would be a reduction in the yew population (more than under Alternative C), but long-term connectivity across the landscape would still be maintained.

\section{Cumulative Effects}

Low risk - There is a low risk of negative impacts on landscape connectivity and the geographic range of yew. As with previous alternatives, there would be some potential cumulative effects on population connectivity in extremely cut over or burned landscapes, and where there is extensive yew harvest on adjacent ownerships.

\section{Direct Effects}

Moderate risk - This alternative has the same numbers of acres available for harvest as Alternative $\mathrm{C}$. This alternative would retain 25 percent of the yew trees or two trees (or shrubs) per acre (whichever is greater). The two trees per acre minimum allows

\section{Alternative $D$}


harvest in areas of more sparse yew distribution, and would impact more acreage than the previous alternatives. A larger portion of the yew trees and shrubs would be harvested under this alternative, leaving more sparse populations of Pacific yew throughout the landscape. There would also be more harvest in the larger diameter classes, which inventory results indicate rarely exceed five trees per acre.

Under this alternative, landscape connectivity should be maintained because some yew trees and shrubs would be retained throughout the entire landscape. This Alternative allows no harvest in areas with the most sparsely distributed yew populations (where genetic reserves cannot be established), which would protect the peripheries of the species range.

Until regrowth of reproductive buds occurs, needle harvest from 75 percent of the yew trees and shrubs could affect short-term natural regeneration of the species. However, overall landscape distribution of Pacific yew should not be affected.

\section{Indirect Effects}

Moderate risk - A proportion of these trees should eventually sprout and regrow, but the future population throughout the landscape would be reduced. Harvesting in areas of sparse yew distribution would leave these areas vulnerable to breaks in yew population connectivity.

\section{Cumulative Effects}

Moderate risk - Harvesting 75 percent of the yew population could lead to a slight reduction in the genetic variation of the species (see Genetics section in Chapter III), which may impact the future distribution by reducing its ability to adapt to changing environments. As with the previous alternatives, there may be some potential cumulative effects on population connectivity in extremely cut over or burned landscapes, and where there is extensive yew harvest on adjacent ownerships. 


\section{Direct Effects}

Moderate risk - This Alternative allows harvest on the same numbers of acres as Alternatives $\mathrm{C}, \mathrm{D}$, and $\mathrm{F}$. The 50 percent harvest should not impact the overall connectivity between yew populations in areas of abundant yew distribution. There would be a reduction in large Pacific yew trees and shrubs throughout the landscape. There would be a moderate risk to landscape connectivity in areas of sparse yew distribution. Harvest would still not be allowed, however, in areas where genetic reserves could not be established. This would protect the peripheries of the species range.

Needle harvest would have no direct effects on the landscape distribution of Pacific yew. No more than half of the foliage would be removed from 50 percent of the trees, no trees would be killed, and reproduction would not be affected (see Biology section in Chapter III).

\section{Indirect Effects}

Moderate risk - A proportion of yew trees and shrubs should eventually sprout and regrow. There would be a reduction in the population, but connectivity should not be threatened in areas of abundant yew populations. Harvesting in areas of sparse yew distribution, however, would leave these areas vulnerable to breaks in yew population connectivity.

\section{Cumulative Effects}

Moderate risk - Overall landscape connectivity would be maintained, except for possible breaks in areas of sparse yew distribution. As with the previous alternatives, there may be some potential cumulative effects on population connectivity in extremely cut over or burned landscapes, and where there is extensive yew harvest on adjacent ownerships.

\section{Alternative $\mathrm{G} 1$}

\begin{tabular}{|l|}
\hline $\mathbf{A}=$ No Action \\
$\mathbf{B}=$ Timber Sales Only \\
$\mathbf{C}=25 \%, 5$ TPA \\
$\mathbf{D}=50 \%, 5$ TPA \\
$\mathbf{F}=75 \%, 2$ TPA \\
G1 $=50 \%, 0$ TPA, \\
G2 $=50 \%, 0$ TPA, OCAs \\
TPA is the minimum \\
number of trees left \\
standing per acre
\end{tabular}




\section{Alternative G2 Direct Effects}

Moderate risk - This alternative would impact the largest area. Yew could potentially be harvested from an estimated 4.62 million acres over the next five years (2.31 to 3.47 million acres after reductions for potential site-specific and other restrictions). The 50 percent harvest under this alternative, while occurring over the largest acreage of all the alternatives, should not impact the overall connectivity between yew populations. There would be a reduction in larger yew trees throughout the landscape.

There would be a moderate risk to landscape connectivity in areas of sparse yew distribution. Harvest would still not be allowed, however, in areas where genetic reserves could not be established. This would protect the peripheries of the species range.

Harvest in owl conservation areas would mean that more of the landscape would be impacted in Oregon, Washington, and northern California. There would not be as many large blocks of undisturbed yew populations for gene flow or species dispersal. Fifty percent harvest in OCAs (retaining a minimum of five trees per acre) should not adversely affect landscape connectivity between yew populations.

Needle harvest would have no direct effects on the landscape distribution of Pacific yew. No more than half of the foliage would be removed from 50 percent of the trees, no trees would be killed, and reproduction would not be affected (see Biology section in Chapter III).

\section{Indirect Effects}

Moderate risk- A proportion of yew trees and shrubs should eventually sprout and regrow. There would be a reduction in the population, but connectivity should not be threatened in areas of abundant yew populations. Harvesting in areas of sparse yew distribution, however, would leave these areas vulnerable to breaks in yew population connectivity. 


\section{Cumulative Effects}

Moderate risk - Overall landscape connectivity would be maintained, except for possible breaks in areas of sparse yew distribution. As with the previous alternatives, there may be some potential cumulative effects on population connectivity in extremely cut over or burned landscapes, and where there is extensive yew harvest on adjacent ownerships. 
In this section we analyze the effects of the proposed alternatives on the ecological relationships between Pacific yew and other ecosystem components. We assess the effects of the different harvest levels on ecosystem structure and function. For the purposes of this analysis, we assumed the continued presence of Pacific yew as a stand component is essential for maintaining healthy, resilient ecosystems.

\section{Terms to Know}

Epiphytic-Living on the surface of plants.

Microclimate-The local climate of a small site or habitat.

Light Regime- The amount of sunlight reaching various levels of the forest canopy.

Nutrient Cycling - A continuous series of natural processes by which nutrients pass through successive stations in water, soil, and organisms.

This analysis focuses on the effects of the alternatives on six primary areas of ecological concern:

- stand structure;

- light regime and microclimate;

- snags and woody debris;

- nutrient cycling,

- invertebrates, fungi, epiphytic plants, microorganisms, and other "less understood" components of the ecosystem; and

- the amount of old growth forest that is impacted. 


\section{Old growth}

The amount of old growth that could be impacted under each of the alternatives is difficult to assess. While yew does occur in young stands, it is more abundant in old growth (See Ecology section in Chapter III). Certainly, old growth stands contain more of the larger diameter yew trees. Yew harvest is already restricted in many old growth set-aside areas. Outside of these areas, individual management units will prioritize stands for yew harvest, excluding areas from harvest after site-specific analysis. Areas valued for extraordinary characteristics such as unique old growth stands (unique due to either their structural characteristics or their position in the landscape) will be avoided. The potential effect on old growth will therefore depend on how much other mature forest (present and future old growth) will be impacted under each of the alternatives.

\section{Ecosystem Structure and Function}

The effect of yew harvest on ecosystem structure and function will vary from site to site. The more yew there is in an area, the greater is the species role in the existing ecosystem. The magnitude of impact in each area would vary by whether there are substitute species or structures in the stand that could fulfill yew's role in the ecosystem. Other tolerant midstory species (chinkapin, madrone, and dogwood are a few examples) may be able to substitute for yew structurally.

Whether there are substitute species that may be able to fulfill yew's functional role in the ecosystem is unknown. Pacific yew has a unique biochemistry and we know very little about its role in ecosystem processes. The following analysis is therefore highly speculative. It is assumed that removal of increasing amounts of yew will have increasing negative impacts on ecosystem function.

Further discussion concerning ecosystem protection may be found in the Wildlife, Soils, Water and Fish Habitat, Recreation, Biology, and Role of Fire sections of Chapters III and IV. 


\section{The Alternatives}

\section{Alternatives Direct Effects}

$A$ and B Low Risk- Alternatives A and B only affect Pacific yew within timber sale units. One-hundred percent of the yew will be harvested in sale areas under Alternative B. There will be no yew harvest under Alternative A, but some yew will be lost due to timber harvest and site preparation activities. The direct effects of yew harvest or loss on ecosystem structure would be minimal compared to the effects of the timber harvest itself.

A timber harvest unit located in an old growth area would directly impact the amount and distribution of old growth. Whether or not yew is retained within the area would not affect the amount of old growth that would be impacted.

There may be some impacts on ecosystem function. Soil chemistry, nutrient cycling and other ecosystem processes may be affected.

Impacts of the 100 percent yew harvest under Alternative B would be reduced by leaving yew trees and shrubs as part of green tree reserves in the sale units. Any organisms (invertebrates, fungi, epiphytic plants, etc.) that may be dependent on Pacific yew or the habitat that it creates could be impacted by these alternatives. Effects would vary by the amount of yew retained on the site (either in green tree reserves or left after timber harvest in Alternative A).

The risk of impact to dependent species and ecosystem processes under these alternatives should be low due to both the relatively small size of the areas impacted and the presence of Pacific yew in stands adjacent to the sale units. The impacts should also be temporary until Pacific yew regrows in the sale areas.

Note: The effects described above of yew harvest in timber sale units are common to the remaining alternatives. 


\section{Indirect Effects}

Low Risk - The spatial distribution and structural contribution of Pacific yew in the regenerated stand will vary by how much yew is retained in green tree reserves. If little residual yew was retained in the timber sale units then there would be more of an impact on the future stand. Yew would be regenerated, but until regrowth of the slow-growing species, structural diversity and the presence of large yew trees for snags and woody debris would be reduced. Reduction of the midstory stand component could also increase light to the understory and impact the microclimate in the stand. Degree of impact would be affected by the amount of yew retained in green tree reserves and their spatial distribution, by the amount of yew retained after harvest in Alternative A, and by the presence of substitute species and structures.

\section{Cumulative Effects}

Low Risk - If many of the timber sale units were located in areas of very sparse yew distribution, any organism or ecosystem function dependent on larger yew trees would be more severely impacted. There could also be more impact in heavily cut over or burned areas, where the local yew population has already been reduced. There may also be more impact in areas where the yew population has already been significantly reduced due to past harvest for fenceposts.

The reintroduction of fire into the ecosystem in many areas could impact yew in the future. These fires will be light, patchy burns and a significant portion of yew populations will be retained. Prescribed burning will reduce the risk of hotter wildfires in the future, which could potentially eliminate yew from some sites.

Note: The effects described below address yew harvest outside of timber sale units. See the previous discussion of Alternatives A and $B$ for the impacts within sale units. 


\section{Alternative C Direct Effects}

Low Risk - A retention level of 75 percent of the yew trees (and shrubs) or five trees per acre (whichever is greater) in each designated size class, should provide for the structural and functional role of yew in the ecosystem. By harvesting a percentage of the trees (rather than leaving a specified number), more yew is retained in areas where it makes up a significant portion of the stand and therefore plays a greater role in the existing ecosystem.

Alternative $\mathrm{C}$ would maintain yew stand structure. It would retain a large portion of the yew population, and most of the larger trees. Inventory results indicate that there are rarely more than five trees per acre in the 11 to 20 inch diameter class, and even less frequently in the greater than 20 inch class (See Inventory section in Chapter III). Yew harvest would primarily occur in the 3 to 11 inch diameter class.

Alternative $\mathrm{C}$ would have the least impact on the light regime and microclimate of any of the alternatives that harvest yew outside of timber sale areas (Alternatives C, D, F, G1 and G2). A 50 percent needle harvest from 25 percent of the trees (evenly distributed throughout the crown) would have negligible effects on the amount of light reaching the understory.

Alternative $\mathrm{C}$ would impact less acreage than alternatives $\mathrm{F}, \mathrm{G} 1$, and G2 and would, therefore, have less potential impact on old growth. Harvesting a portion of the Pacific yew would not destroy an old growth stand, but it would change the character of the stand, and could impact ecosystem function. Alternative $\mathrm{C}$ would have less impact than D, F, G1, and G2, although site-specific effects would vary, depending on the presence of substitute species and structures.

\section{Indirect Effects}

Low Risk - Alternative C would retain most of the larger diameter yew trees for future snags and down woody debris. It is difficult to assess the effect of the different harvest levels on nutrient cycling and other ecosystem processes or on the "less understood" components of the ecosystem. Alternative C would 
most likely have less impact than D, F, G1 and G2 because it would retain a higher proportion of the yew population.

\section{Cumulative Effects}

Low Risk - There would be more of an impact in stands where the yew population has already been reduced due to past harvest for fenceposts, or where the local area has been heavily cut over and/or burned.

\section{Direct Effects}

Low Risk- Alternative D would have slightly greater impacts than Alternative $C$ on stand structure and light regime. The same amount of acreage would be impacted, but only 50 percent of the trees (rather than 75 percent) would be left after harvest. The larger diameter trees, which have the largest crowns and provide the most cover, would not be harvested. Sufficient yew would remain in the ecosystem to ensure maintenance of its functional role.

Alternative $\mathrm{D}$ would impact the same amount of acreage as Alternative $\mathrm{C}$, therefore having the same potential impact to old growth.

\section{Indirect Effects}

Low to Moderate Risk - In areas where Pacific yew is a major midstory component, removal of 50 percent of the trees may greatly alter light and temperature conditions on a site. The amount of light in a stand helps determine the understory vegetation, which, in turn, influences animal use of the stand.

A dense yew midstory buffers temperature extremes in a stand, and helps intercept snow. Harvest in the dense yew stands found in the Nez Perce National Forest, which have only a scattered conifer overstory, would have the greatest impact on light regime and microclimate. These areas may be negatively impacted by a 50 percent harvest.
Alternative $D$
$A=$ No Action
$B=$ Timber Sales Only
$\mathbf{C}=25 \%, 5$ TPA
$\mathrm{D}=50 \%, 5$ TPA
$F=75 \%, 2$ TPA
G1 = 50\%, 0 TPA,
G2 = 50\%, 0 TPA, OCAs
TPA is the minimum number of trees left standing per acre 
Needle harvest on 50 percent of the trees could have more of an impact on light conditions than Alternative $\mathrm{C}$, but harvest would be evenly distributed throughout the crown and the effects would be very minor.

Future production of snags and coarse woody debris would be similar to Alternative $\mathrm{C}$, because most of the trees in the larger diameter classes would be retained, along with a significant percentage of the smaller trees.

Alternative $\mathrm{D}$ would most likely have more impact on nutrient and other ecosystem processes and on "less understood" components of the ecosystem than Alternative $\mathrm{C}$ because it removes more yew trees and shrubs. It would have less of an impact than Alternatives F, G1 and G2.

\section{Cumulative Effects}

Moderate to High Risk - There would be more of an impact in stands where the yew population has already been reduced due to past harvest for fenceposts, or where the local area has been heavily cut over or burned. If harvest were to occur in landscapes with many dense yew stands (such as on the Nez Perce National Forest), cumulative impacts from stand structural changes could result. The large amount of acreage impacted under this alternative has more potential than the other alternatives for long-term cumulative effects.

\section{Alternative F Direct Effects}

High Risk - Harvesting 75 percent of the yew trees (and shrubs) and leaving a minimum of two trees per acre in each size class would not maintain yew as a significant stand component in many areas. There would be more harvest in the larger diameter classes than under Alternatives C and D. Ecosystem function could be affected.

Some stumps would resprout and Pacific yew would continue to exist in harvested areas, but it is unknown how many stump sprouts will survive to maturity. Yew would be concentrated in the 
smaller size classes. It would take from 100 to 200 years for regenerating yew to reach the larger diameter size classes.

This alternative would have moderate to high impacts on light regime and microclimate, especially in stands dominated by yew. Temperature and decomposition rates could be impacted. Needle harvest of 75 percent of the trees could also increase the amount of light that reaches the understory.

Alternative $\mathrm{F}$ would impact more acreage than Alternatives $\mathrm{C}$ and $\mathrm{D}$, because it would allow harvest in areas of sparse yew distribution (where there are only three to five trees per acre in each harvestable diameter class). This Alternative could impact more old growth areas, and could have greater effects on old growth structural characteristics.

\section{Indirect Effects}

High Risk - Alternative F would have more impact on future snag and down log supply than $C$ and $D$, because more of the larger diameter trees would be harvested. A 75 percent harvest in the smaller diameter classes could produce a lag period in the future when there would be a shortage of larger diameter yew trees.

Alternative $\mathrm{F}$ would probably have more of an impact on nutrient cycling and other ecosystem processes and on "less understood" components of the ecosystem than Alternatives $\mathrm{C}$ and $\mathrm{D}$, because it would allow removal of more yew trees and shrubs.

\section{Cumulative Effects}

High Risk - There would be more of an impact in stands where the yew population has already been reduced due to past harvest for fenceposts, or where the local area has been heavily cut over or burned. If harvest were to occur across large land areas, and in landscapes with many dense yew stands (such as on the Nez Perce National Forest), cumulative impacts from stand structural changes could result. 


\section{Alternatlve G1 Direct, Indirect, and Cumulative Effects}

Moderate Risk - The risk of impact on ecosystem structure and function under Alternative G1 would be similar to Alternative G2. Excluding owl conservation areas from yew harvest would mean that less total acreage would be impacted, that there would be less impact on old growth, and the risk of cumulative impacts across the landscape would be reduced.

\section{Alternative G2 Direct Effects}

Moderate Risk - This alternative would allow the harvest of more yew in the larger size classes than Alternatives C and D. Like Alternative D it allows harvest of 50 percent of the trees. Unlike Alternative $\mathrm{D}$, harvest would be allowed where there are less than five trees per acre. Harvesting the larger trees would decrease structural diversity, and would increase light to the understory. There would be a moderate risk to ecosystem structure and function.

Fifty percent of the yew would still be retained. In areas where there are at least ten trees per acre this alternative is no different than Alternative D. Areas of sparse yew distribution, however, could be impacted under this alternative. Again, degree of impact would depend on the presence of substitute species or structures.

This alternative would have the most effect on old growth. It would impact the largest area, allowing harvest in areas of sparse yew distribution and in owl conservation areas, which contain a large proportion of the total old growth area in Oregon, Washington, and northern California.

\section{Indirect Effects}

Moderate Risk - Alternative G2 would have more impact on future snag and down wood supply. It would also leave more down woody debris on-site after harvest than the alternatives with a minimum retention level of five trees per acre. 
In areas of sparse yew distribution there would be more of an impact on ecosystem processes and "less understood" components of the ecosystem than under Alternatives $C$ and D. There would be less of an impact than Alternative $F$ which allows 75 percent harvest.

\section{Cumulative Effects}

Moderate to High Risk - There would be more of an impact in stands where the yew population has already been reduced due to past harvest for fenceposts, or where the local area has been heavily cut over or burned. If harvest were to occur in landscapes with many dense yew stands (such as on the Nez Perce National Forest), cumulative impacts from stand structural changes could result. The large amount of acreage impacted under this alternative has more potential than the other alternatives for long-term cumulative effects. 


\section{Biodiversity}

\section{Alternative A Direct Effects}

Moderate- Under this alternative no actual bark or foliage harvest would take place. However, yew trees and shrubs would continue to be damaged and/or killed by timber harvest activities. No efforts would be made to replace the individual trees lost. This type of management could reduce the genetic and species diversity of areas where yew is relatively rare, such as at the peripheries of the species range. (See Genetics and Ecology sections in Chapter III). Where yew is not a major component of biologic communities, the functions and structures it provides could possibly be shifted to other species. However, Pacific yew may provide some unique functions and structures because of its extremely decay resistant wood and unusual array of biologically active chemicals. It is not known if losing yew in areas where it is rare would have significant effects on biodiversity at the landscape level.

\section{Indirect Effects}

Moderate - The equilibrium of systems where Pacific yew is harvested could be altered. Ecological equilibrium refers to the 
balance that exists between living organisms and their environment. After disturbance, these systems would reach a different equilibrium which may or may not be less stable. If the same functions, habitats, and structures provided by yew could be provided by a better-adapted alternate species, equilibriums may become more stable.

\section{Cumulative Effects}

Minor-Cumulative effects from this alternative would be to continue current trends in biodiversity due to present forest management activities.

\section{Direct Effects}

Minor - The effects of removing bark from sale areas would be to locally reduce those species (fungi and/or small insects) which depend on the bark as a food source and habitat. If these species were able to utilize other food sources or habitat structures, competition for these alternate sources would increase. By ensuring that Pacific yew census numbers remain at preharvest or prescribed levels (through protection and planting), this alternative would protect and enhance species and genetic diversity at the edges of the yew species range (see Genetics and Landscape sections in Chapter III).

\section{Indirect Effects}

Minor-The equilibrium of systems where Pacific yew is harvested could be altered. These systems would reach a different equilibrium after disturbance which may or may not be less stable. As the planted yew trees and shrubs become large enough to provide food and habitat for other species, populations of those species would increase in the local area.

\section{Cumulative Effects}

Minor- Cumulative effects of this alternative on biodiversity would be slight when considered in light of the effects from timber harvesting.
Alternative $B$
$A=$ No Action
B = Timber Sales Only
$\mathbf{C}=25 \%, 5$ TPA
D $=50 \%, 5$ TPA
$\mathbf{F}=75 \%, 2$ TPA
G1 = 50\%, 0 TPA,
G2 $=50 \%, 0$ TPA, OCAs
TPA is the minimum number of trees left standing per acre 


\section{Alternatives $C$ through $G 2$}

\section{Direct Effects}

Minor to moderate - The effects of harvesting bark from sale and non-sale areas would be similar to those in Alternative B. The effect of cutting whole trees would be to remove some individuals from the population completely and remove the habitat and structure provided by the cut trees to other species (see Genetics and other sections in this chapter). Competition for remaining habitat would increase, and if species or individuals depending on Pacific yew were not able to find alternate sources, their numbers would decline. Because yew is not being completely removed from the ecosystem in these alternatives, the presence or absence of yewdependent species probably would not change. If yew does have an allelopathic* effect on some species, however, local abundance of these species could increase. Ecosystem processes which depend on long-term woody debris could be enhanced due to an increase in Pacific yew wood on the ground.

* A plant that produces chemical compounds that are released into the soil environment and are harmful to other nearby plants or germination of seeds is allelopathic.

\section{Indirect Effects}

Minor to moderate - The equilibrium of systems where Pacific yew is harvested could be altered. The more yew removed, the more the equilibrium would be changed. These systems would reach a different equilibrium after disturbance which may or may not be less stable. As surviving stump sprouts begin to grow, and abundance of yew increases, the contributions of Pacific yew to genetic, species, and community diversity would increase.

\section{Cumulative Effects}

Minor to moderate- The cumulative effect of these alternatives in timber sale areas would be the same as for Alternative B. This may be the first management activity in non-sale areas, and in these areas the cumulative effects would be the same as the direct and indirect effects. 
This section deals with the effects of the various alternatives on forest health. In Chapter III, forest health was defined as the forest's ability to return to a desired equilibrium after experiencing "events of change," both natural and human-caused. For the purposes of this analysis, that desired equilibrium is described as a diversity of existing species of trees, including yew, on an ecosystem scale with the harvest of yew as the change event. The underlying assumption is that the presence of yew, at or near existing levels in northwest ecosystems, provides the diversity needed for resilient, healthy forests. Reductions in the number and distribution of yew populations below some threshold level would seriously impair its ability to continue as a species. It is also assumed that the diversity analyzed in this section is at the ecosystem scale, not the landscape or species level (see discussion on ecosystem management below). More specific analyses of effects of the alternatives on diversity at other spatial scales are discussed in the Biodiversity and Genetics sections in this chapter.

\section{Ecosystem Management}

While the Forest Service is committed to managing both ecosystems and individual species, management strategies designed to improve or maintain forest health and diversity may sometimes conflict with the forest and resource management plans standards and guidelines recommended for the management of a single species. In these cases, the overall ecosystem strategy may take precedence over the more species-specific strategy. For example, specific standards and guidelines for the protection of Pacific yew populations on national forest lands in eastern Oregon may conflict with plans to reintroduce fire as an ecosystem component. In this example, individual yew trees and shrubs may be killed or damaged by an activity that favors the health of the ecosystem as a whole, as well as the survival of the larger yew population in the northwest. Resolution of such conflicts must be done during sitespecific analyses and cannot be addressed in this EIS.

The issue of protecting the ecosystem relates directly to forest health, because individual stands of trees and their respective ecosystems are related in ways such that the health of one depends on the health of the other.

\section{Foresthealth}




\section{Alternative A The Alternatives}

\section{Direct Effects and Indirect Effects}

Minor- While no bark or foliage harvesting would take place, yew trees and shrubs would continue to be damaged or killed by harvest activities, site preparation, and burning. It is possible, but unlikely, that specific populations of yew would lose enough individuals to lose viability as breeding populations. We expect that the numbers of yew trees and shrubs in timber sale harvest areas would decline, but distinct populations of yew would not disappear.

\section{Cumulative Effects}

Minor- The long-term effects of the loss of individual yew in stands is unknown. If all stands in the natural range of yew were harvested, the resulting reduction in ecosystem diversity could have a detrimental effect on the health of the forest at the stand and area level. However, existing harvest levels and patterns, as well as the amount needed to meet projected demand, would eliminate the need to enter all stands. This alternative would not threaten ecosystem health.

\section{Alternatives $B$ Direct and Indirect Effects}

through G2 Minor- The harvest levels proposed in all of the alternatives would have no direct impact on forest health. Each of the alternatives that proposes harvest of yew includes mitigation measures requiring some combination of genetic reserves, protection of residual trees, and regeneration of yew. Each of the alternatives would ensure a diverse and well-distributed yew population.

\section{Cumulative Effects}

Minor-The risk of reducing ecosystem diversity to levels below some acceptable threshold would increase with the amount of yew harvested and the acres entered. This threshold would depend on the amount of yew harvested, and the amount of yew originally present. The risk to forest health would increase if yew harvest were to continue beyond the five-year planning period. 
Forest soils are protected by management direction in the regional guides and more specifically by management under the standards and guidelines of the forest plans (Forest Service) or resource management plans (BLM). These standards and guidelines, their effectiveness, and the environmental consequences of management under them, are disclosed in the environmental impact statements accompanying the forest plans and other direction.

The major differences, within the alternatives discussed, will be impacts associated with increased harvest levels due to potential harvest in non-sale areas and owl conservation areas. The degree of impact will depend largely on the resiliency of the soil and the vegetative recovery rate of the site. This is largely a function of the past and present erosional factors as well as the climate and inherent capacity of the soils. Each physiographic province is a reflection of the major erosional processes, parent materials, and climate.

\section{Soils}

\section{Terms to Know}

Increased Soil Temperature-Soil is exposed to the sun's radiant energy when plants no longer shade or insulate it. Steep slopes, facing southward, receive the greatest amount of radiant energy. They can be temporarily heated to temperatures lethal to plant growth. Vegetative recovery rates are strongly affected by this action.

Increased Susceptibility to Erosion- Two types of erosion are considered in this impact:

1. water erosion (sheet, rill, and gully); and

2. wind erosion.

A site becomes vulnerable to one or both of these erosional forces when vegetation and plant litter are removed. 


\section{More Terms to Know}

Induced Soil Compaction-Soil is compacted, that is, made denser, when weight is exerted against it by foot or other traffic. Compaction reduces pore space and, therefore, restricts air and water movement through soil to the plant root system. The site then becomes less productive. Compaction also changes soil hydrologic characteristics and, in severe cases, may induce overland flow. Typically, compaction from foot pressure is about five pounds per square inch, while the pressure exerted by a skidder with rubber tires is usually more than 13 pounds per square inch (static weight).

Induced Soil Displacement-Soil displacement is the removal or rearrangement of surface soil and plant litter. Coarse-textured soils are the most susceptible to displacement since they are loosely aggregated and lack sufficient organic matter as a binder. When soil is disturbed, the most nutrient-rich portion of the soil is often involved. As a result, the site would be less productive or vegetation would recover at a slower rate.

Physiographic Province-A region where all parts are similar in geologic structure and climate, and where the geomorphic history, consequently, has been unified. Provinces differ significantly in the pattern of relief features or landforms.

Water Quality Degradation-This is the alteration of chemical, physical, and biological properties of water. Sediment production is the most frequently mentioned indicator of water quality degradation. 


\section{The Alternatives}

\section{Direct, Indirect, and Cumulative Effects}

None- Alternative A ("no action") has minimal yew harvest involved (historic levels for posts, poles, carving, and bows). This harvest would usually come from areas clearcut for timber harvest. Alternative $\mathrm{A}$ would have no impact on soils.

\section{Magnitude of Effects}

The combined effects of each Alternative can be ranked:
Alternative A - No Impact
Alternative B - 1st (least)
Alternative C - 2nd
Alternative D - 3rd
Alternative F - 4th
Alternative G1 - 5th
Alternative G2 - 6th (Most)

Please note that these effects will vary by province, vegetation zones, land slope and amount of activity.

With the exception of Alternative A ("no action") protection of the perennial stream systems is afforded since yew harvest is restricted within 50 to 75 feet on either side of the high-water level. In addition, there will be no harvest of yew in areas with unusual or uncommon parent rock, geology, or vegetation (e.g., ultramafic rock, sand dunes, or pygmy forests). Harvesting of yew will be considered on clearcuts, shelterwood cuts and seed tree cuts within harvest unit boundaries. Yew harvest in these areas would follow the mitigation measures for timber sale units (Chapter II).

Table IV-15 (next page) provides an indication of the types of impacts that could occur within the physiographic provinces, vegetation zones, and land slope categories. Definitions of these types of impacts are discussed below the Table:
Alternative A

Alternatives $B$

through G2 
Table IV-15: Types of potential impacts on Physiographic Provinces, Vegetation Zones, and Land Slope Categories

* = Non-Pumice Soils

** $=$ Pumice Soils

$A=$ Induced Compaction

$\mathrm{B}=$ Induced Displacement

$C=$ Increased Soil Temperatures

D = Water Quality Degradation

$\mathrm{E}=$ Increased Susceptibility to Erosion

\begin{tabular}{|c|c|c|c|c|}
\hline \multirow{2}{*}{ Phystographic Provtece } & \multirow{2}{*}{ Vegetation Zones } & \multicolumn{3}{|c|}{ Slope Groups } \\
\hline & & $0.30 \%$ & $30-60 \%$ & $60 \%+$ \\
\hline \multirow{3}{*}{ Olympic } & Sitka Spruce & A & A & $A, D, E$ \\
\hline & Hemlock & A & A & $\mathrm{A}, \mathrm{C}, \mathrm{D}, \mathrm{E}$ \\
\hline & Subalpine & $\mathrm{A}, \mathrm{B}, \mathrm{E}$ & $\mathrm{A}, \mathrm{B}, \mathrm{E}$ & $A, B, E$ \\
\hline \multirow{2}{*}{ Coast Range } & Sitka Spruce & A & A & $A, D, G$ \\
\hline & Hemlock & A & A & $\mathrm{A}, \mathrm{D}, \mathrm{E}$ \\
\hline \multirow{2}{*}{ Siskiyou } & Mixed Conifer & A & $\mathrm{A}, \mathrm{C}, \mathrm{D}, \mathrm{E}$ & A,C,D,E \\
\hline & Mixed Evergreen & A & A,C,D,E & A,C,D,E \\
\hline \multirow{2}{*}{ Puget Sound } & Hemlock & A & A & $A, C, D, E$ \\
\hline & Hemlock & A & A & $\mathrm{A}, \mathrm{C}, \mathrm{D}, \mathrm{E}$ \\
\hline \multirow{2}{*}{ Western Cascades } & Mixed Conifer & $\mathrm{A}$ & $\mathbf{A}$ & $\mathrm{A}, \mathrm{C}, \mathrm{D}, \mathrm{E}$ \\
\hline & Subalpine & A,B,C & $\mathrm{A}, \mathrm{B}, \mathrm{C}$ & $\mathrm{A}, \mathrm{B}, \mathrm{E}$ \\
\hline \multirow{5}{*}{ Northwestern Cascades } & Hemlock & A & A & A,C,D,E \\
\hline & Subal pine & A,B,E & $\mathrm{A}, \mathrm{B}, \mathrm{C}, \mathrm{E}$ & $\mathrm{A}, \mathrm{B}, \mathrm{E}$ \\
\hline & Hemlock & B & B & $\mathrm{B}, \mathrm{C}, \mathrm{D}, \mathrm{E}$ \\
\hline & Mixed Conifer & B & $\mathrm{B}, \mathrm{C}, \mathrm{D}, \mathrm{E}$ & $\mathrm{B}, \mathrm{C}, \mathrm{D}, \mathrm{E}$ \\
\hline & Subalpine & $\mathrm{B}, \mathrm{C}, \mathrm{E}$ & $\mathrm{B}, \mathrm{C}, \mathrm{E}$ & $\mathrm{B}, \mathrm{E}$ \\
\hline \multirow{4}{*}{ Recent (High) Cascades } & -Douglas Fir/Grand Fir & $\mathrm{A}, \mathrm{C}$ & $\mathrm{A}, \mathrm{C}$ & A,D,E \\
\hline & * Douglas Fir/Grand Fir & $\mathrm{B}, \mathrm{C}, \mathrm{E}$ & $\mathrm{B}, \mathrm{C}, \mathrm{E}$ & $\mathrm{B}, \mathrm{C}, \mathrm{E}$ \\
\hline & "Ponderosa Pine/Lodgepole P. & A,C,E & $\mathrm{A}, \mathrm{C}, \mathrm{D}, \mathrm{E}$ & $\mathrm{A}, \mathrm{C}, \mathrm{D}, \mathrm{E}$ \\
\hline & *"Ponderosa P.Rodgepole P. & $\mathrm{B}, \mathrm{C}, \mathrm{E}$ & $\mathrm{B}, \mathrm{C}, \mathrm{E}$ & $\mathrm{B}, \mathrm{C}, \mathrm{E}$ \\
\hline \multirow{4}{*}{ Modoc Plateau } & -Douglas Fir/Grand Fir & A,C & $\mathrm{A}, \mathrm{C}$ & A,C,E \\
\hline & * Douglas Fir/Grand Fir & $\mathrm{B}, \mathrm{C}, \mathrm{E}$ & $\mathrm{B}, \mathrm{C}, \mathrm{E}$ & $\mathrm{B}, \mathrm{C}, \mathrm{E}$ \\
\hline & -Ponderosa P.Radgepole P. & $\mathrm{A}, \mathrm{C}$ & $\mathrm{A}, \mathrm{C}, \mathrm{D}, \mathrm{E}$ & $\mathrm{A}, \mathrm{C}, \mathrm{D}, \mathrm{E}$ \\
\hline & - *Ponderosa P./Lodgepole P. & $\mathrm{B}, \mathrm{C}, \mathrm{E}$ & $\mathrm{B}, \mathrm{C}, \mathrm{E}$ & $\mathrm{B}, \mathrm{C}, \mathrm{E}$ \\
\hline \multirow{4}{*}{ Slerta Nevadas } & Subalpine & $\mathrm{B}, \mathrm{C}, \mathrm{E}$ & $\mathrm{B}, \mathrm{C}, \mathrm{E}$ & $\mathrm{B}, \mathrm{C}, \mathrm{E}$ \\
\hline & -Douglas Fir/Grand Fir & $\mathrm{A}, \mathrm{C}, \mathrm{E}$ & $\mathrm{A}, \mathrm{C}, \mathrm{E}$ & A,C,E \\
\hline & - Ponderosa P. Rodgepole P. & A.C & $\mathrm{A}, \mathrm{C}$ & $\mathrm{A}, \mathrm{C}, \mathrm{D}, \mathrm{E}$ \\
\hline & Subalpine & $\mathrm{A}, \mathrm{E}$ & $\mathrm{A}, \mathrm{C}, \mathrm{E}$ & $\mathrm{A}, \mathrm{E}$ \\
\hline \multirow{4}{*}{ Northeastern Cascades } & ${ }^{*}$ Douglas Fir/Grand Fir & A,C & $\mathrm{A}, \mathrm{C}$ & $\mathrm{A}, \mathrm{D}, \mathrm{E}$ \\
\hline & **Douglas Fir/Grand Fir & $\mathrm{B}, \mathrm{C}, \mathrm{E}$ & $\mathrm{B}, \mathrm{C}, \mathrm{E}$ & $\mathrm{B}, \mathrm{C}, \mathrm{E}$ \\
\hline & *Ponderosa P. $/$ Lodgepole P. & $\mathrm{A}, \mathrm{C}, \mathrm{E}$ & $A, C, D, E$ & $\mathrm{~A}, \mathrm{C}, \mathrm{D}, \mathrm{E}$ \\
\hline & * Ponderosa P./Lodgepole P. & $\mathrm{B}, \mathrm{C}, \mathrm{E}$ & $\mathrm{B}, \mathrm{C}, \mathrm{E}$ & $\mathrm{B}, \mathrm{C}, \mathrm{E}$ \\
\hline \multirow{4}{*}{ Okanagon Highlands } & \begin{tabular}{|l|} 
Subalpine \\
\end{tabular} & $\mathrm{B}, \mathrm{C}, \mathrm{E}$ & $\mathrm{B}, \mathrm{C}, \mathrm{E}$ & $\mathrm{B}, \mathrm{E}$ \\
\hline & -Douglas Fir/Grand Fir & $\mathrm{A}, \mathrm{C}$ & $\mathrm{A}, \mathrm{C}$ & A,D,E \\
\hline & - Ponderosa P./Lodgepole P. & $\mathrm{A}, \mathrm{C}, \mathrm{E}$ & $\mathrm{A}, \mathrm{C}, \mathrm{D}, \mathrm{E}$ & $\mathrm{A}, \mathrm{C}, \mathrm{D}, \mathrm{E}$ \\
\hline & Subalpine & $\mathrm{A}, \mathrm{B}, \mathrm{C}$ & $\mathrm{A}, \mathrm{B}, \mathrm{C}$ & $\mathrm{A}, \mathrm{B}, \mathrm{C}, \mathrm{E}$ \\
\hline \multirow{2}{*}{ Blue Mountains } & -Douglas Fir/Grand Fir & $\mathrm{A}, \mathrm{C}$ & $\mathrm{A}, \mathrm{C}$ & $\mathrm{A}, \mathrm{D}, \mathrm{E}$ \\
\hline & - Ponderosa P./Lodgepole P. & $\mathrm{A}, \mathrm{E}$ & $\mathrm{A}, \mathrm{C}, \mathrm{D}, \mathrm{E}$ & A,C,D,E \\
\hline Wallowas & Douglas Fir/Grand Fir & $\mathrm{A}, \mathrm{C}$ & $\mathrm{A}, \mathrm{C}$ & $\mathrm{A}, \mathrm{C}, \mathrm{D}, \mathrm{E}$ \\
\hline \multirow{3}{*}{$\begin{array}{l}\text { Northern Rocky Mountains } \\
\text { North Part }\end{array}$} & Subalpine & $\mathrm{A}, \mathrm{B}, \mathrm{C}$ & $\mathrm{A}, \mathrm{B}, \mathrm{C}$ & A,B,C,E \\
\hline & -Douglas Fir/Grand Fir & $A, C$ & A,C & $\mathrm{A}, \mathrm{C}, \mathrm{E}$ \\
\hline & Ponderosa P./Lodgepole P. & $\mathrm{A}, \mathrm{C}$ & A,C & A,C,D,E \\
\hline \multirow{4}{*}{$\begin{array}{l}\text { Northern Rocky Mountains } \\
\text { Central Part }\end{array}$} & Subal pine & B,C & $\mathrm{B}, \mathrm{C}$ & $\mathrm{B}, \mathrm{C}, \mathrm{E}$, \\
\hline & -Douglas Fir/Grand Fir & $\mathrm{B}, \mathrm{C}$ & $\mathrm{B}, \mathrm{C}$ & B,C,D,E \\
\hline & - Western Red Cedar/W.Hemlock & B,C & $\mathrm{B}, \mathrm{C}$ & B,C,D,E \\
\hline & - Ponderosa P./Lodgepole P. & $B, C$ & B,C & B,C,D,E \\
\hline
\end{tabular}




\section{Direct Effects}

None to Minor-The effects of yew harvest include the possibility of increased road traffic, foot path development, soil compaction, displaced soil horizons and forest floor (litter and duff) around the base of the yew tree. Another effect would be the loss of the shading effect and organic material contribution of the tree itself.

\section{Indirect Effects}

None to Minor - The effects of yew harvest include the possibility of increased road and foot trail erosion, ultimate sediment production, and loss of water quality; a reduction of water infiltration into the soil; a disruption of the nutrient regime; and a slight increase in soil temperature by virtue of the altered physical and biological soil surface characteristics.

\section{Cumulative Effects}

None to Minor - The cumulative effects include the potential for loss of water quality and a reduction in the nutrient cycling process. It would be expected that these effects would not persist for more than a few years.

The harvest of yew needles, rather than bark, will have the greatest impact on soils if economics dictate the use of machines designed to harvest needles. Some soil compaction, responding to foot traffic and machinery around the trees, can be expected.
Alternatives $B$

through G2, cont. 


\section{Water Resources and Aquatic Habitat}

The following section is directly related to the issue of protecting the ecosystem. People who commented expressed concern about the protection and understanding of riparian zones, watersheds, and aquatic habitat.

The harvest of Pacific yew will have little adverse effect on water yield or quality of forest streams.

Yew occurs as an understory species either as a tree or as a shrub. It rarely occurs in dense stands, rather, it is scattered throughout. Felling and bucking yew into strippable logs causes little disturbance to other understory and groundcover species. Its bark is hand-carried to a landing for weighing and packing for shipment to the processing plant. Soil disturbance is nil; therefore, the potential for erosion and the delivery of erosion products to a stream is minimal to none.

Because of the relatively small size of Pacific yew and its scattered nature in the forest, it has little or no measurable effect on the water resources of most timber sale areas. The harvest of yew will most likely occur as an adjunct to an intermediate or final timber harvest, whether confined to the timber harvest unit or expanded to the timber sale area boundary. Therefore, the timber harvest, including road construction and reconstruction, maintenance and use, not the harvest of yew, may impact the area's water resources.

Over the total geographic range, the effects of yew harvest on the water resources and aquatic habitat would be imperceptible due to the large size of the yew range and the scattered nature of its occurrence. However, the overall effects of each alternative would be the same in terms of water resources. While harvesting yew would not affect them, roads or landings associated with timber sales may. 


\section{The Alternatives}

\section{Direct Effects}

None to minor-In small headwater areas, the harvest of Pacific yew could have a favorable effect by adding to the woody debris of the terrestriai, riparian and aquatic elements. It aiso adds to aquatic habitat complexity and stability. Some short-term adverse effects may occur from possible road reconstruction and construction. Those effects would be minor because they would be unnoticeable within a couple of years.

Yew logs left in a larger stream or on its floodplain could add more mobile material that could marginally increase the risk to the stream and to facilities during floods.

The risk to streams would take the form of decreased streambank stability and increased erosion through channel aggradation and degradation. Also, channel widening could occur as the added logs divert streamflow energy against the banks, causing them to be undercut and collapse. The addition of floatable debris to unstable debris jams, when mobilized, could magnify the adverse effects of individual logs.

The risk to facilities (roads, bridges, houses, other buildings, water and sewer lines, power and telecommunication lines, etc.) would come predominantly from the mobilization of debris jams and of stored sediment. It changes or destroys by battering, exposing, breaking, rupturing, inundating, and by burying with sediment. However, yew logs would be an inconsequential component of this debris and the damage it causes.

\section{Indirect Effects}

None to minor - The harvest of Pacific yew could increase the amount of litter on the ground. This would help to better regulate infiltration, while decreasing the chance of overland flow.

Foot travel along paths from the harvest site to the weighing site by crews carrying bark filled bags could increase compaction. This could increase the chance of overland flow and the detachment,
Alternatives A

through $G 2$

$\mathbf{A}=$ No Action
$\mathbf{B}=$ Timber Sales Only
$\mathbf{C}=25 \%, 5$ TPA
$\mathbf{D}=50 \%, 5 \mathrm{TPA}$
$\mathbf{F}=75 \%, 2 \mathrm{TPA}$
G1 $=50 \%, 0 \mathrm{TPA}$,
G2 $=50 \%, 0$ TPA, OCAs
TPA is the minimum
number of trees left
standing per acre


mobilization, and transport of erosion products to nearby streams, seeps, springs, ponds, and other forested wetlands. Where the soils are non-cohesive, overland flow could lead to rilling and gullying of the path's surface.

\section{Cumulative Effects}

None-The harvest of yew needles, rather than bark, would have the least impact on the water resource.

Farther downstream from the yew harvest area, both the favorable and unfavorable effects of the harvest on the water resource and aquatic habitat could quickly become masked by natural variation. Effects could become diluted by the influence of size of the area at any given point and by land management activities in the intervening area. 
Because of the lack of information regarding yew's role in the ecosystem, this discussion is based primarily on comparisons of the magnitude of effects for each alternative. We are unable to provide concrete facts and figures at this time.

Many of the effects of the yew harvest alternatives are related to changes in forest structure and composition resulting from the removal of yew trees and shrubs of various sizes. Effects of subtle changes in habitat structure, composition, and distribution on wildlife are poorly understood, but harvest activities may result in some shifts in species composition and population densities.

The following is a brief comparison of the alternatives as they relate to wildlife and other plant species of concern. The section, "Environmental Consequences for Animals and Plants," located in Appendix $\mathrm{J}$ describes the kinds of direct, indirect, and cumulative effects on wildlife and special status plants that could occur as a result of yew harvest.

The issue of protecting the ecosystem relates directly to this section. Those who commented want protection for the yew's ecosystem in order to ensure forest diversity. People expressed concern regarding the protection of such ecosystem components as wildlife, riparian zones, and plants.

This section is divided into the following segments:

- species associated with late-successional forests;

- species associated with early-successional forests; and

- species associated with riparian areas.

Within each segment is a discussion of the direct, indirect, and cumulative effects of each of the alternatives. 


\section{Terms To Know}

Snow Interception-Overstory and mid-level forest vegetation catches falling snow, reducing snow depths on the forest floor. This ailows for easier movement for wildlife and helps make food more available. This function is especially important in some moose winter range areas.

Multilevel Canopy-A forest stand structure in which several levels of shrub and tree branches are present. Pacific yew, for example, is an understory and midstory canopy level species. Douglas-fir and western hemlock are overstory canopy level species.

Seral-Of, relating to, or constituting a series of ecological communities.

Down Woody Material-Fallen trees, branches, etc., which contribute to the organic layer of the forest floor.

\section{Species Associated with}

\section{Late-Successional Forests}

The yew harvest program would not change the amount of latesuccessional forest habitat. Harvesting yew in late-successional forests would change the character of the habitat and could affect some species. Most of the harvest in "non-sale" areas would probably be in late-successional forests.

\section{The Alternatives}

\section{All Alternatives Direct and Indirect Effects}

\section{Snags and large trees}

None- Wildlife associated with snags and large trees would not be greatly affected by yew harvest. All of the alternatives would retain some yew snags. Live yew trees remaining in an area would 
have the potential to become snags. Because Pacific yew is a smaller understory tree species, the large tree habitat component would not be affected by yew harvest.

\section{Deer and elk}

Minor-The effects of the alternatives on food and cover used by deer and elk are likely to be small unless new roads are built or closed roads are opened. None of the alternatives are expected to affect their populations. There may be instances where the removal of food and cover by yew harvest would have significant effects or where yew browse would be made more available by stump-sprouting material left after harvest could interfere with animal movements. Yew harvest occurring in fawning or calving areas could result in increased fawn or calf mortality rates.

\section{Cumulative Effects}

\section{Snags}

Minor-The cumulative effects on wildlife species associated with snags are expected to be low for all alternatives.

\section{Deer and elk}

Minor-The overall effects of any of the alternatives on food and cover used by deer and elk are likely to be small unless new roads are built or a significant number of previously closed roads are opened. None of the alternatives are expected to affect deer and elk populations. If many roads are built or opened to traffic, the availability of food and cover would be reduced according to the density of open roads in an area.

\section{Direct and Indirect Effects}

\section{Forest Structure and Composition}

None- In Alternatives A and B, yew would not be harvested outside of timber sales units; there would be more yew distributed across the landscape than in Alternatives C through G2. The contribution of yew to habitat features, such as multilayered canopies and plant species diversity, would be greatest with Alternatives $\mathrm{A}$ and $\mathrm{B}$. Animal species that use these habitat features

$\mathbf{A}=$ No Action
$\mathbf{B}=$ Timber Sales Only
$\mathbf{C}=25 \%, 5$ TPA
$\mathbf{D}=50 \%, 5$ TPA
$\mathbf{F}=75 \%, 2$ TPA
$\mathbf{G 1}=50 \%, 0$ TPA
G2 $=50 \%, 0$ TPA, OCAs
TPA is the minimum
number of trees left
standing per acre

Alternatives

$A$ and $B$ 
would be expected to be the most abundant. Animal species diversity within late-successional forest should be greatest under these alternatives. These are poorly understood relationships, however, and the degree to which this would happen is unknown.

The risk of physical damage to plant species of concern (see Chapter III) and other plant species found in late-successional forests would be least with these alternatives.

\section{Logs}

None-There would be no yew logs left in areas outside of timber sales in Alternatives A and B. These alternatives would provide the least amount of habitat for species associated with down woody material. It is unknown if species abundance or diversity would be significantly different between these two alternatives.

\section{Moose}

None-Alternatives A and B least affect moose populations using old-growth grand fir/Pacific yew forests on winter range areas in northern Idaho. These alternatives would be subject to current Forest plan direction for moose winter range and would have similar effects on moose habitat. They would not cause an overall decline in winter range suitability or populations, and would not provide any significant improvements to winter range.

\section{Roads and Wildlife}

None to minor - Deer, elk, and moose would probably have the greatest potential for being affected by changing road access to accommodate yew harvest. Additional roads would probably not be necessary under either alternative. In Alternative A, closed roads would not need to be opened. There would be no additional effects on wildlife from open roads, beyond those resulting from other activities. Under Alternative B, some closed roads may be opened. This could limit effective ungulate use of existing habitat or make animals more susceptible to poaching. 
Fruit

None-Species that feed on the fruit of Pacific yew would be least affected by Alternatives A and B, as yew would not be harvested outside of timber sale units.

\section{Cumulative Effects}

\section{Forest Structure and Composition}

Minor to moderate- There would be few short-term cumulative effects from yew harvest in Alternatives A and B compared to the other alternatives. Timber harvest, not yew harvest, would have more on the vegetative structure and plant species diversity. Under Alternative A no special provisions would be made to regenerate yew after any project. This could lead to changes in the midstory vegetation structure and plant species diversity in all subsequent seral stages. Animal species diversity in future latesuccessional forests could be reduced over time because of the loss of yew from the understory of many former timber sale units. Across the landscape the combined effects of shorter average forest ages and potentially reduced structural complexity in some stands, could result in a regional reduction in the diversity of animal species associated with late-successional forests. Efforts to regenerate yew (Alternatives B through G2) would somewhat counteract this effect. Changes in animal species distribution and abundance could also occur as a result of changed environmental conditions. The magnitude of these potential changes are difficult to assess due to the lack of knowledge about such complex ecological interactions. The risks to plant and animal species distribution and abundance are probably low for these alternatives.

\section{Logs and Fruit}

Minor - The effects of yew harvest on species associated with logs and yew fruit would probably be low.

\section{Moose}

None- There would be no cumulative effects on moose in northern Idaho beyond those caused by other activities such as timber sale harvest. 


\section{Roads and Wildlife}

Minor- Alternative A would have no cumulative effects on wildlife from increased road densities needed to accommodate yew harvest. Under Alternative B, the cumulative effects of opening roads to accommodate yew harvest would probably be low.

\section{Alternatives C Direct and Indirect Effects}

\section{through G2 Forest Structure and Composition}

Minor to high-Yew harvest under Alternatives C through G2 could result in changes in the structure and composition of latesuccessional forest habitats. There would be less yew in all size classes distributed across the landscape. The contribution of yew to habitat features such as multilayered canopies and plant species diversity would decrease as yew harvest increases in Alternatives $\mathrm{C}$ through $\mathrm{G} 2$. The alternatives differ in the number of acres available for harvest but the number of acres that would actually be harvested depends on site-specific and other constraints. The risks of physical damage to plant species of concern would generally increase with yew harvest acres. These risks could be substantially reduced with site-specific restrictions.

Animal species using these habitat features would be expected to be less abundant than under Alternatives A and B. As yew harvest increases, in Alternatives $C$ through G2, species abundance decreases. Animal species diversity would also be expected to show the same pattern. These are poorly understood relationships, however, and the degree to which this would happen is unknown. The Interim Guide assumes that 30 to 50 percent of the yew midstory could be removed without a significant risk of reducing the abundance and fitness of vertebrates using the area. This information is based on findings from a study in the Oregon coast range. The study found that removing approximately 30 percent of the Douglas-fir overstory in half-acre patches did not have appreciable short-term effects on small birds or mammals (USDA Forest Service, 1992a). Removing 25 percent of the yew in an area (Alternative C) most likely would have a low probability of reducing or removing species from that area. Removing 50 percent of the yew (Alternatives D, G1, and G2) presents a higher, but probably still fairly low risk of reducing or removing wildlife 
species from an area. Where 75 percent of the yew is removed from an area (Alternative F), there may be a moderate probability of reducing or removing a few species from areas with low yew densities and a high probability for areas where yew is dense. In site-specific cases, such as in areas important to threatened or endangered species, the consequences of reducing or removing one of these species are much greater and therefore the risks are also increased.

In areas where dense patches of yew make up a higher proportion of the midstory layer, effects on animal and other plant populations and communities may be greater. At the harvest level of Alternative $\mathrm{C}$, it may be possible to maintain the functionality of some dense patches of yew. Under Alternatives D, G1, and G2 a few dense patches of yew would remain, but in fewer areas. Dense patches of yew would be largely eliminated under Alternative F.

\section{Logs}

Minor-If yew logs are left on non-timber sale sites after bark harvest, there would be more logs than in Alternatives A and B, with increasing numbers of logs in Alternatives $C$ through G2. These additional logs would be unlike naturally occurring logs in that they will be peeled, cut into pieces and, possibly, piled. If peeled yew logs are removed from non-timber sale sites, this source of coarse woody debris would be reduced. The effects of these changes to wildlife are unknown, but the abundance of some species may increase with increasing numbers of yew logs. Where yew is abundant, large quantities of woody material left on the ground could impede movements of some species. The role of yew logs in streams and riparian areas is discussed below, as well as in the water quality section.

\section{Moose}

Minor-Moose winter range, located in areas where Pacific yew is an important ecosystem component, would be managed in accordance with the goals presented in the forest plans. In most cases, this would limit yew harvest to fairly light levels and on fewer acres than would otherwise be permissible under Alternatives C through G2. Decisions about yew harvest in particular areas would be based on site-specific analysis.
$A=$ No Action
B = Timber Sales Only
$\mathrm{C}=25 \%, 5$ TPA
$\mathrm{D}=50 \%, 5$ TPA
$\mathrm{F}=75 \%, 2 \mathrm{TPA}$
G1 $=50 \%, 0$ TPA,
G2 = 50\%, 0 TPA, OCAs

TPA is the minimum number of trees left standing per acre 
Alternatives

$C$ through $G 2$,

cont.
On areas where thermal cover and snow interception are not the primary concerns, moose using old-growth grand fir/Pacific yew forests as winter range in northern Idaho could be somewhat benefited by light yew harvest in selected areas where yew has grown out of reach of the moose. Yew harvest under these alternatives would not result in an overall decline in winter range quality, and could possibly improve it. Harvest needs to leave enough vegetation remaining in the overstory and the yew layer to provide for snow interception. More forage would be available approximately two years after harvest. The potential habitat quality of moose winter range could be slightly better with these alternatives compared to Alternatives A and B. However, at this time, the level of understanding of moose habitat relationships with respect to Pacific yew is such that we are unable to determine precisely what yew harvest levels should be in order to obtain this result. Monitoring of moose and yew response would be necessary before proceeding with yew harvest on a substantial scale on this type of moose winter range. Monitoring would need to encompass a variety of winter weather conditions and winter range characteristics.

\section{Roads and Wildlife}

Moderate - Additional road building and/or opening of closed roads occurring in connection with yew harvest could subject deer, elk, and moose to increased stress. Their distribution could become more restricted and their abundance could decline. This could occur with any alternative that allows yew harvest outside of existing timber sale units (Alternatives C through G2). The degree to which this would affect wildlife would depend on the open road densities and the amount of traffic that would result from these activities. Open road densities would likely increase slightly with increasing yew harvest levels and acres available for yew harvest, and could have a moderate affect on wildlife use. Based on this assumption, habitat quality for species affected by open road densities would be worse under these alternatives than under Alternatives $\mathrm{A}$ and $\mathrm{B}$, with habitat quality declining in order of Alternatives $C$ through G2. Disturbance from yew harvest in fawning or calving areas could result in increased fawn and calf mortality. 


\section{Fruit}

Minor to high-Species that feed on the fruit of Pacific yew would have less fruit available under these alternatives than under Alternatives A and B. As yew harvest increases in Alternatives $\mathrm{C}$ through $\mathrm{G} 2$, the amount of available fruit would decrease. Since none of the species known to eat yew fruit are thought to rely heavily on it, Alternatives C, D, G1 and G2 probably would not reduce or remove species from most areas. However, Alternatives D through G2 could result in population reductions for some plant and animal species in areas where fruiting yew is particularly abundant.

\section{Cumulative Effects}

The most serious potential cumulative effects for wildlife are changes to the midstory layer of vegetation, moose winter range habitat in northern Idaho, and disturbance from open roads and human activity.

\section{Forest Structure and Composition}

Moderate to high - The cumulative effects on forest structure would reduce the amount of yew in dense patches throughout its range. In areas where yew makes up a greater proportion of the midstory vegetation layer, yew harvest could have greater effects on wildlife and other plant species than in areas where other tree species contribute more to that layer. The same principle holds for shrub-form yew.

Under Alternative C, harvest at the 25 percent level on all available acres may change the multilayered character of some areas enough to affect the distribution and abundance of some species. Most areas would probably not be altered enough to cause significant changes.

Harvest at the 50 percent level on all available acres under Alternatives D, G1, and G2 would change the multilayered character of more areas, but some areas would still not be altered enough to cause significant changes to species distribution and abundance. These changes would occur on more acres with Alternatives G1 and G2 than with Alternative D. There may be moder- 
ate risks associated with unforeseen effects at this harvest level. Site-specific restrictions could greatly reduce but not eliminate the risks to species distribution and abundance. The short time frame of this program increases the chances of unforeseen effects if applied on a broad scale.

Under Alternative $\mathrm{F}$, harvest at the $\mathbf{7 5}$ percent level on all available acres could affect the distribution and abundance of some species. There may be high risks associated with unforeseen effects.

\section{Logs}

Minor-Yew logs left on the harvest site would remain for a long time due to the decay-resistant nature of yew wood. The degree to which this would benefit species associated with down woody material is unknown, as is the rate of accumulation of down yew wood in the absence of yew harvest. Cumulative benefits in space, and possibly over time, would be greatest for Alternative F, and would decrease for Alternatives G2, G1, D, and C. If yew logs are removed from harvest sites, there would be a cumulative loss of this type of down woody material.

\section{Moose}

Minor-Management that would meet forest plan goals to favor important moose winter range quality would limit yew harvest to fewer acres than would otherwise be permitted under Alternatives C through G2. If these limitations were not instituted, and yew was harvested everywhere on moose winter range in northern Idaho, winter range quality would probably decline to some degree, even under fairly light harvest levels (such as in Alternative C). Although yew harvest would provide additional forage two years after the harvest, the snow interception ability of some areas would be reduced if harvest was not limited, resulting in a net decline in habitat quality. The degree to which this would affect current or potential population levels is unknown at this time. However, factors other than winter range are considered to be the current limiting factors (Blair, 1992). 


\section{Roads and Wildlife}

Moderate - The increased human activity that would occur if yew is harvested on all available acres in a few years could substantially increase the negative effects on ungulates and other species sensitive to human disturbance. Yew harvest on that scale would require opening many closed areas to traffic. Animal distribution and abundance could decline. Based on these assumptions, habitat quality for species affected by human disturbance and open road densities would be worse under these alternatives than under Alternatives A and B. Habitat quality would become increasingly worse in Alternatives $\mathrm{C}$ through $\mathrm{G} 2$ as more roads are opened for longer periods.

\section{Fruit}

Minor to high - Effects due to the reduction in yew fruit would probably be low for Alternative C, but could be moderate for Alternatives $\mathrm{D}$ and $\mathrm{G}$ in regions with relatively high yew densities. Species that feed on the fruit would have the least fruit available in Alternative $\mathrm{F}$. There could be moderate population reductions for some species in local areas where fruiting yew is abundant.

\section{Species Associated with}

\section{Early-Successional Forests}

The yew harvest program would not create early-successional forests, but would affect the structure of early-successional forests created by timber harvest in areas where Pacific yew occurs. Further discussion on the kinds of effects on wildlife and special status plants that could occur in connection with yew harvest is included in Appendix J.

\section{The Alternatives}

\section{Direct and Indirect Effects}

\section{Forest Structure and Composition}

Minor- Alternative A would have the least effect on habitat structural complexity and plant species diversity. There might be less suitable habitat for some early successional species and more

$$
\begin{aligned}
& \mathbf{A}=\text { No Action } \\
& \mathbf{B}=\text { Timber Sales Only } \\
& \mathrm{C}=25 \%, 5 \mathrm{TPA} \\
& \mathrm{D}=50 \%, 5 \mathrm{TPA} \\
& \mathbf{F}=75 \%, 2 \mathrm{TPA} \\
& \text { G1 }=50 \%, 0 \mathrm{TPA} \\
& \text { G2 }=50 \%, 0 \mathrm{TPA}, \text { OCAs } \\
& \text { TPA is the minimum } \\
& \text { number of trees left } \\
& \text { standing per acre }
\end{aligned}
$$

\section{Alternative A}


suitable habitat for others. The magnitude of the effects are likely to be small in most cases.

Logs

None-Compared to the quantity and piece sizes of down woody material that could be contributed by timber harvest activities, the amount that could be contributed if yew logs were left on the site would be minimal.

\section{Deer and Elk}

Minor- There would be less forage and cover for ungulates in some cut over units under Alternative $A$ than in the other alternatives, but the effects on populations would not be significant in most cases.

Yew regenerating in winter range areas may not reach full-size, due to the browsing of ungulates. Where yew is a major component of the snow intercept canopy, this could increase the amount of time before yew would return to its original position in the ecosystem.

\section{Cumulative Effects}

\section{Forest Structure and Composition}

Minor- Under Alternative A, no special provisions would be made to regenerate yew after any project. This could lead to changes in the midstory vegetation structure and plant species diversity in all subsequent seral stages, There could also be possible changes in animal and plant species distribution and abundance. Animal species diversity across the landscape might be reduced over time because of the loss of yew from the understory of many former timber sale units. The magnitude of these potential changes are difficult to assess due to insufficient knowledge of complex ecological relationships, but are likely to be minor. 


\section{Direct and Indirect Effects}

Forest Structure and Composition

Minor- Habitat structural complexity and plant species diversity in sale units containing Pacific yew would be greater in Alternatives B through G2 than in Alternative A. Some earlysuccessional species might benefit from the remaining vertical structure that would offer perching sites and hiding cover, but the magnitude of the effects are likely to be small.

\section{Logs}

None- Compared to the quantity size of woody debris left from timber harvest activities, the amount that could be contributed if yew logs were left on the site would be minimal.

\section{Ungulates}

Minor - Alternatives B through G2 would provide more forage and cover for ungulates in some cut over units. Yew harvest effects on populations would not be significant in most cases.

\section{Cumulative Effects}

\section{Forest Structure and Composition}

Minor- Under Alternatives B through G2, yew would be regenerated in timber sale units and partial-cut units. Animal species diversity across the landscape might be greater over time compared with Alternative A because yew would be retained in the understory of former timber sale units. This would lead to increased complexity in the midstory vegetation structure and greater plant species diversity in all subsequent seral stages. The effects on animal and plant species distribution and abundance in earlysuccessional forests would probably be small in most areas.
Alternatives $B$ through $\mathrm{G} 2$ 


\section{Species Associated with Riparian Areas}

Most of the potential effects of yew harvest on species associated with riparian areas would involve yew harvest close to perennial streams. Species dependent on stream shading and water cooling would be affected by yew harvest in riparian areas. Fewer yew logs would be available for pool formation in streams.

Disturbance caused by yew harvesters in uplands adjacent to riparian areas could temporarily displace or disturb wildlife species using those riparian areas.

\section{The Alternatives}

\section{Alternative A Direct and Indirect Effects \\ through G2 Stream Shading, Water Cooling, Pool Formation}

None- If yew is not harvested within 50 to 75 feet (slope distance) of the average high water level of perennial streams, there would be little impact, in most cases, from any alternative on species associated with riparian areas. Stream shading and water cooling by yew would be unaffected for all of the alternatives, as would the contribution of yew logs to pool formation in streams.

\section{Cumulative Effects}

None- Cumulative effects would not be significant in most riparian areas. Riparian habitats not within 50 to 75 feet of perennial streams would be affected in the same manner as described for late and early-successional forest species.

\section{Alternatives $A$ and $B$}

\section{Direct and Indirect Effects}

Disturbance, Sensitive Plants

Minor-There would be less disturbance caused by yew harvesters in adjacent upland areas compared to the other alternatives. Plant species of concern found in riparian areas within the range of Pacific yew would not be affected by these alternatives beyond the effects of the timber sales. 


\section{Cumulative Effects}

None to minor - In most cases, cumulative effects would not be significant.

\section{Direct and Indirect Effects}

\section{Disturbance, Sensitive Plants}

Minor- If yew is not harvested within 50 to 75 feet (slope distance) of the average high water level of perennial streams, there would be little effect from any alternative on species associated with riparian areas. Disturbance by yew harvesters in adjacent uplands could have small, temporary effects on wildlife using riparian areas (especially in Alternatives C through G2). Several plant species of concern are found in riparian areas within the range of Pacific yew (e.g. Dryopteris filix-mas [male fern], and Ribes oxyacanthoides cognatum [Umatilla gooseberry]). In individual cases where these species are located more than 50 to 75 feet from a perennial stream, adverse effects could be avoided by modifying the harvest unit layout. Riparian habitats not within 50 to 75 feet of perennial streams would be affected in the same manner as described for late and early-successional forest species.

\section{Cumulative Effects}

None to minor - In most cases, cumulative effects would not be significant.

\section{Alternatives \\ C through $\mathrm{G} 2$}


Threatened and Endangered Species
All management activity on Federal lands is governed by a complex set of guidelines (forest plans, resource area management plans, Endangered Species Act, state water quality standards, National Environmental Policy Act, National Forest Management Act, etc.). Some of these guidelines are laws and must be adhered to. Others are guidelines that give direction.

For all alternatives it is assumed:

No federal laws will be broken.

If no federal laws are broken, there will be no adverse impacts to any threatened, endangered, or proposed species.

There will be beneficial and adverse effects from any alternative.

Human disturbance will increase according to the amount of yew harvested.

The lower the minimum number of yew trees left per acre, the more acres available for yew harvest.

The term yew harvest is defined as the harvest of yew bark, needles, twigs, and stems by mechanical or non-mechanical means.

For the purpose of this analysis, any species proposed as threatened or endangered will be analyzed as if it is listed as such.

After final analysis of alternatives the Forest Service will complete the biological assessment and deliver it to the U.S. Fish and Wildlife Service and National Marine Fisheries Service for consultation.

The issue of protecting the ecosystem relates directly to this section. A major concern among those who commented was protecting and understanding threatened or endangered species. 


\section{The Alternatives}

\section{Direct Effects}

Minor - Alternative A has minimal yew harvest involved (historic levels for posts, poles, carving, and bows). This harvest would usually come from areas that have been clearcut for timber harvest. The direct effects from this level of yew harvest would be minimal compared to the effects of the timber harvest. Human disturbance, soil compaction, soil erosion, water quality changes, and local vegetation changes are expected to be almost zero. Very little yew is being removed, and the effects of the timber harvest would overshadow these effects. When yew is removed from areas that are not clearcut, the effects may be marginally higher but they would still be near zero. At this level of harvest, direct effects are expected to be close enough to zero as to be unmeasurable.

\section{Indirect Effects}

None-A minimal amount of yew would be harvested under this alternative, and most would come from clearcut areas. There would be no expected indirect effects.

\section{Cumulative Effects}

Minor-Yew harvest under this alternative would have minor cumulative effects. Clearcutting activities and site preparation and/or fuel reduction (burning) activities in clearcut and planting areas, could reduce the number and vigor of residual Pacific yew. Where yew is the predominate forage species in winter range areas, a reduction in yew could cause a decline in ungulate (deer, elk, moose, and caribou) populations. A decline in the number of these species could reduce the number of predators (wolf, grizzly bear). However, any reduction in habitat over time would be caused more by timber harvest and planting of non-yew species than by yew harvest.

\section{Alternative A}

$\mathbf{A}=$ No Action
$\mathbf{B}=$ Timber Sales Only
$\mathbf{C}=25 \%, 5$ TPA
$\mathbf{D}=50 \%, 5$ TPA
$\mathbf{F}=75 \%, 2$ TPA
$\mathbf{G 1}=50 \%, 0$ TPA,
G2 $=50 \%, 0$ TPA, OCAs
TPA is the minimum
number of trees left
standing per acre




\section{Alternative $B$ Direct Effects}

Minor- Additional human disturbance from harvesting yew would have minor effects on the species listed in sections B and C in Appendix $\mathrm{J}$ (compared to Alternatives $\mathrm{C}$ through G2). Sitespecific disturbance may have significant effects on some animals and plants.

Disturbance to the physical habitat (soil compaction, soil disturbance, soil erosion, vegetation damage, etc.) is expected to be minor. The direct effects from this alternative would be minimal compared to the effects of timber harvest.

\section{Indirect Effects}

Minor-Clearcutting activities and site preparation and fuel reduction (burning) activities in clearcut and planting areas, could reduce the number and vigor of residual Pacific yew. Where yew is the predominate forage species in winter range areas, a reduction in yew could cause a decline in ungulate (deer, elk, moose, and caribou) populations. A decline in the number of these species could ultimately reduce the number of predators (wolf, grizzly bear). Additional human disturbance associated with yew harvest could result in increased stress for ungulates and potentially, wolves. If the increased stress caused winter die off of non-threatened/endangered ungulates, this could be a food source for wolves, grizzly bear, bald eagles, and wolverines. This food source would be a short-term food source (lasting only for the winter). Because this alternative would protect some yew and other plants remaining in timber sale areas after harvest, it would have fewer effects than Alternative A.

\section{Cumulative Effects}

Minor-Across the geographic range of the Pacific yew (during the five-year planning period covered by this EIS), this alternative is expected to have fewer effects on yew-dependent and yewrelated species than Alternative A. Protection of some of the existing yew, and planting to pre-harvest levels, would provide for future yew trees. A reduction in the number and distribution of yew could cause a reduction in the number and distribution of yew-dependent species. 
Because of the present restrictions on where timber harvest activities may occur, the cumulative effects of the yew harvest and human disturbance on threatened and endangered species would probably be minor.

\section{Magnitude of Effects}

By leaving at least 75 percent of existing yew or five trees per diameter class per acre (whichever is greater), Alternative $\mathrm{C}$ has low potential of impacting threatened and endangered species. Alternative D has moderate potential, and Alternatives F, G2, and G1 have increasing potential, with G2 having the greatest. The nature of effects likely to occur as a result of yew harvest are the same for Alternatives C through G2, and are described below.

\section{Direct Effects}

Minor-Additional human disturbance from harvesting and regenerating yew could have some of the following effects on the species listed in sections $\mathrm{B}$ and $\mathrm{C}$ in Appendix $\mathrm{J}$ : wolf dens could be abandoned; ungulates could be stressed for lack of adequate winter range; ungulates, wolves, and grizzly bears could change use patterns; people could be attacked by grizzly bears; eagles and murrelets could abandon nest sites; and any changes in water quality could affect fish (see Appendix J).

Site-specific disturbance could have significant effects on some animals and plants. Additional human disturbance associated with yew harvest could ultimately result in increased stress among ungulates, and could result in displacement. This local absence of ungulates may cause predators to leave their traditional hunting grounds in search of food. More yew would be harvested under these alternatives, resulting in more impacts from human disturbance, than in Alternatives A and B. In addition, there would be impacts from yew harvest in non-sale areas. Because of the many variables involved, the effects from human disturbance are difficult to quantify in this EIS. These effects will need to be discussed in site-specific environmental assessments. Buffer zones and timing restrictions could reduce the impacts caused by human disturbance.

\section{Alternatives $C$ \\ through $G 2$}


Disturbance to the physical habitat (soil compaction disturbance and erosion, vegetation damage, and water quality) is expected to be minor in areas where yew is not a major stand component. These effects would be greater in stands where yew is a major stand component. The magnitude of these effects would depend on the amount of yew harvested, and the techniques used to haul yew bark and logs. These effects could contribute to a reduction in water quality, which would affect the fish species listed in sections $\mathrm{B}$ and $\mathrm{C}$ in Appendix $\mathrm{J}$.

Impacts on the soil from these alternatives could potentially affect listed plants. Soil compaction, seedbed disruption, and soil erosion could affect seed germination, plant vigor, and asexual reproduction in site-specific areas. These impacts would need to be covered in site-specific documents.

Because these alternatives would permit harvest in extensive areas of currently suitable owl habitat, they have the potential to impact spotted owl prey habitat and the quality of spotted owl roosting habitat. The extent of the impact would depend on the proportion of yew in the stand and the amount of yew harvested. (For more information see Appendix J.)

\section{Indirect Effects}

Minor to high - Damage from clearcutting activities and site preparation activities (burning), could reduce the number and vigor of residual Pacific yew. In those winter range areas where yew is the predominate forage species, a reduction in yew could cause a similar reduction in ungulate (deer, elk, moose, and caribou) populations. A decline in the number of ungulates could ultimately reduce the number of threatened and endangered predators (wolf and grizzly bear).

The harvest of yew bark and foliage in winter range areas could result in a reduction in carrying capacity for these areas. If the carrying capacity of one winter range is reduced, ungulates may move to another winter range. This may cause increased browsing in the second winter range, and could lead to a future reduction in carrying capacity for that area. Territorial predators (such as 
wolves) might need to move into another predator's territory in order to follow the ungulates as they move to different winter range areas.

\section{Cumulative Effects}

Minor to high-Across the geographic range of the Pacific yew (during the five-year harvest period covered by this EIS), these alternatives would be expected to have fewer effects on yewdependent/related species than Alternatives A and B. The creation of genetic reserves, protection of a specified percentage of the existing yew, and re-planting yew in clearcuts and shelterwood units, would ensure long-term sustainability for Pacific yew. The reduction in the number and distribution of yew may cause a reduction in the number and distribution of dependent species. We know of no species totally dependent on yew, however, if there is such a species, the reduction of yew could cause it to become threatened or endangered. The protection and regeneration of yew may allow yew and this species to return to present levels.

\begin{tabular}{|l|}
$\mathbf{A}=$ No Action \\
$\mathbf{B}=$ Timber Sales Only \\
$\mathbf{C}=25 \%, 5$ TPA \\
$\mathbf{D}=50 \%, 5$ TPA \\
$\mathbf{F}=75 \%, 2$ TPA \\
G1 $=50 \%, 0$ TPA, \\
G2 $=50 \%, 0$ TPA, OCAs \\
TPA is the minimum \\
number of trees left \\
standing per acre
\end{tabular}




\section{Access for Yew Harvest}

Access to any particular area is always governed by the national forests' or BLM districts' standards and guidelines for each management area. Any access project would require site-specific environmental analysis. Areas already accessible by road systems would most likely be considered first for any yew harvest because of time and cost efficiency.

This section discusses how the alternatives would affect access needs for yew harvest. Under those alternatives in which increased access is a possibility, the relevant issues are wildlife disturbance and changes in recreational use.

\section{The Alternatives}

\section{Alternatives Direct, Indirect, and Cumulative Effects}

$A$ and $B$ None- There would be no yew harvested for taxol production under Alternative A, and none harvested outside of timber sale units under Alternative $B$. Therefore, there would be no change in access to the forest.

\section{Alternatives Direct Effects}

C through $\mathrm{G} 2$

None to minor - Under all of the alternatives, construction could be required to create or improve access to the yew harvest area. This could include road construction, reconstruction, or upgrading, as well as trail construction and upgrading. It is possible that helicopter pads could be required for yew removal in unroaded areas, although this is unlikely.

Road and trail construction and reconstruction could result in increased sedimentation, dust, and noise. These effects would usually be temporary.

\section{Indirect Effects}

None to minor - Creating or improving access to an area usually results in increased use. If access to an area improves because of road and trail construction or enhancement, those roads and trails 
could receive more use than in the past. This could result in increased sedimentation, dust, and noise which would continue as long as the increased use occurs.

Other indirect effects of increased access to an area might include wild life harassment and changes in recreational use (see Wildlife and Recreation sections in this chapter).

\section{Cumulative Effects}

Minor - If access to an area was changed to make opportunities for both yew harvest and timber harvest, then the effects outlined above would have to be considered for both of these activities in conjunction with each other. Typically, the effects would be similar for both types of projects, although the effects associated with the timber sale would be greater in magnitude. 


\section{Pacific Yew \\ Harvest and \\ Timber Harvest}

This section relates directly to the issue of the economic effect of yew harvest on the timber supply. The types of possible effects are listed first and then followed by a discussion of the direct, indirect, and cumulative effects for Alternative A and for Alternatives B through G2, as a group.

Pacific yew harvest may impact or conflict with timber harvest in various ways:

1. Pacific yew harvest may delay timber harvest if the yew is not harvested first in a timely manner.

2. The ability to establish new timber stands may be impacted due to yew protection measures, especially those that limit fire as a tool for site preparation for replanting timber species.

3. Some harvest operations, such as timber falling, may be hindered by additional measures necessary to leave and protect residual yew trees.

4. The genetic reserve areas established for the protection of the Pacific yew species may remove some acres from timber production.

5. The time period to grow an acceptable size yew tree may conflict with the rotation length for timber species.

\section{The Alternatives}

Alternative A Yew would not be harvested, so timber harvest will not be impacted. There are no direct, indirect, or cumulative effects.

\section{Alternatives $B$ Direct Effects}

through G2 Yew harvest may conflict with or impact commercial timber harvest directly because if the yew is not harvested first in a timely manner the harvest of the commercial species may be delayed. (The Yew Act of 1992 requires yew to be harvested before the commercial timber harvest.) Some harvest operations may be physically hindered, delayed or complicated by additional measures required to leave and protect residual yew trees and shrubs. 


\section{Indirect Effects}

Yew harvest may conflict with or impact commercial timber harvest indirectly by changing the composition of future stands somewhat. The ability to establish new timber stands may be impacted due to yew protection measures, especially those that limit fire as a tool for site preparation for replanting timber species. Also, for Alternatives C through G2, the genetic reserve areas established for the protection of the Pacific yew species may remove some acres from timber production.

\section{Cumulative Effects}

Yew harvest may conflict with or impact commercial timber harvest over time by reducing the acres available because of the establishment of yew reserves. Protection and regeneration of yew may change the composition of timber stands over time, and the rotation periods for timber harvests may conflict with the period required to grow Pacific yew of a desirable size.

$\mathbf{A}=$ No Action
$\mathbf{B}=$ Timber Sales Only
$\mathbf{C}=25 \%, 5$ TPA
$\mathbf{D}=50 \%, 5$ TPA
$\mathbf{F}=75 \%, 2$ TPA
G1 $=50 \%, 0$ TPA,
G2 $=50 \%, 0$ TPA, OCAs
TPA is the minimum
number of trees left
standing per acre


Roadless Areas
The effects of timber harvest and related activities (road building, re-opening previously closed roads, site preparation activities) in or adjacent to roadless areas can include impacts on:

- roadless character (natural integrity, apparent naturalness, remoteness, and solitude);

- recreation setting and experience;

- big game habitat quality;

- and available access to future forest management activities.

These effects can be quantified and interpreted based on various factors:

- roadless acres harvested;

- miles of new road constructed and total road density;

- acres retaining roadless character; and

- cumulative effects in combination with past and future activities.

\section{The Alternatives}

\section{Alternative A Direct, Indirect, and Cumulative Effects}

None - There would be no yew harvested under Alternative A and therefore no change in roadless areas or related resources.

\section{Alternatives B Direct, Indirect, and Cumulative Effects}

through $G 2$

None - Each forest plan contains outlines for the percent of roadless area available for entry and the rate at which these areas may be developed. It is unlikely that any roadless areas would be entered for the purpose of yew harvest. However, should entry into an available roadless area be proposed at any time during implementation, a site-specific analysis would be required for all ground disturbing activities, and any potential effects on roadless characteristics would be analyzed according to forest-wide standards and guidelines. 


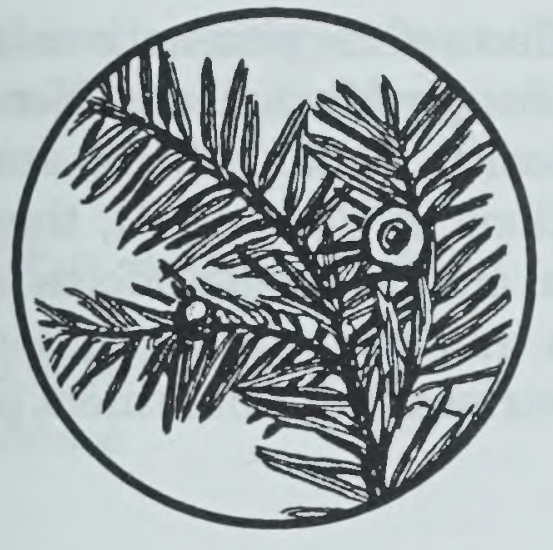

\section{Chapter IV}

Environmental consequences

\section{Part Three: The Yew and People}

\section{Table of Contents}

Social and Economic Effects

The Alternatives

Recreation

The Alternatives

Summary of Irreversible or Irretrievable

Committment of Resources

Irreversible Effects

Irretrievable Effects 


\section{Part Three: The Yew and People}

This part of Chapter IV addresses the effects of the alternatives in terms of people, values, and uses. Although Market and Nonmarket Considerations, Jobs, Public Health, Social Setting, and Cultural Resources were separate sections in Chapter III, they were merged under the heading of Social and Economic Effects in this chapter. The two other sections in this part are Recreation and The Summary of Irreversible or Irretrievable Commitment of Resources.

Issues related to the social and economic effects of yew collection on resources, economies, and future options are varied. People were concerned that maintaining a sustained forest ecology is essential for ensuring the future of taxol and other important drugs yet to be discovered. Many people think that the agreement with Bristol-Myers Squibb company is monopolistic, and that many companies, not just one, should benefit from taxol production. Several people suggested that yew harvest take place only in active timber sale areas. Also, some expressed concern about whether yew would provide jobs, especially for displaced timber workers. People afflicted with several forms of cancer view taxol as a life-saving drug treatment.

Here we discuss how the alternatives affect peoples' lives and the local economy, as well as the availability of yew bark and needles for different purposes. The social and economic effects of the alternatives (Alternatives B through G2) are described in terms of:

Government direction and expenditure

Bark pricing

Bark theft and safety

Patient treatment

Taxol production

Job creation

Local employment (from harvesting)

Cultural values

Traditional use

Affected geographic areas

Returns to the government Alternative $\mathrm{A}$ is fundamentally different than the other alternatives because it is the only alternative under which there would be no formal bark harvest program from federal lands; it has minimal yew harvest activities for such specialized uses as fenceposts, 
poles, carving, lutes, and bows. Harvest of Pacific yew for these uses usually occurs on timber harvest units.

\section{The Alternatives}

\section{DirectEffects}

None

\section{Demand}

Alternative A would not meet the demand for Pacific yew bark from federal land. See Table IV-16 for quantity of bark harvested and taxol supplied under each alternative. The price of bark from other ownerships would increase due to a reduction in total supply.

\section{Govemment Expenditures}

Under this alternative, there would be no government expenditures for the management of yew bark.

\section{Govemment Direction}

There would be no agreements, mitigation measures, or other government commitments concerning Pacific yew.

\section{Bark Theff}

There would be no special protection for the Pacific yew, other than that afforded under normal agency law enforcement. The effect this would have depends on demand for bark. If demand remains high, without procedural checks, we could see a substantial increase in yew bark theft.

\section{Safety}

There would be no increase in injuries associated with yew bark collection.

\section{Indirect Effects}

None

\section{Alternative $A$}




\section{Alternative A, cont.}

Retums to the Govemment

Under this alternative, there would be no harvest of Pacific yew bark from federal lands. This alternative would not be responsive to the need to provide bark for taxol production. There would be no returns to the government from the sale of bark.

\section{Secondary Market and Jobs}

Traditional users would continue to be able to use Pacific yew bark, needles, and wood. There would be no impact to the secondary yew wood market from sale of yew bark, or restrictions on use of other portions of the tree.

There would be no effects to timber harvest from Pacific yew mitigation measures, nor would there be any jobs created as a result of yew bark harvest from federal lands.

\section{Cumulative Effects \\ Minor}

\section{Govemment Direction}

The cumulative effects of this alternative would reflect conditions prior to the 1991 harvest season. There would be no effects associated with Pacific yew harvest mitigation measures because there would be no guides.

\section{Jobs}

It is difficult to estimate what the effects would be on jobs created or taxol produced. If this alternative were selected and the demand for Pacific yew bark to produce taxol still existed, it would be reasonable to assume that some yew bark would be harvested. This may occur legally on private lands, or illegally from Forest Service and BLM lands. If demand for Pacific yew bark continues and this alternative was implemented, some jobs would be created due to increased bark harvest from private and state lands. 


\section{Treatment}

Taxol would continue to be produced, although probably at a lower initial level than under other alternatives. In 1991 and in 1992, over 500,000 pounds of yew bark was harvested from private lands each year and we assume that production in the immediate future is similar to this level. Therefore, under this alternative we can assume that taxol production in the immediate future would be half of current levels. This would place severe restrictions on the number of patients who could be treated, as well as the availability of clinical trials. If clinical trials have to be restricted, then information about the best use of the drug would be delayed. By the end of the five-year harvest period, these effects would no longer exist as taxol would be produced from sources that did not require the use of bark from federal lands (see Figure IV-3).

\section{Affected Groups}

(This discussion assumes that taxol production capacity is not an impediment to taxol supply.) Several groups could be adversely affected under this alternative. Cancer patients currently in clinical trials, as well as patients with ovarian and breast cancers who are not in clinical trials, could be denied access to taxol therapy under this alternative. Women who are at risk for developing these cancers would also see a potential treatment option limited.

\section{Job-Related}

This alternative would not create bark harvesting or processing jobs and would therefore not create job opportunities for woodworkers. Woodworkers and others who wished to purchase Pacific yew logs would still be able to do so.

\section{Recreation and Cultural Values}

Implementing this alternative would have no effect on recreational or Native American uses of the Pacific yew or the forest.

\section{Women and Minorities}

Since taxol therapy is targeted at cancers that mostly affect women, women as a group would be adversely impacted if taxol therapy were limited or not available. Information was available 
Alternatives B through $\mathrm{G} 2$ on cancer rates for African-Americans, but nor for any other ethnic groups. The breast and ovarian cancer rates among that group were similar to those of whites, and thus they would be affected in the same way.

Many of the social and economic effects are very similar among all alternatives except $\mathrm{A}$. This occurs either because the scope of the effect, spread across the five-state region, is very small, or because there is no measurable difference in the effect among alternatives.

\section{Direct Effects \\ Minor to Moderate}

\section{Demand}

Alternative $\mathrm{B}$ does not meet the current annual processing capacity of 130 kilograms of taxol, given the assumed 500,000 pounds yew bark production rate from other landowners. (See Figure IV16 for potential quantities of bark harvested and taxol supplied under each alternative.) Alternatives C through G2 meet current processing capacity at the low end of the production range given the bark production from other sources. Alternatives D through G2 satisfy the future production capacity of 200 kilograms of taxol, and Alternatives F through G2 supply sufficient yew bark to meet future capacity even if no bark is harvested from other sources.

\section{Govemment Expenditures}

There would be government expenditures to manage the yew bark harvest program. Any of the action alternatives would have annual expenditures to include yew bark sale preparation, issuing special use permits, management associated with these sales or permits, and oversight of on-the-ground operations (see Table IV16). This level of expenditure would not result in any additional government employment. There may be a small number of injuries associated with bark collection.

\section{Govemment Direction}

Under any of the action alternatives, the federal government would operate under a memorandum of understanding with Bristol- 
Myers Squibb to provide yew bark or other yew products. Mitigation measures (see Chapter II) would also be issued to guide yew bark and needle harvest activities. Field experience has shown that leave tree requirements increase harvesting costs.

\section{Indirect Effects \\ Minor to Moderate}

\section{Refums to the Govemment}

Under these alternatives, bark and needle harvest would be allowed. The amounts permissable under each alternative are shown in Table IV-16. Returns to federal and state treasuries would vary only minimally among alternatives. The Bureau of Land Management (BLM) is allowed to sell yew bark, and thus generate revenue to the federal government. The recently enacted Pacific Yew Act (1992) gives authority to the Forest Service to also sell yew bark, but as of this writing the Forest Service has not chosen to sell bark. (See Figure IV-16 for potential returns to the government.)

The Forest Service and the BLM are required to return a percentage of the revenues they generate to county governments. On lands formerly owned by the Oregon and California Railroad (O\&Clands), this percentage is 50 percent. On other federal lands, the portion is 25 percent. The amount of potential revenue returned to the counties from the yew bark program would be small (see Figure IV-16). These payments would not be expected to have a substantial impact on county governments since they would be distributed between all counties associated with National Forest land and yew harvest. Not enough site-specific information is available currently to estimate returns to each county from which bark might be harvested.

\section{Secondary Markets and Jobs}

Under these alternatives, yew trees and shrubs, including bark and needles, would be available for taxol production. Generally, the wood left over from bark and needle gathering would be available for other uses. The secondary market for yew logs would 
potentially be expanded as a result of yew operations. This could have a positive impact on local employment. The bulk of these jobs would be seasonal, with employment lasting from late spring to early fall (see Table IV-16 for information on person-hours of employment). However, this market has been so small in recent years that any positive impact would be about the same as the jobs created for bark processing.

Traditional users would continue to be able to use Pacific yew wood. Access to the wood may be somewhat restricted, however, as timing would have to be coordinated with bark harvest.

Under the action alternatives, jobs would be created for bark collectors and others in the processing and taxol production areas.

\section{Cumulative Effects \\ Minor}

\section{Stumpage Values}

The mitigation measures could have the effect of decreasing stumpage values of non-yew trees. Purchasers' costs would be increased by the requirements imposed by the mitigation measures, and would be reflected in lower stumpage values.

\section{Bark Pricing}

There may be variations in the price of bark and taxol over the five-year harvest period. During the five-year analysis period, it is possible that bark would be sold on a competitive basis. If this happens, bark price would be subject to market forces and would most likely fluctuate with changes in supply and demand. If demand remains at current levels (between 750,000 and 1,000,000 pounds per year), but supply restrictions become necessary, then bark price would most likely increase. If demand drops because synthesized taxol becomes available, bark prices would most likely decrease. 


\section{Treatment}

Taxol production and the number of patients who could be treated vary by alternative. See Table IV-16.

\section{Affected Groups}

Cancer patients would benefit under any of the action alternatives because taxol would be available for clinical trials, and eventually for cancer therapy. This availability may vary by alternative, and is discussed in the section for each alternative. In general, any of the action alternatives would benefit women because breast and ovarian cancer treatment options would be expanded.

\section{Job-Related}

The action alternatives would also potentially benefit woodwork: ers through job creation. This is also discussed in more detail under each alternative.

\section{Cultural Values}

Effects on Native American uses of the forest under these alternatives would be localized and could only be determined by local consultation. For most utilitarian uses, effects would be minor due to measures taken to protect the yew.

\section{Affected Geographic Areas}

Communities where bark processing facilities are located (Cottage Grove, OR; Centralia, WA; Orofino, ID; and Noxon, MT) would experience slight employment increases under any of the action alternatives. These communities would also experience positive feelings associated with a project that is perceived as useful and socially beneficial.

Population in the involved states and counties should be minimally affected under any of the action alternatives. In the few cities and towns where processing facilities are located (i.e., Cottage Grove), there may be a slight population increase of fewer than 50 people who are directly or indirectly associated with Hauser Northwest's operations. 


\section{Bark Theff}

During the 1991 harvest season, there were reports of Pacific yew bark being harvested illegally. New administrative controls have been instituted by Hauser Northwest and federal agencies, and have substantially reduced bark theft. These controls are the same for all alternatives.

\section{Recreation Expenditures}

Yew bark harvest could impact recreation experiences, including hunting. There is no evidence that these impacts would result in any decrease of recreationist expenditures.

\section{Women and Minorities}

Since taxol therapy is targeted at cancers that mostly affect women, women as a group would benefit from the alternatives which allow Pacific yew bark harvest for taxol production. Information was available on cancer rates for African-Americans, but not for any other ethnic groups. The breast and ovarian cancer rates among that group were similar to those of whites, and thus they would be affected in the same way. All action alternatives create some job opportunities. These jobs have been filled by men and women, and by members of ethnic groups representative of the area's population. 
Table IV-16: Social and Economic Effects Under Each Alternative

\begin{tabular}{|c|c|c|c|c|c|c|c|}
\hline \multirow[b]{2}{*}{$\begin{array}{c}\text { SUGGESTION: } \\
\text { Consider Socioeconomic } \\
\text { Concerns } \\
\end{array}$} & \multicolumn{7}{|c|}{ ALTERNATIVES } \\
\hline & $\begin{array}{c}\text { A } \\
\text { (No } \\
\text { Action) }\end{array}$ & $\begin{array}{c}\text { B } \\
\text { Timber } \\
\text { Sales } \\
\text { Only }\end{array}$ & $\begin{array}{l}25 \% \\
5 \mathrm{TPA}\end{array}$ & $\begin{array}{l}50 \%, \\
5 \text { TPA }\end{array}$ & $\begin{array}{l}75 \% \\
2 \mathrm{TPA}\end{array}$ & $\begin{array}{c}\text { G1 } \\
\text { Preferred } \\
\\
\text { 50\% } \\
\text { 0 TPA }\end{array}$ & $\begin{array}{c}\text { G2 } \\
\text { 50\% } \\
\text { 0 TPA, } \\
\text { OCAs }\end{array}$ \\
\hline $\begin{array}{l}\text { a. Public Health and Safety } \\
\text {--bark availability in pounds } \\
\text { from federal lands per year }\end{array}$ & 0 & $.3-.4 \mathrm{MM}$ & $1.2-1.8 \mathrm{MM}$ & $2.0-2.9 \mathrm{MM}$ & $3.2-4.9 \mathrm{MM}$ & $3.2-4.7 \mathrm{MM}$ & $3.9-5.8 \mathrm{MM}$ \\
\hline $\begin{array}{l}\text {--taxol available for clinical } \\
\text { trials, in kilograms, based on } \\
\text { bark from federal lands } \\
(15,000 \text { lbs. bark }=1 \text { kilogram })\end{array}$ & 0 & $17.3-26.0$ & $80.2-120.3$ & $130.9-196.3$ & $216.6-324.9$ & $210.0-315.0$ & $257.2-385.8$ \\
\hline $\begin{array}{l}\text {--potential patients treated, } \\
\text { based on bark from federal } \\
\text { lands (assuming } 1 \text { kilogram } \\
\text { treats } 480 \text { patients) }\end{array}$ & 0 & $\begin{array}{l}8,300- \\
12,400\end{array}$ & $\begin{array}{c}38,400- \\
57,700\end{array}$ & $\begin{array}{l}62,800- \\
94,200\end{array}$ & $\begin{array}{l}103,900- \\
155,900\end{array}$ & $\begin{array}{l}100,800- \\
151,200\end{array}$ & $\begin{array}{l}123,400- \\
185,100\end{array}$ \\
\hline --injuries to woodworkers & none & $0-5$ & $0-10$ & $0-15$ & $0-25$ & $0-25$ & $0-30$ \\
\hline \multirow{2}{*}{$\begin{array}{l}\text { b. Social Setting-- } \\
\text { Groups Affected } \\
\text {--access to raw material for } \\
\text { taxol: cancer patients, } \\
\text { women, and others }\end{array}$} & \multicolumn{7}{|c|}{ Health-Related } \\
\hline & $\begin{array}{l}\text { denies } \\
\text { access }\end{array}$ & $\begin{array}{l}\text { access } \\
\text { limited }\end{array}$ & $\begin{array}{l}\text { adequate } \\
\text { access }\end{array}$ & $\begin{array}{l}\text { adequate } \\
\text { access }\end{array}$ & $\begin{array}{l}\text { adequate } \\
\text { access }\end{array}$ & $\begin{array}{l}\text { adequate } \\
\text { access }\end{array}$ & $\begin{array}{l}\text { adequate } \\
\text { access }\end{array}$ \\
\hline \multirow{3}{*}{--bark harvester jobs (seasonal) } & \multicolumn{7}{|c|}{ Jobs-Related } \\
\hline & $\begin{array}{l}\text { no job } \\
\text { creation }\end{array}$ & $75-113$ & $347-521$ & $566-849$ & $937-1,406$ & $909-1,363$ & $1,113-1,669$ \\
\hline & no effect & no effect & no effect & no effect & no effect & no effect & no effect \\
\hline \multirow[b]{2}{*}{--hikers, campers, hunters } & \multicolumn{7}{|c|}{ Recreationists } \\
\hline & $\begin{array}{c}\text { no } \\
\text { effect }\end{array}$ & $\begin{array}{l}\text { minor } \\
\text { effect }\end{array}$ & minor effect & minor effect & minor effect & minor effect & minor effect \\
\hline \multirow[b]{2}{*}{$\begin{array}{l}\text {-ceremonial, cultural, } \\
\text { traditional use of wood }\end{array}$} & \multicolumn{7}{|c|}{ Native Americans } \\
\hline & Effects & on utilization & $\begin{array}{r}\text { uses would be } \\
\text { assesse }\end{array}$ & $\begin{array}{l}\text { minor. Spirit } \\
\text { ed after local ce }\end{array}$ & $\begin{array}{l}\text { ual and medici } \\
\text { onsultation. }\end{array}$ & nal value effec & ts must be \\
\hline
\end{tabular}


Table IV-16: Social and Economic Effects Under Each Alternative

\begin{tabular}{|c|c|c|c|c|c|c|c|}
\hline \multirow[b]{2}{*}{$\begin{array}{l}\text { SUGGESTION: } \\
\text { Consider Socioeconomic Concerns } \\
\text { (continued) }\end{array}$} & \multicolumn{7}{|c|}{ ALTERNATIVES } \\
\hline & $\begin{array}{l}\text { A } \\
\text { (No } \\
\text { Action) }\end{array}$ & $\begin{array}{c}\text { B } \\
\text { Timber } \\
\text { Sales } \\
\text { Only }\end{array}$ & $\begin{array}{l}25 \%, \\
5 \text { TPA }\end{array}$ & $\begin{array}{l}50 \%, \\
5 \text { TPA }\end{array}$ & $\begin{array}{l}75 \%, \\
2 \text { TPA }\end{array}$ & $\begin{array}{c}\text { G1 } \\
\text { Preferred } \\
\\
\text { 50\%, } \\
\text { 0 TPA }\end{array}$ & $\begin{array}{c}\text { G2 } \\
\text { 50\%, } \\
\text { 0 TPA, } \\
\text { OCAs }\end{array}$ \\
\hline $\begin{array}{l}\text { c. Women and Other } \\
\text { Minorities }\end{array}$ & $\begin{array}{c}\text { slight } \\
\text { negative }\end{array}$ & $\begin{array}{l}\text { moderate } \\
\text { positive }\end{array}$ & $\begin{array}{l}\text { moderate } \\
\text { positive }\end{array}$ & $\begin{array}{l}\text { high } \\
\text { positive }\end{array}$ & $\begin{array}{l}\text { high } \\
\text { positive }\end{array}$ & $\begin{array}{l}\text { high } \\
\text { positive }\end{array}$ & $\begin{array}{l}\text { high } \\
\text { positive }\end{array}$ \\
\hline \multirow[t]{2}{*}{$\begin{array}{l}\text { d. Social Setting -- } \\
\text { Geographic Areas Affected } \\
\text {--areas where yew is processed }\end{array}$} & \multirow{2}{*}{\multicolumn{7}{|c|}{ 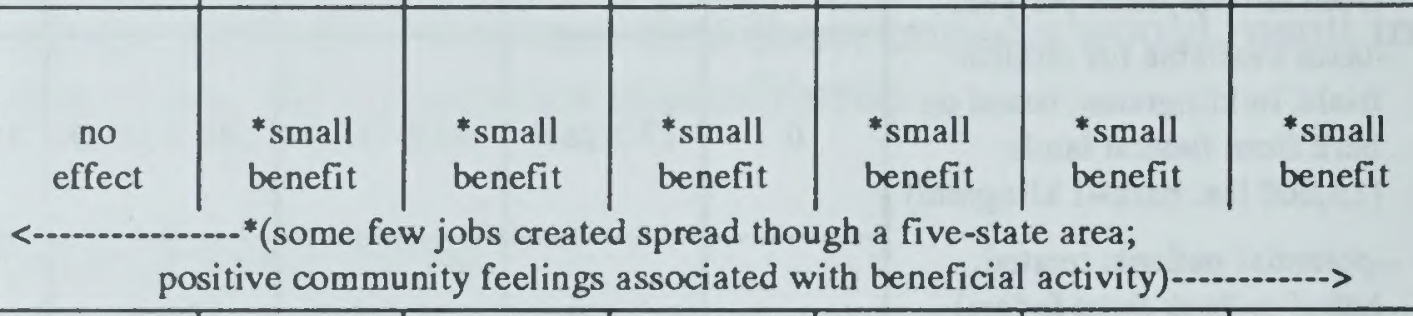 }} \\
\hline & & & & & & & \\
\hline $\begin{array}{l}\text {--areas where yew is not } \\
\text { processed }\end{array}$ & no effect & no effect & no effect & no effect & no effect & no effect & no effect \\
\hline $\begin{array}{l}\text { e. Economles (average annual) } \\
\text {--government expenditures } \\
\text { associated with bark harvest }\end{array}$ & $\$ 0$ & $\$ 0.3 \mathrm{MM}$ & $\$ 5.9 \mathrm{MM}$ & $\$ 5.9 \mathrm{MM}$ & $\$ 5.9 \mathrm{MM}$ & $\$ 2.9 \mathrm{MM}$ & $\$ 4.6 \mathrm{MM}$ \\
\hline $\begin{array}{l}\text {--stumpage values of other } \\
\text { commercial species }\end{array}$ & no effect & decrease & decrease & decrease & decrease & decrease & decrease \\
\hline \multirow{2}{*}{$\begin{array}{l}\text {--potential receipts to } \\
\text { government } \\
\text {--potential returns to counties }\end{array}$} & none & $\begin{array}{c}\$ 0.1-0.1 \\
\mathrm{MM}\end{array}$ & $\begin{array}{l}\$ 0.4-0.5 \\
\text { MM }\end{array}$ & $\begin{array}{l}\$ 0.6-0.9 \\
\mathrm{MM}\end{array}$ & $\begin{array}{l}\$ 1.0-1.5 \\
\text { MM }\end{array}$ & $\begin{array}{l}\$ 0.9-1.4 \\
\text { MM }\end{array}$ & $\begin{array}{l}\$ 1.2-1.7 \\
M M\end{array}$ \\
\hline & none & $<\$ 0.1 \mathrm{MM}$ & $\begin{array}{c}\$ 0.1-0.1 \\
\mathrm{MM}\end{array}$ & $\begin{array}{c}\$ 0.1-0.2 \\
\mathrm{MM}\end{array}$ & $\begin{array}{c}\$ 0.2-0.4 \\
\mathrm{MM}\end{array}$ & \begin{tabular}{|c|}
$\$ 0.2-0.4$ \\
$\mathrm{MM}$ \\
\end{tabular} & \begin{tabular}{|c|}
$\$ 0.3-0.4$ \\
$\mathrm{MM}$
\end{tabular} \\
\hline --costs to collectors & none & $\begin{array}{c}\$ 1.6-2.3 \\
\mathrm{MM}\end{array}$ & $\begin{array}{c}\$ 7.2-10.8 \\
\mathrm{MM}\end{array}$ & $\begin{array}{c}\$ 11.8-17.7 \\
\mathrm{MM}\end{array}$ & $\begin{array}{c}\$ 19.5-29.2 \\
\mathrm{MM}\end{array}$ & $\begin{array}{c}\$ 18.9-28.4 \\
\mathrm{MM}\end{array}$ & $\begin{array}{c}\$ 23.1-34.7 \\
\mathrm{MM}\end{array}$ \\
\hline $\begin{array}{l}\text { MM=millions } \\
M=\text { thousands }\end{array}$ & & & & & & & \\
\hline
\end{tabular}


The harvest of yew bark, cutting of yew trees and shrubs, and leaving the stripped logs where they have fallen, could have the effect of lowering the quality of the visual resource and the setting for recreational activities. The harvest of yew trees and shrubs would result in the loss of a component of the natural and naturalappearing forests of the region. The magnitude of the effects would be determined by the extent and location of the yew harvest and the character of the recreational setting where the harvest would take place.

The harvest of yew in non-sale areas would be most sensitive in foreground (300 feet deep) adjacent to recreation sites, water bodies, trails and roads. In retention and partial retention zones it is critical that forest plan visual quality objectives be met. Sensitivity level analysis should suggest the appropriate level of yew harvest.

Similarly, it is critical that established BLM Visual Resource Management Class objectives be met. The results of visual contrast ratings would suggest appropriate levels of yew harvest.

If yew trees and shrubs are felled and stripped in recreation areas, we may need to remove or relocate the slash. Slash could be an obstacle to some forms of recreation, particularly trail use. It could also be a negative visual impact in sensitive areas. In areas where yew is concentrated and recreation use is heavy, removal of logs could be important.

Effects are very difficult to measure with any degree of accuracy at the program level of analysis; however, impacts would most likely be relatively minor. Site-specific analysis would be required to closely examine effects on the trends and values listed above.

Harvest of yew foliage would have only short-term insignificant impacts on recreation or visual resources in any of the alternatives being considered. The Interim Guide provides direction on foliage harvest that is intended to reduce potential impacts to a minimum.

\section{Recreation}

.


The effects of bark harvest are of greater concern. The array of alternatives being considered here range from no effect in Alternative A to greatest effect in Alternative G2.

\section{The Alternatives}

\section{Alternative A Direct, Indirect, and Cumulative Effects}

None- With no harvest of yew, there would be no direct or indirect effects on recreation settings and no cumulative effects.

\section{Alternative B Direct, Indirect, and Cumulative Effects}

Minor-Only minor unmeasurable direct or indirect effects. Most of the areas scheduled for clearcut or shelterwood harvest provide little scenic value during harvest and would have such a modified appearance after harvest that not much would be lost in terms of recreation settings. Areas of planned harvest are generally not where people would spend much time recreating.

\section{Alternatives Direct, Indirect and Cumulative Effects}

$C$ and D Minor- Yew provides an important element in the forest landscape that more people are specifically aware of - as a result of media attention on taxol and the yew bark from which it is being produced. Under these alternatives, the effects on recreation settings would increase with the extent of harvest. Alternative D would have greater impacts than $\mathrm{C}$, especially in non-sale areas. The greatest effects would occur in areas where people would be recreating or where they would be viewing the foreground of a forest landscape, as opposed to driving through an area quickly. For the purposes of this analysis, it is assumed that forest plan and resource management plan guidelines would apply to areas where scenic values would be most sensitive.

\section{Alternatives F, Direct Effects}

G1, and G2 Minor- These alternatives would increase the harvest of yew in non-sale and partial cut areas. These areas are more likely to accommodate recreation use, and yew harvest would have increasing potential for affecting the quality of recreation settings. 


\section{Indirect Effects}

Minor- Most of the effects of these alternatives would be indirect, and would boil down to the appearance of the settings after yew harvest. Of greatest concern would be the loss of tree-form yew in the understory in foreground areas as seen from recreation sites, water surfaces, trails or roads. Of these two alternatives, $\mathrm{F}$ would result in the lighter touch, while effects of G2 would be more noticeable.

Slash accumulation from yew harvest, could be another indirect effect. It could, be moderated through cleanup of yew slash which accumulates on trails in the heavy harvest alternatives.

\section{Cumulative Effects}

Minor - The primary cumulative effect would involve the appearance of the area over the time after yew harvest is completed. The magnitude of the cumulative effect would depend primarily on the loss of tree form yew in the heavier harvest alternatives (Alternatives C through G2 and especially F, G1, and G2). Harvest cycles may not provide adequate time for stump sprouts to grow into tree form. Planted seedlings or cuttings may not reach the target size in 75 to 100 -year rotations.

Cleanup could be a cumulative impact if too many logs, tops, or limbs were to be left in a sensitive area and removal activities disturbed soil, plants, or animals in that area.

\section{Congressionally Designated Areas and Other Special Areas}

Congressionally designated areas (wildernesses, national volcanic monuments, and national recreation areas) and Research Natural Areas would not be affected by any alternative. No yew harvest would take place in these areas.

Yew would not be harvested in wild river segments of the national wild and scenic river system rivers. Scenic and recreational segments of wild and scenic rivers may yield small quantities depending on local management objectives. Impacts under such circumstances would be minor. 
Summary of Irreversible or Irretrievable Committment of Resources
This section discusses the potential irreversible and irretrievable effects associated with the implementation of the various proposed alternatives. These effects, listed below, are defined as follows:

Irreversible - Applies primarily to the use of nonrenewable resources, such as minerals or cultural resources, or to those factors, such as soil productivity, that are renewable only over long time periods. Irreversible also includes loss of future options.

Irretrievable - Applies to losses of production, harvest, or use of renewable natural resources. For example, some or all of the timber production from an area is irretrievably lost during the time an area is used as a winter sports site. If the use is changed, timber production can be resumed. The production lost is irretrievable, but the action is not irreversible.

\section{Irreversible Effects}

1. If all yew available for harvest under each alternative is harvested within the five-year period covered by this EIS, the option to harvest additional yew (at the same level using the same criteria) would be lost until the yew has regenerated and grown to previous levels and sizes (anywhere from 100 to 200 years). This is considered an irreversible loss of the yew resource. (This effect applies to Alternatives B through G2.)

2. The continued erosion of species range due to the loss of small, peripheral populations is an irreversible loss. (This effect applies to Alternative A only.)

3. There is a potential for an irreversible loss of genetic and ecosystem diversity if populations containing unique genetic combinations are lost. (This effect applies to all alternatives except Alternative C.) 


\section{Irretrievable Effects}

1. The loss of timber production is an irretrievable loss in genetic reserve areas that are established in areas not previously designated or set aside for wilderness, owl conservation areas, etc. (Reserve areas are established adjacent to certain harvest areas for the purpose of maintaining and protecting representative yew populations. Timber harvest is not permitted in these reserve areas.) (This effect applies to Alternatives C through G2.)

2. The delay of seed production and genetic contribution in certain harvest areas would be an irretrievable loss, until residual or planted yew reach reproductive size. (This effect applies to Alternatives B through G2.)

3. The loss of yew in specialized habitat, such as old growth and suitable owl habitat, is an irretrievable loss for associated species. This would be true for the duration that it remains unsuitable due to yew removal. (This effect applies to Alternatives B through G2.)

4. The loss of a treatment option for cancer patients due to limited access to taxol would be an irretrievable loss until other means of producing taxol are developed. (This effect applies to Alternatives A and B.) 



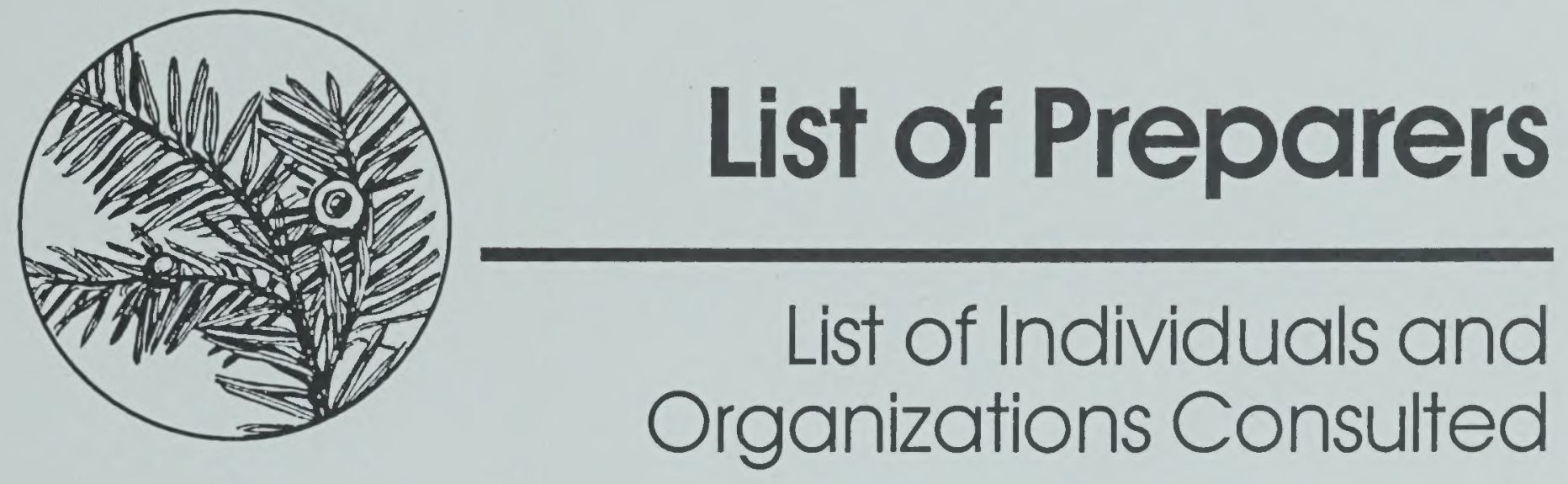





\section{LIST OF PREPARERS}

Jerome Beatty is a plant pathologist with the Forest Service. He has an M.F. in forestry from Duke University and an A.B. in english literature from Wabash College.

Jerry is currently the group leader for pathology in the forest pest management unit at the regional office in Portland, Oregon and has 13 years experience working with forest diseases in both the Southwest and Pacific Northwest Regions.

Katherine C. Bowman is a writer/editor for the Forest Service. She has an A.S. in forestry technology from Central Oregon Community College, and a B.A. from Marylhurst Education Center. She has worked for the Forest Service for 2 years as a forestry technician and 6 years as a writer/editor. She is currently editor for the Greensheet, a regional newsletter for Forest Service employees.

Doug Burns is a silviculturist with the Forest Service. He has a B.S.F. in forest management from Northern Arizona University and attended the Silviculture Institute at Oregon State University. Doug has 15 years experience as a planner and silviculturist in the Pacific Northwest Region.

Don Boyer is a soil scientist on contract with the Pacific yew EIS team. Don has a B.S. in agronomy from Colorado State University. He has worked as a soil specialist for the Soil Conservation Service for 10 years, and the Forest Service for 19 years. Don retired from the Forest Service in 1983, and currently is a hazelnut farmer and soils consultant. 
Sally Campbell is a nursery and regeneration pathologist with the Forest Service in Portland, Oregon. She has a B.S. in biology from Pitzer College, and an M.S. in plant pathology from Oregon State University. Sally is the EIS interdisciplinary team leader for the Pacific yew EIS project and for the Nursery EIS and Seed Orchard EIS projects. She has worked for the Forest Service for 12 years.

Merrill Davis is a forester in the Northern Region's timber, cooperative forestry and pest management group, with responsibilities for special forest products and sales preparation. Merrill graduated from the University of Idaho with a B.S. in forest management. He has worked for the Forest Service for 30 years in a variety of capacities, including administration forester, timber assistant, district ranger, and forest integrated resource coordinator.

David Doede is a forest geneticist working on the Gifford Pinchot and Mt. Hood National Forests. He has a B.S. in forest management from Oregon State University and has done graduate work in forest genetics. Dave has worked for the Forest Service for 16 years.

Cindy Froyd is an ecologist with Clackamas Ranger District of the Forest Service. Cindy has a B.S. in forest resources management, with a minor in botany from Humboldt State University, and an M.S. in forest ecology from Oregon State University. She has worked for the Forest Service for 3 years.

Michael O'Day is a forest resource and computer/data systems specialist with the Forest Service in Portland, Oregon. He has a B.S. in forest management from the University of Michigan. Mike has worked on several regional forest inventory and regional EIS projects for the Forest Service for 11 years. He was also employed for 7 years with the forest products industry specializing in forest inventory and mapping. 
Gloria Perez is a writer/editor for the Forest Service in Portland, Oregon. She has a B.S. in marketing from Metropolitan State College. Gloria has worked on EIS projects for the Forest Service over the last three years. She has worked in private industry in customer service, and has experience with preparing marketing plans, promotions, and newsletter writing.

Frank Roberts is the district wildlife biologist with the Snow Mountain Ranger District, Ochoco National Forest. He has a B.S. from Michigan Technological University in forestry/ wildlife management. From 1981 to 1990 he worked as biological technician on Mount St. Helens National Volcanic Monument, Gifford Pinchot National Forest.

Bernard Smith is currently the recreation facilities group leader for the Forest Service's Pacific Northwest Region. He has a B.S. in botany from California Polytechnic at San Luis Obispo and a Masters of Forestry from Utah State University. He has worked for the Forest Service for 24 years, most of which has been within the natural range of the Pacific yew. He is also a serious woodworker and has harvested yew wood during the past decade to convert it to furniture, boats and carvings.

Michael Srago is the assistant director of timber management with the Forest Service in San Francisco, California. He has a B.S. in forest management from North Carolina State University and a Ph.D. in plant pathology from the University of California, Berkeley. He works in silviculture, timber management planning and inventories, and tree improvement. Mike has worked for the Forest Service for 24 years.

Kent C. Tresidder is a forester with the Bureau of Land Management in Portland, Oregon. He has a B.S. in forest management from Oregon State University. Kent is the Pacific yew coordinator for Oregon and Washington. He was formerly chief of the appraisal section in the BLM Oregon and Washington State Office. Kent also has 15 years experience as a timber appraiser with the Oregon Department of Revenue. 
Joyce Ulbrich is a forest economist for the Mt. Hood National Forest. Joyce has an M.S. in environmental science from the State University of New York at Syracuse, and a B.A. in economics from Hamilton College. She has worked as writer-editor on several EIS projects, and as a major contributor to the Mt. Hood Forest Plan. She has five years' experience outside the Forest Service, including three years of medical research for the University of Pennsylvania School of Medicine.

Dennis Weber is a forester with the Forest Service in Portland, Oregon. Dennis is a writer/editor for the Yew EIS team and for the Nursery EIS and Seed Orchard EIS projects. He has a B.S. in forest management from the University of Wisconsin. Dennis has 15 years of professional experience as a forester and interdisciplinary land management planner on the Willamette and Mt. Hood National Forests.

Rick Wetherill was the regional sociologist with the Forest Service in Portland, Oregon, but has recently accepted a position as director for the newly formed Federal Rural Development Agency. He has a B.A. in sociology from East Central State College, an M.S. in sociology from East Texas State University, and a Ph.D. in evaluation research from Texas A \& M University. Rick had been with the Forest Service for 15 years, with six years in the agency's research branch and the rest in various assignments from coast to coast. He has also worked in the community resource development staff of the Texas Agricultural Extension Service.

Richard Wheeler is a retired forest hydrologist with over 20 years experience with the Forest Service. His career began in South Carolina and concluded in Oregon, serving mostly as a consultant in forest hydrology, forest water quality, and watershed management to forest supervisors and their staff and to district rangers on 21 national forests, and for international projects. He received his B.S. in 1953 in forest management from the University of Maine and in 1969, earned his M.S. in forest hydrology and watershed management from Colorado State University. 
Susan Whitney is a public affairs specialist with the Forest Service in Portland, Oregon. She has a B.A. in humanities from Scripps College and an M.A. in art history from the University of Wisconsin. Susan has worked for the Forest Service for thirteen years: ten years as a visitor information specialist at the Wind River nursery and three years with environmental impact statement projects.

Jerry Williams is a sociologist and social historian with the Forest Service, stationed on the Umpqua National Forest in Roseburg, Oregon, and an adjunct staff at Grey Towers National Historic Landmark (Milford, Pennsylvania). Jerry received his Ph.D. in sociology from Washington State University in 1976, taught for two years at Indiana State University, worked one year as recreation research director for the city of Eugene, Oregon, and began working for the Umpqua National Forest in 1979. He is currently the new regional sociologist for the Pacific Northwest Region.

Karen Wilson is a wildlife biologist with the Forest Service in Portland, Oregon. She has a B.S. in zoology, and an M.S. in biology from the University of Michigan. Karen has worked for the Bureau of Reclamation and the Forest Service for 15 years as an environmental specialist and wildlife biologist.

Ray Zalunardo is a wildlife biologist for the Umpqua National Forest. He has a B.S. and M.S. in wildlife management from Oregon State University. He has 29 years experience as a Forest Service wildlife biologist, and is the team expert on the Northern spotted owl. 
Other Contributors
The following people provided valuable technical assistance and administrative support services:

Jim Allegria, biometrician, Bureau of Land Management, Portland, Oregon

Maria Angobung (Maggie), editorial assistant/desktop publisher, Gifford Pinchot National Forest, Forest Headquarters, Vancouver, Washington

Virginia Bruce, desktop publishing consultant, Portland, Oregon

Sharon Butler, graphics designer, Aloha, Oregon

Sharon Campbell, consultant, Time Engineering, Sula, Montana

David Cox, forester, Mason-Bruce \& Girard, Portland, Oregon

Michael Ellis, photographer, Portland, Oregon

David Hamlin, forester, Mason-Bruce \& Girard, Portland, Oregon

Wayne Hawk, forester, Mason-Bruce \& Girard, Portland, Oregon

Rebecca Layton, receptionist and clerk typist, Portland, Oregon

Sheila Martinson, forest geneticist, Forest Service, Portland, Oregon

Joanna Mastopietro, editorial assistant, Portland, Oregon

Phillip Mattson, regional National Environmental Policy Act coordinator, Forest Service, Pacific Northwest Region, Portland, Oregon

Jay McWhirter, attorney, Office of General Counsel, Forest Service, Washington, D.C.

Jim Merhwin, forester, Mason-Bruce \& Girard, Portland, Oregon 
Linda Morris, editorial assistant, Portland, Oregon

Jim Paradiso, yew program coordinator, Nez Perce National Forest, Northwest Region, Grangeville, Idaho

Jeannine Partridge, writer-editor/desktop publisher,

Wenatchee National Forest, Naches Ranger District, Naches, Washington

Edna Rix, graphics designer, Portland, Oregon

Jocelyn Somers, attorney, Office of General Counsel, Forest Service, Portland, Oregon

Gina Williams, editorial assistant, Portland, Oregon

Diane Austin, attorney, Fox, Bennett \& Turner, Washington, D.C.

Charles Bolsinger, principle resource analyst, Pacific NorthIndividuals and Organizations Consulted west Research Experiment Station, Portland, Oregon.

Samuel Broder, director, National Cancer Institute, Bethesda, Maryland

Diane DeFuria, senior director of business development, oncology \& government affairs, Bristol Myers-Squibb Company, Princeton, New Jersey

Ken Denton, silviculturalist, owl oversight team representative, Forest Service, Pacific Northwest Region, Portland, Oregon

Robert Devlin, director of timber management, Forest Service, Pacific Northwest Region, Portland, Oregon

Michael Ganey, review chemist and director of oncology and pulmonary products, U.S. Food and Drug Administration, Rockville, Maryland

Phillip Hassrick, vice president, Hauser Northwest, Inc., Cottage Grove, Oregon 
Arnold G. Holden, spotted owl EIS assistant team leader, Forest Service, Portland, Oregon

Jerald N. Hutchins, spotted owl EIS team leader, Forest Service, Portland, Oregon

Tom Iraci, photographer, Mt. Hood National Forest, Zig Zag Ranger District, Zig Zag, Oregon

Dan Kizer, attorney, Fox, Bennett \& Turner, Washington, D.C.

Sally Look, review chemist, U.S. Food and Drug Administration, Rockville, Maryland

Jerry Magee, environmental protection specialist, Bureau of Land Management, Portland, Oregon

Fred Page, regional yew coordinator for Pacific Northwest Region of the Forest Service, Portland, Oregon

Saul Schepartz, deputy associate director for developmental and therapeutic research, National Cancer Institute, Bethesda, Maryland

Shimon Schwartzchild, board member (past president), Native Yew Conservation Council, Berkeley, California

Dale Schumacher, chief of regulatory affairs branch, BristolMyers Squibb Company, Princeton, New Jersey

Richard Shaffer, group leader for plans, silviculture and timber management, Forest Service, Pacific Northwest Region, Portland, Oregon

John Teply, biometrician in timber management, Forest Service, Pacific Northwest Region, Portland, Oregon

Mike Trumbull, general manager, Hauser Northwest, Inc., Cottage Grove, Oregon

Phil Vincent, environmental assessment officer, U.S. Food and Drug Administration, Rockville, Maryland 
Tom Atzet, Frank Betlejewski, Charles Bolsinger, Rex Crawford, Douglas Daoust, David Doede, Pat Green, Jennings Kitzmiller, Sheila Martinson, Bill McComb, Don Minore, Thomas Spies, Roger Ward
Conservation Guidelines Committee 



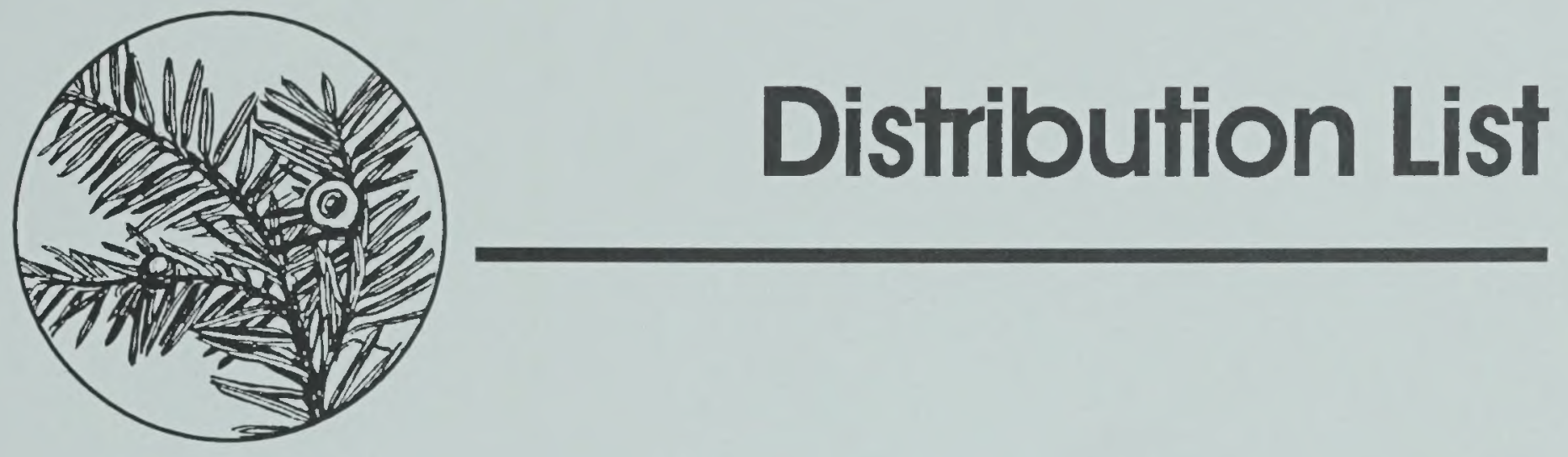





\section{Distribution List}

Table Of Contents

Federal Agencies and Officials

Page(s)

Advisory Council on Historic Preservation ......................... 1

Department of Agriculture .............................................. 1

Forest Service, Washington, DC …................................. 1-3

Department of Commerce ................................................... 3

Department of Defense ...................................................... 3

Department of Energy ....................................................... 3

Department of Health and Human Services ...................... 4

Department of Housing and Urban Development.............. 4

Department of Interior ................................................... 4

Department of Labor .......................................................... 4

Department of Transportation ........................................ 4

Environmental Protection Agency .................................... 4

General Services Administration ...................................... 4

Nuclear Regulatory Commission ..................................... 4

State and Local ................................................... $5-36$

Federal Legislators …................................................... 5

State Legislators ............................................................ 5

State, County, or City Government .................................. 5-7

Other Agencies .......................................................... 8-10

Research ................................................................. 11-12

Businesses ................................................................... 13-20

Interest Groups ......................................................... 21-26

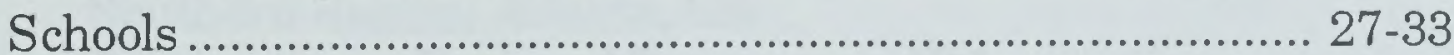

Libraries ..................................................................... 34

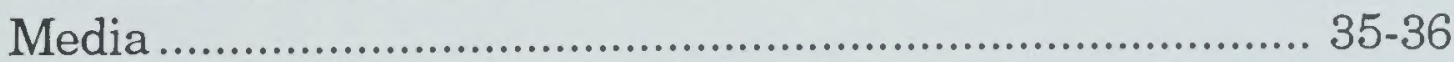

Individuals ...................................................... $37-82$ 


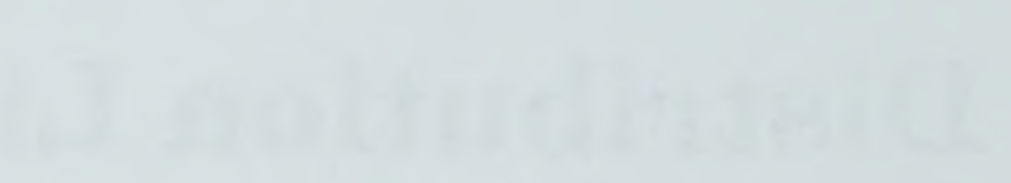




\section{Distribution List}

These are the agencies, organizations, and individuals who were listed to receive this DEIS as of January, 1993. This is not a comprehensive list since requests for copies continue.

\section{Federal Agencies and Officials}

\section{Advisory Council on Historic Preservation}

Office of Architectural and Environmental Preservation, Washington, DC

\section{Department of Agriculture}

Agricultural Stabilization and Conservation Service, Washington, DC;

Animal and Plant Health Inspection Service, Hyattsville, MD

APHIS Plant Protection, Chico, CA

Office of Equal Opportunity, Washington, DC

Rural Electrification Administration, Washington, DC

Soil Conservation Service, Washington, DC

State Conservationist: Boise, ID

Forest Service, Washington, DC

\section{Regional Offices:}

Alaska Region, Juneau, AK

Eastern Region, Milwaukee, WI

Intermountain Region, Ogden, UT

Northern Region, Missoula, MT

Pacific Northwest Region, Portland, OR

Pacific Southwest Region, San Francisco, CA

Rocky Mountain Region, Lakewood, CO

Southern Region, Atlanta, GA

Southwestern Region, Albuquerque, NM 


\section{Distribution List}

National Forests in the Pacific Northwest (Region 6)

Oregon:

Deschutes

Siuslaw

Fremont

Umatilla

Malheur

Umpqua

Mt. Hood

Wallowa-Whitman

Ochoco

Rogue River

Willamette

Siskiyou

Winema

Washington:

Colville

Gifford Pinchot

Okanogan

Mt. Baker-Snoqualmie

Olympic

Wenatchee

National Forests in the Northem Region (Region 1) Idaho:

Clearwater

Idaho Panhandle

Nez Perce

Montana:

Beaverhead

Gallatin

Bitterroot

Helena

Custer

Kootenai

Deerlodge

Lewis and Clark

Flathead

Lolo

National Forests in the Pacific Southwest (Region 5)

Califomia:

Eldorado

Plumas

Klamath

Lassen

Shasta Trinity

Mendocino

Six Rivers 


\section{National Forest Nurseries}

Chico Tree Improvement Center, Mendocino National Forest, CA

Humboldt, Six Rivers National Forest, CA

Placerville, Eldorado National Forest, CA

Coeur d'Alene, Idaho Panhandle National Forest, ID

Lucky Peak, Boise National Forest, ID

J. W. Toumey, Ottawa National Forest, MI

W. W. Ashe, National Forests in Mississippi, MS

Bessey, Nebraska National Forest, NE

Bend Pine, Deschutes National Forest, OR

Dorena Tree Improvement Center, Umpqua National Forest, OR

J. Herbert Stone, Rogue River National Forest, OR

Wind River, Gifford Pinchot National Forest, WA

\section{Experiment Stations}

Intermountain

North Central

Pacific Northwest Southeastern

Pacific Southwest Southern

NortheasternRocky Mountain Forest Products Lab

\section{Department of Commerce}

Interstate Commerce Commission, Washington, DC

National Marine Fisheries Service, Silver Springs, MD;

Northwest and Alaska Region, Seattle, WA

NOAA Ecology and Conservation Division, Washington, DC

\section{Department of Defense}

Army Corps of Engineers, Washington, DC; Portland, OR;

Seattle, WA

Deputy Assistant Secretary of Defense, Washington, DC

Explosives Safety Board, Alexandria, VA

US Air Force, Environment and Safety, Washington, DC

US Army, Army Engineering and Housing, Washington, DC

US Navy, Environment Protection Division, Washington, DC

\section{Department of Energy}

Federal Energy Regulatory Commission, Office of Environmental Review, Washington, DC

Office of Environmental Compliance, Washington, DC 


\section{Department of Health and Human Services}

Food and Drug Administration, Rockville, MD

Special Programs Coordinator, Washington, DC

Center for Disease Control, Atlanta, GA

\section{Department of Housing and Urban Development}

Office of Environment and Review, Washington, DC

Pacific Northwest Regional Office, Portland, OR

\section{Department of Interior}

Environmental Project Review, Washington, DC; Portland, OR

Bureau of Indian Affairs, Washington, DC; Sacramento,CA; Portland, OR

Bureau of Land Management, Offices in the states of California, Idaho,

Oregon, and Washington

Fish and Wildlife Service, Sacramento, CA

National Park Service, Friday Harbor, WA

\section{Department of Labor}

Mine Safety and Health, Arlington, VA

Occupational Safety and Health Administration, Washington, DC

\section{Department of Transportation}

Environmental Division, Washington, DC

Federal Aviation Administration, Washington, DC; Northwest Mountain Region, Seattle, WA

Federal Highway Administration, Washington, DC; Northwest Mountain Region, Portland, OR

Office of Pipeline Safety, Washington, DC

US Coast Guard, Water Resources Coordination, Washington, DC

\section{Environmental Protection Agency}

Federal Agency Liaison Division, Washington DC; Region 10, Seattle, WA

\section{General Services Administration}

Environmental Staff, Washington, DC

\section{Nuclear Regulatory Commission}

Environmental Projects Office, Washington, DC

Region 5, Walnut Creek, CA 


\section{State and Local}

\section{Federal Legislators}

Senators and Representatives of:

California

Idaho

Montana

Oregon

Washington

\section{State Legislators}

Govenors and Sectatary of States of:

California

Idaho

Montana

Oregon

Washington

\section{State, County, or City Government}

Califomia:

Butte County Board of Supervisors, Oroville, CA

Butte County Planning Commission, Oroville, CA

El Dorado City Chamber of Commerce, Placerville, CA

El Dorado County Chamber of Commerce, Placerville, CA

El Dorado County Fish and Game Commission, Placerville, CA

McKinleyville Community Services, McKinleyville, CA

Trinity County Board of Supervisors, Weaverville, CA

Humboldt County Agricultural Committee, Eureka, CA

\section{Idaho:}

Kootenai County Board of Commissioners, Coeur D'Alene, ID

City of Coeur D'Alene, ID

Clearwater County, Orofino, ID 


\section{Oregon:}

Benton County Board of Commissioners, Corvallis, OR

Canby Utility Board, Canby, OR

Clackamas County Board of Commissioners, Oregon CITY, OR

Clatsop County Board of Commissioners, Astoria, OR

Columbia County Board of Commissioners, St Helens, OR

Coos County Board of Commissioners, Coquille, OR

Douglas County Board of Commissioners, Roseburg, OR

Hood River County Board of Commissioners, Hood River, OR

Jackson County Board of Commissioners, Medford, OR

Josephine County Board of Commissioners, Grants Pass, OR

Klamath County Board of Commissioners, Klamath Falls, OR

Lake County Board of Commissioners, Lakeview, OR

Lane County Board of Commissioners, Eugene, OR

Lincoln County Board of Commissioners, Newport, OR

Llin County Board of Commissioners, Albany, OR

Marion County Board of Commissioners, Salem, OR

Multnomah County Board of Commissioners, Portland, OR

Polk County Board of Commissioners, Dallas, OR

Roseburg Chamber of Commerce, Roseburg, OR

Tillamook County Board of Commissioners, Tillamook, OR

Washington County Board of Commissioners, Hillsboro, OR

Yamhill County Board of Commissioners, McMinnville, OR

\section{City of:}

Albany, OR

Bay City, OR

Corvallis, OR

Cottage Grove, OR

Dallas, OR

Eugene, OR

Garibaldi, OR

Independence, OR

Klamath Falls, OR

Lakeside, OR

Madras, OR

Malin, OR

Monroe, OR
Newport, OR

North Bend, OR

Philomath, OR

Redmond, OR

Salem, OR

Sandy, OR

Siletz, OR

Springfield, OR

Sweet Home, OR

Tillamook, OR

Toledo, OR

Waldport, OR

Yachats, OR 


\section{Washington:}

Benton-Franklin Conf of Governments, Richland, WA

Camas-Washougal Chamber of Commerce, Camas, WA

City of:

Colville, WA

Kettle Falls, WA

Riverside, WA

Brewster, WA

Nespelem, WA

Sedro Wolley, WA

Chelan, WA

Okanogan, WA

Tonasket, WA

Conconully, WA

Oamk, WA

Twisp, WA

Coulee Dam, WA

Everett, WA

Oroville, WA

Winthrop, WA

Clark County Department of Public Services, Vancover, WA

Coville Chamber of Commerce, Colville, WA

Coville Indian Agency, Nespelem, WA

Grays Harbor Regional Planning Commission, Aberdeen, WA

Inland Empire Publis Lands Council, Spokane, WA

Kalisperl Indian Tribe, Usk, WA

Moses Lake Conservation District Nursery, Moses Lake, WA

Seattle Water Department, North Bend, WA

Spokane Indian Agency, Wellpinit, WA

Woodland Tourist Information Center, Woodland, WA

Yakima Indian Agency, Toppenish, WA 


\section{Other Agencies}

\section{Califomia:}

Antelope Valley Resource Conservation District Nursery, Lancaster, CA

Board of Forestry, Sacramento, CA

Bureau of Indian Affairs, Sacramento, Redding, CA

California Conservation Corps, Magalia, CA

California Department of Fish \& Wildlife, Chico, Folsom, Sacramento, CA

California Department of Forestry \& Fire, Camino, Sacramento, Davis, CA

CA Department of Forestry, L.A. Moran Reforestation Center, Davis, CA

CA Department of Forestry, Magalia Forest Tree Nursery, Magalia, CA

California Department of Health Service, Redding, CA

California Department of Nurseries, Fortuna, Magalia,CA

California Forest Nursery, Covelo, CA

California Forestry Association, Sacramento, CA

California Regional Water Quality Control Board, Santa Rosa, CA

California Lands Commission, Sacramento, CA

California State Grange, Sacramento, CA

California Water Quality Board, Sacramento, CA

Humboldt County Agricultural Commission, Eureka, CA

\section{Idaho:}

Idaho Department of Agriculture, Boise, ID

Idaho Department of Environmental Quality, Coeur D' Alene, ID

Idaho Department of Health and Welfare, Coeur D' Alene, ID

Idaho Department of Lands/Insect/Disease, Boise, Coeur D' Alene, Orofino, ID

Idaho Department of Fish \& Game, Coeur D' Alene, ID

Idaho Department of Parks \& Recreation, Boise, ID

Idaho Department of Water Resources, Boise, ID

Idaho Soil Conservation Commission, Boise, ID

Kooskia National Fish Hatchery, Kooskia, ID

Kootenai County Extension, Coeur D'Alene, ID

Panhandle Health District, Coeur D'Alene, ID

\section{Montana:}

Montana Department of Fish, Wildlife \& Parks, Kalispell, MT

Montana Department of Lands, Missoula, MT 


\section{Oregon:}

Clackamas County Extension Service, Oregon City, OR

Clackamas County Forest Program, Oregon City, OR

Columbia River Inter-Tribal Fish Commission, Portland, OR

Columbia/Washington Counties Courthouse-Extension Office, St. Helens, OR

Confederated Tribes of Coos, Lower Umpqua \& Siuslaw Indians, Coos Bay, OR

DL Phipps State Forest Nursery, Elkton, OR

Eugene Springfield Metro, Eugene, OR

Jackson Soil and Water Conservation District, Medford, OR

Mid-Willamett Valley Council of Governments, Salem, OR

Natural Resources Assistant, Governors Offices, Salem, OR

Northwest Power Planning Council, Portland, OR

Office of Inspector General, Portland, OR

Office of the Governor, Salem, OR

Oregon Department of Agriculture, Salem, OR

Oregon Department of Economic Development, Salem, OR

Oregon Department of Energy, Salem, OR

Oregon Department of Environmental Quality, Portland, OR

Oregon Department of Fish \& Wildlife, Portland, Corvallis, OR

Oregon Department of Forestry, Salem, OR

Oregon Department of Geology \& Mineral Industries, Portland, OR

Oregon Department of Land Conservation \& Development, Salem, OR

Oregon Department of Parks \& Recreation, Salem, Portland, OR

Oregon Department of Water Resources , Salem, OR

Oregon Division of State Lands, Salem, OR

Oregon Economic Development Department, Eugene, OR

Oregon Farm Bureau, Salem, OR

Oregon Health Division, Portland, OR

Oregon Natural Resources Council, Western Regional Office, Eugene, OR

Oregon State Economist, Salem, OR

Oregon State Parks, Portland, OR

Oregon State Employment Division, Salem, OR

Tillamook PUD, Tillamook, OR

\section{Washington:}

Bureau of Mines, Spokane, WA

Washington Department of Agriculture, Olympia, WA

Washington Department of Fisheries, OLympia, WA

Washington Department of Natural Resources, Olympia, WA

Washington Department of Wildlife, Olympia, WA

Washington Department of Transportation, Bellview, WA 


\section{Other States:}

American Red Cross, Juneau, AK

Division of Forestry, Anchorage, AK

Alabama Forestry Commission, Montgomery, AL

Arkansas Forestry Commission, Little Rock, AR

State Land Dept., Phoenix, AZ

Town of Manchester Water Department, Manchester, CT

Forest Planning Bureau, Tallahassee, FL

Georgia Forestry Commission, Macon, GA

Division of Forestry and Wildlife, Honolulu, HI

Iowa Department of Natural Resources, Des Moines, IA

Division of Forest Resources, Springfield, IL

Kentucky Division of Forestry, Frankfort, KY

National Institutes of Health, Bethesda, MD

Michigan Department of Natural Resources, Gladstone, ME

Division of Forest Environment, Kingston, RI

South Carolina Forestry Commission, Columbia, SC

Tennessee Valley Authority, Norris, TN

Division of State Lands and Forestry, Salt Lake City, UT

Division of Forest, Waterbury, VT

Virginia Division of Forestry, Charlottesville, VA

Wyoming State Forestry Division, Cheyenne, WY

\section{Other Countries:}

British Columbia Forestry, Burnaby, British Columbia, Canada

Ministry of Forest, Burnaby, British Columbia, Canada

Canadian Ministry of Forests, Burnaby, Victoria, British Columbia, Canada

British Columbia Forest Service, Victoria, British Columbia, Canada

Ministry of the Environment, Invermere, British Columbia, Canada

International Boundary Commission, Ottawa, Ontario, Canada

CIBA-GEIGY AG, Basel, Switzerland

Indena, Milano, Italy 


\section{Research}

Califomia:

Cedars-Sinai Medical Center, Los Angeles, CA

City of Hope Medical Center, Duarte, CA

Escagenetics Corp, San Carlos, CA

Kenneth Norris Jr Cancer Center, Los Angeles, CA

Monarch Laboratory, Chico, CA

NASA Ames Research Center, Moffett Field, CA

NFGEL, Camino, CA

Scripps Clinic, La Jolla, CA

SRI International, Menlo Park, CA

Syntex Research, Palo Alto, CA

\section{Oregon:}

Oregon Research Institute, Eugene, OR

Oregon Res. Technology \& Development, Portland, OR

The Research Group, Corvallis, OR

\section{Washington:}

Panlabs, Inc., Bothwell, WA

Fred Hutchinson Cancer Research Ct, Seattle, WA

\section{Other States:}

Southern Research Institute, Birmingham, AL

Arnold Arboretum, Jamaica Plain, MA

National Institutes of Health, Bethesda, MD

National Cancer Institute, Frederick, MD

Echochem Reseearch Inc., Shaska, MN

Missouri Botanical Garden, St. Louis, MO

Bristol-Myers Squibb Co., Princeton, NJ

RW Johnson Pharmaceutical Research Institute, Raritan, NJ

Molecular Biology Research, Lederle laboratories, Pearl River, NY

New York Botanical Garden, Bronx, NY

Merck Sharp \& Dohme Research laboratories, West Point, PA

Philip Morris Research, Richmond, VA

American Cancer Society, Madison, WI

Research Triangle Institute, Research Tri Pk, NC 


\section{Other Countries:}

National Cancer Institute, Brussels, Belgium

Celex Laboratories Inc., Victoria, British Columbia, Canada

Laboratorie Pelagique, Inc., Port-Daniel, Quebec, Canada

Laboratorie De Pharmacognosie, BD Triomphe, Belgium

Rhone Poulenc Centre De Recherche, Sur Seine Cedex, Vitry Sur Sein, France

Rhone Poulenc Rorer Central Research, Antony Cedex, France

Gorlaeus Laboratories, Leiden, The Netherlands

University Hospital, Leiden, The Netherlands 


\section{Businesses}

Califomia:

ALB Ventures Inc., Arcata, CA

Anver Bioscience Design, Inc., Sierra Madre, CA

Arcata Lumber Forest Tree Nursery, Arcata, Smith River, CA

Arguron Pharmaceutical, Inc., San Diego, CA

Baldwin's Forestry Services, Douglas City, CA

Blodgett Forest, Georgetown, CA

Blue Cross, Blue Shield, Chico, Ca

Blue Oak Nursery, Rescue, CA

Bowser Forest Service, Honeydew, CA

Bracut Lumber Co, Arcata, CA

Calbiochem Corporation, La Jolla, CA

Calbiomarine Technologies, Inc. Leucadia, CA

CAPA, Montgomery Creek, CA

Crowell Tree Farm, Diamond Springs, CA

Croxton's Horticultural Gardens, Placerville, CA

Diamond Lumber International, Red Bluff, CA

Dowes Prarie Farm, McKinleyville, CA

Ecoanalysts, Chico, CA

Emmett Baugh Co Inc., Redding, CA

Feather River Forest Products, Marysville, CA

Foothill Nursery and Landscape, Shingle Springs, CA

Forest Landowners of California, Orinda, CA

Forest Seeds of California, Placerville, CA

Georgia Pacific Forest Tree Nursery, Fort Bragg, Mantell, CA

Goldbud Farms, Placerville, CA

Greener N'Ever Nursery, Carmel, CA

H-H Forest Tree Nursery, Sebastopol, CA

Hi-Ridge Lumber Co, Yreka, CA

Home Lumber, San Bernardino, CA

Humboldt Nursery, McKinleyville, CA

Acquier Ranch, Placerville, CA

Ken J. Collins Company, Trinity Center, CA

Kenruth Tree Farm, Somerset, CA

Louisana-Pacific Corp, Feather Falls, CA

Louisiana-Pacific Corp, Clotilde Merlo Forest Nursery, Trinidad, CA

M A Fisher Logging, Klamath River, CA

McCulley Logging Co, Happy Camp, CA

Michigan-California Lumber Company, Camino, CA 
Monarch Laboratory, Chico, CA

Moravek Biochemicals, Inc., Brea, CA

Natural Resources Management Corporation, Eureka, CA

Naylor Farms, Somerset, CA

No. California Indian Development Council, Eureka, CA

North Star Engineering, Chico, CA

Petersem \& Evans Enterprises, Stonyford, CA

Pharmatec, Inc., Cupertino, CA

Pharmagenesis, Palo Alto, CA

Plant Genetics Inc., Davis, CA

Plumas Corp, Quincy, CA

Prater Tree Farm, Clipper Mills, CA

President Nursery, Rutherford, CA

Redding Dump Truck Services, Redding,CA

Redwood Coast Law Center, Mendocino, CA

Rellim Redwood Company, Crescent City, CA

Roberts Tree Farm, Pollock Pines, CA

Ri-Cal, Inc., Hollister, CA

Walker Logging Company, Cloverdale, CA

Wetsel-Oviatt Lumber Co, Folsom, CA

Windy Hill Tree Farm, Cool, CA

W M Beaty \& Associates, Redding, CA

Wood Elegance Inc., Novato, CA

Yurok Cutters, Hoopa, CA

Idaho:

Boise Cascade Corp, Boise, ID

Clifty View Nursery, Inc., Bonners Ferry, ID

$\mathrm{H} \& \mathrm{R}$ Land Co, Craigmont, ID

Fantasy Farms, Lenor, ID

Potlatch Corp, Lewiston, ID

Magic Valley Trail Maching Assoc, Twin Falls, ID

Nishek Nursery, Bonners Ferry, ID

North Woods Nursery, Elk River, ID

Plato Nursery, Bonners Ferry, ID

Three Bear Forestry, Priest River, ID

Triple R Forest Products, Kamiah, ID

Western Forest Systems, Inc., Lewiston, ID

W-I Forest Products, Bonners Ferry, ID 


\section{Montana:}

Champion International Timberlands Nursery, Plains, MT

Lawyer Nursery, Inc., Plains, MT

M \& T Logging, Greenough, MT

Plum Creek Nursery, Pablo, MT

Raintree Nursery, Libby, MT

Time Engineering, Sula, MT

\section{Oregon:}

Aspect Productions, Eugene, OR

Beak Consultants Inc., Portland, OR

Bear Creek Corporation, Medford, OR

Bend Pine Nursery, Bend, OR

Bogle \& Gates, Portland, OR

Bohemia Inc., Eugene, OR

Boise Cascade Corp, Medford, OR

C \& D Lumber Co, Riddle, OR

Cabler Insurance Agency, Medford, OR

Capital Press, Medford, OR

Cavenham Forest Industries, Warrenton, OR

Champion International Corp, Mapleton, OR

Community Relations Associates, Inc., Springfield, OR

Dean Pihlstrom, Inc., Newport, OR

D R Johnson Lumber Co, Riddle, OR

Dell Isham \& Associates, Salem, OR

Diamond Wood Products, Inc., Corvallis, OR

Donahue Distributing, Eugene, OR

Eagles View Management, Eugene, OR

Earth Kids, Salem, OR

Ellingson Lumber Co, Baker City, OR

Erickson Air-Crane Company, Central Point, OR

F \& F Georesource, Inc., Bend, OR

Fibrex \& Shipping Co., Inc., Portland, OR

Forest Engineering Inc., Corvallis, OR

G. Barnes Enterprises, Cottage Grove, OR

Georgia Pacific Corp, Portland, OR

Grayback Forestry Contracting, Inc., Merlin, OR

Green Hills Nursery, Beaver, OR

Hammer Lumber Co, Eugene, OR

Hanna Nickel Smelting Co., Riddle, OR

Hauser Northwest Inc., Cottage Grove, OR 
HCMA Consulting Group, Tigard, OR

Horizon Enterprises, Central Point, OR

Hoskins Lumber Company, Philomath, OR

Hulogosi Publishers, Eugene, OR

IKA Nurseries, Inc., Beaverton, OR

Klamath Consulting Service, Inc., Klamath Falls, OR

International Paper Company, Lebanon, OR

Lane Electric Cooperative, Eugene, OR

Lee A Klecker Cutting, Gates, OR

Lone Rock Timber Co, Roseburg, OR

M \& W Greenhouse, Salem, OR

Mater Engineering, Corvallis, OR

Mckinney Secondary Forest Products, Sutherlin, OR

Medford Corp, Medford, OR

Miller Timber Services, Inc., Philomath, OR

Molecular Probes, Inc., Eugene, OR

Northwest Botanicals, Grants Pass, OR

Northwest Mycological Consultants, Corvallis, OR

Northwest Reforestation Contractors Association, Eugene, OR

Northwest Seed Products, Inc., Brownsville, OR

OKI Nursery, Aurora, OR

OR-CAL Chemical, Junction City, OR

Powder Creek Dairy, Beaver, OR

Pacific Meridian Resources, Portland, OR

Pacific Rim Forest Industry, Inc., Eugene, OR

Pacific West Publishing Service, Eugene, OR

Paul F. Ehinger and Associates, Eugene, OR

PM Hage \& Associates, Inc., Eugene, OR

Random Lengths, Eugene, OR

Research Resources, Klamath Falls, OR

Richard L. Durham \& Assoc., Lake Oswego, OR

Robert Brothers, Williams, OR

Rosboro Lumber Co, Springfield, OR

Roseburg Lumber Company, Roseburg, OR

Rough and Ready Lumber Company, Cave Junction, OR

Saxon's Masonry Inc., Springfield, OR

Silviculture Laboratory, Bend, OR

Simpson Timber Co, Tillamook, OR

Small Business Administration, Portland, OR

Starfire Lumber Company, Cottage Grove, OR

Stone Forest Industries, Inc., Medford, OR 
The Campbell Group, Portland, OR

The Seamless Web, Eugene, OR

Thomas Lumber Co, Klamath Falls, OR

Tillamook Rare Coin Co., Tillamook, OR

Times Mirror Land \& Timber Company, Protland, OR

Torgersen Construction, White City, OR

Turner Regeneration Center, Weyerhaeuser Company, Turner, OR

Waldport Evergreen Unlimited, Waldport, OR

Western Timber Company, Philomath, OR

Westmoreland Manor, Portland, OR

Weyerhaeuser Co, Springfield, Aurora, OR

Willamette Industries Inc., Portland, OR

Yew Wood Industries Co, Portland, OR

Your Country Cousin, Central Point, OR

\section{Washington:}

Aldrich Berry Farm \& Nursery, Inc., Mossyrock, WA

Boise Cascade Corp, Yakima, WA

Broughton Lumber Company, Underwood, WA

Columbia Consulting Group Inc., Issaquah, WA

Forestry Science Lab, Seattle, WA

Guy Bennett Lumber Co, Clarkston, WA

Greenbelt Consulting, WA

Inland Empire Paper Co, Spokane, WA

J Hofert Forest Nursery, Olympia, WA

John Hancock Mutual Life Insurance Co, Olympia, WA

Kask Consultants, Seattle, WA

Landau Associated, Inc., Edmonds, WA

Longevity Herb Company, White Salmon, WA

Marusumi Paper Mfg Co LTD, Seattle, WA

Mundy and Associates, Seattle, WA

Noreco Inc., Bellingham, WA

Northwest Industry Forest Manufacturer, Tacoma, WA

Olympic Reforestation Inc., Port Townsend, WA

Pacific Lumber Sales Co, Packwood, WA

Plum Creek Timber Co, Seattle, WA

Private \& Municipal Tacticians, Republic, WA

Professional Forestry Services Inc., Olympia, WA

Riddell/Williams/Bullitt and Walkinshaw, Seattle, WA

Sabruer Corporation, Medina, WA

Scott Paper Co, Everett, WA 
Simpson Timber Co, Shelton, WA

Tom Arnold Logging Inc., White Salmon, WA

Washington State Tax Facts, Olympia, WA

Washington Timberland Mgmt Inc., Union, WA

Weyerhaeuser Co, Chehalis, Centralia, Longview, Olympia, Rochester, Tacoma, WA

WKO Inc., Carson, WA

\section{Other States:}

Chem-Quest, Longmont, CO

Crown Resources Corp, Denver, CO

Environmental Management Services, FORT Collins, CO

Hauser Chemical Research Inc., Boulder, CO

Medimolecules, Inc., Boulder, CO

NAPRO, Boulder, CO

PIC Technologies Inc., Denver, CO

Bio-Eng Inc., Arlington, MA

Bristol-Myers Squibb Co, Wallingford, CT

Symbiotech, Inc., Wallingford, CT

Ketchum Public Relations, Washington, DC

Broadcast Capital Fund Inc., Washington, DC

Children's Hospital National Medical Center, Washington, DC

Walter Reed Army Medical Center, Washington, DC

Du Pont Merck Pharmaceutical Co., Wilmington, DE

A L Ross \& Sons, West Palm Beach, FL

Bill Haley \& Associates Inc., Tallahassee, FL

The Ivax Corporation, Miami, FL

Georgia Pacific Corporation, Atlanta, GA

Hawaii Biotechnology Group Inc., Aiea, HI

Abbott Laboratories, Abbott Park, IL

Evanston Hospital, Evanston, IL

Eli Lilly and Company, Indianapolis, IN

Dread Laboratories, Lawrence, KS

Environmental Engineering, Medford, MA

New England Deaconness Hospital, Boston, MA

Chemical Synthesis \& Analysis Lab, Frederick, MD

Developmental Therapeutics Program, Rockville, MD

Johns Hopkins Hospital, Lutherville, MD

Program Resources Inc., Frederick, MD

Nova Pharmaceuticals, Baltimore, MD

Social \& Scientific Systems, Rockville, MD 
Warner-Lambert/Parke Davis, Ann Arbor, MI

Upjohn Company, Kalamazoo, MI

Wycoff Chemical Company, Inc., South Haven, MI

Sympol, Inc., Minneapolis MN

Monsanto Corporation, St. Louis, MO

Vanwingerden International, Fletcher, NC

Labat-Anderson, Inc., Bellevue, NE

CIBA-GEIGY, Inc., Summit, NJ

Dr. Madis Laboratories, Inc., So. Hackensack, NJ

Medisperse, LP, Somerville, NJ

Penick Corp., Newark, NJ

Schering-Plough Corp., Bloomfield, NJ

Unimed, INc., Somerville, NJ

Union Camp Corporation, Princeton, NJ

Xechem, Inc., New Brunswick, NJ

Brenmer Industries, Inc., New York, NY

Health Science Communication, New York City, NY

Lederle Labs, Pearl River, NY

McGraw-Hill, Inc., New York, NY

Memorial Sloan-Kettering Cancer CT., New York, NY

Montefiore Medical Center, Bronx, NY

Nippon Kayaku Co., LTD, New York, NY

Phyton Catalytic, Inc., Dryden, NY

Waterford Farms, Big Flats, NY

Neoprobe Corporation, Columbus, $\mathrm{OH}$

Ply-Trim, Inc., Youngstown, $\mathrm{OH}$

E I Dupont De Nemours \& Co., Glenolden, PA

Fox Chase Cancer Center, Philadelphia, PA

Polysciences Inc., Warrington, PA

Rhone Poulenc Rorer, Fort Washington, PA

Smith Kline Beecham Pharmaceutical, King of Prussia, PA

Rhode Island Nurseries, Middletown, RI

St. Jude Children's Research Hospital, Memphis, TN

M.D. Anderson Hospital, Houston, TX

Texas Children's Hospital, Houston, TX

Biowest Inc., Logan, UT

Native Plants Inc., Salt Lake City, UT

Natural Product Sciences, Salt Lake City, UT

Labat-Anderson Inc., Arlington, VA

Vincent Lombardi Cancer Center, Mclean, VA 


\section{Other Countries:}

Forestry Canada, Edmonton, Alberta, Canada

Silvacom, Inc., Edmonton, Alberta, Canada

General Delivery, Merville, British Columbia, Canada

FMG Integrated Biotechnical Laboratories, LTD, Richmond, British Columbia, Canada

Towers Phytochemicals Limited, Richmond, British Columbia, Canada Wescan Laboratory, Richmond, British Columbia, Canada

Gwen Shrimpton Surrey Nursery, Surrey, British Columbia, Canada Reid, Collins \& Associates, Vancouver, British Columbia, Canada

Sandwell Swan Wooster, Inc., Vancouver, British Columbia, Canada

Celex Laboratries, Inc., Victoria, British Columbia, Canada

Pacific Forestry Centre, Victoria, British Columbia, Canada Egan Ecological Services, Victoria, British Columbia, Canada

Ag-West Biotech, Saskatoon, Saskatchewan, Canada

BioInternational Inc., Toronto, Ontario, Canada

The Atul Products Limited, Gujarat, India

Kyowa Hakko Kogyo Co, LTD, Zbaraki-Ken, Japan

Wiggins Teape, Beaconsfield, United Kingdom

Plant Sciences Limited, Sheffield, United Kingdom

TL Pacific Lumber LTD, Cabriola, CN, VOR 


\section{Interest Groups}

\section{Califomia:}

Altacal Audubon Society, Chico, CA

American River Recreation Association, Coloma, CA

Butte Environmental Council, Chico

California Forestry Association, Sacramento, CA

California Native Plants Society, Arcata, Placerville, Chico, CA

California Wilderness Coalition, Davis, CA

Californians for a Clean Environment, Fort Dick, CA

Center for Natural Resource Advocacy, Ukiah, CA

Coast Action Group, Point Arena, CA

Earth First!, Oakdale, CA

Eco-Analysts, Chico, CA

Ecology Center, Berkeley, CA

F.A.W.N., Garden Valley, CA

Friends of Blue Lake, Blue Lake, CA

Friends of Plumas Wilderness, Quincy, CA

Friends of The Forest, North San Juan, CA

Friends of The Van Duzen, Carlotta, CA

Friends of The West Fork, Upper Lake, CA

High Sierra R C and D Council, Auburn, CA

Hoopa Tribal Forestry, Hoopa, CA

Jacoby Creek Canyon Community, Bayside, CA

Klamath-Trinity Watershed Assn, Willow Creek, CA

Mendocino Environmental Center, Ukiah, CA

Mooretown Rancheria, Oroville, CA

Native Plant Society, Chico, CA

Native Yew Conservation Council, Berkeley, CA

Natural Resource Defense Council, San Francisco, CA

Northwest Forest Workers Assn, Trinidad, CA

NFFE Local 1937, Eureka, CA

People for Healthy Forests, Sonora, CA

Regional Opportunity Program, Oroville, CA

Sacramento Audubon Society, Sacramento, CA

Sierra Club, Chico, Placerville, Sacramento, CA

Sierra Club Legal Defense Fund, San Francisco, CA

Siskiyou Forestry Consultant, Arcata, CA

Six Rivers Friends of the Earth, Bayside, CA

Society of American Foresters, Eureka, Camino, CA

South Feather Watershed Council, Feather Falls, CA 
South Fork Mtn Defense Committee, Eureka, Mad River, CA South Fork Trinity Watershed Association, Kneeland, CA Streamfinders, Chico, CA

The Wilderness Society, San Francisco, CA Timber Assn of California, Sacramento, CA

Van Duzen Citizens Observation Group, Brideville, CA

Willits Enviornmental Center, Willits, CA

W M Beaty \& Associates, Redding, CA

Yolo Environmental Resource Center, Davis, CA

88 Spur Riders, Pioneer, CA

Idaho:

Backcountry Horseman, Coeur D'Alene, ID

Blue Ribbon Coalition, Idaho Falls, ID

Boundary Backpackers, Bonners Ferry, ID

Clark Fork Coalition, Sandpoint, ID

Citizens for Environment Quality, St Maries, ID

Clearwater Resource Coalition, Orofino, ID

Coeur D'Alene Wildlife Federation, Coeur D'Alene, ID

Conservation Data Center, Boise, ID

Elk Unlinited, Osburn, ID

Forest Watch, Priest River, ID

Idaho Conservation League, Coeur D'Alene, ID

Idaho Environmental Council, Idaho Falls, ID

Idaho Forest Industry Council, Coeur D' Alene, ID

Idaho Forest Industries, Coeur D' Alene, ID

Idaho Outfitters \& Guides Assn, Boise, ID

Idaho Sportsman's Coalition, Boise, ID

Idaho Trappers Association, Moscow, ID

Idaho Trails Council, Moscow, ID

Idaho Wildlife Federation, Coeur D'Alene, Lewiston, ID

Inland Northwest Wise Use, St Maries, ID

Intermountain Forest Industry Assn, Coeur D'Alene, ID

Kaniksu Bio Regional Council, Sandpoint, ID

Kootenai Tribe of Idaho, Bonners Ferry, ID

National Wildlife Federation, Coeur D'Alene, ID

North Idaho Fly Casters, Coeur D'Alene, ID

North Idaho Audubon Society, Bonners Ferry, ID

Selkirk-Priest Basin Assoc, Inc., Priest River, ID

Senior Environmental Health Specialists, Coeur D'Alene, ID 
The Wilderness Society, Boise, ID

Trout Unlimited Idaho Council, Lewiston, ID

United Paper Workers Union, Lewiston, ID

Wildlife Society, Blackfoot, ID

\section{Montana:}

Alliance for the Wild Rockies, Missoula, MT

$\mathrm{BCH}$, Columbia Falls, MT

Coalition for Canyon Protection, Hungry Horse, MT

Friends of the Wild Swan, Boseman, MT

Montana Ecosystems Defense Council, Kalispell, MT

Montana Native Plant Society, Missoula, MT

Montanans for Multiple Use, Hungry Horse, MT

Mt Audubon Council, Helena, MT

National Wildlife Federation, Missoula, MT

Resources Limited, Polebridge, Mt

The Ecology Center, Missoula, MT

\section{Oregon:}

180 Degrees, Portland, OR

American Cancer Society, Portland, OR

American Conifer Society, Boring, OR

American Forestry Association, Springfield, OR

Associated Oregon Loggers, Salem, OR

Audubon Society, Ashland, Eugene, Portland, Salem, OR

Bohemia Mine Owners' Association, Veneta, OR

Cascade Geographic Society, Rhododendron, OR

Central Oregon Audubon Society, Bend, OR

Confederated Tribes of Coos, Lower Umpqua \& Siuslaw, Coos Bay, OR

Confederated Tribes of Siletz, Siletz, OR

COPE, Hatifield Marine Science Center, Newport, OR

Dorena Tree Improvement Center, Cottage Grove, OR

Douglas County Museum, Roseburg, OR

EF! Stumpfrogs, Eugene, OR

Headwaters, Ashland, OR

Labor Coalition For Environmental Responsibility, McMinnville, OR

League of Women Voters of Umpqua Valley, Roseburg, OR

Local Residents For Old Growth, Lyons, OR

National Wildlife Federation, Portland, OR

Native Forest Council, Eugene, OR 
Native Plant Society of Oregon, Eugene, OR

Native Yew Conservation Committee, Portland, OR

Native Yew Conservation Council, Portland, OR

Northwest Forestry Association, Portland, OR

Oregon Association of Nurserymen, Milwaukee, OR

Oregon Council of Rocks \& Minerals, Salem, OR

Oregon Natural Resources Council, Bend, OR

Oregon Sheep Growers Association, Salem, OR

Oregon Wildlife Federation, Portland, OR

Oregon Forestry Industry Council, Salem, OR

Pegasus Trees of the West, Eagle Creek, OR

Portland Audubon Society, Portland, OR

Public Lands Foundation, Medford, OR

R \& E Plant Project, Lake Oswego, OR

Range Ecology Group, LaGrande, OR

Retree International, Wilsonville, OR

Sand Fleas $4 \times 4$ club, Boring, OR

Sierra Club, Bend, Eugene, Lincoln City, Portland, OR

Southern Oregon Timber Industry Assn, Medford, OR

Special Trees, Corvallis, OR

The Citizen, La Pine, Or

Walter Range Patrol Association, Gilchrist, OR

Western Hardwood Association, Portland, OR

Western Wood Products Assn, Portland, OR

Wilderness Society, Portland, OR

Wildlife Society, Corvallis, Portland, OR

Williams Watershed Protection Assoc., Williams, OR

World Forestry Center, Portland, OR

\section{Washington:}

Audubon Society, Kirkland, Olympia, Spokane, Tacoma, WA

BLack Hills Audubon Society, Olympia, WA

Camas-Washougal Historical Society, WA

Center for Watershed Management, Seattle, WA

Friends of The Earth, Seattle, WA

Greater Ecosystem Alliance, Bellingham, WA

Inland Northwest Wildlife Council, Spokane, WA

Issaquah Valley Rock Club, Inc., Issaquah, WA

Lincoln County Cattlemen's Association, Davenport, WA

Lumni Indian Business Council, Bellingham, WA

Nisqually Indian Tribe, Olympia, WA 
North Cascades Conservation Council, Seattle WA

Northwest Indian Fisheries Commission, Olympia, WA

Pilchuck Audubon Society, Stanwood, WA

Port Gamble S'klallam Tribe, Kingston, WA

PTI Environmental Services, Bellevue, WA

Public Land Users Coalition, Kettle Falls, WA

Quilcene Ancient Forest Coalition, Port Townsend, WA

Sierra Club Legal Defense Fund, South Seattle, WA

Sierra Club Northwest, Seattle, WA

Silver Star Study Group, Vancover, WA

Spokane Audubon Society, Spokane, WA

Spokane Mushroom Club, Spokane, WA

The Nature Conservancy, Seattle, WA

The Wilderness Society, Seattle, WA

Washington Environmental Council, WA

Washington Native Plant Society, Seattle, Spokane, WA

YMCA Earth Corps, Bremerton, WA

\section{Other States:}

American Red Cross, Juneau, AK

EFI Biodiversity Project, Boulder, Co

Sierra Club "Legal Defense Fund, Denver, Co

American Association of Nurserymen, Washington, DC

American Chemical Society, Washington, DC

American Forestry Association, Washington, DC

American Rivers, Wahington, DC

Committee on Science Space \& Technology, Washington, DC

Council for Wildlife Policy, Washington, DC

Environmental Defense Fund, Washington, DC

NASF Hall of States, Washington, DC

National Audubon Society, Washington, DC

National Forest Products Assn., Washington, DC

National Wilderness Institute, Washington, DC

National Wildlife Federation, Washington, DC

The Cancer Letter, Washington, DC

Hawaii Sugar Planters Association, Alea, HI

Iowa Lumber Association, West Des Moines, IA

Idaho Assoc. of Soil Conserv. Dist., Buhl, ID

American Medical Association, Chicago, IL

Cultural Survival, Cambridge, MA

Dana-Farber Cancer Institute, Boston, MA 
Worchester Foundation For Experimental Biology, Shrewsbury, MA FDC Reports, Chevy Chase, MD

Linda Pollin Foundation, Bethesda, MD

NIAID, Bethesda, MD

National Cancer Institute, Bethesda, MD

National Institutes of Health, Bethesda, MD

Natural Sciences, Princess Anne, MD

Society of American Foresters, Bethesda, MD

Consult Gr. on Biological Diversity, New York, NY

National Council Air/Streams Imprv., New York, NY

Baruch Institute Field Laboratory, Columbia, SC

Public Lands Foundation, Mclean, VA

North American Horse \& Mule Logging Assn, Pinedale, WY

\section{Other Countries:}

British Columbia Cancer Agency, Vancouver, British Columbia

Council of Forest Industries of British Columbia

Kyowa Hakko Kogyo Co, LTD, Zbaraki-Ken, Japan

Phytex Australia Pty, LTD, Castle Hill, Australia 


\section{Schools}

\section{Califomia:}

Bakersfield College, Bakersfield, CA

Butte College, Oroville, CA

Cal Poly State University, San Luis Obispo, CA

California State University, Chico, Sacramento, CA

College of The Redwoods, Eureka, CA

College of the Siskiyous, Weed, CA

Fresno City College, Fresno, CA

Humboldt State University, Arcata, CA

Institute of Forest Genetics, Placerville, CA

Kings River Community College, CA

Pasadena City College, Pasadena, CA

San Francisco State University, Wildlands Program, Cazadero, CA

San Jose State University, San Jose, CA

Standford University, Standford, CA

Sierra College, Rocklin, CA

Sonoma State University, Rohnert Par, CA

University of California, Berkeley, Davis, Irvine, Riverside,

Los Angeles, San Diego, Santa Barbara, Santa Cruz, CA

University of Southern California, Los Angeles, CA

\section{Idaho:}

Boise State University, Boise, ID

Idaho State University, Pocatello, ID

University of Idaho, Boise, Moscow, ID

\section{Montana:}

Flathead Valley Community College, E Kalispell, MT

Montana State University, Bozeman, MT

University of Montana, Missoula, MT

\section{Oregon:}

Central Oregon Community College, Bend, OR

Chemeketa Community College, Salem, OR

Cleveland High School, Portland, OR

Eastern Oregon State College, La Grande, OR

Lane Community College, Eugene, OR

Northwestern School of Law, Lewis \& Clark College, Portland, OR 
Oregon State University, Astoria, Corvallis, OR

Portland State University, Portland, OR

Scappoose High School, Scappoose, OR

Southwest Oregon Community College, Coos Bay, OR

University of Oregon, Eugene, OR

\section{Washington:}

Central Washington University, Ellensburg, WA

Kellogg Middle School, Seattle, WA

Spokane Community College, Spokane, WA

University of Washington, Seattle, WA

University of Washington, University Hospital, Seattle, WA

Washington State University, Pullman, WA

Western Washington University, Bellingham, WA

\section{Other States:}

University of Alaska, Fairbanks, AK

Auburn University, Auburn, AL

University of Alabama, Birmingham, AL

University of Arkansas, Monticello, Little Rock, AR

Arizona State University, Tempe, AZ

Northern Arizona University, Flagstaff, AZ

University of Arizona, Tucson, AZ

Colorado State University, Fort Collins, CO

University of Colorado, Boulder, $\mathrm{CO}$

Connecticut College, New London, CT

University of Connecticut, Storrs, CT

University of New Haven, New Haven, CT

Wesleyan University, Middletown, CT

Yale University, New Haven, CT

American Institute of Bio. Sciences, Washington, DC

Georgetown University, Washington, DC

George Washington University, Washington, DC

Howard University, Washington, DC

University of DC, Washington, DC

University of Delaware, Newark, DE

Florida State University, Tallahassee, FL

Lake City Community College, Lake City, FL

University of Florida, Gainesville, FL

University of Miami, Miami, FL 
University of South Florida, Tampa, FL

University of West Florida, Pensacola, FL

University of Hawaii, Honolulu, HI

Abraham Baldwin Agricultural College, Tifton, GA

Emory University, Atlanta, GA

Georgia Institute of Technology, Atlanta, GA

University of Georgia, Athens, GA

University of Georgia Marine Institute, Sapelo Island, GA

Iowa State University, Ames, IA

University of Iowa, Iowa City, IA

Bradley University, Peoria, IL

Eastern Illinois University, Charleston, IL

Northwestern University, Evanston, IL

Southern Illinois University, Edwardsville, IL

University of Chicago, Chicago, IL

University of Illinois, Chicago, Urbana, IL

Western Illinois University, Macomb, IL

Ball State University, Muncie, IN

Indiana University Hospital, Indianapolis, IN

Purdue University, West Lafayette, IN

Kansas State University, Emporia, KS

University of Kansas, Lawrence, KS

Eastern Kentucky University, Richmond, KY

Georgetown College, Georgetown, KY

Morehead State University, Morehead, KY

Murray State University, Murray, KY

University of Kentucky, Lexington, $K Y$

University of Louisville, Louisville, KY

Louisiana State University, Baton Rouge, LA

Louisiana Tech University, Ruston, LA

Northwestern State University, Natchitoches, LA

Tulane University, New Orleans, LA

MGH Institure of Health Profession, Boston, MA

Harvard University, Cambridge, MA

Massachusetts Institute of Technology, Cambridge, MA

Northeastern University, Boston, MA

Quinsigamond College, Worchester, MA

University of Lowell, Lowell, MA

University of Massachusetts, Amherst, MA

Brandeis University, Waltham, MA

Williams College, Williamstown, MA 
Worchester Polytechnic Institute, Worcester, MA Allegany Community College, Cumberland, MD Johns Hopkins University, Baltimore, MD University of Maryland Cancer Ctr, Baltimore, MD University of Maryland, College Park, MD College of the Atlantic, Bar Harbor, ME Unity College, Unity, ME University of Maine, Orono, Fort Kent, ME Central Michigan University, Mt. Pleasant, MI Eastern Michigan University, Ypsilanti, MI Ferris State University, Big Rapids, MI Lake Superior State University, Soult Ste Marie, MI Michigan Biotechnology Institute, Lansing, MI Michigan State University, East Lansing, MI Michigan Technological University, Houghton, MI Northern Michigan University, Marquette, MI University of Michigan, Ann Arbor, MI Wayne State University, Detroit, MI Western Michigan University, Kalamazoo, MI Bemidji State University, Bemidji, MN University of Minnesota, St. Paul, MN University of Missouri, Columbia, MO Washington University, St. Louis, MO Mississippi State University, Mississippi St., MS University of Mississippi, University, Oxford, MS University of Southern Mississippi, Hattiesburg, MS Appalachian State University, Boone, NC

Duke University, Durham, NC Haywood Community College, Clyde, NC North Carolina State University, Raleigh, NC University of North Carolina, Chapel Hill, NC North Dakota State University, Fargo, ND University of North Dakota, Grand Forks, ND University of Nebraska, Lincoln, NE Antioch University, Keene, $\mathrm{NH}$ Glassboro State College, Glassboro, NJ Montclair State College, Upper Montclair, NJ Rutgers University, New Brunswick, NJ Stevens Institute of Technology, Hoboken, NJ Stockton State College, Pomona, NJ William Patterson College, Wayne, NJ 
New Mexico State University, Las Cruzes, NM

University of Nevada, Reno, NV

Albert Einstein College of Medicine, Bronx, NY

Bard College, Anandale-Hudson, NY

Columbia University, New York, NY

Cornell University, Ithaca, NY

Lehman College of Cuny, Bronx, NY

Mt. Sinai School of Medicine, New York, NY

Paul Smiths College of Arts and Sciences, Paul Smith, NY

New York University School of Medicine, New York, NY

Queens College, Flushing, NY

Rensselaer Polytechnic Institute, Troy, NY

Roswell Park Cancer Institute, Buffalo, NY

State University, Syracuse, NY

State University of New York, Stony Brook, Cortland, Amherst, Buffalo, NY

Bowling Green State University, Bowling Green, $\mathrm{OH}$

Case Western Reserve University, Cleveland, $\mathrm{OH}$

Hocking Technical College, Nelsonville, $\mathrm{OH}$

Kent State University, Kent, $\mathrm{OH}$

Miami University, Oxford, $\mathrm{OH}$

Ohio State University, Columbus, $\mathrm{OH}$

Sjawmee State University, Portsmouth, $\mathrm{OH}$

University of Akron, Akron, $\mathrm{OH}$

Eastern Oklahoma State College, Wilburton, OK

Oklahoma State University, Stillwater, OK

Bryn Mawr College, Bryn Mawr, PA

Drexel University, Philadelphia, PA

Jefferson Medical College, Pittsburgh, PA

Pennsylvania State University, State College, PA

Philadelphia College of Pharm. \& Scien., Philadelphia, PA

Slippery Rock University, Slippery Rock, PA

University of Pennsylvania, Philadelphia, PA

University of Pittsburgh, Pittsburgh, PA

Williamsport Area Community College, Williamsport, PA

Brown University, Providence, RI

Rhode Island School of Design, Providence, RI

University of Rhode Island, Kingston, RI

Clemson University, Clemson, SC

Harry-Georgetown Technical College, Conway, SC

Med University of South Carolina, Charleston, SC

Coop Fish \& Wildlife Research Unit, South Dak. St. Un., Brookings, SD 
South Dakota State University, Brookings, SD

University of the South, Sewanee, TN

University of Tennessee, Knoxville, TN

Vanterbilt University, Nashville, TN

Southern Methodist University, Dallas, TX

Stephen F. Austin State University, Nacogdoches, TX

Ferrum College, Ferrum, VA

Rice University, Houston, TX

Texas A \& M University, College Station, TX

Texas Christian University, Fort Worth, TX

Texas Tech. University, Lubbock, TX

University of Houston, Houston, TX

University of North Texas, Denton, TX

University of Texas, Houston, TX

Utah State University, Logan, UT

University of Utah, Salt Lake City, UT

Institute of Marine Science, Gloucester Pt., VA

Medical College of Virginia, Richmond, VA

University of Virginia, Charlottesville, VA

Virginia Commonwealth University, Richmond, VA

Virginia Polytechnic Institute and University, Blacksburg, VA

University of the Virgin Islands, St. Thomas, VI

Johnson State College, Johnson, VT

Vermont Law School, South Royalton, VT

Univerity of Vermont, Burlington, VT

University of Wisconsin, Green Bay, WI

Glenville State College, Glenville, WV

The School of Natural Resources, University of Wisconsin

University of Wisconsin, Madison, Green Bay, Eau-Claire, WI

West Virginia University, Morgantown, WV

University of Wyoming, Laramie, WY

\section{Other Countries:}

University of Calgary, Calgary, Alberta, Canada

University of Alberta, Edmonton, Alberta, Canada

Malaspina College, Nanaimo, British Columbia, Canada

University of British Columbia, Vancouver, British Columbia, Canada

University of Guelph, Guelph, Canada

University of Manitoba, Winnipeg, Manitoba, Canada

Maritime Forest Range School, Frederiction, New Brunswick, Canada 
University of New Brunswick, Frederiction, New Brunswick, Canada Acadia University, Wolfville, Nova Scotia, Canada

Queen's University, Kingston, Ontario, Canada

Sir Sandford Fleming College, Lindsay, Ontario, Canada

York University, North York, Ontario, Canada

Lakehead University, Thunder Bay, Ontario, Canada

University of Toronto, Toronto, Ontario, Canada

University Du Quebec A Chicoutimi, Chicoutimi, Quebec, Canada

McGill University, Montreal, Quebec, Canada

University of Regina, Regina, Saskatchewan, Canada

Plant Biotechnology Institute, Saskatoon, Sackatchewan, Canada

University of Saskatchewan, Saskatoon, Saskatchewan, Canada

Institute De Chimie Des Substances, Gif-Sur-Yvette, France

University of Joseph Fourier De Grenoble, Grenoble Cedex, France

School of Pharmacy, Dublin, Ireland

Hebrew University, Jerusalem, Israel

Kyoto University, Kyoto, Japan

Catholic University of Mijemege, Toernooiveld, The Netherlands

Ecole De Pharmacie De L Universite, Lausanne, Switzerland

Institute For Pflanzenwissenschafte, Zurich, Switzerland

University Chemical Laboratory, Cambridge, United Kingdom

University of Reading, Reading, United Kingdom

Wolfson Institute of Biotechnology, University of Sheffield, Sheffield, United

Kingdom 


\section{Libraries}

Califomia:

Del Norte County Library, Cresent City, CA

Humboldt County Library Eureka, Willow Creek, CA

Idaho:

Coeur D'Alene Public Library, Coeur D' Alene, ID

Idaho State University Library, Pocatello, ID

University of Idaho Library, Document Section, Moscow, ID

\section{Oregon:}

Aubrey R. Watzek Library, Portland, OR

Douglas County Library, Roseburg, OR

Douglas County Library, Myrtle Creek, Roseburg, OR

Jackson County Library, Medford, OR

Josephine County Library, Grants Pass, OR

Lake Owsego Public Library, Lake Oswego, OR

Research Library, Roseburg, OR

Oregon Institute of Technology Library, Klamath Falls, OR

Oregon State Library, Salem, OR

Sheridan Public Library, Sheridan, OR

\section{Washington:}

Camas Public Library, Camas, WA

Castle Rock Public Library, Castle Rock, WA

King County Library, Seattle, WA

Research Library, Duvall, WA

Seattle Public Library, Seattle, WA

Spokane Public Library, Spokane, WA

Stevenson Library, Stevenson, WA

Vashon Library, Vashon Island, WA

\section{Other States:}

Nevada State Library, Carson City, NV 


\section{Media}

Califomia:

Channel 24, Chico, CA

Chico Enterprise Board, Chico, CA

Chico News and Review, Chico, CA

Citizens Review, Los Angeles, CA

Epic, Garberville, CA

KPAY Radio Station, Chico, CA

Sunset Magazine, Menlo Park, CA

The Times Standard, Eureka, CA

Wall Street Journal, San Francisco, CA

\section{Idaho:}

Blue Ribbon Magazine, Idaho Falls, ID

Coeur D'Alene Press, Coeur D'Alene, ID

Idaho County Free Press, Grangeville, ID

KCDA Radio, Coeur D'Alene, ID

KVNI Radio, Coeur D'Alene, ID

\section{Oregon:}

Albany Democrat-Herald, Albany, OR

Aspect Productions, Eugene, OR

Associated Press, Portland, Grants Pass, OR

Business Journal, Portland, OR

Capital Press, Medford, OR

Corvallis Gazette-Times, Corvallis, OR

Cottage Grove Sentinel, Cottage Grove, OR

Daily Argus Observer, Ontario, OR

Daily Journal of Commerce, Portland, OR

Health Magazine, Portland, OR

KGRL/KXIQ, Bend, OR

KOPB-FM, Portland, OR

KEZI-TX, Eugene, OR

Medford Mail Tribune, Medford, OR

Register Guard, Eugene, OR

Springfield News, Springfield, OR

Talking Leaves, Eugene, OR

The Chronicle, St. Helens, OR

The Oregonian, Portland, OR

What's Happening, Eugene, OR 


\section{Washington:}

Associated Press, Spokane, WA

Bainbridge Review, Bainbridge Island, WA

Loggers World Publication, Chehalis, WA

Seattle Times, Seattle, WA

Spokesman Review, Spokane, WA

Tacoma News Tribune, Tacoma, WA

The Columbian, Vancouver, WA

The West, Seattle, WA

United Press International, Spokane, WA

KHQ-TV, Spokane, WA

KREM-TV, Spokane, WA

KXLY-TV, Spokane, WA

\section{Other States:}

Science News, Washington, DC

The Cancer Letter, Washington, DC

American Conifer Society Bulletin, Asheville, NC

\section{Other Countries:}

Readers Digest, London, England

Times-Colonist, Victoria, British Columbia 


\section{Individuals}

\section{Califomia:}

MICHAEL L ALLAN, JUNCTION CITY, CA

BRUCE S ALLEN, SOLOMA BEACH, CA

GORDON AMOS, BLOCKSBURG, CA

JANICE ANDERSEN, SAN FRANCISCO, CA

MARK ANDERSON, EUREKA, CA

LEE ANDERSON, MT SHASTA, CA

CONSTANCE ANDREWS, CAMARILLO, CA

VIRGINIA ANTHONY, CRESCENT CITY, CA

LENORE ANVICK, ARCATA, CA

MARSHA F ARMSTRONG, LOS GATOS, CA

GRADY ATKINS, EUREKA, CA

LOUIE BALDO, OAKLAND, CA

RICHARD L BARBER, ARCATA, CA

TINY BATES, PASKENTA, CA

ROSS BAVORSTONE, GARBERVILLE, CA

STAN BEACH, KELSEYVILLE, CA

FELICIA ROUNDS BEARDSLEY, WRIGHTWOOD, CA

B BEAUSOLEIL, BERKELEY, CA

OREN BECK, ORLEANS, CA

ALBERT J BECK, CHICO, CA

RUDI BECKING, ARCATA, CA

JULIE BENEDICT, ROHNERT PARK, CA

DOROTHY BERNARDI, ARCATA, CA

MELVIN J BERRY, FORKS of SALMON, CA

BILL BLAKE, VACAVILLE, CA

MR \& MRS GEORGE BRIDGES, SAcrAmento, CA

RICHARD L BROWN, CRESCENT CITY, CA

EMILY BURDETTE, DAVIS, CA

JUDY BURNET, EUREKA, CA

MAC CALHOUN, SAN FRANCISCO, CA

RALPH CARDWELL, HUNTINGTON BEACH, CA

PAT CARMICHAEL, CHICO, CA

CRAIG CARTER, PARADISE, CA

DAVID CASTILLO, LAKEWOOD, CA

JOHN CAVERS, ANAHEIM, CA

MIKE CELAYETA, HAPPY CAMP, CA

TORY CESCHI, CORTE MADERA, CA

PAUL H CHISHOLM, HAYFORK, CA

DON CHISM, FORTUNA, CA

MARJORIE CLOTHIER, WOODSIDE, CA

MARGARET M COBB, ESCONDIDO, CA

MARK COFFIELD, OAKLAND, CA

DORIS E COLE, SUSANVILLE, CA

MARVIN COLEMAN, NEWCASTLE, CA

CHRIS COLSON, CHICO, CA 
DALE M CONDON, CRESCENT CITY, CA JOHN B COPELAND, CHICO, CA DAVE CORRINGTON, GARBERVILLE, CA MARK CORTRIGHT, ARCATA, CA LISA CRANE, CHICO, CA MARK CRAWFORD, SEIAD VALLEY, CA MICHAEL CROOK, ARCATA, CA CAROLE CROWLEY, CARMEL, CA LINDA CURRAN, FREMONT, CA EMMA CZAPKEY, BURLINGAME, CA PATRICE DAVISON, RIVERSIDE, CA MARY DE COUX, HAPPY CA'MP, CA JACK \& LEE DE LONG, CRESCENT CITY, CA ROBERT E DEAN, ARCATA, CA MR \& MRS WALTON H DECKER JR, FORT BRAGG, CA JOHN DELEEUW, CHICO, CA DOUG DEMERS, CANOGA PARK, CA ERNEST A DERNBURG, MILL VALLEY, CA REBECCA A DIRSCHEL, ANDERSON, CA JILL DONDERO, ORLEANS, CA CLAUDE C DOUGLAS, PLATINA, CA MIKE DOWLING, ETNA, CA RICHARD E DRESSER, FORTUNA, CA LOIS DROBISH, WESTHAVEN, CA JERRY DUFFY, ANDERSON, CA GORDON M EHRMAN, GREENBRAE, CA GARY ELDER, WHITEHORN, CA LINDA ELKIND, PALO ALTO, CA FRANK ERRIDGE, CHICO, CA RIA O ESTOLAS, PACIFICA, CA WILLIS A EVANS, SAN GERONIMO, CA ROBERT FERARU, EL CERRITO, CA JOHN A FEYK, RANCHO PALOS VERDE, CA PAUL FINN, SANTA ROSE, CA NORMAN E FIOCK, MONTAGUE, CA RAY W FISHER, DAVIS, CA

ED FITZ, ARCATA, CA RUSS FORSBURG, FIELDS LANDING, CA WALTER FRECH, PARADISE, CA STAN \& ELLEN FROYD, CARPINTERIA, CA MR \& MRS CARL A FURRER, COVELO, CA JOHN M GAFFIN, MYERS FLAT, CA MARILYN GAMETTE, CHICO, CA EMMA GILMAN, SAN RAFAEL, CA BONNIE GRAHAM, HAPPY CAMP, CA LISA \& DAVID GREENBERG, SEIAD VALLEY, CA MRS HEAN GRIMM, BURBANK, CA ROBERT GUTHRIDGE, BAYSIDE, CA PHILIP GUTZLER, MT SHASTA, CA 
RICHARD HAHN, MONTAGUE, CA

JOHN HALL, GARBERVILLE, CA

LIZ HAMILTON, SAN ANSELMO, CA

JUDD HANNA, HALF MOON BAY, CA

JOSEPH H HARN, PETALUMA, CA

TED HATZIMANOLIS, CRESCENT CITY, CA

CHRIS HAYNES, ARCATA, CA

DON HEBERLEIN, GARBERVILLE, CA

RALPH HENSON, NEVADA CITY, CA

OSCAR G HERNANDEZ, MCARTHUR, CA

LEAF HILLMAN, ORLEANS, CA

SUE HILTON, ARCATA, CA

CHARLES HINSCH, MENDOCINO, CA

JUDITH \& RON HODGSON, CHICO, CA

RICHARD \& FRANCES HOGAN, PALO ALTO, CA

SUREN HOLBEK, HAYFORK, CA

ALYSON INOUYE, BRISBANE, CA

SAM JACKSON, HAYFORK, CA

RICK JALI, MAMMOTH LAKES, CA

RICHARD JENSEN, SEBASTOPOL, CA

RAYMOND L JERLAND, EUREKA, CA

MAC C JOINES, CRESCENT CITY, CA

STUART H JONES, LA VERNE, CA

DOUG JONES, VALLEY CENTER, CA

NASSER KASHANI, ALBANY CA

NELSON KASS, ARCATA, CA

JOSHUA R KAUFMAN, KNEELAND, CA

PHIL KELTY, SMITH RIVER, CA

CHARLES KERWIN, ARCATA, CA

BRUCE KESSLER, BAYSIDE, CA

MARGARET KETTUNEN ZEGART, MILL VALLEY, CA

STEPHEN KIEWEL, EUREKA, CA

TOM KING, REDDING, CA

CAREY G KINYON, REDDING, CA

LEWIS KLEIN, MCKINLEYVILLE, CA

THEODORE \& ANELLE KLOSKI, WALNUT CREEK, CA

PATRICK KNIGHT, EUREKA, CA

PHILIP KROHN, SAN FRANCISCO, CA

PATRICIA KRUEGER, AZUSA, CA

DAVID KRUEGER, ARCATA, CA

NORA KUMMEL, PACIFIC PALISADES, CA

MARK LANCASTER, WEAVERVILLE, CA

SEAN LANHAM, PETALUMA, CA

MAX O LAYTON, WEED, CA

RAYMOND LEGO, MONTGOMERY CREEK, CA

JOHN LEVY, CRESCENT CITY, CA

PHYLLIS LINDLEY, STONYFORD, CA

CASSANDRA LISTA-HAYNES, SANTA ROSA, CA

GERALD LITZZA, SACRAMENTO, CA 
BARBARA B LOGAN, TRINIDAD, CA JOHN LONG, EL SOBRANTE, CA CURT LONN, ARCATA, CA HOWELL LOVELL, SAN FRANCISCO, CA HOWARD LOVFALD, FORTUNA, CA TONY LUCCHESI, BAYSIDE, CA MARK LURIE, SANTA BARBARA, CA LORNE MACDONALD, LITTLE RIVER, CA DENNIS MACGREGOR, EUREKA, CA LOU MALONE, FORTUNA, CA THOMAS MANGOS, BAYSIDE, CA JEAN MARTIN, LOWER LAKE, CA BOE ANNA MARTIN, WEAVERVILLE, CA PHOEBE MARTONE, FOREST RANCH, CA RON MASTROGIUSEPPE, TRINIDAD, CA MATT MATHES, SAN FRANCISCO, CA NANCY MATHEWS, EUREKA, CA STEPHEN MATTHEWS, MCKINLEYVILLE, CA HELEN MATTHEWS, PACIFICA, CA ROBERT MAULT, MILL VALLEY, CA JOE MAYFIELD, UKIAH, CA LIBBY MAYNARD, EUREKA, CA RENA MAYYAR, DAVIS, CA JOHYN \& R MCBETH, EUREKA, CA RANDE P MCCABE, MT SHASTA, CA CATHERINE MCCANN, HISSBOROUGH, CA JIM MCCAY, WILLOW CREEK, CA NORMAN MCCLINDON, OAKLAND, CA ANN MCCONNELL, SANTA CRUZ, CA DALE MCCORMICK, SAN BERNADINO, CA SALLY MCCRORY, TRINIDAD, CA LYNN MCCULLOCH, FERNDALE, CA CYANNE MCELHINNEY, PALO ALTO, CA BOB MCFARLAND, MCKINLEYVILLE, CA NANCY MCGIVNEY, CALPELLA, CA PATRICK MCILRATH, BERKELEY, CA ROBERT C MCKEE, WHITE THORN, CA MICHELLE MCKENZIE, ARCATA, CA LOUIS MCKEY, BUENA PARK, CA RICHARD L MCKINNON, CRESCENT CITY, CA DAN MCLAUGHLIN, EUREKA, CA MIKE MCMAHON, CHICO, CA RUFUS MCMANARA, ORICK, CA SUSAN MCPHERSON, BAYSIDE, CA ANNETTE MELVILLE, SAN FRANCISCO, CA PETER MENNEN, ST HELENA, CA HARRY METZGER, NAPA, CA PAUL MEYREND, ARTOIS, CA BILL MICSAN, ORANGEVALE, CA 
ROB MILBERRY, LAKEPORT, CA LUCIA MILBURN, OAKLAND, CA FRANK MILEHAM, EUREKA, CA RICHARD MILLER, EUREKA, CA JOHN MILLER, PALO ALTO, CA CORY C MILLER, COVELO, CA OLETA MILLS, EUREKA, CA JOHN MILLS, BEN LOMOND, CA ROBERT MISHICA, ARCATA, CA

RALPH R MODINE, HAYFORK, CA GERTRUDE MOLLIER, ORLEANS, CA MR \& MRS JOHN MONTGOMERY, YREKA, CA PAUL MOORE, EUREKA, CA ROBERTA R MORAN, PALO ALTO, CA BRYAN MORI, SCOTTS VALLEY, CA JOHN MORIARTY, ARCATA, CA LYNN MORRIS, GASQUET, CA JIM MORRISON, EUREKA, CA JANET MORRISON, PETROLIA, CA CHARLES MOYER, ARCATA, CA TERESA MUIR-SMALL, SANTA ROSA, CA ED, BRUCE, \& NOEL MUNN, ARCATA, CA DAYTON MURRAY, EUREKA, CA ERNEST MURRAY, FORTUNA, CA BETTEE MURRAY, REDDING, CA HAROLD NAGLER, PALM SPRINGS, CA ROSS NASH, EUREKA, CA TRAVIS NESTLUND, EUREKA, CA PAT NEVILLE, BERKELEY, CA GEORGE NEWHALL, DAVIS, CA MRS C R NICEWONGER, BERKELEY, CA TOM \& CAROL NICHOLS, CRESCENT CITY, CA EDWARD NILSEN, EUREKA, CA ROD NORDSTROM, EUREKA, CA GERRY NORDSTROM, SUSANVILLE, CA RICHARD E NORRIS, BURNEY, CA STANLEY NUSZKIEWICZ, CRESCENT CITY, CA MARY BELLE O'BRIEN, STINSON BEACH, CA WALT O'CONNELL, FORT BRAGG, CA TIM O'CONNOR, ALTA SIERRA, CA JAMES OBER, SCOTIA, CA CHRISTINE O'HARA, SAN DIEGO, CA ALMA OILAR, MCARTHUR, CA KENOLI OLEARI, BERKELEY, CA ROBERT N OLIVERIA, ARCATA, CA GREG OLSEN, EUREKA, CA ERIC OLSON, ARCATA, CA ROBERT P OPPERMANN, WHITTIER, CA JAMES OVERSTREET, QUINCY, CA 
MARCHETA OWEN, CRESCENT CITY, CA

JIM OWENS, BAYSIDE, CA

KAREN PAFF, PETROLIA, CA

CHARLES PAGE, TRINIDAD, CA

NEIL PALMER, FORTUNA, CA

WILLIAM PARKER, CRESCENT CITY, CA

TRINKET PARKER, BROWNSVILLE, CA

ANNETTE PARSONS, SOMERSET, CA

RICHARD D PASSAGLIA, IRVINE, CA

NELLIE D PATTERSON, PACIFIC PALISADES, CA

SHAN O PATTERSON, GERBER, CA

RAY PEART, MCKINLEYVILLE, CA

NORMAN PECK, ARCATA, CA

DONALD PECK, PLACERVILLE, CA

MARY ANNE PELLA-DONNELLY, CHICO, CA

MIKE PEREIRA, TURLOCK, CA

VICTOR PETERSON, EUREKA, CA

CATHERINE PETERSON, ARCATA, CA

KEITH PETERSON, GASQUET, CA

SVEND E PETERSON, CHESTER, CA

MICHAEL PEZZOLI, EUREKA, CA

LARRY PIERCE, EUREKA, CA

CARLA POWELL, TRINIDAD, CA

CHARLES POWELL, CARLOTTA, CA

FRANK PRATT, FORTUNA, CA

EDWARD PRAUSS, FORT DICK, CA

SUE PRESSER, BURNT RANCH, CA

MARK PRINGLE, TRINIDAD, CA

L LEE PURKERSON, EUREKA, CA

BILL PURYEAR, KNEELAND, CA

TONY QUICK, CRESCENT CITY, CA

MRS R QUINSEY, ARCATA, CA

DEIRDRE \& RANDY RAND, MILL VALLEY, CA

JAMES RANDOLPH, SANTA ROSA, CA

JULIE RANIERI, EUREKA, CA

KEITH REDENBAUGH, DAVIS, CA

NANCY REICHARD, ARCATA, CA

DENNIS REID, EUREKA, CA

ROB \& TAMI REMPEL, EUREKA, CA

WILLIAM RESNECK, OAKLAND, CA

STANTON REYNOLDS, ARCATA, CA

CHESTER RICE, KENTFIELD, CA

WAYNE RICE, EUREKA, CA

STANLEY RICHARDS, EUREKA, CA

KAREN RICHARDSON, GALT, CA

ROY RICHMOND, MCKINLEYVILLE, CA

WALT ROBINSON, SEIAD VALLEY, CA

KIM RODRIGUES, EUREKA, CA

BILL RODSTROM, ARCATA, CA 
JACK ROGERS, BRIDGEVILLE, CA

MIKE RONJOIN JR, CRESCENT CITY, CA

MARY LOU ROSCZYK, HUNTINGTON BEACH, CA

OTTO SCHAIBLE, AUBURN, CA

STANLEY SCHER, BERKELEY, CA

ERICH F SCHIMPS, ARCATA, CA

JOHN SCHNITTKER, SANTA YNEZ, CA

MARY K SCHOLL, LIVE OAK, CA

CARL H SCHWARZENBERG, ETNA, CA

CLAUDE F SCOTT, PARADISE, CA

JON SCOTT, ANDERSON, CA

BILLY M SCRUGGS, HAPPY CAMP, CA

PETER SER, DAVIS, CA

ROY W SHAY, OROVILLE, CA

TED E SIMON, SACRAMENTO, CA

LLYOD A SMITH, SAN DIEGO, CA

EDWARD M SMITH, SAN JOSE, CA

MARY KATE SPENCER, MENLO PARK, CA

MARSEILLE SPETZ, ARCATA, CA

MARILYN STAMPS, MCKINLEYVILLE, CA

MARVIN STAPP, LOLETA, CA

BARBARA J STARK, EUREKA, CA

RANDALL STEMLER, PETROLIA, CA

JOHN STOKES, ARCATA, CA

KIM R STONE, CRESCENT CITY, CA

BILL STONE, UKIAH, CA

GILBERT A STUART-FORESTER, MORENO VALLEY, CA

SUSAN SWECKER, BRIDGEVILLE, CA

TERESA TALBOTT, S. LAKE TAHOE, CA

PHILLIPA TAYLOR, MILL VALLEY, CA

BARRY TAYLOR, REDDING, CA

LYNN R THOMAS, CHICO, CA

PAUL R THOMAS, TRUCKEE, CA

ELVIN A TOLSON, CITRUS HEIGHTS, CA

PHYLLIS M TOMASINI, EAGLE LAKE, CA

PAULA D TRIPODI, TRINIDAD, CA

ARTHUR TRIPP, MCKINLEYVILLE, CA

HENRY TROBITZ, ARCATA, CA

BRUCE TROTTER, NEWPORT BEACH, CA

MIMI VANSICKLE, ETNA, CA

GEORGE S VERBACK, ARCATA, CA

HEATHER VERVILLE, ARCATA, CA

LUCILLE VINYARD, TRINIDAD, CA

MARY WAKEFIELD, COSTA MESA, CA

JAMES WALTHERS, CHATSWORTH, CA

CARL WEIDERT, SHINGLETOWN, CA

SCOTT WESTON, SAN RAMON, CA

LORNIE WHITE, THOUSAND OAKS, CA

JOHN C WIEBE, TRINIDAD, CA 
RICHARD A WILL, EUREKA, CA MARGARET WILLITS, ARCATA, CA

BOB L WILLOUGHBY, OROVILLE, CA

WAYNE WILSON, FORTUNA, CA

RUTH WILSON, RIO DELL, CA

LINDY L WOLF, ARCATA, CA

JOHN WOOLWORTH, SMITH RIVER, CA

MR \& MRS J WRIGHT, WILLOW CREEK, CA

DAN WRIGHT, TRINIDAD, CA

LYLE WRIGHT, LAFAYETTE, CA

MICHAEL \& ANN ZARNOWITZ, SAN DIEGO, CA

FRANK G ZEAN, SANTA MARIA, CA

FLORIAN ZIELINSKI, ESCONDIDO, CA

\section{Idaho:}

BOB ALLEN, KOOSKIA, ID

ANDREW J ARVISH, OROFINO, ID

JO AUSTIN, POST FALLS, ID

DENNIS BAIRD, MOSCOW, ID

DANIEL A BALDWIN, ELK CITY, ID

JAMES J BAUMAN, COTTONWOOD, ID

JOHN A BIEKER, MOSCOW, ID

CHARLES \& MARY BLOODGOOD, COEUR D'ALENE, ID

BRUCE BOWLER, BOISE, ID

MIKE BOWMAN, COEUR D'ALENE, ID

ROGER BURWELL, SAGLE, ID

LIZ CODONI, CALDER, ID

CHARLES CRAM, GRANGEVILLE, ID

DWIGHT CROSS, NEW PLYMOUTH, ID

RICHARD CURRIN, FERDINAND, ID

R KIRK EWART, BOISE, ID

MARY LOU FRANZERE, LEWISTON, ID

ELLEN GLACCUM, KETCHUM, ID

ROBERT GOMEZ, BONNERS FERRY, ID

LARRY \& SANDY GRANT, LEWISTON, ID

CHRIS GREY, COEUR D'ALENE, ID

LINDA D HAGEDORN, BOISE, ID

DON HILL, PINEHURST, ID

MERRIL HOGABOAM, GRANGERVILLE, ID

J D \& BARBARA HOLBART, WALLACE, ID

LEE HOLLINSHEAD, BOISE, ID

DEE JOHNSTON, OROFINO, ID

PENNY J KECK, KOOSKIA, ID

VERN \& PEARL KETZ, PAYETTE, ID

J PHILLIP KEYSER, PRIEST RIVER, ID

JAMES KRAEMER, MOYIE SPRINGS, ID

BOB LIGEZA, COEUR D'ALENE, ID

LON D LOPPNOW, PRIEST RIVER, ID 
WILBUR H LYON, HAYDEN LAKE, ID

ARDEN LYTLE, GRANGEVILLE, ID

RICK NELSON, HAYDEN LAKE, ID

JERRY PAVIA, BONNERS FERRY, ID

JAY PENNIMAN, PRIEST RIVER, ID

NORM PLANK, OROFINO, ID

MARY E PRICE, AVERY, ID

SKIP QUADE, COEUR D'ALENE, ID

ROBERT REGGEAR, OROFINO, ID

MIKE REGGEAR, OROFINO, ID

CYNTHIA ROZYLA, MOSCOW, ID

ANDREW SCHMIDT, AVERY, ID

CLIFF SCHNIDER, COEUR D'ALENE, ID

LIZ SEDLER, SANDPOINT, ID

DAVID B SIEBANTHALER, BONNERS FERRY, ID

PAUL R SIERACKI, NAPLES, ID

ROBERT C SMITH, GRANGEVILLE, ID

PAUL STEENBERG, OROFINO, ID

RUSS SUNRIVER, SANDPOINT, ID

JENNY TAYLOR, SANDPOINT, ID

RITA VANNOY, OSBURN, ID

GARY A VONBARGEN, GRANGEVILLE, ID

CHARLES A WELLNER, MOSCOW, ID

TIM \& LISA WEST, BONNERS FERRY, ID

BILL WHITE, OROFINO, ID

LAUREN WILEY, WALLACE, ID

MIKE WISSENBACH, BOISE, ID

\section{Montana:}

GREGG ANDERSON, LIBBY, MT

ROSEANNE C BLOOM, KALISPELL, MT

DALE BURK, LOLO, MT

JIM CHINN, HAMILTON, MT

JAMES R CONNER, KALISPELL, MT

DAVID R FALEY, HELENA, MT

MELISSA M GARDNER, MISSOULA, MT

PETER LESICA, MISSOULA, MT

LOLENE LITTLE, PLAINS, MT

TOM MARTIN, ST REGIS, MT

MOLLIE MATTESON, LIVINGSTON, MT

SHEILA MORRISON, MISSOULA, MT

DENNIS NICHOLS, TROUT CREEK, MT

KEN RADA, BIG FORK, MT

JAMES SEDIVY, SWANLAKE, MT

PAUL SIHLER, HELENA, MT

MARTI SMITH, SOMERS, MT 


\section{Oregon:}

KATHLEEN E ABBOTT, WARREN, OR

MILTON ADAM, SWEET HOME, OR JOHN ALBRECHT, EUGENE, OR MORTON ALDER, WILLAMINA, OR LOUISE ALFORD, MONROE, OR PETER ALFORD, CHESHIRE, OR NANCY ALLEN, SUNRIVER, OR PAUL ALLEN, OAKLAND, OR RICHARD L ALLEY, LEBANON, OR BOB ALVERTS, PORTLAND, OR ROBERT A AMMETT, NORTH́ BEND, OR PATRICIA J ANDERES, ROSEBURG, OR LORNA ANDERSON, EAGLE POINT, OR MICHAEL ANDERSON, PORTLAND, OR MIKE ANDERSON, EUGENE, OR CHARLEY R ANDERSON, COQUILLE, OR JOLYNN ANDERSON, BLUE RIVER, OR BASIL ANDREWS, SIXES, OR GERALD C ANSELL, CORVALLIS, OR RICHARD \& JAN ANSELMO, OAKRIDGE, OR PHYLLIS W APPLEGARTH, COTTAGE GROVE, OR JOHN APPLETON, PORTLAND, OR JOHN H ARENZ, PORTLAND, OR NEIL ARMANTROUT, EUGENE, OR MELBA ARMSTRONG, OAKRIDGE, OR JAMES E ARMSTRONG, BANDON, OR FRANK G ARUNDEL, EUGENE, OR NABIL ATALLIA, MELVIN, OR DAVID E ATKIN, EUGENE, OR MICHAEL R ATKINSON, EUGENE, OR MARY ATKINSON, MCMINNVILLE, OR MARGARET E ATWOOD, FLORENCE, OR LONA AUFEROTH, EUGENE, OR NED AUSTIN, BEND, OR ARNOLD AUXIER, PRINEVILLE, OR LUKE I AVANI, SALEM, OR MICHAEL AVENALI, EUGENE, OR LOUIS J AYERS, DALLAS, OR RICHARD BABB, MEDFORD, OR GERALD BACON, ROSEBURG, OR PETER BAHLS, CORVALLIS, OR PETE BAILEY, SPRINGFIELD, OR TIM BAILEY, WESTFIR, OR TUG \& LINDA BAILEY, MOLALLA, OR ROBYN M BAIN, LYONS, OR PEG BAKER, PORTLAND, OR DOUGLAS S BAKKE, EUGENE, OR MARI BALDWIN, EUGENE, OR 
JANIK \& N BALL, PORTLAND, OR ROBERT K BALLARD, MONROE, OR PATRICK BANKS, EUGENE, OR WILLAM BARBOUR, MEDFORD, OR PAUL BARLOW, PORTLAND, OR MICHAEL BARR, SPRINGFIELD, OR DONALD D BARR, LAKE OSWEGO, OR MARWIN BARTEL, SALEM, OR MILTON L BARTHOLOMEW, ROSEBURG, OR HAL BARTON, EUGENE, OR BOB \& LESA BARTON, GRANTS PASS, OR MAX \& NORMA BARZEE, PORTLAND, OR JAMES S BASEY SR, ALBANY, OR ANNE G BASKER, GRANTS PASS, OR LEO BASL, MILL CITY, OR LOUIS K BATEMAN, SALEM, OR GELEAL G BAUM, LEBANON, OR MILDRED P BAUMAN, PORTLAND, OR NANCY BEAMER, PORTLAND, OR JERRY \& SHARYN BECKER, PORT ORFORD, OR FRED BEHM, BLUE RIVER, OR RICHARD BEHR, SALEM, OR RANDALL R BEIDERWELL, EUGENE, OR MRS LAWRENCE BENNETT, LEBANON, OR CRETA B BENNETT, ROSEBURG, OR DOUGLAS F BENNETT, YONCALLA, OR MERLYN E BENTLEY, SCIO, OR RICHARD BERGER, EAGLE POINT, OR LINDA W BERGERON, PORTLAND, OR DANIEL J BERGERON, ASTORIA, OR MORRIS H BERGMAN, SALEM, OR BONNIE BETHEL, MILL CITY, OR ED \& DORIS BICHSEL, CRESWELL, OR FAYE BIDLEMAN, OAKRIDGE, OR DALE A BILYEU, LYONS, OR MARJORIE A BISHOP, EUGENE, OR PATRICK S BITZ, BROOKINGS, OR RALPH BLACK, ALBANY, OR SHIRLEY BLACK, SWEET HOME, OR HERB BLACK, NORTH BEND, OR CYNTHIA BLACK, RIDDLE, OR LEONARD J BLACKLOCK, SUNNY VALLEY, OR MICHAEL BLANCHAT, LAKE OSWEGO, OR ART BLEEKER, GRANTS PASS, OR MARILYN BLOCH, WOODBURN, OR MARION BOATWRIGHT, DALLAS, OR PAUL R BOEHNER, COTTAGE GROVE, OR GEORGE BOEHNKE, EUGENE, OR ARTHUR BOESCHEN, MILWAUKIE, OR 
MARION \& CLARA BOGGS, DEXTER, OR MARY L BOICE, LINCOLN CITY, OR PETER BOLANDER, EUGENE, OR MONTY R BOND, MYRTLE CREEK, OR ROSS BONDURANT, PLEASANT HILL, OR WILL \& CHRIS BONE, CAMP SHERMAN, OR LEONARD W BONES, MAPLETON, OR RICHARD BONN, MEDFORD, OR PAUL BONNEY, EUGENE, OR MARY BOOCK, ALBANY, OR LYNETTE L BOONE, EUGENE, OR JIM BORDER, MOLALLA, OR ROBERT BORING, KLAMATH FALLS, OR PETER G BOSSON, BROWNSVILLE, OR LYNN BOWERS, EUGENE, OR MALCOLM BOYD, SANDY, OR MICHAEL BOYD, EUGENE, OR RANDY BOYDSTON, GOLD BEACH, OR MICHELLE BOYLE, SANDY, OR TOM BOYLEN, PORTLAND, OR RICHARD BRAATZ, SWEET HOME, OR RICHARD BRAUN, LAKE OSWEGO, OR RICHARD BREESE, PRINEVILLE, OR MARIAN \& H F BREVOORT, STAYTON, OR. RICK BREWER, PLEASANT HILL, OR SAM BRIDENSTINE, NORTH BEND, OR PHILIP A BRIEGLEB, PORTLAND, OR RICHARD A BRIGGS, EUGENE, OR MICHAEL B BRINK, ALBANY, OR MARGIE BRINKLEY, LEBANON, OR PHILL BRITT, AMITY, OR RICHARD BROCK, ASHLAND, OR MARTIN A BRONSTEIN, CORVALLIS, OR MARCIA D BROWN, GASTON, OR MAX \& RHONDA BROWN, EUGENE, OR ELIZABETH BROWN, ROSEBURG, OR PRESTON BROWN, EUGENE, OR LISA BROWN, CORVALLIS, OR DAVID J BROWN, GASTON, OR CHRISTIAN S BROWN, STAYTON, OR RICHARD D BROWNING, EUGENE, OR DAVID BRUNSMAN, MYRTLE POINT, OR MERLYN C BRUNTON, ROSEBURG, OR DOUG BUCHANAN, WILLAMINA, OR DAVID \& KATHY BUCKMASTER, HILLSBORO, OR VICTOR U BUENZLE, ROSEBURG, OR LYNETTE BULLINGTON, FIELDS, OR MR \& MRS J C BUNN, IDLEYD PARK, OR JANET BURDITT-KELSEY, PHILOMATH, OR 
MICHAEL BURKE, EUGENE, OR

RICHARD BURLEIGH, EUGENE, OR

BILL BURLEY, POWELL BUTTE, OR

MARK B BURNETT, PORTLAND, OR

NAOMI H BURNHAM, JEFFERSON, OR

PAT BURNS, SPRINGFIELD, OR

WILLIAM BURT, HUBBARD, OR

MICHELLE BURTON, ASHLAND, OR

GEORGE W BUTTS, TENMILE, OR

JONATHAN BUYS, PHILOMATH, OR

MARY L BYFORD, MYRTLE CREEK, OR

DAVID M BYRNES, PORTLAND, OR

RICK CADY, SILVERTON, OR

REX CAFFALL JR, SALEM, OR

ANN CAGLE, EUGENE, OR

TERRY CAIN, SELMA, OR

PETER R CAINE, BEND, OR

SHIRLEY A CAIRNS, ROSEBURG, OR

PAUL CALDWELL, SALEM, OR

SHAUN CALLAHAN, DILLARD, OR

RICHARD A CAMPBELL, SPRINGFIELD, OR

JOHN R CAMPBELL, BROOKINGS, OR

ALLAN CAMPBELL, MEDFORD, OR

SHEILA CANAL, JACKSONVILLE, OR

HARRY A CANOY, BEND, OR

YVONNE V CARDEMIL, TILLER, OR

RANDY CAREY, WILLIAMS, OR

JOHN \& JULIA CARLSON, WESTLAKE, OR

BOB CARLSON, PORTLAND, OR

DON CARLTON, DEADWOOD, OR

RACHAEL CARNES, EUGENE, OR

DON CARPENTER, BLY, OR

MICHAEL G CARRIGAN, PORTLAND, OR

PAULA J CARSON, BEAVERTON, OR

TIM CARSON, SUTHERLIN, OR

MARGARET CARSTENS, NEWPORT, OR

WILLIAM A CARSTENS, ROSEBURG, OR

ROBERT \& LUCY CART, MYRTLE CREEK, OR

JOHN CARTER, NOTI, OR

LAWRENCE J CASEY, NORTH BEND, OR

MATTHEW CASTELL, EUGENE, OR

ANN W CAVANAGH, SALEM, OR

MARY CHAFFIN, PORTLAND, OR

EDWIN L CHAFFIN, DEXTER, OR

NATALIE CHAMBERLAIN, EUGENE, OR

ELLEN CHAMBERLAIN, EUGENE, OR

MERL CHAPPOEN, BEAVERTON, OR

GARY CHARTRAW, ALBANY, OR

ALLAN CHASE, UNION, OR 
JOHN T CHATT, CORVALLIS, OR ROBERT CHAVES, LEBANON, OR BILL CHENOWETH, BEND, OR HILDE K CHERRY, EUGENE, OR MARIAN F CHEWNING, LEBANON, OR DAVE CHOLEWINSKI, SPRINGFIELD, OR MAVIS CHRISTIAN, COOS BAY, OR LINDA CHRISTIAN, EUGENE, OR LARRY M CHRISTIANSEN, CORVALLIS, OR MAXE CLAMPITT, DUFUR, OR MAURIE D CLARK, PORTLAND, OR MIKE CLARK, MILWAUKIE, 'OR RAYMOND CLARK, JR, PENDLETON, OR JIM CLARKE, NORTH BEND, OR SALLY CLEMENTS, CAVE JUNCTION, OR PAUL CLIMA, CRESWELL, OR EVERETT C CLYMER, THE DALLES, OR DONNA L COATES, REDMOND, OR MICHAEL J COE, PORTLAND, OR NEAL L COENEN, NEWPORT, OR LEIGH COFFEY, PORTLAND, OR PATRICIA COKE, EUGENE, OR CORY COLBURN, VERNONIA, OR MICHAEL M COLE, PORTLAND, OR MICHAEL J COLE, PORTLAND, OR GENIE COLEMAN, CORVALLIS, OR MRS ROBERT CUMMINGS, SALEM, OR MINNIE L COLVER, PORTLAND, OR JON COMSTOCK, SUTHERLIN, OR MONTY CONNELLY, WALTERWILL, OR MERLE M CONVERSE, WOLF CREEK, OR MARGARET COOK, BLODGETT, OR MARY L COOKMAN, AZALEA, OR RICK COPHER, CANBY, OR JENNIE \& BRYAN CORNELL, CORVALLIS, OR STEVE CORNELL, BLY, OR MIKE COUNTS, EUGENE, OR NORM COVER, OAKRIDGE, OR TIM COWLES, GRESHAM, OR OSCAR R COX, FLORENCE, OR BOB CRAIN, FLORENCE, OR MICHAEL CRAMBLIT, SPRINGFIELD, OR MR \& MRS ANDY CRANE, SALEM, OR RANDAL CRANOR, CAVE JUNCTION, OR LARRY L CRIBBS, LA GRANDE, OR LOU CRIST, FALL CREEK, OR JACK CROCKER, COTTAGE GROVE, OR RENDALL CUDDLEBACK, EUGENE, OR WYNN W CUDMORE, DALLAS, OR 
IRENE M CURRIN, KLAMATH FALLS, OR JOAN CURTIS, WALDPORT, OR

PHILIP CUSACK, WINSTON, OR

WANDA M CUSTANCE, JACKSONVILLE, OR

PATRICK DADEY, LEBANON, OR

KAY DAILY, APPLEGATE, OR

BERNICE DAIN, FLORENCE, OR

DOMINIC DALEY, EUGENE, OR

PAUL H DANE, TIDEWATER, OR

SCOTT DANO, SPRINGFIELD, OR

DON M DARLING, LEBANON, OR

MAY D DASCH, PHILOMATH, OR

NEIL E DAUGHERTY, EUGENE, OR

MARK C DAVIS, CARLTON, OR

PAMELA DAVIS, ALBANY, OR

PAUL F DAVIS, CORVALLIS, OR

PLATT DAVIS, ALBANY, OR

REBECCA DAVIS, PORTLAND, OR

RICHARD DAVIS, BUTTE FALLS, OR

DIANE DAVIS, GRESHAM, OR

VINCE DAVIS, MILWAUKIE, OR

MICHAEL M DAY, EUGENE, OR

MARK DAY, PORTLAND, OR

JOYCE DE MONNIN, CORVALLIS, OR

JAMES DELSMAN, ASHLAND, OR

MARK DENNER, EUGENE, OR

NELLIE M DENNISON, BROWNSVILLE, OR

DEBBY DENNISON, CHESHIRE, OR

IVAN DENT, WILLAMINA, OR

KENDALL DERBY, CORVALLIS, OR

JEAN DESPAIN, VENETA, OR

MARK A DEVONGY, CORVALLIS, OR

MR \& MRS DHAGA, NESKOWIN, OR

STAN B DILL, ALBANY, OR

LYNN M DILTZ, GLENDALE, OR

GUY DITORRICE, EUGENE, OR

MEL DIXON, CRESWELL, OR

BONNIE DOCKERY, COQUILLE, OR

HUDSON DODD, EUGENE, OR

RICHARD DOLGONAS, ROSEBURG, OR

CAROL N DOTY, TALENT, OR

BERNARD DOUGLAS, HILLSBORO, OR

M LEE DOUTHIT, NORTH BEND, OR

TOMMI DRAKE, GRANTS PASS, OR

MIKE DRUMMOND, VENETA, OR

PAT DUBS, EUGENE, OR

ELLIE DUMDI, EUGENE, OR

PAUL L DUNCAN, ALBANY, OR

LARRY A DUNCAN, DAYS CREEK, OR 
RALPH L DUNCAN, DAYS CREEK, OR JAMES T DUNCAN, ASHLAND, OR FRANK G DURINGER, COOS BAY, OR PATRICIA A DURKEE, SILVERTON, OR LOIS DUVALL, LAKE OSWEGO, OR LIL DYCK, SHADY COVE, OR ELEANOR DYKE, SALEM, OR LOIS EAGLETON, EUGENE, OR MERI EALY, SANDY, OR JOE EARP, EUGENE, OR JAMES B EBLIN, LAKE OSWEGO, OR RALPH ECKIS, STAYTON, OR MRS WALLY EGGE, EUGENE, OR RON ELLER, SPRINGFIELD, OR LISA J ELLINGSON, CORVALLIS, OR MARK S ELLIOTT, EUGENE, OR LOIS A ELLIS, SALEM, OR MAYNARD ELLIS, OAKRIDGE, OR RUSSELL L ELLWOOD, EUGENE, OR LOREN ELMALEL, PORTLAND, OR BARBARA A ELSEN, EUGENE, OR BARBARA EMGE, EUGENE, OR HAL ENGELEN, PORTLAND, OR JOANNE P ENGELKE, THE DALLES, OR STEVE ERICKSON, ROSEBURG, OR WILL ERNST, GILCHRIST, OR ALAN \& MYRA ERWIN, ASHLAND, OR OLGA N ESSELSTROM, SALEM, OR GARY W ESTES, AURORA, OR WALLY EUBANKS, MYRTLE POINT, OR RICHARD EWING, EUGENE, OR NICK FACAROS, EUGENE, OR RICH \& TERRY FAIRBANKS, PLEASANT HILL, OR JIM FAIRCHILD, PHILOMATH, OR RICK L FALSETTO, DALLAS, OR NEIL FAMILY, CORVALLIS, OR KEN FAULK, SPRINGFIELD, OR DUANE FELIX, COLTON, OR JOYA FELTZIN, CAVE JUNCTION, OR TOM FENCL, MILL CITY, OR HUGH W FERRAR, EAGLE CREEK, OR RICHARD \& KATHY FERRELL, SALEM, OR R WAYNE FIELDS, GLADSTONE, OR MALVIN FINKELSTEIN, EUGENE, OR NINA FINTEL, LEBANON, OR NANCY W FIRTH, GRANTS PASS, OR MORGAN FISHER, EUGENE, OR WILLIAM FISHER, ROSEBURG, OR MICHAEL FITZGERALD, KLAMATH FALLS, OR 
PAM FITZPATRICK, EUGENE, OR RICK FLETCHER, CORVALLIS, OR HAZEL FLOCK, POWELL BUTTE, OR RICHARD FOHS SOHN, ROSEBURG, OR TIM FOLEY, CORVALLIS, OR PAM FOLTS, CORVALLIS, OR PAUL T FONTANINI, WALDPORT, OR SUSAN FORD, LAKE OSWEGO, OR SCOTT FORESTER, TIGARD, OR NANCY FORREST, EUGENE, OR MARY FORRESTER, FLORENCE, OR MARY C FORST, PORTLAND, OR MARGARET G FORSYTHE, SALEM, OR MONTE \& CYNTHIA FOSTER, SALEM, OR CHRIS FOULKE, ALBANY, OR TOM FOUST, CRESWELL, OR JAMES E FOWLER, MILWAUKEE, OR MILTON M FOX II, BRIGHTWOOD, OR RICHARD P FRANCISCO, EUGENE, OR JOSEPH FRANK, PORTLAND, OR MICHAEL H FRAZIER, LAPINE, OR SAMUEL T FREAR, EUGENE, OR PHYLLIS J FREEMAN, SCIO, OR HENRY FREEMAN, PORTLAND, OR WALTER FREEMAN, CAVE JUNCTION, OR NANCY L FRENCH, CANYONVILLE, OR KEN FRENCH, CANYON, OR LIZ FRENKEL, CORVALLIS, OR ROB FRERES, LYONS, OR NATHAN FREY, EUGENE, OR MILLY FRIESEN, MONMOUTH, OR SHIRLEY FROYD, COTTAGE GROVE, OR PETER F FRY, CORBETT, OR DAVID FULLER, GRANTS PASS, OR MARY L FULTON, EUGENE, OR CHRIS FULTON, DAYTON, OR RICHARD FULWILER, EUGENE, OR LOWELL FUNK, SWEET HOME, OR PAM FUQUA, WILLAMINA, OR MARGIE GAGE, TOLEDO, OR MARCIA A GAISER, JACKSONVILLE, OR MARADEE K GALE, EUGENE, OR COLE H GARDINER, PORTLAND, OR RACHEL L GARNER, SALEM, OR ROGER C GARRETT, TIGARD, OR RICHARD GARRISON, DALLAS, OR WILLIAM A GASS, PLEASANT HILL, OR SUE GEBBY, WOLF CREEK, OR ED GEE, GOLD BEACH, OR 
MICHAEL H GEIDER, SPRINGFIELD, OR

MELISSA GENTRY, MOLALLA, OR

NOLAN A GERATHS, STAYTON, OR

JANICE GERDEMANN, YACHATS, OR

WALTER GILE, SUTHERLIN, OR

MARTY GILES, ASTORIA, OR

CARL L GILES, DAY CREEK, OR

ALAN \& FRAN GILLESPIE, EUGENE, OR

TIMOTHY GILLETT, ASHLAND, OR

MICHEAL S GISH, DALLAS, OR

ROLF GLERUM, PORTLAND, OR

ALTHEA GLINES, EUGENE, OR

MARY LOU GOERTZEN, DEADWOOD, OR

LLYOD W GOFF, SPRINGFIELD, OR

RICHARD A GOFF, ASHLAND, OR

TERRI GONZALEZ, BEAVERTON, OR

LORRI GOODMAN, EUGENE, OR

LEE GOODMAN, EUGENE, OR

PIPER GOODSON, EUGENE, OR

KATHY GORHAM, TILLAMOOK, OR

PETER E GOSSEN, AUMSVILLE, OR

NORM \& EVE GOULD, GLIDE, OR

HAROLD GOULD, EAGLE POINT, OR

MICHAEL \& NANCY GRAHAM, PORTLAND, OR

PAMELA GRAHAM, PORTLAND, OR

MICHAEL H GRAHAM, PORTLAND, OR

BRIDGE GRANGE, MYRTLE POINT, OR

ELSIE L GRATE, JEFFERSON, OR

ANN GRAVES, WILLIAMS, OR

MATTHEW GRAY, CORVALLIS, OR

DAN GREGG, WILLIAMS, OR

MICHAEL D GREGORY, LEBANON, OR

PAUL M GREINER, TURNER, OR

MARY GRIFFIN, COOS BAY, OR

DON GRIMM, ESTACADA, OR

EUGENE A GRINNELL, EUGENE, OR

HAROLD A GROBEY, NEWBURG, OR

RICHARD GROSS, DEADWOOD, OR

MIKE GROSS, CASCADIA, OR

RICHARD K GRUBBS, EUGENE, OR

MARVIN GRUNBERG, LEBANON, OR

WILLIAM J GUENTHER, NORTH BEND, OR

CARL \& MYRTLE GUSTAFSON, ALOHA, OR

DONALD G GUTCHER, SALEM, OR

GARY GUTTORMSEN, SPRINGFIELD, OR

RENEE HAAKE, EUGENE, OR

CARL L HAGSTROM, ROSEBURG, OR

GORDON E HAINES, FLORENCE, OR

MAHLON HALE, BEND, OR 
MARION HALL, MAPLETON, OR MELVIN L HALL, STAYTON, OR QUINTON HALLETT, NOTI, OR VIRGINIA HAMBLEY, EUGENE, OR LOUISE HAMBY, BEND, OR KEVIN HAMILTON, BLACHLY, OR A J HAMILTON, CANYON CITY, OR DAVID HAMPTON, WILLAMINA, OR MARK HANCE, STAYTON, OR DONALD T HANCOCK, SALEM, OR MIKE HANDLEY, EUGENE, OR BILL HANEL, HOOD RIVER, OR CRAIG HANNEMAN, SALEM, OR SUSAN HANSCOM, EAGLE POINT, OR TED HANSEN, FLORENCE, OR NATHAN L HANSON, EUGENE, OR RICHARD D HANSON, MT ANGEL, OR ELIZABETH HANSON, ROGUE RIVER, OR J D HARDCASTLE, EUGENE, OR MARK E HARDER, CORVALLIS, OR MERLE F HARGIS, IDLEYLD PARK, OR NADINE HARRANG, EUGENE, OR PETER HARRELL, BROOKINGS, OR RENEE HARRIS, PORTLAND, OR BETHEL \& ALBERT HARRIS, GATES, OR BRUCE N HARRSCH, PLEASANT HILL, OR PHYLLIS HART, JUNCTION CITY, OR RICHARD A HART, SPRINGFIELD, OR CLIFF HARVEY, BROGAN, OR MARY JO HARVIE, MEDFORD, OR LLOYD HASTINGS, ROSEBURG, OR JOHN S HATCH, SALEM, OR MICHAEL HATTEN, EUGENE, OR HAROLD HAUGEN, GRANTS PASS, OR MICHAEL A HAUTH, CORNELIUS, OR PHILLIP HAYS, CORVALLIS, OR PAULA HEARNE, FLORENCE, OR RICHARD H HEATH, COTTAGE GROVE, OR LESTER HEDGECOKE, EUGENE, OR DOUG HEIKEN, EUGENE, OR RICHARD P HELFRICH, VIDA, OR MARGOT HELLENGA, EUGENE, OR MIKE HELM, EUGENE, OR PATRICK HENDERSON, MEDFORD, OR FRED A HENDRIX, ALSEA, OR HARLEY HENDRIX, ALSEA, OR MRS JIM F HENIGAN, GLIDE, OR PATRICIA HENRY, PORTLAND, OR MICHAEL C HENSON, MYRTLE POINT, OR 
MRS KARL D HENSON, WESTLAKE, OR P SYDNEY HERBERT, PORTLAND, OR JANE H HERBST, LAKE OSWEGO, OR BILL HERR, CORNELIUS, OR PETER HERRING, EUGENE, OR VERNA HERSHBERGER, LYONS, OR KURT HERZOG, GRANTS PASS, OR MARY F HEUBEL, EUGENE, OR LUCIA HEWITT, EUGENE, OR RAY S HEWITT, CORVALLIS, OR WALLACE G HICKS, JACKSONVILLE, OR MARK HIGHFILL, EUGENE, OR LYNN HILL, MEDFORD, OR MARY L HILL, PORTLAND, OR MURIEL W HILLIARD, FLORENCE, OR MIKE HILT, LEBANON, OR MURRAY E HILT, LEBANON, OR RANDY HINKE, GRANTS PASS, OR MARLENE HIRONS, MILL CITY, OR RALPH HOBERG, FLORENCE, OR DAVE HOCKER, CAVE JUNCTION, OR HOWARD HOFFER, COOS BAY, OR MICHAEL HOLLISTER, PORTLAND, OR PEGGY L HONEYWELL, SWEET HOME, OR MICHAEL HOOSER, ELMIRA, OR DONALD E HOPKINS, SWEET HOME, OR MICHAEL L HORTON, EUGENE, OR CARL HOSTICKA, EUGENE, OR LLYOD C HOUSE, DALLAS, OR HOWARD A HOUSEKNECHT, VENETA, OR PAUL HOWARD, EUGENE, OR RALPH \& WILMA HOWARTH, EUGENE, OR MARK J HOY, EUGENE, OR MILDRED HUBBERT, PORTLAND, OR ROGER HUFFMAN, GRANTS PASS, OR PHYLLIS HUGHES, JACKSONVILLE, OR LON HUMPHREY, EUGENE, OR RICHARD A HUNT, LYONS, OR LEE O HUNT, WINSTON, OR MATTHEW HUNTER, EUGENE, OR DAVE HUNTER, PORTLAND, OR NOLAN HUNTINGTON, FLORENCE, OR PHILIP HUNZIKGER, SALEM, OR MICHAEL HUTCHINS, UNITY, OR GEORGE B HUTCHINSON, ASHLAND, OR PATRICIA HUTTON, PORTLAND, OR MICHAEL INGRAM, EUGENE, OR EDWARD W INMAN, CENTRAL POINT, OR MILES C IRVINE, CORVALLIS, OR 
JIM IRWIN, PORTLAND, OR

RICHARD N ISAACSON, LA GRANDE, OR

GERALD S ISLEY, ASHLAND, OR

NORM JACOB, EAGLE POINT, OR

NATE JACOB, UNION, OR

RICHARD JAKIOUS, EUGENE, OR

SUE ANNE JENKINS, CORVALLIS, OR

JO JENNER, PORTLAND, OR

HUGHIE P JENNINGS, MEDFORD, OR

LOUISS A JENSEN, CORVALLIS, OR

PETER J JENSEN, EUGENE, OR

RALPH JENSEN, SPRINGFIELD, OR

PAT JERMOV, BEAVER, OR

PAUL JESKE, CORVALLIS, OR

CINDY M JOHNS, GRANTS PASS, OR

MARY JOHNSON, EUGENE, OR

MATTHEW JOHNSON, LEBANON, OR

MAURICE D JOHNSON, EUGENE, OR

BECKY JOHNSON, REDMOND, OR

MYRA E JOHNSON, WILLAMINA, OR

PAMELA JOHNSON, EUGENE, OR

JAMES H JOHNSON, SALEM, OR

VIOLET JOHNSON, EUGENE, OR

EVERETT P JOHNSON, ROSEBURG, OR

FRED L JOHNSTON, TIGARD, OR

GARY JOHNSTON, DALLAS, OR

MICHAEL JONES, SPRINGFIELD, OR

DONALD C JONES, GASTON, OR

MICHAEL P JONES, RHODODENDRON, OR

JAMES K JONES, BAKER CITY, OR

JOHN J KAIB, SPRINGFIELD, OR

MARY L KAMPPI, SALEM, OR

CHERIE S KANGAS, MEDFORD, OR

JOHN \& DAROLINE KANGER, CAVE JUNCTION, OR

MARCUS KAUFFMAN, CAVE JUNCTION, OR

ROY H KEENE, EUGENE, OR

LINDLEY KEENEY, EUGENE, OR

PATRICIA R KELLOGG, GRANTS PASS, OR

CHARLES KELLY, WOLF CREEK, OR

MARK KELZ, CAVE JUNCTION, OR

LOIS KEMP, PORTLAND, OR

TOM \& NANCY KENDALL, CAVE JUNCTION, OR

OREM KENNEL, LEBANON, OR

LOIS KENTOP, CAVE JUNCTION, OR

MELVIN W KENWORTHY, HOOD RIVER, OR

RICK KENYON, EUGENE, OR

ETHELYN A H KERN, LEBANON, OR

DONALD Z KESSI, BLODGETT, OR

ANNE KINNAMAN, MILWAUKIE, OR 
REED KINNEY, CORVALLIS, OR

ROBERT KINTIGH, SPRINGFIELD, OR

CLAIR KLOCK, CORBETT, OR

PETE KLOSTER, CRESWELL, OR

PAUL B KNAPP, DETROIT, OR

LLOYD KNAPP, APPLEGATE, OR

YVONNE KNOUSE, ROSEBURG, OR

RANDALL KOCH, NESKOWIN, OR

FRED V KOEHLER, EUGENE, OR

CAT KOEHN, EUGENE, OR

PERRY KOONTZ, SPRINGFIELD, OR

RYAN KOPPERUD, SELMA, OR

ARLINE W KOPPLIN, EUGENE, OR

ANDRISS KOUPERT, SPRINGFIELD, OR

NANCY KRAPE, PORTLAND, OR

CAROL KRASEL, MAPLETON, OR

LLOYD \& SUE KRAUSE, BEAVERTON, OR

RALPH W KROLL, LEBANON, OR

PAUL J KRUPIN, SALEM, OR

DAVID H KRUSE, GLADSTONE, OR

MARK KYNSI, ROGUE RIVER, OR

DONALD LAATSCH, TRAIL, OR

ROBBIN LACY, ASHLAND, OR

CYNTHIA LAGOUDAKIS, TILLER, OR

RICH LAGUE, CORVALLIS, OR

PAT LAKE, EUGENE, OR

OLIVER B LAMB, SWEET HOME, OR

JESSE \& JEAN LAMB, BANDON, OR

BERNARD LAMBRECHT, AUMSVILLE, OR

MURRELL \& DIXIE LANCASTER, TILLER, OR

REGINALD S LAND, COTTAGE GROVE, OR

LOLA LANDIS, WALDPORT, OR

PAUL LANDRUS, LEBANON, OR

MILTON C LANKTON, PORTLAND, OR

WILLIAM A LANSING, NORTH BEND, OR

PAUL R LANZ, EUGENE, OR

RONNIE D LAPP, PORTLAND, OR

FLORENCE P LAPP, AZALEA, OR

MARK LARSON, BEND, OR

JAMES \& CORA LARSON, MYRTLE CREEK, OR

STAN \& KATHERINE LARSON, DUNDEE, OR

MARGARET LAURINE, EUGENE, OR

TOM LAWLER, COTTAGE GROVE, OR

STEPHAN LAWN, COTTAGE GROVE, OR

CHARLES M \& JEAN LEACH, CORVALLIS, OR

BEVERLY LEACH, EUGENE, OR

MCKIM LEBER, EUGENE, OR

NORMAN LECOMPTE, EUGENE, OR

CHARLES E LEIERER, SALEM, OR 
PETER F LEITHAUSER, SISTERS, OR

JAMES LEMERY, ROSEBURG, OR ANDY LENGYEL, PORTLAND, OR

RICHARD L LESLIE, LINCOLN CITY, OR

BRUCE N LETHIN, SCIO, OR

MICHAEL LEUTWYLER, HILLSBORO, OR

ADAM LEVERENZ, WELCHES, OR

MARTHA B LEVERETT, MILWAUKIE, OR

MARA LEVIN, DEADWOOD, OR

MILTON LEVINGS, COTTAGE GROVE, OR

CHARLOTTE LEVINSON, EUGENE, OR

MICHAEL LEWIS, GRANTS PASS, OR

CHARLES S LEWIS, ALBANY, OR

PAUL E LIBBY, PORTLAND, OR

WOLF \& DIANA LIEBE, MEDFORD, OR

MEL LINDLEY, EUGENE, OR

MARGARET A LINDORFER, EUGENE, OR

LLOYD H LINK, REEDSPORT, OR

PETER LIST, CORVALLIS, OR

NICK O LIVERMORE, EUGENE, OR

MARSHA \& ERNEST LIVINGSTON, PORTLAND, OR

JAMES LLOYD, ASHLAND, OR

PAULA LOCKHART, EUGENE, OR

LYNN A LOMAX, EUGENE, OR

KATHY LOMBARDO, O'BRIEN, OR

LOWELL LONG, SPRINGFIELD, OR

BUD LONG, SUTHERLIN, OR

RAYMOND L LOOMIS, SPRINGFIELD, OR

NATHANAEL B LOONEY, SWEET HOME, OR

PAT LOVELAND, CORVALLIS, OR

MICHAEL R LOVELL, EUGENE, OR

JAN LOVELL, WILLIAMS, OR

NENA LOVINGER, EUGENE, OR

CHERI LOVRE, SALEM, OR

JACK LOWE, PORTLAND, OR

DONALD R LOWRANCE, CLATSKANIE, OR

MICHAEL LOWRY, CORVALLIS, OR

KENNETH LUCAS, PORTLAND, OR

MIKE LUND, ROSEBURG, OR

DAVID LYNCH, SPRINGFIELD, OR

NANCEY LYNCHILD, EUGENE, OR

LISA LYON, ESTACADA, OR

NANCY MACHACEK, EUGENE, OR

RICK MADSEN, IDANHA, OR

BENJAMIN F MAGILL, DALLAS, OR

DAVID R MAGIN III, PORTLAND, OR

JAMES W MAHONEY, BEND, OR

RICHARD D MAINVILLE, HARRISBURG, OR

RICHARD MAJOR, NORTH BEND, OR 
MARENS MALTBY, SALEM, OR RICK MALUSKY, LEBANON, OR ARTHUR E MANCL, EUGENE, OR PETE MANDRAPA, EUGENE, OR STEVEN L MANKLE, LEBANON, OR CLIFF MANN, NORTH BEND, OR ALEX MARCH, PHILOMATH, OR PEGGY MARLER, DEADWOOD, OR NORMAN MARRS, PORTLAND, OR NORM MARSH, SALEM, OR PETER MARSHALL, EUGENE, OR RICHARD MARTIN, SALEM, OR MARY ANN MARTIN, EUGENE, OR NEIL MARTIN, WILSONVILLE, OR PETER MARTIN, LAKESIDE, OR RICHARD L MARTIN, SPRINGFIELD, OR CLAYTON J MARTIN, SWEET HOME, OR TOM MARTIN, ESTACADA, OR PETE MARTINI, YONCALLA, OR MARK MARVEL, PORTLAND, OR MARY T MASKELL, PORTLAND, OR MARY B MASON, PORTLAND, OR DOROTHY J MATHEWS, PORT ORFORD, OR JEFFREY M MATHISEN, PORTLAND, OR PAUL B MATNEY, EAGLE POINT, OR RAYMOND P MATTHEW, THE DALLES, OR LLOYD MAXFIELD, EUGENE, OR MICHAEL \& LINDA MCBRIDE, SHERIDAN, OR KENNETH R J MCCABE, EUGENE, OR KATHLEEN MCCANN, PORTLAND, OR FRANCES A MCCARTER, SALEM, OR KATE MCCARTHY, PARKDALE, OR MAC MCCLOUD, LEBANON, OR LLOYD MCCLURE, WHITE CITY, OR NATASHA MCCOMBS, EUGENE, OR MERTHEL S MCCONNEL, CORVALLIS, OR MIKE MCCRACKEN, SALEM, OR RICHARD MCDEVITT, TIGARD, OR LUCILLE F MCDONALD, STAYTON, OR NANCY K MCDOWELL, EUGENE, OR JOHN MCEVOY, CORVALLIS, OR ESTHER H G MCEVOY, CORVALLIS, OR MIKE MCFARLANE, EUGENE, OR GREG MCFARLANE, GRESHAM, OR JOHN H MCGHENEY, NEWBERG, OR MARLENE MCGINNIS, PRINEVILLE, OR MR \& MRS KEITH MCGONAGIL, BAKER, OR MARK MCGUIRE, EUGENE, OR PAUL MCINTIRE, EUGENE, OR 
KELLY MCINTYRE, LAKE OSWEGO, OR MICHAEL J MCKEOWN, COOS BAY, OR NEIL MCLEAN, CLACKAMAS, OR PATRICK E MCLEAN, EUGENE, OR FERGUS MCLEAN, DEXTER, OR MELVIN MCLEOD, CAMAS VALLEY, OR MYLES MCMILLAN, AUMSVILLE, OR MARK MCNUTT, DEADWOOD, OR MARK MCQUEEN, MEDFORD, OR MICHAEL J MCTAGUE, PORTLAND, OR MICHAEL J MEANS, EUGENE, OR ANTHONY MEEKER, AMITY, OR DAVE MEJIA, SALEM, OR GAY B MELVIN, DUFUR, OR RICHARD MENDENHALL, WILLAMINA, OR RICHARD MERCATANTE, PORTLAND, OR CARL MERKLE, SPRINGFIELD, OR LHOTSE C MERRIAM, EUGENE, OR KATHY MERRIFIELD, CORVALLIS, OR PAT METKE, BEND, OR BRUNO C MEYER, MEDFORD, OR RICHARD E MEYERS, SWEET HOME, OR VIC MEYERS, LORANE, OR DAVID L MICKELSON, COOS BAY, OR RANDALL J MICKEY, MILL CITY, OR RAY MILBRETT, SWISSHOME, OR PATRICK D MILES, LEBANON, OR TERESA C MILLAR, PORTLAND, OR MARK MILLER, SPRINGFIELD, OR MARY L MILLER, CRESWELL, OR MAX MILLER, FOREST GROVE, OR NANCY MILLER, PORTLAND, OR R BONNIE MILLER, TURNER, OR U GALE MILLER, MAPLETON, OR BOBBIE MILLER, THE DALLES, OR SUSAN MILLER, PORTLAND, OR MAX \& ANN MILLIS, PORTLAND, OR MRS DEL MILNE, SALEM, OR RICHARD L MINKLER, EUGENE, OR RICK MINOR, EUGENE, OR MR \& MRS ARTHUR MINOR, SALEM, OR RICHARD MISHAGA, PORTLAND, OR HARLEY MISHLER, WILLAMINA, OR MIKE MISKA, MARCOLA, OR DONN MITCHELL, WILLAMINA, OR CURT MITCHELL, LORANE, OR JUANICE MITTS, EAGLE POINT, OR CAREY MOFFETT, JUNCTION CITY, OR MICHAEL J MOLLAY, SALEM, OR 
MORRIS W MONTGOMERY, MONMOUTH, OR

MR \& MRS JOHN MONTGOMERY, CENTRAL PONT, OR VICTORIA MONTGOMERY, MEDFORD, OR PAULINE MONTGOMERY-BORG, TILLER, OR BLAIR MOODY, MEDFORD, OR RICK \& PAMELA MOON, EUGENE, OR MICHAEL MOORE, SANDY, OR TERESA MOORE, MAUPIN, OR JEANY MOORE, BUTTE FALLS, OR AUDREY H MOORE, SANDY, OR JEANNE M MOORE, IDLEYLD, OR TAM MOORE, MEDFORD, OR MORACE S MOORE, BUTTE FALLS, OR MR \& MRS MOREY, NEWPORT, OR MICHAEL \& WILLIAM MORGAN, SUBLIMITY, OR CHARLES A MORGAN, GOLD HILL, OR MARK MORGANS, SALEM, OR RICHARD L MORRIS, SHERIDAN, OR ANNA MORRISON, FLORENCE, OR MIKE MORROW, EUGENE, OR MARCIA MORSE, ALBANY, OR PETER C MORTENSON, COQUILLE, OR MERLE A MOSAR, SISTERS, OR ARTHUR E MOSHER, DALLAS, OR LYLE E MOSS, SWEET HOME, OR RICHARD MUELLAR, CORVALLIS, OR GAIL E MUELLER, MYRTLE POINT, OR RICHARD MUIR, CHEMULT, OR R W \& HAZEL MULKEY, WALTON, OR PAT MULLER, ALSEA, OR PATRICIA A MULLER, ALSEA, OR LEWIS MURDOCK, WINSTON, OR QUINN J MURK, NEWPORT, OR RICHARD D MURPHY, WINCHESTER, OR LOUISE MYERS, TURNER, OR MELVIN \& CAROL MYGAARD, WILSONVILLE, OR MARY BETH NEARING, CORVALLIS, OR CLAMORE P NEEDHAM, ROSEBURG, OR MARIAN NELSON, SWEET HOME, OR MURDINA M NELSON, CAMP SHERMAN, OR OWEN NELSON, EUGENE, OR ANN NETZ, ALSEA, OR OTTO G NEUMEN, PHILOMATH, OR ERIC J NEVILLE, YACHATS, OR MAUREEN NEWBY, CORVALLIS, OR TRENT NEWCOMB, DALLAS, OR RICK NEWTON, GRESHAM, OR JACK NICHOLLS, MCMINNVILLE, OR ROBERT E NICKEL, EUGENE, OR 
RANDY NICKLOUS, SWEET HOME, OR MICHAEL G NIDA, BROWNSVILLE, OR JAMES NIELSEN, COQUILLE, OR STANLEY S NIEMIEC, CORVALLIS, OR MARVA J NIKIRK, HILLSBORO, OR MARVIN NOBLE, CLOVERDALE, OR MARY NOLAN, PORTLAND, OR PERCY NORDSTRAND, LEBANON, OR OBERT \& DOROTHY NORGARD, PORTLAND, OR NORMA NORONA, OAKLAND, OR

PALMER NORSETH, PORTLAND, OR CLARA NORTON, NORTH BEND, OR REED NOSS, CORVALLIS, OR MELVIN \& BARBARA NOVINGER, PORTLAND, OR THOMAS E O'DELL, CORVALLIS, OR MILDRED O'DONNELL, SPRINGFIELD, OR RICHARD N O'DONNELL, PORTLAND, OR MICHAEL O'MALLEY, SWEET HOME, OR ESTHER O'CONNELL, SALEM, OR SALLEE O'DELL, GOLD HILL, OR WILLIAM F OGG, MILL CITY, OR MIKE OGLE, BEND, OR

PAT O'KEEFE, BEND, OR

CATHIE OLCOTT, SALEM, OR

PAUL OLLSWANG, EUGENE, OR MARK OLSEN, SWEET HOME, OR NANCY OLSON, PORTLAND, OR PAUL \& VIOLET ORR, SALEM, OR WAYNE E ORR, SPRINGFIELD, OR MICHAEL ORZEN, EUGENE, OR MIKE OSHEROFF, CORVALLIS, OR GEORGE OSTERTAG, SALEM, OR RENNY C OTJIN, GRAND RONDE, OR NICK OTTING, CORVALLIS, OR RICHARD OURADA, COTTAGE GROVE, OR GALE OVSELE, NESKOWIN, OR BERNICE M OWEN, PORTLAND, OR RAY OWNES, WILLAMINA, OR RONALD PAJORK, EAGLE POINT, OR MICHAEL PALANDRI, EUGENE, OR DENNIS A PALMER, GRANTS PASS, OR PAULA PARKEL, EUGENE, OR MARY ALICE PARR, GRESHAM, OR JAMES E PARRETT, OAKRIDGE, OR MARGARET PARROTT, HOOD RIVER, OR THOMAS L PARSONS, DALLAS, OR SAL PASSANTINO JR, DALLAS, OR LOWELL E PATTON, CARVER, OR CHARLES M PATTON, EUGENE, OR 
PETE PAUL, WEST LINN, OR PAUL C PAULSON, PORTLAND, OR MIKE PAYNE, CORVALLIS, OR MARY PEARMINE, GERVAIS, OR PAUL PEARSON, PROSPECT, OR MRS LONNIE PECK, SWEET HOME, OR JERI PECK, SHERWOOD, OR MELVIN L PEDERSEN, JEFFERSON, OR NORMAN R PENDELL, EUGENE, OR SUSANNE L PENEGOR, EUGENE, OR MARGARET E PEPER, SALEM, OR PEYTON \& RUTH PERKINS, ALBANY, OR LOUIS B PERRY, PORTLAND, OR LINDA PERSON, PLEASANT HILL, OR C RONALD PETERS, SALEM, OR BOYD PETERS, WOLF CREEK, OR MATT PETERSON, MCMINNVILLE, OR FLORENCE PETERSON, ROSEBURG, OR HOWARD PETERSON, COTTAGE GROVE, OR EVERETT PETERSON, ROSEBURG, OR

PAUL PETREQUIN, EUGENE, OR RICHARD PETTERSON, MYRTLE CREEK, OR PAUL PETTIT, VIDA, OR WALTER PHILLIPS, PORTLAND, OR RICHARD PHILLIPS, MILL CITY, OR CINDY PHILLIPS, ROSEBURG, OR REUEL G PHILLIPS JR, ROSEBURG, OR DAVID PIERCE, MEDFORD, OR LOUIS PIHA, LEBANON, OR NED \& LARRY PIPER, COQUILLE, OR PHILIP PJURA, EUGENE, OR DONALD PODRABSKY, SWEET HOME, OR RICHARD R POOLEY, BEAVERTON, OR DELORES PORCH, PORTLAND, OR

PAT PORTER, BEND, OR

RAY PORTER, AUMSVILLE, OR RICHARD L POSEKANY, SALEM, OR MARY POTTER, EUGENE, OR OSCAR D POTTER, WILBUR, OR DENNIS L POURNELLE, SALEM, OR BOB POWNE, PORTLAND, OR RICK PRAIRIE, SPRINGFIELD, OR RICHARD PREST, SEAL ROCK, OR PAM PRICHARD, EUGENE, OR THOMAS PRINGLE, EUGENE, OR SCOTT E PRINGLE, EUGENE, OR MICHAEL PRITCHARD, PORTLAND, OR ALICE PROPES, DALLAS, OR FLOYD PROZANSKI, EUGENE, OR 
BOB PRUITT, GRANTS PASS, OR

PAUL PRZYBYLOWICZ, CORVALLIS, OR

MEL \& KAREN PURVIS, EUGENE, OR

MARVIN QUASCHNICK, SALEM, OR

LOUISE QUESTAD, PORTLAND, OR

LLOYD QUICK, NORTH BEND, OR

LAURIE \& ERIC QUINN, AZALEA, OR

PHILLIP \& FRIEDA RABER, CLACKAMAS, OR

MARY KAY RADICH, PORTLAND, OR

LOREN RAINBOTH, GOLD BEACH, OR

VAUGHN RAINS, LAKESIDE, OR

VITTZ-JAMES RAMSDELL, PORTLAND, OR

MIKE RANDALL, FLORENCE, OR

EUGENE RANDALL, CULP CREEK, OR

MICHAEL RANDLES, EUGENE, OR

LON \& LAURA W RANKIN, LEBANON, OR

MARVIN R RASCHE, WARREN, OR

MARK RASMUSSEN, EUGENE, OR

NORM RAUSCHER, STAYTON, OR

RALPH N RAWSON, WINSTON, OR

RICHARD L READ, SCIO, OR

MAYA JULIA REAMES, WILLIAMS, OR

JOYCE RECTOR, MERLIN, OR

ROGER REDFERN, PORTLAND, OR

SARA K REDFIELD, PORTLAND, OR

RICK REECE, SALEM, OR

MARI REED, EUGENE, OR

PATRICK A REEDY, GRANTS PASS, OR

MARK REHMAR, O'BRIEN, OR

CHRIS REID, RIDDLE, OR

STEVE \& VICKY RENNEMAN, SPRINGFIELD, OR

PAUL M RENNINGER, JEFFERSON, OR

RICHARD RENOUD, FOSTER, OR

LOREN A REYNOLDS, INDEPENDENCE, OR

LUE RHOADS, EUGENE, OR

MELVIN RHODES, BEAVERTON, OR

GEORGIA RICE, PORTLAND, OR

MARTHA RICH, PORTLAND, OR

LEN RICHARDSON, WOLF CREEK, OR

PHIL RICKEL, EUGENE, OR

PAT RICKERT, WILLIAMS, OR

JEAN RIDONE, EUGENE, OR

RICHARD RIES, PLEASANT HILL, OR

RANDY RIMBY, EUGENE, OR

FRED RIPP, SUBLIMITY, OR

MICHAEL W RITTER, COTTAGE GROVE, OR

RICK RITTER, SALEM, OR

CHARLES J RITZMAN, TENMILE, OR

LORETTA RIVARD, CORVALLIS, OR 
PAM ROBBINS, EUGENE, OR MEGAN ROBERTS, EUGENE, OR RAY E ROBERTS, SALEM, OR DOAK ROBERTS, EUGENE, OR MATTHEW ROBINSON, EUGENE, OR RON ROBINSON, LORANE, OR PEGGY ROBINSON, SPRINGFIELD, OR FRED L ROBINSON, SALEM, OR LYLE H ROGERS, STAYTON, OR JIM ROGERS, PORT ORFORD, OR ANN B ROGERS, CORVALLIS, OR BILL ROGERS, VIDA, OR RICHARD RONDEAU, MYRTLE CREEK, OR FAY ROOKARD, EUGENE, OR PRICE ROOP, EUGENE, OR RAMONA ROPEK, MT HOOD-PARKDALE, OR PAULA RORBAUGH, SALEM, OR MARTI ROSENTHAL, PORTLAND, OR AMOS R ROTEN, GATES, OR NATHAN ROTH, LEBANON, OR MYRON \& MARY ROTHBART, EUGENE, OR WALTER M RUDE, TOLEDO, OR REBECCA RUEDE, FLORENCE, OR JIM \& HELEN RUNNING, PORTLAND, OR MICHAEL A RUSSELL, SALEM, OR JOHN P RUSSELL, MITCHELL, OR DON SAGEHORN, SMAQUE RIVER, OR MANUEL B SAINZ, ELKTON, OR LOREN R SAPP, CORVALLIS, OR MARVIN SARGENT, WHITE CITY, OR ED SARGENT, EUGENE, OR DAN SARRETT, CAVE JUNCTION, OR MARY ANN SARVER, YACHATS, OR MICHELLE SAXTON, DEADWOOD, OR PAUL H SCHAFFNER, EUGENE, OR NANCY SCHARY, CORVALLIS, OR FRANK SCHENCK, MOLALLA, OR KEVIN SCHERER, BROOKINGS, OR CHARLES A SCHIEDLER, SILVERTON, OR PAUL SCHIERHOLTZ, EUGENE, OR MARK SCHLACHTER, PORTLAND, OR MICHAEL H SCHMEER, PORTLAND, OR OWEN SCHMIDT, PORTLAND, OR CURT SCHNEIDER, ASTORIA, OR TOBY SCHOAF, TRAIL, OR MILO SCHOENBORN, INDEPENDENCE, OR MILDRED \& LENORE SCHOOR, HUBBARD, OR PERRY SCHROCK, LEBANON, OR NAOMI SCHROCK, BEAVER, OR 
WALT SCHROEDER, GOLD BEACH, OR FRITZ SCHUFOR, MONMOUTH, OR LOWELL D SCHULTZ, CRESWELL, OR MATTHEW SCHUMAKER, APPLEGATE, OR LISA SCHWARTZ, PHILOMATH, OR SHIRLEY SCHWARTZ, NESKOWIN, OR KATHY SCHWEITZER, MONMOUTH, OR DANIEL SCOLLARD, CORVALLIS, OR LEONARD SCOTT, CANYONVILLE, OR SHELLY SCOTT, WOLF CREEK, OR IMOGENE J SCOTT, AZALEA, OR LOUIS B SCRUGGS, SALEM, OR TIM SCULLEN, GOLD BEACH, OR MRS ALEX SEAVEY SR, BANKS, OR JEROME P SEDLAK, SPRINGFIELD, OR CURTIS SEIDE, EUGENE, OR CHARLES W SELDEN III, FLORENCE, OR PETER SERAFIN, ROSEBURG, OR RUDOLPH SEVERNS, COTTAGE GROVE, OR GARY SHADE, MEDFORD, OR THOMAS SHARKEY, AZALEA, OR LYNN SHARP, MILWAUKIE, OR PAUL SHEARER, PORTLAND, OR MICHAEL SHEEMAN, EUGENE, OR MARGARET P SHELLEY, EUGENE, OR PHILLIP SHEPARD, JUNCTION CITY, OR JERALD P SHIPMAN, ALBANY, OR MICHAEL SHIPPEY, EUGENE, OR MARI SHIRAZI, EUGENE, OR LOUIS H SHOCKEY, SWEET HOME, OR NOLAN SIEG, EUGENE, OR PETER SIKORA, ELKTON, OR RANDY SILVERS, LOWELL, OR ANDREW J SIMMONDS, CORVALLIS, OR ANNETTE SIMONSON, ALBANY, OR PAM SIMPSON, NEWPORT, OR MICHAEL J SINGER, EUGENE, OR JACK SIVERTSON, LAKE OSWEGO, OR LUTHER F SKEELS, BLUE RIVER, OR MARY B SLABAUGH, CORVALLIS, OR LOUIS SLEGEL, CORVALLIS, OR ANNA SLEMMER, ROSEBURG, OR MARK SLEZAK, KLAMATH FALLS, OR ARTHUR E SLOVER, SALEM, OR LOUISE W SLY, HALFWAY, OR MR \& MRS EARL SMILEY, REEDSPORT, OR BILL SMITH, BEND, OR

MRS DEAN SMITH, ALBANY, OR MRS WILTON SMITH, SISTERS, OR 
OWEN SMITH, PORTLAND, OR

RAYMOND C SMITH, CRESWELL, OR

HOWARD E SMITH, EUGENE, OR

DENNIS W SMITH, ROSEBURG, OR

STEVEN SMITH, CAVE JUNCTION, OR

CY \& DOROTHY SMITH, SANDY, OR

ROY E SMITH, SALEM, OR

BERNIE SMITH, BEAVERTON, OR

ED SMITH, WILLIAMS, OR

ROGER F SMITH, ROSEBURG, OR

C WYLIE SMITH, COOS BAY, OR

PAUL SMOLAND, FOREST GROVE, OR

RICHARD L SNIDER, EUGENE, OR

STAN SNOOK, CENTRAL POINT, OR

MICHAEL R SOBOL, EUGENE, OR

BARBARA SOCHACKA, WOODBURN, OR

MICHAEL \& SUSAN SOLOMAN, EUGENE, OR

ROLF SOMMER, SELMA, OR

ALVIN L SORSETH, EUGENE, OR

MARK SOUGSTAD, MONMOUTH, OR

RICHARD V SOUND, ST HELENS, OR

ELD SPARKS, O'BRIEN, OR

MARCIA L SPENCE-STILES, PORTLAND, OR

PENELOPE SPIRO, SILETZ, OR

FRED STALLARD, FOREST GROVE, OR

MRS WILLIAM STANGE, MILL CITY, OR

RAY STANLEY, BAKER, OR

VEVA STANSELL, GOLD BEACH, OR

TED STARK, NORTH BEND, OR

DON STASEK, TILLAMOOK, OR

RANDALL L STEFFEN, SILVERTON, OR

WAYNE A STEFFEN, SILVERTON, OR

LYNDA K STEINER, TIGARD, OR

DONALD STEINER, PORTLAND, OR

DAVID STEINFELD, ASHLAND, OR

RICHARD E STEINKE, MCMINNVILLE, OR

JENNIFER STELLER, SPRINGFIELD, OR

SAM STEMBER, PORTLAND, OR

CHARLES A STENSRUD, MOLALLA, OR

PHILIP STEVENS, GATES, OR

LUCILLE STEWARD, EUGENE, OR

RICHARD M STEWART, CORVALLIS, OR

JANET L STEWART, BEAVERTON, OR

LORNA STICKEL, PORTLAND, OR

WILLIAM C STILES, ROSEBURG, OR

THOMAS R STIOLAS, CANBY, OR

WALTER STIPE, SUTHERLIN, OR

MARTIN \& CAROL STITT, EUGENE, OR

MARTIN STOCKDALE, CENTRAL POINT, OR 
DAVID STOCKER, CORVALLIS, OR

PETER STOEL, PORTLAND, OR

MARGERET STOLT, EUGENE, OR

RICHARD G STONEX, SILVERTON, OR

JERRY STOOPES, PORT ORFORD, OR

MARC STOUT, PORTLAND, OR

RICHARD STOUTENBURGH, GOLD BEACH, OR

RAY STREET, FLORENCE, OR

MRS ROBER STREICHER, PORTLAND, OR

LARRY L STRICKLAND, EUGENE, OR

MARY STROUD, EUGENE, OR

ROY STUART, TRIAL, OR

RAY STUCKART, STAYTON, OR

GRETCHEN STUDD, EUGENE, OR

BRUCE SUMMERS, SHERIDAN, OR

DEBBIE SUMMERS, EUGENE, OR

CARL M SUMMERS, SELMA, OR

RICHARD S SUND, NORTH BEND, OR

LOU A SURCAMP, WALTERVILLE, OR

FRAN G SUTHERLAND, ENTERPRISE, OR

RALPH L SWAN, PORTLAND, OR

MARSHA SWANSON, CORVALLIS, OR

DAVID SWEETMAN, MYRTLE POINT, OR

MARK SWIFT, SISTERS, OR

NORM SWORDS, PHILOMATH, OR

LIVIA SZEKELY, SPRINGFIELD, OR

ANNE TAGGART TUNZI, MYRTLE CREEK, OR

R CRAIG TAYLOR, SALEM, OR

FORREST \& VALERIE TAYLOR, NORTH BEND, OR

SCOTT TAYLOR, DILLARD, OR

SANFORD TEPFER, EUGENE, OR

RICHARD TERREL, SUTHERLIN, OR

VERNE W TERWILLIGER, ROSEBURG, OR

RALPH W THEDE, SALEM, OR

OLLIE THOMAS, PORTLAND, OR

PHILIP THOMAS, ASHLAND, OR

RANDY V THOMAS, DALLAS, OR

OSCAR R THOMSEN, EUGENE, OR

NICOLE TIFFANY, EUGENE, OR

LOU TIPTON, WEST LINN, OR

RAYMOND H TIPTON, AUMSVILLE, OR

LOUIS \& LOIS TOBEY, GOLD BEACH, OR

FRANK A TOBEY, BROOKINGS, OR

BRUCE K TOLONEN, GRESHAM, OR

PATRICK TOMLIN, PARKDALE, OR

NETA TOMLINSEN, GLENEDEN BEACH, OR

MARK TONEY, LYONS, OR

MARIE TOOZE, PORTLAND, OR

DON \& PEG TOWNSEND, SALEM, OR 
NANCY TRACY, PORTLAND, OR LINDA TREE, SELMA, OR JAMES W TREES, PORTLAND, OR R DALE TRUAX, DALLAS, OR ROY E TUCKER, SWEET HOME, OR CRAIG TUPPER, EUGENE, OR MARVIN TURLEY, WILLIAMS, OR NOEL S TURNER, EUGENE, OR KATHLEEN TYAU, NORTH PLAINS, OR PAT J TYLER, SWEET HOME, OR TRAVIS M TYRRELL, ARCH CAPE, OR NORMAN R UPDEGRAVE, SWEET HOME, OR JAMES VAN LOAN, IDLEYLD PARK, OR MINDY VANATTE, EUGENE, OR MOLLY VANAUSTIN, LINCOLN CITY, OR PETER VANDUINE, CANYONVILLE, OR PETE VANHANDEL, STAYTON, OR DAN VARSANO, CAVE JUNCTION, OR HAROLD W VAUGHN, WALTON, OR MANSON V VAWTER, GRANTS PASS, OR ROBERT E VINCENT, PHILOMATH, OR MARY VOGEL, BEND, OR MICHAEL E VOLK, SALEM, OR PHILLIP VOLLMAN, WILLAMINA, OR MARC VOMOCIL, CORVALLIS, OR PETER VORBECK, BUTTE FALLS, OR NORM WADDELL, EUGENE, OR MARILYN WAFF, EUGENE, OR MARK T WAGNER, SCIO, OR MIKE WAGNER, LYONS, OR MEL E WAGONER, LEBANON, OR LOUISE WAITT, PORTLAND, OR RONALD WAITT, ASHLAND, OR PETER WALCZAK, NEHALEM, OR DIANA WALES, ROSEBURG, OR MATTHEW W WALKER, SPRINGFIELD, OR STEVE WALLMANN, GRANTS PASS, OR MARK \& JUDY WALLULIS, OREGON CITY, OR RAYMOND \& LORRAINE WALTER, WALDPORT, OR MR \& MRS JOHN M WARD, MYRTLE CREEK, OR JEAN WARD, GRANTS PASS, OR CATHY WARD, JEFFERSON, OR TOM WARD, ASHLAND, OR PHILIP WARNER, EUGENE, OR KELLY M WARREN, SALEM, OR JEFF WARREN, ALBANY, OR JACK WARREN, BEAVERCREEK, OR ANTHONY D WARREN, LEBANON, OR MARGUERITE N WATKINS, COOS BAY, OR 
PHILIP WEAVER, EUGENE, OR RICHARD R WEAVER, OAKLAND, OR MYSTI L WEBER, CORVALLIS, OR RANDY WEBSTER, CORVALLIS, OR REBECCA WEEKS, EUGENE, OR MARY \& DAVE WEIL, DUNDEE, OR PAUL WEINHOLD, EUGENE, OR FLOYD WEITZEL, EUGENE, OR MIKE \& JANELLE WELLING, SPRINGFIELD, OR NANCY WELLS, OAKRIDGE, OR G GREELEY WELLS JR, JACKSONVILLE, OR PAUL D WELSTER, EUGENE, OR MARY ALICE WEST, PORTLAND, OR NIELS WEST, OAKLAND, OR REBECCA D WEST, EUGENE, OR RICHARD C WEST, GLIDE, OR NIELS WEST, OAKLAND, OR JOAN WEST, CENTRAL POINT, OR MR \& MRS RON WESTERLUND, ASTORIA, OR GENE WESTERMAN, SALEM, OR PETER WETHERWAX, EUGENE, OR LORIN WEYMOUTH, PHILOMATH, OR LARRY WEYMOUTH, PHILOMATH, OR JIM WHARTON, GOLD BEACH, OR MICHAEL WHEELOCK, MERLIN, OR LONNY WHELCHEL, FLORENCE, OR PAUL WHIPP, SPRINGFIELD, OR CAROL WHIPPLE, ELKTON, OR CHARLES R WHITE, SANDY, OR RICHARD WHITMAN, PORTLAND, OR PAT WICK, PRINEVILLE, OR MICHAEL WIDMANN, GLIDE, OR MOLLY WIDMER, EUGENE, OR STEPHAN WILCOX, CULP CREEK, OR PAUL A WILDUNG, ALBANY, OR FRANCIS J WILKENS, FLORENCE, OR MARVIN \& ELOISE WILLIAMS, SPRINGFIELD, OR REX WILLIAMS, SALEM, OR GEORGE WILLIAMS, MCMINNVILLE, OR CLARENCE A WILLIAMS, JACKSONVILLE, OR DON WILLIAMS, COTTAGE GROVE, OR LINN WILLS, FLORENCE, OR LOUISE WILSON, BEAVERTON, OR MARQUEITI C WILSON, PORTLAND, OR PAUL WILSON, PORTLAND, OR RAYMOND C WILSON, EUGENE, OR LOVERNA WILSON, CORVALLIS, OR MARVIN O WILT, CORVALLIS, OR MARRIANN WIMER, ALBANY, OR 
MARVIN C WINES, EUGENE, OR LAURA WINNEN, PORTLAND, OR ROBERT S WINNIFORD, SWEET HOME, OR LORE WINTERGREEN, EUGENE, OR NORMAN WISHART, CANBY, OR PAUL WITTBRODT, PORTLAND, OR RAY WOLD, LEBANON, OR PRENTICE WOLF, FLORENCE, OR MARK WOLFE, EUGENE, OR RAY WOLFE, EUGENE, OR MARY CHRISTINA WOOD, PORTLAND, OR BILL WOOD, KLAMATH FALLS, OR STEVE WOODARD, COTTAGE GROVE, OR SHERRY WOODWORTH, SELMA, OR DONNA P WOOLEY, DRAIN, OR DESIREE WOOLLEY, SCIO, OR MIKE WOOLS, ROSEBURG, OR RICHARD WRIGHT, GRANTS PASS, OR BILL G WRIGHT, GRANTS PASS, OR KEN WRIGHT, MYRTLE CREEK, OR BRAD YAZZOLINO, PORTLAND, OR ORETA \& ROBERT YERGEN, TILLAMOOK, OR CATE YOCUM, ASHLAND, OR JAMES YORK, CANYONVILLE, OR JOHN YOUNG, CASCADIA, OR LOUISE R ZENEV, EUGENE, OR PETER ZIKA, CORVALLIS, OR ARTHUR ZIMMER, ALVADORE, OR KEITH ZIMMERMAN, LYONS, OR PAT \& BECKY ZURCHER, BEND, OR MARTIN A ZURN, EUGENE, OR RANDY ZUSTIAK, WESTFIR, OR

\section{Washington:}

SYDNEY ABRAMS, MERCER ISLAND, WA ORVILLE ALTENEDER, SPOKANE, WA THOMAS ALWAY, STEVENSON, WA PHIL ANDRUS, CHIMACUM, WA PETER ANSINGH, WINTHROP, WA RALPH BACKSTROM, SEATTLE, WA ROBERT BACUS, ROY, WA MITCH BAKER, SEATTLE, WA RON \& NETTIE BARCA, VANCOUVER, WA GREGORY R BARCUS, BATTLE GROUND, WA DAVID BAUERMEISTER, SPOKANE, WA CLAY \& GERRI BEAL, CARSON, WA MARY BEAN, TROUT LAKE, WA RAY BEDNAR, OLYMPIA, WA 
MATT BERGUALL, KETTLE FALLS, WA

BARNEY BERNHARD, BREMERTON, WA

MAURICE BERNIER, RANDLE, WA

RICHARD K BEST, TACOMA, WA

CAROL BORDIN, SEQUIM, WA

MITCHELL BOWER JR, VANCOUVER, WA

KALMAN BRAUNER, SEATTLE, WA

MARSHA A BRAUNER, KETTLE FALLS, WA

JACK BREDESON, PUYALLUP, WA

ROBERT BROCKHAUS, SEATTLE, WA

ARLENE BROOKS, AUBURN, WA

JOHN BRUGMAN, TOUTLE, WA

LOIS \& GEORGE BRUHN, GLENOMA, WA

LELAND L BULL JR, SEATTLE, WA

VALERIE BUONANTONY, BAINBRIDGE IS, WA

MARY BURKE, CLE ELUM, WA

LE ROY BURNS, VANCOUVER, WA

ERIC BURR, MAZAMA, WA

KATHY BURTSCHER-PETERSON, TROUT LAKE, WA

JERRY CALBAUM, LONGVIEW, WA

MARY C CAMPBELL, GLACIER, WA

IAN N CAMPBELL, SEATTLE, WA

EVA M CAMPBELL, BELLINGHAM, WA

WALTER CARRIVEAU, SPOKANE, WA

GEORGE \& JUDY CARTER, SKAMANIA, WA

RICHARD CHANEY, ABERDEEN, WA

STUART CHAPIN, WHITE SALMON, WA

CRAIG L CHASE, BELLEVUE, WA

PHILLIP CHRISTY, RANDLE, WA

CHARLES A CLARIDGE, WOODINVILLE, WA

SHELLEY CLARK, OLYMPIA, WA

REBECCA CLEMENS, SEATTLE, WA

DUANE CLOCKSIN, CHIMACUM, WA

KENNETH COBLEIGH, ISSAQUAH, WA

STEVE COCHRANE, BELLINGHAM, WA

MICHAEL COLLINS, OLYMPIA, WA

JAMES F CONATY, SPOKANE, WA

MIKE CONAWAY, LONGVIEW, WA

DOUGLAS CONNER, PASCO, WA

TOM CONNOR, OLYMPIA, WA

GRANT COOMER, SEATTLE, WA

RALPH K COON, OLYMPIA, WA

HAROLD COOPER, MORTON, WA

BOB CORBETT, TACOMA, WA

RALPH CRAIG, WASHOUGAL, WA

KATHY CRAPPER, CARSON, WA

PAUL \& DEBORAH CROSETTI, ASHFORD, WA

BOB CROWLEY, PORT TOWNSEND, WA

PEGGY A DAVIDSON, OLYMPIA, WA 
TOM H DAVIS, SKYKOMISH, WA CONNIE DAVIS, BATTLEGROUND, WA ARCHIE DAWSON, BRUSH PRAIRIE, WA RUTH DEERY, LONGVIEW, WA GLENNA DELP, CAMAS, WA PHIL J DEROUSSEAU, TACOMA, WA JOHN DESTITO, TUMWATER, WA TONYA DOWSE, PORT ANGELES, WA STACY A DRURY, LYNNWOOD, WA GLENN B EADES, REDMOND, WA MR \& MRS ELDERING, TACOMA, WA RICHARD H ELLIS, SPOKANE, WA JODI ENGLE, NACHES, WA PETER ERBEN, QUINAULT, WA VERNE FARRELL, FORKS, WA MICHAEL G FEELEY, LEAVENWORTH, WA LARRY FRANK, WALLA WALLA, WA

LEN GARDNER, SEATTLE, WA MIKE GARSKE, COLVILLE, WA DON GATES, VANCOUVER, WA MIKE GILLETT, SEATTLE, WA GORDON EDWARD GLOCKNER, BATTLE GROUND, WA JOHN GOLD, LEAVENWORTH, WA MILLIE GORDON, OLYMPIA, WA JERRY GORSLINE, PORT HADLOCK, WA AL GRAFT, SHELTON, WA JOANNA GRAMMON, STEVENSON, WA LIZ GREENHAGEN, SEATTLE, WA PHILO GREGG, AMBOY, WA SCOTT GRIMMETT, VERADALE, WA DONALD W HACK, LONGVIEW, WA JIM HALVERSON, QUILCENE, WA MR \& MRS OTTO HANELL, OLYMPIA, WA DONALD HANSEN, PORT ANGELES, WA VERA HAYDUK, SEATTLE, WA DONALD J HELSER, HOQUIAM, WA FRED L HENLEY, FRIDAY HARBOR, WA R GARY HENRY, PACKWOOD, WA ANNE HERFINDAHL, TACOMA, WA MICHAEL HILL, ELBE, WA KEN HILLMAN, PORT GAMBLE, WA ANNE HILLYER, WHITE SALMON, WA JACQUELIN M HOFFMAN, VANCOUVER, WA MARI HOFFMAN NELSON, KELSO, WA ANDREW HOLMAN, GOLDENDALE, WA BRENDA HONG, BELLINGHAM, WA HOWARD K HOPKINS, LONGVIEW, WA PAUL HUNT, STEVENSON, WA MIKE IRWIN, TWISP, WA 
RAYMOND ISSACSON, RICHLAND, WA RON JACKSON, BRUSH PRAIRIE, WA LAWRENCE M JACOBSON, OLYMPIA, WA RALPH JASZKOWSKI, OAK HARBOR, WA SUSAN JENNY, ASHFORD, WA HELEN JOHNSON, COOK, WA CLARENCE JOHNSON, FEDERAL WAY, WA KATHERINE JOHNSON, LAKE STEVENS, WA DELPHA JORDAN, BREMERTON, WA ALLYSON E KEMP, BELLINGHAM, WA RENEE KENNEDY, FORKS, WA OREM KENNEL, SEQUIM, WA PHILIP H KIMERY, SHELTON, WA CHARLES F KNAUFT III, DEMING, WA DOROTHY L KNOTT, AMBOY, WA MERRILY KNUTSEN, ONALASKA, WA RAY KOON, PORT ANGELES, WA ARNIE KUBIAK, BAINBRIDGE IS, WA LYDIANE KYTE, CENTRALIA, WA MARK LANGE, SEQUIM, WA MARY PAT LARSEN, SEATTLE, WA LLOYD H LARSON, LACEY, WA RICHARD LARSON, COLVILLE, WA MARK LAWLER, SEATTLE, WA MIKE LAZZARI, FRIDAY HARBOR, WA JOHN A LEE, SEATTLE, WA MRS JOE LEONARD, LILLIWAUP, WA ROSEMARY LHURSEN, SHELTON, WA JIM LICHATOWICH, SEQUIM, WA THOMAS LINDE, CARSON, WA HAL LINDSTROM, ELLENSBURG, WA HANS A LITTOOY, OLYMPIA, WA TED W LLOYD, SEATTLE, WA PHIL LOE, SEATTLE, WA HOWARD W LOGUE, LYLE, WA BYRON W LOUCKS, CENTRALIA, WA FRED \& BEVERLY LOUSHIN, BEAVER, WA SARAH A LOWRY, BELLINGHAM, WA MR \& MRS JACK L LUCAS, COPALIS BEACH, WA DEAN A LYDIG, SPOKANE, WA DAVID MACFARLANE, LAKE STEVENS, WA JILL MACKIE, SEATTLE, WA

LARRY C MAECHLER, SNOHOMISH, WA J WILLIAM \& GAIL MAKI, HOQUIAM, WA BILL MAQUIRE, REDMOND, WA JOHN \& LORRAINE MARIS, FORKS, WA PETER MARSHALL, BELLEVUE, WA CHARLOTTE MARTIN, VANCOUVER, WA LARRY MASON, BEAVER, WA 
KUNO MASTERSON, EVERETT, WA TOM MAY, SPOKANE, WA VICKI MCNEAL, WASHOUGAL, WA DALE MCCOY, QUILCENE, WA JIM MCCULLOUGH, ABERDEEN, WA TOM MCDOWELL, YACOLT, WA VINCENT \& SHIRLEY MCELWEE, ABERDEEN, WA MARLER MCGINNIS, KENT, WA MICHAEL G MCGREEVY, KETTLE FALLS, WA BOB MCIRVIN, LAURIER, WA

ROBERT G MCLACHLAN, SEATTLE, WA EVA MEASSICK, STEILACOOM, WA JERRY \& COLLEEN MELTON, PUYALLUP, WA JAMES \& DONNIS MELZER, SEATTLE, WA LOUIS W MESSMER, ABERDEEN, WA SONNY METTLER, GLENOMA, WA DAVID MEYERS, ROSEBURG, WA HOWARD W MILLAN, CAMANO ISLAND, WA RUTH \& DENNIS MILLER, TENINO, WA CHARLENE MILLER, SHELTON, WA JOHN N MILROY, QUILCENE, WA CLEON MOEN, LONGVIEW, WA MRS DAVID N MOORE, BREMERTON, WA LINDA MOORE, EVERETT, WA PETER MORRISON, SEATTLE, WA LEE MOYER, SEATTLE, WA RUTH MUNSON, LYNNWOOD, WA DALE MYERS, BRINNON, WA DAVID MYERS, SHELTON, WA JUSTINE NAGEL, VASHON, WA MILDRED NEAL, OLYMPIA, WA ROBERT NELSON, ABERDEEN, WA MR \& MRS BOB NESBITT, PORT TOWNSEND, WA STEVE \& CARRIE NESS, SHELTON, WA

SALLY \& PAUL NEWELL, UNDERWOOD, WA HAROLD NYBERG, POULSBO, WA IRENE O'CONNOR, AMANDA PARK, WA ROSALIE \& TOM O'DONELL, HOQUIAM, WA PATRICK J O'NEILL, ABERDEEN, WA DORIS M OBERST, CARSON, WA CATHERINE O'DONNELL, VASHON, WA MRS EVERETT OLSON, OLYMPIA, WA HARVEY T OLSON, PORT HADLOCK, WA JOHN OSBORN, SPOKANE, WA NANCY A OSBORNE, SEATTLE, WA JOHN M OSTENSON, WASHOUGAL, WA CHRIS PALMQUEST, HOQUIAM, WA WENDY PARSON, SEATTLE, WA IRENE E PAYNE, TUMWATER, WA 
STEVEN BOULE, OLYMPIA, WA

PAIGE PAYNE, OLYMPIA, WA

MR \& MRS JOHN V PEDERSEN, BRINNON, WA

MIKE PEIL, SNOQUALMIE, WA

PAMELA PENNINGS, PORT GAMBLE, WA

RICHARD C PETERS, VANCOUVER, WA

ALBERT \& HARRIET PETERSEN, SHELTON, WA

PAUL PETERSON, MOSSYROCK, WA

MARTIN PETTIT, VANCOUVER, WA

GARY PHILIPS, QUILCENE, WA

RON PIERCE, OLYMPIA, WA

JIM H PISSOT, OLYMPIA, WA

DENNIS POBST, LEAVENWORTH, WA

TOM PRICE, EDMONDS, WA

RON PRINDLE, OMAK, WA

JANIE PULSIFER, LANGLEY, WA

NIKI E QUESTER, INDIANOLA, WA

BILL RAMSEY, SEQUIM, WA

DAVID \& DELLA RANDALL, BREMERTON, WA

STUART RASPONE, CLARKSTON, WA

RICHARD RAY, CASTLE ROCK, WA

HANSEL REED, BREMERTON, WA

CHAZ REEDER, HOODSPORT, WA

GARY \& VIRGINIA REID, OLYMPIA, WA

PETER REISERT, PACKWOOD, WA

COLIN E RELPH, BAINBRIDGE IS, WA

SYLVIA E RETHERFORD, HOME, WA

MR \& MRS HOWARD RICE, TUMWATER, WA

CLARENCE W RICHEN, VANCOUVER, WA

SUNNY RINEHART, SEQUIM, WA

JUDITH ROAN, MERCER ISLAND, WA

TIM ROBBINS, MARYSVILLE, WA

THOMAS S ROBINSON, SEATTLE, WA

MEG ROELLICH, NEWPORT, WA

JOHN ROLLINS, BELLINGHAM, WA

DENNIS RONDORF, COOK, WA

CHARLES B ROSENGARTEN, WOODINVILLE, WA

RICHARD J RYAN, PUYALLUP, WA

GERALDINE SABOTTA, OLYMPIA, WA

JOANNE SAMPLE, ALMIRA, WA

SUSAN SAUL, VANCOUVER, WA

PAUL G SCHAUFLER, OLYMPIA, WA

FRANK SCHEBERLE, HOQUIAM, WA

PAUL SCHIELKE, LEAVENWORTH, WA

RICHARD SCHROEDER, ISSAQUAH, WA

WALTER A SCHULTZ, VANCOUVER, WA

NATHAN SCHUMAKER, SEATTLE, WA

MICHAEL SCUDERI, AUBURN, WA

MICHAEL D SHANNON, CASTLE ROCK, WA 
LOREN SHARON, GOLDENDALE, WA MILDRED SHELTON, CARSON, WA DENNIS SHERWOOD, GIG HARBOR, WA DONNA SIMMONS, HOODSPORT, WA RON SIMON, LEAVENWORTH, WA SANDRA SMITH, QUILCENE, WA GEORGE A SMITH, TWISP, WA SHARON SORBY, NEWPORT, WA JASON S SPADARO, BINGEN, WA DAN SPATZ, WHITE SALMON, WA TERRI S SPENCER, ARLINGTON, WA IRA SPRING, EDMONDS, WA

DEL J STAFF, KENT, WA ERNIE STANTON, WHITE SALMON, WA ARVILLA F STANTON, VANCOUVER, WA DOUG STINSON, ELMA, WA DALE A STIRLING, EDMONDS, WA ALBERT SUTER, MINERAL, WA PAULA SWEEDEN, BELLINGHAM, WA ELEANORE SZYDLO, STEVENSON, WA BARBARA TARILTON, SEATTLE, WA MARY TAYLOR, OLYMPIA, WA AUBREY F TAYLOR, PORT TOWNSEND, WA JUDY TEITZEL, CARSON, WA DENNIS TOMKINS, SUMNER, WA JOAN TRACY, CHENEY, WA MIKE TRUAX, SEATTLE, WA MARK TUCKER, SEATTLE, WA JOHN R URQUHART, PASCO, WA FRED WAKLEY, CAMAS, WA JOHN WARTH, SEATTLE, WA CLINT WATKINS, SPOKANE, WA BILL WEILER, LYLE, WA JOSEPH WERNEX, ELLENSBURG, WA DAVID WERNTZ, SEATTLE, WA GARY WESTERLUND, KENT, WA RICHARD WHITMORE, BELLINGHAM, WA OZZIE WIKA, CATHLAMET, WA JACK F WILBERT, RANDLE, WA STANLEY G \& S ANNE WILLARD, GRANITE FALLS, WA BENTON G WILLIAMS, PORT ORCHARD, WA ROSINA E WILLIAMSON, LONGVIEW, WA DOUGLAS \& CAROL WILLISCROFT, SEATTLE, WA ANN WILSON, BAINBRIDGE ISLAND, WA GENE WIRSIG, CLARKSTON, WA EDWARD WOLF, SEATTLE, WA BLAIR WOLFLEY, STEVENSON, WA NEIL \& JO ANNE WOOLMAN, RANDLE, WA GEORGE WOOTEN, WINTHROP, WA 
DAVID WORTMAN, SEATTLE, WA GRAHAM WRIGHT, POULSBO, WA MEGAN YEARY, COUGAR, WA KATHY YOUCKTON, BUCODA, WA ELEANOR S ZAHM, PORT LUDLOW, WA

RICHARD \& ELSIE ZARNOWITZ, BELLINGHAM, WA

\section{Other States:}

MARGARET BEILHARZ, JUNEAU, AK RICHARD J GORDON, JUNEAU, AK CHRISTINE HEADY, CRAIG, AK RICHARD MIETZ, KETCHIKAN, AK RICH DONNELL, MONTGOMERY, AL MARGARET BAILEY, FLAGSTAFF, AZ JENNESSE CATHERS, YUMA, AZ EVA DANIELS, PHOENIX, AZ KURT FLYNN, GLENDALE, AZ PAT GARBUTT, FLAGSTAFF, AZ BILL GERSHAR, PHOENIX, AZ JERRY GONZALES, FLAGSTAFF, AZ LYNN JACOBS, TUCSON, AZ MARI N JENSEN, TUCSON, AZ ROGER \& MARIAN JOZWIAK, TUCSON, AZ WILLIAM J \& MILDRED KARP, SUN CITY, AZ DONALD LUE, PHOENIX, AZ MERLIN F NIKOLAUS, KEARNY, AZ DAVID WEGENER, FLAGSTAFF, AZ MICHAEL BURNEY, LAFAYETTE, CO LOUIS A LEPRY, ENGLEWOOD, CO DAVE NASLUND, EDGEWATER, CO JULIE SCHAEFERS, FORT COLLINS, CO RICHARD TECT, FT COLLINS, CO CHARLES P VAN EPPS, BROOMFIELD, CO PETE ZWANEVELD, CANON CITY, CO MRS THOMAS A DINE, WASHINGTON, DC DAN KISER, WASHINGTON, DC RICHARD STONE, WASHINGTON, DC PAUL A CONLEY, PONTE VEDRA BEACH, FL DIANE PIERCE, BONITA SPRINGS, FL ULRICH HARDT, BONN, GERMANY RONALD J KURTZ, GRINNELL, IA LLYOD J BARNOR, SCHAUMBURG, IL OWEN \& MARILYN CARTWRIGHT, JOY, IL PAUL FRIESEMA, EVANSON, IL GERHARD \& DOROTHY PILZ, ALTON, IL JAMES E SARGENT, W LAFAYETTE, IN MICHAEL \& DONNA BUTLER, LAWRENCE, KS LOREN D MAI, HOISINGTON, KS ROBERT D BOONE, NICHOLASVILLE, KY 
PATRICIA JONES, BOWLING GREEN, KY RICHARD H WILSON, HAWESVILLE, KY MARION D CARSON, CAMPTI, LA PAUL WILHITE, DOWNSVILLE, LA JEFFREY GILMAN, LOWELL, MA PERRY HAGENSTEIN, WAYLAND, MA MICHAEL J KELLETT, CONCORD, MA DEBORAH REITER, AMHERST, MA BRIAN SCHWARZTRAUBER, MALDEN, MA RANDE BROWN, CUMBERLAND, MD MARIE ANNE ERICKSON, BRADDOCK HEIGHT, MD FAY C GRANNG, COLLEGE PARK, MD MISTY JOY, CUMBERLAND, MD RICHARD G MILLER, ARNOLD, MD PAT MULLIGAN, COLLEGE PARK, MD CARL J NIELSEN, FREDERICK, MD PENELOPE SCOTT, BALTIMORE, MD JACK WILLIAMSON, ROCKVILLE, MD SANDRA CHURCH, CLARKSTON, MI MICHAEL D ELLS, BIG RAPIDS, MI DANIEL J FOSTER, MIDLAND, MI GUY FREDRICK, GRAND RAPIDS, MI STEVEN L JOHNSON, NOVI, MI MR \& MRS STEVE MUELLER, SALINE, MI JESSE SEDLER, TROY, MI KEN \& SUSAN ULREY, ANN ARBOR, MI MICHELLE HOVE, MINNEAPOLIS, MN WILLIAM V PETERSON, LITCHFIELD, MN RICHARD CAMPBELL, CARTHAGE, MO ERIC RASKAS, ST LOUIS, MO BRENDA SMITH, COLUMBIA, MO FRED E BOETTNER, HIGH POINT, NC PHIL ESSNER, OMAHA, NE DAVID W CUPPLES, MANCHESTER, NH BERNARD BERNSTEIN, BRANCHBURG, NJ RICHARD JORDAN, MONTCLAIR, NJ LYNN WIGHTMAN, MORRISTOWN, NJ MURIEL WILLIAMS, MONTCLAIR, NJ JOHN GEDDIE, ALBUQUERQUE, NM WILLIAM KEELER, RENO, NV PATRICK K SPENCE, CARSON CITY, NV LOIS ALMADRONES, NEW YORK, NY BERNICE BERNSTEIN, NEW YORK, NY MICHAEL COLAVITO, CHAPPAQUA, NY PAUL DINBERG, BROOKLYN, NY ABI G EIGER, ITHACA, NY RUSTIN R HOWARD, FREEVILLE, NY JAN A SNEED, NEW YORK, NY HOWARD D STERLING, NEW YORK, NY 
MARY WALL, SYOSSET, NY

TABER ALLISON, MARION, OH

STEPHEN D COTNER, GARRETTSVILLE, OH

ELSIE GRAPENTIN, PARMA, OH

HENRY PECK, NEW CARISLE, OH

NATHAN POTTER, XENIA, OH

DAVID DECALESTA, WARREN, PA

RON NAYPAVER, ENON VALLEY, PA

CARLA L PHILLIPS, LITITZ, PA

DANNE POLK, RADNER, PA

LAURA WAGNER, UNIVERSITY PARK, PA

PETER BRUCKER, NEW SHOREHAM, RI

PHOEBE MARTONE, CRANSTON, RI

WALLACE MCINTYRE, HILTON HEAD ISLAND, SC

BOB EINHAUS, COMFORT, TX

FRED J LILES, ARLINGTON, TX

NOLA SCHMIDT, NACOGDOCHES, TX

MITCHELL C WOMMACK, CORPUS CHRISTI, TX

SCOTT GEORGE, LOGAN, UT

JESSICA GONZALES, WEST VALLEY CITY, UT

KEVIN HOLLADAY, MOAB, UT

PAUL MAURER, SALT LAKE, UT

RICK STRATTON, OREM, UT

MARGUERITE WHEELOCK, OGDEN, UT

BRUCE WILCOX, LOGAN, UT

SAM PATTEN, BOYCE, VA

LOUIS R RUDOLPH, ANNANDALE, VA

MARTHA SLOVER, CLIFTON, VA

ERIC L BOUGH, ST CROIX, VIRGIN ISLANDS

MARY ANN AMANN, MADISON, WI

BETTY PINNO, FOND DU LAC, WI

JAMES TELLIER, MILWAUKIE, WI

\section{Other Countries:}

MICHAEL BORINS, QUEEN CHARLOTTE CITY, BC

SIDNEY BORINS, TORONTO, ONTARIO

RIA BOS, VICTORIA, BC

JEFFREY BOYCE, VICTORIA, BC

TOM BROWN, VICTORIA, BC

BEA CARCARSON, VICTORIA, BC

TOM CLARK, ONTARIO, CANADA

GAVIN DAVIDSON, VICTORIA, BC

MARGARET DAWKINS, VICTORIA, BC

BRIAN EGAN, VICTORIA, BC

CHRISTINE FLETCHER, VICTORIA, BC

HAROLD D FOSTER, VICTORIA, BC

HOPE FUNK, VICTORIA, BC

PATRICIA KIRK, VICTORIA, BC 
MATT LAMBERT, SOOKE, BC

LORNA LANYON, MERVILLE, BC

ANNA-MARY SCHMIDT, VICTORIA, BC

GEORGE STEWART, PALIANO ISLAND, BC

ADAM SZCZAWINSKI, VICTORIA, BC

GRANT TOMLINSON, VANCOUVER, BC 
References Cited 



\section{References Cited}

All documents cited are available at universities, libraries, or from Federal agencies such as the USDA Forest Service.

In the text of this document, references are cited in parentheses using the author-year system of citation. When an organization (such as a governmental agency or scientific society) is listed as the author in the parenthetical citation, an acronym or an abbreviation form of that organization's name generally is used in place of its full title. Below is a list of acronyms and abbreviations that are used in citations, along with the corresponding full titles that are used in this reference section:

$\begin{array}{ll}\text { USACE } & \text { U.S. Army Corps of Engineers } \\ \text { USDA, FS } & \text { U.S. Department of Agriculture, Forest Service } \\ \text { USDC } & \text { U.S. Department of Commerce } \\ \text { USDE } & \text { U.S. Department of Energy } \\ \text { USDI } & \text { U.S. Department of the Interior }\end{array}$

In addition, three other abbreviations are used. FSM is used to cite Forest Service Manuals, while FSH is used to cite Forest Service Handbooks. For example, FSM 2109.11 refers to Forest Service Manual 2109.11. These manuals and handbooks are located in most Forest Service offices. The abbreviation CFR refers to the Code of Federal Regulation. A parenthetical reference such as (29 CFR 1910.1200) cites book 29, section 1910.1200 of the Code of Federal Regulation. These are available at many federal government offices, and some public and university libraries. Citation for FSM and CFR are not included in the following literature cited section since the parenthetical reference provides all the information needed to locate the document. 


\section{A}

Anderson, D.R.; Bart, J.; Edwards, T.C., Jr.; [and others]. 1990. Status review. northern spotted owl Strix occidentalis caurina. USDI Fish and Wildlife Service. 99 p.

Anderson, Linda. 1992. National Cancer Institute (NCI), personal communication.

Arno, Stephen F.; Hammerly, Ramona P. 1977. Northwest trees. Seattle, WA: The Mountaineers. 222 p.

Arno, S.F. 1980. Forest fire history in the northern Rockies. Journal of Forestry. 78: 460-465.

Atzet, T.; Wheeler, D.L. 1984. Preliminary plant associations of the Siskiyou mountain province. Portland, OR: U.S. Department of Agriculture, Forest Service, Pacific Northwest Region.

Atzet, Tom A. 1991. Personal Communications. Grants Pass, OR: USDA Forest Service, Siskiyou National Forest.

\section{B}

Bailey, R.G. 1978. Description of the ecoregions of the United States [map and manual]. Ogden, UT:

U.S. Department of Agriculture, Forest Service. Intermountain region. $77 \mathrm{p}$.

Barbour, M.G.; Billings, W.D., eds. 1988. California upland forests and woodlands. In: North American Vegetation. Cambridge: Cambridge University Press. 434 p.

Barrows, C.; Barrows, K. 1978. Roost characteristics and behavioral thermoregulation in the spotted owl. Western Birds. 9: 1-8. 
Barrows, Cameron W. 1981. Roost selection by spotted owls: an adaptation to heat stress. Condor. 83(4): 302-309.

Betlejewski, Frank. 1991. Personal Communication. Medford, OR: USDI Bureau of Land Management.

Blair, G.S. 1992. Nez Perce National Forest. Unpublished memo. January 13.

Bolsinger, C.L.; Minore, D.; Radwan, M.A.; [and others]. 1988. Pacific yew (Taxus brevifolia Nutt.) - a research prospectus. Unpublished paper on file at: U.S. Department of Agriculture, Forest Service. Missoula, MT: Intermountain Research Station, Fire Sciences Laboratory. 13 p.

Bolsinger, Charles L. 1990. Forest Inventory and Analysis. Unpublished Mimeo. Pacific Northwest Research Station. (Copy on file.)

Bolsinger, Charles L.; Jaramillo, Annabelle E. 1990. Taxus brevifolia. In: Burns, Russel M.; Honkala, Barbara H., eds. Silvics of North America, Volume 1. Conifers. Agriculture Handbook 654. Washington, DC: U.S. Department of Agriculture: 573-579.

Brockway, Dale G.; Topik, Christopher, Hemstrom, Miles A.; Emmingham, Williams E. 1983. Plant associations and management guide for the Pacific silver fir zone, Gifford Pinchot National Forest. R6-Ecol-130a-1983. Portland, OR: USDA Forest Service, Pacific Northwest Region.

Brown, E.R., tech. ed. 1985. Management of wildlife and fish habitats in forests of western Oregon and Washington. Publ. R6-F\&WL-192-1985. Portland, OR: USDA Forest Service, Pacific Northwest Region. 


\section{C}

Carey, A.B. 1991. The biology of arboreal rodents in Douglas-fir forests. In: Huff, M.H.; Holthausen, R.S.; Aubry, K.B., tech. coords. 1991. Biology and management of old growth forests. Gen. Tech. Rep. PNW-GTR276. Portland, OR: USDA Forest Service, Pacific Northwest Research Station. 46 p.

Center for Population Research and Census. 1992.

Personal communication. Portland, Oregon:

Portland State University, Center for Population Research and Census.

Clements, F.E. 1916. Plant succession. An analysis of the development of vegetation. Publ. 242. Washington, DC: Carnegie Institute. 512 p.

Collingwood, G.H.; Brush, D. 1978. Knowing your trees. Butcher, D., ed. Washington, DC: American Forestry Association. 389 p.

Conkle, T. 1990. Presentation at IUFRO meeting on population genetics. Corvallis, OR.

Cooper, S.V.; Neiman, K.E.; Roberts, D.W. 1991. Forest habitat types of northern Idaho: at second approximation. USDA Forest Service, Intermountain Research Station, General Technical Report. INT-236. $143 \mathrm{p}$.

Crawford, R.C. 1983. Pacific yew community ecology in northcentral Idaho with implications to forest land management. University of Idaho. Ph.D. dissertation.

Crawford, Rex. 1992. Personal communication; remarks received with $\mathrm{Ch}$ III review. June 1.

Crawford, Rex C.; Johnson, Frederic D. 1985. Pacific yew dominance in tall forests, a classification dilemma. Canadian Journal of Botany. 63(5): 592-602. 
Daly, Douglas. 1992. Tree of life. Audubon. March-April: 78-85.

Daubenmire, R.F. 1968. Plant communities: a textbook of plant synecology. New York: Harper \& Row. 300 p.

Davis, Merrill. 1992. Personal Communication. Yew Coordinator, Forest Service Northern Region. Coeur d'Alene, ID.

Dawson, W.R.; Ligon, J.D.; Murphy, J.R. [and others] Report of the advisory panel on the spotted owl. Audubon Conserv. Report 7. 46 p.

Deevy, David. 1991. Personal communication. Forester, Kootenai National Forest, Libby, MT.

Del Moral, R.; Cates, R.G. 1971. Allelopathic potential of the dominant vegetation of western Washington. Ecology 52(6): 1030-1037.

Eblin, James B. 1991. The Yew and We. Portland, OR: Lewis and Clark Northwestern School of Law. 25 p. Seminar paper.

Everett, Percy C. 1957. A summary of the culture of California plants at the Rancho Santa Ana Botanic Garden 1927-1950. Claremont, CA: The Rancho Santa Ana Botanic Garden. 223 p. 
Fites, J. 1992. Distribution and habitat of Pacific yew in the northern Sierra Nevada and southern Cascades of California. Unpublished. Document on file.

Forman, R.T.; Godron, M. 1986. Landscape Ecology. New York: John Wiley and Sons, Inc. 619 p.

Forsman, Eric D. 1976. A preliminary investigation of the spotted owl in Oregon. Corvallis, OR: Oregon State University. 127 p. M.S. Thesis.

Forsman, Eric D. 1980. Habitat utilization by spotted owls in the west-central Cascades of Oregon. Oregon State University, Corvallis, OR. 95 p. Ph.D. Dissertation.

Forsman, E.D.; Meslow, E.C.; Wight, H.M. 1984. Distribution and biology of the spotted owl in Oregon. Wildlife Mono. No. 87. 64 pp.

Franklin, J.F.; Dyrness, C.T. 1973. Natural vegetation of Oregon and Washington. General technical report PNW-8. U.S. Department of Agriculture, Forest Service, Pacific Northwest Research Station. [Not Paged].

Franklin, J.F. 1988. Pacific Northwest forests. In: Barbour, M.G.; Billings, W.D., eds. North American Vegetation. Cambridge: Cambridge University Press. 434 p.

Franklin, Jerry F.; Moir, William H.; Hemstrom, Miles A.; [and others]. 1988. The forest communities of Mount Rainier National Park. Scientific Monograph Series No.19. Washington, DC: U.S. Department of the Interior, National Park Service. 194 p. 
Franklin, J.F.; Spies, T.A. 1991. Composition, function, and structure of old growth Douglas-fir forests. In: wildlife and vegetation of unmanaged Douglas-fir forests. U.S. Department of Agriculture, Forest Service. Pacific Northwest Research Station, General Technical Report. PNW-GTR-285.

Funk, A. 1981. Parasitic microfungi of western trees. BC-X-222, Canadian Forestry Service. Victoria, BC: Pacific Forest Research Center. 190 p.

Funk, A. 1985. Foliar fungi of western trees. BC-X-265, Canadian Forestry Service. Victoria, BC: Pacific Forest Research Center. 159 p.

Gerdemann, J.W. 1975. Vesicular-arbuscula mycorrhizae. In: Torrey, J.G.; Clarkson, D.T., eds. The development and function of roots. New York: Academic Press, Inc.: 575-591.

Grant, John A.; L. Carolyn. 1990. Trees and shrubs for Pacific Northwest gardens. Second Edition. Portland, OR: Timber Press. 456 p.

Gruell, G.E. 1983. Fire and vegetative trends in the northern Rockies: interpretations from 1871-1982 photographs. U.S. Department of Agriculture, Forest Service. General Technical Report. INT-158.

Gunther, Erna. 1973. Ethnobotany of western Washington. Revised edition. Seattle: University of Washington Press. $71 \mathrm{p}$. 


\section{H}

Halverson, N.M.; Topik, C.; Van Vickle, R. 1986. Plant and management guide for the western hemlock zone, Mt. Hood National Forest. Portland, OR: USDA Forest Service, Pacific Northwest Region. R6-Ecol-232A-1986. 111 p.

Hamrick, James L. 1983. The distribution of genetic variation within and among natural plant populations. In: Cos, Christine M.; Chambers, Stephen M.; MacBryde, Bruce; Thomas, W.L., eds. Genetics and conservation: a reference manual for managing wild animal and plant populations. Menlo Park, CA: The Benjamin/Cummings Publishing Co., Advanced book program.

Hamrick, J. 1990. Presentation at IUFRO meeting on population genetics. Corvallis, OR.

Harlow, W.M.; Jarrar, E.S.; White, F.M. 1979. Textbook of dendrology, covering the important forest trees of the United States and Canada. P. 210-213.

Hartzell, Hal. 1990. Personal Communication. Author, manager of Hodads, a forest worker organization. Eugene, OR.

Hartzell, Hal. 1991. The Yew tree: a thousand whispers. Eugene, OR: Hulogosi.

Hassrick, Phil. 1992. Personal communication.

Hauser Chemical. 1991. Internal memo.

Hemstrom, Miles A.; Emmingham, William H.; Halverson, Nancy M.; [and others]. 1982. Plant association and management guide for the Pacific silver fir zone, Mt. Hood and Willamette National Forests. R6-Ecol-100-1982a. Portland, OR: USDA Forest Service, Pacific Northwest Region. 104 p. 
Hemstrom, M.A.; Logan, S.E. 1986. Plant association and management guide. Siuslaw National Forest. USDA Forest Service, R6-Ecol-220-1986A. Portland, OR: Pacific Northwest Region. 121 p.

Henderson, J.A.; Peter, D.H.; Lesher, R.D.; Shaw, D.C. 1989. Forested plant associations of the Olympic National Forest. USDA Forest Service, Pacific Northwest Region. R6-Ecol-TP 001-88. 502 p.

Hepting, George H. 1971. Diseases of forest and shade trees of the United States. Agriculture Handbook 386. Washington, DC: U.S. Department of Agriculture. 655 p.

Hitchcock, Leo C;; Cronquist, A; Ownbey, M.; Thompson, J.W. 1971. Vascular plants of the Pacific Northwest. Part 1: Vascular cryptogams, gymnosperms, and monocotyledons. Seattle: University of Washington Press. $914 \mathrm{p}$.

Hoadley, Bruce R. 1990. Identifying wood: accurate results with simple tests. Taunton Press, Newtown, Ct. 223p.

Hofmann, J.V. 1917. Natural reproduction from seed stored in the forest floor. Journal of Agricultural Research. 11(1): 1-26.

Hosie, R.C. 1969. Native trees of Canada. 7th ed. Ottawa, ON: Canadian Forestry Service, Department of Fisheries and Forestry. 380 p.

Hunt, FA. 1986. National register of big trees. American Forests. 92(4): 21-52. 
Johnson, Charles G, Jr.; Simon, Steven A. 1987. Plant associations of the Wallowa-Snake Province: WallowaWhitman National Forest. R6-ECOL-TP-255A-86. Baker, OR: U.S. Department of Agriculture, Forest Service, Pacific Northwest Region, Wallowa-Whitman National Forest. 399 p.

Johnson, C.G. 1992. Pacific yew: distribution, biology, and ecological status in the Blue Mountains. La Grande, OR: Pacific yew forum. November 19.

Johnson, C.G.; Clausnitzer, R.R. 1992. Plant associations of the Blue and Ochoco Mountains. U.S. Department of Agriculture, Forest Service, Wallowa-Whitman National Forest, R6-ERW-TP-036-92. 164 p.

Johnson, Warren T.; Lyon, Howard H. 1976. Insects that feed on trees and shrubs, An Illustrated Practical Guide. New York: Cornell University Press. 464 p.

Junod, Tom. 1992. Tree of hope. Life. 15(5): 71-76. 


\section{K}

Keystone Center. 1991. Biological diversity on federal lands report of a Keystone policy dialogue. Keystone, $\mathrm{CO}$ : The Keystone Center. 98 p.

Kirk, Ruth. 1986. Tradition and change on the Northwest coast. British Columbia Provincial Museum. Seattle: University of Washington Press. $256 \mathrm{p}$.

Kruckeberg, A.R. 1982. Gardening with native plants of the Pacific Northwest. Seattle: University of Washington Press. 252 p.

Kuchler, A.W. 1964. Potential natural vegetation of the conterminous United States [map and manual]. Am. Geog. Soc. Spec. Publ. 36. 116 p.

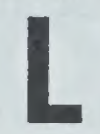

Lattin, Jack. 1992. Personal Communication. Oregon State University, Dept of Entomology.

Leopold, Luna B. 1953. Round River: from the journals of Aldo Leopold. New York: Oxford University Press. 173 p.

Li, P.; Adams, W.T. 1989. Range-wide patterns of allozyme variation on Douglas-fir (Pseudotsuga menziesii).

Little, Elbert L., Jr. 1971. Pacific Yew native range map 86W and 86N. In: Atlas of U.S. Trees, Vol. 1, Conifers and Important Hardwoods, UDSA, Forest Service. Misc. Publications: 1146.

Lowe, Daphyne P. 1969. Check list and hast index of bacteria, fungi, and mistletoes of British Columbia. Information Report BC-X-32. Department of Fisheries and Forestry. Victoria, BC: Forest Research Laboratory. 392 p. 


\section{M}

MacArthur, R.H.; MacArthur, J.W. 1961. On bird species diversity. Ecology. 42: 594-598.

Mannan, Robert William. 1977. Use of snags by birds, Douglas-fir region, western Oregon. Corvallis, OR: Oregon State University. 114 p. Ph.D. Dissertation.

Maser, C.; Tarrant, R.; Trappe, J.M.; Franklin, J.; tech. eds. 1988. From the forest to the sea: a story of fallen trees. Gen. Tech. Rep. PNW-GTR-229. Portland, OR: USDA Forest Service, Pacific Northwest Forest and Range Experiment Station. 153 p.

McCune, Bruce. 1982. Site, history and forest dymanics in the Bitterroot Canyons, Montana. Madison, WI: University of Wisconsin. 166 p. M.S. Thesis.

McFeat, Tom, ed. 1966. Indians of the north Pacific coast. Seattle: University of Washington Press: 18.

McGarigal, Kevin; McComb, William C. 1992. Streamside versus upslope breeding bird communities in the central Oregon coast range. Journal of Wildlife Management. 56(1): 10-21.

Mehan, W.R., ed. 1991. Influences of forest and rangeland management of salmonid fishes and their habitats. Bethesda, MD: American Fisheries Society. 19: 751 p.

Miller, Richard. 1991. Personal Communication.

Minore, Don. 1991. Personal Communication. USDA Forest Service, Pacific Northwest Research Station. Corvallis, OR. 


\section{$\mathbf{N}$}

Namkoong, G. 1988. Sampling for germplasm collections.

Hortscience. 23: 79-81.

Nehlsen, W.; Williams, J.; Lichatowich, J. 1991. Pacific

salmon at the cross-roads: stocks at risk in California, Oregon, Idaho, and Washington. Fisheries. 16(2): 4-21.

Neitro, William. 1992. Personal Communication. Remarks received with Ch. III. review, June 1.

Noss, Reed F. 1990. Indicators for monitoring biodiversity: a hierarchical approach. Conservation Biology. 4: $355-364$.

Odum, E.P. 1971. Fundamentals of ecology. 3rd edition. W.B. Toronto: Saunders Co. 574 p.

Omernik, J.M. 1987. Ecoregions of the United States [map].

U.S. Environmental Protection Agency, Environmental Research Lab. Corvallis, OR.

Onat, Astrida R.; Hollenbeck, J.L., ed. 1981. Inventory of Native American religious use, practices, localities, and resources: Mt. Baker-Snoqualmie National Forest. 


\section{P}

Paster, R.D.; Kovalchik, B.L.; Arno, S.F.; and Presby, R.C. 1977. Forest habitat types of Montana. USDA Forest Service, Intermountain Research Station, General Technical Report. Int-34. 174 p.

Peek, J.; Pierce, D.J.; Graham, D.; Davis, D. 1987. Moose habitat use and implications for forest management in north central Idaho. Proceedings of the Second International Moose Symposium. Swedish Wildlife Research Supplement 1.

Pierce, D.J. 1983. Food habits, movements, habitat use and population parameters of moose in north-central Idaho and relationships to forest management. Moscow, ID: University of Idaho. 205 p. M.S. Thesis.

Pierce, D. John. 1984. Shiras moose forage selection in relation to browse availability in north-central Idaho. Canadian Journal of Zoology. 62(12): 2404-2409.

Pierce, D.J.; Peek, J.M. 1984. Moose habitat use and selection patterns in north-central Idaho. Journal of Wildlife Management. 48(4): 1335-1343.

Pirone, Pascal P. 1970. Diseases and pests of ornamental plants. The New York Botanical Garden.

Preston, R.J. 1976. North American Trees. 3rd edition. Ames: Iowa State University Press. 399 p.

Price, Robert A. 1990. The genera of Taxacea in the southeastern United States. Journal of the Arnold Arboretum. 71: 69-82. 


\section{$\mathbf{R}$}

Rice, E.L. 1974. Allelopathy. New York: Academic Press, Inc. $353 \mathrm{p}$.

Richardson, Sherri. 1991. Pacific yew: a miracle cancer cure? Forestry Research West, U.S. Department of Agriculture, Forest Service.

Ricker, W. 1972. Hereditary and environmental factors affecting certain salmonid populations. In: Simon, R.C.; Larking, P.A., eds. The stock concept in Pacific salmon. Vancouver: Univ. British Columbia: 19-160.

Rudolf, Paul O. 1974. Taxus L. Yew. In: Schopmeyer, C.S., ed. Seeds of woody plants in the United States.

Agriculture Handbook 450. Washington, DC: U.S. Department of Agriculture, Forest Service: 799-802.

Ruggiero, Leonard F.; Jones, Lawrence L.C.; Aubry, Keith

B. 1991. Plant and animal habitat associations in Douglas-fir forests of the Pacific Northwest: an overview. In: Ruggerio, Leonard F.; Aubry, Keith B.;

Carey, Andrew B.; [and others], tech. coords. Wildlife and vegetation of unmanaged Douglas-fir forests. Gen. Tech. Rep. PNW-GTR-285. Portland, OR:

U.S. Department of Agriculture, Forest Service, Pacific Northwest Research Station: 447-462. 
Safir, G.R. 1980. Vesicular - arbuscular mycorrhizae and crop production. In: Carlson, P.S., ed. The biology of crop production. New York: Academic Press, Inc: 231-251.

Scher, S.; Jimerson, T.M. 1989. Does fire regime determine the distribution of Pacific yew in forested watersheds? In: Berg, Neil H., technical coordinator. Proceedings of the symposium on fire and watershed management. 1988. October 26-28. Sacramento, CA. Gen. Tech. Rep. PSW-109. U.S. Department of Agriculture, Forest Service: 160-161.

Shadbolt, Doris. 1986. Bill Reid. Seattle: University of Washington Press. 192 p.

Shaw, Charles Gardner. 1973. Host fungus index for the Pacific Northwest.-I. hosts. Washington Agricultural Experiment Station Bulletin 765. Pullman, WA: College of Agriculture, Washington State University. $121 \mathrm{p}$.

Sinclair, Wayne A.; Lyon, Howard H.; Johnson, Warren T. 1987. Diseases of trees and shrubs. New York: Cornell University Press. 574 p.

Solis, David M. 1984. Summer habitat ecology of spotted owls in northwestern California. Arcata: Humboldt State University. 168 p. M.S. Thesis.

Spies, Thomas A. 1991. Plant species diversity and occurrence in young, mature, and old growth Douglas-fir stands in western Oregon and Washington. In: Ruggerio, Leonard F.; Aubry, Keith B.; Carey, Andrew B.; Huff, Mark H., Tech. coords. Wildlife and vegetation of unmanaged Douglas-fir forests. Gen. Tech. Rep. PNW-GTR-285. Portland, OR: U.S. Department of Agriculture, Forest Service, Pacific Northwest Research Station: 111-121. 
Spies, Thomas A. 1991. Report to the yew technical committee. $4 \mathrm{p}$.

Standley, Paul C. 1921. Flora of Glacier National Park, Montana. Contributions from the United States National Herbarium. Vol. 22, Part 5. Washington, DC: United States National Museum, Smithsonian Institution: 235-438.

Stickney, Peter F. 1980. Discovery and early development of taxol. Abstract. In: Workshop on taxol and Taxus, current and future perspectives. Bethesda, MD: National Cancer Institute. June 26.

Storer, T.I.; Usinger, R.L. 1963. Sierra Nevada natural history. Berkeley: University of California Press. 374 p.

Thomas, J.W.; Forsman, E.D.; Lint, J.B.; [and others]. 1990. A conservation strategy for the northern spotted owl. In: A report by the Interagency Scientific Committee to address the conservation of the northern spotted owl. Portland, OR: USDA Forest Service; USDI Bureau of Land Management; Fish and Wildlife Service; National Park Service. 427 p.

Thomas, Jack Ward; Maser, Chris; Rodiek, Jon E. 1979a. Riparian zones. In: Thomas, Jack Ward, tech. ed. 1979. Wildlife habitats in managed forests: the Blue Mountains of Oregon and Washington. Agric. Handb. 553. Washington, DC: U.S. Department of Agriculture. 512 p. In cooperation with: The Wildlife Management Institute and the U.S. Department of the Interior, Bureau of Land Management. P. 40-47. 
Thomas, Jack Ward; Miller, Rodney J.; Maser, Chris; [and others]. 1979b. Plant communities and successional stages. In: Thomas, Jack Ward, tech. ed. 1979. Wildlife habitats in managed forests: the Blue Mountains of Oregon and Washington. Agric. Handb. 553. Washington, DC: U.S. Department of Agriculture. 512 p. In cooperation with: The Wildlife Management Institute and the U.S. Department of the Interior, Bureau of Land Management. P. 22-39.

Tirmenstein, D. A. 1990. Taxus brevifolia. In: Fischer, William C., compiler. The Fire Effects Information System [Data base]. Missoula, MT: U.S. Department of Agriculture, Forest Service, Intermountain Research Station, Intermountain Fire Sciences Laboratory. Magnetic tape reels; 9y rack; 1600 bpi, ASCII with Common LISP present.

Trappe, J.M. [n.d.] Personal Communication. Corvallis: Oregon State University.

Turner, Nancy J. 1988. Ethnobotany of coniferous trees. In: Thompson and Lillooet Interior Salish of British Columbia. Economic Botany. 42(2): 177-194. 


\section{U.S. Department of Agriculture, Forest Service. 1974.}

Seeds of Woody Plants. Agriculture Handbook 450.

U.S. Department of Agriculture, Forest Service. 1987.

Managing competing and unwanted vegetation, Draft

Environmental Impact Statement. Appendix G: Gr-16.

U.S. Department of Agriculture, Forest Service. 1987. Nez Perce Forest Plan.

U.S. Department of Agriculture, Forest Service. 1988a. FSH-2509.24. National forest system watershed codes handbook, Chapter One. (New handbook, material moved from Forest Service manual 2541).

U.S. Department of Agriculture, Forest Service. 1988b. Spotted owl guidelines. In: Final supplement to the environmental impact statement for an amendment to the Pacific Northwest regional guide. USDA Forest Service, Pacific Northwest Region. Vol. 1.

U.S. Department of Agriculture, Forest Service. 1990. Silvics of North America, Volume 1, Conifers. Agriculture Handbook 654. 573 p.

U.S. Department of Agriculture, Forest Service. 1991. Pacific Northwest Research Station. Forest inventory records.

U.S. Department of Agriculture, Forest Service. 1992a. An Interim Guide to the Conservation and Management of Pacific Yew. Pacific Northwest Region. 78p.

U.S. Department of Agriculture, Forest Service. $1992 \mathrm{~b}$. Final Environmental Impact Statement on Management for the Northern Spotted Owl in the National Forests.

U.S. Department of Agriculture, Forest Service. 1992c. Unpublished data. 
U.S. Department of Commerce, Bureau of the Census.

1981. 1980 Census of Population, Idaho. Volume 1,

Characteristics of the Population, Chapter A:

Number of Inhabitants. PC80-1-A14. Washington,

DC. U.S.G.P.O.

U.S. Department of Commerce, Bureau of the Census.

1981. 1980 Census of Population, Oregon, Volume

1, Characteristics of the Population, Chapter A:

Number of Inhabitants. PC80-1-A39. Washington, DC: U.S.G.P.O.

U.S. Department of Commerce, Bureau of the Census.

1982. 1980 Census of Population, Washington.

Volume 1, Characteristics of the Population, Chapter A: Number of Inhabitants. PC80-1-A49.

Washington, DC: U.S.G.P.O.

U.S. Department of Commerce, Bureau of the Census. 1991. Census of Population and Housing, 1990: Public Law (P.L.) 94-171 Data for Washington State. Washington, D.C.: U.S.G.P.O. Summaries provided by the Washington State Office of Financial Management/Forecasting, Olympia, WA.

U.S. Department of Energy, Bonneville Power Administration. 1982. Appendix I: Economic/Demographic Projections - Inputs to BPA Energy Forecasting Models. May. Portland, OR: U.S. Department of Energy, Bonneville Power Administration.

U.S. Department of the Interior, Bureau of Indian Affairs. 1990. Indian Land Areas [U.S. Map]. Reston, VA: U.S. Department of the Interior Geological Survey in cooperation with the Smithsonian Institution and the Bureau of Indian Affairs.

U.S. Department of the Interior, Bureau of Indian Affairs. 1992. Native American trust lands acres provided by the Oregon Area (Portland) and California Area (Sacramento). 
U.S. Department of the Interior, Bureau of Land Management. 1991. Oregon State Office, Portland, OR. Forest inventory data.

U.S Department of the Interior, Fish and Wildlife Service. 1987. The Northern Spotted Owl Status Review. Portland, OR $47 \mathrm{p}$.

U.S Department of the Interior, Fish and Wildlife Service.

1989. The northern spotted owl: a status review supplement. Portland, OR 114 p.

U.S. Department of the Interior, Fish and Wildlife Service. 1992. Draft Recovery Plan for the Northern Spotted Owl. Washington, D.C. US Fish and Wildlife Service.

\section{V}

Van Dersal, William R. 1938. Native woody plants of the United States, their erosion-control and wildlife values. Washington, DC: U.S. Department of Agriculture. $362 \mathrm{p}$.

Vance, Nan. 1992. Personal communication. 


\section{W}

Wheeler, Nicholas C.; Guries, Raymond P. 1982. Population structure, genic diversity, and morphological variation in Pinus contorta (Dougl). Can. J. For. Res. 12: 595-606.

Wheeler, N.C. 1991. Personal communication.

Wheeler, N.C.; Brobst, Susan W.; Snader, Kenneth M.; [and others]. 1992. Effects of genetic, epigenetic, and environmental factors on taxol content in Taxus brevifolia Nutt. and related species. Journ. of Natural Products. In press.

Whittaker, R.H. 1960. Vegetation of the Siskiyou Mountains, Oregon and California. Ecol. Monogr. 30:279-338.

Wilke, Philip J. 1988. Bow staves harvested from juniper trees by Indians of Nevada. Journal of California and Great Basin Anthropology. 10(1): 3-31.

Williams, C.K; Lillybridge, T.R.; and Smith, B.G. 1990. Forested plant associations of the Colville National Forest. USDA Forest Service, Colville National Forest. $133 \mathrm{p}$. 


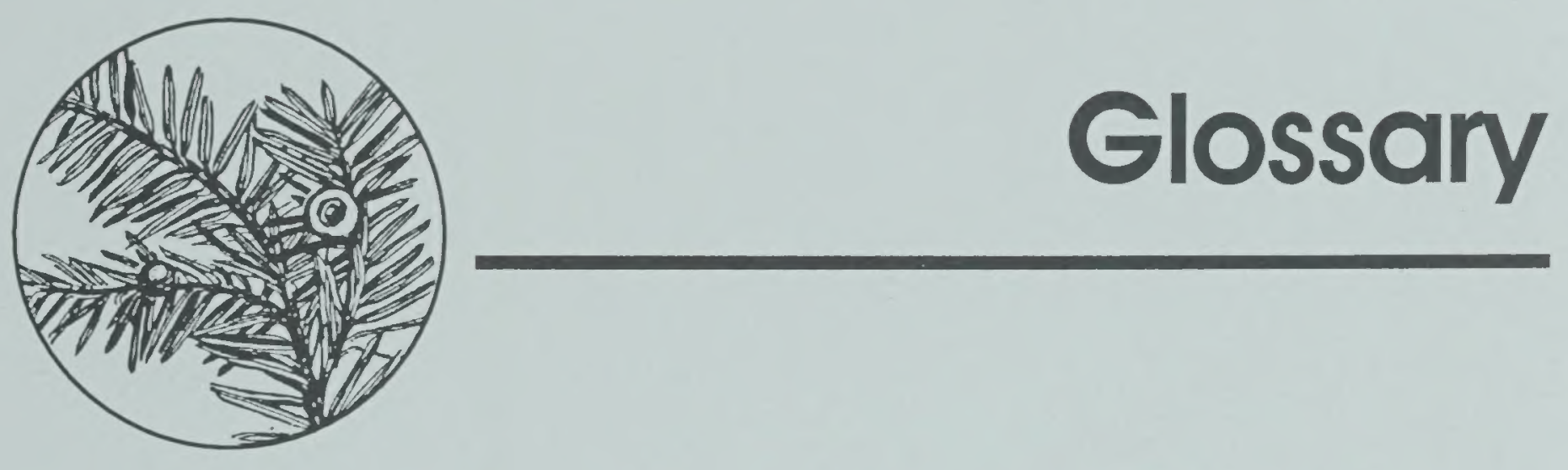





\section{Glossary}

\section{A}

Abundance: An estimation of the numbers of individuals in an area.

Adventitious: Plant organs produced in an unusual or irregular position, or at an unusual time of development.

Allele: One of a series of possible alternative forms of a given gene, differing in DNA sequence, and affecting the function of a single product (RNA and/or protein).

Allelopathy: The biochemical inhibition between organisms caused by the release of metabolic substances into the environment.

Apical dominance: The influence exerted by a terminal bud in suppressing the growth of lateral buds that usually results in stem elongation.

Aquatic: Living or growing naturally in or under water.

Aril: The fleshy, berry-like structure that encases the seeds on female yew trees.

Axil: The angle between the stem and a branch, or any appendage attached to it.

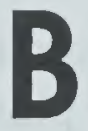

Bark stripping: The mechanical removal of the bark from a stem on live standing trees or logs.

Broadcast burn: A prescribed fire that is spread uniformly over an area. 


\section{c}

Cambium: The layer of growing cells located between the inner bark and the wood which is responsible for the increase in girth of stems or trunks.

Canopy cover: The horizontal projection of the upper vegetation layer onto the ground.

Cervil: A member of the deer family (deer, elk, caribou, moose).

Clearcut: A type of harvest where an entire stand of trees is removed in one cutting operation, leading to the establishment of an even-aged stand.

Climax plant community: A mature, highly stable, self-replacing plant community (Clements, 1916). It is the end result of the successional development of a plant community, in the absence of disturbance.

Clinal: A gradual change in a trait or in the frequency of a trait within a species over a geographical area.

Clone: A group of genetically identical individuals.

Common garden study: An investigation in which different seed sources are grown in a uniform environment to examine genetic variation in traits.

Community: All of the populations in a given area.

Complex of plant communities: The spatial arrangement of plant communities across the landscape.

Constancy: The frequency of occurrence of a species throughout a plant association or plant community type (not the same as the frequency within a particular plant community); it is the number of stands in which a species occurs expressed as a percentage of the total stands sampled and used to define a particular plant community type or plant association. 
Coppice system: A silvicultural system in which trees are regenerated vegetatively from stump sprouts.

Cover: Vegetation used by wildlife for protection; see thermal cover and hiding cover.

Critical winter range: The portion of the area used by a species that is essential for survival of a population or a species during severe winter conditions.

Cytotoxic: A substance that kills cells.

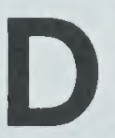

Designated Conservation Area (DCA): See owl conservation areas.

Dioecious: Plants having male and female reproductive parts on different individuals; contrast with monoecious.

Double canopy: Forest stands with a tall overstory of trees over a second layer of shorter trees both providing cover to the ground.

Dominant: A species, due to its size and numbers, that determines the character of a plant community, typically the most abundant species in the tallest layer of vegetation.

Down woody material: Fallen trees, branches, etc., which contribute to the organic layer of the forest floor. 


\section{E}

EA: Environmental Assessment; a document required by the National Environmental Policy Act because the proposed action might have significant environmental impacts.

Ecology: The study of the relationship between organisms and their environment.

Ecosystem sustainability: This concept represents a balance of all the interrelated aspects of an ecosystem that allows the system to maintain and perpetuate itself throughout time.

EIS: Environmental Impact Statement; a document required for major federal actions under Section 102 of the National Environmental Policy Act in which anticipated environmental effects of alternative courses of action are evaluated.

Electrophoresis: A laboratory technique used to distinguish biological entities by inspecting the differential movement of charged molecules through a porous medium in an electric field.

Endangered: Those species in danger of becoming extinct throughout all or a significant portion of their range.

Epicormic: Adventitious buds or shoots that develop laterally on the trunk of a tree.

Epiphytic: Living on the surface of plants. 
Forest health: Describes the forest's ability to meet the goals of the land manager and the landowner. In a broader sense, it also describes the "relationship between biotic and abiotic influences, including the influence of human activities, on forests and their short and long-term impact on management objectives for a forest unit."

Forest plan: A summary of the analysis of the management situation for each national forest, which describes multiple-use goals and objectives and includes a description of the desired future condition of the forest. Each forest plan contains multiple-use prescriptions and associated standards and guidelines for each management area, as well as monitoring and evaluation requirements that will provide a basis for a periodic determination and evaluation of the effects of management practices.

Fuel ladder: Combustible materials that usually connect burnable ground vegetation and material to the crowns of trees, thus providing a means for a ground fire to climb into the canopy of trees. 


\section{G}

Gamete: A reproductive cell. The female gamete and male gamete unite to form the cell that develops into a new individual.

Gene migration: The movement of alleles between populations. In plants this is accomplished by pollen and/or seed movement.

Genetic drift: Chance fluctuations in allele frequency due to small numbers of parents contributing to the next generation.

Genetic variation: The divergence among individuals or populations that is attributed to differences in their genetic constitution.

Genotype: The genetic constitution of an individual or group that may be either expressed or unexpressed, depending on the environmental effects of a given location; contrast with phenotype.

GIS: Geographic Information System, which is a means of storing, retrieving, and analyzing spatial (mappable) data.

GST values: Indicate the proportion of genetic diversity due to differences among different populations. 


\section{H}

Habitat: The sum total of environmental conditions of the place where a population or species normally lives and grows.

Habitat Conservation Area (HCA): See owl conservation areas.

Habitat type: All land areas potentially capable of producing similar plant communities at climax or the same plant association.

Heterozygosity: The condition of having one or more pairs of dissimilar alleles at a locus.

Hiding cover: Any vegetation used by wildlife for security or to escape from danger.

Horizontal structure: The distribution and spatial arrangement of life forms and species.

Indicator species: Plant or animal species which signify certain environmental conditions.

Induced soil compaction: Whenever soil is compacted, that is, made denser, from weight exerted against it by foot or other traffic.

Induced soil displacement: The removal or rearrangement of surface soil and plant litter.

Intense fire: Fires which burn hot enough to consume much of the forest floor organic matter, along with most of the vegetation and surface fuels in a stand.

Internode: The length of stem between branches or leaf attachments.

Isozyme: Different forms of the same enzyme. 


\section{L}

Late-successional forests: In this analysis, refers to mature and old-growth forests.

Layering: Adventitious rooting along a branch usually attached to the parent plant; see vegetative reproduction.

Leachates: Soluble constituents removed through percolation of water.

Light ground fire: A prescribed, often patchy fire, creating a mosaic of burned and unburned areas.

Light regime: The amount of sunlight reaching various levels of the forest canopy.

Local management area: For the Forest Service, management planning area generally not greatly exceeding 20,000 acres in a single National Forest System watershed (fourth or fifth-order stream basin.) For the Bureau of Land Management, a tree seed zone as established by the Western Forest Seed Tree Council.

Locus (plural, loci): Location of a gene on a strand of DNA. 


\section{M}

Management area: An aggregation of areas which have common management direction and may be noncontiguous in the forest.

Mature tree: An individual plant that has or is capable of producing seed or pollen; sexually mature.

Metastatic: Cancers which tend to spread from one body part to another.

Microclimate: The climate in the immediate vicinity of an organism or of a local habitat.

Midstory: Portion of vegetation which forms the intermediate vertical structural position below the overstory canopy.

Monoecious: Plants with male and female parts in different structures but on the same individual; contrast with dioecious.

Morphological: The form and structure of an organism.

Multilevel canopy: A forest stand structure in which several levels of shrub and tree branches are present. Pacific yew, for example, is an understory and midstory canopy level species. Douglas-fir and western hemlock are overstory canopy level species.

Mycorrhizae: A symbiotic association between a root tip of a plant and one of several species of fungus. The mycorrhizal relationship aids a plant in absorbing water and minerals. 


\section{$\mathbf{N}$}

Node: The region on a stem where leaves or branches are attached.

Non-sale area: For this analysis, an area in a national forest or district where no timber sales are scheduled in the next five years, but where yew harvest is allowed according to land use plans.

Nutrient Cycling: A continuous series of natural processes by which nutrients pass through successive stations in water, soil, and organisms. 
Old growth: A forest comprised of many large trees, large snags, and numerous large down logs with a multilayered canopy composed of several tree species, usually the final or a transitional stage of forest stand development.

Overstory: The portion of vegetation that forms the uppermost canopy later in a community.

Owl conservation areas: Those areas formally designated for protection of the northern spotted owl. They provide a contiguous block of habitat to be managed and conserved for breeding pairs, connection between blocks of habitat, and for proper distribution of the owls. Habitat Conservation Areas (HCAs), as described in the Final EIS on Management for the Northern Spotted Owl in the National Forests, will be the type of owl conservation area used on national forests. For BLM forest lands, owl conservation areas are defined as OldGrowth Emphasis Areas (OGEA), Connectivity Areas (CON), and Owl Pair Sites (OPS), as described in the preferred alternative of the BLM's draft resource management plans and Klamath Resource Area Management Plan. 


\section{$\mathbf{P}$}

Partial-cut sale unit: An area within a timber sale which has a silvicultural prescription to cut only part of a stand. Techniques which involve partial cutting include thinning, salvage operations, and prescriptions designed to produce an uneven-aged stand of trees.

Phase: A subdivision of habitat type or association that represents variation in geographic, environmental, floristic, historic, or structural differences in climax or mature vegetation.

Phenotype: The physical attributes of an organism that result from the interaction of its genetic composition and the environment; contrast with genotype.

Phenotypic variation: Total variation between phenotypes.

Phloem: The principle food-conducting tissue of a vascular plant; when located on the trunk it lies between the cambium and the bark and generally is called the inner bark.

Phylogenetic analysis: Analysis used to determine relationships among taxonomic groups.

Physiographic province: A region where all parts are similar in geologic structure and climate, and where the geomorphic history, consequently, has been unified. Provinces differ significantly in the pattern of relief features or landforms. 
Pioneer: An organism that establishes itself on a relatively or completely bare area with little or no competition.

Plagiotrophic growth: The horizontal growth of branches, stems, and roots.

Plant association: A unit of plant community classification typically based on potential vegetation; consult each reference for specific definition.

Population: A group of individuals of any one kind of organism.

Prescribed burn: Fire deliberately set to reduce fuels in an area; boundaries carefully controlled to prevent spread to other areas.

Proembryology: Examination of the development of reproductive buds.

Proposed species: Those species that are under consideration for listing as endangered or threatened species.

Prostrate: For this analysis, refers to a branch or trunk growing flat on the ground. 


\section{$\mathbf{R}$}

Regeneration: Young trees arising from seed or from vegetative regrowth from stumps, branches, or roots.

Regeneration harvest: Any removal of trees intended to assist regeneration already present or to make regeneration possible.

Reserve: An area set aside for a particular purpose or condition.

Residual green tree reserve: Green trees left on a site to provide a local seed source or for other purposes. Where silvicultural prescriptions call for retaining green trees, the inclusion of yew trees in the green tree reserve provides a local seed source for natural regeneration.

Resource management plan: A land use plan prepared by the BLM under current regulations in accordance with the Federal Land Policy and Management Act.

Riparian: Pertaining to areas associated with or directly influenced by streams, ponds, or lakes. 
Seedbed: The soil or other stratum onto which seed falls, overwinters, and germinates.

Seed tree cut: A type of harvest similar to a clearcut, except that a few of the better trees of the desired species are left scattered over the area to provide seed for regeneration.

Selection: The differential survival of genotypes under a particular environment that preferentially yields individual characteristics; a process of evolution (natural selection) or of selective breeding (artificial selection).

Sensitive: Those species designated by regional foresters or BLM state directors for which population viability is a concern. Sensitive species are not federally designated under the Endangered Species Act.

Seral stage: A defined transitory step in an ecological succession.

Series: A group of associations or habitat types with the same climax or potential tree species.

Set-aside areas: For this EIS, these are defined as lands where timber harvest is precluded by other resource management objectives.

Sexual reproduction: Reproduction involving the formation of gametes and fertilization to form a unique genotype; in trees, sexual reproduction results in formation of seed; contrast with vegetative reproduction.

Shelterwood cut: A type of harvest method where a portion of the mature stand is retained as a source of seed and/or protection during the period of regeneration. The mature stand is removed in two or more cuttings.

Site preparation: Any planned measure used to prepare a site for the establishment of artificial or natural regeneration. 
Slash: Branches and other woody material left on a site after logging; often removed by burning or piling in one spot.

Snow interception: When overstory and mid-level forest vegetation acts to catch some falling snow, reducing snow depths on the forest floor. This allows for easier movement for wildlife, and helps make food more available. This function has been recognized as being especially important in some moose winter range areas.

Snowmelt-dominated stream flow regime: Typically has one peak flow period which commences with snowmelt and terminates with the onset of base flow, or the period when groundwater releases regulate flow levels.

Standard deviation: In statistics, a measure of dispersion in a frequency distribution; a measure of variability; the square root of the mean of squares of the deviations from the mean.

Standard error: In statistics, the standard deviation divided by the square root of the number of observations.

Stratification: A method for overcoming seed dormancy which usually involves varying temperature and moisture storage times.

Strobili: Cones; structures with spore-bearing (e.g. pollen) or ovulebearing appendages concentrated on a common axis.

Succession: The sequence of change in communities during development of vegetation in an area; often broken into seral stages.

Subdominant: A species growing below the tallest layer of vegetation and, due to its abundance, has an important influence on the character of a community.

Suppressed: Plants whose growth and health are reduced by the presence of other plants, typically trees under a closed canopy and receiving very little or no direct sunlight. 
Taxane: A chemical compound (such as taxol) found in yew species.

Thermal cover: Vegetative cover used by animals to modify the adverse effects of weather, usually temperature extremes.

Threatened: Those species that are likely to become endangered in the foreseeable future.

Timber sale unit: An area within a timber sale which has a silvicultural prescription for a (1) clearcut, (2) shelterwood, or (3) seed tree harvest method. It also refers to an area that is to be cleared for road or building construction.

Tree seed zones: These are used for BLM lands and refer to the areas established by the Western Forest Tree Seed Council; they delineate areas of similar climatic and geographic conditions. 


\section{U}

Ultramafic: Some igneous rocks and most varieties of meteorites containing less than 45 percent silica and virtually no quartz or feldspar, and composed essentially of ferro magnesium silicates, metallic oxides and sulfides, and/ or native metals.

Understory: Vegetation growing under the canopy of taller vegetation.

Ungulate: Hoofed mammals, for example, moose, elk, and deer.

\section{V}

Vegetative reproduction: The asexual formation of offspring by layering, sprouting, rhizomes, tubers, or other vegetative means that are genetically identical to the parent.

Vertical structure: The layering of vegetation, the vertical arrangement of herbs, shrubs, midcanopy and canopy trees, and snags. 


\section{W}

Water quality degradation: The alteration of chemical, physical, and biological properties of water. Sediment production is the most frequently mentioned indicator of water quality degradation.

Winter range: See critical winter range.

\section{$\mathbf{X}$}

Xenograft: A tissue graft carried out between members of different species. 


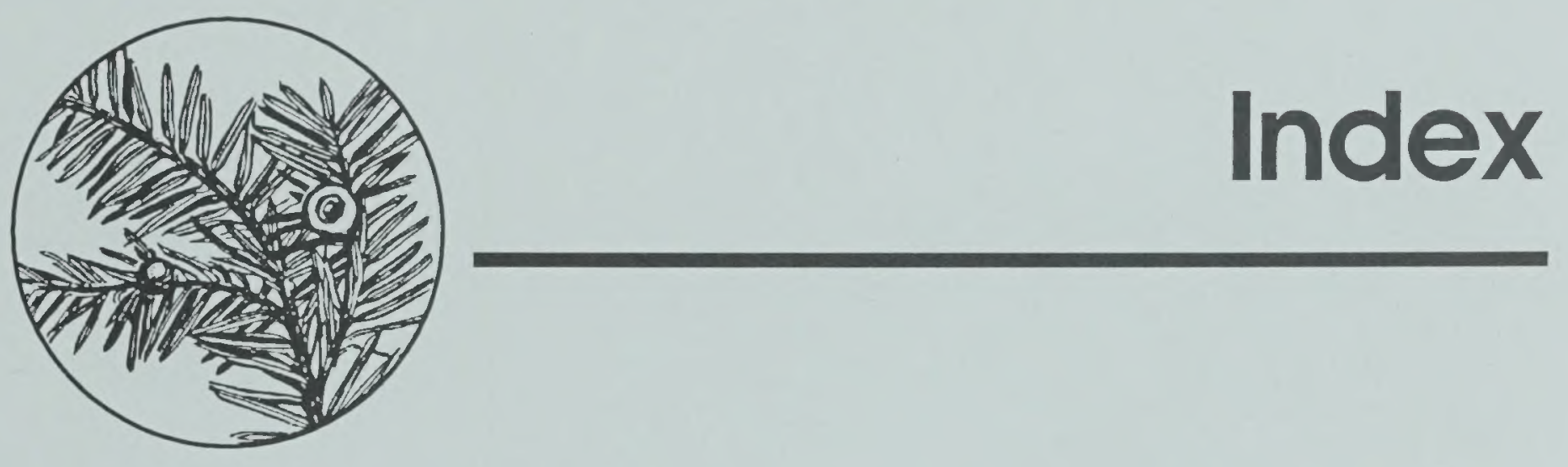





\section{INDEX}

A

Access, travel II-53, II-55, III-88, IV-52, IV-107-108, IV-117

Air quality IV-44

Alternative A II-16, II-21-22, II-45-55, IV-20, IV-26, IV-35, IV-43, IV-48, IV-66-67, IV-81, IV-90-92, IV-97-98, IV-104-105, IV-108, IV-110-112, IV-114-116, IV-126, IV-128

Alternative B II-16, II-23-24, II-45-49, II-52, II-54, II-57-58, IV-20, IV-27, IV-35, IV-44, IV-66, IV-76, IV-81, IV-90, IV-92, IV-108, IV-118, IV-126

Alternative C II-16, II-25, II-27-28, II-47, II-49, IV-21, IV-37, IV-59, IV-68-70, IV-81, IV-92-93, IV-95-97, IV-105

Alternative D II-17, II-28, II-30, II-47, II-49, IV-22, IV-38, IV-69-70, IV-72, IV-81, IV-105, IV-126

Alternative E II-13, II-19, II-30

Alternative F II-17, II-31, II-33, II-45-47, II-49, IV-22, IV-39, IV-71, IV-73, IV-81, IV-93, IV-96-97

Alternative G1 II-2, II-15, II-18-19, II-34, II-36, II-46, II-49-53, IV-23, IV-52, II-54, IV-72, IV-81, IV-126

Alternative G2 II-18, II-35, II-37, II-39, II-45-55, II-60, II-67-70, IV-24, IV-31, IV-72, IV-81, IV-126

Alternatives, Eliminated II-10, II-11

II-2

Alternatives, Mitigation measures II-1, II-3, II-11, II-13-14, II-23-26, II-28-29, II-31-38, II-47, II-49, II-56-57, II-60, II-67-70, IV-78

B

Bark, demand for I-2, I-5, I-7, III-16, III-17, III-103, III-105-108, III-111-117, III-119-121, IV-85, IV-93, IV-102

Bark harvest II-3-5, II-54, IV-114, IV-116, IV-118, IV-120, IV-122, IV-126

Big game III-79

Biodiversity II-49, III-58, III-61
C

Cancer I-2, I-5, III-91, III-103-105, III-113, III-122-123, IV-117, IV-121, IV-129

Cancer patients II-53

Clearcut II-16, II-17, II-18, II-20, II-26, II-29, II-32, II-56, II-64, IV-48, IV-81, IV-103, IV-104, IV-106, IV-107

Community impacts II-3, II-49

Cover, forage for animals II-51, II-65, II-68, III-72, III-77-79, III-87, III-90

Cultural resources I-6, III-74, III-110, III-125

D

Demand for bark I-5, II-21, II-54, II-55, III-12, III-106, IV-6, IV-20, IV-78, IV-115-116, IV-118, IV-120

Disease see Insects and Diseases

Diversity see Biodiversity or Genetic Diversity

$\mathbf{E}$

Ecology I-7, III-48-50, II-53

Economic impacts see Social and economic impacts

Ecosystem management II-3, II-25, II-28, II-31, II-34, II-37, II-40, II-45, II-48, III-25, III-32-33, III-50-51, III-57, III-59, III-62, III-88, IV-54-56, IV-64--78, IV-87, IV-93, IV-98

Employment, jobs see Social and EconomicImpacts

Endangered species II-3, II-50, III-74-76, III-87, IV-93, IV-102, IV-104, IV-105, IV-106, IV-107

Endangered Species Act III-58, III-74, III-131

Environmental consequences/impacts I-6, I-10, II-2, II-10, II-21, II-45-46, IV-1-2, IV-4, IV-7, IV-51, IV-79, IV-87, IV-113

Environmental monitoring II-57, II-62, III-131 
F

Fire II-48, II-58, II-65, II-60, II-63, III-23, III-30, III-31-2, III-41, III-42, III-44, III-45, III-46, III-56-57, III-62, III-66, IV-1, IV-5-7, IV-41-46, IV-67, IV-77, IV-110

Fish habitat, fisheries II-51, III-52, III-70-74, III-80, III-87, IV-105, IV-106

Forest health II-51, II-52, III-62, III-63, III-64, IV-52, IV-77, IV-78

Forest Plans I-9, II-16, II-23, II-26, II-29, II-32, II-35, II-38, II-49, II-51, II-68, II-69, III-5-7, III-88, IV-5, IV-11, IV-79, IV-90, IV-93, IV-96, IV-102, IV-112

Fuels IV-5, IV-41, IV-42, IV-43, IV-45

G

Genetics III-16, III-24-29, III-59, IV-8, IV-26, IV-28, IV-32-39, IV-40

Genetic diversity III-12, III-25, III-28, IV-75

Genetic reserve area II-26, II-29, II-32, II-35, II-39, II-61IV-56-58, IV-60-62, IV-78, IV-107, IV-110, IV-111, IV-129

Geographic range of yew III-15, III-2I, III-26, III-36-37, III-48, III-65-66, III-68-69, IV-52-53, IV-55, IV-58-59, IV-84, IV-104, IV-107

Geology IV-81

H

Habitat Conservation Area II-20, II-67, III-6 Human Health III-122

I

Illegal harvest see Theft

Indicator species III-53, III-54

Insects and disease II-4, II-47, II-70, III-33-34 III-57, III-60-63, IV-1, IV-47-50

Interdisciplinary team I-5, I-6, II-40, II-69, IV-4

Interim Guide I-10, II-4, II-10-13, II-19, II-22, II-24-25, II-27-28, II-30-31, II-33-34, II-36-37, II-39, III-13, III-50, IV-17, IV-28, IV-92, IV-125

Inventory of yew II-4, II-19, II-68, III-8-9, III-121, III-8-9, III-11-12, IV-7, IV-17, IV-68

Irreversible and irretrievable effects IV-114, IV-128
Issues II-1-9, II-40, II-45, IV-7, IV-25, IV-32, IV-41, IV-47

$\mathbf{L}$

Landscape III-48, III-60-62, IV-52-55, IV-58-63, IV-89, IV-91-92, IV-98

Long-term viability of yew II-13, II-45, III-12, IV-78, IV-107

M

Mature habitat see old growth/mature forest Mitigation measures see Alternatives, Mitigation measures

Monitoring see Environmental monitoring

$\mathbf{N}$

National Environmental Policy Act (NEPA) I-6, II-21, III-58, IV-3, IV-102

Native Americans III-73, III-91, III-98-99, III-110, III-125-127, III-131

IV-25

Needle harvest I-2, III-16, III-17, III-33, III-111-114, III-118, III-125, III-126, IV-4, IV-11, IV-14, IV-17, IV-20-24, IV-32, IV-43, IV-47, IV-49, IV-58-62, IV-68, IV-70, IV-71

Northern Spotted Owl, impacts of yew harvest on I-7, I-9, II-3, II-6, II-12-13, II-19-21, II-23, II-26, II-29, II-32, II-37-39, II-49, II-51, II-61, II-67, IV-62

$\mathbf{O}$

Old growth/Mature forest III-53-56, III-76-78, IV-64-72, IV-129

Opportunities III-102

Owl conservation area IV-62, IV-72, IV-79, IV-129

\section{$\mathbf{P}$}

Pest Management see Insects and Diseases Phytophthora lateralis III-34, IV-47, IV-50, IV-129

Plant associations III-38, III-53-54, III-56 Population distribution and inventory see Inventory

Prescribed burning II-20, II-58, II-60, II-63 Public involvement I-6 
$\mathbf{R}$

Recreation and scenery III-101, III-128-131

Reproduction III-18, IV-26-31, IV-35,

IV-38-39, IV-43, IV-46 sexual IV-31, IV-38, IV-39 vegetative III-19, IV-25-31, IV-43, IV-46

Riparian management III-44, III-52, III-60, III-71, III-76, III-80

Roadless areas III-35, III-88

Roads III-88, III-131

$\mathbf{S}$

Seeds III-14, III-18-19, III-21, III-26, III-28-30, III-57, III-80

Seed trees IV-27, IV-28, IV-30

Sensitive species III-82, III-87

Set-aside areas II-6, II-13, II-19, II-21, II-23, II-25-26, II-28-29, II-31-32, II-34, II-37-38, III-48, IV-56, IV-58, IV-65

Slash disposal II-57-59, II-62, II-64, III-30--32, III-87, IV-41, IV-43

Social and economic impacts I-7, II-4-6, II-12, II-53-54, III-92, III-96, III-100-101, III-120-121, IV-110

Soils III-50, III-65-67

Standards and Guidelines for Pacific yew III-6

Sustainability/sustained yield II-19, II-22, II-24, II-27, II-30, II-33, II-36, II-39,

III-11, III-12, IV-17

$\mathbf{T}$

Taxoi I-2, I-4, I-5, I-7, I-11, II-2-4, II-7-8, II-14, II-21, II-40, II-45, II-52-53, III-25, III-91, III-103-108, III-111-114, III-118-120, IV-4, IV-6-7, IV-17-20, IV-25, IV-32,

IV-48, IV-114-120, IV-122, IV-126, IV-129

Theft of bark II-9, II-61, IV-115, IV-122

Threatened and endangered species II-3, II-50, III-76, III-82-83, III-87, IV-8, IV-61, IV-62, IV-93, IV-102, IV-104, IV-105, IV-106, IV-107
$\mathbf{U}$

Utilization of yew II-8, II-61

V

Vegetation management IV-5

W

Water resources III-130, III-69

Wilderness II-3, II-6, II-10, II-1-13, II-21, II-23, II-26, II-29, II-32, II-34, II-38, II-49, II-61, III-48, III-67-69, III-72, III-88, III-128, III-129-130, IV-127, IV-129

Wildfire III-56, III- 66 , IV-5, IV-41

Wildlife III-60, III-76-80, III-90, III-99, III-132 
Pacific Yew Draft Environmental Impact Statement

\section{What do you think?}

Please let us know by March 15, 1993. Thank you.

Do you agree with the preferred alternative?

Why or why not?

I prefer Alternative

because:

What other comments do you have?

(Please Print)

Name:

ID\# (from label)

Organization:

Address:

City:

State/Province:

Zip Code:

Country: 
FOREST SERVICE, USDA PACIFIC YEW EIS TEAM

P.O. BOX 3623

PORTLAND, OREGON 97208 


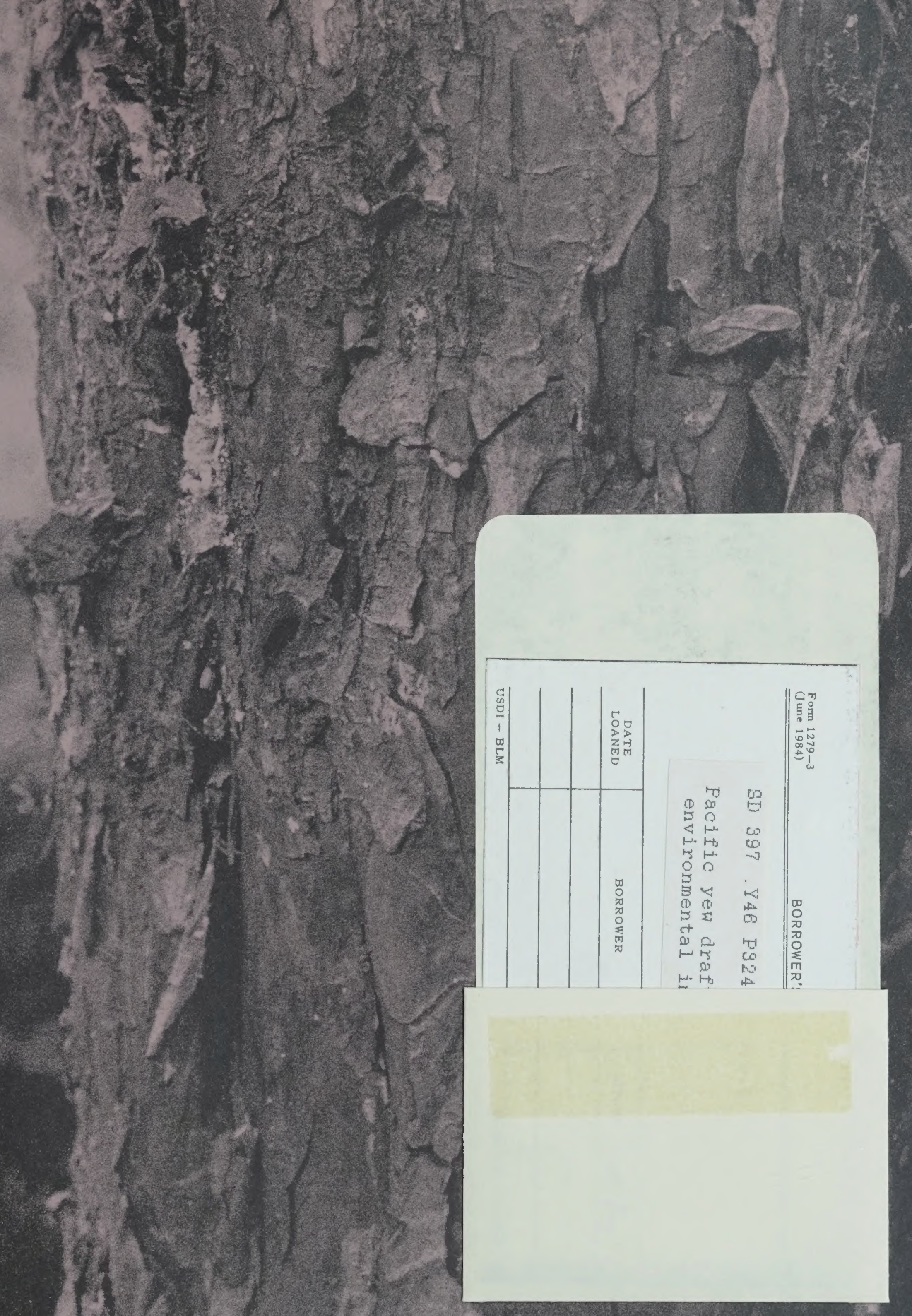


